\title{
THE POLITICAL GEOGRAPHY OF FEDERALISM AN INQUIRY INTO ORIGINS AND STABILITY
}

Ramesh Dutta Dikshit

THESIS SUBMITTED FOR THE DEGREE OF DOCTOR OF

PHILOSOPHY IN THE AUSTRALIAN NATIONAL UNIVERSITY 
Except where otherwise acknowledged in the text, this thesis represents the original research of the author.

Ramesh Dutta Dikshit May, 1971 
CONTENTS

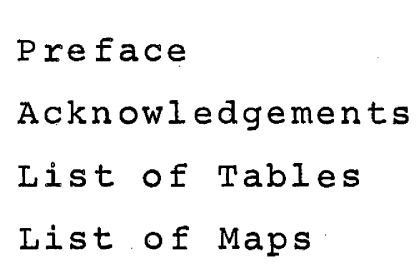




\section{Part 5 CONCLUSION}

Chapter

$x$ Some General Observations:

1. Origins of Federalism . . . 331

2. What Maintains Federalism? . . 349

Appendix

Federal Capitals and Territories

as Factors in Federal stability . . 361

Appendices typed at the end of respective chapters:

Appendix to chapter III:

"A Further Note on Turner and

Beard"

. . 105

Appendix to chapter $V$ :

"A Note on the 'New States'

Movement in Australia" $\quad$. 171

Appendix to chapter IX:

"Disparities Between the Two

Wings of Pakistan"

Bibliography

- . 372 


\section{$\underline{\text { PREACE }}$}

This study was undertaken with a view to arriving at some general propositions on the origins and stability of federalism. Indeed, every discipline "needs theo[ries] that. - [are] based on empirical generalizations which - - subsume particular facts". In order to make my generalizations broadly based I have tried to test them with respect to all the relevant examples, for the "greater the array of facts subsumed, the more general the theory and the better the understanding of the causal nature of whatever phenomena are being discussed". 1 It is for this reason that in this thesis a general study of all the functioning federations was preferred to an intensive study of a few examples. This approach to the subject has been possible because "(1) federalism is a precisely definable and easily recognizable constitutional artifact, (2) it has been used in enough instances to permit generalization but not in so many instances as to defy systematic examination, and (3) in all instances in the present world, the artifact of federalism is derived. [since 1787] from one source (i.e., the United States), but it is encased in diverse institutional and cultural settings so that one should be able to distinguish between general and local features of the artifact". 2

By its very nature this study covers a fairly large number of countries--too large for each one of them to be treated in full detail. But in any research project a choice has to be made between saying all about a few things and saying a few general truths about many of them. Since my choice here has been for the latter type of research, I have of necessity relied upon the works of specialists on history, politics and laws of the various federations studied for the background information on which my analyses and conclusions are based. My method of approach and other

1

Lewis A. Froman, Jr., "Public Policy", International Encyclopaedia of the Social sciences, vol. 13, New York: Macmilian Co. and The Free Press. Both the quotations 2 are on p. 206.

William H. Riker, Federalism: Origin, Operation, Significance, Boston: Iittle, Brown \& Co., 1964, pp. xixii. 
related points have been explained in the first chapter of the thesis. Suffice it here to repeat that by its very nature this study is essentially a work of what has been called a "general practitioner" rather than an "area specialist". Hence, since much of the work must depend on specific case histories, and much is of the nature of a critical examination of other views, the argument inevitably involves a good deal of direct quotation of important statements of facts and ideas. A clarification about the style of footnotes seems desirable. Although I have kept my footnotes for each chapter in running order, chapters 6,8 , and 9 are exceptions to this rule. This is because each of these chapters deals with two or more countries, and since the literature on the different countries involved in each of the three chapters is very diverse in nature, I have kept separate numbering of footnotes for each major country studied in a single chapter. Although somewhat unusual, this appeared a more sensible and readable arrangement. In chapter 7, where the literature on West Germany and Austria is largely similar, a single continuous order of footnotes has been maintained. 


\section{ACKNOWLE DGEMENTS}

The subject of this thesis was suggested to me by my supervisor Professor O. H. K. Spate, who after reading a preliminary version of my essay on the nature and geography of federalism thought that it could be a useful piece of research if $I$ were bold enough to undertake a general geographical study of federalism. Professor A. T. A. Learmonth (my joint supervisor until the end of 1969) encouraged and advised me to accept the challenge of this research on a virtually new frontier of geography. I have enjoyed working on this subject, and I am thankful to the above two scholars for having induced me to choose it as the subject for my Ph. D. thesis. professor spate's expertise in historical geography and his extensive studies in history have been of great help: they have guarded me against many errors of facts and interpretation. Although Professor Learmonth left this University when my work was just halfway through, he has been kind enough to retain interest in my work, and has very kindly gone through the entire draft that was sent to him in England.

Elsewhere my acknowledgements are due to Professor J. E. spencer, the former Editor of the Annals, Association of American Geographers, through whose courtesy I was able to obtain a most competent professional review of my essay "Geography and Federalism" which in a modified form appears as the first chapter of this thesis. Professor william s. Livingston, Editor of the Journal of Politics, not only provided me with helpful critical reviews of my article on the military interpretation of federal constitutions but also was kind enough to clarify (in private communication) certain points regarding his so-called "sociological approach" to federalism. Within this university my thanks are due to the various members of the two departments of geography who greatly encouraged me through their participation in my seminars on federalism, to Dr Hector Kinloch of the Department of History (SGS) who critically reviewed my chapter on American federalism, and to Dr: G. J, R. Linge of the Department of Human Geography who did the same with my chapter on Australia. I am also thankful to Mr M. Pancino who drew several of my maps. 
Financial support for the research has mainly come from a Commonwealth Scholarship and. Fellowship Plan award jointly administered by the governments of India and Australia. I am thankful to the CSFP committees in the two countries for making the award, and to the University of Gorakhpur for granting me a long term study leave which enabled me to complete the project. 


\section{LIST OF. TABLES}

Table 2.1 Switzerland: Languages Spoken (1960) . . 64a

Table 2.2 Switzerland: Dominant Religions in

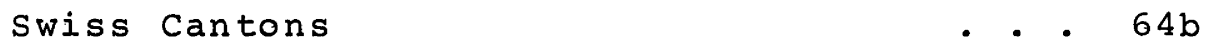

Table 4.1 Distribution of Ethnic and Religious Minorities in the Provinces of Canada. . . 141

Table 6.1 Communal Composition of the Population of Malaysian States - . 215

\section{IIST OF MAPS}

\section{following Page}

Fig. 2.1 Cross-cutting Communal Cleavages in Switzerland

Fig. 3.1 Spread of English Settlements, $1660-1775$

Fig. 3.2 Territorial Growth of the United states

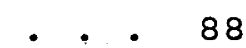

Fig. 3.3

Railroads in Operation, 1850 and 1860 . . 90

Fig. 3.4 Parties and sectionalism, 1848-1860

-. 91

Fig. 3.5 The United States, March 4, 1861

Fig. 3.6 Declaration of War. Vote on Passage, June 4,1812

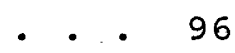

Fig. 4.1 Territorial Growth of the Canadian Union

Fig. 4.2 The Distribution of Population

Densities in Canada

Fig. 4.3 British North America Before

Confederation

- . 126

Fig. 4.4 Factors in Canadian Regionalism

- 139

Fig. 5.1 Evolution of Australia's Political

Boundaries

Fig. 5.2 Economic Regions of Australia in the $1890 \mathrm{~s}$

Fig. 5.3 Railroads in Operation

. . 168

Fig. 6.1

India Before the Transfer of Power Evolution of India's Internal political Boundaries 
Fig. 6.4 Malaysia: The Political Pattern

in 1939

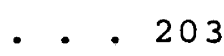

Fig. 6.5 Malaysia: Communal Composition of Population

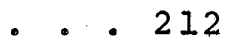

Fig. 7.1 The Weimar Republic: Prussia Writ Large $\quad$ - . 233

Fig. 7.2 Federal Units of Austria and West Germany

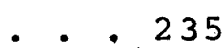

Fig. 8.1 Viceroyalties, Trade Centres and Trade Routes of Spanish America in 1776

-. 255

Fig. 8.2 The Central African Federation

- 272

Fig. 9.1 Pakistan 1947-1955

- 291

Fig. 9.2 The Federation of the West Indies

-. 304

Fig. 9:3 Political Units of Nigeria: Before and After the Civil war 
part 1

INTRODUCTION 
Chapter I

INTRODUCTION : *

NATURE OF THE PROBLEM. AND SCOPE OF THE THESIS

Although the relevance of geographical inquiry to the study of federalism is now recognized by most political geographers, systematic research on the subject has badly lagged behind. There has been singularly little discussion (among geographers) of the concept of modern federalism. A close study of the existing literature on the subject would reveal the prevailing confusion among geographers regarding the nature of this polity. Many still cling to the old concept of federalism as a "three layer cake" of government. In fact, despite a general agreement that federalism is "the most geographically expressive of all political systems", little effort has so far been made to explain the essential geographical basis of this polity. ${ }^{1}$

Then, because of a generally held notion that "we [as political geographers] are handicapped in developing scientific principles, and are restricted to the consideration of unique cases", little attempt has so far been made by geographers toward the search for generic concepts on federalism. ${ }^{2}$ In

1 Quotation from K. W. Robinson, "Sixty Years of Federation in Australia", Geographical Review, Vol. 51, 1961, p. 1. 2

Quotation from Richard Hartshorne, "The Functional Approach in Political Geography", Annals, Association of American Geographers, Vol. 40, 1950, p. 102. Though there are a couple of useful journal articles on certain aspects of some federations, spate's article of 1944 (O. H. K. Spate, "Geography and Federalism", Indian Geographical Journal, Vol. 14, 1944, pp. 24-36) is the only attempt by a geographer at a general nomothetic study of federalism. This study was, however, presented at a time when the so-called classical federations were virtually the only examples of true federations. For this reason as also because of its particular method of approach, the writer's inferences in the article are now out of tune with the present-day far more expanded span of *

This chapter is a slightly modified version of my paper "Geography and Federalism", Annals, Association of American Geographers, Vol. 61, 1971, pp. 97-115. 
fact, because of our over-involvement with the study of the specific and the unique, we have so far failed to develop any comprehensive approach to the study of general problems in political geography. This in itself might partly have accounted for the lack of generic studies in the field. This thesis, designed as a general inquiry into the origins and stability of federal political systems from a spatial interactional perspective, should, it is believed, partly contribute to fill some of these gaps.

The present chapter, which, is intended as a general introduction to the thesis, is divided into five sections. The first section presents a synthesis of different views on the nature and development of modern federalism. section two attempts to explain the geographical basis of this polity in a greater detail than, perhaps, has so far been attempted. This section also hints at some of the possibilities of geographical research on federalism. Section three attempts a general review of the existing geographical literature on federalism, and points to the need for a general geographical inquiry into the origins and stability of this polity. Section four presents a critical review of the existing methodology in political geography, and tries to outline the methodological framework of this thesis. A fifth, and the last, section explains the general scope and plan of the thesis.

\section{THE NATURE OF FEDERALISM}

Although federalism is so much in currency and the federal form of government by no means uncommon, federalism is not easy to define. In fact, "Devised as a form of constitutional government to express imperfect unity and multinationalism, federalism is a particularly complicated form of western democracy [i.e., a government based on Westernstyle democracy]". ${ }^{3}$ The term "federal government" is often

3

F. G. Carnell, "Political Implications of Federalism in New States", in U. K. Hicks (Ed.), Federalism and Economic Growth in Underdeveloped Countries, London: George Allen \& Unwin Ltd., 1961, p. 16. 
used very loosely in political discussions and it is seldom given a meaning that is at once clear and distinct. 4

The main features of the system are, however, well known. A federation is born when a number of usually separate or autonomous political units (or units with some pretensions to autonomy) mutually agree to merge together to create a state with a single sovereign central government, while retaining for themselves some degree of guaranteed regional autonomy. 5 The merger of the regional units in a federation is not absolute but partial, and its degree may vary depending upon the circumstances of the particular groups of the political communities involved. The legislative and executive powers in a federation are divided in a coordinated fashion between the federal (i.e., central) and the unit governments, each of which acts directly on the people--the central government having jurisdiction over all matters that have bearing on the development and security of the nation as a whole and the unit governments with their right to regulate the matters of local and more immediate importance to their respective peoples.

Federalism is therefore essentially a compact. Like other compacts, it has a written constitution that cannot be unilaterally altered. The terms of the compact and the division of "powers" or "functions" therein are made by the federating units as coordinate constitutional bodies and not by a dictatorial third party or an overbearing unit within the group. To ensure that no undue and unathorised inroads are made by one level of government into the sphere of the other, there is usually a judicial review by a supreme court

\footnotetext{
4

K. C. Wheare, Federal Government, London: Oxford University Press, fourth edition, 1963, p. 1 . 5

Throughout this thesis, unless within quotations, "state" stands for sovereign nation states. When written as "state" it means a constituent unit of a federation.
} 
acting as "the ark of the federal covenant". 6 Moreover, as "Money is. . the vital principle of the body politic.. . which sustains its life and motion and enables it to perform its most essential functions", in order that the federal government and the units are truly coordinate in authority, it is necessary that each has a good measure of control over its finances and, usually, an access to taxing powers. ${ }^{7}$

It should, however, be emphasized that federalism is a set of institutions erected to serve a particular type of social, political, and economic situation. The phenomenon that is so created is not static but dynamic. It goes through a process of evolution and change because a complex of psychological, social, political, and economic factors which necessitate federalism may require one type of instrumentality at one time and another type at some other time. In fact, "As the nature of the society changes; demands for new instrumentalities are created and these demands are met by changing or abolishing old instrumentalities and establishing new ones in their place." 8

\section{Federation, Confederation, and Unitary States}

Federalism differs from certain other forms of government. The two words "federation" and "confederation" have often been used as synonyms even by serious students of constitutions in the past; the authors of The Federalist itself did not distinguish between the two terms; and even a jurist of Dicey's standing used the two words loosely when he wrote "The physical contiguity . . of countries which are to form a

\section{6}

M. Ruthnaswamy, "The Ark of the Federal Covenant", New Review, December 1946.

The quotation is from the Federalist essay No. 30 whose authorship is attributed to A. Hamilton. See A. Hamilton, J. Madison, J. Jay, The Federalist Papers, with an introduction, table of contents and index of ideas by C. Rossiter, New York: The New American Library, 1961, p. 188. 8 W. S. Livingston, "A Note on the Nature of Federalism", Political Science Quarterly, Vol. 67, 1952, pp. 81-95. Reference on p. 93. 
confederated state is certainly a favourable . . condition for the success of federal government". 9 (Italics added.) And, etymologically there is little to distinguish between "federal" and "confederal", for each of the two terms implies a covenant, compact, or treaty among independent states. The oldest meaning of the expression "federal government" appears in its use to refer to loose linking together by treaty of sovereign states for specific military or economic purposes. Hence "Examples of federation in this form can be found as far back in history as confederacies of ancient Greece". 10

Modern scholarship has, however, insisted on drawing a clearcut distinction between the two terms despite the fact that such federal states as Canada and Switzerland describe themselves as "confederation"(s). As K. C. Wheare writes, a "confederation" is now described as "That form of association between states in which the general government is dependent upon the regional governments". It is represented by countries whose constitutions "embody the principle of subordination by the general government to regional governments". 11 . Thus a federation differs from a confederation in that in the latter the central government is subordinate to the unit governments in the sense that it runs at the mercy of regional governments. But in a federation neither level of government is at the mercy of: the other.

In a confederation there is no airect contact between the peoples of the several constituent units and the central authority. The central authority in a confederation is compelled to reach the people only through the respective regional governments, which may or may not allow this contact. In a federation, by contrast, there is a direct relationship between the central government and the people, who not only. share in the task of constituting it but also submit to its

\section{9}

A. V. Dicey, Introduction to the study of the Iaw of the Constitution, London: Macmillan Co., first edition 1885, 10 ninth edition 1939, p. 603 .

R. I. Watts, New Federations: Experiments in the Commonwealth, 11

Oxford: Clarendon Press, 1966 , pp. 9-10.

K. C. Wheare, op. cit., footnote 4, p. 32 . 
rule (in the spheres of its competence) without interposition of the regional governments as intermediaries. ${ }^{12}$

In a confederation the member states retain their sovereignties, and therefore, the central authority cannot compel its decisions on any of the constituents, for the central authority in a confederation can act only when all the constituents are unanimous. As The Federalist recorded: ${ }^{13}$

In our case the concurrence of thirteen sovereign wills is requisite, under the Confederation, to the complete execution of every important measure that proceeds from the union.

But in a federation there is no division of sovereignty, the constituent units are only autonomous in certain limited spheres. Once a federation is created the states have to abide by the decisions of the properly constituted central government in matters where the constitutional compact empowers it to act. Thus as Macmahon says: ${ }^{14}$

The logical difficulty of divided sovereignty can be avoided. . by regarding a confederation as merely comprehensive and cohesive form of international administrative union, whereas a federal system is regarded as a multiple government in a single state.

A federation differs from a unitary government in that in a unitary polity "states", if any, exist at the mercy of the central government; while in a federation each level of government is, in theory, autonomous within its allocated sphere of competence, and is free from any non-agreed intervention from the other except in emergency, if the constitution so provides.

Thus what distinguishes federalism from a unitary government is the constitutional autonomy, not the formal division of powers.

12

C. J. Hughes argues that a "confederacy" is a form of union in which the federal link is more strongly political than legal. See C. J. Hughes, Confederacies, Leicester University Press, 1963. See also C. J. Hughes, "The Theory of Confederacies" paper read at the 6 th Congress of the International political Science Association, 13

Oxford Round Table Meeting, September 19-24, 1963, pp. 13 . 14

The Federalist, op. cit., footnote 7, No. 15, p. 112 .

A. W. MacMahon, "Federation", Encyclopaedia of the social Sciences, New York: Macmillan Co., 1931, Vol. 6, p. 173. 
Federalism as a Constitutional Compromise or Bargain

As A. V. Dicey pointed out, federalism rests on the peculiar psychology of the peoples of the political units involved, of desiring union without desiring complete unity. ${ }^{15}$ A federation is born when the political units in a region possess some very strong factors of individual identities which create in them a genuine desire to maintain their separate existence, while at the same time there are certain factors of vital import that all these units share in common and, for that matter, they desire a strongly coordinated and united existence. Faced with such a dilemma when they can neither set up separate houses of their own without losing far greater advantages from union, nor can they amalgamate into a complete union without forgoing their individual identities which they so greatly value, the political units enter into a compromise to create a halfway house between complete unity and complete separation and a federation results.

Federalism is thus essentially a compromise between centripetal and centrifugal forces that are operative at the same time. It is born only when a characteristic balance between these forces is reached, although it is clear that because federalism is essentially a bargain, the units would merge into a federation only when the centripetal forces in some senses overwhelm the separatist ones and the units in general see greater advantages in union than in separation. 16 still the basic problem of a federation has traditionally been. for the federating units "to keep the centrifugal and centripetal forces in equilibrium so that neither the planet States shall fly off into space nor the sun of the central government draw them into its consuming fire". 17 Erected essentially as a halfway house between complete unity and

\section{5} 16

Dicey, op. cit., footnote 9, p. 602 .

The concept of federalism as a bargain has recently been further refined by W. H. Riker, Federalism: Origin, 17

operation, Significance, Boston: Little, Brown \& Co., 1964.

J. Bryce, American Commonwealth, New York: Macmillan Co., 1888, Vol. 1, p. 348 . 
complete separation, federalism clearly has a wide spectrum. 18 Stages of Federalism

During its pre-twentieth century phase federalism was more or less a dualistic polity "in which the federal and the state governments pursued virtually independent courses of action during a period when government activity was in any case minimal". 19 Federalism then consisted of "two separate federal and state streams flowing in distinct but closely parallel channels". ${ }^{20}$ Describing the American federalism in. 1858 the U. S. Supreme Court Chief Justice Roger B. Taney observed that: 21

The powers of the general government and the state, although both exist and are exercised within the same territorial limits, are yet separate and distinct sovereignties, acting separately and independently of each other, within their respective spheres.

This traditional dualistic approach to federalism had since been expounded by scholars like Freeman, Dicey, and Garran and has in more recent years been refined and justified by K. C. Wheare. 22

This legal theory of divided sovereignty and the two distinct and separate spheres fitted the facts of the time well enough though not perfectly, for till long after the Civil war in the United states the few activities of the

18

W. S. Livingston, Federalism and Constitutional Change, London: Oxford University Press, 1956, p. 4, see also 19 Livingston, op. cit., footnote 8 .

D. J. Elazar, "Federal-state Collaboration in the Nineteenth Century. United States", Political Science Quarterly, Vol. 79, 1964, pp. 248-281. Reprintedin A. Wildavsky (Ed.), American Federalism in Perspective, 20

Boston: Little, Brown \& Co., 1967, p. 191.

J. P. Clark, The Rise of New Federalism, New York: Columbia University Press, 1938, quoted in D.J. Elazar, op. cit., 21 footnote 19, p. 191.

Chief Justice R. B. Taney, in the name of the United states Supreme Court in Ableman vs Booth. Quoted in D. J. Elazar, 22 op. cit., footnote 19.

A. E. Freeman, History of Federal Government in Greece and Italy, London: Macmillan Co., second edition, edited by J. B. Bury, 1893; A. V. Dicey, op. Cit., footnote 9; J. Quick and R. R. Garran, Annotated Constitution of the Commonwealth of Australia, Sydney: Angus and Robertson, 1901; wheare, op.cit., footnote 4 . 
national government could go along side by side with the limited state activities without either impinging seriously on the other. It was, william Anderson says, almost, if not quite, a "functionless federalism" when compared with the present conditions. 23 But the economic philosophy on which this dualistic federalism was based has become quite outmoded now. No modern state, whatever its economic and political philosophy, can now avoid an extensive degree of state intervention.

This is an era of the active, public-service state, not that of the negative laissez-faire state. The performance of functions and services is the keynote of modern government, and in that performance cooperation, interdependence, interpenetration of national and state agencies are inevitable. ${ }^{24}$ For this reason older constitutions have been adapted to fit the needs of the present time by the development of extraconstitutional devices such as administrative cooperation between governments, the coordination of state policies by conditional grants from the federal government, and the purchase of federal monopoly or near-monopoly of taxation of incomes and profits. Many scholars, therefore, think that federalism has become obsolete in the twentieth century for, as Karl Loewenstein believed, economic planning is the DDT of federalism. ${ }^{25}$ But federalism has only entered a new phase. In fact, whereas the guiding principle of the eighteenth- and nineteenth-century federalism was the independence of state and federal authorities, the guiding principle of the mid-twentieth-century federalism is the need of cooperation between them. ${ }^{26}$ It is only the pest of 23

W. Anderson, Federalism and Intergovernmental relations: A Budget of Suggestions, Chicago: Public Administration 24 Service, 1946, p. 13. 25

Anderson, op. cit., footnote 23, p. 14 .

K. Loewenstein, "Reflections on the Value of Constitutions in Our Revolutionary Age", in A. Zurcher (Ed.), Constitutions and Constitutional Trends since World War II, New York: New York University Press, 1951, pp. 191-224. Reference 26 on p. 212 .

A. H. Birch, Federalism, Finance, and social Legislation in Canada, Australia, and the United States, London: Oxford University Press, 1955, p. 305. 
dualism that economic planning (the DDT) has killed. It is the dualistic phase of federalism that has now become a relic of the "horse and buggy days". 27

This new phase of federalism has rightly been called cooperative federalism which, in essence, is a system by which state and national governments supplement each other and jointly perform a variety of functions. The national government, in the new phase, with its greatly enlarged powers and functions, has only "supplemented rather than supplanted the performance of functions by the states". 28 The philosophy of the earlier federalism was, Grover Cleveland (President of the United States, 1884-1888, and 1892-1896) is reported to have said, that it is the duty of the people to support the government and not that of the government to support the people. Now the philosophy has greatly changed. "There is no longer any question about the national government's power to act, but only about the appropriate means and amounts and the proper timing of the actions to be taken". 29

As some recent studies show, the traditional picture of the nineteenth century American federalism is unreal, and federalism in the united states, in practice if not in theory, has traditionally been cooperative. 30 In fact no two governments operating on the same people in the same area could possibly be so inactive as to remain unaware of each other. The theory of dual federalism was not viable when applied to concrete problems in specific situations even in the early days of the American Republic, says Elazar and adds that federalism when interpreted to mean demarcation

\section{7} 28

Carnell, op. cit., footnote 3, p. 18.

W. S. Livingston, "Canada, Australia and the United States: Variations on a Theme", in V. Earle (Ed.), Federalism:

Infinite Variety in Theory and Practice, Itasca, Illinois: 29

F. E. Peacock Publishers Inc., 1968, p. 132 .

W. Anderson, Intergovernmental Relations in Review, 30

Minneapolis: University of Minnesota Press, 1960, p. 12 .

M. J. C. Vile, The Structure of American Federalism, London: oxford University Press, 1961; and D。 Jo Elazar, The American Partnership in the Nineteenth Century United States, Chicago: Chicago University Press, 1962. 
of responsibilities and functions has never worked in practice. While the amount of governmental activity on all planes in relation to total activity of the American society has increased, the governmental activity that existed in the nineteenth-century was shared in much the same manner as governmental activity in the twentieth-century. Indeed, the roots of cooperative federalism are entwined with the roots of federalism itself. 31

In view of the changed emphasis on state and federal government cooperation, Wheare's insistence that each of the two levels of government should be limited to its own sphere and within that sphere should be independent of the other, appears excessive. ${ }^{32}$ Birch, therefore, proposed to delete these clauses in Wheare's definition of federalism. As Birch puts it: 33

a federal system of government is one in which there is a division of powers between one general and several regional authorities, each of which, in its own sphere, is coordinate with the others, and each of which acts directly on the people through its own administrative agencies,

This avoids the confusion regarding federalism and quasifederalism. Approached thus, federalism will not appear "obsolete" or a relic of the horse and buggy days. 34 wherever the problem of securing political unity in face of regional diversity is to be reconciled in future, federalism would prove adaptable enough to continue to serve a fruitful purpose. 35

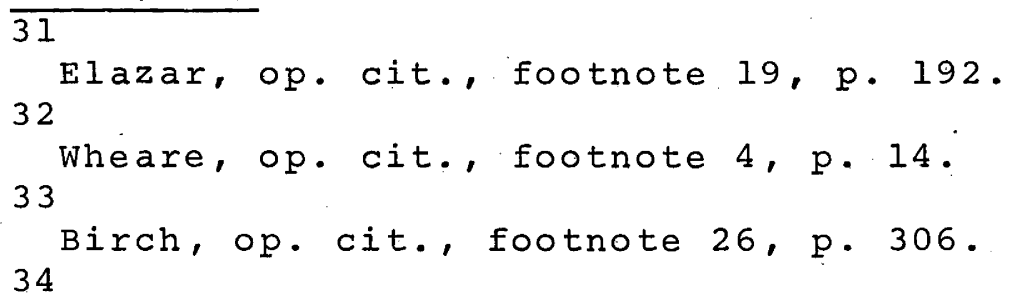

The earlier views on the new phase of modern federalism were expressed by Clark, op. cit., footnote 20 ; G. C. S. Benson, The New Centralization: A Study of Intergovernmental Relations in the United States, Toronto: Oxford University Press, 1941; and A. N. Halcombe, Our More Perfect Union, Cambridge, Mass.: Harvard University Press, 1950. 
Wheare has found the above modification of his definition by Birch as one of the "most constructive and fruitful", and most students of modern federalism would agree that on the whole this modified definition provides "the most serviceable definition of modern federalism". 36 In fact, "Under the heat and pressure generated by social and economic change in the twentieth-century, the distinct strata of the older federalism have begun to melt and flow into one another". 37

The following excerpts from some recent studies would further clarify the concept of modern federalism. Morton Grodzins writes : 38

The American form of government is often, but erroneously, symbolized by a three-layer cake. A far more correct. image is the rainbow or marble cake, characterized by an inseparable mingling of differently colored ingredients, the colors appearing in vertical and diagonal strands and unexpected whirls. As colors are mixed in a marble cake, so functions are mixed in the American federal system.

Thus the nineteenth-century primarily legalistic and dualistic phase of federalism is now over. Federalism is no longer: 39

- . like a great factory wherein two sets of machinery are at work, their evolving wheels apparently intermixed, their bands crossing one another, yet each doing its own work without touching or hampering the other.

As William Anderson says: 40

- . the entire network or structure of American [so also other federal] governmental units--national, state, and local--has become so close-meshed in recent decades that a strain or change at any point has repercussions in other parts of the fabric. One part cannot be understood if separated from others.

Now regional and central governments in a federation

36

Wheare, op. cit., footnote 4, p. 14. The second quotation 37

is from Carnell, op. cit., footnote 3, p. 20 .

J. A. Corry, "Constitutional Trends and Federalism" in

A. R. M. Lower and others, Evolving Canadian Federalism, 38

Durham, N. C.: Duke University Press, 1958, p. 122 .

M. Grodzins, "The Federal System" in The Goals for Americans, The Report of the President's Commission on National Goals, New York: Prentice-Hall Inc., 1960, pp. 265-282, Quotation 39 on p. 265 . 40

Bryce, op. cit., footnote 17, p. 432 .

Anderson, op. cit., footnote 23, p. 3 . 
should not only be coordinate but they should also be cooperative. Modern federalism is, therefore, basically a federalism of functions rather than of powers--a federalism more of politics than of laws. 41 It is worthwhile to remember, however, that the difference between the two versions of the federal concept is chiefly one of emphasis; while the "dual federalism" views the two sets of government primarily as equal rivals, the "cooperative federalism" views them as equal partners. (Although the central government tends to become more equal than the others.) What lies at the root of both views is the premise that in a federation (in principle) neither level of government is subordinate to the other. 42

Although the states-rights sentiment continues to exist in some form or the other in almost every federal state, it would appear that now the nature and degree of rivalry between the states and the central government that was supposed to exist in the dualistic phase of federalism has undergone a great change. Through a long process of adjustment the main areas of state and central functions are largely agreed (though disputes by no means are uncommon), and now the main rivalry is between the states themselves where the "centralized regulator [the federal government] plays the fundamental role as in any living organism". This is so because "different regions [or states in a federation] tend to regard themselves as rivals just as much as small nations are within a common market". 43 The states are also rivals in their recourse to central government finance as a help to their regional development.

This role of the federal government as the centralized regulator brings us to a possible new phase in the development of federalism. This new phase has been termed organic federalism and may, in view of the discredit that the word. "organic" has got in political geography, be called integrated federalism. This is, however, still a "recent

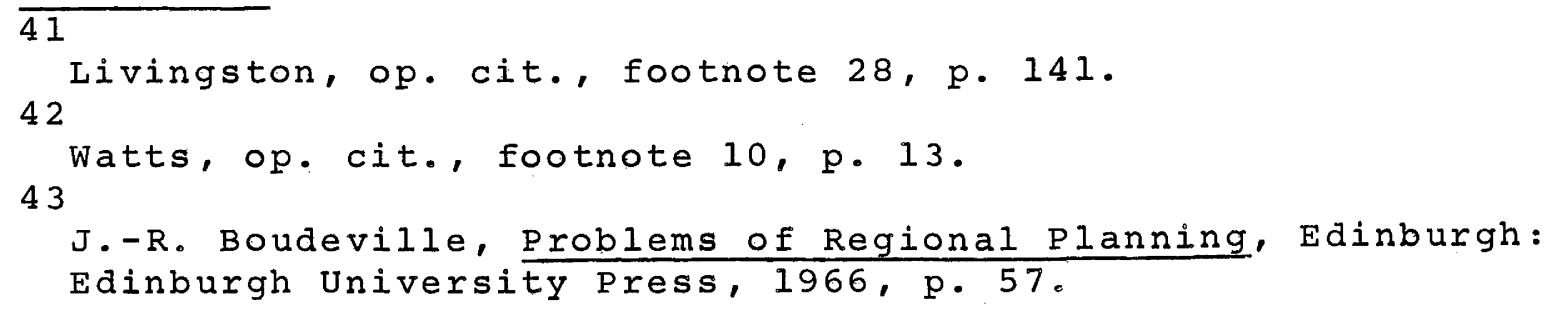


and ill-defined concept". Organic federalism is the federalism in which the centre has such extensive powers, and gives such a strong lead to the state governments in some of the most important areas of their individual as well as their cooperative activities, says G. Sawer, that the political taxonomist may hesitate to call it federal at all. Sawer regards Austria as the most obvious candidate for the organic category because here although the "Centre dominates every aspect of policy", "Region autonomy, within the limits of the Region competence is no sham, and the values inherent in such autonomy are protected both by the constitutional structure and by the pattern of politics". 44 Sawer thinks that among the older federations the united States is the only one where a surge towards organic federalism could take place in the near future similar to the surge towards cooperative federalism in the late $1930 \mathrm{~s}$.

Now the question arises: What is the line of demarcation between an "organic" federalism and an organic decentralized unitary state? The answer is not very difficult. We have seen that the essence of federalism is that each level of government should have a guaranteed autonomy. Thus "so long as the amending procedure, the operation of the judicial review and the pattern of politics or a combination of any two of them restrict the ability of the centre to abolish a Region structure. . the position of a Region is sufficiently secured", and so the polity in question should be called federal. 45

\section{THE GEOGRAPHY OF FEDERALISM}

We now proceed to discuss what may be called the "geography of federalism". Although most political geographers now regard federalism as "the most geographically expressive of all political systems", so far little attention has been given by geographers (or any one else) to explain the geographical basis of the federal polity. In fact,

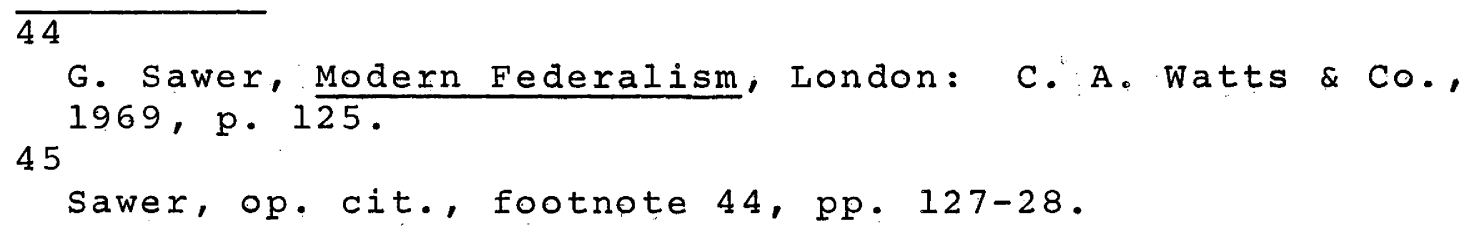


Livingston who revived the concept of federalism as a polity based essentially on regionally grouped diversities, and to whose writings much of the recent interest in federalism by geographers is due, himself described the concept as sociological rather than geographical. 46 The result is that students of federalism in general have wondered whether Livingston has, indeed, provided us with "a useful tool for analysis". 47

There are two reasons why federalism is considered as the most geographically expressive of all forms of government. First, it is based on the existence of regional differences or a sense of locality, "the belief that the area in which one lives is different from other areas, even though contiguity with them may provide many interests in common". 48 Federalism has been described as "the process by which a widening sense of social [and political] solidarity is reconciled with the attachment for local identity, through the provision of dual political organization." 49 secondly, because of a sort of "dual" political organization and the grant of substantial regional autonomy the regions in a federal state remain highly articulate. This means that spatial interactions in a federal state, unlike in other forms of government, are most clearly and easily recognized. Now because federalism starts with a tacit recognition of the immutability of regional personalities, and because spatial interactions in the political life of federal states are most clearly recognized, federalism becomes a suitable

\section{6}

Although the concept of federalism as a polity based on essentially regionally grouped diversities has in the recent literature been almost invariably attributed to Livingston, op. cit., footnote 8 , actually it is much older, going back at least to Hugo Preuss in 1889 (cf. S. Mogi, The Problem of Federalism: A Study in the History of Political Theory, London: George Allen \& 47 Unwin Ltd, 1931, Vol. 2, pp. 735-752).

A. H. Birch, "Approaches to the Study of Federalism", 48 Political Studies, Vol. 14, 1966, p. 17 .

J. D. B. Miller, Australian Government and Politics, 49

London: Duckworths, third edition, 1964, p. 138 .

D. G. Karve, Federations: A Study in Comparative Politics, London: Oxford University Press, 1932, p. 8. 
subject for geographical inquiry, for geography is properly described as a science of spatial interactions. 50

Since the basic geographical premise of federalism is the existence of regionally grouped diversities, no government has ever been called federal that has been organized on any other but regional basis. ". .. federalism becomes nothing if it is held to embrace diversities that are not territorially grouped". 51 It is true that regional differences, or strong sense of locality may sometimes exist even in states that are not organized on federal basis. But the main fact to be remembered is that only when the sociological unit of the region is powerful enough to demand and receive social accounts does federalism become inevitable. The regional differences that, for example, exist in France have so far not been strong enough in this respect. The country, therefore, remains organized on a unitary basis. Similarly once very diverse regions with very strong regional identities may, be found joined together under a single unitary state where even though regional identities continue to be present, through a long process of adjustment the cultural or sociological unit of the region has ceased to demand accounts. This happens when the regions concerned were brought together by imperial conquest and the region or the regions in question were not in a position to assert the recognition of their special position. It may here be relevant to remember that federalism is a democratic and voluntary union of essentially equal partners, and not a union dictated by some outside agency or an overbearing unit within the group.

A further reason why even very clearly identifiable regions in a unitary state are not able to demand social accounts in the manner that regions in a federal country are, is that while in a federal state regional identities are respected and protected by the constitution which guarantees the claim of each component unit of the state to perpetuate its identity, in a unitary system, to the contrary, these differences and diversities are large-

50

E. L. Ullman, "Human Geography and Area Research", Annals; Association of American Geographers, Vol. 43, 1953, p. 56. 51

Livingston, op. cit., footnote 18, p. 3. 
1y suppressed or ignored. It needs clarification, however, that federalism does not mean the perpetuation of sovereignties if there be any. The very basis of federal union is a clear recognition of the limitations of the individual units as self-sufficient and completely functional entities.

Federalism, it is true, unlike a unitary system, does not force unity out of diversity. It allows the two to coexist. But in the process of its progress towards maturity, contrary to what is sometimes stated, it does create unity through the greatly enlarged functions of the federal government, national planning and the like, as also because of the falling down of the once rigid barriers--physical, psychological, and economic etc.-between the component units of the state. Confusion of this nature will be avoided if we remember that like all things human,, federalism is also constantly in flux. It is not a static phenomenon but a dynamic process. Federalism is, in some senses, truly a halfway house to unity and integration though not a unitary state, for once a federation is established it tends to rigidify existing regional identities by giving them continued opportunities for articulation; and even though the central and the regional governments become largely cooperative, the regional governments continue to remain rivals. Indeed, as Boehm says, "The antithesis of federalism is not unitarism, but particularism and separatism" of an extreme kind. 52

Although we have shown that regionally grouped diversities are the fundamental fact of federalism, it is necessary to point out that the geographical distribution of diversities within a federation need not always rigidly follow the boundary lines of the component units of the state. As federalism often embraces a series of diversities on a number of issues, it can hardly be expected that the

52

M. H. Boehm, "Federalism" Encyclopaedia of the Social Sciences, Vol. 5, p. 170, New York: Macmillan:Co., 1931 . 
state boundary lines will mark off areas which coincide with all the different interests and opinions which may be held on all questions. The essential fact to remember is that the units in question should possess a total complex of diversities strong enough to distinguish them from their fellow members in the group and thereby make them desire and demand recognition of their individual identities. Regionalism of this kind, in which diversities spill over state boundaries, is considered a valid manifestation of the federal principle. Our study of the swiss and other federations shows that it is a beneficial manifestation also.

Diversities within a federal society or political community may turn on all sorts of questions--economic, religious, historical, linguistic and cultural. Any of these, or any combination of these may produce a group demand for self-expression. These major diversities in a nation's life may, however, have two different patterns of geographical distribution: they may either be territorially or regionally grouped, or they may be mixed and scattered like the strands of different colours in a marble cake. If the major identifying diversities within a state are arranged territorially, then the society or the political community is potentially federal. But if the distribution of diversities follows a marble cake pattern, the society is plural and nonfederal. Only when a society contains territorial groups so markedly different from one another that they require some instrumentality to protect and express their peculiar qualities, does the need for federalism genuinely arise. Doubtless, "One such circumstance. . does not make the society or constitution federal. But two or six or twenty may produce a result that may properly be so called". 53

A word of explanation is needed lest the above statement regarding the geographical pattern of diversities creates

\footnotetext{
53

Livingston, op. cit., footnote 18, pp. 2-3.
} 
confusion. Here we are talking of the distribution of diversities and not of functions that the quotation from Morton Grodzin in the first part of this chapter refers to. While the distribution of functions in modern federations may sometimes resemble the marble cake pattern, the major diversities on which a federation is based must essentially be territorially arranged otherwise the society cannot be called federal. This, it should be noted, does not contradict the pattern of diversities exemplified by switzerland where each of the two major diversities in the nation's life is territorially arranged though one cuts across the other and thereby creates a unifying factor in that federation.

For long federalism remained a subject matter for purely legal discussion. But legal answers are of value only in solution to purely legal problems. Federalism is concerned with many problems other than legal ones. Hence, a purely legal approach to federalism has not sufficed. Indeed,

The essential nature of federalism is to be sought for, not in the shadings of legal or constitutional terminology, but in forces--economic, social, political and cultural--that have made the outward form of federalism necessary. 54

Like most other institutions of man federalism is an attempt to solve the problem of human organization. The particular problem of federalism is to find solution to governmental questions involved in a complex interaction of spatial differences and similarities. Federalism is, therefore, essentially a product of geography. In this sense the essence of federalism lies not in the constitutional structure but in the geography of the society itself.

This geographical view of the nature of federalism, I believe, does away with the confusion that over-emphasis on the sociological view of federalism often creates. Sawer objects to Livingston's statement that federalism is "a

54

Livingston, op. cit., footnote $18, \mathrm{p} .1$. 
function not of constitutions but of societies" for such statements, he says: 55

can be misleading, because they suggest that there is a sort of general social attitude, or type of social structure, which corresponds uniquely with the constitutional form known as federalism... I do not believe that these attitudes or structures are specific to federalism. . . the favourable social attitude is an attitude towards government, administration and law in general, not towards federalism as such.

But unlike the social structures and attitudes the geography of the society (as explained above) is to a very large extent unique and specific to federalism, though this geography of the society in no absolute sense determines the federal or nonfederal form of government that ultimately evolves in any state. Sometimes federations that are created under or enforced over largely non-federal situations may survive as the post-War II federalism in. West Germany does. But such federations survive largely because during the long period that the federation remains enforced the society within the country, in the process of adjustment to the new political situation that it cannot undo, develops regional identities and vested interests that in effect change the effective political geography of the state and make it, inturn, suitable to federalism. But federalism created under a nonfederal situation, unless enforced by external forces, can hardly develop into anything but the federalized unitary state of the type that Austria represents which, sawer says, the political taxonomist may hesitate to call federal at all. On the other hand, if a unitary state structure is imposed over a region that is essentially federal in its politico-geographic structure, the government can be run only by military dictatorship as in Burma or pakistan, or by one-party rule (i.e., group dictatorship) as in the Soviet Union or Yugoslavia.

As a particularly dynamic and complex phenomenon federalism is, it would appear from the foregoing discussion: 56

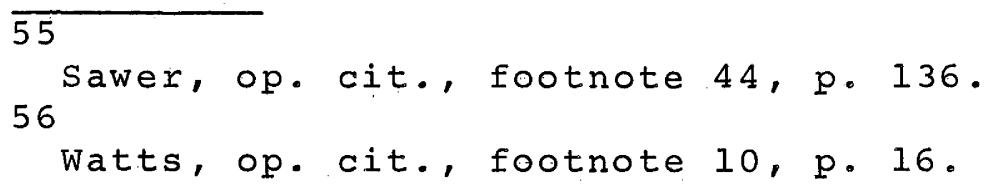


of interest not only to the constitutional lawyer concerned with the nature of legal frameworks, and the students of political institutions occupied with the operation of the particular types of political institutions; but also to the sociologist... the economist.. the geographer.. the historian - and the political theorist.

Although of special relevance to politico-geographic study federalism may, in fact, be found of interest to the social geographer interested in the phenomena of social integration and diversity, the economic geographer engaged in the study of the role of political institutions in fostering or. hindering economic growth, and the historical geographer interested in the evaluation of spatial interactions in the genesis and evolution of some of the greater "new" nations of today. 57

\section{GEOGRAPHERS AND FEDERALISM}

We now proceed to review the work done by geographers on federalism. Although most geographers now seem to agree that federalism is the most geographically expressive of all governmental systems, we believe that contrary to what Prescott thinks published work by geographers does not show a keen awareness of this fact. 58 Besides Prescott's own article on Nigeria (to a certain extent), only the article by K. W. Robinson among the works that Prescott refers, shows this awareness. ${ }^{59}$ prescott does not refer to spate's

\section{7}

A framework for the study of "Influences of Governmental Systems on the Location of Economic Activities" is set out in my paper of the same title in G. JoR. Linge and P. J. Rimmer (Eds.), Government Influence and the Location of Economic Activities, Canberra: Department of Human 58 Geography, Australian National University, 1971. (forthcoming).

J. R. V. Prescott, The Geography of State Policies, London: Hutchinson University Library, 1968, p. 120. 59

J. R. V. Prescott, "The Geographical Basis of Nigerian Federation", Nigerian Geographical Journal, Vol. 2 , 1958, pp. $1-13$. 
article of 1944, nor does he mention Edmund Dale's article on the west Indies which, although it shows little of this awareness is, nevertheless, a not very successful attempt to study an important aspect of a federation that failed. 60 Fisher's book and articles on South-East Asia present, no doubt, an incisive treatment of the political geography of the area they deal with, and because there are or have been some federations in that region, he does make some important observations on some of the federal problems of these states. ${ }^{61}$ But these can hardly be said to show this awareness.

Whittlesey drew attention to the need for studying the impress of effective authority on the landscape in 1935.62 Soon after this Ullman presented his study of the effect of an interstate boundary in a federal state on its surrounding landscape. 63 Among other important works of this nature are those by Rose and Logan. 64 . Two new attempts on certain other aspects of federalism may also be noted: one, the

60

E. H. Dale, "The State-idea: Missing Prop in the West Indies Federation", Scottish Geographical Magazine, Vol. 61 $78,1962, \mathrm{pp} .166-176$.

C. A. Fisher, South-East Asia: A Social, Economic and Political Geography, London: Methuen \& Co., 1964 , and several related articles between 1956 and 1968 (cited 62 in the bibliography).

D. Whittlesey, "The Impress of Effective Authority on the Landscape", Annals, Association of American Geographers, Vol. 25, 1935, pp. 85-97. 63

E. L. Ullman, "The Eastern Rhode Island-Massachusetts Boundary Zone", Geographical Review, Vol. 29, 1939, pp. $291-302$. 64

A. J. Rose, "The Border Between Queensland and New South Wales: A Study of Political Geography in a Federal union," Australian Geographer, Vol. 6, 1955, pp. 3-18; A. J. Rose, "Some Boundaries and Building Materials in Southeastern Australia" in M. McCaskill (Ed.), Land and Livelihood, Geographical Essays in Honour of George Jobberns, Christchurch: New Zealand Geographical Society, 1962, pp. 255-276; and W. S. Logan, "The Changing Landscape Significance of the Victoria-South Australia Boundary", Annals, Association of American Geographers, Vol. 58, 1968, pp. 128-154. 
study of federal grants-in-aid in the united states by Brunn and Hoffman; and the other, a case study of the geography of political affiliation in a federal-state system by solomon. 65

Van Valkenburg was the first among textbook writers on political geography to recognize forms of government as relevant to the study of political geography. 66 since then other textbook writers have also included a discussion of the forms of government in their books on political geography and in their treatment of individual states have discussed the political geography of federal states as well but seldom the geography of federalism in those states. Pounds in his book on political geography considers the politico-administrative systems of states in a greater detail than others have done. 67 For this reason he has given a better coverage to federalism. Pounds quotes Robinson and says that geographers should study federalism because it is the most geographically expressive of all governmental systems. He then proceeds to enumerate the federal states of the world and makes some oft-repeated observations on the communist and Latin American federations rather than giving a geographical approach to the problem or attempting a discussion of the federal concept. 68

Credit should perhaps be given to Jackson for including for the first time two readings on federalism (from political scientists of course) in his reader on political geography. 69

65

S. D. Brunn and.W. L. Hoffman, "The Geography of Federal Grants-in-aid to states," Economic Geography, Vol. 45, 1969, pp. 226-238; and R. J. Solomon, "The Geography of political Affiliation in a Federal-state system: Tasmania 1913-1966," Australian Geographical studies, Vol. 7, 1969, pp. 28-40. 66

S. van Valkenburg, Elements of Political Geography, London:

Isacc Pitman \& Sons, first printing 1939, eleventh printing 1949, pp. 302-310.

67

N. J. G. Pounds, Political Geography, New York: McGraw 68 Hill Book Co., $19 \overline{63 .}$

Pounds does, however, provide a constructive approach to the study of "politically organized areas" which may with profit be adapted to the study of individual federations; pounds, op. cit., footnote 67, p. 193. 69

W. A. D. Jackson (Ed.), Politics and Geographic Relationships, Englewood Cliffs, N. J. : Prentice Hall, 1964. 
It may be taken as a proof of his awareness of the special relevance of federalism to politico-geographic study that while he has included two readings on federalism, no reference is made to the unitary form of government. The systematic political Geography edited by de Blij that followed Jackson's readings closely in time, besides including Robinson's paper on the "sixty years of Federation in Australia", contains an introduction on federalism by de Blij himself. 70 This introduction speaks of the justification for politicogeographic study of federalism by quoting from Robinson. It also presents a very arbitrary classification of federations.

In my opinion Robinson is the only geographer writing on federalism recently who has shown an awareness of the modern trends in federalism. He studied the centre-state relations in a federal state in a historical perspective and therefore drew upon the works of Livingston and Birch. While Dale was satisfied with Wheare's definition of federalism, and prescott in 1962 was still talking of "quasifederalism", none has shown the awareness that federalism is a dynamic process and not a static phenomenon. 71 while participating in a discussion on a paper by wheare in 1952 spate urged the need to "recognize that there are in fact different types of federation in existence today". ${ }^{2}$ He said nothing further perhaps because the concept of cooperative federalism was then only taking root. To say this is, however, not to discredit these geographers. This awareness and a deeper understanding of federalism could come only with a concentrated study of the problem of federalism which none of these scholars had set out to do. It seems to me that Hartshorne, although he never set 70

H. J. de Blij (Ed.), Systematic Political Geography, New York: John Wiley, 1967. 71

Dale, op. cit., footnote 59, p. 173, says: "Federalism is really a division of power between central and regional governments, each independent. within its sphere". See also J. R. V. Prescott, "Geographical Basis of Kenya's Political problems," Australian Outlook, Vol. 16, 1962, 72 pp. 270-82.

Discussion included in G. Sawer (Ed.), Federalism: An Australian Jubilee Study, Melbourne: F. W. Cheshire, 1952, pp. 131-132. 
out to study federalism as such, shows, nevertheless, an awareness of the geographical basis of federalism as also its cooperative nature. The very fact that he recommends a functional approach to the study of federal states as well, shows that unlike others he did not think that the state and the central governments in a federation are independent of each other. ${ }^{73}$ Hartshorne writes that if the regional differences in the intensity of state-idea: ${ }^{74}$

- . are relatively minor, as in most of france... , the regions may accept a unitary government . . If the differences are great, the attempt to impose such a uniform system may provoke opposition endangering the national unity. . .

From this review of the work done by geographers it would appear that spate's article of 1944, which the writer himself stated was only a "very cursory and preliminary view of a subject which merits closer study", is the only attempt at a general approach to the problem of federalism and its geographical relationships. But for reasons already noted this "cursory" view has not led to conclusions that axe valid today.

Although spate's observation that mast federal states are large in area and small in population is still largely true, this, however, does not validate any causal relationship between size and the federal form of government. There is, similarly, no causal relationship between federalism and population density. Not only switzerland, which then appeared to the author as an atypical federation, but new federations like India have also a high density of population. spate's next point, that modern federalism is essentially a form of government appropriate to new lands with vast area and thin population, is valid in the sense that every new political and administrative experiment has a better chance of success in new and relatively empty lands where people do not have a long history to remember, and where strong and conflicting cultural identities in the component

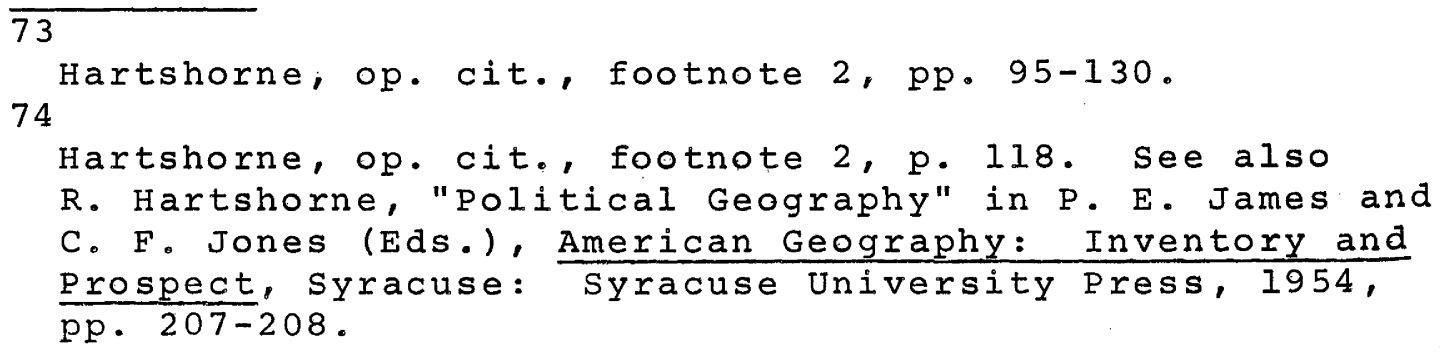


regions have not developed. But for all this, there is no cause and effect relationship between vast spaces and thin population on the one hand, and federalism on the other.

As the preceding discussion shows, the task that spate pointed out to geographers a quarter of a century ago, i. e., "to examine the geographical layout of the existing federal states in an endeavour to establish those conditions which are common to most of them and which. . . favour the establishment and maintenance of this type of political organization", remains largely unaccomplished and practically the whole field awaits detailed investigation.

Relationship between Area, Population and the Federal form of Government

It appears necessary to take stock of the prevailing ideas among geographers in particular and other students of federalism in general, on the relationship of the size of states and the density of their population to the federal form of government, in order to place spate's observations in the right perspective. Robinson thought that: ${ }^{75}$

Countries of large areas and small population, or even rather large population concentrated in widely scattered areas, are obviously suitable for this [i. e., federal] form of government.

De Blij styles what he calls "our rule" which reads: ${ }^{76}$

Theoretically, the federal framework is essentially suitable in a large or very large size category... . when we view a list of federal states of the world, we should expect to find that they are large, comparatively sparsely populated, multicore, and possess several large cities.

Turning to political scientists, we find Parker writing in 1949 that: 77

All modern federations were, at their inception, political unions covering unprecedentedly huge areas with scattered centres of population and comparatively underdeveloped communications . . and federalism seemed the necessary form of government primarily for this reason.

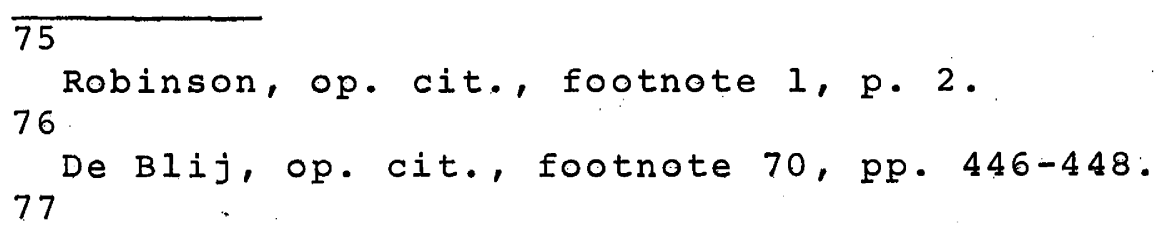

R. S. Parker, "Australian Federation: The Influence of Economic Interests in Political Pressures", Historical Studies (Australian and New Zealand), Vol. 4, 1949, p. 1 . 
It needs emphasis that here Parker is speaking of "all modern federations"--as of 1949--and not of Australia alone. Carnell wrote that many political scientists think that "Federalism may well have been suited to a particular phase of unification of large continental states with small populations and poor communications". 78 And as sawer says "Even today the size of a country and the efficiency of its communications are regarded as factors contributing to a choice between unification and federalism". 79

What, in fact, seems to have been missed is that the important fact about federalism is not the type or size of population and territories but the fact that federalism is based on regional loyalties or a sense of locality. In some, particularly in "new" lands with vast open spaces and having a few cores of population widely set apart, this sense of locality may well be born only or primarily because of physical distance playing the role of a great separator. But in older and densely populated countries this sense of locality or regional identity may be (and often is) based on historical traditions, linguistic, religious, and other ethnic diversities or economic disparities and differences that are regionally grouped. The fallacy in establishing a causal relationship between the sheer area of states and the federal form of their government will be revealed if we remember that the Thirteen Colonies in 1787 or the four provinces of British North America in 1867 constituted only very small portions of the areas now covered by these federations.

To give the doubters their due, however, it should be remembered that "over centralization in [a large country] - Leads to anaemia at the extremities and apoplexy at the centre". 80 Hence large size in itself does, to a certain

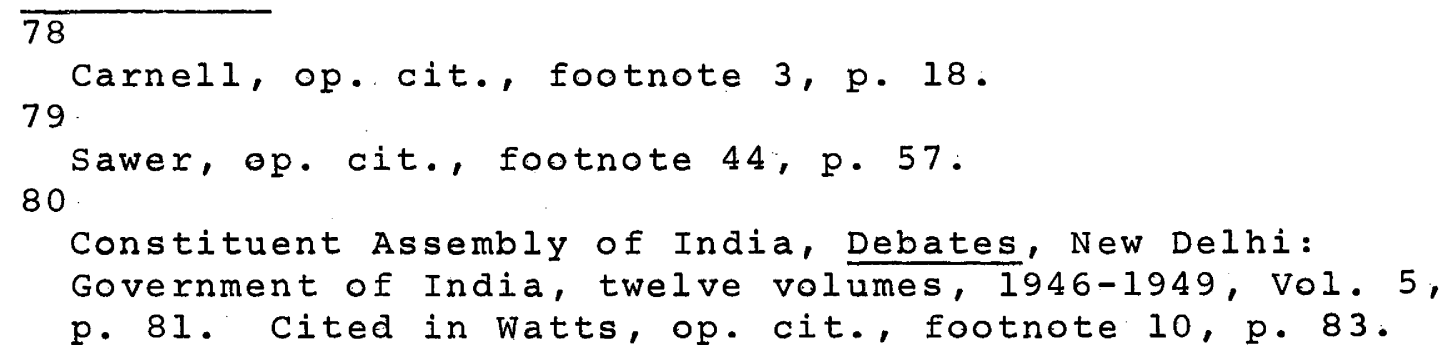


degree, favour the rise of federalism even though size and federalism do not have a cause and effect relationship.

This whole discussion on the nature and geography of federalism would perhaps remain incomplete without a brief reference to the so-called. (new but increasingly becoming popular) concept of symmetry and asymmetry of federalism initiated by Tarlton. $\overline{81}$ It should be clear from the foregoing discussion that one of the fundamental premises of federalism is that the regionally-grouped communities that are involved in a federation should possess enough common interests as to desire union, but they ought simultaneously to possess some important elements in their regional makeup that separate their interests from one another in some important spheres, and for that reason make them desire to retain their regional autonomy in order to preserve their special regional interests and identities. If the groups involved are homogeneous and similar in all important respects, the resultant state organization should be unitary; if the units involved are almost completely discordant, the best that they can do is to enter some limited purpose confederal alliance. These two extreme situations cannot therefore be called "ideal symmetrical" and "ideal asymmetrical" models of federalism. But this is what, in essence, Tarlton seems to be doing. The prevailing confusion on the real nature of federalism would be clear from the quick popularity that this concept seems to be gaining--both among political scientists as well as political geographers. 82

\section{1}

Charles D. Tarlton, "Symmetry and Asymmetry as Elements of Federalism: A, Theoretical speculation", Journal of Politics, Vol. 27, 1965, pp. 861-874.

82

The concept has been further reiterated by Tarlton in his "Federalism, Political Energy, and Entropy: Implications of an Analogy", Western Political Quarterly, Vol. 20, 1967, pp. 866-874 (especially pp. 866-867). The increasing popularity of the concept may be judged from its inclusion in some readings in political science as well as political geography, e. g., J.P. Meekison (Ed.), Canadian Federalism: Myth or Reality, Toronto: Methuen, 1968 ; and R. E. Kasperson and J. V. Minghi (Eds.), The structure of Political Geography, Chicago: Aldine Publishing Co., 1969. 
We now address ourselves to the question: how should the study of spatial interactions in the rise and survival of federal states be approached? The traditional method would be the environmentalistic approach pioneered by philosophers and students of politics like Bodin, Montesquieu and others who tried to explain every activity of man (including his choice of the form of government) as essentially a response to the physical forces of the environment. Under this approach one would be required to study the physical geographical environment of each of the existing federal states and through an elaborate process of elimination try to establish the relationship between such visible geographical features as area, shape, relief, latitudinal location, climate etc. and the choice of the federal form of government. A sophisticated variant of this approach is to be found in what has been stated as "to examine the geographical layout of existing federal states" with a view to isolating those conditions which appear to favour the establishment and maintenance of this type of political organization. 84 Though there may be little to say against this pioneering attempt in the field, surprisingly enough it was being pursued even in the late sixties. De Blij's introduction on federalism is the case in point. It needs little elaboration to suggest that such an approach is bound to be superficial and would lead only to faulty conclusions. These external visible geographical features are only the leaves of the federal tree. What we really need to look for are the roots which alone would lead us to valid conclusions.

83

This section draws upon my article "Toward a Generic Approach in political Geography", Tijdshrift voor. 84 Economische en Sociale Geografie, Vol.61, 1970, pp. 242-245, spate, op. cit., footnote, 2, p. 24 . 
A more sophisticated variant of this "layout" approach was made in 1953 by a historian Mackirdy. ${ }^{85}$ Being based on a sound historical knowledge this study was saved of many of the environmentalistic pitfalls to which the lack of a proper historical perspective might lead. Mackirdy presents a comparative study of "The Geogiraphy and Federalism in Australia and Canada". The author's method of approach is clear from the opening lines of his paper: 86

Take two large areas, the third and the sixth largest in the world's political entities... Sprinkle them unevenly with relatively small populations. Provide them with types of federal political organisations. Call them "Canada" and "Australia". The result should provide some interesting examples of the influence of geography on politics.

This study, however, takes a somewhat broader view of the "geographical layout", and considers factors such as urbanization and regional specialization of economic activities. Then, as the study limits itself to the two individual federations without making any attempt at broad generalizations, it has been saved of some obvious errors and is, on the whole, fruitful. The limitations of the approach are, nonetheless, clear. What is going to be achieved if we compare switzerland and the united states, or India and Australia?

our search for a solution in the existing methods of approach developed in political geography so far, is not very helpful. Hartshorne's "Functional Approach in Political Geography" and Jones' "Unified Field Theory of Political Geography" have by now attained the status of almost classic statements in politico-geographical methodology, and the general consensus among political geographers seems to be that these two approaches in themselves cover all the problems

\footnotetext{
85

K. A. Mackirdy, "Geography and Federalism in Australia and 86

Canada", Australian Geographer, Vol. 6, 1953, pp. 38-47.

Mackirdy, op. cit., footnote 85, p. 38 .
} 
in methodology in politico-geographic studies. 87 But a closer look would reveal that though very competent and comprehensive these statements are, they both stand of value only in respect of specific problems and individual cases. The functional approach, as its author rightly. claims, offers us a systematic method of establishing "the basic factors and relationships involved in the primary problem of political geography--the analysis of the degree to which the diverse regions of the state constitute a unity". 88 But the functional approach would stand of value only in the study of specific politicogeographic entities that function as units--specially a state. It seems to offer little help in generic studies. Similarly Jones' "Unified Field Theory" approach with its emphasis on "Idea-Decision-Movement-Field-Political Area" chain completes, as its author claims, "the tie between morphology and functions. . . between 'grand-ideas' and the earth's surface". ${ }^{89}$ But it is also of value only in the study of specific politico-geographic problems--both national and international--such as the birth of new states like Israel or Pakistan, or of boundaries, and capitals etc. It seems of little help in the study of generic problems. The difficulty with these approaches may well be that they are products of a phase in geography when our science was over-obsessed with the study of the specific and the unique, a phase in. which it was generally believed that as political geographers (more than other of our colleagues) "we are handicapped in developing scientific principles, and are restricted to the consideration of the unique cases". 90 It was then thought that the "idea and purpose of the generic

\section{7}

Hartshorne, op. cit., footnote 2 , and S. B. Jones, "A Unified Field Theory of Political Geography", Annals, Association 88 of American Geographers, Vol. 44, 1954, pp. 111-123. 89

Hartshorne, op. cit., footnote 2, p. 117 . 90

Jones, op. cit., footnote 87, p. 122 .

Hartshorne, op. cit., footnote 2, p. 102 . 
state--the purposes that is that are common to all states" were the sole concern of the political scientists, and that this concern.ignores "The very thing that is of direct concern to the geographer--namely the idea that is distinct for the particular state in contrast with that of other states...".91 (Italics added.)

Looking for a solution we find that a historical approach may be more useful for this study, for, as Whittlesey said, "Any specific arrangement of earth-space becomes fully intelligible only when it i.s linked with preceding combinations of nature and culture in the same area". 92 . We may examine the historical evolution of the units involved in a federation, reconstruct their economic; political and social geography of the period immediately preceding and since the federation and thus try to isolate the spatial relations that were in each case largely responsible for the rise of that particular psychology among the political communities concerned of desiring union, without desiring complete unity, as also the factors that finally overwhelmed their centrifugal tendencies and helped to bring the different units together into a single body politic. This genetic approach, as it may be called in absence of a fasionable label, would give us, we believe, a truer picture of the differences and similarities involved in the process of the rise and maintenance of federal states in the world. Any generalizations that this study may evince would, we trust, be free from the superficialities that the environmentalistic or the "geographical layout" approach often leads to.

It is necessary to point out that although the functional approach seems to be of little help in a generic study of federalism per se, nevertheless, with the changed emphasis of modern federalism, the approach may prove of great value

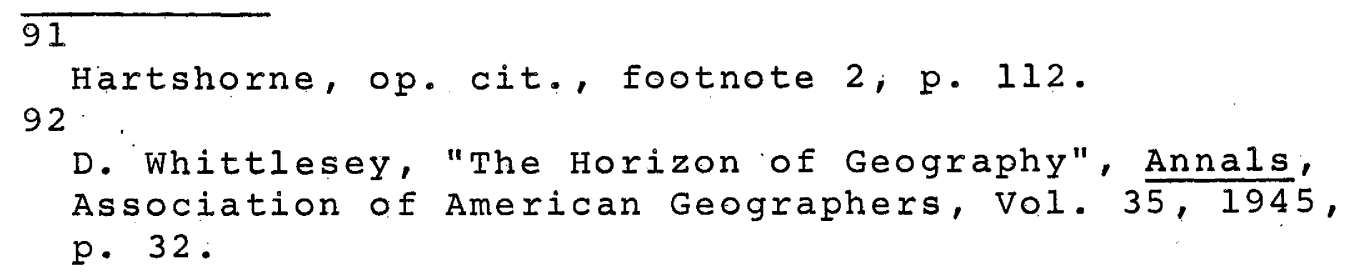


in the study of individual federations. And because in our study of federalism we are also interested in establishing the factors that help to maintain this type of political system, the use of the functional approach in a limited sense would be inevitable.

In fact, the marriage of our "genetic" approach to Hartshorne's "functional" one would give rise to what can essentially be called "structural-functional analysis", which was first formulated by Woodger in biology, and was later adapted by Merton to the study of the social sciences. 93 The approach has since been developed and refined by many scholars including $M$. J. Levy Jr., who has recently presented an excellent synthesis. 94 The term "function" is defined as "any condition, any state of affairs, resultant from the operation (including in the term 'operation' mere persistence) of a unit of the type under consideration in terms of a structure(s)". The term. "structure" is defined as "a pattern, i. e., an observable uniformity in terms of which action (or operation) takes place". 95

In a federal political system the "structure" consists of the underlying geographical pattern of regional diversities, and the constitutional instrumentalities created to preserve them. Here the "function" will consist of the process or the dynamics of federalism, $i$. e., the federal-state relations and the overall progress of the system towards maturity. As federalism is born out of the peculiar psychology among the political units of desiring union but not complete unity, in a genetic study of federalism our primary concern

93

J. H. Woodger, Biological Principles: A Critical study, London: Routledge, first published 1924, reissued 1948; R. K. Merton, Social Theory and Social structure: Towarda Codification of Theory and Research, Glencole, Ill. : Free Press, first published 1949, rev. ed. 1957. 94

M. J. Levy, Jr., "Structural Functional Analysis" in International Encyclopaedia of the Social Sciences, New York: 95 Macmillan Co. and The Free Press, 1968, Vol. 6, pp. 21-29. Levy, op. cit., footnote 94, p. 22 . 
in reviewing each individual federation would be, first, to outline the salient historical facts about the political communities involved in the federation and, then, to delineate the politico-geographical factors that were largely responsible for creating among those units strong regional identities and a desire for separate existence on the one hand, and the factors that in the end overwhelmed their feelings for separatism and compelled them to unite into a federal state, on the other. One may therefrom proceed to infer the general geographical relationships (or spatial interactions) that helped the rise of federalism in each case and thus arrive at certain hypotheses in this respect. While reviewing each federal state for this study one would keep in perspective the working and dynamics of the federations since their inauguration, and try to derive therefrom the patterns of spatial interactions in the success or otherwise of each federal experiment. The sum total of these conclusions on the rise and survival of federal states, past and present, would give us, we believe; certain fruitful hypotheses on the role of spatial relations in the origin and stability of federal states.

Such a study would inevitably be concerned with stateideas and the raison d'être of states. ${ }^{96}$ General historical works have, therefore, provided the raw materials for this research. It is inevitably so because: 97

The state-idea is a complex of traditions, experience,

96

The concept of state-idea (and raison d'être of states)

was first introduced in political geography by F. Ratzel.

But the recent revival of interest in this concept is

due mainly to $R$. Hartshorne especially in Hartshorne, op. cit., footnote 2, and "Political Geography" in P. E. James and C. F. Jones (Eds.), American Geography: Inventory and 97 Prospect, op. cit., footnote.74, pp.167-225.

P. E. James, "Some Fundamental Elements in the Analysis of the Viability of States" in C. A. Fisher (Ed.), Essays in Political Geography, London: Methuen \& Co., 1968, p. 33 . 
and objectives. It is made up of written history, folklore, stories of national heroes, religious beliefs, and the language and the art forms in which these things are communicated. . And it is the characteristic economic social and political institutions. The state is created to defend and develop the state idea.

As the state-idea is "not always easy to identify", the task may often be difficult. But since some excellent historical studies of the relevant periods in the history of most of these states exist, it has seemed possible to do so for the limited purposes of this study. Use is also made of relevant works of political scientists, although most of what has interested the political scientists and students of constitutions does not seem of much interest to the geographer.

\section{SCOPE OF THE THESIS}

It is generally agreed that modern federalism was born with the United States Constitution of 1787. As this study is concerned with modern federalism alone, we shall here be discussing only those federations that followed the United states in time. Furthermore, as should have been clear from the foregoing paragraphs, in this study by federalism we mean the federal form of governmental organization as applied to internal political organization of sovereign nation states. We shall not, therefore, concern ourselves with international political organizations like the European Economic Community and others that are also sometimes referred to as federal. 98

98

Besides, technically even the E. E. C., the most sophisticated of international organizations, cannot be considered a federation in the sense that this term is understood in the modern scholarship. As sawer says: "The formal weakness of the system considered as a federation, is that its supreme legislative and policy organ, the council, directly represents the member governments and on many critical questions has to act unanimously . .. The predominant attitude of the governments and the people still places ultimate authority in the national legislatures, not in the community institutions". Sawer, op. cit., footnote 44, p. 61. See G. Sawer, The Constitutional system of the European Common Market, Canberra: Royal Institute of Public Administration, A. C.T, Group, 1963, pp. 41, especially pages 12-14. 
Even among the sovereign nation states that describe themselves as "federal", many do not satisfy the minimum condition set for federalism in the beginning of this chapter. The basic minimum condition for federalism in government is, as sawer has so clearly demonstrated, that the constituent state governments have guaranteed regional autonomy, i. e., they should be safe from peace-time encroachments from the central government concerned. For regional autonomy to be effective it would seem necessary that freedom of speech and expression are guaranteed and the country in question possesses a multi-party functioning democracy. Only when free opposition and multi-party politics are assured can the constituent regional governments within the state maintain their individuality and ineffaceable regional identity, and thus alone can a proper kind of federal articulation (of regional diversity within overall unity) emerge. On the contrary, if a state is under one-party rule, "democracy" becomes a farce. It becomes, in fact, a dictatorship not of an individual but of a group, i. e., a party. Under a dictatorship of whatever sort, a genuine opportunity for free play of the diverse regional interests that comprise the state can hardly exist. One-party rule instead of fostering unity in diversity, in practice imposes an over-all uniformity allowing regional diversity to exist only in so far as it does not clash with "national interests", and what these national interests are only the top echelons of the party. decide. It would therefore seem that multi-party democracy is the sine qua non of a functioning federalism, and as Elazar says: "The federal structures occasionally adopted by non-democratic systems must generally be considered as 'window dressing'. . . ". 99

99

D. J. Elazar, "Federalism", International Encyclopaedia of the Social Sciences, 1968 , Vol. 5, p. 361 . 
This proposition is nothing new. Most serious scholars of modern federalism, from Freeman to the present, have regarded functioning democracy as a necessary adjunct to functioning federalism. Greaves regards federalism as an "essentially democratic phenomenon... [which] is incompatible with dictatorial forms of government". 100 Maddox wrote that "There can be no such thing as a federation which includes totalitarian regions denying free political action". 101 In fact, as wheare says, it may be possible in theory to conceive of a federal government in which the general and the regional governments are dictatorships and yet each remains strictly within its own sphere; but it is difficult to imagine such a government coming into existence in the realm of practical politics or continuing to exist for any length of time. Dictatorship with its autocratic government and its denial of free elections, Wheare rightly notes, is incompatible with the working of federalism. In summary: 102

Federalism demands forms of government which have the characteristics usually associated with democracy or free government. There is a wide variety in forms which such government may take, but the main essentials are free election and a party [i.e., multi-party] system, with its guarantee of a responsible opposition.

For this reason, Communist federations such as the soviet Union, Yugoslavia, and Czechoslovakia cannot be treated as examples of functioning federalism. They are, therefore, not included in this study. Scholars have a genuine "suspicion that the federal form of their written constitutions is not merely a 'form' but a 'sham', the 'real' government being vested in the highly centralized Communist Party hierarchy". 103

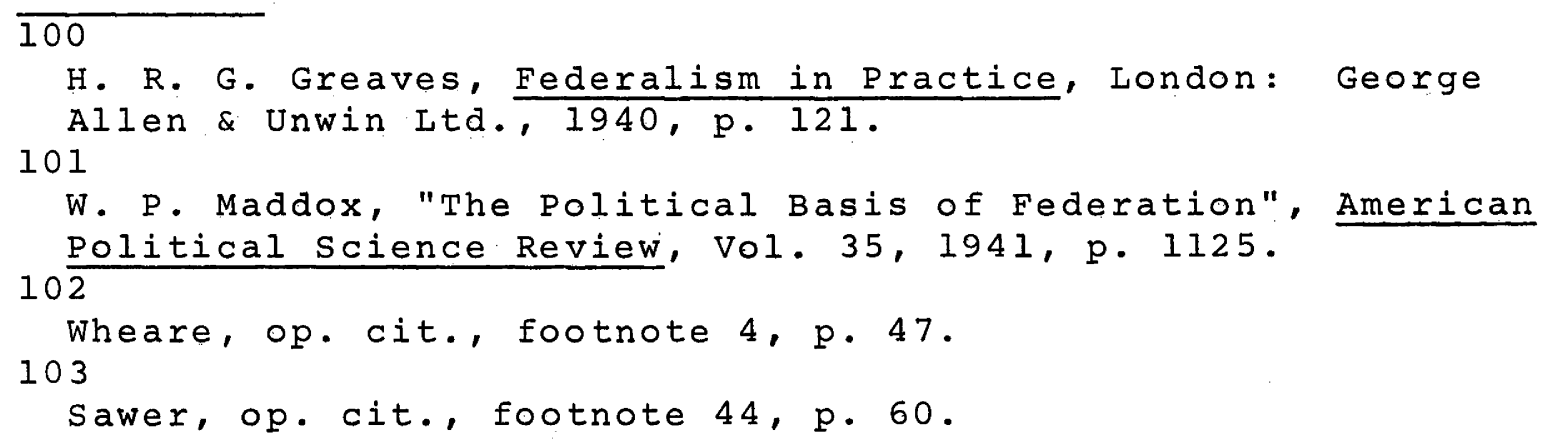


Furthermore, in the Communist federations the role of the Communist party is not only a fact; it is also explicitly stated in their constitutions. As sawer says, in the soviet Union there is no suggestion of judicial review or other check on the validity of central laws, and there would need be a remarkable dilution of the authority of the communist Party and increase in the independent authority of the central and the regional legislatures before this system could be regarded as within the federal spectrum. Yugoslavia's position under the Constitution of 1963 is considered more arguable, partly because in that country the character of the Communist party has in fact changed and may continue to change, and the possibility of the official legislative organs becoming autonomous centres of authority is greater. Although there are no separate effective legislatures for the six constituent regions of the state, the constitution at its face value provides a substantial region-based check on political actions of the centre that may be prejudicial to regional autonomy. Institutionally, therefore, Yugoslavia may seem to possess, what sawer calls "the makings of a federal arrangement". But as it exists today, it is not federal.

However, both Yugoslavia and the Soviet Union, by virtue of their regionally-grouped diversities, possess potentially federal geographical bases. The main difficulty in the way of the rise of a functioning federalism in either of these countries is their one-party "democracy". Thus:

The formal structure in both these countries might become real not only through the loosening up of the social structure generally, and the emergence of some legal or at least tolerated [?] opposition to the Communist party, but also through the federalization of the Communist Party itself within the relevant countries. 104

When it so happens these countries might well form proper subjects for the study of federalism, but as they exist today,

104

Sawer, op. cit., footnote 44, p. 60 . 
they do not qualify for inclusion in this study.

While a general survey of all the functioning federations of today is attempted, in the study of "Failed Federations" a selection is made with a view, first, to select only those examples where the generally federal nature of the polity (at the time of its origin) is not in question, and secondly, those examples have been excluded where a federal union was talked of but never actually inaugurated (as in French West Africa or British East Africa), as also the examples like Chile and New Zealand where, it is believed, the federal experiment should be regarded as an initial wrong step which was soon rectified and a unitary government, more in keeping with the needs of the society, was firmly established.

The criterion applied in determining the functioning examples of federalism is the existence of guaranteed regional autonomy, as explained in first part of this chapter. That is, we believe that "so long as the amending procedure, the operation of the judicial review and the pattern of politics or a combination of any two of them restrict the ability of the Centre to abolish a Region structure. . . the position of a Region is sufficiently secured", and therefore the country in question is an example of functioning federalism. ${ }^{105}$ These examples of functioning federations are classified into two groups: first, the so-called Classical Federations: Switzerland, the United States, Canada, and Australia; secondly, the Post-1945 Federations which have been divided into two sub-groups: the Post-1945 Asian Federations (India and Malaysia), and the Post-1945 European Federations (Western Germany and Austria). While the four "Classical Federations" form the part two of the thesis and are discussed respectively

105

Sawer, op. cit., footnote 44, pp. 127-128. Because of similarity in the criterion adopted, the list of functioning federations discussed in this thesis is almost the same as in sawer's book. 
in chapters second, third, fourth, and fifth; chapters six and seven. (comprising the part three) are devoted respectively to the Post-1945 Asian and Post-1945 European federations. Part four of the thesis, which is devoted to the study of Failed Federations, consists of chapters eight and nine devoted respectively to "Federations created. Under Potentially Nonfederal Situations", and "Federations that Failed Despite their Potentially Federal Bases". In the first group are included the Latin American Federations, and the Central African Federation, while the latter group. (in chapter nine) consists of Indonesia, Pakistan, the West Indies, and Nigeria. It needs clarification, however, that it is not held here that federalism in Nigeria has finally failed. It may well be (and most likely is) that Nigeria's recent troubles, like the American Civil War, were only a passing phase in the country's march towards national integration and adjustment from which will soon emerge a stable centralized federalism. But, in any case, Nigeria, like the United States of the Civil War days, offers some valuable lessons with regard to failure of federalism. It has, therefore, been thought proper to include it in the group of failed federations for the purposes of this study.

While in the study of working examples of federalism a fuller analysis of politico-geographic factors in the origin and stability of federations has been attempted, in the examples of failed federations attention has mainly been focused on the factors contributing to the failures of the federations studied. As the study proceeds, beginning with the first example, hypotheses are set forth which are tested and modified, in so far as relevant, in the analysis of each subsequent case studied. These inferences, conclusions, and hypotheses are summarized in a final section where some general propositions on the origin and stability of federalism are put forward. Relevant, but not integral to this discussion, is the role of federal capitals and territories in the general stability of federal states. 
A brief note on these has therefore been included in the appendix.

As the study concerns itself only with the origin and overall stability of federal political systems, only those matters have been dealt with which in the author's opinion have a clear bearing on either the maintenance of the state as a union or its continuance as a federal in contrast to a unitary political organization. For reasons of this limitation of scope, many features and movements that may appear very important with regard to the future internal structure of individual federations--such as the new state movements in Australia and India-have not been dealt with, and any reference to them is only incidental. These factors, the author thinks, do not affect the ultimate survival of the state as a federation and, therefore, are not relevant to this study.

Since it is hopefully designed as a study in political geography, several important aspects of federalism that have been of great interest to political scientists and students of constitutions, are only barely touched. For, as Alexander says, political geographers (as specialists of a science) are:

not concerned with the form or structure of government by itself, that is, the division of functions among executive, legislative and judicial branches . . These are the matters for the political scientist.106 Attention to form and structure of individual federations has therefore been limited to a brief summary in order only to make clear the broadly federal character of the states' constitutions. It is now generally granted that:

Geography . . must pay attention to the spatial arrangements of the phenomena in an area and not so much to the phenomena themselves. Spatial relations are the ones that matter in geography. . . 107

L. M. Alexander, The World Political Patterns, New York: Rand MacNally \& Co., 1957, p. 32 . 107

F. K. Schaefer, "Exceptionalism in Geography: A Methodological Examination", Annals, Association of American Geographers, Vol.43, 1953, p. 228. 
As Norton Ginsburg says, "The 'spatial organization' lies at the very heart of . ogeographical investigation, whereas it is [only] peripheral to the main thrusts of other fields"。108

While like most studies in geography in the past, the present study is also basically synthetic and analytical, it is hoped, however, that it differs from its predecessors in one respect: in the past "the formulation of general propositions has tended to be more implicit than explicit, more derivative than primary", while here attempt has been made to focus attention on the formulation of general propositions as the explicit and primary objective of the study. 109 While our subject of investigation remains the federal pattern of state organization, in line with contemporary research in geography, attempt has here been made to move "away from pre-occupation with patterns per se". For, as Robert Platt pointed out, pattern is a function of organization; hence any proper study of patterns should concern itself with the formulation of general propositions and theories of organization. 110 It must, however, be emphasized that the propositions and theories (if they could properly be called so) that this study aims to offer, are basically concerned with what kenneth. Boulding terms the levels of frameworks and clockworks. ${ }^{111}$ This is inevitably so, for "a typical theoretical situation in geography is described usually by way of patterns". 112 Thus in political geography, in contrast to political science, we are more concerned with "pattern laws" than "process laws".

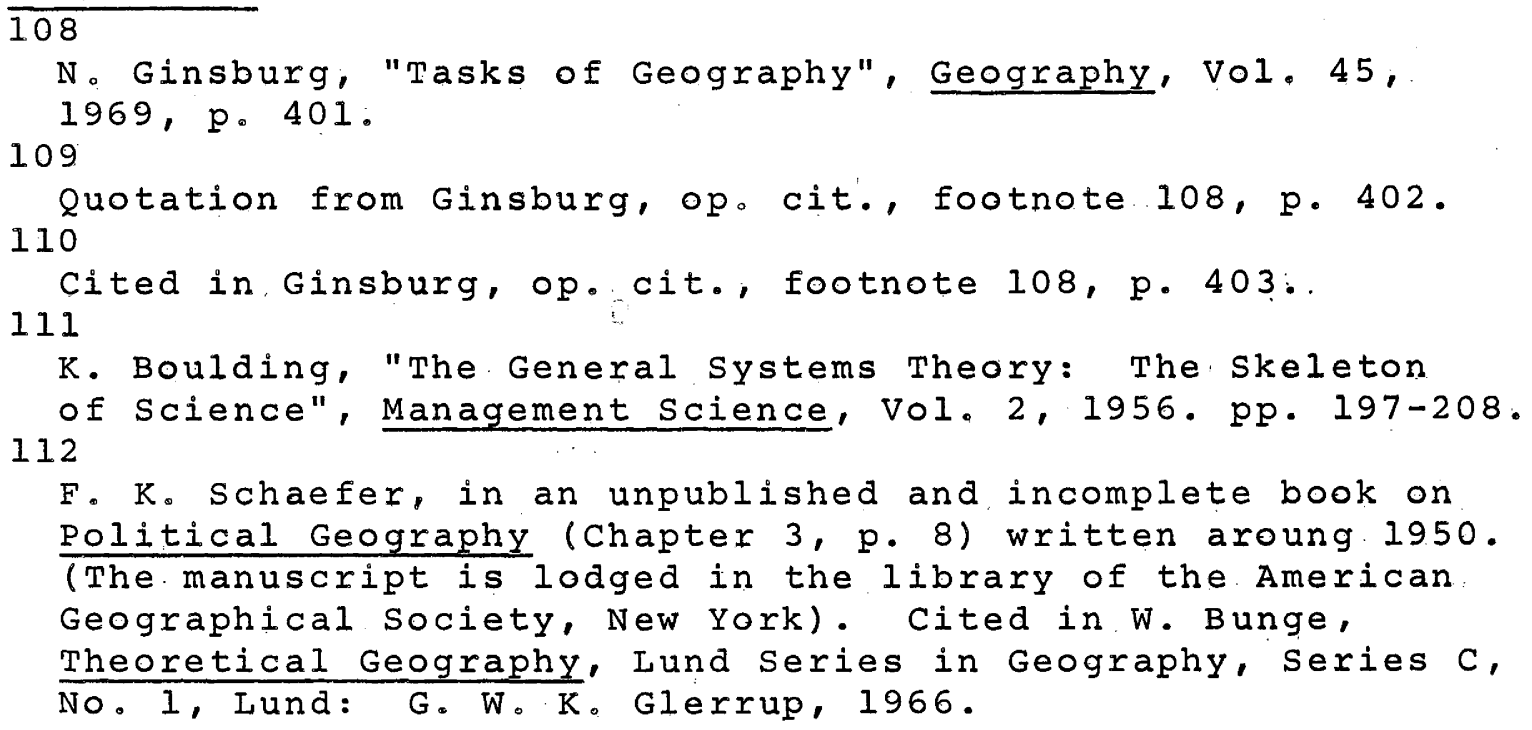


It seems necessary to explain that the "pattern laws", as conceived here, are clearly distinguished from the socalled "morphological laws" which "make scant mention of the phenomena involved, and concentrate solely on spatial properties".113 In fact, as Blaut has noted, structure (the areal arrangement of phenomena) and process (the arrangement of these phenomena over time) are one and the same thing. In other words, " . . . structures of real world are simply slow processes of long duration". 114 But while writing in political geography--the frontier between geography and political science--a distinction between "pattern laws" and "process laws" becomes necessary in view of an altogether different connotation associated with the term "process" in political science. As Gross writes: 115

"political process" refers to the activities of people and various groups as they struggle for--and use-power to achieve personal and group purposes. Its most carefully studied forms have been the efforts of conflicting political parties, factions, cliques, and leaders to attain formal positions of legitimate authority in the central organ of public government-unitary and federal, national and local.

The study is planned with the conviction that a better understanding of the nature of federalism can be secured by trying to picture its workings as a process in which the diverse elements that compose a federal state integrate and compromise their differences, rather than a set of institutions and procedures whose operation is wholly determined by the legal norms and structures. 116 A complete politico-geographical examination of federalism from this point of view would require, as Livingston says, much more

113

J. Co Hudson, "A Location Theory for Rural Settlements", Annals, Association of American Geographers, Vol. 59, 1969, p. 366 . 114

J.M. Blaut, "Space and Process", Professional Geographer, Vol. 13, July 1961, p. 4. This notion, first recognized by philosophers of science, seems to have been clearly set forth for the first time in geography by $W$. J. Cahnman, "Outline of a Theory of Area Studies", Annals, Association 115

of American Geographers, Vol. 38, 1948, pp. 233-243.

B. M. Gross, "Political Process", in International

Encyclopaedia of the Social Sciences, Vol. 12, p. 273. $11 \overline{6}$

Livingston, op. cit., footnote 18, preface. 
than a single volume. This study has, therefore, limited itself to a detailed examination of spatial interaction in the rise of federal states, and to a more general scrutiny of spatial relations involved in the stability of federal political systems.

From the nature of its subject matter, this thesis becomes more a work of what may be termed a general practitioner, than of an area specialist. For this reason, in so far as historical and political facts are concerned, the emphasis is on synthesis rather than analysis, but in respect of the spatial relations involved, the analysis is largely the author's own. Out of all this, like the general practitioners in other fields, the author has hopefully tried to weave "other men's threads (and some of his own) into patterns which they had not foreseen or even suspected". 117 How far this attempt has been successful I do not know.

At several places, throughout this study, some wellestablished hypotheses and opinions have been questioned and alternatives have been suggested. While no finality is claimed regarding the inferences and hypotheses that have been put forward, I have done this in the belief that history and social sciences share "this characteristic with the natural sciences, in that the greatest advances.. . in knowledge and understanding come from a continual intellectual questioning, readiness to challenge even the best-established conventional wisdom, provided that adequate facts and logical arguments can be mobilized against it". 118 I hope that the facts and arguments I have mobilized in the pages that follow, are adequate to make my points clear and (perhaps) convincing. How far they are in fact so, is for the reader to judge.

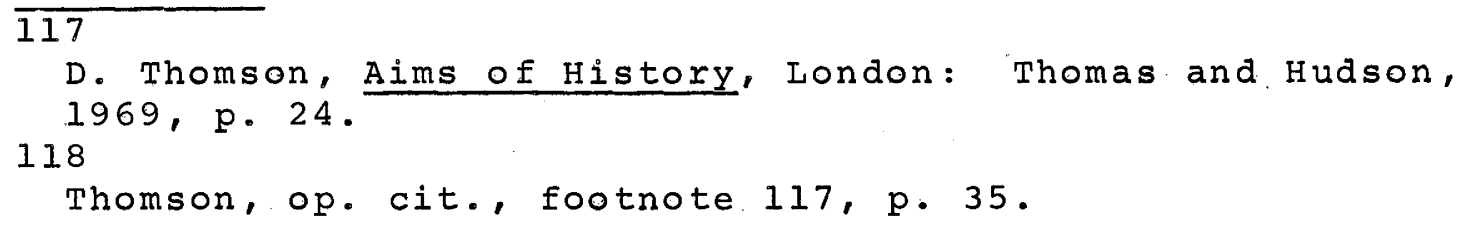


Part 2

THE CLASSICAL FEDERATIONS 
Although as a centralized federation Switzerland is second to the United States of America, it is the State with the longest history of continuous experiment in federalism, and is the oldest multi-ethnic federation. Though abounding in a great number of diversities-topographic, cultural, linguistic and religious--Switzerland offers an example of an integrated nation, a mature federal state. ${ }^{1}$ How this diversity has been fostered into unity (not uniformity), makes a rewarding study in the geography of federalism.

\section{RISE OF SWISS FEDERALISM}

The first beginning of the Swiss Confederation in 1291 was "the product of that tendency towards cooperation which, with varying success, inspired the mediaeval communes of all lands". 2 with the death of the king of Burgundy in 1032, the whole of Helvetia (Switzerland) became part of the Holy Roman Empire. In the beginning the Germanic kings exercised considerable power over the area, but with the passage of time their hold began to decline. This decline was almost complete in the thirteenth century. Now as the central power declined, many communities of the Empire began to experiment with self-government and some of these emerged as almost free entities. With a view to winning the loyalties of these communities and thereby to strengthen his military power in

1

The maturity of the swiss partnership is evident from the fact that despite its multifarious diversities it is one of the leading nations in nonviolent conflict resolution in its internal politics. See J. Steiner, "Nonviolent Conflict Resolution in Democratic Systems: Switzerland", 2 Journal of Conflict Resolution, Vol. 13, 1969, pp. 295-304.

Paul E. Martin, article on Swiss Confederation in The Cambridge Mediaeval History, London: Cambridge University Press, 1932, Vol. 7, p. 183. 
the struggle against the Papacy, the Holy Roman Emperor Frederick II granted them the status of free (i.e., autonomous) units of the Empire. Because the imperial power at the time was too weak to guarantee the security of all the areas of the Empire, many of these communities began to organize themselves into groups for purposes of common defence. Everywhere confederations were emerging. The Swiss Confederation, originally an association of rural communes, was one of these.

The three communities of Uri, Schwyz and Unterwald, after the decline of the Holy Roman Empire, had fallen under the possession of the Hapsburgs. But Uri in 1231 and schwyz in 1240 had received charters from Frederick II declaring that they were freed from the Hapsburg control and were now directly under the Emperor. During the period from 1254-1273 when Germany was without a generally recognized ruler, the valleys made considerable progress towards selfrule. But with the rise of the Hapsburg power under Rudolf IV, and his subsequent election as the Holy Roman Emperor in 1273 , this progress towards regional autonomy was gravely threatened. Rudolf attempted to integrate the Swiss communities into the imperial system. This proved very irksome to the communities which had so long enjoyed virtual autonomy in their internal matters. After Rudolf.'s death (on July 15, 1291) the leaders of Uri and Schwyz along with those of Unterwald entered (on August 1, 1291) into an Everlasting Alliance for mutual defence. The Alliance affirmed that the three communities would help any member threatened with loss or damage, by providing without limit. or reserve men and materials for defence and aggression. They refused to receive any tax farmers in their valleys or any representatives of a higher athority against whose decisions they could not appeal to leaders of their own communities. Unlike other mediaeval leagues, the swiss Confederation was, according to its text, an Everlasting Alliance. It was in this sense a truer beginning of a federation. The reason for this was that the "interests 
which the first confederates sought to defend were not narrowly political, and therefore not likely to change with the passage of time. Facing common dangers and common enemies, they were conscious of complete unity." ${ }^{3}$

The confederation succeeded well in preserving the autonomy of its members. It also helped to awaken in them a sense of solidarity capable of giving birth to a real state. A serious threat to the confederation came in 1315 when Duke Leopold tried to re-impose Hapsburg authority over Schwyz and Unterwald. But the Confederates' victory over the Hapsburg forces at Morgarten, greatly enhanced their prestige and self-confidence, and the Confederation soon began to attract new allies from among the neighbouring communities which were disenchanted with or threatened by the Hapsburgs. First to join was the town of Lucerne (1332). Next came Zurich (1351), then Glarus and zug (1352). Berne joined in 1353. Thus the original strong confederation of three was extended into a loose alliance of eight. There was no single all-embracing pact binding all the members together. Six separate pacts linked the eight cantons. Between Berne, on the one hand, and zurich, Glarus and zug, on the other, there was no alliance at all, until at the sempach Convention in 1386, after defeating the Hapsburg forces, the Confederates entered a fresh agreement for mutual military help in the form of a common military law.

The Confederates conquered the Austrian territory of Argau in 1415 and Thurgau in 1460. As time passed the rising prestige of the confederation brought her new allies in the geographically contiguous areas. These included the monastery and town of St. Gallen, the town of schaffhausen, the community of Toggenburg, the league of Graubunden. (Grisons) and the towns of solothurn, Fribourg, and Bienne as well as the town and country of Neuchatel. These were accorded

3

Charles Gilliard, A History of Switzerland, with concluding pages brought uptodate by J. C. Biaduct, translated by D. L. B. Hartley; London: McMillan Co., 1961, p. 19 . 
the status of "associated districts" and were under obligation to supply troops whenever required.

Fribourg and Solothurn were admitted to full membership in 1481, Basle and Schaffhausen in 1501, and Appenzel in 1513. This brought the membership of the confederation to thirteen. But throughout the sixteenth century, with the oncoming of the Reformation, the loose unity of the Confederation was turned into discord. The Confederation was divided into two opposite camps--the Protestants, who looked to France, and the Roman Catholics who looked to spain. Of the thirteen cantons, Zurich, Berne, Basle, and Schaffhausen were Protestant, while Uri, Schwyz, Unterwald, Lucerne, Zug, Fribourg, and Solothurn followed the Catholic faith. Glarus and Appenzel had the two faiths side by side. This religious discord continued for about two centuries, but a number of historical events helped to save the confederation from complete disintegration. One of the chief factors helping to hold the Confederation together was the French alliance of 1521. It was in France's interest that the Protestant and Catholic cantons remained at peace with each other, otherwise France would not have been able to recruit swiss troops as agreed in the 1521 alliance. For this reason France worked towards the maintenance of domestic peace among the Confederates. Later it was the conquest of switzerland by Revolutionary France that laid the foundation of switzerland as an organic political entity. Napoleon Bonaparte was the man who outlined the real beginning of a centralized federation in the country by initiating the Act of Mediation of 1803. At the close of the eighteenth century the swiss Confederation was an elaborate edifice that, it is said, only Providence could maintain erect. 4 Besides the thirteen full members, the Confederation had a number of allies and associated districts. There were, besides, a number of subject areas. Practically each member canton had its subject areas. Some territories were subject to two or more cantons, and some

4

Gilliard, op. cit., footnote 3, p. 56. 
were under seven or ten. A large part of Ticino was the common property of all except Appenzel. Some attempts from within to end the confusion failed. So it remained for the forces of Revolutionary France to end the confusion. on April 12, 1798 the "One and Indivisible Helvetic Republic" was proclaimed on the dictates of France. The country was divided into twenty-three cantons; the ten new cantons were carved out from the associated districts and common bailiwicks.

A representative democracy with universal male suffrage, rigidly centralized on the French model, was established, thus ignoring a long historical heritage of variety in political outlook and regional autonomy. There was, naturally, great dissatisfaction with the new arrangement among the constituents. This, coupled with bad administration by new, inexperienced, and greedy officers, and the anti-clericalism of the French, provoked a revolt in the central cantons. Government in the country became highly unstable.: Five different constitutions followed in quick succession. It was under these conditions that Napoleon Bonaparte offered his mediation and presented the Act of Mediation on February 19, 1803. The territories of Mulhouse, Geneva and Bienne, annexed by France, were not returned. A representative federal democracy of nineteen equal cantons, thirteen old and six new--st. Gallen, the Grisons (Graubunden), Argau, Thurgau, Ticino and. Vaud--was established. The cantons regained practically all of their old rights and privileges. But recognizing the disadvantages of a loose confederation, Napoleon incorporated some of the lasting results of the Revolution in the new order and gave them constitutional force. The Constitution proclaimed freedom before the law, recognized a general swiss citizenship and guaranteed the right of freedom of settlement and occupation.

The supreme authority of the confederation was the federal Diet composed of deputies from each of the cantons. The Diet was responsible for internal security and foreign policy. The individual cantons contributed to the federal 
treasury in accordance with their size and representation. As there was no permanent federal capital, the meetings of the Diet had to take place alternately for a year, in turn, in six cantons--three protestant and three Catholic. Napoleon took the Act of Mediation under his guarantee, and no amendments to the Constitution--national or cantonal-could be made without his consent. The new Diet was fundamentally different from the old:

Whereas the traditional Diet was a body of plenipotentiaries of sovereign cantons who could as a rule act only when unanimous, the Napoleonic institution was more like a parliament. It could reach valid decisions by simple majority vote on all ordinary matters. Wars, however, could be declared and treaties concluded by the Diet only by a majority of three-quarters of the cantons". 5

Constitutional progress and structure

With the fall of Napoleon, a new constitution, this time sponsored by the Allies, was adopted on August 7; 1815. Neuchâtel and Geneva were given over to switzerland and made autonomous cantons of the confederation. Thus the number of cantons was raised to twenty-two. Because the Act of Mediation had suited the needs of Switzerland so well, the new Constitution incorporated most of the essential features of the Napoleonic Constitution. Equality of representation in the Diet was restored. In place of six only three cantons-Zurich, Berne, and Lucerne--were, by turn, to be the seats of the Diet on a two-year term basis. Although majority decision in the Diet was to prevail, the Diet had no authority to ensure the acceptance of the majority decision by all the cantons. Neutrality of switzerland in peace and war was recognized by all European powers.

During the eighteen-thirties the old rivalry between Catholic and Protestant cantons raised its ugly head, and by the mid-forties it threatened to break the solidarity of the Confederation. Seven Catholic cantons organized themselves into the sonderbund League. 6 In 1847 the Diet, 5

W. E. Rappard, Collective security in Swiss Experience, 6 1291-1948, London: Allen and Unwin, 1948, p. 27 .

The Roman Catholic cantons under the Sonderbund League were: Lucerne, Uri, Schwyz, Unterwald, Fribourg and Valais. 
by a majority vote, decided to dissolve the League. Federal troops accomplished the task in November 1847. In 1848

a new constitution, which represented a compromise between the two extreme views of a completely unitary and an extremely loose confederal polity, was adopted. The cantons no longer remained sovereign. The central government was given the sole charge of the army, customs, currency and postal services. Government in each canton was to be democratic and republican. The central government was empowered to enforce the articles of the constitution and also to take necessary steps to promote national welfare. A bicameral legislature on the American pattern was adopted. A Federal Assembly was to be elected by the people in ratio of one deputy for 20,000 (now 22,000) population. The Council of state had forty-four members-two from each canton. The system of cantonal instruction to the representatives to the council of state was abolished. A joint session of the two houses of the legislature was to elect the Federal council (the central executive body of. seven members, each presiding in turn), the Federal Tribunal and the Commander-in-Chief of the Army. But any new law had to receive a majority in both the houses separately. This saved the cantons from extreme central control. cantons were to manage administration of law, justice and education, but freedom for religion and worship was guaranteed to all. Berne was made the federal capital.

Ever since the centralized constitution of 1848 the Swiss nation has steadily grown into maturity. As the interests of the people became more unified, the more redundant have proved the disparities in the laws of the cantons. With the people's consent the constitution has been revised over fifty times since 1874 but the spirit of federalism, the diversity within unity, has remained. Power from the cantons has gradually been transferred to the federal government and the central authority has continued to play a greater role in the daily life of the people. The Swiss system took its unique shape as a federation after the constitutional 
reform of 1874, which made it a federation of nineteen full and six half cantons. The latter rank full for practically all purposes, and in particular have the same degree of autonomy as the rest, but they have only one vote each in the council of state where others have two. They count as half when reckoning the concurrence of the people in a majority of cantons for the purposes of constitutional revision.

Switzerland had a centuries-old tradition of government by public meetings. In 1874 this principle of referendum was adopted as a basic feature of the swiss constitution for federal purposes as well. The Federal Court in Switzerland can invalidate cantonal laws but not the central ones. Central laws can, however, be submitted to the people as referenda on both legislative and popular initiative. Any amendment needs the support of the majority of the people in the country, as well as a majority of the cantons. "But amendment is also virtually achieved if the centre enacts a law not within its enumerated powers, and either no referendum is demanded, or if demanded results in approval by a majority of people as a whole--not necessarily in a majority of: Regions as well. This method of 'breaking through' the Constitution is freely used where the degree of departure from the established constitutional power is relatively small". 7 Further, the "decrees" of the Federal Assembly are not subject to referendum if the Assembly declares them to be urgent or not of general application. This, says sawer, "has become in practice a kind of emergency provision, under which important extensions of Centre competence have been enacted, chiefly to deal with economic and defence crises, without any possibility of electoral check". All this has tended to draw

7

G. Sawer, Modern Federalism, London: C. A. Watts \& Co. Ltd., 1969, p. 28 . 
Switzerland "towards the unificationist end of the federal spectrum". 8

\section{POLITICO-GEOGRAPHIC FACTORS IN THE RISE OF SWISS FEDERALISM}

\section{Pactors for Regional Identities}

one need not be a determinist to suggest that swiss federalism, in its early phases, was somewhat conditioned by the physical forces of its environment. With the Jura in the northwest covering one-tenth of its surface area, and the Alps in the south covering another sixty percent, Switzerland has a very rugged topography. In between the two mountain ranges is the Swiss plateau, mostly lying above 1500 feet. The Swiss Alps run into three parallel southwestnortheast waves-called, from north to south, the prèalps (or the foot hills), the northern Alps, and the Meridional Alps. The latter two are separated by the valleys of the Rhine flowing to the north, and the Rhone flowing to the southwest. The Swiss Alps form a great European watershed. Besides the two great rivers mentioned above, Ticino and Toce flow to the south to form tributaries of the River Po. The Inn flows to the east to join the Danube. The Swiss Alps are, therefore, criss-crossed by a number of valleys. The Jura is also broken up into valleys separated by ridges. The plateau region enclosed by the two mountain ranges is itself compartmentalized by a few low hills that cross it. This compartmentalization of the surface was reflected in the pattern of human occupance of the area. The existence of small valleys separated from one another by rugged hills or

\footnotetext{
8
}

sawer, op. cit., footnote 7, p. 29. A comprehensive study of the swiss constitution is to be found in Christopher Hughes, The Federal Government of switzerland, oxford: clarendon Press, 1954. Briefer, though good, studies of the Swiss government are to be found in: W. E. Rappard, The Government of Switzerland, New York: D. Van Nostrand Company, 1936; and G. R. Codding; Jr., The Federal Government of Switzerland, London: Allen \& Unwin Itd. 1961 edition and 1965 impression. 
mountain ranges helped the rise of quasi-independent settlements of small dimensions, distinct in cultural community from one another. Each settlement, although small, came to possess a strong identity born out of its isolation and nearly independent subsistence economy. As André siegfried says, the various areas in switzerland were of such marked individuality that their inhabitants were conscious of the differences. In each circumscribed valley or distinctive pays, corresponding to the boundaries of a canton, each citizen knew instinctively why he belonged to his particular valley. This, siegfried thinks, was the solid basis of a federal democracy which had its roots both in the soil and in the hearts of men. 9 However "the physical and material handicaps imposed by Nature have been overcome by the swiss to a remarkable extent, it is only the psychological effects of living in narrow valleys that they could never fully overcome". 10

The sense of independence and individuality among the Swiss cantons was also fostered by their historical experience as parts of the Hapsburg Empire or of the Holy Roman Empire (at least nominally till 1648). As these cantons, because of the difficulties of access, could never be effectively controlled from the distant seat of imperial government, the imperial masters had to satisfy themselves with whatever revenue they could extract through their intermediary vassals or bailiffs. The cantons were, for all practical purposes, left free to enjoy their internal autonomy. That the imperial masters recognized the autonomy of these communities is evident from the fact that Frederick II granted several of these cantons the status of free communities of the Empire. Later, as the membership of the original Confederation of the three increased, other diversities and identifying

$\overline{9}$

André Siegfried, Switzerland: A Democratic Way of Life, translated by Edward Fitzerald, Iondon: Jonathan Cape, 10 1950, p. 25 .

J. Christopher Herold, The Swiss Without Halos, New York: Columbia University Press, 1948, p. 10 . 
elements in the makeup of the cantons were introduced. originally the confederation was homogeneous in language and religion. First, diversity in respect of language was introduced as several of the new members were French-speaking. With the religious Reformation of the sixteenth century many of the cantons became protestant while others retained the Catholic faith. Thus religion became a strongly identifying element in the makeup of the swiss cantons. Fortunately, however, the religious and linguistic divisions among the cantons did not coincide. As we shall explain later in this chapter, the existence of cross-cutting (or interlinking) cleavages of language and religion have greatly helped to neutralize the divisive forces of the either and have thereby helped to maintain the confederation.

\section{Factors for Unity}

Although difficulties of transport and communication tended to locilize human activity in the swiss valleys and made each canton to live in a world of its own, the intervening barriers did not completely isolate the cantons from their neighbours. Throughout the Swiss Alps there are narrow corridors connecting the different valleys. Through these corridors there has been a continuous traffic all through history. This tended to make the valley communities in switzerland independent but interrelated families--a unity in diversity.

The mountain environment of the swiss cantons contributed to their sense of belonging together in another sense also. As the communities lived under broady similar geographical conditions, themature of their economies and their modes of living were also very similar. This made mutual understanding of one another's problems and way of life easier. While in modern times similarities in economy tend to pull communities apart by creating economic competition, in the midale ages, when the first foundations of swiss federalism were laid, these communities were largely self-sufficient and hence the element of competition as a divisive force was largely absent. 
Switzerland's location on the cross-roads between France, Italy, Austria, and Germany was an important factor in the rise of a sense of unity among the valley communities. The Swiss realized quite early that in order to control traffic through their mountain cross-roads, and thereby to extract capital out of their strategically advantageous location, they had to remain united. For while individually they could not hold the mountain passes to themselves, united they made them invincible. Herold calls switzerland an antechamber with its doors leading to the four main European apartments.

The four adjacent rooms--France to the west, Germany to the north, Austria to the east, and Italy to the south--have their own connecting doors, it is true, but since they are invariably locked and bolted whenever the tenants cease to be on speaking terms, the most convenient routes from Germany and northern France to Italy and from Austria to France lead through Switzerland's windowless antechamber. It is windowless in the sense that Switzerland is landlocked; in order to get air, it must keep its doors to the surrounding rooms open at all times, even when the neighbours barricade their own interconnecting doors. I1

A further factor in drawing the cantons together was that with the increasing population of their valleys the cantons realized the narrowness of their space and its insufficiency to meet the demands of their growing numbers. As this recognition came, trade and commerce between the cantons increased, which in time bound them together into an economic unit. This increased interregional commerce loosened the barriers--physical and mental--that stood between the valley communities, and thereby laid the foundation of a closer political union. The plateau cantons of the north were of value to the mountain cantons for their surplus supplies of grains, while the city-states themselves provided a market for the products of the pastoral industry of the mountain cantons. Their interests were also bound together because the mountain cantons controlled the crossroads on whose free and uninterrupted use the prosperity of some of the city-states greatly depended. This inter-

11 Herold, op. cit., footnote 10, p. 5. 
dependence of the Swiss cantons is rather overemphasized (on rather deterministic lines) by siegfried when he says:

juxtaposition of the two mountain systems which enclose it is the essential factor which permitted the establishment of a political unit between France, Germany, Italy and the Danubian countries, and, to a certain extent, against them. The area thus formed is diverse in character, but balanced, and well organized and it contains within itself all the conditions necessary for a free and autonomous existence. On the one hand there has been a tendency toward diversity, towards formation of separate compartments, . . but on the other hand there is also a tendency to homogeneity, and the logic of this politico-geographic complex leads to the strongest conceivable form of national unity.12 Siegfried thinks that "The national life of switzerland is essentially a combination of altitudes". 13

But perhaps the most important factor that gave the swiss communities a consciousness of kind and fostered, rather enforced, unity among them, was the recognition of a common danger to their survival as autonomous communities. It was the threat of the Austrian Hapsburgs that had initiated the Confederation and had served to keep it together until the conquest of Switzerland by Revolutionary France. In the period after 1815, although the unity and neutrality of Switzerland were recognized by the leading European powers, the international rivalry between them continued to keep the swiss alert towards their national security, for the preservation of which attempts were continuously being made towards greater centralization of governmental powers. The Sonderbund war further awakened the sense of urgency for greater centralization, and after the defeat of the Catholic cantons in 1848, a more centralized constitution was proclaimedan objective that was more fully achieved by the constitutional revision of 1874. This continued sense of military insecurity and external interference in swiss affairs may be seen in

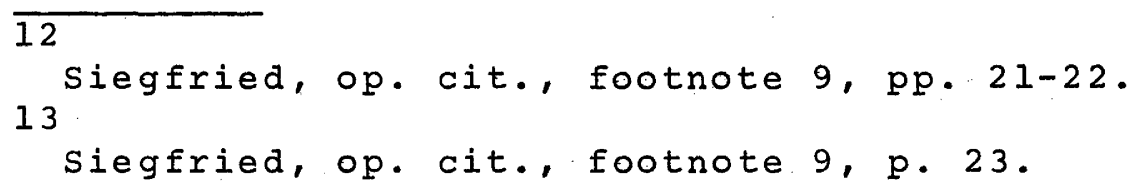


the fact that Austria, Prussia, France and Russia at first forbade the constitutional revision of 1848, but later owing to the revolutionary movement which swept Europe that spring, they were unable to interfere further in swiss affairs. 14

\section{POLITICO-GEOGRAPHIC INFERENCES}

1. This study of swiss federalism would support "the military interpretation of federal constitutions" 15 which has been "rather over-stressed by Professor William Riker". 16 Although we do not think that the "military condition" as Riker calls it, is a necessary factor for the rise of federalism in all cases, it may nevertheless be a necessary condition in a particular type of federal situation. Before the rise of modern centralized federalism and its further course of integration necessitated by the rise of large scale industrial economy and need for centralized national planning, federalism was essentially an alliance for the limited purposes of military security in face of a common danger. In these earlier experiments (in which category the pre-Napoleonic phase of swiss federalism is included), the military condition in the rise of federalism may well have been necessary (and sometimes even sufficient), for often military security was the primary raison d'etre of such unions or alliances. But with the changed emphasis of modern federalism, military security can no longer be a sufficient raison d'être of a centralized federation. Now federations are no longer limited-purpose-alliances. The primary objective of modern federalism is to create a body politic--an integrated and fully functioning political

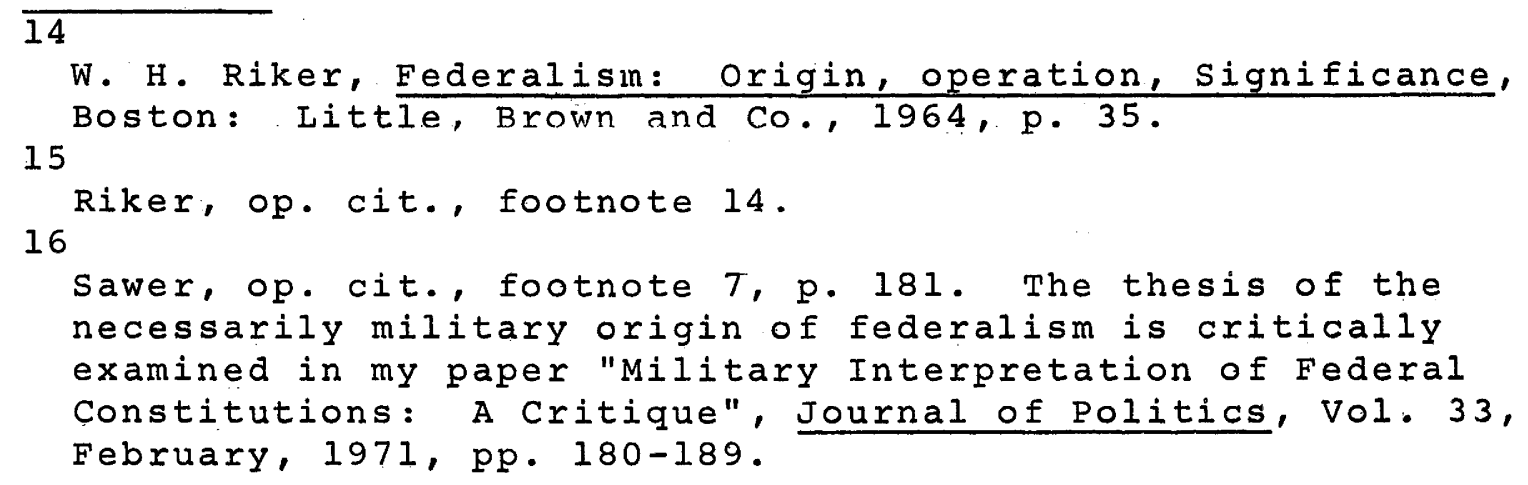


unit. For this it is necessary that the purposes that bind the prospective partners together are not narrowly political or military.

However, if we give a closer look to these earlier experiments in federalism, we may well find persistence of a politico-geographic situation essentially similar to certain possible type of federal situation in modern times. Put simply, the bases on which these earlier experiments in federalism were usually built consisted of a number of regionally-grouped communities, with small power potentials but strong regional identities, that were faced with a common threat to their survival. While their strong individual identities prevented the communities from coming closer than a loose confederation, their individual weaknesses and insufficiencies forced them to at least this degree of unity if they wanted to survive at all. In this sense the earlier experiments in federalism were essentially cases of union born under conditions of uniform geographical distribution of power--a case where a number of strongly self-identifying political units with individually weak power potential were faced with a common threat to survival. These units, in the absence of an over-arching force to guide them and coordinate their activities, came closer together in order to create jointly their own central source of light-- the sun of political power--in the form of a central Federal Government. These experiments also point to the fact that federalism is essentially a union of equal partners.

It is essentially this pattern of geographical distribution of power that seems to have brought the three forest cantons into the confederation, and it was again an important force in keeping the diverse swiss cantons together. But prior to 1798 , when Berne and Zurich possessed extensive dependent territories and large population and economic resources, there was a distinct tendency towards an asymmetrical development since the more powerful cantons were often tempted towards actions and alliances independent of the rest of the confederation. It should be remembered that 
the real foundation of the centralized swiss federalism was laid by Napoleon when he converted the dependent territories of the cantons into autonomous members of the confederation, thus bringing about a uniform geographical distribution of political status in the area, and--with its units so smal1-making intercantonal close cooperation and union under the Confederation necessary to the very existence of the individual cantons threatened by mutual rivalries and common external threats. In the earliest phase, what had prevented an actual break of the Confederation was the presence of a continued external threat (as also the great military solidarity of the original forest cantons) coupled with France!s interest in the maintenance of domestic peace in switzerland.

In modern times somewhat similar federal situations have arisen, and may well arise in the future, wherever regionally grouped political communities possess very strong (and to some extent partly mutually exclusive) identifying elements in their makeup. In such examples the "mllitary condition" may well be a necessary factor in the rise of federalism. 2. The highly complex linguistic-cultural base of Switzerland consists of four strongly identifying and regionally-grouped elements of various strength. There is a large majority of German- (69.3 percent), a good number of French- ( 18.9 percent), and small minorities of Italian( 9.5 percent) and Roman $n_{h}^{5} C h-(0.9$ percent) speaking groups. Cultural pulls from across the borders in north, south and west have often been strong, and perhaps it is truly said that it was a number of historico-political accidents in juxtaposition with certain environmental conditions that gave birth to the swiss nation. The unity of the swiss cantons, possessing highly divergent cultural-linguistic bases, was born in the first place, out of their desire for self-identity and autonomy which their own cultural homelands, treating them as mere annexes, were not prepared to give. At the heart of this desire for autonomy was the historical 
fact that each of the peoples, despite having cultural attachments to their respective cultural homelands, had throughout maintained some kind of local autonomy in view of the looser central administration in these remoter areas. The union that was originally initiated by this consciousness of kind, was later reinforced by other factors--economic, political, and strategic in nature.

But if historico-political accidents initiated the Swiss federalism, it was the politico-geographical fact of their location surrounded by powerful, and at times hostile, neighbours that greatly helped to maintain the union. This politico-geographical factor of location between strong powers--against whom their internal division would be a sure invitation to doom-fostered a strong sense of unity among the apparently diverse population groups that these cantons represented. The force of this factor has been recognized, in different contexts, by a number of students of swiss history and politics. "success in war and the pride in common triumph counted for much in the earlier stages of the process [of evolution of a democratic state], while in the latest the existence of four great states to the north, east, south, and west had, so to speak, squeezed the swiss together, keeping them always on their guard against dangers from abroad", says Bryce. 17 The Federalist records that the swiss cantons have been kept together, besides other things, "... by the fear of powerful neighbours, to one of which they were formerly subject". 18 Indeed, the national unity of Switzerland "was not and. is not., based on race, tongue, creed, or allegiance to a common ruler, but rather on a very

17

James Bryce, Modern Democracies, London: Macmillan Co., 18

1929, Vol. I, p. 372 .

A. Hamilton, J. Madison," and J.Jay; The Federalist Papers (with an introduction by Glinton Rossiter), New York: The New American Library, 1961, essay no. 19, p. 133 . 
conscious solidarity and need of reciprocal protection". 19

While, on the one hand, this politico-geographic location helped to maintain the Federation by fostering a sense of unity among the constituents, on the other it also helped to stabilize the federal arrangement externally. The neighbours of Switzerland, however rapacious, realized the futility of overrunning this country, for in the event of attack by one switzerland was likely to get the support of a powerful rival. As Herold remarks "Switzerland, would, in all likelihood, have disappeared from the map long ago had it not been for the balance of power of the European states". 20

The hypothesis is that in multi-ethnic or highly heterogeneous federations with strong regional identities, a continued external threat is a favourable factor in the maintenance of the state as a federation; for if the external threat continues for a long enough time, the parties to the federal union, despite their individual identities which may at times be mutually exclusive, are compelled to adjust their differences and thus learn to live together as a close-knit family. A secondary hypothesis, supplementing the above, is that the presence of mutually hostile political pressures on the borders of such a federation is a further favourable factor for the stability of the union: while on the one hand, it helps to keep the constituents of the federation together by squeezing them into unity, on the other, the conflicting external threats nullify themselves and instead of harming the state maintain the status quo on its borders, thus saving the nation from much wastage on defence etc.

3. Switzerland possesses perhaps the highest degree of diversity per unit area among the nations of the world.

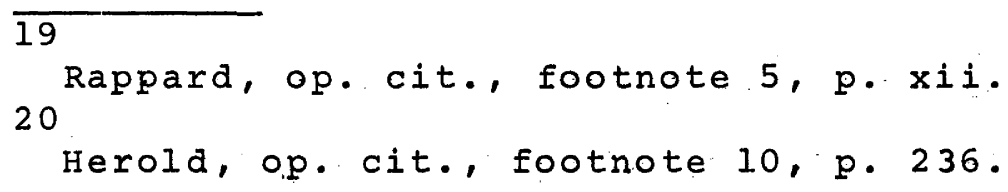


These diversities permeate practically all aspects of swiss life, e. g., language, religion, culture, and economic structure. Simply stated these diversities enforced upon one another would make a federal union of the swiss cantons look impossible. But, in fact, the geographical distribution of these diversities is such that these seemingly divisive forces have themselves been converted into a strong unifying force, and have thus helped to create in switzerland one of the world's most harmonized, stable, and integrated nations. Among the regionally identifying diversities in switzerland, language and religion are of special note. It is interesting that while in some other parts of the world language and/or religion have played havoc with national unity, in switzerland the geographical pattern of their distribution is such that despite the regional groupings of religion and of language, each of these two diversities finds its house divided against itself. The net result is that members of neither group are in a position to present a united front against their counterparts. Large sections of German-speaking swiss are Roman Catholics and large sections of French-speaking Swiss are protestants. These sharply cross-cutting cleavage lines of language and religion (as shown, in figure.2.1) neutralize each other's divisive forces and the cleavages are thus transformed into linkages helping to foster an urge for linguistic and religious harmony which alone could be the basis of switzerland's existence as a nation.

As the tables 2.1 and 2.2 show, the total percentages of German-, French-, Italian-, and Romanche-speaking groups are $69.3,18.9,9.5$ and 0.9 respectively, while the percentage breakdown of the two religious faiths--protestant and Roman Catholic--is 52.7 and 45.9 respectively, with 1.4 percent people professing other faiths or having no religion at all. While five full cantons have a French-speaking majority, only one has an Italian-speaking majority, and none has Romanch $\$$. The rest of the sixteen cantons have a German-speaking majority. In respect of religion, however, the cantons are evenly divided. Of the ten and a half cantons 


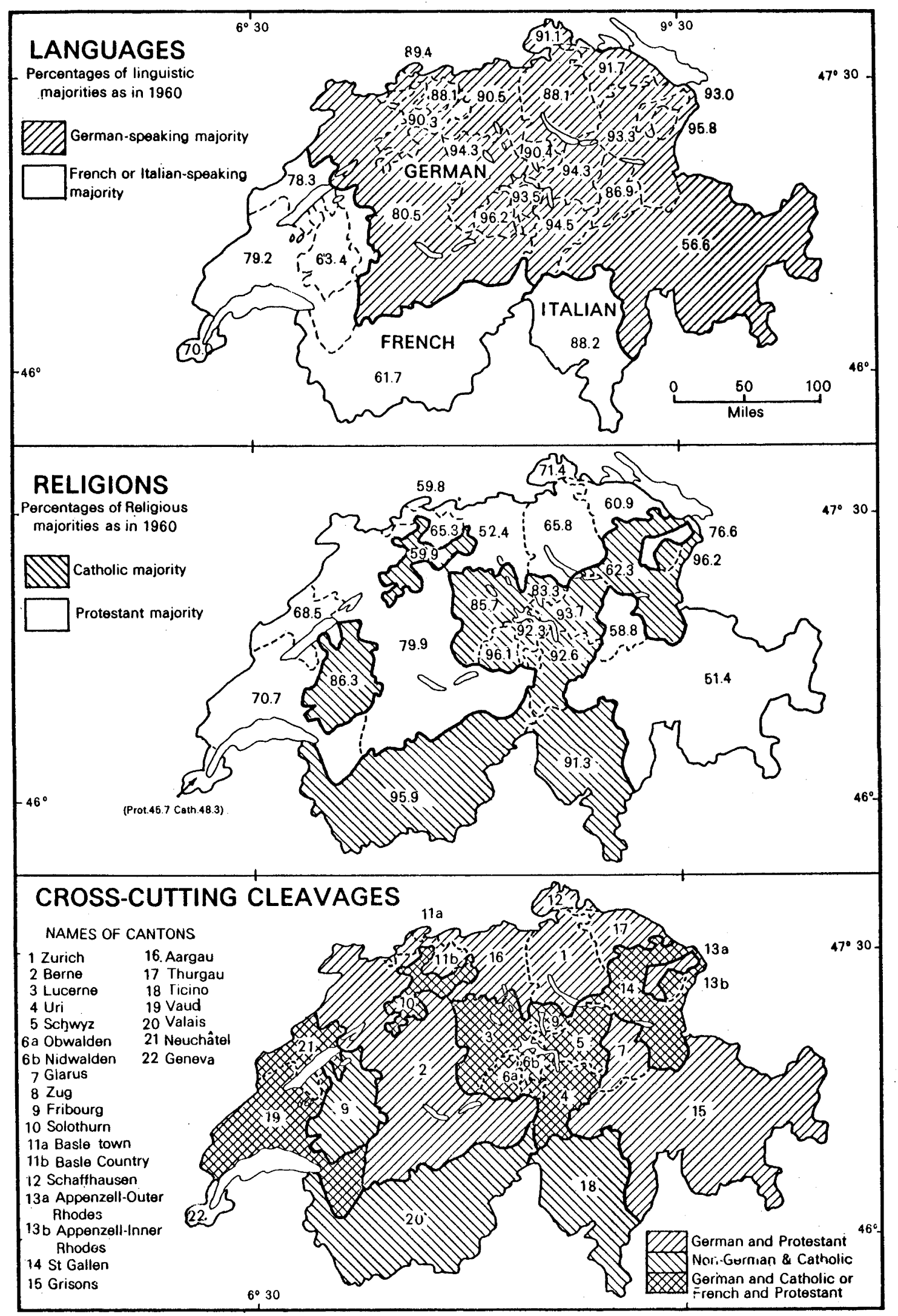

Fig. 2.1 THE PATTERN OF COMMUNAL CLEAVAgES IN SWITZERLAND. The overlapping cleavages of language and religion neutralize each other's divisive force, and the cleavages are transformed into linkages. This has fostered an urge for harmony among the otherwise conflicting cantons and thereby has maintained the Swiss partnership. 
with Catholic majorities, two (Fribourg and Valais) are French-speaking, one (Ticino) is Italian-speaking, and the remaining seven and a half (Obvalden, Appenzel-Inner Rhodes, Schwyz, Uri, Nidwalden, Lucerne, zug, st. Gallen and Solothurn) are German-speaking majority cantons. Similarly, of the ten and a half cantons with protestant majorities, two (Vaud and Neuchâtel) are French-speaking, and the remaining eight and a half (Berne, Appenzel-outer Rhodes, Schaffhausen, Basle Country, Basle Town, Zurich, Glarus, Thurgau, Argau and Grisons) are German-speaking majority cantons. 21 These highly overlapping boundaries of language and religion in switzerland have weakened both language and religion as divisive forces, because each of them, on account of this peculiar pattern of spatial distribution, is divided against itself. Hence, neither is able to fortify its camp without risking sizable segments of its group in the other camp. Thus neither of them can overplay its hand and the fissiparous tendencies cancel out.

The hypothesis is: when the boundary lines of regionallyidentifying diversities in a federal state highly overlap, the cleavages are transformed into linkages and the result is a stable federalism. From this it is also deduced that in multi-ethnic or highly heterogeneous states with strong regional identities, other things being favourable, the greater the factors of "felt" diversities in the national life, the greater are the chances of a stable federation, for under such conditions the chances are greater that the geographical patterns of the major diversities, such as religion and language, will not coincide, and their overlap will tend to neutralize their divisive force. Under the neutralized forces of the main identifying diversities national unity will be longer lasting and easier to achieve. The examples of Canada, India, and Malaysia would support this hypothesis in different ways.

21

Although in 1950 Geneva had an overall majority of Protestants who comprised 50.6 percent of the total population of the canton, in 1960 neither religious faith had an overall majority. Percentage share of the two faiths in 1960 was: protestants 45.7 , Catholics 48.3 . 
Table 2.1

LANGUAGES SPOKEN IN SWISS CANTONS (IN 1960)

(Percentages)

\begin{tabular}{|c|c|c|c|c|c|}
\hline Canton & German & French & Italian & Romanch s. $^{5}$ & Othex \\
\hline zurich & 88.1 & 1.9 & 8.0 & 0.4 & 1.6 \\
\hline Berne & 80.5 & 14.4 & 4.3 & 0.1 & 0.7 \\
\hline Lucerne & 94.3 & 0.9 & 4.0 & 0.2 & 0.6 \\
\hline Uri & 94.5 & 0.3 & 4.7 & 0.4 & 0.1 \\
\hline Schwyz & 94.3 & 0.4 & 4.7 & 0.3 & 0.3 \\
\hline Obwalden & 96.2 & 0.4 & 2.9 & 0.1 & 0.4 \\
\hline Nidwalden & 93.5 & 0.5 & 5.6 & 0.2 & 0.2 \\
\hline Glarus & 86.9 & 0.4 & 11.7 & 0.4 & 0.6 \\
\hline Zug & 90.4 & 1.1 & $7: 0$ & 0.4 & 1.1 \\
\hline Fribourg & 34.0 & 63.4 & 1.7 & 0.0 & 0.9 \\
\hline solothurn & 90.3 & 2.0 & 6.9 & 0.2 & 0.6 \\
\hline Basle Town & 89.4 & 4.2 & 4.7 & 0.3 & 1.4 \\
\hline Basle Country & 88.1 & 2.4 & 8.3 & 0.2 & 1.0 \\
\hline Schaffhausen & 91.1 & 0.9 & 7.1 & 0.2 & 0.7 \\
\hline $\begin{array}{l}\text { Appenzell- } \\
\text { Outer Rhodes }\end{array}$ & 93.0 & 0.4 & 5.5 & 0.2 & 0.9 \\
\hline $\begin{array}{l}\text { Appenzell- } \\
\text { Inner Rhodes }\end{array}$ & 95.8 & 0.1 & 3.8 & 0.1 & 0.2 \\
\hline st. Gallen & 93.3 & 0.5 & 5.1 & 0.4 & 0.7 \\
\hline Grisons & 56.6 & 0.5 & 16.1 & 26.1 & 0.7 \\
\hline Aargau. & 90.5 & 1.0 & 7.6 & 0.2 & 0.7 \\
\hline Thurgau & 91.7 & 0.5 & $7: 1$ & 0.2 & 0.5 \\
\hline Ticino & 9.4 & 1.5 & 88.2 & 0.2 & 0.7 \\
\hline Vaud & 11.0 & 79.2 & 6.7 & 0.1 & 3.0 \\
\hline Valais & 33.6 & 61.7 & 4.4 & 0.0 & 0.3 \\
\hline Neuchâtel & 11.9 & 78.3 & 8.6 & 0.1 & 1.1 \\
\hline Geneva & $13.3^{\circ}$ & 70.0 & 9.6 & 0.1 & 7.0 \\
\hline Switzerland & 69.3 & 18.9 & 9.5 & 0.9 & 1.4 \\
\hline
\end{tabular}

Source: Annuaire statistique de la suisse, 1967, p. 27.

Note: All cantons have a German-speaking majority except for those whose percentages are underlined. 
Table 2.2

DOMINANT RELIGIONS IN SWISS CANTONS (IN 1960)

\begin{tabular}{|c|c|c|c|}
\hline Canton & $\begin{array}{l}\text { Protestant } \\
\text { percentage) }\end{array}$ & & $\begin{array}{l}\text { (Potholic } \\
\text { percentage) }\end{array}$ \\
\hline Zurich & 65.8 & & 32.4 \\
\hline Berne & 79.9 & & 19.5 \\
\hline Lucerne & 13.7 & & 85.7 \\
\hline Uri & 7.3 & & 92.6 \\
\hline Schwyz & 6.2 & & 93.7 \\
\hline Obwalden & 3.8 & & 96.1 \\
\hline Nidwalden & 7.6 & & 92.3 \\
\hline Glarus & 58.8 & & 41.0 \\
\hline $\mathrm{zug}$ & 16.2 & & 83.3 \\
\hline Fribourg & 13.3 & & 86.3 \\
\hline Solothurn & 39.3 & & 59.9 \\
\hline Basle Town & 59.8 & & 37.1 \\
\hline Basle Country & 65.3 & & 33.7 \\
\hline Schaffhausen & 71.4 & & 27.9 \\
\hline $\begin{array}{l}\text { Appenzell- } \\
\text { Outer Rhodes }\end{array}$ & 76.6 & & 22.7 \\
\hline $\begin{array}{l}\text { Appenzell- } \\
\text { Inner Rhodes }\end{array}$ & 3.7 & & 96.2 \\
\hline St. Gallen & 37.2 & $\checkmark$ & 62.3 \\
\hline Grisons & 48.0 & & 51.4 \\
\hline Aargau & 52.4 & & 46.9 \\
\hline Thurgau & 60.9 & & 38.7 \\
\hline Ticino & 6.8 & & 91.3 \\
\hline Vaud & 70.7 & & 27.2 \\
\hline Valais & 3.9 & & 95.9 \\
\hline Neuchâtel & 68.5 & & 29.2 \\
\hline Geneva & 45.7 & & 48.3 \\
\hline Switzerland & 52.7 & & 45.9 \\
\hline Source: Annuaire & Statistique de las & Suisse, & p. 29 \\
\hline
\end{tabular}


Chapter III

\section{AMERICAN FEDERALISM}

The United States is the country that invented modern centralized federalism through its Constitution of 1787--that "most wonderful work ever struck off at a given time by the brain and purpose of man". 1 It has been described as a federal country in spirit, in its way of life, and in its Constitution. ${ }^{2}$ Its paramount significance in the development of the modern idea of federalism is clear from statements such as: "Any definition of federal government which, fails to include the United States would be thereby condemned as unreal". ${ }^{3}$ C. J. Friedrich has traced in detail the impact of the American Constitution abroad. 4

\section{THE RISE OF AMERICAN FEDERALISM}

The foundations of the Anglo-Saxon nation in what is now the United States, were laid in 1607 when the first English colony. was planted in Jamestown, Virginia, which after some initial hardships of the wilderness soon proved a success. Attracted by the success of virginia, new colonies began to take root. Plymouth and Boston were planted in 1620 and 1630 respectively; Rhode Island and Connecticut in 1636, and Maryland in 1634. New Netherlands, established by the Dutch in $16 \%$, was conquered by England and renamed. New York in 1664. Charleston was founded by the Carolina Proprietors in 1670. This was followed by the royal province

\section{1}

Statement by Gladstone, the British statesman. Cited in B. Schwartz, The Reins of Power: A Constitutional History of the 2 United States, London: Chatto \& Windus, 1964, p. 2 .

M. J. C. Vile, The Structure of American Federalism, London: 3 Oxford University Press, 1961, p. I.

K. C. Wheare, Federal Government, London: Oxford University 4 Press, fourth edition, 1963, p. 1 .

C. J. Friedrich, Impact of American Constitutionalism Abroad, Boston: Boston University Press, 1967 . 
of New Hampshire in 1679. In 1729 Carolina was split into North and South, centred respectively on wilmington and Charleston. New Jersey had already been founded in 1664 . Pennsylvania in 1681, and Delaware in 1702 were founded by the Quaker, William Penn. Only one more colony, Georgia, was established (in 1733) before Independence was achieved. From the beginning, conditioned in part by their geographical and political circumstances, these scattered little pockets of plantation or trading post planted in the wilderness of the eastern coast of North America, often removed from one another by long distances, developed strong individual identities. While the intervening distances restricted inter-colonial intercourse, the geographical circumstances of the colonies, greatly differing from north to south, gave rise to marked differences in their economies and way of life. Especially marked were the contrasts between the colonies in the extreme north and the deep south. South of the Chesapeake Bay, mountains lie 200 to 250 miles inland leaving a wide and fertile coastal plain with a warm and humid climate, while the New England region in the northeast is almost entirely hilly. Hills rise abruptly not far back from the shore, the terrain is rugged, the soil stony and acid, and the growing season short. Besides these factors, differences in religious faiths and the diverse origins of the colonies also tended to keep them apart.

But while on the one hand these factors tended to keep the colonies apart, there were other factors, both physical and political, that were fostering in them a consciousness of kind. The colonies were hedged by spanish territory to the south and French territory to the north, while the seemingly unsurmountable barrier of the Appalachians to the west narrowed the British horizon and "shut off the great beyond; it took away the temptation to wide expansion 
which was defeating the aims of the spanish and the French . . ". 5 It was natural that as these discrete foundations expanded, they discovered further mutual interests along their borders and became, in that process, "the building blocks" that after nearly two centuries were built into the federation of the United States of America. 6 Civil war and other internal troubles in England during 1641-1653 left all the English colonies to grow in their own ways. This "salutary neglect" was continued by cromwell when he became the Lord Protector of the English Commonwealth in 1653. Being thrown on their resources, the colonies sought their own markets, undertook their own defence, and by 1660 had begun to develop local institutions with a distinctive cast, when with the restoration of the monarchy in England there came a perceptible shift in the policy towards the colonies. But this period of neglect was long enough to give the colonies a sense of manhood. Each--the New England group, Virginia, and Maryland--were by now "full-fledged commonwealths

E. C. Semple, American History and its Geographical Conditions, New York: Houghtón Mifflin, 1933 edition, p.46. As another geographer writes "At first the Appalachians were thought to be so formidable as to prohibit easy communication across them, but this belief. . was abandoned in the light of exploratory accounts [and] the spirit of optimism reached . . by the $1790 \mathrm{~s}^{\prime}$. R. H. Brown; Historical Geography of the United States, New York: Harcourt, Brace 6 \& Co., 1948, p. 96 .

D. Whittlesey, "The United States: The origin of a Federal State", in W. G. East and A. E. Moodie (Eds.), The Changing World, London: George G. Harrap \& Co., 1956, p. 242. The standard work on the colonial period of American history is C. M. Andrews, The Colonial Period of American History, four volumes, New Haven: Yale University Press, 1943-1947. Andrews has beautifully summarized his ideas in The Colonial Background of the American Revolution, New Haven: Yale University Press, revised edition, fifth printing 1948. Especially relevant is the first essay titled "The British Colonies in America", pp. 3-36, in the latter book. Also relevant is D. J. Boorstin, The Americans: The Colonial Experience, New York: Random House, 1958. 
possessing most of the apparatus of civilized life as developed up to that time. - [and] conscious of their peculiar interests and capable of defending themselves against foreign enemy". 7 perhaps the most significant development of the period was the formation of the New England Confederacy in 1643, largely for defence against the Dutch, the French. and the Amerinds. The union, which lasted till 1684, has been regarded as having "In several respects . . anticipated the confederation of 1781 ". 8

Under the influence of their. Confederacy the relationship of the New England colonies with the mother country became "one of sentiment and tradition rather than of compulsion: they were every bit as self-reliant and independent as the British Commonwealth of today". " In 1651 Massachusetts declared "Our allegiance binds not to the laws of England. any longer than while we live in England, for the laws of the parliament of England reach us no longer". 10 "The declaration, was re-echoed in other colonies, and was a favourite statement of many spokesmen at the time of the Revolution. All in all the colonies, by the mid-seventeenth century, were developing into virtual little countries.

After 1660, however, things began to change. Under Charles II New Netherland was conquered and the gap between New England and Maryland was filled by the Middle Colonies (Pennsylvania, New York, New Jersey, and Delaware); the southern frontier was extended by the foundation of carolina. The English parliament laid down a definite economic policy

7

S. E. Morison and H. S. Commager, The Growth of the American Republic, Vol. 1, New York: Oxford University Press, fifth 8 edition, 1962, p. 72 . 9

Morison and Commager, op. cit., footnote 7, p. 71 . 10

Morison and Commager, op. cit., footnote 7, p. 65 .

Cited in W. Miller, A New History of the United States,

London: Faber \& Faber, 1958, p. 56 . 
for the colonies in the Acts of Trade and Navigation. The Acts were motivated by mercantilist doctrine, which held that the individual and corporate enterprise should be controlled by the state to enhance the wealth of the nation. The Empire was regarded not as a federation but as a unit, a consolidated state, in which it was supposed that the colonies should contribute to national wealth and power by giving employment to imperial shipping and by producing articles which the home country. would otherwise have to buy from foreign lands; such as sugar, tobacco, rice, naval stores, and other raw materials. The mother country should, in return, supply manufactured goods to the colonies.

Though the first elaborate Navigation Acts were passed in 1651, little effort was made to enforce them. With the restoration of the monarchy, however, the parliament "set about to closing the breaches in the mercantilist walls which remained after the Act of $1651 "$. 11 To the basic Acts passed between 1660-1663, some important ones were added in 1696 which with a few minor alterations and extensions were operative for nearly a hundred years. 12

Till late in the eighteenth century the Acts of Navigation were honoured more in the breach than in the observance, but the mercantilist system had served the mother country well. As an Englishman observed in 1766 an. "American [is] apparelled from head to foot in our manufactures. . he scarcely drinks, sits, moves, labours, or recreates himself without contributing

II

J. C. Miller, origins of the American Revolution, London: 12

Faber \& Faber, 1945, p. 56.

The Acts of Navigation and Trade restricted all trade between the colonies and England to English ships; enumerated commodities that could be sent nowhere but to England; and made it necessary for all imports to the colonies to be routed through English ports where taxes were collected. Later industrial manufactures in the colonies were generally restricted. In 1673 limits were put on intercolonial trade itself. 
to the emoluments of the mother country". ${ }^{13}$ To the colonists, however, the system was most unpalatable, especially as it came after that period of "salutary neglect" during which the colonies had attained manhood. The resentment is apparent from the declaration of the Massachusetts General Court in 1651, cited above.

It was an important factor in this early rise of selfconsciousness and independence in the English colonies that wherever the English went they carried with them in theory the rights of free-born. Britons. In the charter of the very first English American colony (i. e., Virginia) it was clearly stated that the colonists were to enjoy all the liberties, franchises, and immunities "as if they had been abiding and born within this. . . realm of England". Because of this, almost from the beginning the colonies began to rear their own fabric of constitutional government, contending for a stronger representative system, control of the purse and fuller guarantees of personal liberty. Soon after their inception each of the colonies could boast of a popular assembly elected by citizens possessing the prescribed property qualifications. Virginia had its first elected assembly twelve years after its foundation, and Massachusetts after only four years. Founders of the proprietary colonies, in order to attract settlers, invited their people to participate in the government of their respective colonies.

The colonial society, like English society itself, was stratified virtually from the beginning. The colonial assemblies were elected by property owners alone. Being controlled by men. of property interested in resisting taxation by the mother country, the colonial assemblies developed a sense of unity vis-à-vis the mother country.

From their small beginnings the assemblies soon grew in. diginity and took some of the pomp and circumstance long associated with the House of Commons in England. Exercising the right of laying taxes, raising troops, incurring debts, issuing currency, fixing the salaries of royal officers

13

Reported in London Magazine, 1766, Vol. 35, p. 34. Cited in Miller, op.cit., footnote 11, p. 13 . 
and appointing judges to the colonial courts, the assemblies became, in course of time, virtual "little parliaments" which by the eighteenth century, like the Parliament in England "used their control of purse to usurp the control of the entire government". 14 The assemblies were the

- . laboratories in which were formulated all the grievances of the colonists against the government of England. They were training schools where lawyers could employ their talents in political declamation, in outwitting royal officers by clever legal devices.15

As C. A. and M. R. Beard remark, possessing a ruling class experienced in the art of government and commanding economic resources of great magnitude, the colonies needed only two things to transfer them into an independent nation-a mastery of the art of warfare and the capacity to cooperate on a continental scale. Extreme necessity of self-defence against the natives, and later the consciousness of their encirclement by the hostile imperial power of France taught them both. Thirty-one years out of seventy-four from 1689 to 1763, the colonists were battling by the side of the British army against France and the natives. This helped to give them valuable "experience in the use of that unanswerable argument of sovereignty, military force". 16 Military conflicts and the threat of a common, enemy in France taught the colonies their first lessons in cooperation. Though the Britishsponsored Albany Congress for intercolonial union in 1754 failed, the seven years war that followed drove the colonies into cooperation on a "continental" scale, and the conquest of New France removed the French threat almost for ever.

The common threat from the French having disappeared, the colonists, with their enhanced self-confidence, were now ready to remove any source of common irritation. Fortunately for them, and unfortunately for the Empire, soon after the French war fresh taxes levied on the colonies by the British

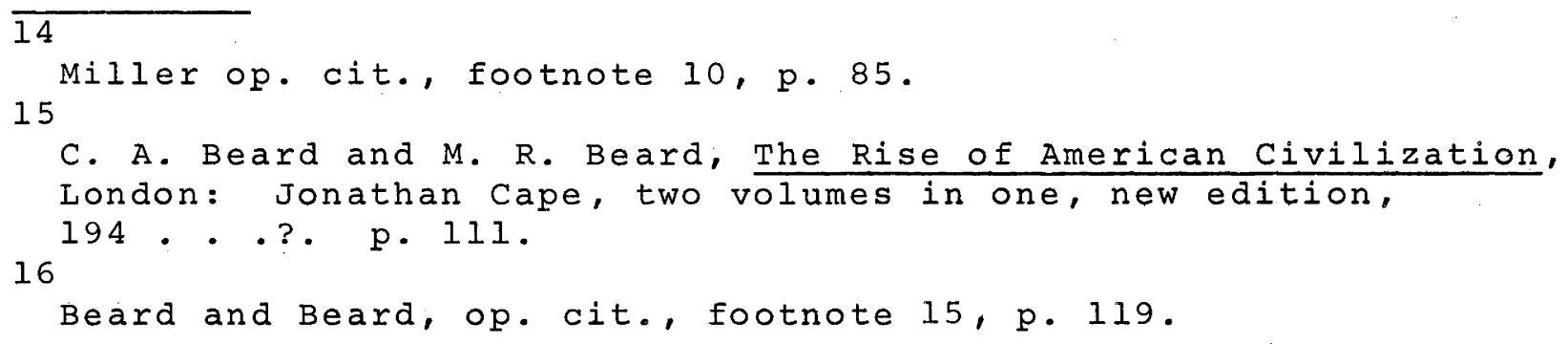

C. A. Beard and M. R. Beard, The Rise of American Civilization, London: Jonathan Cape, two volumes in one, new edition, 16 
government were of a nature that alienated all sections of the colonies in America, while efforts were made to strengthen the power of the crown by reducing the dependence of the Governors on the Assemblies. This made the British imperial government the next target for colonial action.

The Seven Years War had almost doubled the national debt of England and increased the expenditure on the colonial administration in America by almost four times. The imperial government decided to derive this additional revenue for defence and administration of the American possessions from the colonies themselves. With this view the Acts of Trade and Navigation were tightened up, and new and supplementary Acts were passed. The sugar Act of 1764 prohibited colonial imports of molasses from the French and spanish West Indies. This greatly hurt the New England colonies which had based a flourishing distilling industry on these imports. The same year, the stamp Act made it compulsory for every document in daily use to bear requisite stamps. Then came the Currency Act (1764) which excused English merchants from accepting paper money in the American colonies in payment for their debts. It also put a ban on the issue of paper money in the colonies. To cap these all the Mutiny Act was passed in 1765 , providing for despatch of troops to America for maintaining order. "By the Quartering Act the colonies were made to bear the burden of supporting the troops. Already in 1763 the Royal proclamation Line had shocked the land-hungry colonists by closing to them "any purchases or settlements" in the vast region between the Alleghenies and the Mississippi. from Florida to Quebec.

While different taxes had affected the different colonies differently, the stamp Act stung all of them together. Further, by imposing a duty that affected all sections of the society, the Act made the colonial grievances universal. A violent united protest was made by the stamp Act Congress (June. 1765), which succeeded in getting the Act repealed in 1766 . Tempers cooled for some time, to rise soon against the Townshend Duties which resulted in the Boston Massacre of March 1770. The mother country yielded again. Then followed the Boston Tea Party of December 16,1773 in protest against the grant 
of monopoly to the East India Company for trade in tea to America. This taxed the patience of the imperial government. Early in 1774 the "Coercive" or "Intolerable" Acts were passed according to which the port of Boston was.closed, the charter of the colony revoked, and meetings in the town banned; capital offenders were to be sent to England for trial, and quartering of troops in Massachusetts was legalized. By the Quebec Act the boundaries of quebec were extended to the ohio river, and toleration was granted to Roman Catholics in Canada. It was this last Act that prompted Virginia to call for the First continental congress in september 1774. And as George III wrote, "the die [is now] cast, the colonies must either submit or triumph". 17 In the protracted struggle that ensued the colonies ultimately triumphed, and the thirteen colonies were transformed into the United states of America.

Though the independence of the United States was recognized by nations of the world, the new nation was still very weak. Indeed, says Adams, there scarcely was a nation, for the confederation which bound the old colonies together had neither the reality nor the semblance of power. Inaking an effective central government, it was "merely an empty shell of loose union". 18 As usual, when the war was over, there were a couple of years of hectic but spotty prosperity, and

\footnotetext{
17

George III in a letter to Lord North; cited in Morison \& 18 Commager, op. cit., footnote $7, \mathrm{p} .176$.

J. T. Adams, The Epic of America, Boston: Iittle, Brown \& Co., 1947 reprint, p. 87. It should, however, be conceded to the credit of the confederation that it was able to enact the North-west ordinance of 1787 through which the territory between the Alleghenies and Mississippi ceded by the states to the United states after the adoption of the Articles was to be organized and governed. Merril Jensen in his The New Nation: A History of the United States During the Confederation, 1781-1787(New York: Knopf, 1950)contends that the picture given by The Federalist is overdrawn, and that far from being a period of disintegration and disillusionment it was a period of "exuberant optimism". But that the government of the Confederation was weak and inefficient, remains a fact.
} 
then the crash came. Discontent was rife, and an exodus began from the older colonies to the new western. frontier. The success of the new experiment began to look doubtful. Britain was treating the colonies with contempt and was not carrying out the terms of the peace treaty. Neither were the United States; and the Confederacy was too weak to force either England or its own people to do so. The future of the country appeared bleak, for "if the states were to leave their debts unpaid, become a mere pack of small republics quarrelling among themselves . . [ [hey were likely to be] gobbled up singly by some European power". ${ }^{19}$ Alarmed by these grim prospects, national leaders rose to the occasion and at last in February 1787 the Congress sent invitations to the states to elect delegates to a convention to meet at Philadelphia in the month of May for the sole purpose of revising the Articles of the Confederation. After about three months of deliberations the document was complete.

It was a novel compromise between unitary and confederal principles of government, for, as Tocqueville noted, here for the first time a federal government was created, in which the central and the unit governments both acted directly on the people of the respective units. 20 This helped to make the central government an effective authority over the whole of the nation. It could make and enforce law on matters of common interest allotted to it by the constitution, while the unit governments surrendering their sovereignties (at least in part) to the centre retained autonomy in respect of all matters not specifically given over to the central control. The constitution created two Houses of the central legislature--a lower House consisting of representatives elected on the basis of population, and an upper House having equal representation of each unit, big or small. This was a device to reconcile the interests of the smaller states. A supreme Court was created as the ark of the federal covenant.

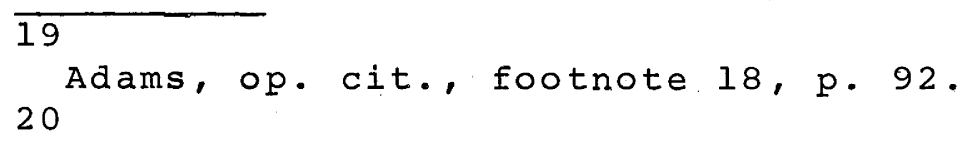

A. de Tocqueville, Democracy in America, New York: Knopf, two volumes, 1945 reprint. 
Judges to the court were to be appointed by the president, with the advice of the senate, for life terms on good behaviour. It may, however, be noted that the U. S. Constitution was not, as is sometimes erroneously believed, a product of manufacture rather than of evolution, though, no doubt, it was one of the most constructive achievements of its age, 21 The system, as it finally evolved, was built upon an experience of a century under the British Empire. It was an empire in which powers were distributed between central and local governments. Parliament had controlled all matters of general concern, while the colonial assemblies had exercised practical control over all matters of local interest. It is said that "The British Empire of the mid-eighteenth century, in operation and in fact, . . [though] not in theory or law, was a federal empire". 22

\section{POLITICO-GEOGRAPHIC FACTORS IN THE RISE \\ OF AMERICAN FEDERALISM}

\section{Factors Giving Rise to Regional Identities}

There was something in the very nature of the American colonies that favoured their rise as a federation rather than an amalgamated unitary state. In this politics, social forces, and environmental circumstances, all played their hand. looking at the physical factors of the environment we find that certain features of the Atlantic seaboard of America were destined to have a marked effect on the future development of political life in the area. The many bays and inlets on the Atlantic coast provided opportunities for numerous small foundations rather than a few large ones. Thus thirteen separate colonies came to be established on the eastern seaboard south of quebec, each growing independently of the others, and each clinging tenaciously to its own character. So when independence came there were almost thirteen different nations each possessing its own little "homeland". Any union of these

\footnotetext{
21 22

Schwartz, op. cit., footnote 1, p. 2 .

A. Nevins and H. S. Commager, America: The story of a Free People, Oxford: Clarendon Press, third edition, 1966, p. 64 .
} 
was, by their very nature, bound to be a federation.

Rivers on the eastern seaboard of America, facing Europe, did not form an interconnected system like that of the Mississippi. Each one flowed more or less directly to the sea. In New England they were hardly navigable. South of it the rivers flowed in drowned river valleys. The Hudson and Delaware rivers, as also the Chesapeake, were navigable right across the coastal plain, and were enormously important, though only the first provided the real corridor through the highlands. Most of the others were navigable only short distances from their mouth. The southern rivers in general, though navigable for only relatively short distances to the "Fall Iine", did provide basic transport, though connected into a system only by the coastal waters. Each accommodated along its easily accessible banks a narrow isolated border of settlements "hugging closely to the rivers which kept them in touch with the sea and thus with Europe". 3 Behind the colonies stretched a tangled growth of virgin forests that were highly difficult and dangerous to penetrate.

Distance and isolation played a very important role in the rise of strong regional identities among the colonies. In the beginning these settlements were only dots on the wide open spaces on the seaboard, each separated from the others by long distances without any developed and with few natural means of transport and communication. The natural cover of forests in which dangerous beasts and hostile Amerinds took cover helped further to heighten this effect. Besides, the nature of the colonial economy and politics offered little incentive for intercolonial intercourse. Each colony. was separately governed from london; and whatever trade the colonies possessed was, for a long time, confined to maritime trade with the mother country. Great distances and hazards in the river and sea navigation along a dangerous and unlighted coast discouraged trade and commerce between the colonies. Thus "The very forces of physical geography would seem to

23

C. H. Van Tyne, The Causes of the War of Independence, Boston: Houghton Mifflin Co., 1922, p. 74 . 
have conspired. . to make the colonies self-centred, individualistic and disunited". ${ }^{24}$ In 1673 the English Acts of Navigation and Trade further encouraged this regionalism by restricting intercolonial commerce. The compound effect of this was that, in the words of a contemporary, the colonies remained "as much divided in their interest and affection as Christian and Turk". 25

As the colonies were spread in a north-south direction, covering sweven Feen degrees of latitude, their environmental circumstances were greatly varied. Besides the differences in climatic conditions that this latitudinal extent implied, geological and topographical circumstances of the colonies were also highly different. North of New York cultivable lowlands were extremely. limited. Much of the arable area lay in the valleys of the Connecticut and Mohawk rivers away from the coast. This was in sharp contrast to the everwidening coastal lowlands to the south. This, allied with climatic and social factors, gave rise to completely different economies in the northern colonies (New England) and those of the south, while the Middle Colonies shared some of the characteristics of both. Being an area of rugged topography with very limited lowlands and poor soils, New England developed an economy essentially based on small, well-tilled farms, and with a large number of people engaged in lumbering. But in the south the wide coastal lowlands allied with the humid tropical climate and large land grants favoured largescale plantation economy carried with the help of slave labour from Africa. In course of time the contrast between the northern and southern colonies further increased as the New England colonies developed a maritime interest in fishing and trade to supplement the meagre produce from the 1 and. The contrast was only to be further heightened after independence as industrialization came to America and machines became as essential to the North as the slave was to the south. 
The diverse origins of the colonies, the dissimilar provisions of their charters, and their different social and religious foundations coupled with their democratic heritage from England, helped further to enforce separate colonial identities. Because of popular participation in the government of the individual colonies the people in the respective areas of British America, unlike those in spanish America, were sentimentally attached to the political-administrative peculiarities of their.colonies. This helped to give them a set of popularly recognized regionally-grouped diversities which, even in the absence of any marked ethnic differences between the colonies, provided them with a durable federal base: Each colony had remained differently responsible to the crown. Before the establishment of the Board of Plantations and Trade in 1696, there was no common coordinating agency for the colonies. And even after the Board was founded, its functions remained largely supervisory, for the ultimate decisions rested with the crown. Thus till the close of the Seven Years War, the relationship with the mother country remained an independent and distinctive one in the case of each of the thirteen colonies.

Though no doubt exaggerated, the following observation of a contemporary traveller (during the seven Years War) gives some idea of the prevailing differences between the British American colonies: "fire and water are not more heterogeneous than the different colonies in North America". 26 From these inherent differences among the colonies, it was apparent that if the colonies ever united, they at least could not completely forgo their rights to manage their own regional affairs. Each colony having enjoyed the taste of self-government for so long a period, was loath to subordinate its interests completely to a unified central government. Thus, if union was ever to be achieved, the salvation of the colonies lay only in a federation--that halfway house between complete unity and complete separation.

26

Cited in Van Tyne, op. cit., footnote $23, \mathrm{p} .82$. 


\section{Folitico-geographic Factors Fostering Union}

Despite a number of conflicting diversities that made many like James otis feel, as late as 1765 , that "were these colonies left to themselves tomorrow, America would be a mere shamble of blood and confusion", there had all through been certain under-currents of unity which could and did make the colonies forget their family quarrels to cooperate for a common cause; only the cause would have to be clearly defined.

A very important factor in the rise of the sentiment for intercolonial union was what some historians have called the "sense of special destiny", though we do not think that this sense developed because the colonists thought that "they had before them a career such as no other nation was likely to achieve". Nor, perhaps, did "this faith [arise]... naturally from the general wealth of the country, the energy of the people, and the atmosphere of freedom which enveloped both". 27. The real factors that seem to have given rise to this sense of common or special destiny in the colonies were that all the thirteen colonies by virtue of their geography, politics, and culture formed a distinct group surrounded by the French in the north, spanish in the south, and blocked by the seemingly unsurmountable barrier of the Appalachians to the west.

The wide and wild barrier of the Appalachians seemed so hard to cross that the coastal settlements grew fairly thick and sturdy, with well-rooted ways, before the colonies embarked upon trans-Appalachian expansion. The net result was that the colonies, which were only widely scattered little pockets of plantation or trading posts till 1660, became by 1760 virtual little countries, though still scattered but much solider and more connected as the area between the Appalachians and the sea was gradually filled in, and settlements began to spill over into the ohio valley. [Fig. 3.1]

\section{7}

Nevins and Commager, op. cit., footnote 22,1942 edition, p. 50 . 


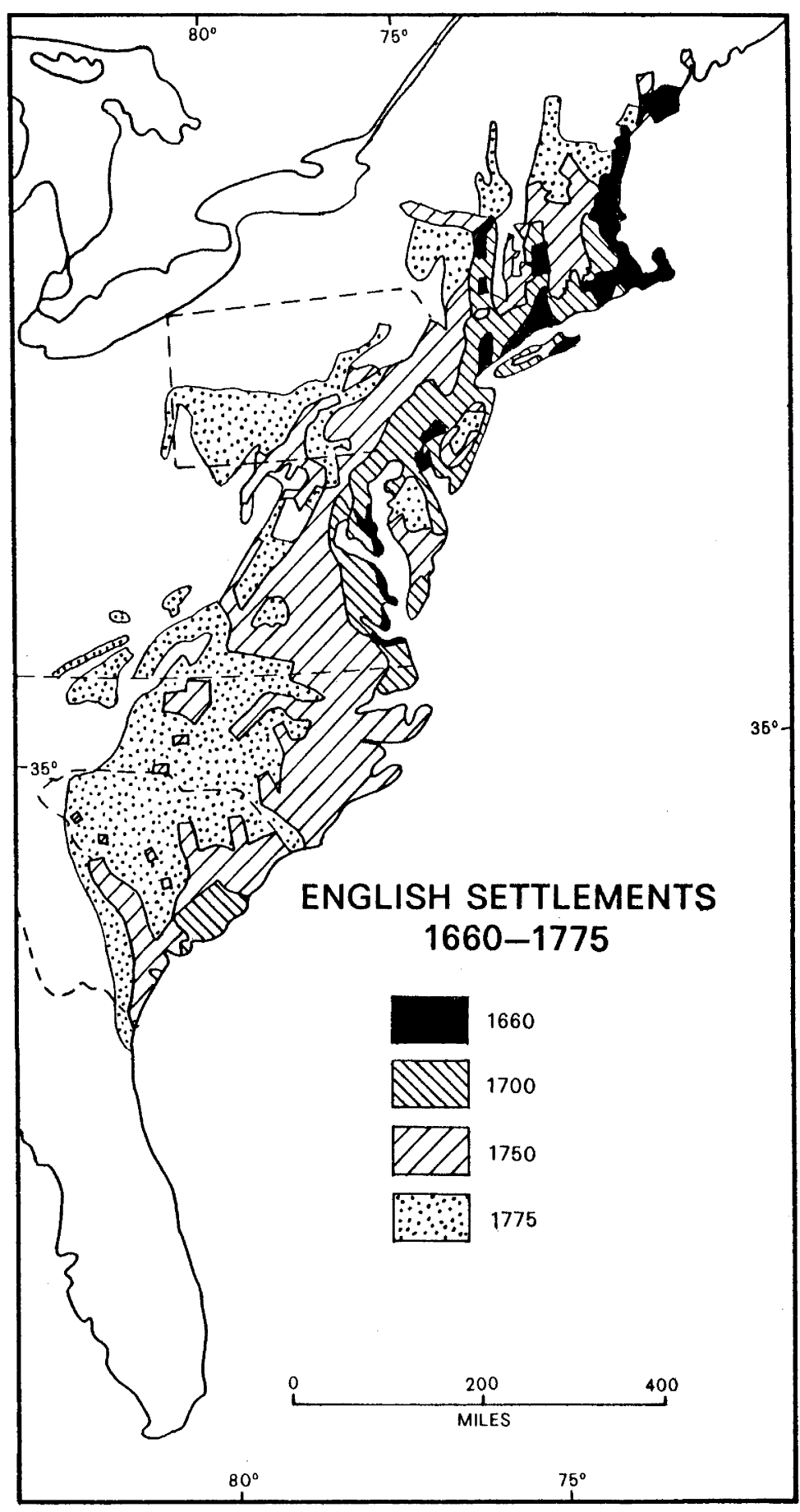

Fig. 3.1 SPREAD OF ENGLISH SETTLEMENTS, 1660-1775. The colonies were only widely scattered little pockets of settlement till 1660; a century later, though still scattered, they were much solider and more connected as the area between the Appalachians and the sea was gradually filled in, and settlements began to spill over into the Ohio valley. (Adapted from maps A, B, $C$, and $D$ on Plate 60 of C. O. Paullin, Atlas of the Historical Geography of the United States, 1932.) 
That all the colonies hemmed between the mountain and the sea had a common general origin (though diverse specific origins), a common language, and a common metropolis to deal with, helped greatly to foster in them a strong consciousness of kind. While on the one hand, it fostered consolidation, on the other, it imparted to the colonies a sense of a wellcarved out common territory of inhabitance, a factor which invariably gives rise to the sense of a common fatherland-the feeling that imparts to a people that strong sense of belonging together which is the sine qua non for the growth of a Nation. The facts of political geography further helped to enforce this feeling as the colonists found themselves surrounded on three sides by the territories or at least the claims of imperial France and spain.

When in 1677 the French explorer La salle sailed all the way down the Mississippi to its mouth on the Gulf, the entire basis of the French power in America was changed. In place of a thinly populated ribbon of settlements along the banks of the st. Lawrence, cut off from Europe during all those months of winter when the st. Lawrence is frozen, the way was now open for a great western empire extending in a hugh arc from the estuary of the st. Lawrence to the delta of the Mississippi. This establishment of a French frontier down to their borders along the west appeared to the English colonies to pose a great danger to their survival. It seemed to "restrict their [westward] growth as a dam holds back a stream". 28 By a line of forts and trading posts the French had steadily marked out a huge crescent-shaped domain stretching from Quebec through Detroit and st. Louis down to New orleans on the Gulf. This would pin the colonies to the narrow belt east of the Appalachians. Further, France was a stronger nation militarily than Britain, and the "highly centralized government of New France was better fitted for conducting war than the loose association of the ill-coordinated colonial governments". 29 Thus as a contemporary army officer put it

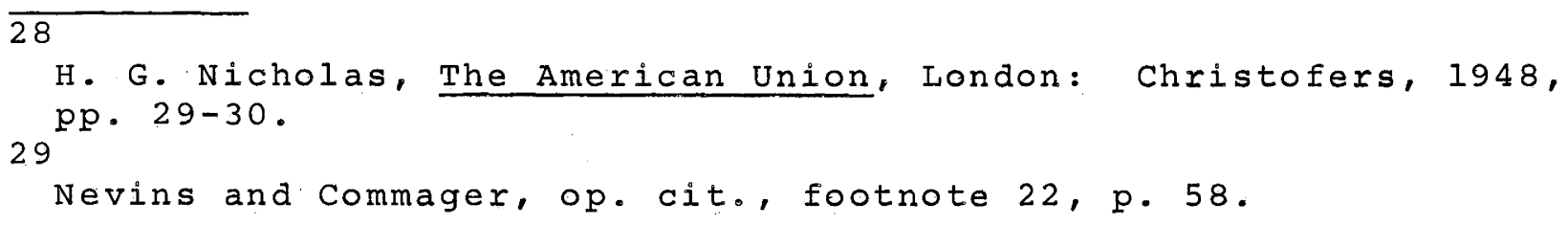


before the House of Commons "They [the French] hold our Colonies between the two Ends of a Net which if they tighten by Degrees, they may get all of them into the Body of it, and drown them into the sea". 30

The overall effect of the encircling presence of France and spain was to squeeze the colonies into unity. Thus

- . though they carefully nursed their dislike of one another, [the English colonies] had grown by 1750 into a veritable nation of nearly a million and a half persons who were feeling increasingly hemmed in and harassed by the maritime activity, the territorial claims, and border violence of New France. 31

As the presence of the French threat had united the colonies and goaded them into action, so the disappearance of New France in 1763 helped to bring them into a compact to struggle for complete sovereignty.

With no powerful neighbours now thundering on their gates, the governing classes of the thirteen American colonies were free to try their.strength with the governing classes of England.. . [and indeed] the very war that set the bells of London ringing with acclaim to the news of victory borne on every breeze opened the way to another explosion. 32

Observant people like that anonymous French writer in the early years of the eighteenth century were long thinking this possibility. If Canada fell, wrote this writer, then the colonies would "unite, shake off the yoke of English monarchy, and create themselves into a democracy". 33

After the removal of the French threat, the raison d'etre of colonial cooperation appeared, temporarily, to vanish. But fortunately for the colonies the British government through its new measures to enforce the Acts of Navigation and Trade, and through its new duties and taxes, and legislation affecting all sections of the American society, provided the colonists, now risen high in self-esteem, the much-needed spur to cooperation and united action. While the various

\section{0}

Cited in R. W. Van Alstyne, Empire and Independence: The International History of the United States, New York: John 31 32 wiley \& Sons, 1965, p. 14.

Miller, op. cit., footnote 10, p. 89. 33

Beard and Beard, op. cit., footnote 15, p. 120.

Cited in Van Alstyne, op. cit., footnote 30 , p. 3 . 
other Acts affected only certain groups of colonies at a time, the quebec Act and the stamp Act were the ones that alienated all the regions together. The colonies now came increasingly to the realization that British overlordship was the greatest stumbling block in the way to their fuller expansion and progress. It was this feeling, and the continued irritations offered by Britain, that finally led the colonies to revolt and achieve independence.

A further geographical factor of great importance was that as the eighteenth century wore on, as the population and wealth grew, and as the society became more complex, so economic and social ties in the colonies began to cut across intercolonial boundaries. (It needs to be remembered that salvery was till then not an issue of so great a significance as it later became.) In the rise of cross-cutting intercolonial cleavages the frontier of settlement in the west played a very important role. Stretching like a cord of union (to use Turner's telling phrase) on the western margins of the colonies, the frontier was the zone of most rapid and effective Americanization. The wilderness of the frontier mastered the colonists and "the outcome [was] not the old Europe, not simply the development of Germanic germs", but "a new product that is American". 34. The net result was the rise of a composite American nationality, "English neither in nationality nor characteristics". ${ }^{35}$ The pioneers on the border were everywhere stamped with the same traits.

It should here be noted that despite separate colonial identities, people all through the American colonies were much of a piece. As de Crèvecoeur. wrote in 1782, the colonies from the beginning served as an asylum where "the poor of Europe met together. [Where] Everything... tended to

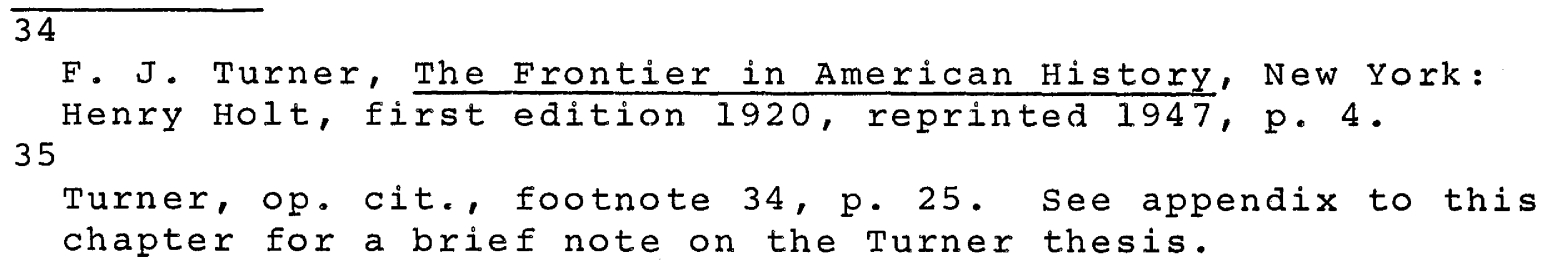


regenerate them . . " . 36 The old differences--religious and linguistic--that divided them in Europe, were largely forgotten for "Hither they had fled not from the tender embraces of the mother but from the cruelty of the monster". 37 Save for a small number of Germans in Pennsylvania and the Dutch in New York, the non-English-speakers were so scattered throughout the colonies that they of necessity had to merge and mingle with the English-speaking majority and adopt their culture. ". . at the time of the Revolution probably over. three-fourths of the white colonists were still of British blood". 38 The importance of this melting-pot character of the whole of America south of quebec, will be borne out by later discussions which will seek to show how because of this the United States was saved from the divisive cleavages that have often plagued the federal relationship in Canada.

A further force in this direction was the apparently mutually complementary nature of the colonial economies of the various sections of British America in the later eighteenth century; only later developments introduced the sectional economic interests that proved divisive. The force of this argument will be appreciated if we remember that sane thinkers like John Adams were dreaming as early as 1775 of a united America which even "the united force of Europe will not be able to subdue". 39

Scholars may differ from Charles Beard when he says that the U. S. Constitution was "an economic document drawn with superb skill by men whose property interests were immediately at stake", 40 but most will agree that the constitution was an

36

Hector st. John de Crèvecoeur (1735-1813), Ietters from a Farmer. Cited in D. Potter and. T. G. Manning (Eds.), Nationalism and sectionalism in American History: select Problems in Historical Interpretation, New York: Henry 37 Holt, 1949, pp. 26-27.

Thomas Paine, Common Sense, a pamphlet published on January 10, 1776. Cited in Potter and Manning, op. cit., footnote 38 $36, p \cdot 16$. 39

Nevins and Commager, op. cit., footnote $22, \mathrm{p} .24$. 40

Cited in Van Alstyne, op. cit., footnote $30, \mathrm{p} .1$.

C. A. Beard, Economic Interpretation of the Constitution of the United States, New York: The Macmillan Co:, first published 1913, 1948 reprint used, p. 188 . 
economic document in the sense that the nationalism of the Constitution "was created by a welding of economic interests that cut through state boundaries". 41 As Beard puts it, the Southern planter was as much concerned in maintaining order against slave revolts as the creditor in Massachusetts was concerned in putting down shay's desperate debtors. The consolidation of interests in support of the Constitution was nationwide. The following excerpt from a contemporary writer would explain how the constitution promised benefits to all sections of the Union. 42

The eastern states will receive advantages... [from] the regulation of trade; . . Connecticut and New Jersey will receive their share of general imposts; the middle states will receive the advantages surrounding the seat of government; the southern states will receive protection, and have their Negroes represented in the legislature; and large back countries will soon have a majority in it. This system promises a large field of employment to military gentlemen, and to the clergy, salary men and others depending on money payments.

Further, even though the imperial relationship in the case of each of the colonies remained independent and distinctive, and efforts at intercolonial cooperation through the institution of the Board of Trade and Plantations were only partly successful, all the colonial governments, whether directly under the Crown or not, had the same basic problem of reconciling the interests of the colonists with those of the mother country. There was a strong tendency for this situation, to find expression through similar institutions of government. 43 This helped to make America what has been termed as the "most common-schooled" nation in the world.

Thus, as Boorstin says, 44

41

Beard, op. cit., footnote 40, p. 30. See appendix to this 42

chapter for a brief bibliographical note on the Beard thesis.

R. H. Lee, Letters of a Federal Farmer, written in october

1787. Included in potter and Manning, op. cit., footnote 36 , 43 p. 58 .

H. C. Allen, The United States of America, London: Ernest 44

Benn Ltd., $1964, \mathrm{pp} .34-35$.

Boorstin, op. cit., footnote $6, \mathrm{p} .362$. 
There is. . no paradox in the fact that the colonies were willing to "revolt" and yet unwilling to unite; on the contrary the two facts explain each other.... And these were the reasons which would make American federalism difficult, necessary, and in the long run spectacularly successful.

As Merritt writes, the colonies "demonstrated their willingness to think of themselves as a single community without permitting the collective concept to overshadow the importance of the individual colonies. It was this image of unity in diversity, essential to American federalism that carried over into the Constitutional Convention of 1787" and was responsible for the rise of the peculiar political structure of the United states. 45

TRIALS OF FEDERALISM : UNEASY BALANCE, THE STORM,

\section{AND CALM}

The Constitution came into operation in March 1789 , but the new government was weak and untried. The Constitution had been ratified in many states by the narrowest margins, and even if a majority of population approved of it, the dissenting minority was nearly as large. Fortunately no sectional parties had yet come, into being. The only division was between the Federalists and the anti-Federalists--a division that cut across colonial boundaries. The young government was, therefore, saved from divisive sectional contest and a partisan president.

There had all through been a certain amount of friction between the growing mercantilism of the North and the planter class in the south. But at the time of constitution-making the division between the slave and free states was not so sharp, even though their different circumstances had fostered the development of different patterns of life in North and south. At the time the Federation was inaugurated, many

R. L. Merritt, "Perception of Unity and Diversity in Colonial America, 1735-1775", paper read at the 6th Congress of the International Political Science Association, oxford Round Table Meeting, September 19-24, pp. 1-20 text 21-30 tables. Reference on p. 15. 
Southerners themselves were in favour of a gradual abolition of slavery. But in 1792, with the invention of Whitney's cotton gin, cotton became king in the South. This doomed the slave to his slavery, and the pattern of southern culture was now fixed for a long time to come.

In the meantime industrialization received a great impetus in the North as cotton textile machinery began to be manufactured in America. Though differences between the North and South had always existed, these came to be increasingly emphasized during the next half century as the two sections became devoted more and more to contrasting economic interests. Fortunately, however, a new section, the West, soon to become of great importance, was emerging to the west over the mountains. Promising rich rewards both to the North and South the New West helped to maintain federal balance between the two. It also helped to win their loyalties for the union government which alone controlled the entire Western lands.

It soon became apparent that the North and South were drawing so far apart that union could be maintained only so long as the west was able to maintain the balance between the two sections. In the beginning, because of the Mississippi river, which was the only outlet to the sea for the whole of the western area, the relations between the west and south were closer. Further, as both the regions were agricultural, their interests were also to some extent similar. This appeared to tilt the balance against the North. In fact this liaison between the south and, West was so disturbing to the North that Josiah Quincy of Massachusetts declared in the Congress in January 1811 that if Louisiana were to be admitted as a state--as she was the next year--the bonds of union would be dissolved, and that "as it will be the right of all, so it will be the duty of some, to prepare, definitely, for a separation; amicably, if they can; violently, if they must". 46 During the 1812-1815 war with Britain the malcontents of

46

Cited in Adams, op. cit., footnote 18, p. 130. 
New England had gone to the very verge of secession. They had sent delegates to a convention at Hartford, Connecticut, in 1814, to consider the question of setting up a separate union?

Soon after the war large scale manufacturing became very important in New England and the Middle states. This further intensified the economic conflict between the agricultural South and a North which was becoming increasingly industralized. slaves were as vital to the southern plantations as machines became to the Northern factories. The West was still set off against both the North and south, though its southern section was becoming slave. Slave and free states had been admitted alternately, and there were eleven of each, giving the two economic systems equal representation in the senate. However, the inevitable conflict came in 1819 with the controversy over the admission of Missouri as a slave state. Missouri lay north of the line which had hitherto tacitly been accepted as marking the northern limit for slavery. The North was, therefore, thrown into ferment by what seemed to it as a new aggressiveness on the part of the south. The matter was settled by the Missouri. Compromise; by which Maine and Missouri both were admitted, one as slave and the other as free, but extension of slavery in the Louisiana Purchase area to the north of latitude $36^{\circ} 30^{\prime}$ was prohibited.

Till now the West was in closer alliance with the south because of the Mississippi. The North had all through been viewing this alliance with concern. But with increase in industrialism and decrease in agriculture, the North needed. markets as well as food. Part of the problem could be solved if the West and North could be linked. In 1825 through the efforts of De Witt Clinton, the Governor of New York, the Erie Canal, following the lowest watershed between the Atlantic and the Great Lakes, was opened and helped to make New York city the principal gateway of commerce for the northern West, and the financial centre of the country. The whole of the Mississippi valley was no longer an enclosed. area which could trade only down the river. The human geography of the whole area was rapidly changing. And this greatly influenced the political geography of the nation. 
The south was bound to view the new relationship between the North and west with alarm, especially because while slavery restricted free immigration to the south, the nonslave states of the North were increasing their population very rapidiy, and thereby constantly threatening to put the South into a minority position. The south now realized that safety lay in limiting the powers of the central government over the states so that they could maintain their institution at least within their own area. But the North which, for the first fifteen years of the century, was talking of secession and nullification, now became strongly federalist as the new link with the west began to offer it new rewards. It became clear that the former postures of the North and south in the federal relationship would soon be reversed. When the North-sponsored tariff bill of 1828 was passed with the support of the West, the south was indignant. south Carolina threatened secession. The legislature of the state passed an ordinance of Nullification, and armed resistance to the national government was threatened. But North and south were still fairly evenly balanced in the senate, and a compromise was soon reached. However, the contest was on, and each of the two eastern sections in order to get better of the other continued to vie for the support of the ever expanding West.

Secessionist voices were soon to be heard again as the question of the admission of Texas to the union came up. While the Vermont legislature "solemnly protested" (November 1837) against the admission "of any state whose constitution tolerates domestic slavery", Calhoun, of south Carolina, as solemnly announced that any attempt to exclude a state for reasons of its "peculiar institution" would be virtual dissolution of the Union. Though recognition was given to the independence of Texas from Mexico, its admission had to wait till 1845. In the meantime two by two, slave and free, new states had been admitted to the Union: Michigan-Arkansas, Iowa-florida. The admission of Texas was balanced by that of wisconsin. (Territorial growth of the united states is shown in Fig. 3.2.) 


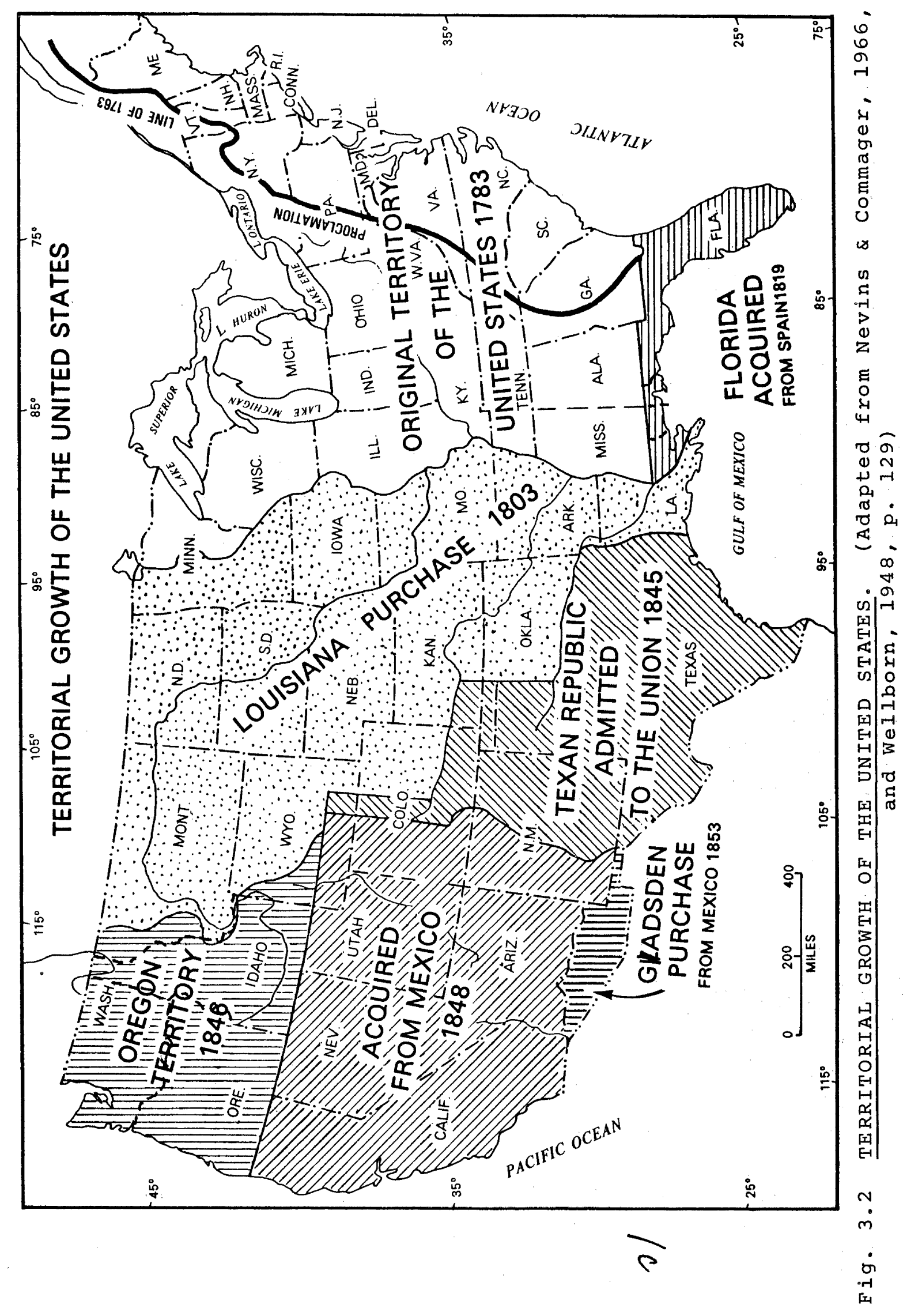


But the collapse of this uneasy balance was well in sight. The West continued to expand, but now in areas that were hardly suitable for plantation, and, hence, for slavery. The south appeared doomed to a minority position at the federal level. As new territories were conquered or acquired from Mexico, and the question of admitting new states came up, the thin cord of union that had bound the North and south reached almost the breaking point. When in 1850 the question of the admission of California as a free state to the Union came up, it was with very great difficulty that Henry clay was able to bring about a temporary compromise (truce?) by which California was admitted as a free state but New Mexico and Utah were left to be organized as territories without any mention of slavery or freedom. In order to satisfy the south a more stringent fugitive-slave law was passed. Now while the southern spokesman, Calhoun, was warning the senate to the imminent danger of United States' "end in disunion" (March 4, 1850), it was now a Massachusetts senator who was speaking ". . not as a Massachusetts man, nor as a Northern man, but as an American.. . for the preservation of the Union." 47 What a contrast to the speech of Massachusetts representative Josiah Quincy delivered in January 1811 (cited above)!

\section{7}

Speeches cited in F. W. Wellborn, The Growth of American Nationality 1492-1865, New York: Macmillan Co., 1948, pp. 748-749. The broader transitions in southern life which led to Nullification are analyzed in C. S. Sydnor, The Development of Southern Sectionalism, 1819-1848, Baton Rouge: Louisiana State University Press, 1948. The psychological anxieties which beset slaveholders are finely portrayed in C. G. Sellers, Jr., "The Travail of Slavery" in Sellers Jr. (Ed.); The Southerner as American, Chapel Hill: University of North Carolina Press, 1960, pp. 40-71. The latest fullscale study of nullification is W. W. Freehling, prelude to Civil war: The Nullification Controversy in south Carolina, 1816-1836, New York: Harper, 1966. Also relevant is A. O. Craven, The Growth of Southern Nationalism, 18481861, Baton Rouge: Louisifana State University Press, 1953. J/ 
However, the compromise proved only a calm before the storm. The West by its very nature was becoming non-slave. Gold discoveries in the west gave further impetus to the development of transport and communications. Railroad building progressed rapidy and it was soon to join the west firmly with the North, almost completely changing the former south-andWest alliance dictated by the southward course of the Mississippi. As the railway map shows, in 1850 railroads hardly penetrated the middle west. By 1860 their network covered it [Fig. 3.3]. Railroad construction was far more advanced in the North than in the south. Of the almost twenty thousand miles of railroad built during 1850-1860, most were in the North. Thus now nature and man together were tilting the balance against the south. The year 1856 saw the foundation of a North-and-West political alliance which shattered the dream of a perpetual south-and-West alliance based on the arms of the "Ol' Man River". It was this development that four years later caused the south to seek safety for slavery in secession.

Sectionalism against Nationalism: The Great split

A dangerous division between the North and South came on the issue of organization of the Kansas-Nebraska territory with a view to creating new states, an issue which itself was brought up with a view to obtain a more northerly route for a transcontinental railway. As the territory lay north of the $36^{\circ} 30^{\prime}$ line, the South was against its organization. A bait was offered to get the support of the south, by providing in the Kansas-Nebraska Bill of 1854 that it would be left to the people of the territory to decide whether or not they would have slavery as soon as they obtained a territorial legislature. This enraged the North because to it the Bill appeared to extend the bounds of slavery beyond the prohibited line. However, the Bill was passed in May 1854. With this began the tug of war between the pro- and anti-slavery elements that turned Kansas into "the theater of cold war. . . that led to the Civil War". 48

48

Morison and Commager, op. cit., footnote 7, p. 649. 


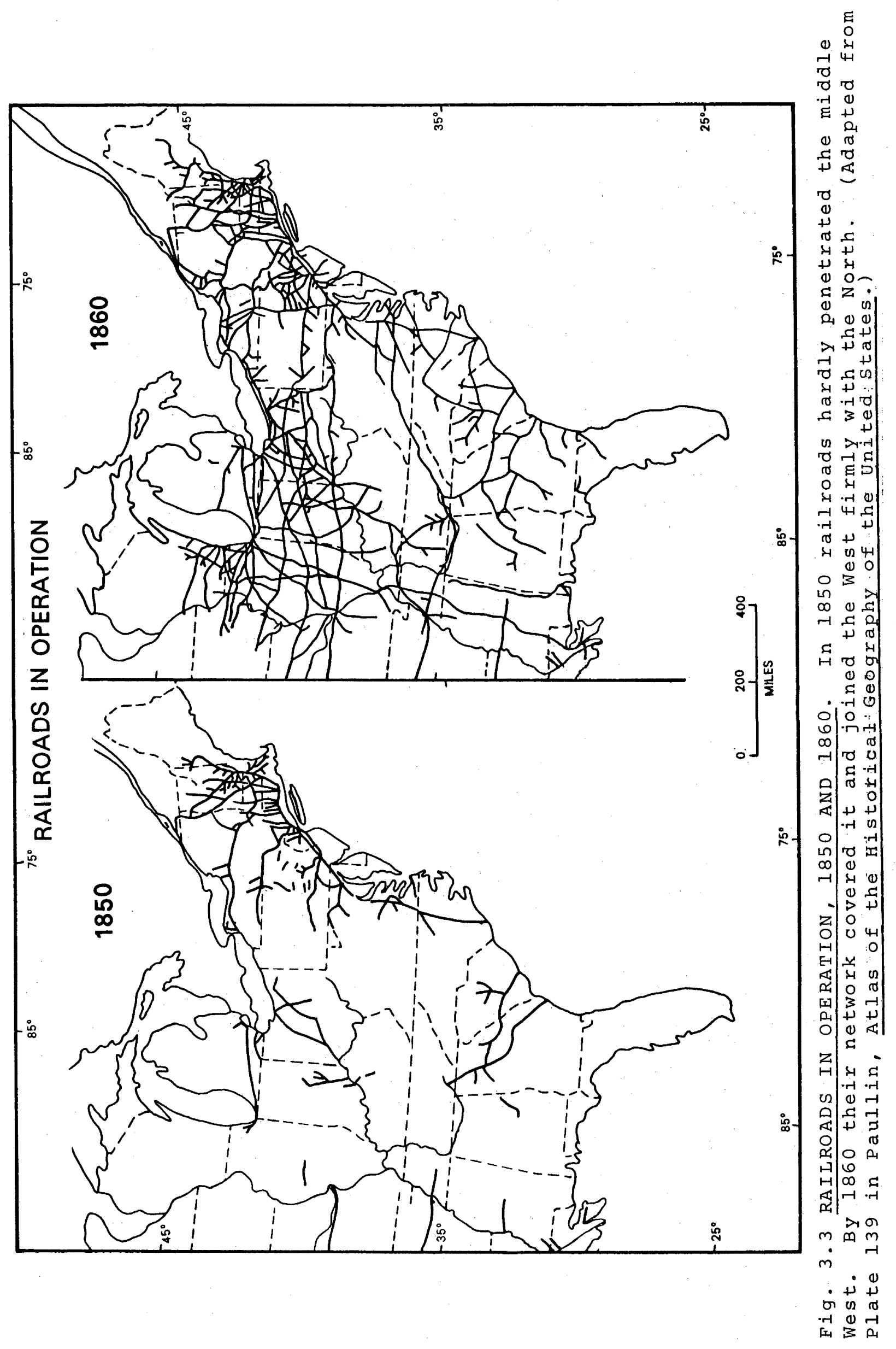


Though a south-supported candidate (Buchanan) became the President in 1856, party divisions were now approaching dangerously close to the Mason-Dixon Iine. The Division was further intensified during the next four years, so much so that in the 1860 presidential election the extension of slavery became the dominant issue of the election politics, and party divisions which had so long cut across sectional boundaries, now almost coincided with the Mason-Dixon Line [Fig. 3.4]. And as the new Republican candidate, Abraham Lincoln, won the election carrying every free state, though scarcely polling a vote in the south, "the curtain.. . rung up for the central act of the great tragedy". 49 on December 20,1860 the south Carolina legislature unanimously declared "that the Union now subsisting between south Carolina and other states under the name of the 'United States of America' is hereby dissolved". 50 By the first of February 1861, Georgia, Alabama, Florida, Mississippi, Louisiana, and Texas were out of the Union; on the eighth of February the "Confederate states of America" was formed [Fig. 3.5]. This started the tragic Civil War from which it was with very great difficulty that the Union was able to emerge intact. As the confederate states were defeated in 1865, slavery was abolished, the south was completely humbled and the indestructibility of the union was finally established.

Like Switzerland after 1848, the United States after 1864 emerged as an indestructible union that has with the passage of time become more and more centralized and strong. As more unified have the interests of the people become, the less dualistic and more cooperative and integrated has become the federal polity. The net result has been that from "a group of small, weak, poor, agricultural, selfish, discordant states", the United States has emerged as a powerful, wealthy, and mainly urban and industrial nation. 51 As

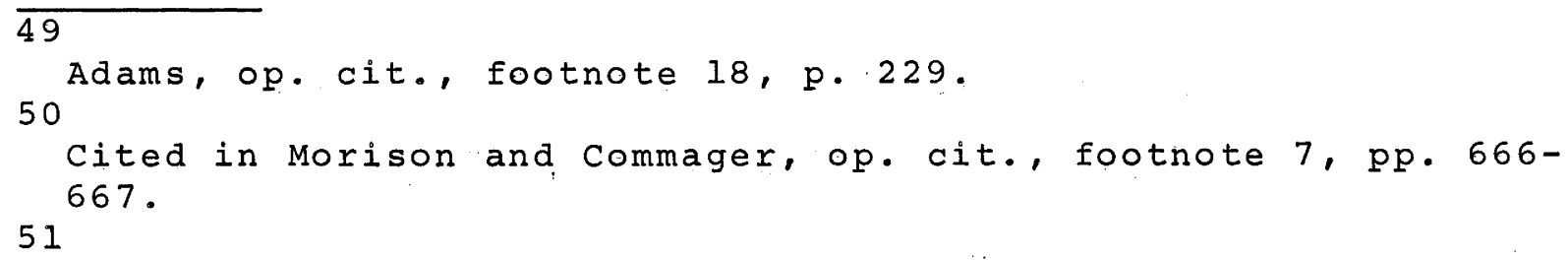

W. Anderson, Federalism and Intergovernmental Relations: A Budget of Suggestions, Chicago: Public Administration Service, 1946, p. 1 . 


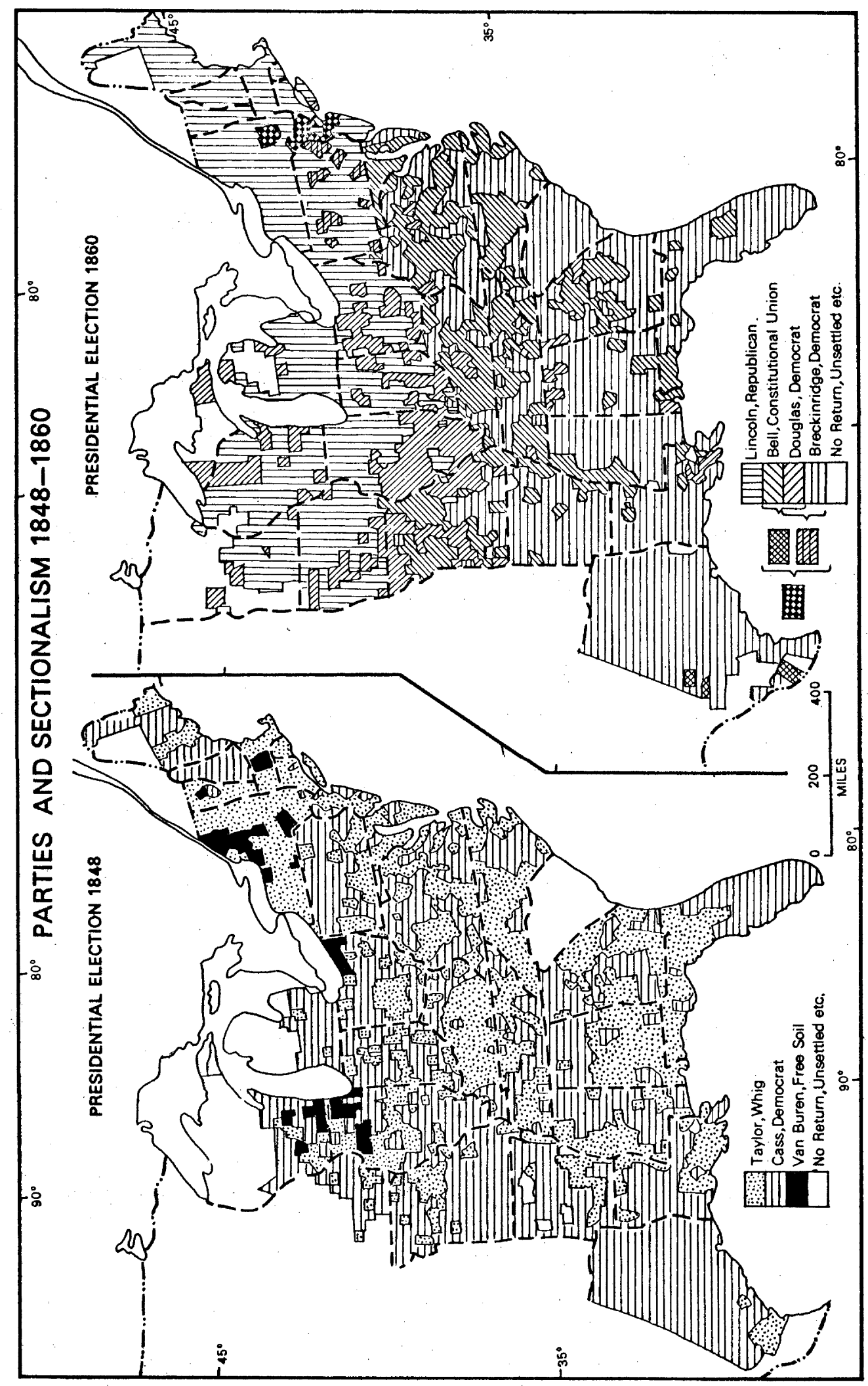

$>$

त $\rightarrow$ a 1

तु व द

(1) $+\underbrace{}_{0}$ द

ह मे म द्य

0 r 00 O 0

4- on 1 ก

त व 4 मे

मे 40

0 O 0 -

Q 0 ० द द

다 इ 0 \%

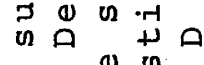

$30 \pi 0$

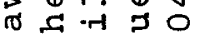

मे त्व

更

0 $\because=$ - 0

(1) 步

+5 उ

प्र 0 O

त्र

थ थ थ

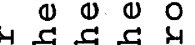
○卉出出。 तै द द द 0 o द्व न न म 0 व $c+\nu \otimes \Omega_{1}=\pi$ म 4 in पर 0 O लि م 0 क

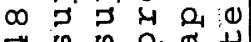

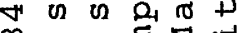
$\begin{array}{lllll}\infty & 0 & 0 & 0 & \Sigma\end{array}$ - $\begin{array}{llll} & 0 & 0 & 0 \\ & 1 & 0 & 0\end{array}$ 号苛

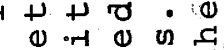
का म 0 म

ํㅣㅇ 0 ? 0 西 $\infty$ ro 0 r $v$ v -1 0 on 4 प $1 . r \quad=c$ $\infty$ 다요

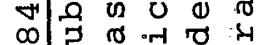
-1) व 030 : $\sum$ म 0 约 $0 \stackrel{\circ}{口}-$ 도 다 म 可

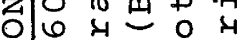
$\begin{array}{llll}H & \infty & 0 & 0\end{array}$ 텀다일 ज्ञा \& 约囸 व म

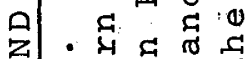
बद बै 0 巫

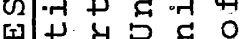
俉

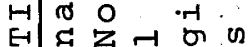

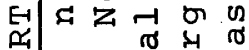

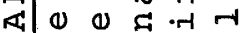

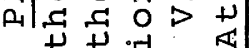
$D$ G ه 4 ه m 0 द्व

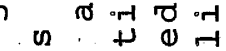
- + व वर म \& द व 开 


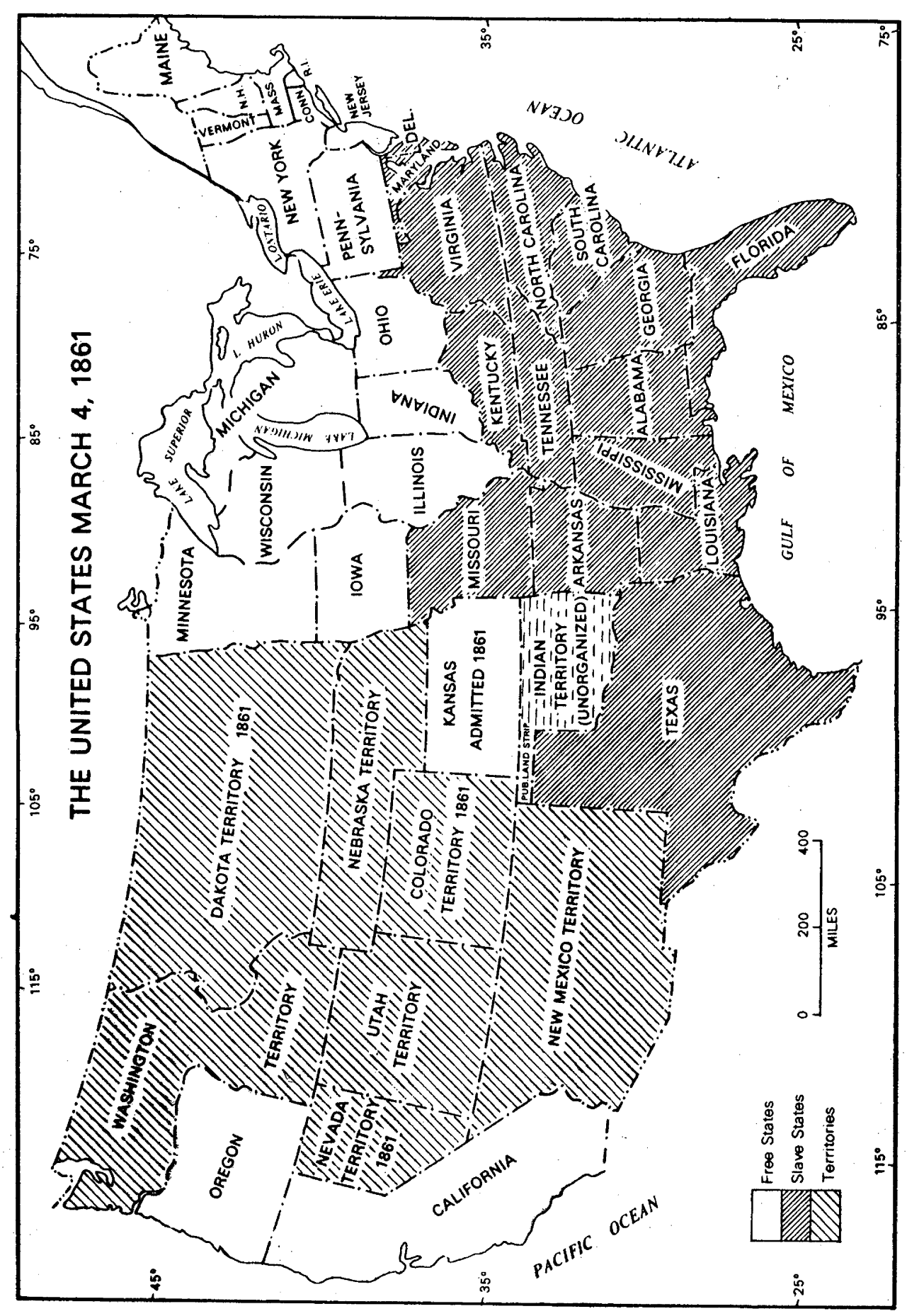

1) 1 ते $y$ o

1) H $\mathrm{H}$ तथ 0 4 4 ब 0 तो (1) - म द B B (1) 0 \& 3 ह 3

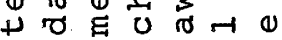

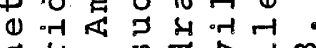
द. 4 थ $>$ त् $m$

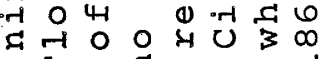
प 4 म $4-0$ on 000

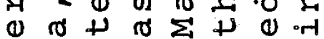

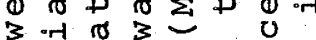
का द व 1 द ब. म U 0 H n

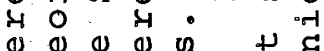

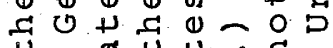
$-4+1$

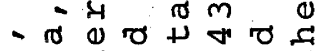

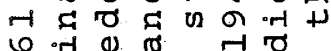
అ

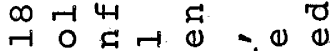
मे 0 ro 0 गे मे

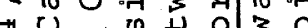

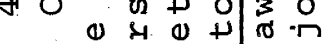

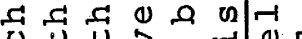
$\begin{aligned} & 4 \\ & 0\end{aligned}+\frac{1}{1}$ in

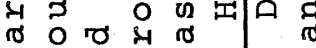

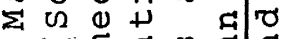

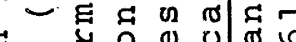

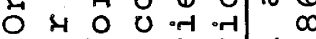

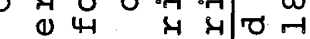

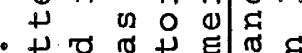

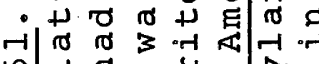

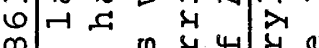

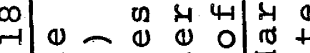

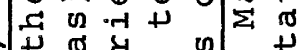

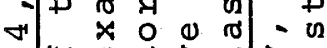
4 忨 $O$ E म द व पे थ गे

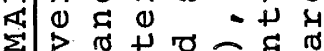
$0 \quad \dot{1} \dot{0} \Omega$

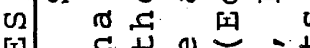
E्र

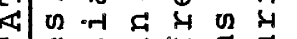
E ब थ न भ ह इ ह $\Omega$ ग $0+0$ म 0 < $n$. 4

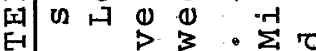

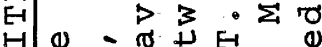

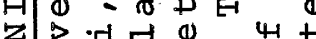

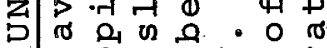

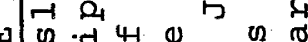
II 0 \& द 0 尺

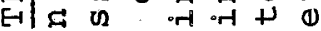
0 or $n$ n

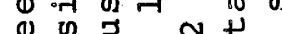
ก - H. 4 थ त 00 ०ण $\therefore$ -

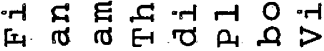


Whittlesey points out, it is significant to note that before the Civil War the country was referred to in the plural

("The United States are..."). Since then the singular verb has become the universal usage in spite of its derogation of grammatical English ("The United States is..." ..$^{52}$ Now "State citizenship has given way to national citizenship, and the national government has risen to supremacy over the States in all matters of commercial, industrial, agricultural, and fiscal policy." 53 It is truly said,

As the nation changed from farming to industry, from rural to urban and more recently to metropolitan, and from a minor role in world affairs to the leader of the free world, and as the nature of the problems to be attacked by government changed accordingly, the concept and functioning of federalism underwent continuous. evaluation as well, until adaptability became its basic principle, flexibility its very core. 54

Two things, however, need pointing out. First, it is true that dualism in. the federal polity did not completely vanish with the Civil War,

Till long after the Civil war the few activities of the national government could go along side by side with the limited state activities without either impinging seriously on the other. It was almost. $\cdot a$

"functionless federalism" when compared with present conditions. The legal theory of divided sovereignty - . fitted the facts of the time well enough though not perfectly. 55

52

Whittlesey, op. cit., footnote 6, p. 270. Though some philosophers of dualistic federalism may still write: "The United states are at a lower level of national integration - . ",D. W. Brogan, The American Political system,

London: Hamish Hamilton, first published 1933, the 1947 53

reprint used here, p. 100. 54

Anderson, op. cit., footnote 51, p. 1 .

R. H. Leach, "Intergovernmental Cooperation and American

Federalism" in G. Dietze (Ed.), Essays on the American

Constitution, Englewood Cliffs (N. J.): Prentice-Hall Inc., $1964, \mathrm{p} \cdot 128$. 55

Anderson, op. cit., footnote 51, p. 13. 
But all this soon changed as governments cast off the inactivity of laissez-faire policies and entered upon an era of active intervention in economic and social life of the nation. Thus the picture of the nineteenth century American federalism as entirely dualistic, Elazar has analyzed, is unrealistic. 56 William Anderson goes so far as to say that "Independent of each other, separate from each other, they [the states and the federal government] never were after the constitution was adopted." 57 secondly, it should be remembered that in this process of centralization.

- . the states have not been excluded; they remain as important partners in these aspects of government activity, sometimes junior partners it is true, but still exercising a degree of independent [i. e., autonomous] power and influence which is certainly not characteristic of local authorities in a unitary state. 58

\section{POIITICO-GEOGRAPHIC INFERENCES}

1. The preceding study of the rise of federalism in the United states would show that the base on which the American federalism was built consisted, as in the swiss example, of a number of regionally-grouped communities, having small power potentials but strong regional identities, that were faced with common threats to their survival. While their regional identities prevented them from amalgamating into a unitary state, their individual weaknesses and insufficiencies forced them to unite if they wanted to maintain any semblance of independence. The thirteen colonies, in the absence of an over-arching force to guide them in the struggle with the mother country, came closer together in order jointly to create a central source of light in the form of their Federal Government. Each of the early colonies was individually weak;

56

D. J. Elazar, The American Partnership: Intergovernmental Cooperation in Nineteenth Century United States, Chicago: 57 Chicago University Press, 1962 .

Anderson, op. cit., footnote 51, p. 15. See also Anderson, The Nation and the states: Rivals or Partners?, Minneapolis: University of Minnesota. Press, 1955, and W. Anderson, Intergovernmental Relations in Review, Minneapolis: 58 University of Minnesota Press, 1960.

Vile, op. cit., footnote 2, p. 15. 
in the beginning all of them were like lone stars in the firmament. They had no organized threat to their existence. Each colony with a few guns found itself strong enough to frighten the natives. But soon, when powers strong enough to engulf each one of them individually began to appear on the American scene, the colonies began to seek strength in union. The New England Confederacy of 1643, erected as a "firm and perpetual league of friendship and unity, for offense and defense, mutual advice and succor", 59 was the first significant beginning whose success encouraged and inspired later Americans. Some later attempts such as Penn's "brief and plain scheme" of 1696, or Benjamin Franklin's scheme of 1754, failed primarily because "there was no urgent need, no special and immediate fear, to cement the bond of union", 60 for it was in the interest of Britain to interpose between the colonies and any external menace, i.e., to fight the French.

But when conflict broke out with the mother country itself, the only hope for these scattered little colonies was to combine in order to create a strong central power that would guide them through the confusion, and lead them to victory. The Congress of the United Colonies when passing the Articles of Confederation on 15 November 1777 impressed upon the constituents "the absolute necessity of uniting all our councils, and all our strengths, to maintain and defend our common liberties. . . surrounded by the same imminent dangers". 61 Ten years later when it again appeared to them that the existence of thirteen sovereign wills ${ }^{62}$ was proving a great stumbling block in the achievement of their economic and political goals, and that their ineffective union was virtually opening the doors for some European power to gobble each one of them individually; the wise Fathers at Philadelphia

59 60

Cited in Morison and Commager, op. cit., footnote $7, \mathrm{p} .71$.

H. R. G. Greaves, Federalism in Practice, London: Allen 61 \& Unwin, 1940, p. 21 .

Cited in E. C. Burnett, The Continental Congress, New York: 62

Macmillan Co., 1941 , p... 246 .

The phrase "thirteen sovereign wills" appears in A. Hamilton, J. Madison, and J. Jay, The Federalist Papers, No. 20 . 
decided to create a more perfect union.

2. The study supports my hypothesis that in highly heterogeneous federations where the constituent units possess strong regional identities, a continued external threat to survival of the state helps to maintain federal cooperation. If political frontiers remain active for a long enough time, the constituent parties, through a process of mutual adjustment, learn to live like a close-knit family. This leads to the evolution of an integrated polity within the state, for a continued external threat to national survival has the effect of squeezing the constituents into unity. This factor has much to explain why Americans are today one nation rather than a collection of isolated states.

The effect of active frontiers with the war-like natives and hostile foreign powers as a consolidating agent in American history is visible all through. Throughout the struggle with France in America the British suffered from the reluctance of colonies that did not border on the troubled French frontier to fight for the common defence. Pennsylvania, in particular, contended that the war which was fought mainly along the borders of New York and New England, was none of her concern; while the colonies of the deep south regarded themselves as safely. "walled off from the formidable barrier of the Alleghenies". $63^{\circ}$ After independence the British frontier to the north, and spanish (later French) to the south and west, acted strongly against internal divisions and thus helped to maintain the Union.

Later when relations with Britain normalized and pressures along the northern settled frontier ceased to exist, the cord of unity became looser in states not bordering on the active frontier of expansion. Events of the 1812-1815 war with Britain are sad reminders of it. When on 4 June 1812 the Congress declared war, the voting in the House was 79 to 49 , and in the senate 19 to 13. New England, New Jersey, and New York opposed the war and discouraged volunteering. But the states to the west and the south bordering on the active

63

Nicholas, op. cit., footnote 28 , pp. 31-32. 
frontiers inland, were conscious of the threat and of the opportunity. Part of the explanation may be that while these southern and western areas found the British and spanish areas damming their westward expansion, the states to the northeast thought that the War, though its ostensible cause was seamen's rights, only wrecked their trade and endangered their territory by making an otherwise calm international boundary alive to their north. So great was the resentment that some delegates from the New England states met in convention to discuss revision of the Constitution and even plan for secession. As Julius pratt says, if plotted on a map, the constituencies of the Congressmen who voted for the War resolution would show that their districts stretched from New Hampshire to Georgia in the form of a great crescent bending westward. "From end to end" says Pratt, "the crescent traversed frontier territory, bordering foreign soil, British or spanish, or confronting dangerous Indian tribes among whom foreign influence was respected and feared. . . ".64 [Fig.3.6] 3. The history of federalism in the United States also satisfies my hypothesis that cross-cutting social, economic, and political cleavages in a federal state with marked regional identities help to change the cleavages into linkages, and thereby foster unity and cooperation among the constituents of the federation. As already noted, immigration to America had taken place in a way that made the English language and English institutions dominant in all parts of the country. Neither Germans nor French. Huguenots set up separate colonies. They mingled with the first British comers adopting their language and outlook. In New York English migration had soon swamped the Dutch. People of different religions and nationalities from Europe were so mixed up in the melting pot of the American frontier that a unity of tongue and basic institutions co-existed with diversity in national origins. Though some Germans concentrated in the interior, and the different original colonies had developed strong regional

64

J. W. Pratt, Expansionists of 1812, Gloucester, Mass.: Peter Smith, first edition 1925, 1957 reprint used, pp. 126-127. 


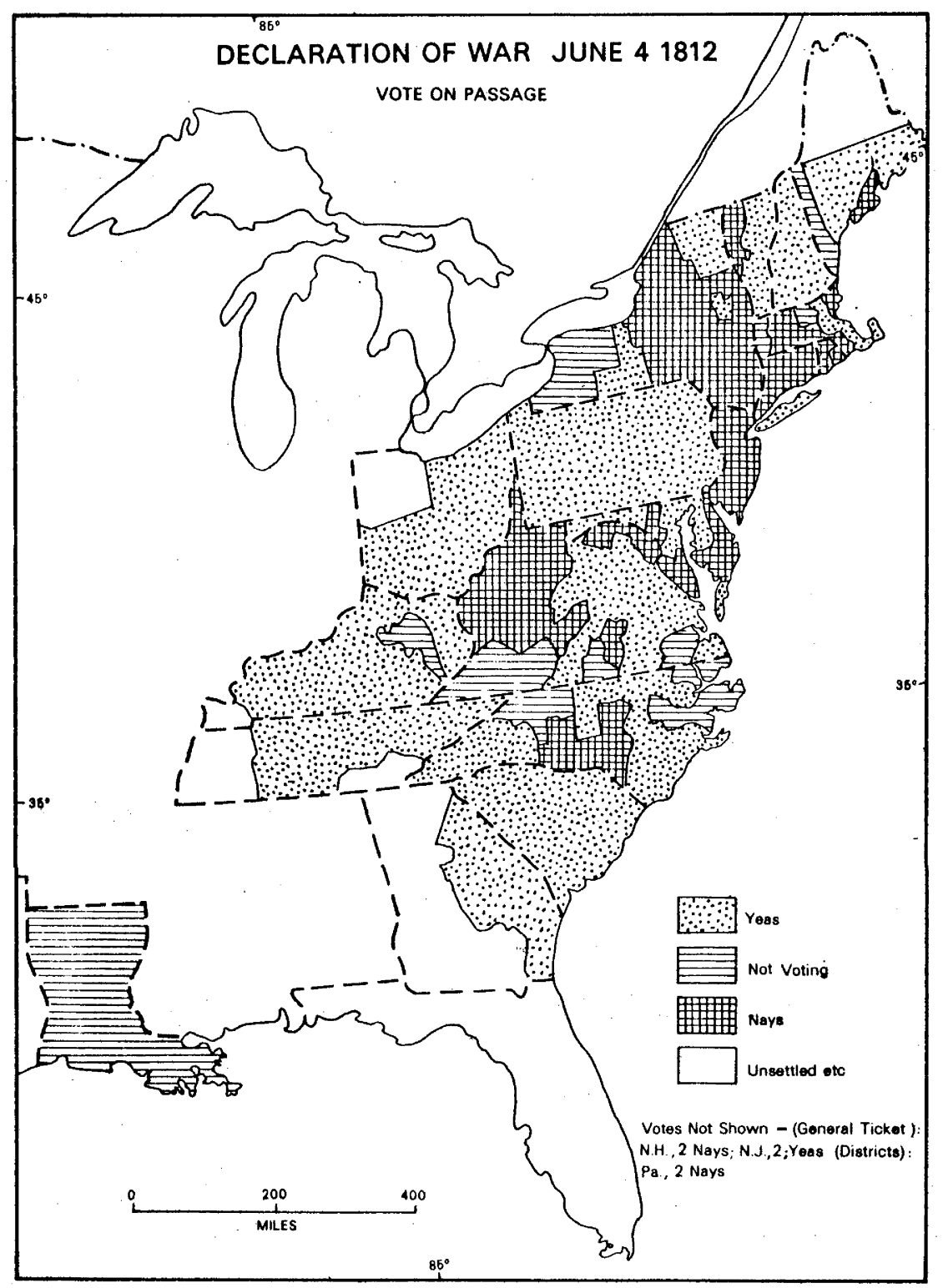

Fig. 3.6 DECLARATION OF WAR, JUNE 4, 1812. The constituencies of the Congressmen who voted for the war resolution stretched from New Hampshire to Georgia in the form of a crescent which "traversed frontier territory, bordering on foreign soil, British or Spanish, or confronting dangerous Indian tribes among whom foreign influence was respected and feared". (Adapted from Plate 113 A in Paullin, Atlas of the Historical Geography of the United States.) 
identities, intercolonial migrations were soon breaking down the barriers of purely local circumstance. In the veins of many colonists of the second generation ran the blood of two or more nations, and an English name might well cover a Dutchman, a swede, or a scot. ${ }^{65}$ It is true that the crosscurrents of population movements were not heavy, still migrations were mixing many strains and weakening rigid cleavages by extending cultural ties across political boundaries. This development was greatly facilitated by America's vast empty spaces. It is rightly said that against Europe's "time people" rooted in the past, Americans developed as a "space people" with no strong local roots. From the beginning America remained a "nation on the march". This

physical mobility has been accompanied by social mobility characterized by a ceaseless movement up and down the ladder. . . The migrants moving from the East into North Central Area, or from old South into the new South West, have carried their political loyalties and traditions with them. The result has been to establish in the new areas enclaves of Republicans or Democrats whose partisanship has its roots in the older areas from which the migrants came. 66

This all-round mobility in the American population prevented icing of the cake in American society, and thereby helped to establish a pattern of cleavages cutting across state boundaries. The net result was that in social as well as political life, every where overlapping diversities engendered a spirit of compromise which blunted the teeth of religious and social particularism. This promoted national harmony.

The institution of slavery remained the only significant social and economic institution that sharply divided the states of the union on the federal level; and this, even after three quarters of a century of coordinated existence of the constituents, threatened to cause a collapse of the

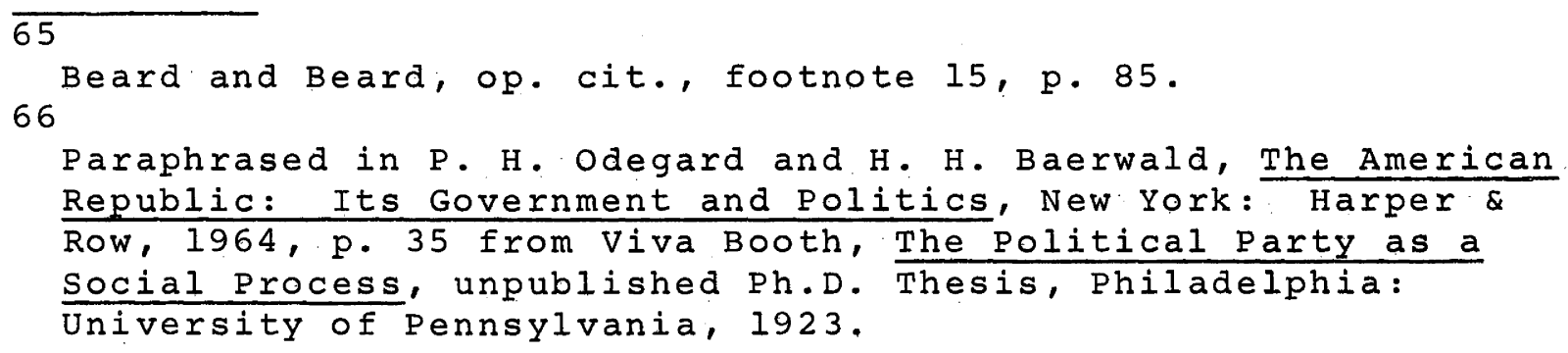


federal edifice of the United states. It is interesting to note that the institution of slavery, divisive as it always was, did not break the federal tie so long as the social and economic cleavages in the Mississippi valley cut across each other. While on the issue of slavery and freedom most of the West was sentimentally attached to the North, economically. the whole of the Mississippi valley area was till about 1850 very closely tied with the south through the arms of the Mississippi which provided the main outlet for the commerce of the area. When in the next decade railroads tied the upper West more closely to the North than to the south, the cleavage lines became sharply defined almost along the Mason-Dixon Line; this eventually led to secession and the Civil War.

It should again be remembered that this cross-cutting pattern of social and economic cleavages was present as a binding influence in the union right from the beginning. As Beard has shown, the opposition to the adoption of the Constitution came principally from "the agricultural regions, and from areas in which debtors had been formulating paper money and other depreciatory schemes"; while the support for the new system came principally from the "regions in which mercantile, manufacturing, security, and personality interests generally had their greatest strength." 67 A. N. Holcombe has shown that these cleavages in the battle over the adoption of the Constitution were projected into politics under the new government. "Jefferson succeeded in organizing the greater portion of the back country grain growers from Maine to Georgia into a coherent 'bloc', which formed the strongest element in his victorious combination." 68 Thus "Jefferson and Jackson built their fences on the solid soil of unity of the sectional interest of the then West". 69

67 68

Beard, op. cit., footnote 40, pp. 290-291.

A. N. Holcombe, The Political Parties of Today, New York: 69 Harper, 1924, p. 83 .

V. O. Key, Jr., Politics, Parties \& Pressure Groups, New York: Thomas Y. Crowell Co., fifth edition, seventh printing, 1969, p. 231. See also J.A. Woodburn, "Western Radicalism in American Politics", Mississippi Valley Historical Review, Vol. 13, 1926. pp. 143-168. 
4. The vicissitudes of federalism in the United states strongly support my hypothesis that in highly heterogeneous or multi-ethnic federations the existence of a larger number of diversities within the state helps to sustain federal cooperation by creating cross-cutting cleavages and, thus, putting a check on divisive sectionalism. Although the United states, being made up, overwhelmingly, of the people of White European stock speaking the same language, and following the same broad religious faith, is not a multiethnic federation; still, because of its large size it covers a variety of areas with distinct economic interests. It is, in this sense, a heterogeneous federation composed of various sections.

Conditioned by their circumstances, New England and the South had early developed nearly contrasting patterns of social and economic life, while the Middle Colonies shared the characteristics of either. But soon, as the frontier expansion increased, a new cleavage between the coast and the back country was imposed upon the existing one, which became the main basis of the political division between Federalists and anti-Federalists. While with further evolution in the economic life of the nation, the existence of the Midale States as a separate section was blurred; the continued expansion of the nation, and the addition of new states added to the number of new sections in the United states until by the close of the nineteenth century the American sections were becoming what has been termed "more and more the American version of the European nation." 70

With the opening of the new West in the Mississippi valley, each Atlantic section--North and South--became engaged in increasing struggle for power, and power was to be gained by drawing upon the growing west. This growing interest of the two Atlantic sections in the West created overlapping cleavages in which the emergence of the west as a section

70

F. J. Turner, The Significance of Sections in American History, with an introduction by $M$. Farrand, New York: peter Smith, 1932, reprinted 1950, p. 23. 
in its own right helped to balance the two warring sections and keep them together in the Union. Whenever the west seemed to tilt the federal balance between the two sections overwhelmingly to one side, the Union was threatened with collapse. As this balance tilted unfavourably against the North in the beginning of the nineteenth century, the New England states were planning secession at Hartford. But soon after the war with Britain the interests of the west and North became more closely linked as canals and railroads tied them together. This new alliance between the North and West was as disturbing to the south as the southern alliance with the west had been to New England in the past. By the mid-century the sectional strife between North and South developed into a virtual cold war until the resentments precipitated into the tragic Civil war. As a southern writer wrote in 1847 - . the contest between north and south [was] not limited to slavery or no slavery, . . [it was rather] a contest... whether the growing commerce of the great West shall be thrown upon New orleans or given over to the Atlantic cities.71

Had there remained only three well-defined sections in the United States, a permanent alliance between two would very likely have emerged which would have repeatedly subjected the out-cast minority section to injustices, actual or imagined. The result would have been a repetition of the same gloom. Fortunately, however, the cleavages were not fixed because of the continuing expansion of the country. As Turner wrote, unlike the small states of Europe the "United states has . . . the clash of economic interests closely associated with regional geography on a huge scale"; all through American history national politics seems to have closely approximated to the "geographical" regions of the country. 72

Because state boundaries do not coincide with physical boundaries (even if these could be exactly defined), and because one state is often divided in more than one economic section, the existence of a number of sections in the country has

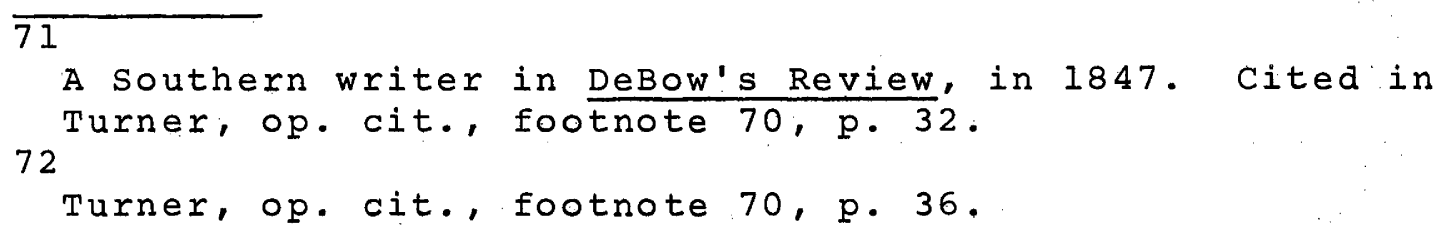


assured an overlapping pattern of cleavages and, consequently, a shifting political balance. As Turner has noted, the results of the Presidential elections from 1836 to 1852 clearly showed the influence of these cross-cutting cleavages. 73 In these elections the rough and the poorer lands, and the illiterate counties, were for the most part the Democratic counties; while the fertile basins were, for the most part, Whig. These cross-cutting cleavages, or intersectional linkages, served to unite the several states in a national citizenship by mobilizing their common interests in the national arena. 74

A distinction is sometimes drawn between regionalism and sectionalism. Sectionalism is said to involve arrangements of much greater permanence which persist despite the emergence of immediate conflicts or divergences among its components from time to time. Regionalism, on the other hand, is regarded essentially as a transient phenomenon that brings adjacent states together because of immediate and specific common interests. ${ }^{75}$ It often runs across sectional boundaries in order to obtain specific federal assistance with a view to overcome some specific problems that face the respective states in two or more adjoining sections. A good example is offered by the states from Albama to Pennsylvania that are crossed by the Appalachian Mountains and that have united to improve the lot of the depressed mountain communities on a regional basis. 76

73 74

Turner, op.cit., footnote 70 , pp. 47-48.

O. H. K. Spate in his "Toynbee and Huntington: A study in Determinism", The Geographical Journal, Vol. 118, 1952, p. 422, 75 refers to these data in support of his idea of "probableism".

H. W. Odum and.H. E. Moore, American Regionalism: A CulturalHistorical Approach to National Integration, New York: Henry Holt, 1938, write: ". . . inherent in it [i. e., sectionalism] is the idea of separatism and isolation; . . . [while] regionalism implies a unifying function. . . Here the distinctions are clear between the divisive power of selfseeking sections and the integrating power of coordinate 76 regions fabricated into a united whole", p. 39.

D. J. Elazar, American Federalism: A View from the States, New York: Thomas.Y. Crowell Co., 1966, pp. 112-124. 
To H. U. Faulkner the United States appeared "fundamentally a group of economic sections rather than an agglomeration of states". 77 And because economic interests are often shifting; the sectional boundaries in America, unlike the boundaries of fixed ethnic sections, are ever changing and creating, in that process, ever-shifting alliances among the constituent states. In this sense, American sections represent the "consciousness of differences between kindred". 78 walter Kollmorgen, has analyzed the endless overlapping, criss-crossing, and interpenetration of activities and interests in all, the major physiographic sections of the United states. Spread of iron and steel industry from the Great Lakes through the Atlantic coast to Alabama, or that of oil from Pennsylvania to the Pacific, says Kollmorgen, "must confound the advocates of regionalism" who regard sections as something fixed in American life. 79

It is, therefore, a mistake to regard sections as "the American analogue of European nations". 80 Further, the United States is fortunate that unlike ethnic elements which are often fixed in their territorial surroundings (such as language in India, or language and religion in Canada), the economic interests which form the bases of American sections, are often shifting. The ever shifting nature of economic cleavages in the United states constantly help to strike new balances which help to prevent the development of divisive rigidities.

5. Scholars and laymen alike often wonder why new federations all the world over are passing through so much of internal stress and strain that threaten to break their unity. It

77

H. U. Faulkner, American Economic History, New York: Harper, 1943, p. 558 . 78

F. Mood, "The Origin, Evolution, and Application of the Sectional Concept, 1750-1900", in M. Jensen (Ed.), Regionalism in America, Madison: University of Wisconsin 79 Press, 1952, p. 6 .

W. Kollmorgen, "Political Regionalism in the United states-Fact or Myth", Social Forces, Vol. 15, 1936-1937, 80 especially pp. $119-20$.

Turner, op. cit., footnote 70, p. 193 . 
is often thought that the reasons are to be sought in illiteracy, backwardness, and political immaturity of the new countries. But as this study would reveal, despite all the maturity, wisdom, affluence, and the consciousness of the so-called "manifest destiny", in its early phases the American Union also had to pass through very serious stresses and strains, even though its Western European heritage "established certain common traditions in advance, facilitating the task of harmonizing differences of language, culture, religion, and politics." 81 In reality, in spite of all this "Throughout the colonial period, the Americans tended to assume that these differences of language, culture, and religion would prevent the growth of a common loyalty." 82

So the question is: Why the United States, her teething troubles apart, faced her severest threat to existence as a federal union some three quarters of a century after its inauguration, whereas in many of the newer nations of today the federal edifice has collapsed or is threatened with collapse in the very first few years of its erection? A close look at the "new federations" would show that a common factor in their federal instability or failure has been the disappearance of their raison d'être for union once independence from foreign rule was achieved. In states where a charismatic leadership and/or a strong central authority existed from the beginning, as in India or Malaya (later Malaysia), the federation had a smoother run because the central government was able to present the nation with a new raison d'être for union by taking up in hand plans and projects of national importance which helped to carry the loyalty of the major components of the nation with the central government. But elsewhere the cause of union languished.

$\overline{81}$

D. S. Rothchild, Toward Unity in Africa: A Study of Federalism in British Africa, Washington: Public Affairs 82 Press, 1960, p. 6 .

M. A. Jones, American Immigration, Chicago: Chicago University Press, 1960, p. 40. 
As Elkins and McKitricknote, in America, too, following the War of Independence the spirit of unity generated by the struggle for independence lapsed, and the older generation began to revert to their own. ways--the particularism and inertia of local authority. ${ }^{83}$ The United states was, however, fortunate in the possession of its vast and open frontier of pioneer settlement, under the control of the Federal Government, where almost every section of the nation, every partner in the federal bargain, could receive a pay off. The frontier, therefore, presented a very strong raison d'etre for the American Union. It was only in the midale of the nineteenth century when a section of the nation found that frontier seemingly closed to itself, that, in the view of this section, the raison d'etre for union appeared to exist no longer. The result was the tragic Civil war.

The Western frontier contributed to the maturity of the new nation in two ways. First, the progressively shifting frontier provided a motive force for strong mobility in the nation's population; and "Nothing works for nationalism like intercourse within the nation". 84 what the Mediterranean Sea was to the Greeks, that and more the ever retreating frontier has been to the United states. ${ }^{85}$ secondly, because the entire frontier of settlement in the west remained under the control of the central government, so long as the frontier existed there was opportunity for the competence of the centre vis-à-vis the states. And, fortunately for the United states, this opportunity for the competence of the central government existed for long enough time (nearly a century and a quarter) for the states to consolidate into a nation and a state, rather than remain what Brogan regarded "a continent [?] with a disjointed government which . . has few and imperfect organs of national will." 86

83

S. Elkins and E. McKitrick, "The Founding Fathers: Young Men of the Revolution", Political Science Quarterly, Vol. 76, 84 1961, p. 202 . 85

Turner, op. cit., footnote 35, p. 30 . 86

Turner, op. cit., footnote 34, p. 38 .

Brogan, op. cit., footnote 52, p. 94 . 
Appendix to Chapter III

FURTHER NOTE ON TURNER AND BEARD

(cf. footnotes 34 and 41 )

Although both the Turner and the Beard theses have been put to close, and sometimes quite adverse, scrutiny, the basic facts as cited in this chapter are largely granted.

TURNER: Most critics of the Turner thesis would concede that the western Frontier stood as a great melting pot in which diverse cultural strains were mixed together, and where the linguistic, cultural, and other differences that had divided the people in their parent countries were largely forgotten. As Ray Billington says "of the many forces helping to create a distinct American culture, none was more important than the existence of a frontier during the three hundred years needed to settle the continent" - R. A. Billington, "Frontiers" in C. Vann Woodward (Ed.), A Comparative Approach to American History (Voice of America Forum Lectures, 1967, p. 82). The frontier was a cord of union in the sense that it helped to strengthen the peoples' loyalties to the Union because each state (and its people) looked to the virgin frontier of settlement as a great treasure-house in the hands of the Union government, on which each of them could draw in times of need. The role of the frontier as a nationalizing force receives a good treatment in D. J. Elazar's books: The American Partnership: Intergovernmental Cooperation in The Nineteenth Century United States (Chicago: Chicago. University Press, 1955), and American Federalism: A View from the States (New York: T. Y. Crowell, 1966). A strong defence of the frontier as a moulding force is in H. C. Allen, "F. J. Turner and the Frontier in American History" in H. C. Allen and C. P. Hill (Eds.), British Essays in American History (London: Edward Arnold, 1957, pp, 145-166). A summary and appraisal of the extensive writings on the subject are to be found in R. A. Billington, The American Frontier (Washington, D. C.: Service Center for Teachers of History, 2nd edition, 1965). Also useful is R. A. Billington (Ed.), Frontier Thesis: Valid Interpretation of American History? (New York: Holt, Rinehart \& Winston, 1966). Almost a complete condemnation of the Turner thesis is to be found in J. F. McDermott (Ed.), The Frontier Re-examined (Urbana: University of Illinois Press, 1969) especially in the first essay by McDermott titled same as the book. Two notable references in geography are M. Mikesell, "Comparative Studies in Frontier History", Annals, Association of American Geographers, Vol. 50, 1960, pp. $\overline{62-74 ;}$ and J. L. M. Gulley, "The Turnerian Frontier: A Study in the Migration of Ideas", Tijdschrift voor Economische en Sociale Geografie, Vol. 50, 1959, pp. 65-72 and 81-91. 
BEARD: The dispute over the Beard thesis on economic interpretation of the Constitution has largely centred around the questions: whether or not the Constitution was a "counter revolution" by the rich whose property interests were immediately at stake; and whether the process of the Constitutional Convention was democratic or not. As R. E. Brown, one of the chief critics of the Beard thesis, himself agrees; "most of the evidence, while supporting a thesis that economic factors are important in constitution making, disproves the particular kind of economic interpretation that we have accepted in the past". (From a selection from R. E. Brown, in I. W. Levy (cited below), p. 97).

Two important critiques of the Beard thesis are: R. E. Brown, Charles Beard and the Constitution: A Critical Analysis of "An Economic Interpretation of the Constitution" (Princeton: Princeton University Press, 1956), and F. MacDonald, we the People: The Economic origins of the Constitution (Chicago: Chicago University Press, 1958). An important support for the Beard thesis is Jackson Turner Main, "Charles A. Beard and the Constitution: A Critical Review of Forrest MacDonald's 'We the People'", William and Mary Quarterly, 3rd Series, Vol.17, 1960, pp, 86-102. A further support for the thesis is in E. J. Fergusson, The Power of the purse: A. History of the American Public Finance, 1776-1790 (Chapel Hill: University of North Carolina Press, 1961, especially pp. 337-343) which concludes that. "The broadest cleavage in American society . . [was] that which ranged mercantile capitalists and their allies against agrarians both great and small". Other notable contributions are: J. P. Roche, "The Founding Fathers: A Reform Caucus in Action", The American Political science Review, Vol. 55, 1961, pp. 799-816; ands.M. Elkins and E. MCKitrick, "The Founding Fathers: Young Men of the Revolution", Political Science Quarterly, Vol. 76, 1961, pp. 181-216. A selection from the above authors (along with some others) is to be found in L. W. Levy (Ed.), Essays on the Making of the Constitution (New York: oxford University Press, 1969). The selection contains useful editorial notes and a helpful bibliography. 
"Some people are born nations, some achieve nationhood and others have nationhood thrust upon them" parodies a Canadian historian and adds that "Canadians seem to be among these latter". 1 In fact, "Canada was more a name than a nation on that first Dominion Day and for some time thereafter". ${ }^{2}$ In contrast to most post-colonial nations the Fathers of Canadian confederation were faced with the task of reluctantly replacing the rather nominal union under the crown which was proving inadequate to defence and development. Hardly any federation born under these circumstances has ever been successful. The history of Canada in this sense, is indeed "A story of Challenge", 3 and the politico-geographic factors that played their part in keeping this multi-ethnic union together offer a challenging inquiry into the dynamics of federalism.

\section{THE RISE OF CANADIAN FEDERALISM}

Although the history of modern Canada starts in 1534 with the arrival of the French Captain Jaques Cartier on the banks of the st. Lawrence, the history relevant to this study begins much later, in 1763, with the British conquest of quebec and the eclipse of French power from North America after the conclusion of the seven Years' War. This brought the entire area north of Florida and east of the Mississippi under the British flag, and New France passed under the British Crown

1

A. R. M. Lower, Colony to Nation: A History of Canada, 2 Toronto: Longmans, Green and Co., 1946, p. 325.

D. F. Warner, The Idea of Continental Union: Agitation for the Annexation of Canada to the United states 18491893 , Lexington: University of Kentucky Press, 1960 , 3 p. 60 .

J. M. S. Careless, Canada: A Story of Challenge, London: Cambridge University Press, 1952. 
after a distinct existence of a century and a half. With the returning French army went some of the French seigneures, businessmen, priests and officials, but

the real New France remained: the men and women... . who inherited a way of life that was more solid than the frowning wall of Quebec.. . These were les Canadiens. Half-consciously they had developed a new culture that drew part from the old civilization from which they came and part from the soil, the forests, and the rivers of the land they had come to know and love.4

There were now four British possessions in the presentday area of Canada: Quebec, Nova Scotia, Newfoundland, and Rupert!s land. However, they in no way formed a separate group: along with the Thirteen Colonies they comprised the British North American Empire. Ever since its conquest in 1713 Nova Scotia was fashioned almost on the pattern of the New England colonies and was often looked upon as one of them. The initial plans were to end the anomalous position of quebec by bringing it in line with the other British colonies on the continent. Despite its unique French background andits solidly French-speaking Roman Catholic population, Quebec was to receive no special treatment. Policies were to be set forth for the British American Empire as a whole. The Royal Proclamation of 1763 , which redefined Quebec's boundaries, laid. down a common land policy for the entire American West, and promised regular British institutions, including representative government, to quebec. Nova scotia had already been cleared of its original French Acadian population in 1755, and had received a representative government on the New England model in 1758. Similar developments were to be expected for Quebec as wel1.

By closing the land beyond the Appalachians, to the west of the Thirteen Colonies, the Royal Proclamation of 1763 invited migrants to Quebec. The intention was to deflect the tide of American settlement northward, as in Nova scotia, until the French in Quebec were submerged in an. English-speaking

4

G. P. de T. Glazebrook, A Short History of Canada, London: Oxford University Press, 1950, p. 82 . 
population. But as Quebec seemed too far, too cold, too alien, and not at all like the tempting lands in the ohio valley just across the mountains, settlers did not come. The only English-speaking settlers to Quebec were a small number of merchants who originally came as contractors and suppliers to the British army and later filled the gap left by the French merchants and fur traders who returned to France after the Paris Peace Treaty. These British merchants were soon able to establish a new flourishing fur trade on the st. Lawrence, and by virtue of their wealth and their membership of the ruling "race" they soon came to control the economic life of the province.

The Proclamation failed completely in its aim of submerging the French elements in an English-speaking population. Outside the fur trade the two peoples--French and English-were treading separate paths. The French majority were engaged mainly in agriculture, and the English minority in trade. The two sides were acquiring different traits. Each looked down the other's way of life. Thus seeds of strife were being sown and trouble was being stored for the future. Though the Act of Proclamation had promised representative government to Quebec, there were great difficulties in calling a general assembly in the province because under the existing British law Roman Catholics were barred from political rights. In view of this any assembly in this overwhelmingly Catholic population would have been highly unrepresentative. Further, responsible British administrators thought that it was diplomatic to keep the aristocratic and military-looking seigneurial system of quebec intact in order to keep His Majesty's French subjects pacified. In view of the increasingly radical and disorderly politics in the Thirteen colonies, it was realized, scarcely ten years after the 1763 proclamation, that the strategy of the time demanded not British institutions but full recognition of the existing french traditions of the province which alone, it was thought, could win over the French population and bind Canadian loyalty tightly to the Empire. It was with this view that the Quebec Act, which "still stands, honoured by French Canadians as the Magna Charta 
of their national rights and privileges" ${ }^{5}$ (though it was a great stimulus to disaffection in the strongly anti-papist New England), was passed in 1774. The Act ensured the survival of the French language and culture in Quebec. Though there was to be an appointed Council of both French and English, no provision was made for an assembly. Though the English criminal law was instituted, the French civil law was maintained, and the Catholic Church in Quebec became a body backed by the state. With the outbreak of the Revolution, in the Thirteen Colonies a large body of Loyalist Americans fled to the northern provinces of quebec and Nova scotia. The distinctive traditions of the Loyalist migrants coupled with equally distinctive traditions of the French in Quebec were destined to modify profoundly the normal, course of colonial development in the north, for like the French elements the Loyalists too harboured a distaste for the radical New Englanders. Hence "demography like geography was to prove a variable and baffling factor in the development of Canadian nationhood". 6 Thus, the "American Revolution bore not one but two nations in its womb-the American, its obvious offspring, and a more obscure progeny, the Canadian." ". . . Canada was the offshoot of the losing, conservative side of a gread racial [sic] upheaval." 7 . Indeed, "The rock [of 'the old Colonial system'] which wrecked the first American dominion was to become the cornerstone of the second". 8

In all nearly forty thousand Loyalists came to the northern provinces--thirty thousand in Nova scotia and the

5

G. F. G. Stanley, "Act or Pact? Another Look at Confederation", Canadian Historical Report, 1956, reprinted in Confederation, a selection of articles from the Canadian Historical Review and other volumes, edited with an introduction by Ramsay Cook, Toronto: Toronto University Press, 1967, pp. 94-118, 6 reference on p. 96.

Chester Martin, Foundations of Canadian Nationhood, Toronto: 7 University of Toronto Press, 1955, p. 47.

8 Lower, op. cit., footnote 1, p. 85.

D. G. Creighton, Dominion of the North: A History of Canada, Boston: Houghton Mifflin Co., 1944, p. 174. 
rest in quebec. The first tangible result of the loyalist migrations was the establishment of two new colonies in the north. At the mouth of st. John River grew up a new Loyalist town of st. John. So considerable was the influx of migrants in the area that a new province, New Brunswick, was carved out of the old Nova. Scotia in 1784. Similarly the Loyalist settlement in the $s t$. Lawrence-Lakes region of quebec became the English-Canadian province of Upper Canada in 1791. Intangible results of the migrations were no less important. The anti-republican animus of all Loyalists, great and small, made it certain that there would be a second group of English communities in North America. The anti-republican sentiment supplied the migrants with a common bond the primary expression of which was anti-Americanism, and the secondary a strong sentiment of loyalty to the conception "British". This indirectly gave birth to a Canadian nation separate from the American.

The independence of the United states, and the large influx of migrants to quebec, changed the legal position of the province. Canada could no longer be retained as a purely French province with French laws and traditions. Authorities in London were also drawn to the opinion that an Assembly in quebec with powers of taxation would relieve the mother country of some of the financial burden involved in the administration of the colony. It was with this view that the constitutional Act of 1791 was passed. Quebec was divided into upper and Lower Canada, the common boundary between the two provinces running along the ottawa River. Each of the two new provinces received a Governor and a legislature consisting of an appointive Council and an elected Assembly. The problem of civil law was left to each legislature. The French civil law was continued in Lower Canada, and the English civil law was opted for in the Upper province. Thus within a generally British administrative structure diversities of "race", language, and culture were retained, and it was almost finally destined that two different streams would flow in Canadian life for a very long time to come, for now the Act "provided the French fact with a geographical as well as political buttress". It was a 
"renewed consecration of the French fact in Canada". 9

After the independence of the Thirteen Colonies the Maritimes were cast to play the role in the second Empire that New England had played in the first. The Maritimes were, however, a very poor replacement for New England, for apart from fish they could not supply sufficient foodstuffs to the British West Indies. Still, because the Acts of Navigation had decreed that the Empire commerce should be kept to the Empire ships, the Maritimes remained protected from a good deal of American competition, and Nova. Scotia, in particular, was able to build a flourishing trade by sea. New Brunswick was more concerned with lumbering and ship-building than fishing and sea-faring. However, because of the preferential treatment given to its timber by Britain during the Napoleonic wars, the province gained prosperity by its lumber trade. The imperial framework was benefiting the Canadas also. By 1800 lumbering had become, along with the fur trade, one of the main industries of the two provinces. ${ }^{10}$ Then, as new land was being cleared in the Upper province, a new staple was developed in wheat. By cutting Britain off from the European grain market, the Napoleonic wars created a large market for the Canadian wheat in Britain. This laid the foundations of the future granary of Canada. With their exports of fur, lumber, and grain receiving preferential treatment in the British market, the Canadas, like the Maritimes, found a very happy lot under the imperial system. And since in all this commerce the British North American provinces were in direct competition with the united states, the imperial economic system helped greatly to reinforce in the people of these northern provinces a very strong sense of special destiny separate from the United States. Thus were laid the foundations of a new nation in North America.

9

Canon Groulx, Histoire du Canada Français, III, 133. Cited in stanley, op. cit., footnote 5, p. 98 . 10

A brief summary of these economic factors may be found on pp. 105-107 of D. G. Creighton, The Story of Canada, London: Faber and Faber, 1959. 
The continued insecurity of the canadian boundary with the United States, and later the war of 1812, only further helped to harden this sense of separate identity and destiny among the British North Americans. With the conclusion of the War, Upper Canada, where the Loyalist and anti-American sentiments had become less pronounced because of the later immigration of frontiersmen from the United states (who had no pro-British feelings), also became definitely anti-American. By 1820 British North America was on a far more solid footing than it had ever been before the war of 1812. Pride in successful defence against invasion had planted the roots of specifically Canadian national feeling, and the war by "turning the people of the republic into foes, completed the separation which the war of Revolution had begun, and confirmed Canadians in that determination of which their separate nationhood more than anything has been built, the determination not to be 'Americans'". Il It is possible that there would have been a Canadian nation without the War of 1812 but it would have been much less self-conscious, less securely based emotionally, and one whose continued existence would have been much less certain. Though the war of 1812 is only a footnote in British and only a minor chapter in American history, it was Canada's great.struggle for survival. The war not only confirmed the political independence of British North America, it also "completed its economic revolution" for the "economic design of British North America since 1783, which was to co-operate with the Empire, and to compete with the United states in new staples, seemed [in 1812] almost to have passed into reality of achievement". ${ }^{12}$ From its demonstration that the British seapower balanced the American landpower there came the peaceful completion of the continental partition. Thus were spun the threads of a new Canadian destiny, both French and English, both colonial and national. 13

11

A. R. M. Lower, Canadians in the Making: A Social History of 12

Canada, Toronto: Longmans, Green \& Co., 1958, p. 174.

Creighton, op. Cit., footnote 8, p. 194 . 13

W. L. Morton, The Kingdom of Canada: A General History from Earliest Times, Indianapolis: The Bobbs-Merrill Co. Inc., 1963, p. 144 . 
After the Treaty of Ghent (1815), the British North American colonies, now free from the menace of war, turned their attention to their own internal problems. The Constitutional Act of 1791 had provided for appointive Councils in the two Canadian provinces. These councils, in course of time, had become "oligarchies entrenched around the governor" that administered the government of their colonies without regard to popular wishes. ${ }^{14}$ By the 1830 s the colonies had outgrown the form of government laid down for them in 1791. As the grievances of the colonists grew, reform movements developed, and in 1837 the reform actually moved into armed rebellion in the two interior provinces. This shocked the imperial government in London. Early in 1838 the Earl of Durham was appointed the Governor-General for all British North America with instructions to calm the provinces and to report on their grievances. In his report, submitted in 1839, Lord Durham recommended the institution of responsible governments in all the colonies, and to create a political union of the two canadas. In response to the latter recommendation the Act of Union was passed in 1840, and in 1841 the United Provinces of Canada came into being. But contrary to Durham's recommendation, the structure of the two units was retained almost intact, and the units were given oqual representation in the Assembly. "The new constitution was thus, in effect, a vague, unintended, and undefined form of federalism, with the provinces of Upper and Lower Canada continuing in existence under the names of canada west and Canada East, despite their union in one political entity called the Province of Canada. . the name. [of course] does not affect the substance so long as the identity is manifest." 15

As the industrial leadership of Britain was established in the world, the British interest in her colonies began to wane, for now that every country was willing to buy British goods the small protected colonial markets seemed of little value. The corn Laws were repealed in 1846, and by 1849 the

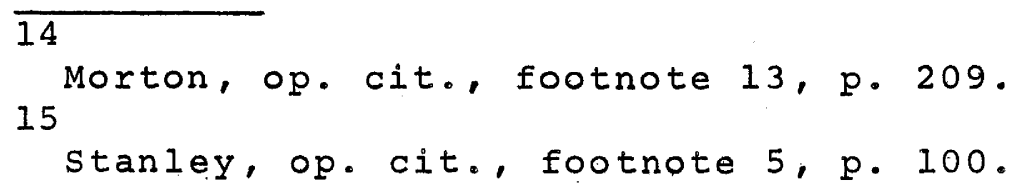


old colonial system came to an end. Now that the economic life of the colonies was no longer to be controlled the British government could have little objection in granting responsible government to the colonies. Canada and Nova scotia received it in 1848. Prince Edward. Island had its responsible government in office in 1851, New Brunswick in 1854, and Newfoundland in 1855. Soon after, various factors including economic problems with the loss of British mercantilist protection, the relative disinterest of Britain in her colonial affairs, and the mother country's desire to be relieved of the burden of administering the colonies coupled with tensions on the boundary with the United States awakened British North American colonies to the need for greater cooperation and a closer union. Various plans for union began to be talked of until their efforts finally succeeded in creating the Canadian Confederation in 1867. Originally the confederation was a centralized federation consisting of the united Province of Lower and Upper Canada (that now became the separate provinces of Quebec and ontariol and the two provinces of Nova Scotia and New Brunswick. The new state was called Canada. Manitoba became a province of Canada in 1870, British Columbia joined the Confederation in 1871, and Prince Edward Island in 1873. Later new provinces were created from the Northwest Territory. The newest member of the Confederation is Newfoundland which joined the union only in 1949. [Fig. 4.1]

Whether the Canadian Confederation was in spite of, or because of "geography" has been a much disputed point among Canadian historians. The chief proponent of the first view was Goldwin smith who regarded the confederation as an entirely unnatural creation because "God and Nature never designed a trade between ontario and the Maritime provinces". 16 since the major lineaments of North American geography run north-south everything seemed to him to point to a union of all the English-

A statement by the Attorney General of Nova Scotia. Quoted by Goldwin Smith in Canada and the Canadian question, Toronto: Macmillan Co., 1891, pp. 205-206. This line of thinking has been followed by many including André Siegfried in his Canada: An International power, translated from French by D. Hemming, London: Jonathan Cape, 1949. 


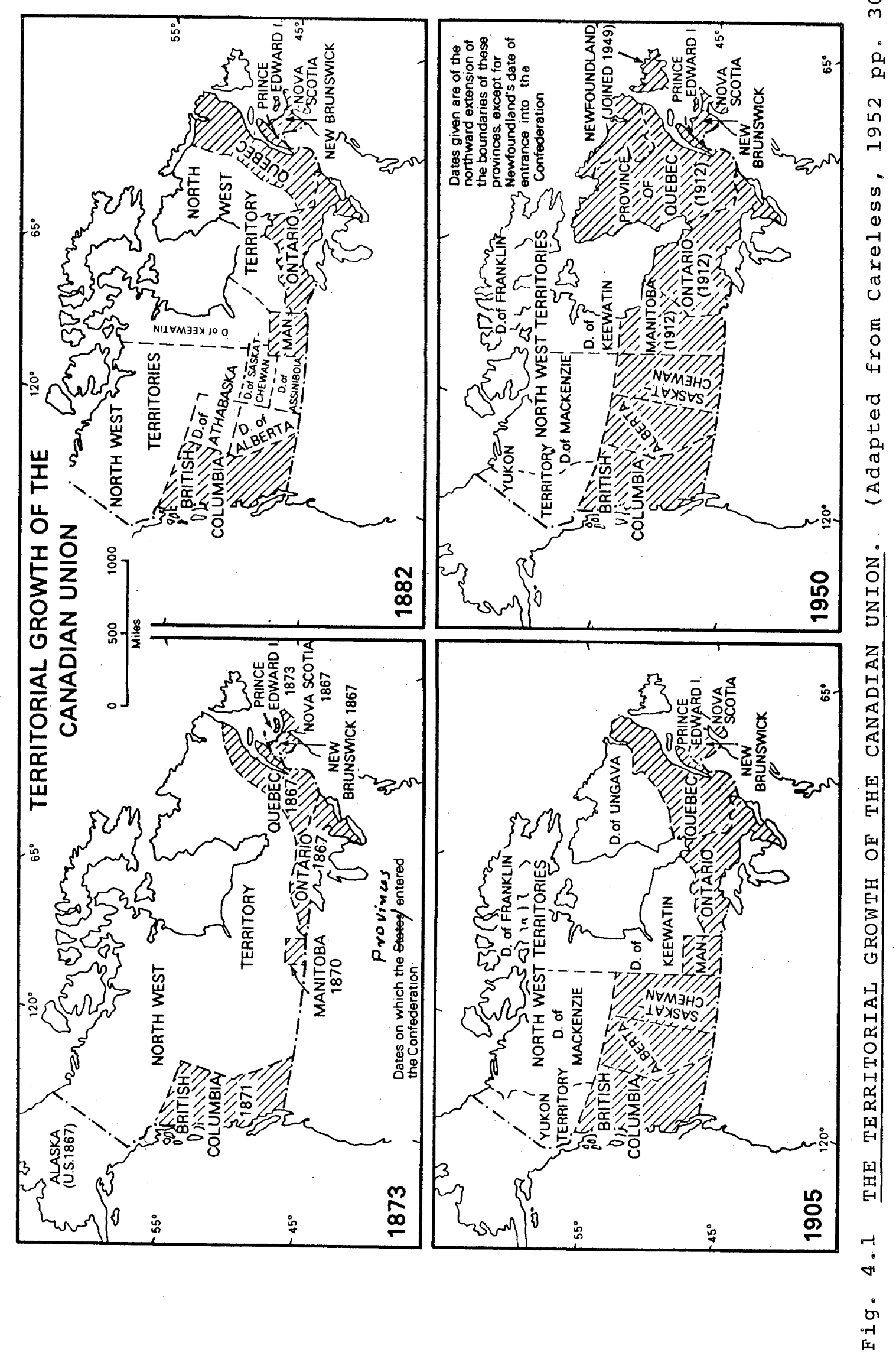


speaking people in North America. Diametrically opposed to this view is the line of thinking that began with the economic historian Harold Adams Innis who insisted that the history. of staple trades in Canada based on the st. Lawrence system showed that the natural geographic axis of the country was in fact east-west. The Confederation to him was, then, a constitutional structure built on a natural geographic base. As he put it: "The present Dominion emerged not in spite of geography, but because of it". 17 Innis has found a great follower in Donald Creighton. 18

The truth however lies between the two extremes. "Geography" is hardly a fixed thing. In fact, "Geography.. . is man's concept of his environment at any given time", 19 for in human affairs the idea is what ultimately counts. 20 Ideas are as much a part of our environment as physical features are. And the basic idea of Canada was, the crown connexion and anti-Americanism. As Watson says,

Indeed, hardly any factor has been of greater importance in the geography of Canada than the Crown Connexion. Where the Appalachians, the Shield, and the Rockies tended to keep the original colonies apart, the crown Connexion drew them together and eventually enabled them to form such a union between themselves as to give unity to their several geographies, and to create the geography of a united country a mari usque ad mare. 21

But there was no question of man against Nature as such. The east-west pull of history and politics that was imposed upon the north-south grain of the land, produced a new arrangement, a

17

H. A. Innis, The Fur Trade in Canada: An Introduction to Canadian Economic History, Toronto: University of Toronto 18 Press, first published in 1930, new edition, 1956, p. 393.

D. G. Creighton, The Commercial Empire of the St. Lawrence, 19

1760-1850, Toronto: Ryerson Press, 1937 .

W. L. Morton, "The Geographical Circumstances of the Confederation" in W. J. Megill (Ed.), Patterns of Canada, Toronto: 20 Ryerson Press, 1967, p. 62 .

L. Febvre in collaboration with Lionel Bataillon, $\underline{A}$ Geographical Introduction to History, translated by E. G. Mountford and J.H. Paxton, London: Kegan Paul, Trench, 21

Trubner \& Co., Ltd., 1932, chapter 4.

J. W. Watson, North America: Its Countries and Regions, New York: Frederick A. Praeger, 1967, p. 197. 
new balance of natural physical features by harnessing them to good purpose wherever they had of political, strategic, and economic value. Indeed, a country's "geography" may sometimes have little meaning outside its history. In Canada's case

History . . put its own interpretation on coasts and riverways, on upland and lowland. . . until.. . these things began to express. . . a specific character, differentiating them from others, and making them without question Canadian. 22

The primarily north-south grain of Canada which cuts off habitable parts of the country from one another by physical barriers of more difficult country is clearly visible in the growth of separated communities "like separated melons on one long vine, strung out across the continent close to canada's southern boundary". 23 [Fig. 4.2] But a natural connexion between the eastern colonies had already existed in the st. Lawrence route which the railways extended westwards across the Prairies and the Rockies to the Pacific coast until at last they knotted together all parts of Canada into a single "steel-bound" entity. This geographic compartmentalization was indeed one of the chief factors in the rise of strong regional identities among these colonies which in effect made federal type of union a necessity.

\section{The Federal structure}

Although the Constitution of 1867 made Canada an independent federation the country continued to be a British Dominion. with the British crown as its symbolichead. The Constitution provided for a general legislature of two houses: an appointed senate with life tenure (amended in 1965 to provide for retirement on reaching seventy-five years of age), and an elected House of Commons. Executive and legislative powers are in close identification through the control of administration by leaders of the parliamentary majority. An appointed judiciary is virtually independent

22

Watson, op. cit., footnote 21, p. 219. Very relevant are Watson's "Canadian Regionalism in Life and Letters" The Geographical Journal, Vol. 131; Part 1, 1965, pp. 21-33; and "Role of Illusion in North American Geography: A Note on the Geography of North American settlement" , Canadian 23 Geographer, Vol. 13, 1969, pp. 10-27.

Careless, op. cit., footnote $3, \mathrm{p} .5$. 
\)

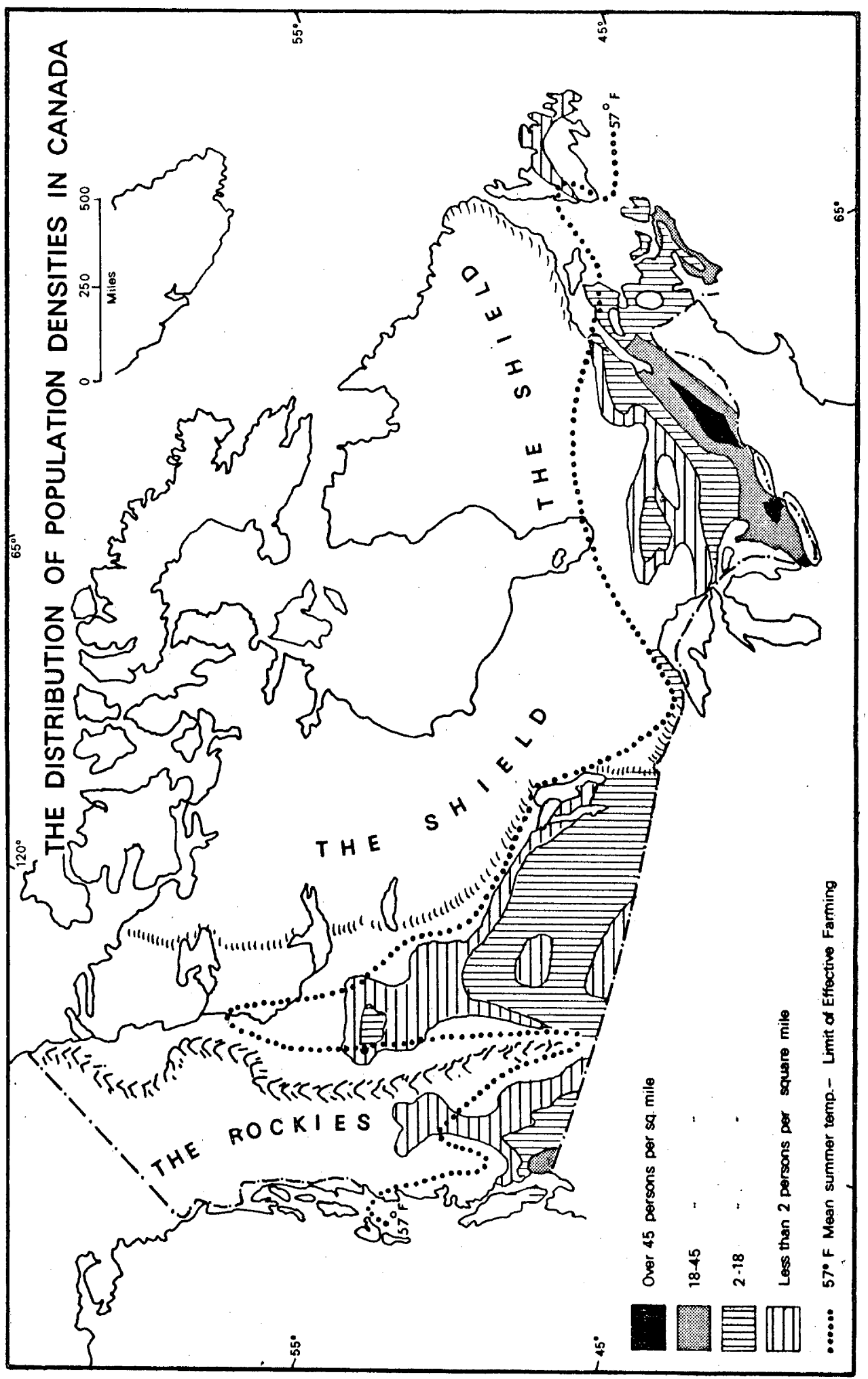

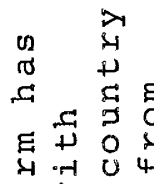

03

c 00

मे से स्त

ज $\frac{\sigma}{2}$ ल

द 0 'ठ

(1) 0 थ

ह 20

हु

जा प्र श्र

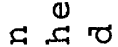

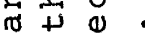

(1) $\nabla \pi=$

: 0 \%

पा थ य

(1) U $>$

당

낭 क म

(1) 0 0 त

芹 0 吕

†

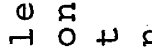

त $\mathrm{A}$ द 0

ती 0

उ. द्न थ

प्र म्न

बiा $\begin{array}{lll}+ & 0 \\ 0 & 0\end{array}$

㞔

Z 0 \%

药

व

\begin{tabular}{llll}
$Z$ & \multicolumn{1}{|c}{} & 4 & 4 \\
$H$ & 0 & 0 & 0
\end{tabular}

U 1

० यन थ

मा ते

E- $=$ - 4 मे

ज 0 O

曷记

D $E+=$

○ 02

ค E $\begin{array}{lll}0 & 0 \\ 0 & 0 & 0\end{array}$

प्य 10

O) स त्व

Z ब 4 is 0

\begin{tabular}{l|lll}
$Z$ & 0 & 1 & 0 \\
O & U & 0 & 0
\end{tabular}

H

点祭

$m$ म त 10 .

H ग

番 $+\infty$

सम त

H $\begin{array}{lll} & 0 & 0\end{array}$

ब)

4 40010

至

E б

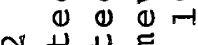

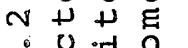

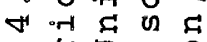
प⿺ 口 $0+0$ का $01+$

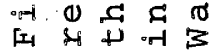


of control by either the executive or the legislative

branches of government and holds office during good behaviour.

Endeavouring to profit by the experience of the united States where exaggerated states' rights appeared to have produced dissension and civil war, Canada adopted a modified form of federalism that initially leaned strongly towards centralization. The parliament was endowed (by section 91 of the BNA ACt) "to make laws for the peace, order and good government of Canada, in relation to all matters not coming within the classes of subjects by this Act assigned exclusively to the provinces". The central government was empowered to control most important fields of national interest as : the Armed Forces, regulation of trade and commerce, banking, credit, currency, criminal law, postal services, navigation and shipping, railways, canals and telegraphs, and the raising of money by any mode of taxation. The provincial governments were given enumerated powers embracing matters chiefly concerning regional affairs. Provinces were given exclusive authority with respect to education subject only to certain safeguards for minority communities. Both English and French were recognized as official languages of the union. 24

But despite its greater emphasis on central powers, the Canadian confederation also remained essentially a dual polity where both unity and genuine diversity would flourish. This classical federalism worked with considerable success until World War I, but soon after the depression of the thirties transformed it tremendously. "Although the change has been effected without any striking amendments in the formal constitution. . the alteration in the working governmental structure. - ohas been profound". "There has been a persistent and rapid acceleration in the centralizing of the prime initiative in government, if not so much the formal exercise of

A thorough study of the constitutional development in canada is W. P. Kennedy, The Constitution of Canada, 1534-1937, An Introduction to its Development, Law and Custom, London: oxford University Press, 1938. An authoritative, but very brief, summary of the constitutional structure may be found in Canada One Hundred 1867-1967, (pp. 26-48), prepared by the Dominion Bureau of statistics, ottawa: Queen's Printers, 1967. 
governmental power". 25 However, there is little to lament, for, indeed, "Those who want to get back the substance of the classical federalism will have to reduce greatly big business, big government, and economic interdependence". 26

\section{POLITICO-GEOGRAPHIC FACTORS IN THE RISE OF CANADIAN FEDERALISM}

\section{Factors for Separate Identities}

Except for the fact that Upper and Lower Canada were linked in uneasy partnership by the st. Lawrence, till the Confederation was actually born. "the only connection between the various British North American colonies lay in the word 'British'. In nearly all particulars of their life they lived in separate worlds with no inter-communication". 27 so little was this inter-communication that as late as the $1830 \mathrm{~s}$ the steamship Royal William, which attempted to pioneer a passenger run between Quebec and Halifax, failed dismally because of the lack of traffic. The roots of this separative particularism lay in diverse factors-physical, and cultural.

Ever since Canada became a British province, the "Two Ways of Life" have constituted the principal theme of its history. As a Canadian historian puts it, among white and Christian peoples no two more complete opposites could have been found in juxtaposition than the French and English as

25

J. A. Corry, "Constitutional Trends and Federalism", in A. R. M. Lower and others, Evolving Canadian. Federalism, Durham, (N. C.) : Duke University Press, 1958, both 26 quotations on p. 96 .

Corry, op. cit., footnote 25, p. 125. The changing phases of Canadian federalism are beautifully summarized by J. R. Mallory, "The Five Faces of Federalism" in P.-A. Crepeau and C. B. Macpherson: (Eds.), The Future of Canadian Federalism, Toronto: University of Toronto Press, 1965, pp. 3-15. Very relevant are D。 V. Smiley, "The Two Themes of Canadian Federalism", The Canadian Journal of Economics and Political Science, Vol.31, 1965, pp. 80-97; and.J.M.

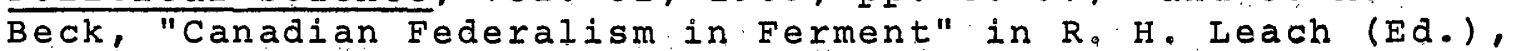
Contemporary Canada, Durham (N. C.) : Duke University Press, 1967, pp. 148-176.

27

Lower, op. cit., footnote 11, p. 189. 
they grew up in North America. 28 Though the two people were traditional foes, the two civilizations had many common bridges in the old world. But while the post-Enlightenment French culture had not emigrated to the New world, the extreme French Catholicism had. Similarly, the English protestantism in America was on the whole of a harsh and bigoted kind, more extreme than that of England. The differences between the two communities covered diverse aspects of life--religion, language, and institutions; and because the two communities possessed distinctly marked areas of habitance, they developed from the beginning highly separate identities. As the Earl of Durham wrote, the French and the English were virtually "two warring nations in the bosom of a single state". 29 Even the English-speaking colonists in British North America were hardly of a piece. Settlers to the northern colonies were made up of diverse groups--the pre-loyalists, Loyalists, and later-Loyalists from the United States; the Irish, English, and scots from Britain. As these different groups in the northern colonies came to possess somewhat localized areas of settlement, their ethnic heterogeneity gave rise to a strongly federal situation. Whereas Nova scotia was largely settled by the pre-Loyalists, New Brunswick regarded itself as the Loyalist province par excellence. Besides these differences that divided the Maritimers, there was a world of difference between the Maritimers, on the one hand, and the English-speaking Canadians on the other. Upper Canada was largely settled by immigrants from the frontier regions of the United States, and later, by Irish and other poorer immigrants from Britain. Compared to these rough and little-educated frontiersmen of Upper Canada, the Maritimers were on the whole a sophisticated group. As whitelaw says "not only was the rebellious character of the Canadians contrasted with the

\section{8}

A. R. M. Lower, "The Two Ways of Iife: The Primary Antithesis of Canadian History", The Canadian Historical 29 Association Report of the Annual Meeting, 1943, pp. 5-18.

R. Coupland, The Durham Report, An abridged version with an Introduction and Notes, Oxford: Clarendon Press, 1945, p. 15 . 
loyalty of the maritime sentiments, this Canadian characteristic was commonly held [by the Maritimers] to be the result of poorer stock". To the Maritimers the French Canadians were a "fossilized branch of the seventeenth century France", while they regarded the English Canadians as a "strange conglomerate of economic misfits recently migrated from Ireland and Great Britain, and worse still, downright republicans who had of late been pouring over from the United states". No doubt, there had in Upper Canada been a substratum of the United Empire Loyalists, but these had been submerged by the recent immigration; whereas in spite of its recent migrants New Brunswick was still inhabited by the native-born. Although one in every three Englishspeaking Canadians was not native-born, eight out of every nine persons in the Maritimes were so. 30

Though, it is said, Nature might have seemed to intend the Maritime provinces to face inward and northward on the Gulf of st. Lawrence, and history and politics emphasized this frontage by linking them with the rest of British North America to the west in a common, country, first under the French and later under the British, in spite of its spacious harbours, good supplies of coal, and its strategic position, the north shore had not flourished and the Maritimes

tended to look to the Atlantic for whatever contact it might have with the outside world. Almost three times the amount of shipping entered the ports of New Brunswick along the Bay of Fundy as entered its north shore ports. In Nova Scotia, Halifax was connected with the Bay of Fundy by a railway to tidewater at windsor ten years before a similar connection was completed with the north shore at Pictou. None of the three Maritime capitals faced north. There was no north, shore port in New Brunswick that could, vie with St. John; and in Nova Scotia although over a thousand ships a year left pictou, the town was no rival to Halifax, and its importance was owed to its rich deposits of coal rather than the Gulf frontage.3 1

Thus the Maritimes had found their real frontage not towards the north and west where the rest of British North American provinces lay, but to the south and east facing the New England states.

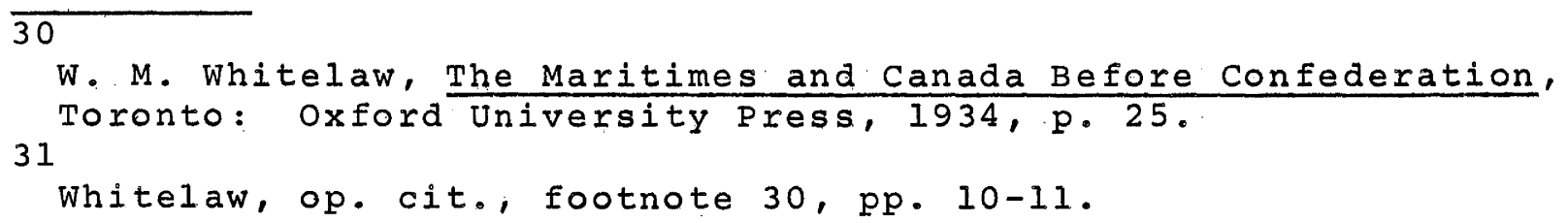


Not only were the south shore ports of Nova scotia and New Brunswick nearer and more accessible to New York and Boston than to the Canadian ports on the St. Lawrence, they were, in fact, nearer and more accessible to these American ports than their own ports on the north shore. A trip from Halifax to the West Indies was, in fact, less hazardous than the one from Halifax to Montreal. While risky in summer owing to its shifting currents, dense fogs and treacherous rocks and shoals, the st. Lawrence route remained closed for about seven months during winter because of ice. The result was that the Atlantic frontage of the Maritimes had become as much psychological as geographic. The provinces were Maritime in a deeper sense than that of merely bordering on the sea. They lived on and by the sea. This gave them a feeling of intimacy with the North Atlantic world, and they, therefore, faced not towards Canada but away from it. ${ }^{32}$ During winter Quebec could have its contact with the outside world not through the British American ports in Nova Scotia or New Brunswick, but overland through the United States territory to the American ports of Portland, Boston, or New York.

As the imperial soldiers found in 1861, the overland route between Canada and the Maritimes via the Temiscouta road was extremely difficult. ${ }^{33}$ only a small fraction of mails destined for Canada were carried over the route between Truro and Rivière du Loup, and even telegraphic communication between Canada and the Maritimes was carried largely over American lines. ${ }^{34}$ The northward extension of the Appalachian system in Canada had only further reinforced the physical division between the Maritimes and the interior.

This particularism was further reinforced by the greatly varied economic bases of the colonies. The gold of British Columbia, the furs of the prairies, and the cereals and lumber of Canada stood in sharp contrast to the fisheries, coal, and timber of the Maritimes. The result of all this

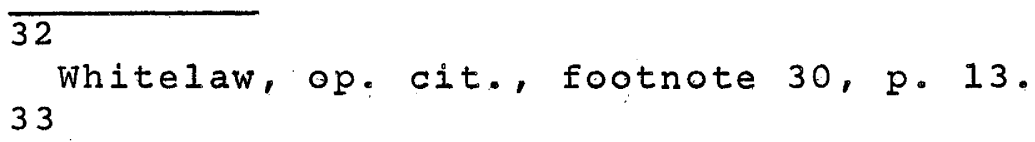

R. G. Trotter, Canadian Federation: Its origins and 34

Achievement, London: J. M. Dent, 1924, pp. 190-192.

William smith, History of the Post Office in British North

America, London: Cambridge University Press, 1920, pp. 327-32 
was that

the interrelations of British North America on the eve of Confederation were not provincial but regional. Canada was an economic unit; the ties which bound the maritime provinces were strong and close; but the relation between Canada and the west on the one hand, and Canada and the Atlantic provinces on the other, were undeniably tenuous wherever they existed at all. 35

Conditioned by the mercantilist policy of the Empire, the colonial pattern of trade further emphasized this colonial isolation. As the bulk of the trade of the provinces was with the mother country or the Empire, that great binder of separate communities--intercolonial trade--could have little chance to develop till late in the mid-nineteenth century. Though the mercantilist restrictions had slowly been removed, not till the confederation was actually born was there freedom of trade in manufactured goods between the colonies, though raw materials could be freely exchanged. In absence of a customs union, the provinces confronted each other, as well as the outside world, with distinct tariff systems. 36 Trade between Canada and the Maritimes formed only a small part of the total commerce of these territories. In 1863 Canada's export to the colonies of British North America were valued at only $\$ 935,196$ out of a total outward trade of $\$ 39,347,890$. similarly the total value of commodities shipped annualiy from the Maritime provinces to canada did not always reach $\$ 100,000$. The Maritime exports to Canada were largely made up of fish, fish oil, coal, and re-exports of west Indian sugar and molasses; similarly most of the canadian exports to the Maritimes consisted of flour and other agricultural products with a little quantity of manufactured goods.

35

D. G. Creighton, British North America at Confederation, Ottawa: Government Printers, first published 1939, reprinted 36 1963 , p. 36 .

J. C. Hammeon ("Trade and Tariffs in British North American Provinces Before Confederation", proceedings of the Canadian Political Science Association, 1934, Vol.6, pp. 51-59) estimates that in 1861 the ratio of duties collected to the total value of all dutiable imports in the different provinces was: Canada 19\%, New Brunswick $133 / 4 \%$, Nova scotia $113 / 8 \%$, and $103 / 4 \%$ in Prince Edward Island: 
A further force making for provincial particularism was the highly disparate size and population of the provinces in general, and the Maritimes and "Canada" in particular. Together the Maritime provinces were less than one-sixth of the area of the United Province of Canada, and much smaller than either of the two units of the Province. By 1861 Upper and Lower Canada each had over a million population but the total population of the Maritimes had as yet not reached seven hundred thousand. Montreal alone had twenty thousand more people than prince Edward Island. Thus, except for Upper Canada (which then had more population than Lower Canada) in every province of British North America there were genuine apprehensions against any move for political union of the provinces. While the tiny provinces on the Atlantic were afraid of their giant neighbour which they thought would be bound to rule the union to its own benefit, the French Canadians were afraid that in a general union of the provinces they would be overwhelmed by the Englishspeaking elements, and this, in their.view, appeared as the death-knell of their language, culture, and religion that they had so painfully guarded for over a century now.

Thus, although a little exaggerated, the following analysis of the component parts of the "New Nation" (that was being born in 1866-67) by a contemporary journal contains a fair amount of truth:

We don't know each other. We have no trade with each other. We have no facilities, or resources, or incentives, to mingle with each other. We are shut off from each other by a wilderness, geographically, commercially, politically and socially. We always cross the United States to shake hands. Our interests are not identical but very opposite--they are antagonistic and clashing. our political habits and history run in different channels. - - Our wants are different. The laws of the two countries are different, and framed for different states of things. 37

Whereas in Canada "the centralizing tendency of the St. Lawrence was at war with the divisive force of the two distinct cultures"; in the Maritimes "economic decentralization and political particularism were in harmony". ${ }^{38}$ This is how P. B.

37

Acadian Recorder, July 27,1866 . Quoted in Creighton, op. 38 cit., footnote 35, p. 36 .

Creighton, op. cit., footnote 35, p. 37 . 
Waite describes the eastern provinces in 1867:

Newfoundland, its population clinging precariously to a living wrested from the Labrador current and a hard land; Prince Edward Island, complacent, defiant, and parochial; Nova Scotia, afloat on seven oceans, proud of herself and jealous of Canada; New Brunswick, halfAmerican in politics and attitude; Quebec, determined to get every jot and title of privilege with or without ottawa; Ontario, sleek, bigoted, and stentorian.39

Factors Creating the Urge for Union

"Canada is a colony, not a country, it is not yet identified with the dearest affections and associations, remembrances and hopes of its inhabitants: it is to them an adopted, not a real mother" essayed a writer in 1838.40 By 1850, however, "a new British North America had come into existence. . . working itself towards the point where it could clothe these things with 'dearest affections... remembrances . . hopes'". British North America had now begun to take an observable collective meaning. It now became "a phrase which had begun to possess some discernible content and reality". Now the various colonial streams had begun to converge, and there were prophetic overtones about it which cast the shadows of the coming events. 41 so prophetic were these overtones that some historians believe that "even. if there had been no Confederation, even if there had been no federal government, the forces acting upon British North America would have involved the different provinces in common difficulties and spurred them to comparable efforts and enterprise". 42

The overriding allegiance to British memories and attachments had thrown the British North American colonies together in a hostile world. Yet just as most loving family memories do not prevent sisters from losing touch with each

39

P. B. Waite, The Life and Times of Confederation 1864-67, 40

Toronto: University of Toronto Press, 1962, p. 328.

Mrs. Jameson, Winter Studies and Summer Rambles, London, 1838. 41

quoted in Lower, op. cit., footnote ll. p. 208 . 42

Lower, op. cit., footnote 11, pp. 208, 240, and 271 .

Creighton, op. cit., footnote 35, p. 9 . 
other if they remain apart too long, so the common allegiance of the colonies probably would have become less significant as they found their individual roles in the world, had not devices appeared which could bring them together. 43

Although the destinies of the St. Lawrence colonies lay in the interior, and for the Maritime provinces the ocean remained the great highway, while the Appalachian ridges emphasized the isolation between the two, by the middle of the nineteenth century on a basis of "flour down, and coal up" the st. Lawrence had begun to attract the northern and eastern parts of the Maritime provinces into its orbit again as it had done in the days of New France. While the oceanic forces towed the Maritime colonies out to sea, the continental ones held them back. Each successive improvement in transportation only increased the attraction of the st. Lawrence link. Railways had proved a great unifying factor in the States to the south and they were destined to be more potent than ocean navigation in the British North American colonies in tying them together in one tight geographical entity. An intercontinental railway, and the extended Grand Trunk had great attractions. It would give the st. Lawrence region a British American winter outlet; it would provide the Maritime ports a great continental hinterland, and above all, it would offer, in the emergency of American attack, a completely British American route for the movement of troops. The assurance of the intercolonial railway went a long way in bringing Nova Scotia and New Brunswick to the Confederation table. [Fig. 4.3]

The fear and jealousy of the United states provided another important factor for intercolonial unity. Speaking of the haste with which the British North American union was brought about in 1867 , a historian remarks that it was necessary in order to forestall the Americans who threatened to gobble the colonies up if they did not act quickly. "Somewhere on the Parliament Hill in ottawa. . . there should be erected a monument to this American ogre who so often

43 Lower, op. cit., footnote 1, p. 310 . 


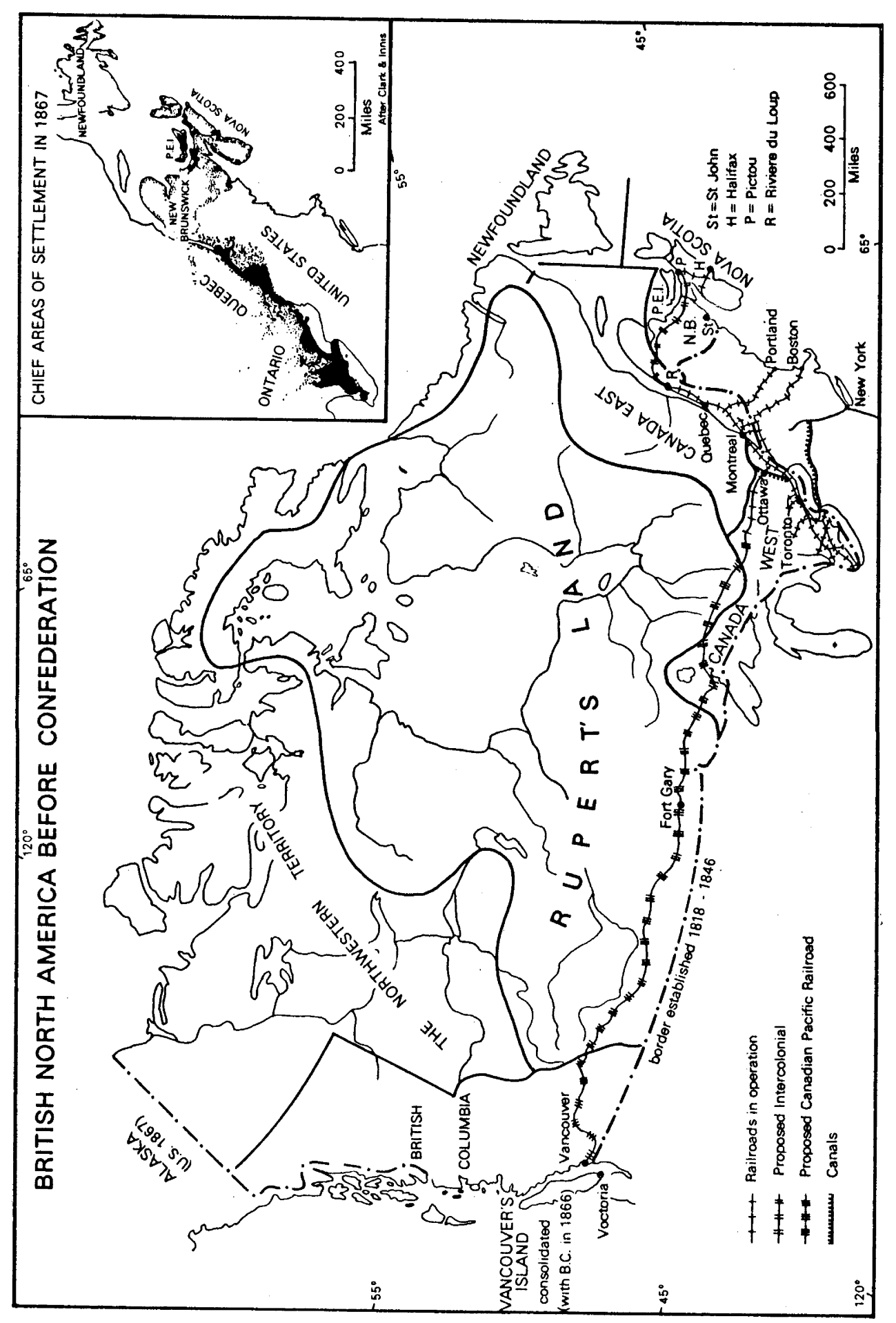

- थ 110

द $\Leftrightarrow$ O

न 0 म $\gg$ प

$\begin{array}{llll}-1 & 0 & 0 & 0\end{array}$

7 मे 40

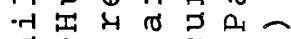

U 01

\begin{tabular}{lllllll}
4 & 0 & $\sim$ & 0 & \multicolumn{1}{c}{} & $\infty$
\end{tabular}

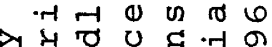

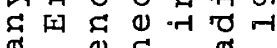

(1) -4 द

4 द प्र

0 i 4 H U U

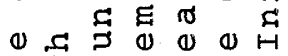

0 का 0 मे

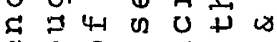

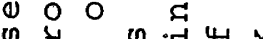

ब ह 3 लि 0 मे

$\begin{array}{rlllll}0 & 0 & 4 & & 0 \\ -1 & 0 & 0 & 0 & -1\end{array}$

(1) म $\rightarrow$ प्र जी

म

एम $\mathrm{H}$, 0 O द

म 0 न 0 ल

- H v

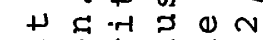

उ n 0 मे

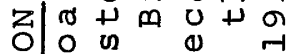

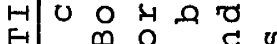

(1)

되

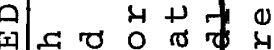

प

Z

0 म

(1) 4 म 4 4 $\$$

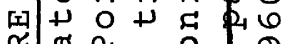

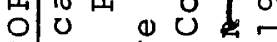

II

团

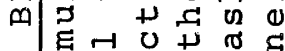

死 至

U 0 तु $4 \begin{array}{llll}4 & 0 & 4\end{array}$

a 0 का

国

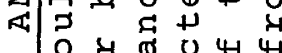

西 000 元 0

E 0 म

番

Oठ

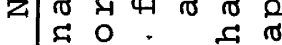

计

थ U स तु मे

$H=3 \quad 35$

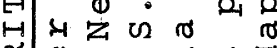

म

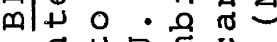
म + 口骂 0

$m \stackrel{\circ}{3} \lambda_{0} 0$ म

$\therefore$ का 0 \%

द म त स 3

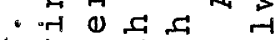

का 4 W

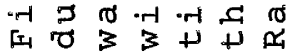


performed the function of saving us from drift and indecision." 44 There were strong memories of boundary disputes (along Maine and oregon in the 1840s), quarrels over fisheries, and the war of 1812 which were currently being further reinforced by the strained American-British relationship born out of incidents in the Civil war. After the Northern victory in the Civil war, the balancing role of the southern states disappeared. This greatly alarmed the colonies, and hastened to bring them together for their collective security against the post-Civil war United states that now seemed "a vast and encroaching organization, politically truculent, [and] economically aggressive". 45

As Chester Martin has analyzed, the Canadian Confederation was preceded by the failure of the British North American colonies to float new loans in the London markets; and the Union was in a large measure put through by the British authorities. $^{46}$ Heavy British investments were involved in Canadian municipal bonds, and in the Grand Trunk railway. While the Grand Trunk had reached a chronic financial chaos, in the depression following 1857 many municipalities had defaulted in payment. Thus, the "British assistance [to the move for Confederation] might be interpreted as an effort to assist in the creation of a great holding company in which could be amalgamated all those divided and vulnerable North American interests whose protection was a burden of the British capital".47 A union of all the provinces would give a larger base for financing provincial liabilities, while the railroad would profit by the increased traffic.

Thus the nationalism of Canadian Confederation was

44

F. H. Underhill, The Image of Confederation, Toronto: 45

Canadian Broadcasting Corporation, 1964, p. 4. 46

Creighton, op. cit., footnote 35, p. 10 .

C. Martin, "British Policy in Canadian Confederation", 47

Canadian Historical Review, Vol. 13, 1932, pp. 3-19.

Creighton, op. cit., footnote 35, p. 10 . 
in a great measure an economic nationalism. Time and again the leaders of the Confederation emphasized the complementary nature of the resources and industries of North America, which they thought would, under a union, provide the requisite base for a balanced and stable national economy. in the proposed Union" said Galt,". . we shall obtain some security against those providential reverses to which as long as we are dependent on one branch of industry. . , we must always remain exposed". 48 The confederation seemed to offer an economic pay-off to large sections of the population both in the Maritimes as well as in the canadas. While it was expected that Lower Canada would become "the great commercial centre for the whole of the Provinces", the Upper Canadians had the "last best West" at their doors. The Maritimes had their own high expectations for the prosperity of st. John and Halifax. "We form" said the Maritime leader Lynch, "the nearest point to Europe, while British America extending across the whole continent, is laved by waters of the Atlantic and Pacific". He thought that a mighty railroad running across this great country would bring the region in juxtaposition to the best part of Asia--China and Japan. If the Maritimes could only be made "a place of transit for the mighty trade... it would be of incalculable benefit... What made Venice or Genoa but their. . . being situated somewhat as we are, but without half the advantages". 49 Nova scotians believed that the "geographical advantages" and the "geological attributes" of their province had destined her to a role in the confederation similar to the role of Great Britain in the world, or of the New England states in the United states. New Brunswick was no less optimistic. And almost every colony had some expectations of benefit from the "last best west" to whose share the membership of the confederation would entitle them. Indeed the intention of the Fathers was to create a structure "stronger financially, commercially, and politically--a structure which would command

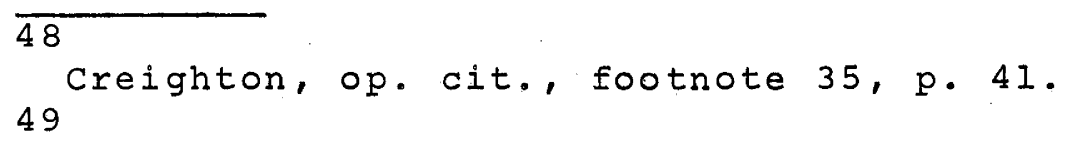

Evening Express, January 9, 1865. Quoted in Creighton, op. cit., footnote 35, p. 4 . 
the confidence of investors, as well as the interest of merchants and the respect of statesmen". 50 Even though their separation and remoteness from one another had created among these British American colonies a sense of regional independence and individual identity, the limitations of their individual economies made for their political dependence. 51

The two communities--English and French--in Canada had no doubt followed two separate ways of life; still, as recent studies reveal, the geography of religion in the provinces tended to unite rather than divide them in the $1860 \mathrm{~s}$. Religion rather than nationality was the main concern of the French Canadian leaders of the time. And because of the existence of members of the Roman Catholic Church other than French, religion made for unity rather than separation. "The great concern of both the French as such, and the Roman Catholics as such, was education rather than their relative standing in respect of English or protestants in either political or economic matters". 52

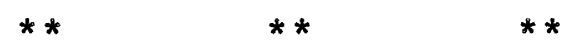

Thus the overall picture of the $1860 \mathrm{~s}$ was that the British North American provinces were torn between diverse factors of unity and separation; and it is truly said that the real Father of the Confederation was the "deadlock".

Upper and Lower Canada, like the man and the woman in the fable, had come sadly to realize that they could get along neither together nor apart. They had tried both and succeeded in neither. Separation had proved to be economically impossible, union to be politically intolerable. 53

The predicament of the union was so severe by the $1850 \mathrm{~s}$ as to suggest that a more flexible alliance alone could maintain unity while safeguarding, at the same time, the interests of the sections. The United Province of Canada had to divide politically as it had to expand economically; and it could do

\section{0} 51

Creighton, op. cit., footnote 35, p. 48 .

W. I. Morton, The Canadian Identity, Madison: University of Wisconsin Press, 1961, p. 99.

52

W. Lo Morton, The Critical Years: The Union of British North America 1857-1873, Toronto: McClelland and Stewart, 1964, p. xi 53

Whitelaw, op. cot., footnote $30, \mathrm{p} .1$. 
both only in a union of all British America. ${ }^{54}$ While to the English Canadians the larger union with the Maritimes offered an inalienable majority for their language and "race", to the French, on the other hand, it seemed that with their highly different economy and outlook that strongly contrasted with the frontiersmen of Upper Canada, the Maritimes might provide in the union a balancing factor between them and the English Canadians.

The Maritimers, it is true, were highly "particularist in spirit, regional in outlook, often parochial in sentiment.. and fiercely independent and still elevated by the heady political wine of responsible government". 55 Their constitutional machinery functioned with reasonable efficiency, and they thought more in terms of a Maritime than a general union. But obstacles in the Maritime union were many. Geographically they were dispersed by the sea, the mountains, and the forests. They possessed no interconnecting roads and railways. Institutionally their existing provincial assemblies were stiff-necked vested interests with little desire to merge in a larger union. And but for a Maritime fellowfeeling there were few economic benefits in the smaller union. In order to tide over their geographic obstacles of separation and isolation they needed money. And money could come only in the larger union of all British America. Thus even though the Maritime provinces felt themselves "secure within the imperial art of Britain and the friendly neighbourhood of the 'Boston states'";

- . each [of the provinces] had a problem, or problems, of weight that neither the imperial connection nor the friendship of the United states were to solve. In each instance the failure of the imperial administration or American influence to solve these matters was the cause of the Atlantic provinces, except Newfoundland, entering the union of British America by 1873.56

But like the French Canadians, these provinces ("particularist in spirit", "fiercely independent", and "elevated by the heady political wine of responsible government")

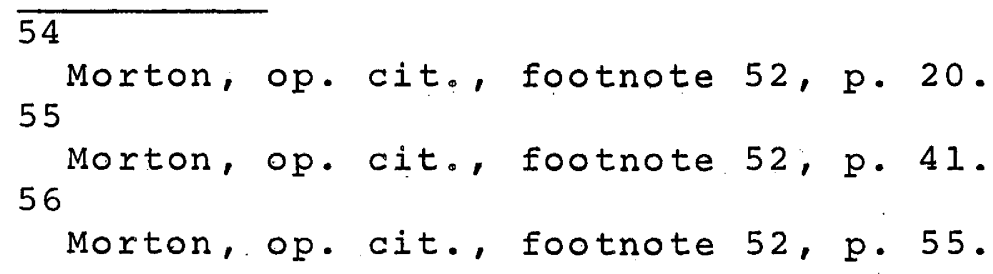


also could not be expected to enter a completely centralized union. For them all the salvation lay in a federation.

\section{POLITICO-GEOGRAPHIC. INFERENCES}

1. This study supports my hypothesis that federalism is a form of union that originates when a number of regionallygrouped political communities with small power potentials but strong regional identities are faced with a common threat to their survival; and that federalism is essentially a union of equal partners. In the pre-Confederation British North America the geographical distribution of power potential did, apparently, not appear uniform; and thus it does not seem to have been a union of equal partners. Even each of the sections of Canada was larger in area and population than all the Maritime provinces put together, and this was one of the reasons why the Maritimes were till the last not very enthusiastic about the union. A closer look would show, however, that the actual distribution of political status and prestige in the provinces in relation to their vulnerability to attack from the unfriendly republic to the south, and to the retreating British imperial protection, was not so anomalous as it appears at the first look. Though Upper Canadians regarded themselves as heirs to the great North-west, and Lower Canadians thought of themselves as custodians of the st. Lawrence commerce, both, cut off from the sea in the absence of any all-weather approach road, found themselves highly indefensible against the potentially encroaching Union from the south. The military weakness of the canadas had been evident once, and in future they could possibly not be defended if free and effective movement through the Maritime ports was not guaranteed. Thus, without a general union of British North America the two sections of "Canada" were far more helpless than the Maritime provinces singly or collectively.

Because of her strategic position and her accessibility to British armed support, Nova scotia had a standing in British North America which none of the other provinces possessed. Since the others needed the assistance of the British army for their defence, they felt their position of dependence, however free they might be in legislating for local interests. 
In fact, while "The other provinces felt their need of defence: Nova scotia felt it was helping in the defence of the whole." 57 This need for defence increased in ascending order as one moved from east to west. In fact, it was generally thought that Britain might afford to abandon the province of Canada, it could not afford to abandon the Maritimes as long as it had a western empire to defend. As The Times wrote in 1849

in surrendering Canada they the British statesmen will take care not to surrender one jot of sea or 1 and the possession of which effectively concerns the maritime and commercial importance of Great Britain. They will not cede Nova scotia, they will not cede Cape Breton; they will not cede the seaboard and those harbours which must ever command the mouth of the St. Lawrence and protect the trade of the Atlantic.58 However, as British disinterest in the colonies increased, and as the advantages of British mercantilist protection began to disappear, each of the colonies, howsoever particularist, was faced with a grim future--some economically and some militarily. And in view of the impending crises that faced all of them together, they sought strength in union, and the Confederation was the obvious result.

2. This study further supports my hypothesis that in multi-ethnic or highly heterogeneous federations with strong regional identities, a militarily alive political frontier serves as a consolidating agent by tending to squeeze the dissenting partners together into unity. This consolidating role of the militarily alive political frontier may be traced all through the history of Canada. It was this factor that had helped to change even the non-Loyalist elements in upper Canada into staunch Canadian nationalists after the 1812 war. It is significant to note that throughout the period before the Confederation, all the more serious plans for union originated in the Canadas whereas the Maritimes (having almost no live political frontiers, and being effectively shielded by the British Navy) were till the last wavering between join or not to join. 59

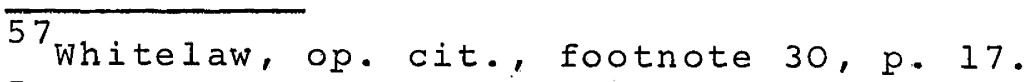

58 The Times, November 2,1849 . Quoted in whitelaw, op. cit., footnote 30, p. 17 .

${ }^{59}$ R. G. Trotter, "An Early Proposal for the Federation of British North America", Canadian Historical Review, Vol. 6 , 1925 , pp. 142-154. 
Although looking back to Canadian history one can see that general peace between Canada and the united states dates from 1815, in the mid-nineteenth century there was no sense at all that permanent peace had yet been secured. There had been boundary fighting in 1838, and a war-scare over oregon in 1846. Strained relations between Britain and the United States during the Civil War--exemplified by the Confederate raid from Canada on st. Albans, Vermont--had kept the possibilities of a desperate struggle with the Republic ever alive. And the Fenian raids from American soil in 1866 reminded that the risk of a struggle with the Republic had not ended when the Civil war was actually over in 1865. As the Colonial Secretary Edward Cardwell wrote in June 1865 "the Provinces of British North America are incapable, when separated and divided from each other, of making those just and sufficient preparations for national defence, which would be easily undertaken by a Province uniting in itself all the population and all the resources of the whole". 60 Thus,

in part [at least] the Confederation was an attempt to band together the strength of British North America to resist any American threat. The United states, therefore, not only supplied an example for a new northern federation: it supplied an urgent reason for it.61

Just as the military pressure on the frontier varied from the east to west so also did the awareness of the need for defence and the consequent urge for union. Although primarily a Maritime colony, New Brunswick was more inclined to the confederation than the other colonies on the coast: Part of the reason may be that it also, like the Canadas, had a longer frontier to defend. Support for the hypothesis may also be seen in the greater enthusiasm of Upper Canada relative to Lower which was closer to the British bastion in the Maritimes

60

In a letter from Edward Cardwell to the Lieut.-Governor of New Brunswick, June 24, 1865. Quoted in C. P. Stacey, "Britain's Withdrawal from North America 1864-1871", Canadian Historical Review, Vol. 36, 1955, pp. 185-198. See also, C. P. Stacey, "Fenianism and the Rise of National Feeling in Canada at the time of Confederation", Canadian Historical Review, Vol. 12, 1931, pp. 238-261; and H.A. Davis, "The Fenian Raid on New Brunswick", Canadian Historical Review, 61 Vol. 36, 1955, pp. 316-334.

Careless, op. cit., footnote 3, p. 238 . 
The announcement of the U. S, intention, during the Civil War, of a plan to rearm the Great Lakes (which were left free of warships since 1817), the abrogation of the Reciprocity Treaty, and later reports of responsible Americans talking of the plans to annex Canada to the United States, kept the military threat alive and, thereby, helped to keep the provinces together. ${ }^{62}$

Fortunately for the Confederation, the British North American settlements were aligned along a narrow ribbon following the United states border, which was a militarily alive political frontier. Had the settlements been northsouth instead of east-west, under the circumstances then prevailing, this union of strange bed-fellows, as the Confederation then was, would most probably not have been sustained, since security from all sides would have made the northern colonies complacent like the Maritimes and, in that event, a single province of canada might not have had enough resources to bargain union with so many reluctant partners. 3. This study also suggests the favourable effects of geographical contiguity in the rise of federal unions. British columbia, it may appear, was not geographically contiguous to the rest of the federal units in the east. But because all through its existence British Columbia was oriented towards the Hudson Bay Company and the Northwest territory, it had in effect possessed close ties with what later became the Dominion of Canada. When the construction of a link-railway within ten years was promised, the geographical contiguity was in fact created. This along with the anti-American sentiment born from the oregon war-scare, as well as the lure of "the last best west", that lay in the backyard of the province, as it were, brought British Columbia into the Confederation. Further, British Columbia, unlike the other provinces, had come to possess borders with the United states both to her west as well as to south consequent

\section{2}

J. Patterson Smith, ("A United States of America, Shadow or Substance?", Canadian Historical Review, Vol. 26, 1945, p. 118), says that it was because Americans assumed that the absorption of British North America was an inevitability which time would consummate, that they begot a sense of nationality in canada which ultimately destroyed any notion of union. The whole question of annexation and continental union is ably dealt with in warner, op. Cit., footnote 2 . 
upon the United States' purchase of Alaska $y$ in 1867.

4. The Canadian example also satisfies my hypothesis that when boundary lines of regionally identifying diversities within a federal state highly overlap, the cleavages are transformed into linkages, and the result is a stable federalism. The point is made negatively, however, since the greatest weakness in the Canadian Confederation is the virtual concentration of the major cultural deviance or dissidence in one unit only, $i$. $e$, quebec. The absence of cross-cutting cleavages in Canada has proved a great divisive force which for some time now has been posing a threat to the stability of the Federation. Unlike Switzerland where the cleavages of language and religion are highly overlapping, in Quebec the Roman Catholic Church is so closely identified with the French language and culture that the province has become altogether a different world within Canada.

Here one is tempted to point out that had A. T. Galt's plan of dividing Canada at the time of Confederation into three autonomous units been accepted, the central Canada (or call it the province of ottawa or Montreal) with its heterogeneous population of both English- and French-speakers would have acted as a link in keeping the communities together. This argument also applies to the short-sighted measure of taking away the privilege of separate Catholic schools for the minorities in Manitoba in the year 1890.63

A closer look at the history of the Confederation, in fact, shows that cross-cutting cleavages in the form of religion did play a significant role in the rise of the confederation in 1867. Bonenfant thinks that it is wrong to criticize cartier, the French-Canadian Father of the Confederation, for not sufficiently ensuring the protection of his compatriots outside Quebec.

At the most one can reproach him. . . for having had a [wrong] conception of federalism.. . [which] He expressed - . in 1865 in these words: "Under the federal system, which leaves to the central government questions of general interest in which racial differences are not

63

on this point see Creighton, op. cit., footnote. 8 , pp. $377-378$. 
concerned, it will not be possible that rights of race and religion fail to be appreciated".

Because at that time "the problems of education were much more centred on religion than on language... the protection claimed for the minorities depended more on the former than the latter"。64 And as there were a good number of Roman Catholics, other than French, in other parts of the colonies, the religious cleavage made for unity rather than separation. Had minority privileges been maintained in the new areas that were being opened in the west, a cross-cutting pattern of cultural cleavages would have emerged. This would have done a great deal to promote unity between the two communities, and would thereby have made the federal arrangement more stable.

5. In order to build a strong national loyalty the central government in a federation must succeed in attaching major groups in the constituent units of the state to the national government as the centre of their primary interest. The United states was able to do this through the federal control of the Great West. Like the United States in Canada, too, the "last best West" with its rich wheat lands in the prairies helped a great deal in binding the component units of the Federation together by providing in. it a forum of common. interest and a common source of reward to all participants in the Union. Favourable effects of the frontier region on the federal relationship in Canada may still, to some extent, be discerned. It is said that "The line which marks off the frontier from the farmland, the wilderness from the baseland, the hinterland from the metropolis, runs through every Canadian psyche". 65 Developed or not, the North remains all-important to the Canadian's self-image. It makes their country the second largest in the world. "Its promise of riches is a lottery in which every Canadian holds a ticket - . [and] its brooding physical presence over the land is

\section{4}

J. C. Bonenfant, The French Canadians and the Birth of Confederation, The Canadian Historical Association, Historical Booklets No. 21, 1966, p. 16 . 65

Morton, op. cit., footnote 51, p. 93 . 
a warning [and a consolation (?)] that Canadians have not yet conquered their universe" ${ }^{66}$ and, therefore, there is, in effect, still much to be optimistic about.

But the Western frontier in Canada did not prove a melting pot in the manner that the Great west in the United States had been. The existence of Quebec as almost a distinct cultural island in Canada proves the point. Looking for its reasons we find that for a century and a half of its existence uniformity in language, culture, and "race" was the rule in New France. By the time heterogeneity was introduced in 1763, a distinct French culture was deeply implanted in quebec. Further, it was a heterogeneity introduced by a victorious "race" over the vanquished nation that had always considered its language and culture superior to the conqueror's. The need for change was, therefore, seldom felt or accepted. A continuing factor in this hardening of the separate communal shells was the British imperial policy which was aimed at keeping the French Canadians very much les Canadiens and Catholics so that the quebecers continued to feel themselves separate from, and antagonistic to, the "rowdy" protestants to the south. Then as long as there was land for settlement in the fertile valley of the st. Lawrence there was little to induce the French Canadians to move out into the frontier wilderness. At the time when the "last best West" could have provided a real force for mobility--that great antidote to localism--among the quebecers, the short-sighted legislation to end the privilege for special schools for the Catholic minority in Manitoba, only further helped to impress upon the French Canadian people the notion that although no longer a physical wilderness, the west to them had now become a hostile cultural wilderness. The unhappy memories of the largely French or méti and Catholic Riel Rebellion had greatly contributed to English Canadian suspicion of the French community in the

$\overline{66}$

Brian Moore and the Editors of the Life, Canada, Life World Library, Time-Iife International, 1965, p. 109. 
area. 67 Behind all this was the underlying psychology of a conquered "race" which was satisfied with its lot among its own people rather than going as inferiors among the members of the victorious "race".

6. As in the United States here also sectionalism has been an important force in the federal relationship. In Canada topographicbarriers tend to consolidate groups of provinces, though in extreme east and west single units are isolated. The Rocky Mountains are so scenically spectacular that their barrier effect on British Columbia might often be over-rated. Though economic activity in British Columbia differs from that to the east of the Rockies, fish and timber of the Pacific coast and fruit products of the interior are complementary to the grain crops and dairy products of the west across the Rockies. For this reason the province of British Columbia, despite the Rockies, finds itself so strongly tied to the province of Alberta that the talk of closer Alberta-British Columbia relations appears recurrently, and the British Columbians claim an associate membership in the "West" which is usually defined as the region between the Rockies and the Great Lakes specializing in wheat production.

The Great Shield intervenes between the "West" and the densely populated regions in the lower Great lakes-st. Lawrence region--i. e., the most of ontario and quebec. The shield is, however, not a completely uninhabited waste. It is true that its precambrian rocks provide little inducement to agriculture, but the railway construction revealed its great wealth in minerals which, coupled with softwood forests, have given it considerable sprinkle of mining settlements as well as pulp and paper mills. As the financial interests of Toronto are deeply involved in the area, the barren-looking shield has helped to keep the west and the st. Lawrence region together, and there is a continuous

\section{7}

For brief but excellent accounts of the Riel Rebellion see D. F. Warner "Drag lach Norden: The United States and the Riel Rebellion", Mississippi Valley Historical Review, Vol. 34; 1953, pp. 693-712; and A. C. Gluek, Jr., "The Riel Rebellion and Canadian-American Relations", Canadian Historical Review, Vol. 36, 1955, pp. 199-221. 
federal interaction between the two sections.

ontario and Quebec, though divided politically, culturally and linguistically, are nevertheless economically and geographically bound together by the common pull of the st. Lawrence commerce. The Maritimes in the east are, however, cut off from the rest of their co-linguists by the interposition of the French-speaking Quebec. The isolation of this region is further emphasized by the fact that the st. Lawrence, which is frozen for almost seven months during winter, ceases to be the main carrier of the area's commerce. [Fig. 4.4] This sectionalism--physical, and cultural--has helped to create a kind of shifting balance in Canadian federalism because the physical geographic sectionalism has given rise to a sort of economic sectionalism which often works against the cultural divisiveness and thereby helps to maintain unity. Though culturally rivals, ontario and Quebec, which together produce three-fourths of the manufactures of canada, find their interests (on the federal level) to a great extent united. The Canadian production of export wheat is centred in the three Prairie provinces, while the production of pulp and paper, another important export item, comes largely from ontario and Quebec. Since forest and minerals are subject to regional competence, the manufacturing and other industries associated with them have a vital impact on federal politics for like the wheat farmers, the groups engaged in the industries also have a special interest to guard, though, no doubt, these interests are much less forceful and distinctive compared to those associated with wheat, for wheat, being the king of the relatively densely settled prairies, supports more votes than pulp and paper do.

A strong farmers' bloc, sometimes taking the form of a separate group, sometimes within a traditional party, can always be found in the federal parliament advocating the current farmers' panacea, be it lower tariff or federal price support, and fighting a constant battle for low freight rates. As in the United States, in Canada too "The existence of regional specialization.. - [has led] to a type of federal government dominated by 'log-rolling' deals and concessions negotiated by different interest groups promising to support other sectional projects in return for support 


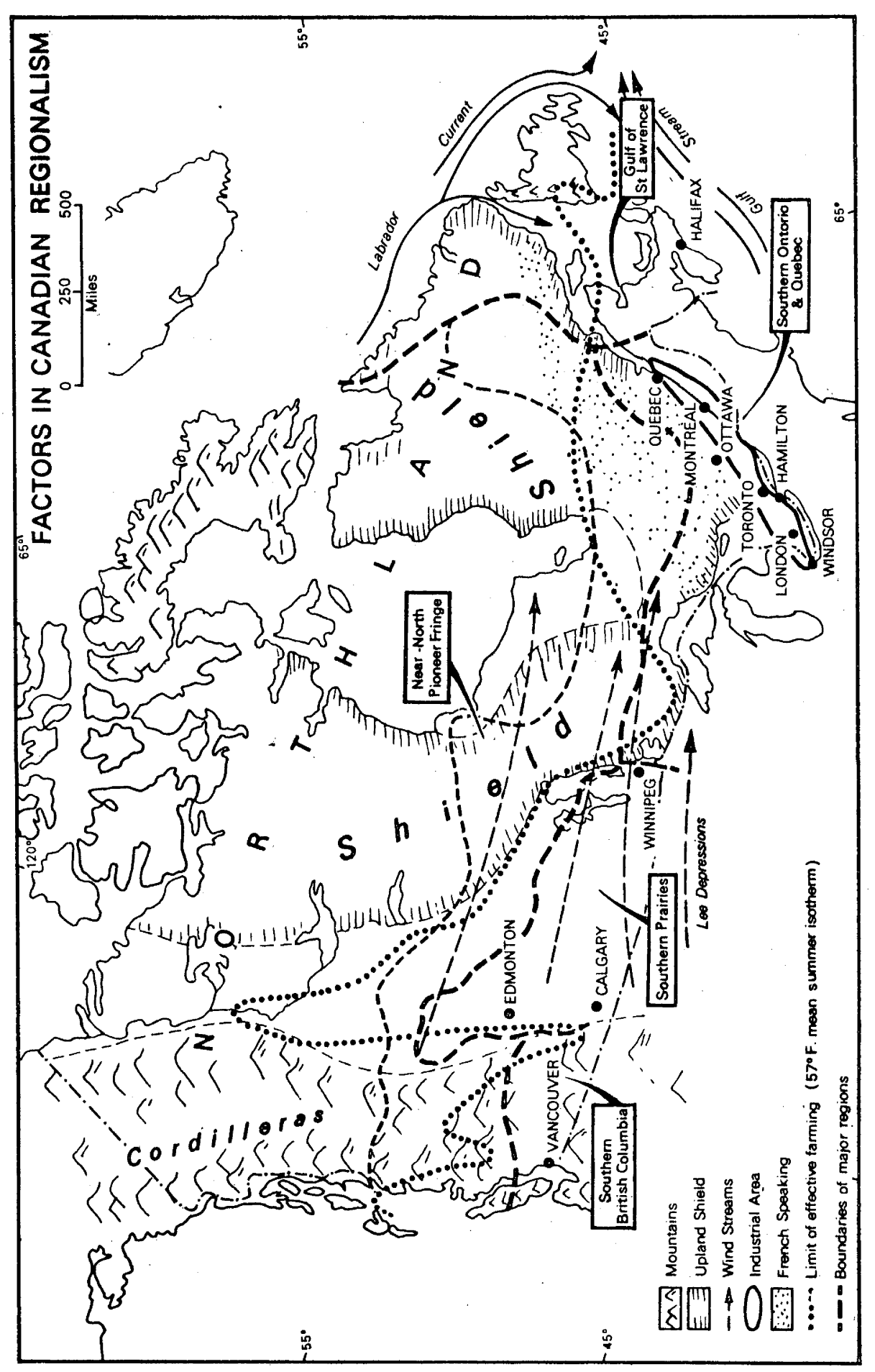

(1) $101+0$

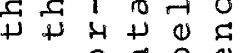

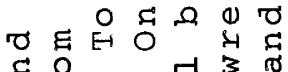
दि 0 त्र प

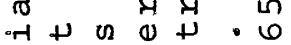

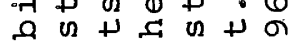
है थ 0 ज ए उ 1000

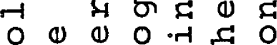
Uद + प स द 0 क

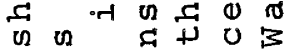

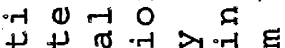

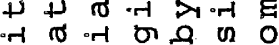
मै मे 0 ब - 0 व

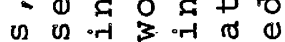
1) 4 स 0 त न ठ 0 兵 ब द्ञ त द थ 4 न

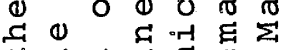
工平 † द O O ॥) व $\gg>0$ हा क $0-1$ त o) $\square$ म $\Rightarrow$ मे द्व 0 ते

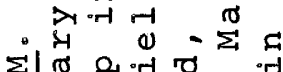
था ता वर 0

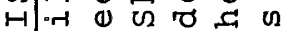
거

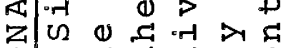
에 (1) द $\gg 0$ 国政 = 0 न + 0 的 $z$ z दा हुत 30 क 约 a

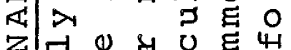

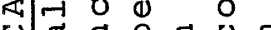

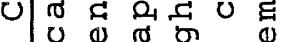
Z है $3000+$

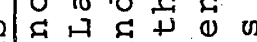
म 0 त के

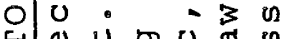
U थ 2 ह 0 月 बा 01 .

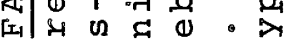
की * थ 若 - 0म द

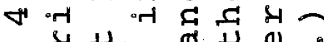
म 0 o 0 बंत्र क्ष क्ष 岳 मै 
of their own". 68 But owing to its simpler economy and a less powerful senate, and, most important of all, a solid concentration of cultural-linguistic dissidence in a single unit ( uebec), Canada has not been able to benefit from sectional interaction to the same degree as the united states. The position of the Maritimes is specially anomalous because economic interdependence, which is a marked feature of the rest of Canada, is extremely weak in the Maritimes. The st. Lawrence commerce bypasses them for seven months during winter when the river is closed to navigation.

As the preceding analysis would show, the greatest difficulty in Canada's rise as a centralized mature federalism is that here, unlike in the swiss example, the two cultural streams in the country flow quite apart and, thus, avenues of intercultural intercourse are virtually blocked. Because of this Canada has not been able to create a distinctive allCanada nationality. Strangely enough it continues to be so in spite of the fact that raw materials for interlocking or cross-cutting cleavages have been present in the country all through its history. Out of a total population of $18,248,247$ in 1961, 8,342,826 were of the Roman Catholic faith. There are sizable numbers of French-speaking people in Manitoba and New Brunswick besides quebec. At present the Catholic and French-speaking people living outside Quebec do not provide an element for cross-cutting ethnic ties because their minority privileges are not recognized. If a way out could be found to do so, the French Canadians in quebec could cease to consider their province as a French-Catholic cultural island in an English cultural ocean, constantly threatened by the encroaching waves of the English and, hence, needing constant vigilence and fortification. A geographer, therefore, finds his convictions echoed when the historian says:

We must find institutions that will give full expression to the cultural duality of the Canadian nation-state. - . French-language education must be provided where there are enough French-speaking Canadians to make it practical. These institutions.. would.. . increase

68

K. A. Mackirdy, "Geography and Federalism in Australia and Canada", Australian Geographer, Vol. 6, No. 2, March 1953, p. 46 . 
the mobility of the Quebecers, who are at present reluctant to leave their province because of the lack of educational facilities in French for their children.69

And as Turner said, "nothing works for nationalism like intercourse within the nation". 70 similarly some method may be found to harness the federalizing effects of the over fortyfive percent. Roman Catholic population spread all over Canada (see Table 4.1). Thus, it is within the reach of Canadian statesmen to change the internal political geography of canada, and create therein conditions which will be conducive to a centralized and stable federal polity. 71

\section{Table 4.1}

\section{DISTRIBUTION OF ETHNIC AND RELIGIOUS MINORITIES \\ IN THE PROVINCES OF CANADA}

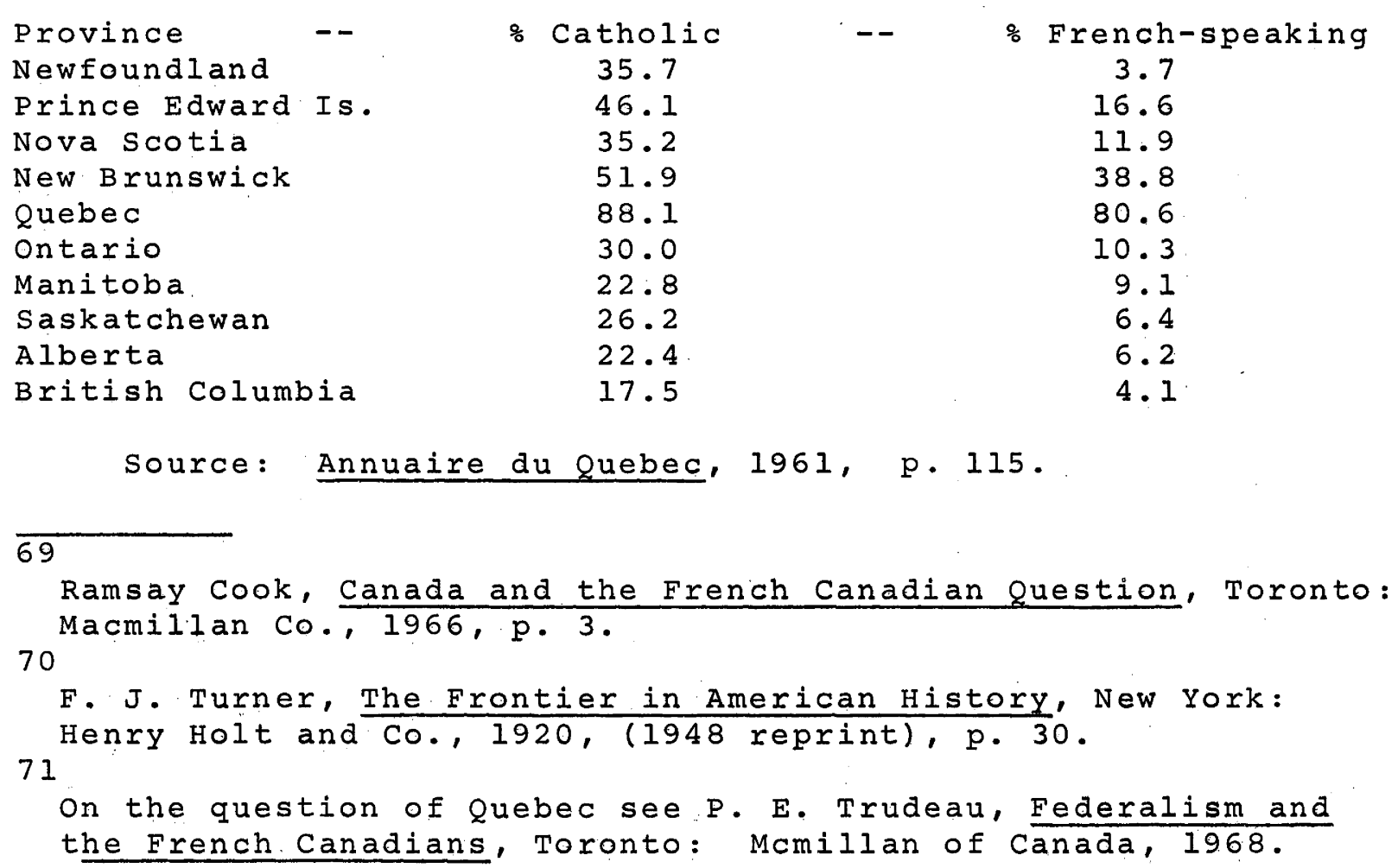




\section{AUSTRALIAN FEDERALISM}

Historically the last of the so-called classical federations, Australia offers the best example of what is called "structural" federalism, ${ }^{l}$. for here in the opinion of many scholars the states "no longer correspond with distinct interests or attitudes: there are no longer any solid economic or social foundations for the political divisions within the federal structure". They are merely administrative political units, and "it is the existence of six separate governments which chiefly produces the sentiments, attitudes and interests which support those governments". "Thus to many who believe that federalism. is usually "a road to unification" 3 "the evidence [seems to point] decisively to the conclusion that the [Australian] federal system has outlived its usefulness". 4 William Riker "wonders, indeed, why they bother with federalism in Australia" for in his opinion "the divisions in Australian culture seem to be economic and religious with hardy any geographic base". Australia appears to him the singular case of a federation where national "patriotism is unobstructed by loyalties to states." 5 "That prophet of doom for Australian federalism, A. P. Canaway, wondered why the Australian Fathers made such a complete departure from the best British tradition

1

A. Wildavsky, "Party Discipline Under Federalism: Implications of Australian Experience", Social Research, Vol. 28. 1961, 2 pp. $437-458$.

P. H. Partridge, "The Politics of Federalism" in G. Sawer (Ed.), Federalism: An Australian Jubilee study, Melbourne: 3 Melbourne University Press, 1952, both quotations on p. 195.

A. V. Dicey, An Introduction to the Study of the law of the Constitution, London: Macmillan Co., first edition 1885, 4 tenth edition 1959, p. Ixxxvi.

G. Greenwood, The Future of Australian Federalism, Melbourne: Melbourne University Press, 1946, p. viii. 5

W. H. Riker, Federalism: Origin, operation, significance,

Boston: Littie, Brown \& Co., 1964, p. 113 . 
when in fact at the time of the federation "The respective [Australian] colonies were less differentiated from one another than are certain counties of England," and "as compared to the divergences between England, wales and Scotland. . . the distinctions between the respective colonies were in verity microscopic." 6

Such views, however, only show the utter disregard that scholars sometimes show to the role of geography in a nation's polity. To establish an analogy between English counties (separated from one another by negligible distances) and the colonies in Australia, whose cores were separated from one another by several hundred miles, is thoroughly unrealistic. In fact, a closer look at the Australian history would show that although the "crimson thread of kinship" runs through all the Australian people--the federal slogan of sir Henry Parkes in 1890--their geography compels them to remain only somewhat imperfectly joined units of a federation, because oppressed by the "tyranny of distance" they are not prepared for the economies of a complete unification of their polity under a unitary form of government.

\section{AUSTRALIA'S RISE TO FEDERATION}

For nearly a decade and a half after Captain cook landed at Botany Bay, little attention was paid to the new continent in the south, until the American Revolution and the independence of the Thirteen Colonies finally stimulated action. With the independence of the Thirteen Colonies, the British government needed a new area to take convicts transported from Britain. To remove the apprehension to the English gentleman's "person and property" and to promise him "security in his bed", the antipodes were ultimately thought of value for the establishment of a "colony of thieves." In the words of the then Home Secretary, Lord Sydney, New South wales was "a very proper region for the establishment of criminals condemned to transportation." Thus Governor Phillip with his party of 1030 ,

A. P. Canaway, Failure of Federalism in Australia, London: Oxford University Press, 1930, pp. 1-2. 
including 736 convicts, landed at sydney Cove on January 26 , 1788, and the first foundations of Australia were 1aid. 7

Beginning as a remote gaol, New South wales had a bad start as a colony. It could not emerge as a land of hope and second opportunity until 1823, when its formal recognition as a Crown colony triggered a flow of private money and free immigrants. Swollen by immigration the white population of Australia grew to 190,000 in the year 1840. Thousands of square miles had now been brought under sheep grazing. The assumption of sovereignty over New Holland made Britain the mistress of the whole continent, and a new British colony was begun in the west. Van Diemen's Land was made independent of New South Wales, and a free colony of South Australia was founded.

While a strong despotic government was essential in the penal days, even in the "free" settlements "ample government" by a paternal administration was needed in order to overcome the initial difficulties of foundation. However, as the numbers

7

Although this is the generally agreed view, the mystery why England decided to send many of its convicts to the opposite side of the world was given a new interpretation by Dallas in 1952. He suggested that England needed a new base and a refitting port in order to strengthen her commercial empire in the East, and Botany Bay was to be that maritime base. Geoffrey Blainey, who has further refined this argument, has gathered evidence to the effect that the probability of growing flax (a sure supply of which, wrote Lord sydney, "would be of great consequence to us [Britain] as a naval power") was a reason for the selection of New South Wales. Tall trees which grew in the islands near Australia would, it was thought, yield masts of unparalleled size and quality for the British fleets in India. Australia was thus thought to be reciprocally beneficial both to English gaols and the English seapower. See K. M. Dallas, "The First settlement in Australia: Considered in relation to seapower in world Politics", Papers and Proceedings, of the Tasmanian Historical Research Association, Hobart, 1952, No. 3; and G. Blainey, Tyranny of Distance, Sydney: Sun Books, 1967. For further discussion of the problem see the Blainey-Boulton controversy in the following articles in the Australian Economic History Review, Vols. 8 and 9 (1968 and 1969): G. C. Boulton, "The Hollow Conqueror: Flax and the Foundation of Australia." 1968 , pp. 3-16; Geoffrey Blainey, "Botany Bay or Gotham City?", 196 \& pp. 154-163; and G. C. Boulton, "Broken Reeds and smoking Flax," 1969, pp. 64-70. 
of free settlers and the colonial free-borns gradually increased, the danger to society in the grant of free institutions became less. In fact, by 1840 the political divisions in New south wales had begun to follow the more usual groupings of rich and poor, rather than the temporary and particular distinction between the bond and free. ${ }^{8}$ Transportation to New South Wales had been abolished in 1840 (though the colony finally stopped receiving convicts only in 1850), and Van Diemen's Land stopped receiving convicts in 1853 and changed its name to Tasmania the same year. Both the colonies attained self-government in 1855 .

With its 77,000 settlers and about five million sheep the Port Phillip District (founded in 1836) was renamed Victoria in 1850 when it gained independence from New South wales. South Australia had already been founded in 1836 as a Crown Colony of entirely free settlers. Western Australia was also rising slowly. Transportation, stopped elsewhere, continued in Western Australia till 1868, for here the prime question was not of responsible government but of survival. And survival was possible only if labour could be sent because it refused to come voluntarily, for immigrants having come so very far thought it worth going another relatively short leg to have advantages of an already settled community in eastern Australia. Queensland was born in 1859 when the 24,000 people north of the twenty-eighth parallel were granted independence from New South wales with a constitution modelled on that of the parent colony.

So by the close of the first half of the nineteenth century these different prosperous communities, largely self-governing, were winning wealth from the wilderness, and the social and. cultural foundations for a new nation had been laid. By 1860 , Australia in fact had five parliaments and political reforms in advance of its mother country; Western Australia was finally granted self-government only in 1890. Government from a distance was coming to an end. But what had emerged was a democracy of the middle classes, not of the wage-earners, for howsoever radical the new assemblies, the privileges of the

A. G. L. Shaw, The Story of Australia, London: Faber \& Faber, 1961, p. 91 . 
conservative land-owners in the Legislative Councils remained as an effective check on popular government. 9 However, the separate colonies, freed from the immediate British control, and unhampered by any common national feelings, were going their own ways, tackling in their own fashion the urgent problems that beset them. This tended to make each one a kind of "little world" in itself.

With the discovery of gold in 1851 immigration to Australia increased tremendously. The population of the continent trebled in the ten years after the discovery, and the "diggers" reduced the convict elements in the population to more modest proportions. Liberal elements in the colonies were now able to introduce many reforms such as manhood suffrage and vote by ballot. By 1858 property qualifications for membership of the New south Wales and Victorian legislative assemblies were abolished. In a decade (December 1851 to December 1861) the total White population of Australia increased from 437,665 to 1,168,149. It is during this period that large numbers of chinese came to Australia--by 1857 there were 23,623 Chinese on Victorian goldfields, and by 1861 their number had increased to 24,062 . For various reasons, the Chinese immigration became the cause of that common abhorrence for coloured,immigration on which, as much as anything else, Australian nationalism was initially based.

The discovery of gold became the occasion for, if not the cause of, the rapid material progress and the strong movement for democracy. Gold and new constitutions had set colonists free to shape their own destiny, but the long opposition to the Colonial office rule was not the best training for political independence. Only after 1880 did the colonists' ideas become quite distinctive because of the lessons learnt in the twenty important years of experiment. Before that period a good deal of the militant and theoretical radicalism was imported from the old World. "As imported radicalism was modified by colonial conditions, a distinctly Australian democracy was born". This colonial democracy, no doubt, had an earlier

9

D. Pike, Australia: The Quiet Continent, London: Cambridge University Press, 1962, p. 104. 
beginning; but it was only after the gold rushes that "its main outlines were clearly drawn". 10 In fact, though the Australian colonies were still clinging to fringes of the continent, in pockets set apart from each other, by the $1860 \mathrm{~s}$ they had begun to grope their way toward closer acquaintanceship. Between 1861-1883 the bourgeoisie upset squatterdom's domination, and land-laws in the colonies were changed. Everywhere the cry was to unlock the land, while in the cities there was an intense clamour for the principle of equality of opportunity. New South wales in 1861, Victoria in 1862, Queensland in 1868 and South. Australia in 1869 had their different land-selection Acts to enable the small farmers to own land, though by one trick or another the small farmer was still largely excluded, and the best land usually went to the rich. Further, as we will explain below, the Australian frontier was basically a "big man's frontier". Still, because of mechanical inventions and other reasons, in the twenty years of land reform the area under crops doubled in New South Wales, and multiplied six times in victoria and south Australia. Facilities for transport were greatly improved. Railway mileage increased from 200 miles in 1860 to 4,000 miles in 1880. All this had helped the spread of agriculture. "As reforms weakened the political power of the rich, electors slowly began to see the government as a friend and provider that could turn each colony into a paradise for working men. For good or ill, these new attitudes were to do more than wool or gold in shaping modern Australia". 11

Rapid progress of transport and communications was bringing the isolated colonies closer together. A trunkline (though with a break of guage) joined sydney and Melbourne in 1883, Melbourne and Adelaide in 1887, and sydney and Brisbane (again with a break) in 1888. Western Australia, because of the vast gap of the almost desert Nullarbor which made it virtually an island, was not connected with the eastern colonies by rail until 1917. The total railway mileage had reached

\footnotetext{
10

R. M. Crawford, Australia, London: Hutchinson University 11

Library, 1952, p. 107 .

Pike, op. cit., footnote 9, p. 126.
} 
13,500 in 1900. Electric telegraph linked Melbourne and Adelaide in 1858; Sydney and Melbourne the same year; Sydney and Brisbane in 1861; Sydney and Adelaide in 1867; Launceston and Melbourne in 1859; and Adelaide and Perth in 1877. By the 1890s the colonial parliaments had placed ownership and control of telephone services under their colonial post offices. 12

Native-born Australians had long begun to outnumber immigrants. In 1861 just over 50 percent of the people were born in Britain. In 1871 nearly 60 percent were native-born. The figure increased to 75 percent by 1891 , and to 82 percent in 1901. The total population also increased rapidly. The number rose to $3,773,801$ from a mere $2,306,736$ in. 1881 .

As their population and material prosperity increased, sydney and Melbourne began to look for markets for their industrial and other goods outside the boundaries of their own respective colonies, but the existing institutional barriers stood in the way. The idea that the colonial economies were being thwarted by the dead hand of the past increasingly crystallized. While the past divided Australia into six separate colonies, economic development, even though impeded by tariff and other barriers, rushed ahead and was helping to bring the colonies closer together. Intercolonial trade unions were also moving in the same direction.

All through the 1880 s government and private enterprise helped to expand economic activities recklessly. Rapid immigration, a spell of good seasons, further protection, and mining discoveries, all combined to stimulate the boom which in its turn encouraged the growth of a vigorous labour movement, and a strong nationalistic feeling that cut across the colonial borders. Almost until the year 1890 there seemed to be no limit to progress, though, in fact, it was a case of sowing the wind to reap the whirlwind. 13 During the boom, less than three million people of the colonies borrowed over $£ 200,000,000$. The colonial governments had

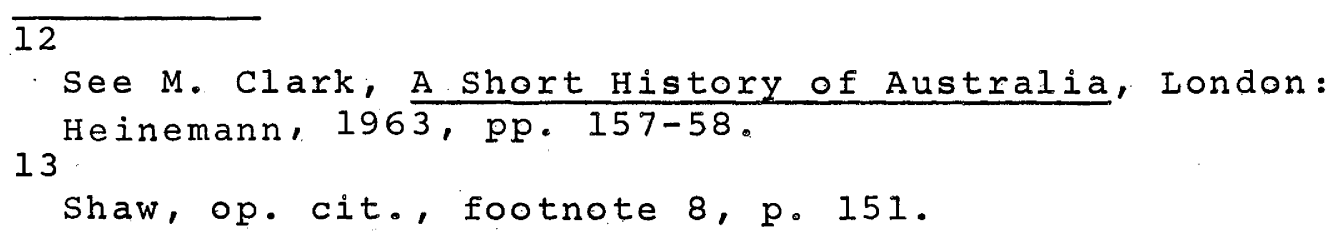


raised loans in London in excess of their ultimate capacity to pay. So when in July-August 1890 a financial crash occurred in Argentina (which was then the centre of world speculation), and in November the great firm of Barings failed in London, the British investors were greatly alarmed and rapid withdrawals of deposits from Australian financial institutions began. One bank failed in March 1892, and by May fifteen banks had closed their doors in Victoria, New South Wales, and queensland: A great many public and private works were stopped, leading to mass unemployment. Farmers and squatters were hard-hit by drops of up to 50 percent in the prices of their produce. Land values were heavily depreciated.

This devastating depression converted the colonial bankers and financiers into nationalist Australians who, with a view to escape the repetition of such disasters, began to urge the creation of a federal parliament with powers to legislate on banking and currency. But this increased interest of bankers, financiers and other capitalist groups in an intercolonial federation as a servant to their material interests helped to plant in the mind of labour thinkers a dark suspicion that federation might become a means of preventing in perpetuity their own cherished reconstruction of society, though their own intercolonial trade unions had been steps in the same direction. 14

A series of strikes between 1890-94 led to similar thinking on the part of both labour and capital. The labour conception of trade unions changed. They were no longer confined to the struggle for higher wages and improved standard of living. They now busied themselves with the idea of the overthrow of the society that imposed these hardships. With this objective in view, labour electoral leagues were formed in New South wales, Victoria, South Australia, and queensland which won several seats in the respective parliaments. Thus both labour and capital were marching in the same direction (i. e., intercolonial union) though on the question of federation, each continued to be apprehensive of the other.

Although in retrospect the depression can only be regarded as the bursting of a bubble that had blown to an. inordinate 
size, its psychological effects were profound 15 It brought people up against the stubborn fact that the country's material prosperity could be undermined by what happened overseas. This gave them a sense of urgency for standing on their own. And this seemed possible only in an intercolonial union. As will be discussed in a following section, the mother country's indifference to Australian defence in New Guinea and the South Pacific had led some to the same conclusion even earlier. But now the great combination of circumstances led to final effort, and despite various lions in the path the great Commonwealth was consummated by the turn of the century.

\section{The Federal structure}

The Australian Federal Fathers adhered more closely to the model of the United States than has any other federalism before and since. ${ }^{16}$ However, the system borrowed considerably from Canada and switzerland, and though in its original form the system had no markedly distinctive features, the modification on the originals in detail were significant. As in the United states, the states retained their existing constitutions and their power to amend them, as also the residual competence; while the federal centre received an express list of powers. Powers of the central government under the terms of the Constitution are limited, as in the U. S. A., to obvious national subjects with but few additions suggested largely by the difficulties experienced by American federalism. The centre has express powers over banking and insurance. It was also granted the power to arrange conciliation and arbitration of industrial disputes extending beyond the limits of one state. Some express welfare powers were extended by amendment in 1947, but as sawer says, they still go no further than (if so far as) the U. S. "general welfare" power. The residual powers of the states are therefore quite extensive. They include the general civil and criminal law, most aspects

15

V. Palmer, The Legend of the Nineties, Melbourne; Melbourne 16 University Press, 1954, p. 73.

This discussion of the federal structure of Australia closely follows G. Sawer, Modern Federalism, London: C. A. Watts \& Co., 1969, pp. 42-44. For further details see G. Sawer, Australian Government Today, Melbourne: Melbourne University Press, 1967 . 
EVOLUTION OF AUSTRALIA'S POLITICAL BOUNDARIES

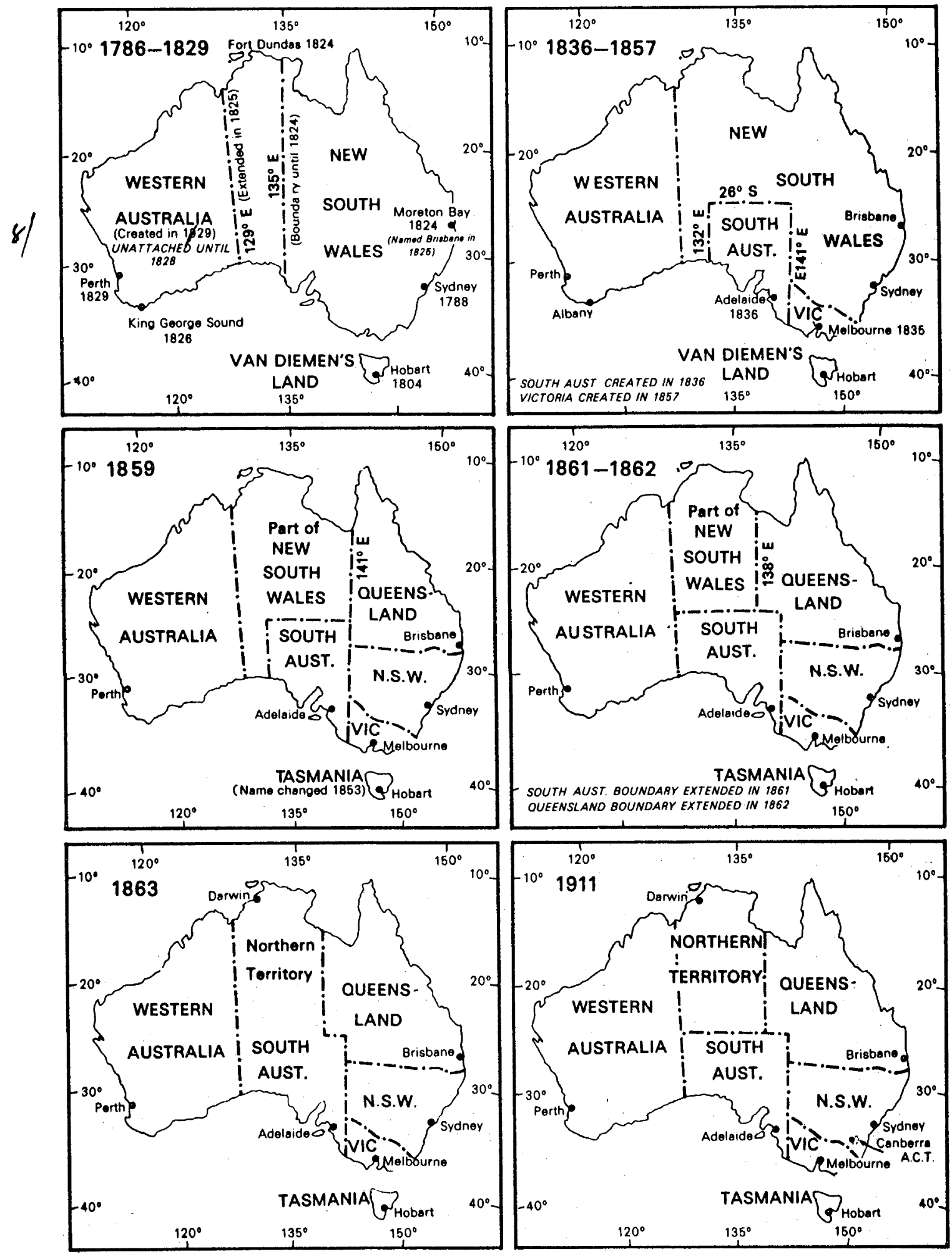

Fig. 5.1 EVOLUTION OF AUSTRALIA'S POLITICAL BOUNDARIES。 In 1926 Northern territory was divided along $200 \mathrm{~S}$ latitude to form two new territories of North and Central Australia, but this lasted only until 1931. (Map adapted from a twelve-figure map in The Australiar Encyclopaedia, Vol.8, p. 273, and K. W. Robinson 1961。) 
of production--agricultural and industrial--and of distribution which does not actually cross a state border, the principal utilities (water, power, land transport), the major aspects of internal order and police, most of the problems of urban concentrations in which seventy percent of the people live, as also a large part of education. There is more explicit provision for joint centre-state action in Australia than in any federation that preceded it. The centre and the states jointly have concurrent power over all tax fields, except that the centre has a monopoly of customs and excise so as to produce a common market and provide an absolute freedom of interstate trade; but as regards income tax, in practice, though not in strict constitutional theory, this has been reserved to the centre since World War II. The High court of Australia is a Commonwealth-appointed judicial body that acts as a general Court of Appeal both from the centre and the states.

The new Commonwealth though healthy was "perhaps hardly a lusty child" for it lacked that "quasi-revolutionary energy" which is so often associated with new states. 17 But because the federal government was, under the terms of the constitution, given fairly wide powers, important leaders from the colonies were attracted to the commonwealth--a factor the lack of which proved so fatal in the case of the West Indian experiment in federalism. Then the badge of nationalism in the "White Australia" policy appealed to every section of the Australian society, and thereby gave the Commonwealth a sense of purpose in the eyes of its citizens. This greatly helped to strengthen the hands of the central government in building a strong. national loyalty.

It is possible that the first fervour and support for the Commonwealth might soon have declined once the immediate objectives were achieved had not a national crisis in the form of the first war soon intervened. Only an hour after London's ultimatum on August 4, 1914 the first British shot of the War was fired at a German merchantman leaving Melbourne, and Australia pledged "the last man and the last shilling"

17

O. H. K. Spate, Australia, London: Ernest Benn Ltd., 1968, p. 67 . 
to the support of Britain. Participation in the war gave a sense of manhood to the young nation, and finally assured Australia that she was a nation in her own right. Involvement in the war strengthened the Commonwealth vis-à-vis the states in economic activities generally. And as spate remarks "If, as some say, true [?coordinate] federalism is dead in. Australia, it died under the pressure of the first war". 18

Though in the twenties Australia seemed to have settled back into a comfortable unawareness of world affairs, the changed strategic position in the pacific soon dented this complacency. The Japanese had supplanted the Germans in Micronesia, and Rabaul, the main port of New Guinea, was only 900 miles from their advance base at Truk. And as the later events showed "The Near North was terrifyingly close; the Yellow peril was incarnate in arms". 19

The second war led to further centralization of power in the commonwealth. A system of uniform income tax was introduced, the states vacated this field against Commonwealth grants. The effects of the increased emphasis on social services and reconstruction and planning with a stress on full employment were similar. The overall impact of these developments has been "to override state identity in order to produce uniformity in the economic, political, and. administrative fields. It has not destroyed state identity, but . . it has strengthened the centralist tendencies within each state". The greatly extended powers and functions of the central government have tended to make the Commonwealth as a disbursing authority and the states as the developmental agencies. 20

\section{POLITICO-GEOGRAPHIC FACTORS IN THE RISE \\ OF AUSTRALIAN FEDERALISM}

Factors for strong Regional Identities

The Australian colonies had developed as six unconnected

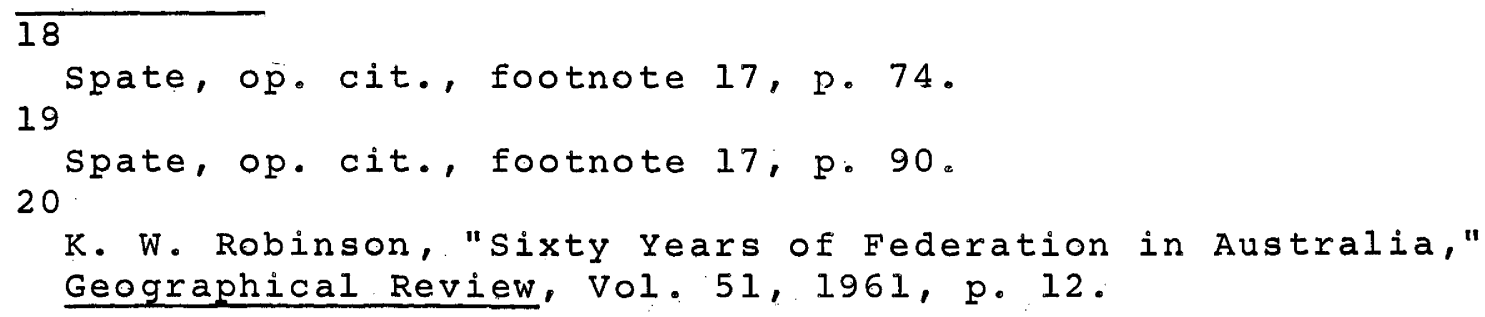


social islands on the coast of a continent, facing three different seas. Having developed as "six seaports with independent legislatures devoted to their special interests" 21 the six colonies were to all intents six independent states in so far as their internal matters were concerned. Each had developed virtually a world of its own. Distance, indeed, is as characteristic of Australia as mountains are of switzerland. It has been one of the very strong moulds which shaped Australian history. As Blainey says, "In. understanding Australia's history [politics too], the idea of distance may be as revealing as say Frederick Jackson Turner's 'frontier theory' is in probing the history of the United States." 22

Before the 1880s major commercial links between the colonies were by sea. Railway links between the colonies had not developed, and each colony was very closely identified with its capital city which alone served and supervised its people and all the routes in the colony converged to it. Intercolonial contacts in Australia were greatly handicapped beckuse of the lack of long and reliable inland waterways. Everywhere in the world before the oncoming of the railway-age inland waterways had been the most efficient agents in binding dispersed continental communities. Further, while over a thousand miles of sea stood between Western Australia and the eastern colonies, the rough sea on the south and eastern coast of the continent presented no easy problems for the small vessels of the day. Later when the railways were laid, each colony laid its railways almost independently of the others. Thus there came to be established different railway gauges in the different colonies. While Victoria and the main lines in South Australia adopted the broad guage (5'3"), the remoter parts of South Australia and the whole of queensland had a 3'6" gauge. New South wales

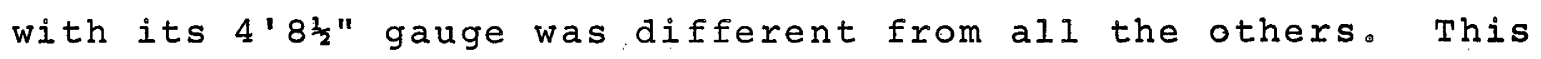
greatly hampered intercolonial transport and commerce even where a rail link existed.

\section{1}

A. Jose, Australia: Human and Economic, London: George 22

Harrap \& Co., 1932, p. 73.

Blainey (1967), op. cit., footnote 7 , preface. 
Though the Australian colonists were predominantly British and English-speaking, there were nonetheless some social limitations to a general cultural homogeneity. While New South Wales and Tasmania had started as convict settlements, Western Australia regarded itself as less tainted, and south Australia having remained all through a "free" settlement was extremely proud of its high caste. Thus the "crimson thread of kinship" was not very crimson, indeed. It became crimson enough to be able to bring the Australian communities together only when other circumstances forced them to join together for their own larger interests.

All of the colonies had developed as largely selfsufficient primary-producing communities with near-similar economies--exporting their surplus produce to Britain and receiving from there manufactured goods in return. For this reason that great binder of dispersed communities-interregional trade--was very slow to develop. There were some institutional barriers as well. A provision in the Australian Colonies Government Act of 1850 prohibited free trade between the colonies. A request for repeal of this provision was turned down by the mother country in 1868, 23 This further helped to fortify particularist tendencies in the colonies, and made the foundations of their six little worlds stronger still.

The absence of a customs union gave rise to highly contrasting policies with regard to protection and free trade. The postures of Victoria and New South Wales, in particular, were opposite on this issue. In view of the rising demand for employment and the declining fortunes of gold diggings, Victoria was all for high tariffs. New south wales, on the other hand, stood for complete free trade. So strong was the division on this issue that even when the colonies forced by other circumstances had become reconciled to the idea of a. united nation, the tariff question still stood as a great "lion in the path." 24 The New South wales politician George

J. Quick and R. R. Garran, Annotated Constitution of the Commonwealth of Australia, Sydney: Angus \& Robertson, 1901, 24 pp. 104-105.

From a speech by James Service in 1890. Quoted in Quick and Garran, op. cit., footnote 23, p. 119 . 
Reid was voicing the opinion of the majority of his people when attacking the resolution for federation by sir Henry parkes in the New South wales parliament he said that New south wales, a complete teetotaller, could not contemplate keeping house with five drunkards. 25

Then because of the highly disparate size of their populations, ${ }^{26}$ the smaller partners were afraid that in a union the larger colonies, by virtue of their majority, might manipulate the central administration in a manner prejudicial to their (i.e., smaller colonies') interests. Queensland, Tasmania, South Australia and Western Australia were so far removed from sydney and Melbourne that to these colonists a complete union under a unitary polity appeared as the substitution of one distant control by another--a lesser evil, but evil nonetheless. These colonies were not inclined to exchange King Log in London for king stork/in sydney or Melbourne. The result was that so long as the devastating depression and the strikes of the 1890 s did not completely shake them from their particularist little mansions, all efforts at union went to waste. South Australia's resolution in her legislative Council on Earl Grey's federation scheme in 1849 was characteristic of the prevailing attitude of the colonies. 27

\section{Factors for Intercolonial Unity}

Despite all their differences the Australian colonies had all through possessed a measure of fellow feeling born out of

25

In a speech in the New South Wales Parliament in 1891. Quoted 26

in Quick and Garran, op. cit., footnote 23, p. 145.

The following are the figures showing the populations of the six colonies in 1901: New South. Wales 1,354,846; Victoria $1,201,070$; Queensland 498,129; South Australia 363,157; 27 Western. Australia 184,124; Tasmania 172,475.

The South Australian Council rejected the federation proposal of Earl Grey in 1849 on the following grounds: "1. There is a great dissimilarity in the pursuits and interests of the several colonies. 2. The overwhelming predominance that the larger colonies would have in the Assembly would be greatly injurious to the lesser. 3. The Council cannot see any point upon which benefit would accrue to any of the provinces by the establishment of such an assembly." Cited in Quick and Garran, op. cit., footnote 23 , p. 86 . 
their unity of "race" and language. Unlike in Canada the union of the colonies was not a case of binding the opposites. Though the colonists followed different Churches, unlike in British North America there were no regional divisions in religion and culture. Nor were the colonies, unlike the Thirteen Colonies, divided between slave- and nonslave-holding groups. Queensland's Kanaka labour did raise some difficulties but they were soon resolved.

Three million people for a continent of three milion square miles were, no doubt, a small number. Still, the precedents of the United states and Canada had made these six daughters of British imperialism highly conscious of their manifest continental destiny. If the Thirteen colonies could do it a century and a quarter before, why could not a united Australia do the same if not better? The colonists believed that Nature had neatly shaped Australia to be the home of one homogeneous people and to stand as the mistress of the south seas. Only in union could they make Australia the home of a homogeneous people, and only their united country could become the mistress of the south seas.

Railways, telegraph, and telephone connections had already begun to weaken the walls of particularism that had separated them for so long. Now with increased production and the development of manufacturing the arbitrarily drawn intercolonial barriers began to irritate both the farmers and the manufacturers Regions on the intercolonial borders felt that their economic destinies lay across rather than within the borders of their own particular colonies. The drawbacks of governing a continent divided into six independent colonies with their separate tariff barriers were now becoming too clear as the shoe of intercolonial customs barriers began to pinch them hard.

These intercolonial barriers were especially irksome to the people in the valley of the Murray and its tributaries. A small steam boat could enter the river system near the southern coast not far from Adelaide 28 and steam more than 2,000 miles to the western New South Wales. Though very narrow and shallow, compared to the Mississippi system, it was

\section{8}

Steam boats could not, however, enter the Murray mouth. Nothing came of the attempts at a port there. 
nevertheless very valuable in a continent where navigable rivers are so scarce. Burning wood cut from the river banks the steamers were many times cheaper than bullock teams. often they would carry goods 1700 miles upstream to points near the goldfields of north eastern Victoria at a cheaper cost than bullock teams could carry from Melbourne, a journey only one-tenth as long. Then, the river was navigable in winter when the roads to the goldfields became quagmires. 29 Though merchants and intercolonial travellers cursed the intercolonial barriers, merchants and intercolonial travellers were but a small proportion of the population. The financial collapse of the 1890s, however, shook the colonists from their particularistic slumber. Now

The general stagnation of trade set everyone enquiring for himself into the causes which clogged the wheel; and the folly of interprovincial barriers became increasingly apparent. Federation [now] began to appeal to the pocket as well as to the heart; and the people began to wake up to the fact that the "fad of federalism" with which politicians and parliaments had been dallying so long, meant the salvation of Australia. 30

"Five and twenty years ago, nine-tenths of the European inhabitants of Australia regarded the country as a campingground for money making purposes, but now nine-tenths of them think of it as their home", wrote a visiting Englishman in 1878. 31 Australia by now had come to possess a history of its own, a history of British people accommodating themselves to a new environment and being changed by their experience. The colonists' love for the country of their adoption had become so intense by the 1880 s that many a "son of the soil" like one Robert Thompson had begun to regard 1788 as "a date that will be classed in the world's history with the founding of Rome, the landing of the Pilgrim Fathers, or the storming of the Bastille." And this Robert Thompson and his like had begun to believe that "There will be but one greater day in our own Australia's annals, and that will be the anniversary of the declaration of Independence." The "hopes, desires, and

29 30

See Blainey (1967), op. cit., footnote. 7, pp. 240-24l. 31

Quick and Garran, op. cit., footnote 23, p. 150.

Quoted in W. K. Hancock, Australia, Brisbane: Jacaranda Press, first published 1930, reprinted 1961, p. 46. 
aspirations" of these people became now "bound up with the interests of the Australian continent." ${ }^{32}$ This rising sense of Australianness also heightened in the colonists' mind the sense of Australian unity and independence.

Almost three-fourths of the Australian community in the $1880 \mathrm{~s}$ and $1890 \mathrm{~s}$ was comprised of urban and rural wage-earners. This gave rise to trade unions cutting across the colonial boundaries. The late fifties had seen the building tradesmen in Melbourne, sydney and Brisbane attain an eight-hour working day. The principle was later extended to other trades. The First Intercolonial Trade Union Congress met in 1879, followed by five more in the next decade. At the eight-hour celebration accompanying the Intercolonial Trade union Congress of 1888 the loyal toasts were replaced by "the day we celebrate," and the three cheers were given for the "Federated Republic of Australia." 33 The first platform of the Labour Electoral League in New South wales included the plank "the federation of Australian colonies upon a national as opposed to an imperial basis." 34 In fact, many streams helped to swell the flood, and the conservative classes, too, were sending down roots in the Australian soil, and were now quick to resent the suggestion of patronage in the word "colonial". 35

With the increased activities of foreign powers in the Pacific, Australians now began to think that they could no longer regard their continental defence as a matter to be decided from the other side of the globe, i.e., London. There were in 1883 strong rumours of annexationist designs

32 33

Quoted in Hancock, op. cit., footnote 31, p. 46.

Reported in Boomerang, dated 3 March, 1888. Cited in R. Gollan "Nationalism, the Labour Movement and the Commonwealth", in G. Greenwood (Ed.)., Australia: A Social and Political History, Sydney: Angus \& Robertson, 1955, reprinted 1965, p. 152 . 34

Cited in R. A. Gollan, op. cit., footnote 33, p. 152. Though, as noted elsewhere in the chapter, the federation movement as it finally developed was essentially bourgeoisiff, for labour was basically suspicious. It was, however, a different matter 35 once the federation was inaugurated.

Hancock, op. cit., footnote 31, p. 47. 
of France and Germany, in New Hebrides and New Guinea. To forestall the Germans in New Guinea, the Queensland Premier Sir Thomas McIllwraith sent an officer to take possession of the eastern part of the island in the name of the queen. While other colonies supported the action of the queensland government, the Home Government undid it. The French also were displaying clear designs on New Hebrides, and were continuing to transport habitual as well as political criminals to New Caledonia.

The mother country's indifference to colonial defence, as evidenced by the New Guinea episode, led to the realization that although the umbrella of the British Navy protected them, there were issues of vital importance to the colonists that might at times clash with the imperial interests of Britain. The colonies had been growing up, but they thought that they must now grow up together. The New Guinea episode taught them how much they could lose through disunity. This was a convincing argument for federation; and it was made the most of. A Convention of Australian colonies, New Zealand, and Fiji meeting in sydney on November 28,1883 , ended with the conclusion that on many issues of importance

the colonies, though of one mind, are unable to obtain united action owing to the absence of some common authority, the time has now arrived for drawing closer ties which bind the colonies to each other by the establishment of a Federal Union. 36

And then there was the white colonists' distaste for coloured labour. As Keith Hancock wrote, the Australian democracy pictured itself as a vine brought out from Europe, and dreamt of a time when its boughs would be like the goodly cedar tree. But the vine was still young and tender and had to be encompassed with a hedge lest the wild boar out of the woods should root it up..$^{37}$ Besides the "capitalist boar of Europe's industrial woods", the vast reservoir of "yellow humanity" appeared a formidable one. The fear of black labour had greatly helped to transform queensland provincialism into Australian patriotism, ${ }^{38}$ and coloured immigration was an

\section{6} 37

Quoted in quick and Garran, op. cit., footnote 23, p. 111. 38

Hancock, op. cit., footnote 31, p. 63.

Clark, op. cit., footnote 12, p. 163. 
important issue in fusing the separatist and jealous colonies into a united whole. Wrath against England for her half-hearted support was nearly as great as against the coloured immigrants who threatened to steal the "Australian heritage". It was obvious to the colonists that in order to safeguard this "heritage" the six colonies acting together were stronger than the six guarding their independence of action. ${ }^{39}$

The stage was nearly set when the final spur to action came from the depression of the nineties which made it clear to the colonies that without a strong intercolonial union they could not stand as a great holding company that would attract the confidence of overseas investors, which was vitally important to their developing economy.

Though for long the essential unity of Australia as a country with common interests was taken for granted, till late in the nineteenth century the six Australian colonies were still consolidating as widely separate islands with all, the paraphernalia of "little kingdoms." Though federation had for quite some time been talked of in the colonial capitals, till late in the nineteenth century "it was regarded almost as an alliance between countries foreign to one another and having rival economies." 40 This, indeed, adumbrated the future, and when Australians finally recaptured the continental ideal what they essentially propolsed was to coordinate their particularist colonies, not abolish them, and to enforce coordination through a government with powers to deal nationally with certain specific matters but leaving to the existing regional governments the sole authority to manage their own local and regional affairs.

\section{POLITICO-GEOGRAPHIC INFERENCES}

1. The origin of the Australian federation fits into my hypothesis that when a number of small and separate political units with marked regional identities are faced with a common threat against which none of them is able to stand firmly,

39

M. Barnard, A History of Australia, Sydney: Angus \& Robertson, 40 1962 , p. 540 .

Palmer, op. cit., footnote 15, p. 142 . 
the tendency for these units is to come close together and seek strength in union. If the political units are geographically close together ( $i$. e., not separated by formidable physical barriers) without any marked regional concentrations of cultural and/or economic deviations, the result may often be a unitary state. But if the units are separated by long distances, and possess competitive and/or contrasting and incompatible economic interests, or have marked regional deviations in religion, language, and culture etc. then the more likely result is a federation wherein the regional units would retain their regional autonomy.

It is sometimes thought that the Australian colonies federated without any serious military threat to their existence. But incredible as it might appear "It is necessary to have been born in Oceania" says André Siegfried, to appreciate "to what extent neighbours seven to nine hundred miles away can be thought annoying." 41 Facing the northern approaches of Australia were vast reservoirs of "yellow humanity" whose outpourings, if unchecked, would ruin what the Australians held most precious--the economic and racial foundations of their egalitarian society. 42 At the Federal Conference of 1890 Sir Henry Parkes, pointing to the Chinese threat, quoted Napoleon's words that if the Chinese only acquired European arts, they would conquer the world. 43

Then, the Pacific was being increasingly drawn into international conflict, and Japan was emerging as a formidable military power in the north and was overtaking china. In the meantime Major-General Edwards had informed the colonies in 1889 that if they were to rely separately on their own defence resources, their position would be dangerous. As John Cockburn put it in 1890, Major-General Edwards did, indeed, come "at an opportune time and grasped the skirts of happy chance." 44

\section{1} 42

A. Siegfried quoted in Hancock, op. cit., footnote 31, p. 49. 43 44 Hancock, op. cit., footnote 31, p. 50.

Cited in Palmer, op. cit., footnote $15, \mathrm{p} .133$.

South Australian Legislative Assembly Debates, June 26, 1890. Quoted in L. F. Crisp, Parliamentary Government of the Commonwealth of Australia, London: Longmans, Green \& Co., $1962, \mathrm{p} \cdot 3$. 
The general policy that had emerged after the Royal Commission of 1879 was that while the British Royal Navy would maintain the freedom of the seas, and would be at call in the unlikely event of invasion, the colonies had to maintain and pay for internal order and the defence of their ports. The British regiments had already been withdrawn and replaced by militia. Major-General Edward's report heightened the impact. What the colonies feared, and what Britain did not realize, was not immediate danger of invasion but the setting of foreign bases within striking distances of the vulnerable Australian coast. Having learnt from their experiences in New Guinea and elsewhere as to how little could they expect in the way of aid from Britain, it was plain to the colonies that they had to stick together for their individual and collective security. Still the dangers were small compared to those that drove the Swiss, the Americans or the Canadians to union. And this was the reason why some colonists could still say "Time enough to federate when danger threatens." 45 As in 1867, in 1891 still the colonists were in no great hurry "to see a new constellation of six stars in the heavens" when they left the Conference room. ${ }^{46}$ But the urgency was greater now, and the military threat coupled with the economic crisis succeeded in bringing about the federation.

2. The Australian example also supports my hypothesis that cross-cutting cleavages are favourable factors in bringing about and keeping the constituents together in a federation. At the time of federation in Australia the major cross-cutting cleavages between the colonies were two. First, there were large numbers of people from one colony living in another. secondly, the economic interests of the people on the intercolonial borders often ran across their colonial boundaries. The favourable effects of the first were clearly visible in Western Australia's voting pattern in the referendum on

45

J. H. Want's speech in the New South Wales Assembly on May 46

14, 1890. Cited in Crisp, op. cit., footnote 44, p. 3.

An excerpt from the speech of Henry Parkes in 1867. Quoted in Quick and Garran, op. cit., footnote 23, p. 104. 
July 31, 1900. As the results of the referendum showed, the people on the recently discovered goldfields were the most ardent supporters for federation in this otherwise indifferent colony. The diggers, who had in large proportion come from the Eastern colonies,

apparently saw in the continental nationalism of federalism a way of escaping from the isolation they felt in Western Australia and from the political domination of the politicians in perth whose views were, by inheritance essentially isolationist, and reintegrating themselves into the larger Australian community then, as today, centred in the east. 47

The people on the goldfields felt so strongly about the federation that at one stage they even threatened to secede from Western. Australia and form a colony of their own which would promptly join the federation.

As regards economic cleavages we find that the "people in general. . judged . . [the federation] not on a class basis, and not on a state Right basis, but in terms of regional economic interest." 48 As parker says, the intercolonial jealousies on which the colonies laid so much stress amounted to little more than the rivalry of trade competitors. "What the voting at different referendums suggest is that the apparent division of opinion along state lines is really a division along rather different lines, which can be well seen if the results of each colony are dissected instead of being looked en bloc." 49 parker pictures the map of the continent in the $1890 \mathrm{~s}$ as a series of economic regions exporting their produce to or through a small number of large urban entrepots, the latter serving and exacting tribute from segments of territory of roughly equal radius. 50 [Fig. 5.2]

\section{7}

C. H. Grattan, The Southwest Pacific to 1900, Ann Arbor: 48

University of Michigan Press, 1963, p. 371.

R. S. Parker, "Australian Federation: Influence of Economic Interests and Political Pressures," Historical studies, Selected Articles, First Series, Melbourne: Melbourne University Press, 1962 , p. 167. Originally published in Historical Studies in Australia and New Zealand, Vol. 4, 1949, 49 pp. 1-24.

Parker, op. cit., footnote 48, p. 166. 50

Parker, op. cit., footnote 48, p. 167 . 


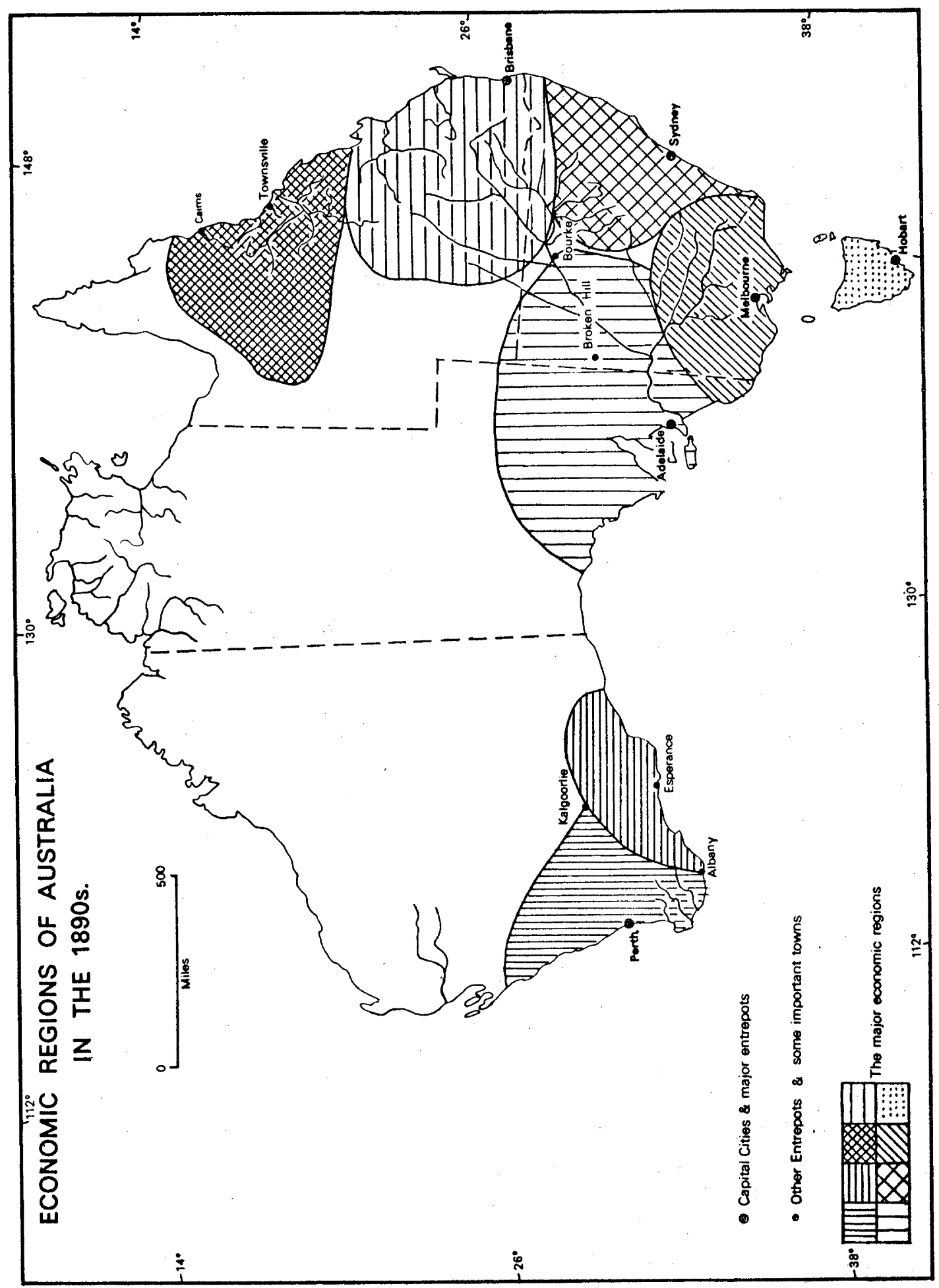

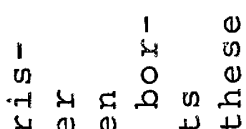
Q 0 (1)

है

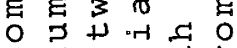

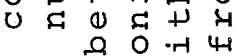

थ न्- $>0$ त

का ति मे $U=$

$\infty$ E $\rightarrow$ प द 0

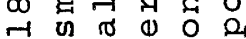

$>+\sqrt{1} \Omega_{1}$

(1) त

ए द मे मे

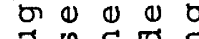

० 0 \& 10 .

मे 10 प

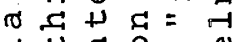

न म

ते ${ }^{H}$ ब

पै द व स मे

in $0>>$

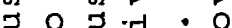

बि न न थ

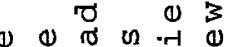

E 0 मे मे द्र ठ

i) ब ज० 0 व

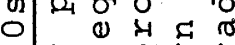

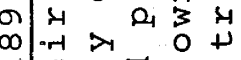

-1)

도 당 40

IT 5 ब 10 \%

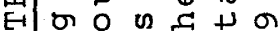

\& 4 म

Z में 0 मे के

$\begin{array}{llllll}1 & 4 & 0 & 0 & 0 & -1\end{array}$

$\begin{array}{lllll}4 & 0 & 0 & 0\end{array}$

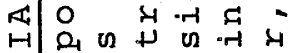

可至

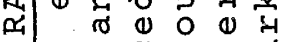

E ज त 0 U 0 \%

I द मे दे ते मि

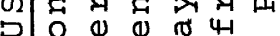

ब.

का द व

[1 0 व

द哣

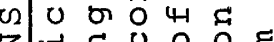

Z

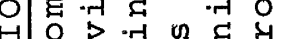

0 म $4 \Rightarrow 4$

I I 0 (1) > 0

म 0 थ

\% फ W

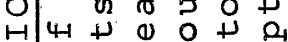

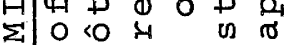

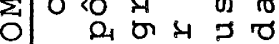

乙 $\begin{array}{lllll}0 & 0 & \text { ज } & 0 & \text { त }\end{array}$

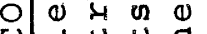

U

I I म $4<0+$ तo (1) 11 ल 4 N 0 \& 0 - ro on $\begin{array}{lll}4 & 4 & 0\end{array}$

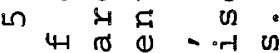
$\therefore$ ○ U हू तो

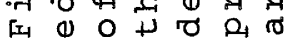


The areas of contact between any two regions were, naturally scenes of competition between the entrepots of two regions. As a result, the producers and traders in the economic border areas came to regret the existence of political borders and wished them to perdition. The federation which would establish a customs union, and would set some limits to railway competition and ensure unhampered transport on the Murray system, was inevitably attractive to border residents but repulsive to those urban interests which relied on discriminatory legislation in order to participate in an otherwise uneconomic commerce. Commenting on the Queensland situation in 1899 the Bulletin recorded:

The North. . . is decidedly in favour of saying good-bye to provincialism while the sugar districts (despite the black labour question) want to unite with the province that will supply them with a market. Southern queensland, with the exception of [Brisbane, the octopus, and Toowoomba which was afraid of New South Wales cabbages and potatoes]. . . is federally inclined.51

3. The Australian frontier of settlement did not work as a very large scale melting pot in the way the American frontier in the West did. The reason was that

Unlike the Middle West, the Australian frontier was and largely still is, a "big man!s frontier". The costs implied by distance to markets, the high overheads of bringing in bulk supplies, the constant risk of drought, bush fires, and floods, all conspire to make Australia by and large inhospitable to the small farmer.52

Secondly, the Australian government, unlike the American or Canadian, did not inherit large habitable areas where it could settle people and create new states and, thereby win the loyalties of the poorer sections of society in its constituent regions. The Northern. Territory that the federal government did actually take over was of hardly any value in this respect. In fact, the Australian continent was fully divided into the six colonies before the federation was born. Each colony controlled large unsettled areas and thus possessed its own frontier of settlement whose development remained the full responsibility of the respective regional government. Still, as in America, the people on the "out back"

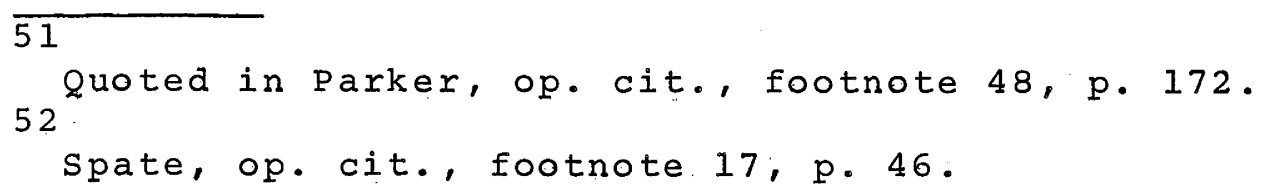


were much of a piece. The "out back" did act as a cord of unity, and the federation movement was, in fact, "supported by big majorities throughout the 'out back' and up the north coast." 53

In a sense, however, the geography of frontierism has, indeed, played a favourable role in the stability of Australian federalism. The continent still remains a frontier of settlement for the European people. Because of this there are large numbers of people in almost every state for whom regional loyalties (as opposed to the central) have little meaning. This weakens the sense of state-parochialism and thereby encourages the centralizing tendency in the regions. 54 4. As already noted, in order to build a strong national loyalty the central government in a federation must succeed in attaching to itself the majorities in its constituent regions as the centre of their primary interest. The Great west in the United states, and the protective tariff and the transcontinental railway in Canada had provided this highly desirable motivation for national loyalty in the two North American federations. In Australia, too, the federal government was able

\section{3}

Shaw, op. cit., footnote 8, p. 196. The point is amply clear in the South Australian example studied by R. Norris in his "Economic Influences on the 1898 South Australian Federation Referendum" (included in A. W. Martin (Ed.), Essays in Australian Federation, Melbourne: Melbourne University Press, 1969, pp. 137-166). An appendix on page 166 of the essay shows that whereas two of the city electorates recorded unfavourable majorities, all the country electorates registered favourable votes for the Federation Bill. Further, while only three of the seven city electorates recorded above sixty percent majority "yes" votes (the highest being 67.40 percent), all the country electorates had above 60 percent "yes" votes-54 the highest being 95.21 percent.

As Russel Ward's Australian Legend (Melbourne: Oxford University Press, 1962), and Tom Collins' Such Is Life (first published 1903; re-issued in 1948 by Angus \& Robertson, syaney) bring out, even in the colonial days roving bush workers (often enough not sufficiently settled for long enough in any one place to have a colony vote) had a definite all-Australian feeling, perhaps before anyone else. Explaining the reasons for a greater all-Australian consciousness in Victoria (relative to New South Wales) Geoffrey Serle hints at somewhat similar factors when he writes: "[The colony's] mere half century of history did not allow any deep rooted provincial loyalty based on long tradition to exist". Geoffrey Serle, "The Victorian Government's Campaign for Federation 1883-1889" in. A. W. Martin (Ed.), op. Cit., footnote 53, pp. 1-56, reference on p. 53. 
to retain the faith of its people for long because of the much needed "ring fence" of protection both against coloured immigration and foreign manufactures which the federal government with her continental resources was alone able to provide. 5. As the constituent units of the Australian federation were culturally of a piece, keeping the federal family together was relatively easier. For this reason the importance of live political frontiers in the maintenance of federal stability in the country was less vital. Still fear of external threat did play an important role in consolidating national loyalties. Australians' consciousness of their land as a bowl of food placed next door to the hungry millions of Asia was a strong factor in the stability of the union. 55 It was clear to Australians that in order to reserve the bowl to themselves they needed to forge a united front. The German military presence in the south Pacific was a further force in the same direction.

Western Australia's move for secession in the 1930 s (when 138,653 of its population voted for, and 70,706 voted against secession in 1933) may now be dismissed as the act of an angry baby striking against his mother's breast, for it is said that "a great number of those who voted for secession did not believe that it was likely to be brought about" and that "What the people did want to do was to show their sense of grievance . . and record a protest against commonwealth policy sufficiently emphatic to ensure that the federal government would take some action to pacify opinion within the state." 56 It is true that with the return of a measure of prosperity secession lost much of its force and the movement receded into

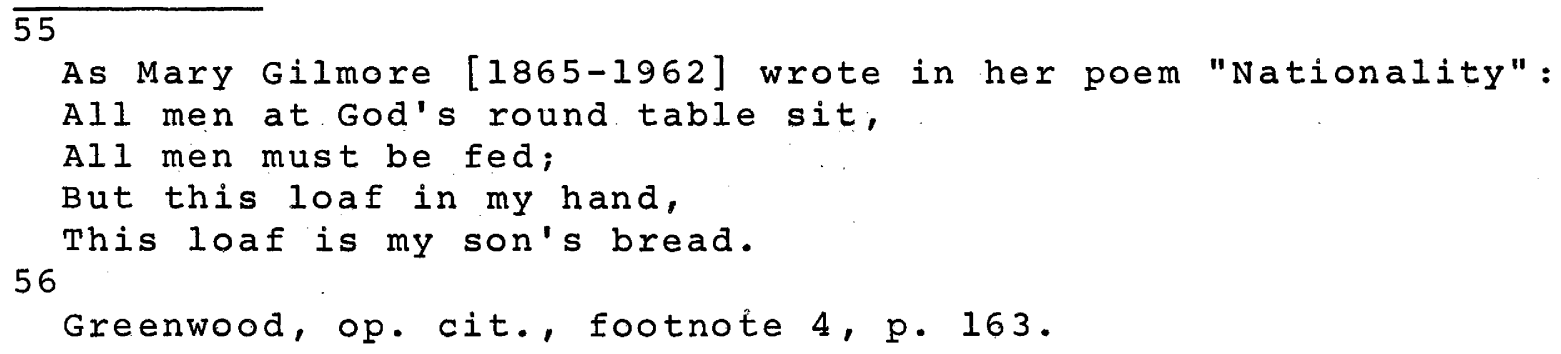


the background, 57 but it could well have emerged to the forefront again had not the devastating 1939-45 War intervened and reminded the constituents of the federation that if they did not jointly trim the sails of the ship of Australia the oncoming storm might sink all of them together. Soon after the War Western Australia found that she no longer bordered on a British lake. It could therefore no longer afford to be complacent and fissiparous.

6. Although it was a kind of sectionalism that had helped to pull the different colonies together into the federation, still because of certain factors of economic geography sectionalism has not been an active force in Australian federalism. Australia lacks regional specialization of the type found in the United States or Canada. All the Australian states produce wool and wheat, and at least four of them produce exportable quantities. This brings about a kind of homogeneity in the economic interests of the states and discourages sectional divisions at the federal level. Then as

every state has its capital city with metropolitan ambitions, and since the important service of transportation is a state matter, farmers' grievances are likely to be directed toward the state capital. Friction within the state rather than an alliance of urban and rural interests of the region to exact concession from another region is the more common Australian development. 58

State identities have continued to be fostered by metropolitan rivalries. The agrarian discontent in each state tends to assume the form of an anti-capital city feeling. There are no groups of contiguous states sharing common, grievances, aspirations and vested interests. Further, some questions which bring these regional groupings to the fore, such as freight rates in Canada, do not exist as federal problems

57

"In the new expansionist age that dawned after the war, the government at Canberra was seen by Western Australians to have some of the marks, not of a distant ogre, but of Santa Clause bringing gifts to distant dependants."

F. Alexander, Australia Since Federation: A Narrative and Critical Analysis, Melbourne: Thomas Nelson (Australia) Itd., 58 1967 (1969 reprint), p. 123.

K. A. Mackirdy, "Geography and Federalism in Australia and Canada," Australian Geographer, Vol. 6, No. 2, 1953, p. 46 . 
in Australia. 59 Then, in contrast with the United states, Australia has a relatively inconsiderable amount of interstate trade. As the railway map of Australia shows, channels of trade still largely run within the various state boundaries, up and down from the interior to the sea. [Fig. 5.3]

It has been suggested that the great wool-wheat belt in the south-east, or the pastoral and mining belt in the north could supply the economic and cultural base for a sectionalism in the American manner, but they are split up between three or four states and yet not dominant in any one. This is probably the main factor in the failure of Australian senate to act as a state's House. With only six units the possibilities of bloc-making are extremely limited. spate regards a unitary state with provinces as the most rational organization of Australian space, which, he thinks

could mean a smoother machinery for constitutional problems, more local participation in local problems, the emergence of sections in the American sense, corresponding to real and homogeneous regional interests and to some extent offsetting the prevailing and increasing cultural uniformity.

He, however, concedes that on a practical plane there is no visible basis of support for such a recasting, for any one who can see the state machines of any of the major political parties "yielding an iota of their power and patronage is a visionary indeed." 60

We may now examine the question of whether the Australian "federal system has outlived its usefulness."6l such opinions are based on the conviction that Australia has evolved to a stage of political development when the sense of regional identities born out of physical isolation etc. have largely been overcome. If it were so federalism, indeed, would have outlived its usefulness. Recent studies show, however, that this is by no means so. As colin clark has written

in the present state of Australian transport, the Australian manufacturer finds that the population and industries of a neighbouring Australian state might almost

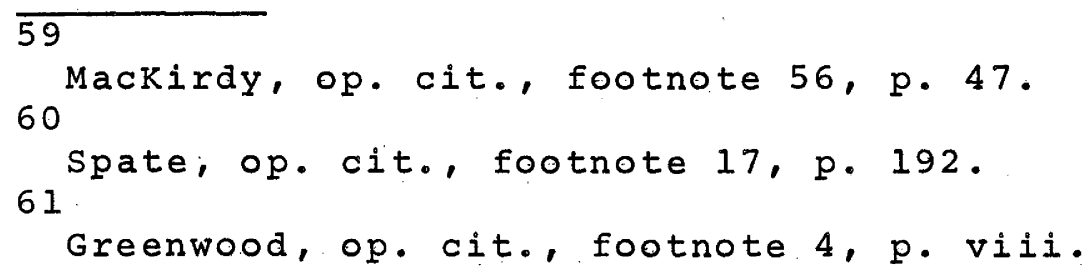




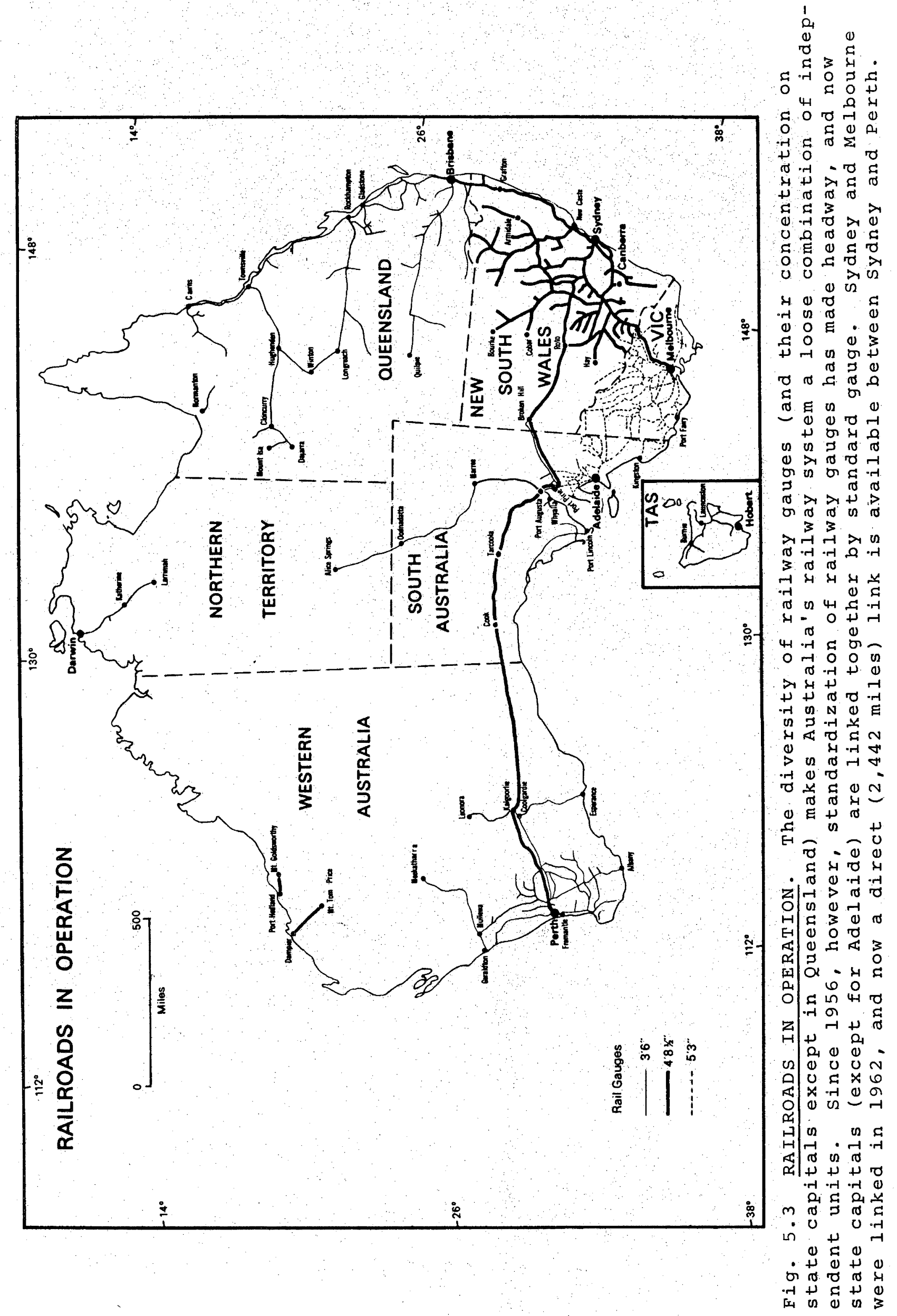


as well be in Europe for all the good they can do him as markets or suppliers . . The freights on sending goods between one Australian state and another are as high, in some cases higher, than the cost of sending goods to or from Europe or North America.. .62

Though this is somewhat overdrawn, it seems likely to some scholars that, until well into the future, lines of commercial intercourse will probably continue to flow outward rather than inward, knitting Australia in that process closer to Europe and the United States but leaving the six Australian states still rather independent economic units, 63 . The diversity of railway gauges (and their concentration on state capitals, except in Queensland) makes Australia's railway system a loose combination of independent units. This has greatly encouraged state-parochialism. Indeed, the railways have tended to divide Australia into five separate "islands" instead of welding the continent into a great political and economic unit. 64

However, since Sir Harold Clapp made the above observation, many improvements in interstate rail links have taken place. Since 1956, under various Commonwealth-state standardization Agreements several hundred. miles of standard (4ft. 8hin.) gauge track have been completed. Melbourne was linked to sydney (and hence, also to Brisbane) by a standard gauge railway in 1962, and now direct $(2,442$ miles long) standard link is available between sydney and Perth. Bogie exchange facilities have been installed at Melbourne and Port Pirie (South Australia) to eliminate the physical transfer of goods between the rolling-stock of the standard gauge and that of the broad gauge ( $5 \mathrm{ft}$. $3 \mathrm{in.}$ ) systems serving Victoria and the large parts of South Australia. Development of air transport, and the improvement of road communications between the states have also facilitated interstate movement. 65 But it may by large

62

C. Clark, Australian Hopes, and Fears, London: Hollis \& Carter, 63 1958, p. 72 .

R. I. Leach, Interstate Relations in Australia, Lexington: 64

University of Kentucky Press, 1965, p. 18 .

H. Clapp, "Australia a Nation," (1946) p. 148. Cited in 65 Leach, op. cit., footnote 63, p. 159.

For details see the official Yearbook of the Commonwealth of Australia, No. 55,1969, p. 391 . 
be true to say that

Australians, perhaps to a greater extent than other people, will never see eye to eye with each other on everything. Certainly complete cooperation between the Australian states is imposible. The states are at least semisovereign, and even if they had the maximum desire to cooperate, their interests are not identical. Geography alone limits the number and kind of cooperative arrangements that can be worked out. 66

As Miller notes, part of the reason for the elaborate framework of government in Australia lies in the inhospitable nature of the country, in the remoteness of one centre of population from another, and the sparseness of population between the main centres. The political expression for this has been the demand of the far away areas for special representation in their local parliaments, equal representation in the senate, and a place at the Premiers' Conference.

Geography has been assisted by the stubborn fact of a continuing federalism in. Australian life, the retention of "State sentiment" not so much in the sense of patriotism toward a particular state and its form of government, as attachment to special interests which characterise the state and are assumed to be protected by its separate existence.67

Hence, despite all that has been said of "the failure of federalism," "the states remain cardinal factors in the society and politics of Australia, in its human and economic geography, and not only in the sense of filing boxes."68. "Despite the arbitrary nature of their boundaries," the states are "the primary geographical regions in the country."69

Given the present state of affairs federalism is bound to remain a continuing factor in Australia's political life.

$\overline{66}$ 67

Leach, op. cit., footnote 63, p. 162 .

J. D. B. Miller, Australian Government and Politics: An Introductory Survey, London: Gerald Duckworth \& Co., third 68 edition, 1964, p. 217. 69

spate, op. cit., footnote 17, p. 185.

K. W. Robinson, "Diversity, Conflict and Change--The

Meeting Place of Geography and Politics", Australian

Geographical studies, Vol. 8, 1970, p. 5. Also see

K. W. Robinson, "Political. Influence in Australian Geography", Pacific Viewpoint, Vol. 3, 1962, pp. 73-86. 
Those who wonder "why they [Australians] bother with federalism" 70 overlook not only the fact that Australia continues to be oppressed by the tyranny of distance, but also ignore the truth that the Australian states through their long existence have now become historical entities incarnating strong and multiplex traditions and interests that differ in their details from one state to another.

\section{Appendix to Chapter V}

\section{A NOTE ON the "NEW States" MOVEMENT IN AUStralia}

It may not be irrelevant to ada as a postscript a few remarks on the current force of regionalism in the Australian politics as expressed in the "New States" movement. The movement starts with two basic premises: first, that very large political units create "apoplexy at the centre and anaemia at the extremes" leading to neglect of the areas away from the capital; secondly, the supposition that federal articulation in Australia would increase (and undue centralization would cease) if the present six large states are split up into three or four times that number. The fallacy in the second argument is clear. It is true that a more balanced federation could have resulted if the Commonwealth had originally started with a larger number of constituents, for that might have facilitated sectional groupings that could promote greater federal articulation. But, after such a long period of evolution

the unscrambling of the existing structure into three or four times as many units would [not] produce any positive effects. More likely the Commonwealth, faced with so much weaker components (which would have lost the intangible but real strength of historic tradition possessed by the present states), would become even more centralized; unless indeed something like the sectional blocs of the American States had developed.71

Faced. with initial problems of establishment and coordination, the "new states" might, in fact, because of the absence of any inhibiting historical loyalties, agree for greater powers to the centre. The result might be a more centralized polity rather than less.

The first argument, no doubt, has its strength but there are obvious difficulties in the creation of new states. The proposed new states may be of two types. First those that would comprise regions that are at present divided into two contiguous states. The other type is of the states that 
may be carved out of the outlying areas of a single state.

The first type is an almost impracticable proposition because

the Constitution provides that new states can be created

only with the consent of the old state(s) affected. And the prospect of joint assent at a relevant time is indeed.a pure fantasy. The most obvious case of this type would be the Riverina-Murray valiey. of the second type two are most important-northern queensland with Townsvilie as the regional capital, and second, New England in New South Wales, the movement for which has by far been the more active. With its 64,000 square miles and about 750,000 people, and its coal and industry of the Hunter Valley, New England could be a workable state on the Australian scale. Though the movement for $\mathrm{New}$ England state gained a great momentum when the long-awaited referendum was held in 1967, although reasonably good majorities were secured in the tablelands, and the north coast, Newcastle and the Lower Hunter valley balanced. it by even more striking "No" votes. 
Part 3

$\underline{\text { THE POST-1945 FEDERATIONS }}$ 
Chapter VI

POST-1945 ASIAN FEDERATIONS

\section{INDIA}

Although the roots of political life in India go back further than in any other modern federation, in a brief study of this nature we would primarily be concerned with the more immediate historical factors. There has, no doubt, been a general consciousness, among. the élites, of India as a single geographical and cultural entity from the very early times, and the great Rishis of India had tried to enforce this consciousness of a common motherland of all Hindus through their numerous hymns and through the institution of pilgrimage to the Holy. Places (Tirthas) spread through the four corners of the country. 1 . But nationalism in its modern sense (as developed in nineteenth century Europe) is only of recent growth in India, and arose largely in opposition to the all-pervading British rule. It must, however, be remembered that though the British rule became the immediate cause for the rise of this all-India nationalism, by providing a single target against which the aspirations of the leaders of every region in the country struck, the genuine foundations of this sentiment lay much deeper. The people realized that just as they had a common "enemy" to fight against, they also had a common heritage to safeguard. 2

The realization of a common heritage came from a number of factors. The first and foremost was the existence of a common, culture and a common (though complex) religion that had through centuries knitted the diverse regions of the nation together. The Indian élites were highly conscious of: the fact that though different kingdoms with their distinct regional bases had fought with each other for a large part

\section{I}

See R. K. Mookerjee, The Fundamental Unity of India, Bombay: 2 Bharatiya Vidya Bhawan, 1954 .

R. D. Dikshit, "India's Evolution as a Nation-state", IndoAsian Culture, october 1967, pp. 211-226. Salient differences between the nature of Indian and European nationalism are discussed and some of their underlying causes explained in R. D. Dikshit, "The Idea of Nationalism: Indian and European", Indo-Asian Culture, January 1966, pp. 15-30. 
of Indian history, in fact each one of them, with any claim to greatness, strove for a chakravarti samrajya, an all-Indian empire of Himachala-setu paryantam (extending from the Himalayas to the sea). The modern élites felt that if many of the great men of the past failed to achieve a lasting allIndia union, it did not mean that such a thing was unachievable. What kings and emperors had failed to achieve, they hopefully thought that a modern people could attain, for they knew that they were armed with far better tools than had ever existed in the past.

THE HISTORICAL FOUNDATIONS OF INDIAN FEDERALISM

As many historians have pointed out, it was India's traditional concept of paramountcy dating back to pre-Christian times and reflected in the traditional Ashwamedha yajna (Horse Sacrifice) that had helped the Mughals, and after them the British, to attain paramountcy all over the country. Save for this underlying sense of an all-inclusive unity side by side with the numerous regional diversities (a kind of incipient federalism), the roots of the present-day all-India republican federalism date almost from the rise of British power in the country, although, as Panikkar writes, "In fact, the doctrine of the unity of India was taken over by the British from the disembodied idea of a national state which the Moghals represented at the beginning of the nineteenth century." ${ }^{3}$

The foundations of British power in India may be traced to the establishment of the East India Company in December 1600, but Britain did not become a ruling power in India till the second half of the eighteenth century. The British began, like their European competitors, with little extra-territorial enclaves conceded by the Mughals or the local rulers. But the rapid decline of the Mughals and the virtual elimination of the French in the eighteenth century left them opposed only by the weak and often disunited "country powers". Supremacy over the region of Bengal, Bihar and orissa had been achieved as the result of victories at Plassey (1757) and Buxar (1764). After the defeat of Tipu sultan (1800) and 
the destruction of the Marathas (1818) most of the country came under British paramountcy, and when the sikhs were defeated in 1849 the British dominion in India was established from the Indus to the Brahmaputra, from the Himalayas to the Cape comorin--over the whole of the traditional territory of Bharatvarsha.

The unity of India which the sacred writings of the Hindus had postulated centuries before christ... . had. [now] in fact come into being. The doctrine of the national state which the mind of India accepted in the eighteenth century was realized through the force of British arms. 4

But underneath the placid surface other forces were taking shape which culminated into that tremendous thunderstorm for the British power--the so-called Mutiny or the war of Independence of 1857. Uniting the diverse factions in the country, this great national uprising was "at bottom . .. the last rally of the old indigenous India" against the foreign rule. 5 It indeed.was "a heroic effort of a dispossessed people to assert their national dignity". 6 This proved a great divide in modern Indian history. In 1858 the British Crown took over the government of India, and the crown, having learnt a lesson from the Indian discontent that had given rise to this uprising, formulated some fundamental changes in the policy of government.

The ninety years of British rule following the uprising of 1857 formed, indeed, a period of great recovery. The all-India services initiated by Cornwallis were strengthened to make them the great steel frame of ali-India administration. Gradual. Indianization of these services was begun till only a very small top fraction remained European. Railways and telegraph lines knit the country together. A uniform law under a modernized jurisprudence (yet with allowance for customary laws in religious and family matters) was administered throughout the country. A uniform system of education through. a common medium of instruction (i. e., English) provided the 5

Panikkar, op. cit., footnote 3, p. 202 .

O. H. K. Spate and A. T. A. Learmonth, India and Pakistan:

A General and Regional Geography, London: Methuen \& Co. 6 Ltd., third edition, 1967, p. 195.

Panikkar, op. cit., footnote 3, p. 202 . 
government with a large corps of clerks to work in her offices. It also gave the Indian élite, after a long interval, a common language of intellectual communication such as the country had possessed in the very distant past. This uniform education through a common medium helped to create a broadbased middle-class élite who throughout the country talked the same language, had the same intellectual training and thought broadly in terms of the whole nation.

In the mid-nineteenth century the cotton boom of the American Civil War had greatly encouraged commercial speculation, and the suez Canal by bringing India nearer to Europe helped to tie Indian agriculture to the world market. This induced road and rail construction which helped to knit the country into a close economic unit. In time indigenous capital started factory industries which soon found themselves in competition with manufactured goods imported from Britain, and began to clamour for protection. Thus the middle-class nationalist élite soon found a following in the urban classes, and sympathy and silent support from capital. With Mahatma Gandhi's appeal to the masses the high and low in British India were brought together, and the stage for national regeneration was set. The Indian National Congress as an all-India political party had already been established in 1885. To this growing nationalist feeling Curzon's unpopular partition of Bengal in 1905 provided a further impetus.

Japan's victory over Russia in 1905 ended the myth of European invincibility and added profoundly to the nationalist self-confidence towards which Tilak was already striving through his revival of the cult of sivaji. By the first decade of the present century the spirit of all-India nationalism became increasingly militant and pitted its expectations higher. The fortuitous arrival of Mahatma Gandhi and the great national shock at the Jalianwala Bagh massacre watered the seeds of nationalism sown broadcast by Tilak, Gokhale, Lajpat Rai, Moti Lal Ghosh, Aurobindo Ghosh and others. Abrogation of the Bengal partition in December 1911 showed that the British government could not altogether resist allIndia national sentiments. "It was the first retreat of the Government before the onslaughts of Indian nationalism and became the prelude to the many more open conflicts between 
the two, the final outcome of which could never be in doubt"; although by a strange irony of history the year 1947, which saw the final victory of Indian nationalism in the achievement of complete independence, also saw its final defeat on the issue of Bengal partition.

It is necessary to review India's constitutional evolution during the British period in order to appreciate fully the rise of republican federalism in the country for, in fact, the present federal Constitution embodies the changed sense of Indian unity that was brought about by a century of evolution under British rule. In a sense, however, the roots lie deeper still, for the British themselves had inherited from the Mughals a strong political system, albeit in the process of disintegration. The British took advantage of Mughal legacies in revenue and judicial administration, in the division of the country into subas and sarkars, as well as the concepts of paramountcy and paternalism. The first step in the constitutional advance of British India began with the Regulating Act of 1773 by which the British parliament set up a Governor-General and a Council for the Presidency of Fort William in Bengal, and a Governor and Council for each of the Presidencies of Madras and Bombay: the latter two were subordinated to the Governor-General-in-Council on questions of war and peace as well as in their relations with the native powers.

The next significant step was taken with the Charter Act of 1833 which named the Governor-General and Council of Fort William as the Governor-General-in-Council of India; in his hands became concentrated the supreme executive and legislative authority for the entire subcontinent.: Legislative powers hitherto enjoyed by the provincial councils were withdrawn and the Governor-General-in-Council assisted by a Law Member became the sole legislative authority for the whole of British India. By the Government of India Act of 1858 the GovernorGeneral, who had so long been responsible to the court of Directors and the Board of Control of the Company, was made responsible to the secretary of state for India acting on

$\overline{7}$

V. B. Kulkarni, British Dominion in India and After,

Bombay: Bharatiya Vidya Bhawan, 1964, p. 110. 
behalf of the British Crown.

But the defects of this extreme centralization in government soon became clear to the authorities concerned, and indeed. "If one word could sum up the post-1858 administration of British India it was 'decentralization"". 8 Conceding the advantages of legislation being enacted by those. who reside "in or nearer the spot", Sir Charles wood, the secretary of State for India, proposed to restore to the presidencies of Madras and Bombay the power of passing laws and enactments on local subjects. This was achieved by the Indian Councils Act of 1861. As new provinces were created, they also received their own Councils with similar powers. Decentralization of a limited charactex in financial matters can clearly be noticed from 1870 onwards. 9

The Councils Act of 1909 (the Morley-Minto Reforms) considerably enlarged the size of the central and the provincial Councils, and made further additions to their powers. But all this still failed to satisfy local hopes and aspirations. Faced with this dilemma the Government of India sent a Despatch (August 25,1911 ) to the secretary of state for India clearly stating that "the only possible solution for the difficulty would appear to be gradually to give the provinces a larger measure of self-government until at last India would consist of a number of administrations autonomous in all provincial affairs, with the Government of India above them all • . . 10 This idea of provincial autonomy was given a fuller expression in the Report on the Indian Constitutional Reforms (the Montagu-Chemsford Report) of 1918 which envisaged the future of India as "a sisterhood of states, self-governing in all matters of purely local or provincial interest". 11 This Report was the basis of the Government of India Act of

$\overline{8}$

M. V. Pyle, India's Constitution at Work, Bombay: Asia Publishing House, 1962, p. 111 . 9

B. Prasad, Origins of Provincial Autonomy 1861-1920, 10

Allahabad: Kitabistan, 1941, p. 369.

C. Ilbert, Government of India, London: Oxford University 11

Press, third edition, 1915, p. 115 .

Report on the Indian Constitutional Reforms (or The Montagu-Chelmsford Report), 1918, para 349. 
1919 which Sir Charles whyte has aptly described as "the finger-post to federalism" and which, in fact, introduced in the country a "federalism in embryo".12 Despite statutory restrictions hedged around the taxing and borrowing powers of the provinces, the provincial governments acquired almost complete freedom to frame their budgets and a considerable latitude in the expenditure of their funds. ${ }^{13}$ Thus the Act in effect "gave rise to something like the beginning of a federal system for India. . the provinces were now, for all practical purposes, masters in their own houses". 14 The long-term effects of the Reforms were tremendous. As a recent study summarizes it: ${ }^{15}$

- . the small dose of provincial autonomy injected into the Indian political system by the Montford Reforms created a strong appetite in the country for a substantial expansion of the area of provincial self-government. - . The noteworthy advance in the democratization of provincial administrations, providing for a substantial popular participation and placing effective though not unrestricted power in the hands of the people's representatives, generated and, galvanized those social and political factors the impact and interaction whereof, coupled with the unavoidable effect of the natural and geographical factors.. . made federalism the only practicable solution of the political and constitutional problem of India. The Montford Reforms contributed towards this development. . . by setting in motion pressures for linguistic redistribution of provincial boundaries, by accentuating the fears of the Indian Muslims of being swamped by the numerically stronger Hindus in a majoritarian democracy and, consequently, giving keener edge to their demand for further safeguards to ensure their own future as a distinct political entity. At the same time the march of democracy in the provinces of British India could not but arouse apprehensions in the minds of the rulers of Indian states who, inevitably, became increasingly aware of the impossibility of indefinitely preserving their feudal fiefs by purchasing for themselves a position of protected isolation from the main currents of political development in British India... As was to

Sir Frederick Whyte, India: A Federation?, Simla: Government of India press, 1926, the first quotation on p. 34 and the 13 second quotation on p. 297.

K. R. Bombwall, The Foundations of Indian Federalism, Bombay: 14

Asia Publishing House, 1967, p. 117.

J. Coatman; India, the Road to self-government, 1908-1941, 15

London: George Allen and Unwin Ltdo, 1941, p. 52 .

Bombwall, op. cit., footnote 13, pp. 122-123. 
be expected, they began to bestir themselves and their manoeuvres to enter into some form of federal association with the British. Indian provinces without surrendering their despotic authority in their own dominions became another factor in the federalization of Indian policy and in shaping the federal pattern of 1935.

There were two other factors working in the same direction. First, Muslims, though an overall minority, were, in fact, substantial majorities in certain geographically compact areas. This created a federal situation in respect of Hindus vis-à-vis Muslims, and gave rise to the Muslim demand for a federal political organization for India wherein they could achieve regional autonomy in their majority areas. Secondly, as A. B. Keith says, "It is difficult to deny the justification of the contention in India that federation was largely evolved by the desire to evade the issue of extending responsible government to the Central Government of India". 16 Federalism with its promise of regional autonomy seemed to offer the solution for the problems of the Muslims, the Princes, the linguistic patriots, as well as the imperial interests of Britain. Only the congress, which alone could contemplate the capture of power at the centre, was not satisfied. Viewed thus, the federal scheme under the Government of India. Act of 1935 was an inevitable next step.

The Act of 1935 envisaged an all-India federation

including the states as well as the provinces. The union could, however, not be fully implemented because the princes, though enthusiastic in the beginning, became indifferent to the proposal. Although taken as a whole the federal scheme was full of many incongruities and anomalies, and perhaps "a priori, a more unworkable federation could not have been devised by the ingenuity of man", 17 still the Act provided a kind of "plaster cast". for the pattern of union-state relations which was set in the constitution of 1950. As the Provincial part of the Act came into force in 1937, the British Indian provinces attained a measure of autonomy in their regional administrations.

\section{6}

A. B. Keith, Constitutional History of India 1600-1935,

London: Methuen \& Co, first published 1936, 2nd. edition, 17 1937 , p. 296 .

K. B. Punniah, India As a Federation, Madras, 1936, p. 63; cited in Bombwall, op. cit., footnote 13, p. 197. 
With the independence of India and the creation of Pakistan, one of the chief forces for a federal political organization of the country disappeared, since now all the geographically compact Muslim majority areas in the provinces went to pakistan。 18 This made the problem of union much more simplified. But given the several hundred autonomous princely states, the near-autonomous provinces, and the self-conscious and geographically compact linguistic groups, it was inevitable that some kind of federalism alone could resolve the problem of political organization of the country.

At the height of British rule, over two-fifths of the entire area of the subcontinent had continued to be ruled by the subordinate Princes. The political fragmentation of the country was "indescribable verbally and well-nigh unmappable". 19 Direct British rule was largely confined to the Punjab, the Ganga valley, and to the provinces bordering largely on the coasts. Vast tracts of the interior remained under princely rule. The states of Hyderabad and Mysore between them ruled over 100,000 square miles of the southern tableland. The whole of Kashmir in the north, Travancore in the south, and vast territories in Rajasthan were ruled by the Princes. It was an index of the divided character of the country that the $B B \& C I$ (Bombay, Baroda and the Central Indian) railway line from Delhi to Bombay in its direct route of 1,000 miles covered only 150 miles of British territory. All this made a federal solution to India's problems inevitable. [Fig:6.1] It is great tribute to Sardar Patel and his associates that within the course of a year and a half the princes had voluntarily withdrawn from the government of the states, accepting a financial settlement for themselves and retiring into private life. [Fig. 6.2A] With the reorganization of

The situation is clear from a study of the maps in J.E. Brush, "The Distribution of Religious Communities in India", Annals, Association of American Geographers, Vol. 39, 1949, pp. 81-98. See also G. S. Gosal and A. B. Mukerji, "The Religious Composition of India's Population: A Spatial Analysis", Tijdschrift Voor Economische en Sociale Geografie, Vol. 61, 19 1970, pp. 91-100.

O. H. K. Spate, "India and Pakistan" in W. G. East and O. H. K. Spate (Eds.), The Changing Map of Asia: A Political Geography, London: Methuen \& Co., third edition, 1958, p.131. 


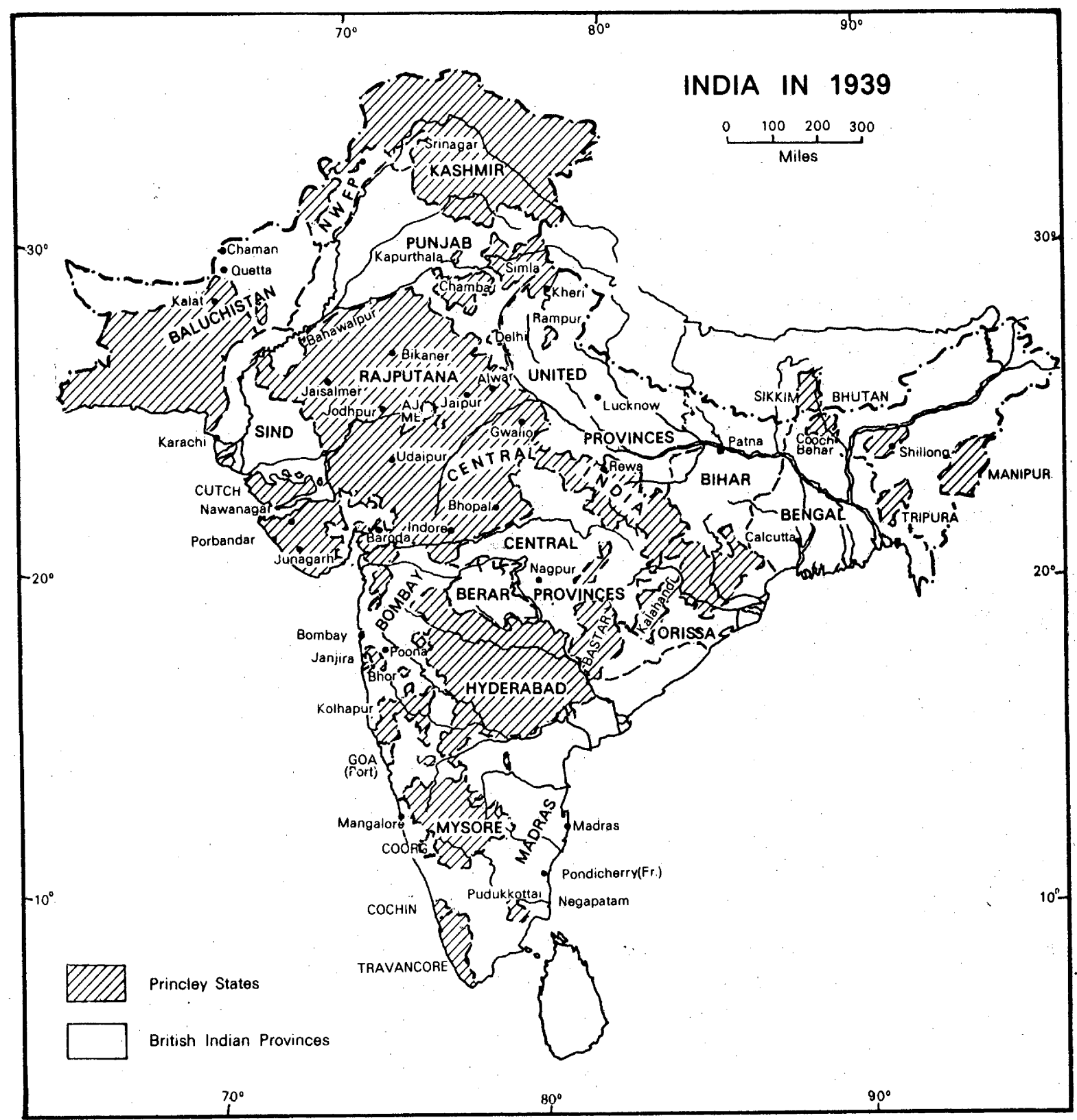

Fig. 6.1 INDIA BEFORE THE TRANSFER OF POWER. At the height of British rule, well over two-fifths of the entire area of the subcontinent continued to be ruled by the subordinate princes. Direct British rule was largely confined to the punjab, the Ganga valley, and to the provinces bordering largely on the coast. The B. B. \& C. I. railway from Bombay to Delhi in its direct route of one thousand miles covered only 150 miles of British territory: an index of the divided character of the country. (Map adapted from C. C. Davies, An Historical Atlas of the Indian Peninsula, London: Oxford University Press, 1954, p. 96.)

Berar merged with Contrel Provinues as "C.P. \& Bera" 
the state boundaries on linguistic basis in 1956, nearly all the vestiges of old, feudal, and imperial India had formally disappeared. [Fig. 6.2B]

\section{The Federal structure}

India's Constitution has often been described as federal but with strong unitary features. Sawer thinks that it is "But for one circumstance, . . a federal reaction to a federal situation,. . " . This one circumstance is the "emergency power" of the President which "while it operates, makes the Constitution a unitary one. . . from the viewpoint of the constitutional lawyer". In practice, however, sawer agrees, "the government of the country has continued to be carried on during the emergency in a substantially federal fashion". 20

The federal legislature consists of two Houses: a popularly elected House of People (the Lok Sabha) and a Council of states (the Rajya Sabha). Unlike the U. S. A. and Australia, the upper House does not have equal representation for all the states. The federal executive is substantially on the British pattern of cabinet government. The Ministers are required to be members of the Lok sabha or should become so within six months of appointment. But the President, who is chosen for a five-year term by the elected members of central legislature and the members of the lower Houses of the states, though far less powerful than his American counterpart, has far more independent discretion than either the British monarch or the West German President.

There are three lists of the division of powers: exclusive centre, exclusive state, and concurrent; though the centre is expressly given the residue powers. The main powers of the states are the fields of police, land, agriculture, local manufactures and trade, and education. The centre competence is, therefore, quite substantial.

The state Governors are appointed by the President, the Governors are empowered to reserve bills of their respective states for the President's assent. The states are required to give effect to the laws of the centre, and not to impede

G. Sawer, Modern.Federalism, London: C. A. Watts \& Co., 1969 , pp. 46-47. 


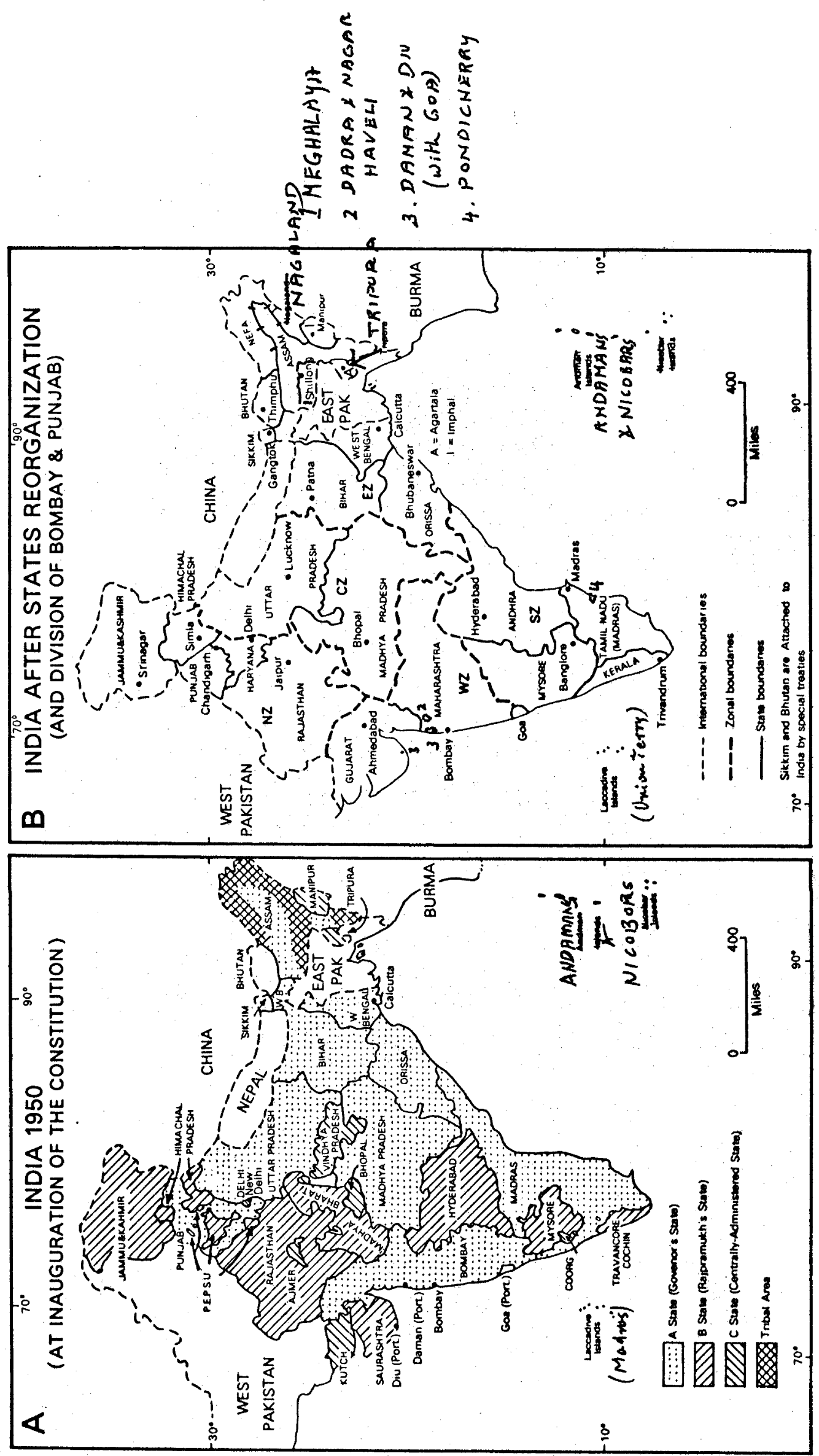

$>1-5$

() नान

न म $\begin{array}{lll}4 & 0\end{array}$

ग $0 \begin{array}{lll}0 & 0 & 0 \\ + & 0 & 0\end{array}$

(1) ⿷匚

† $\Rightarrow$

$\lambda>\overrightarrow{0}$

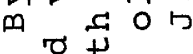

क न

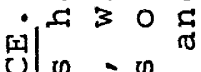

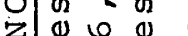

国 0 in o 6

- द्व $\sigma$.

公

का मा मे

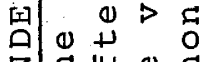

उ. 4 4 0 व

H+

团 0 r

Uढ口

苞合

द $\overrightarrow{0}>\overrightarrow{0}$

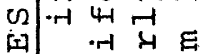

匈

牙

D)

z 4 क

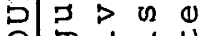

일

का गु प्र जि

베 0 व

ป艹

H) व द .

स 0 क म

빙

0 त्रे कू

मा

造

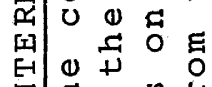

告 n

0 -

थ 4 मे त्र

- $\begin{array}{llll}0 & + & 0 & 0 \\ 0 & 0 & 0 & 0\end{array}$

H. L

3.1 \&

H) क्र 0 Q

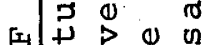

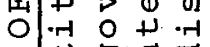

$z$ का का मे

ठ द्व 0 ⿰彳

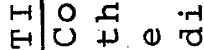

吕 द

기도 태 मे

D

国. 4 出 0 \%

든

N 300

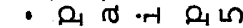

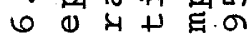
प्र 0 \% - द $\mathrm{N}$

का 0 स म त म

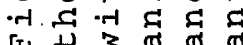


central administration. If the president is satisfied that the government of a particular state cannot be carried on in accordance with the constitution, he may with the assent of the two Houses of the central legislature assume all functions of the state government for six months. This period may be further extended with the approval of the two Houses.

Despite this overall paramountcy of the central government, in matters of finance, however, "the constitution goes a surprising distance towards dividing tax fields so as to give the Regions some degree of financial autonomy". 21 The freedom of trade and commerce between the states is guaranteed. The judicial system is highly integrated because not only the supreme court but the High courts also remain a centre responsibility. The supreme court is a general Court of appeal on all questions of importance.

\section{POLITICO-GEOGRAPHIC FACTORS IN THE RISE OF INDIAN FEDERALISM}

\section{Factors for Regional Identities}

India is, no doubt, a better "geographically intelligible isolate" than most other countries, but because of its great size and population, the country, though it lacks any internal barriers of impassable magnitude, is parcelled by nature into a number of somewhat self-contained units which, before the coming of modern communications, had for centuries developed in relative isolation and so had come to possess their own distinctive cultural and linguistic complexes. Though this isolation was seldom complete, and all the diverse regional units were daughters of the same mother culture, still these were daughters that had set their houses at places far removed from one another long before the era of mechanized transport. With the opportunities for inter-regional intercourse being greatly limited, despite an overall sense of belonging together each of the units developed its own. identity to some extent conditioned by its own geographical circumstances. [Fig. $6.3 \mathrm{~A}]$

The Vindhyas stand as a formidable barrier between the 


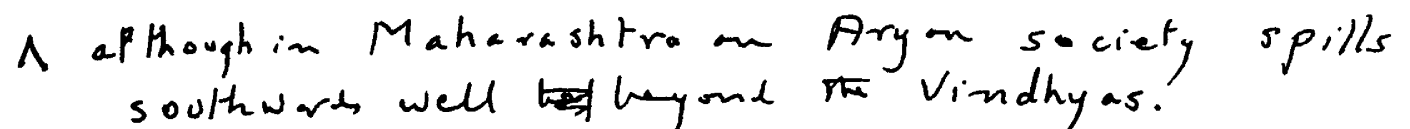

northern plain and the southern plateau: Before the railways were laid, the Vindhyas with their tangled growth of forests presented a barrier of magnitude. The dividing effect of the system may be seen in the presence of a so-called Aryan north and a Dravidian south, $\Lambda$ The predominantly Aryan north with its Indo-Aryan languages and its predominantly vaishnavite religion differs to a degree from the Dravidian south with its different "racial" characteristics, its different linguistic complex, and its predominantly shaivite religion.

But the change from the north to south is not sudden. Between the cores of the two regions stands a midale zone which shares the characteristics of either, while the forestcovered tracts of central India along the Vindhyan zone have been the traditional homeland of the dispossessed tribal groups whose cultures differ from the either two. The north and south are themselves divided into several smallex linguisticcultural subdivisions by certain topographical lineaments of the landscape. The Indus valley region is separated from the Ganga-Yamuna plain by the wide expanse of the Rajputana desert, and is connected with the latter only by a narrow corridor to the north of Delhi. Though all the time in close touch with the main cultural hearth in the Ganga valley, this western region developed, in course of time, an identity of its own--developing its own language and its own script. But from here to the far east there is no geographical divide in the plain. It has resulted in the development of a homogeneous cultural complex from the west to east till the northward projecting horn of the plateau in the chhota Nagpur region is reached. This projection with its forestclad surface forms a break in the otherwise unimpeded transport and communication of the plains (and this must have been a real break before the coming of modern transport and in the formative period of the regional cultures). Thus Bengal, beyond the bottleneck between chhota Nagpur and the Himalayas, though culturally one with the rest of the plains developed its own language (though clearly derived from the sanskrit root as the other north Indian languages are) and its own script. Separated from the Bengali-speaking areas by the Shillong plateau is the Brahmaputra valley of Assam with its own linguistic-cultural complex in the Assamese. 
South of the Indus-Ganga plain are, from west to east, Gujarat, Maharashtra, Madhya Pradesh and Orissa--each of them (except Madhya Pradesh), though still Indo-Aryan in its linguistic-cultural complex, has developed its own language and script. Gujarat, separated from the Indus-Ganga plain by the Rajputana desert and the central Vindhyan districts, and from Maharashtra by the forested Satpural sahyadvi, has developed its own language and literature in Gujarati. Separated by the Vindhyan districts and the Satpura-Maikal zone from the north, and occupying the Deccan lava country, is the region of Maharashtra with its indomitable identity that has stood firmly against foreign onslaughts throughout the mediaeval and modern times. Its language, though from the same root and having the same script as the languages in the northern plains, has its own identity in the Indo-Aryan family. Further east, Madhya Pradesh, again Hindi and Hindu, is in close touch with the Ganga plain outside its tribal areas. East of it is the orissa region bordering on the Bay of Bengal. Separated by the Chhota Nagpur plateau region from Bihar and Bengal, and by the forest-covered tribal country from Madhya Pradesh, Orissa has, through the ages, developed its own regional identity and a separate language:

South of the Deccan lava country in Maharashtra is the Kannada-speaking Mysore. Kannada, unlike Marathi, belongs to the Dravidian group. Further south of it is the Malayalamspeaking Kerala separated from the Kannada-speaking Mysore and the Tamil-speaking Madras by the Western Ghats. The Tamil-speaking area is roughly separated by the Mysore Ghats from Mysore and the Western Ghats from Kerala, and has its heartad around averi plains. Being farthest removed from the zone of tension in the north, this area was rarely penetrated by a northern power. North of Tamil Nadu (Madras) and east of the Kannada- and Marathi-speaking areas is the Telugu-speaking Andhra Pradesh which is dominated by the riverine tracts of krishna and Godavari. 22 [Fig. 6.3C]

\section{2}

The dynamics of Indian history in relation to its geographical personality are best treated in B. Subbarao, Personality of India, Baroda: M. S. University, 1956; and Y.A. Raiker, Indian History: A Study in Dynamics, Baroda: M. S. University, 1960 . 


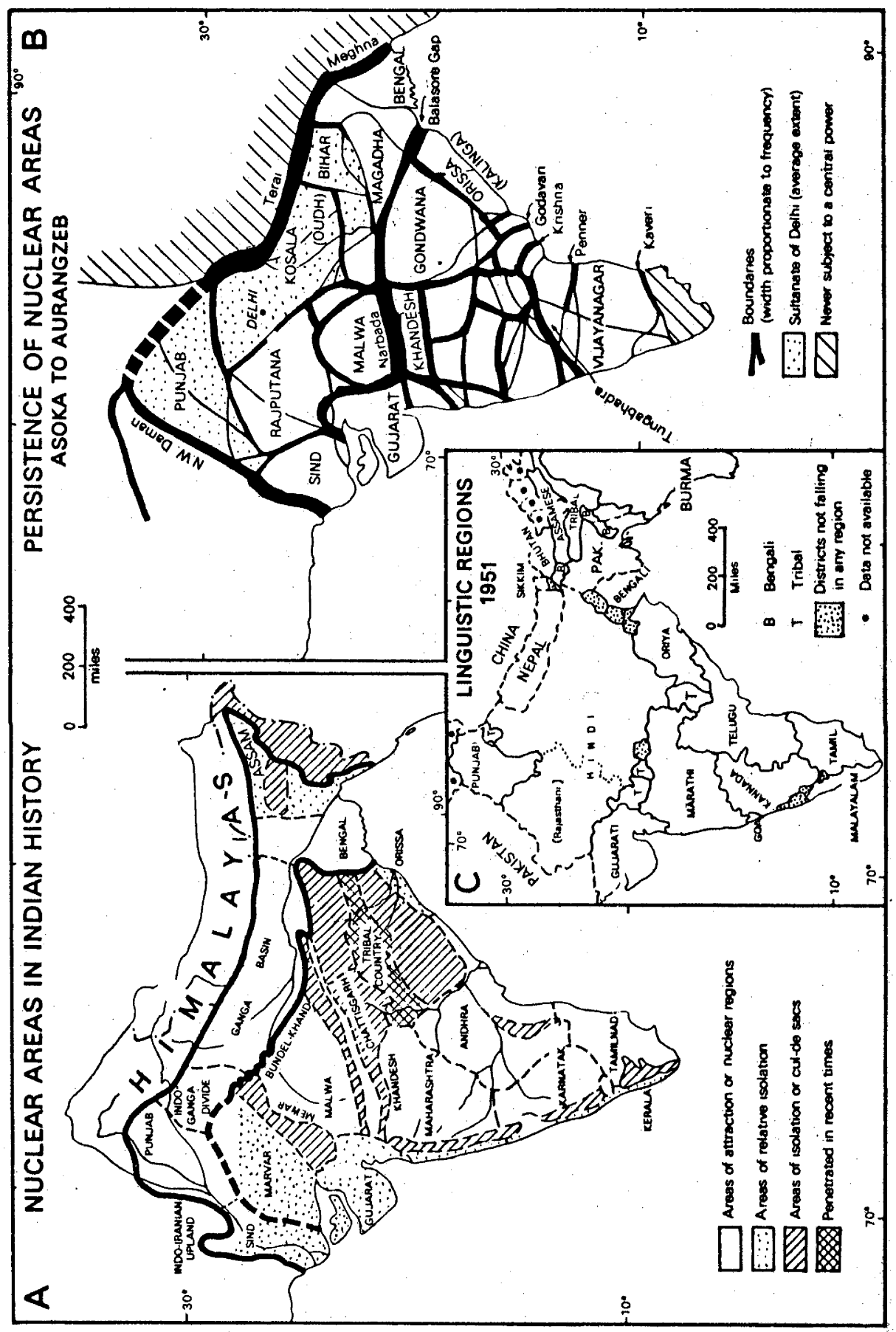

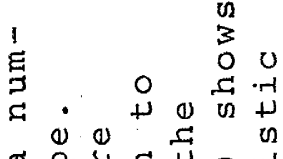

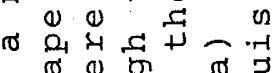
0 3 ग + ⿰ 034 स

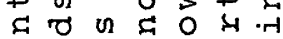
- द्व द व वन नूत्व उ 000000 $\rightarrow+4+\Omega$ Q न 0 ब 10 出 0 थ थ +3 जी

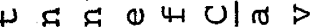
द 0 . (1)

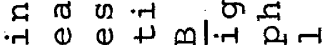

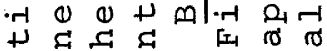
द $0 \rightarrow$ व का बा का द्व

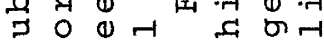
थ 430.30 0 ह घ व है $\stackrel{2}{\rightarrow}$ O

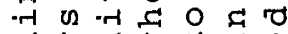

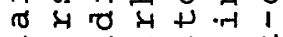
- +0 व 0 on

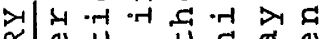
(1)

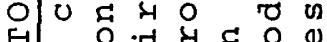

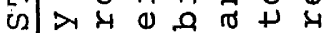
H. (2) 0 तै द व थ Zद द्E 4 H ब 0 प 0 .

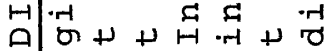
Z

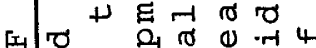
O 0 U 0 \& $\rightarrow 0$ द 3 त मत

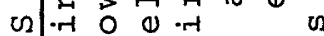

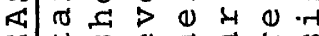

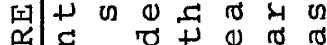
द $\quad \sigma+0$ \%

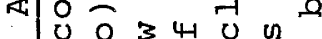

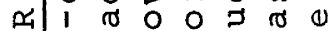

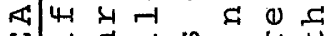

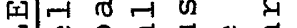

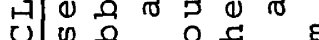

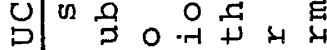
z) त 02 w 04

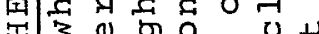

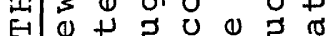

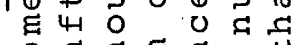
○ $m$ o -00000

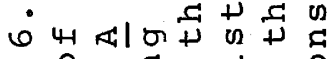
- 0 . E 0 a

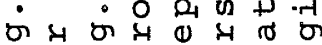
-r 0 o

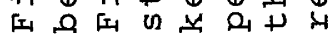


, although protakly through its later Mughal form

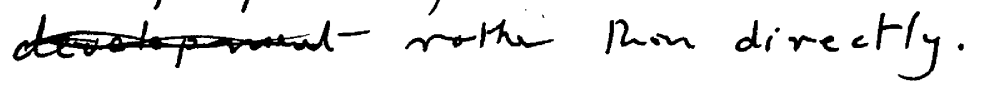

Throughout history each of these different geographicalcultural entities (or nuclear areas) maintained some kind of separate historical identity, though some of them were divided into a number of rival principalities. [Fig. 6.3B] There were, no doubt, continued attempts to weld these diverse regions together into a single body politic, and some measure of success was achieved in the different periods of history; but through the ages, under India's traditional concept of samrajya (or paramountcy), the regional units, while recognizing the paramountcy of the central power, retained their regional autonomy. Thus a kind of incipient federalism was present all the time in. India's historical past. As already noted, the British, recognizing the advantages of a decentralized administration in India, soon accepted this legacy, $\wedge$ The regionalizing effects of the gradual devolution of authority to the provinces in British India have already been referred to and need no repetition. Then the princely states were, we have seen, an altogether different world in themselves. While a uniform legal and educational system prevailed in the British provinces, in the states "in most cases autocracies continued unmasked and in a few states it was covered with a thin veneer of democratic government". 23

\section{Factors for Unity}

Despite the long distances and the differences in climate and physical features involved in an area of this magnitude, nature does not compartmentalize the country into discrete units. Most of the geographical features separating one area from the others were more like boundary fences than total barriers. The fences were high enough to safeguard privacy of the separate households, but low enough to enable some consciousness of what was going on to the other side. Thus while maintaining their separate identities the regions were all the time conscious of their essential cultural unity. Unlike most other areas of similar extent in the old World, India has all through been a vast cultural realm made up of a number of regional units always conscious of their

White Paper on States, quoted in P. Griffiths, Modern India, London: Ernest Benn Ltd., third edition, 1962, p. 113 . 
unity in separation. The Ramayana and the Mahabharata embody "common links in the realm of thought, literature and social customs of the various regions" of India. 24 Because of the concept of Rama "the whole of the country has [fundamentally] one idea, one inspiration--one personification of many virtues". 25 Indeed, "Under favourable. . geographical circumstances, Hinduism was able to build up throughout India a common culture and a uniform way of life. . . The foundations thus existed on which, under favourable political conditions, a structure of true unity might be created". 26 Thus the statement that "Multilingual. India's separate territories have failed as consistently as Europe's to hold together as a political unity" takes a narrowly political view of India's history. ${ }^{27}$ As Percival spear says, the division in the political life of India was not so much a chronic malady as suggested by many British historians, as a periodic malaise caused by the nature of Indian polity and the tensions produced by overlapping "races" and rival "cultures" in a subcontinent which provides few convenient physical compartments for the growth of integrated nationalities. Many historians have drawn attention to what percival spear has so beautifully summarized in the following lines:

Groups which developed into nations tended to grow into empires, ossify into aristocracies, and decay into dispersion. There never was an Indian concept of a balance of power of stable states within the orbit of Indian culture. Instead there was a continuing tradition of empire and overlordship from the Chakravarti raja. with his horse sacrifice as token of supremacy in ancient times to the great Mughals of the seventeenth century.28 Before the arrival of the British there was a complete absence in India of the linguistic and cultural nationalism

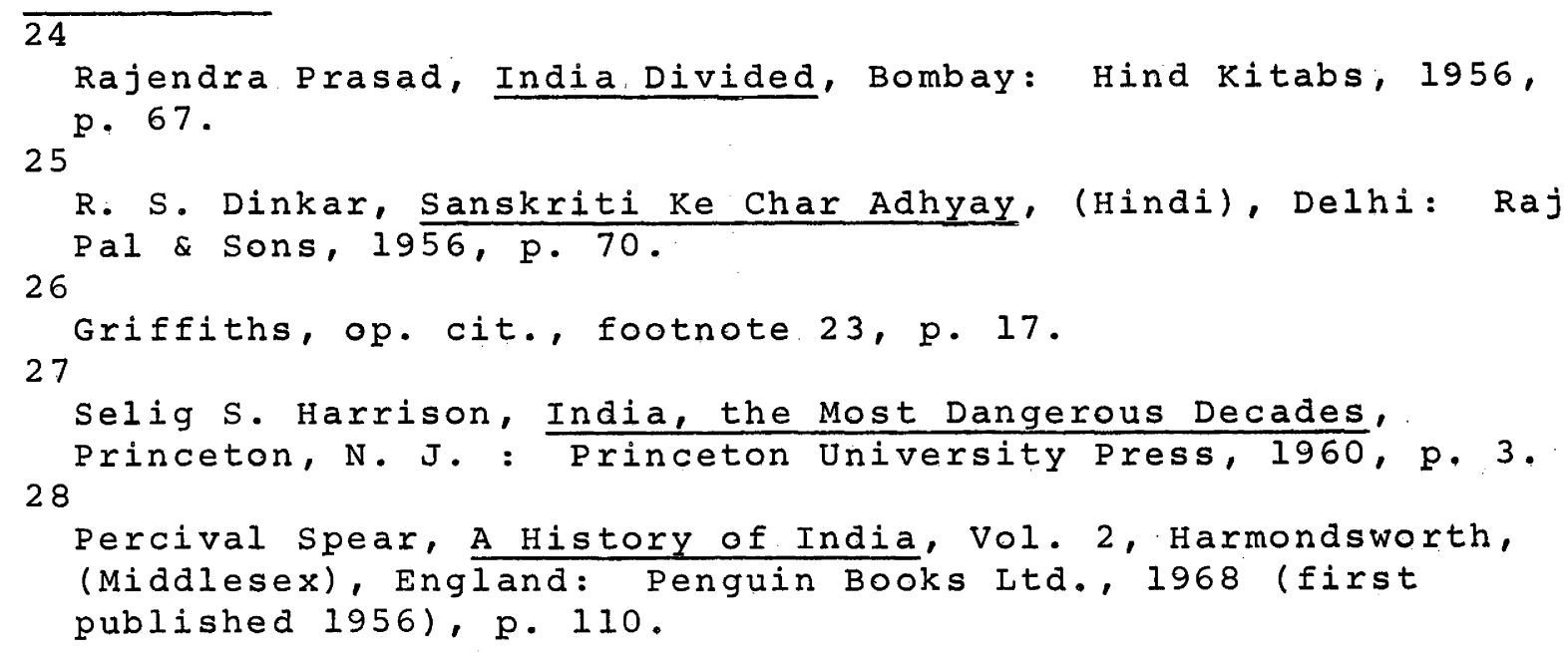

R. S. Dinkar, Sanskriti Ke Char Adhyay, (Hindi), Delhi: Raj 26 27

Selig S. Harrison, India, the Most Dangerous Decades, 28

Princeton, N. J. : Princeton University Press, 1960, p. 3.

Percival Spear, A History of India, Vol. 2, Harmondsworth, (Middlesex), England: Penguin Books Ltd., 1968 (first published 1956), p. 110 . 
then and since so dominant in Europe. As Percival spear notes, in India the horizontal division of caste and the vertical division of religion were more important than those of "race" or language. Tribalism was important as with Afghans, but it seldom deepened into any thing like nationalism because geographic dispersion did not favour it, and the community separation in the institution of caste hindered it. The Rajputs largely remained an aristocracy divided by clan spirit. only the Marathas, enjoying the advantages of a geographically distinct homeland, a common language, and love of independence, and fanned by the genius of sivaji in calling for the defence of the desh (homeland) and the cow (religion), federated the different communities on a functional basis and developed an incipient nationalism based on the hatred of the Islamic $x$ ule of Aurangzeb. 29

However, the more immediate factors giving rise to allIndia nationalism were largely products of the British rule. As the British Indian provinces were governed by officers of a centralized bureaucracy amenable to transfers, rather than smaller vassals often deeply rooted in their own regions, almost for the first time in India did the common man come into direct contact with an all-pervading central authority, though, no doubt, some beginnings in this direction had been made by the Mughals. The question of centre-state relations no longer remained a matter between a local $\mathrm{Nawab}$ and the paramount power. Now, because they were aimed directly at the common central authority, the grievances of the common man in all parts of the country became united. This realization of a united grievance gave rise to the feeling that their salvation also lay in united action. Thus when nationalism finally came to India, it came as an all-India nationalism. The vertical division of religion and the horizontal division of caste no longer stood in its way, for the Brahmin and the Sudra, the Hindu and the Muslim, whatever language he spoke and whatever part of British India he lived in, felt almost

\section{9}

spear, op. cit., footnote 28, p. 111 . 
equally aggrieved by the same authority. 30

one hundred years of British rule, though to some extent decentralized but with a uniform mould of administrative style, united the different regions of India into a single political and economic structure. Even the princely states, which lay interspersed with the British Indian territory, followed closely behind. A customs union transformed the whole of India, with the exception of Kutch, into a single unit for purposes of external trade. After the first world War, India was internationally recognized as a single political entity, and international treaties entered by the British Indian government became binding on the Indian states. While wide-spreadiog railway systemsand improved roads made inter-regional communication easy and isolation of the provincial units difficult, the centrally governed postal, telegraph, and telephone services, and the broadcasting system bound the entire country together. The unifying effects of a uniform system of education through a common medium of instruction, and the uniform legal and judicial administrative system have already been noted.

The whole of the subcontinent developed as a single economic unit. The provinces had no raison d'etre as independent economic organizations. Industrial development took place at the centres most conveniently located from the economic viewpoint disregarding the political boundaries. The republican federation of independent India was, therefore, not an artificial creation but the genuine emergence of a single nation welded, together by social, economic and political forces. ${ }^{31}$ Having for so long developed as the organic parts of the same economic. whole, it would have been suicidal for either the provinces or the states to have parted company as independent units. Thus, after the two areas on the

\section{0}

One of course does not discount certain regional and class- and caste-based political movements in British India, or some strong appeal to religious traditions and loyalties. But the Indian National Congress with its all-India appeal did provide a more or less united national front that for the most part overrode the distinctions 31 of class and caste.

K. M. Panikkar, The Foundations of New India, London: George Allen \& Unwin Ltd., 1963, p. 152. 
peripheries of the country were cut apart to form pakistan, it was natural for the remaining states and the provinces to join together into single organic political unit.

But while the large size of the country, the geographically compact linguistic groups, and the highly diverse princely states made a centralized unitary polity unsuitable, the legacy of a unified administration and a unified economy that had existed over a long period of time, made a loose coordinate federalism appear as a retrograde step. India's solution lay, therefore, either in a highly federalized unitary polity or in a highly unified federal one--that is somewhere between a normal unitary and a classical federal organization, and something like the twentieth century mature federalism in practice. Thus when India decided upon a federal political organization she achieved by her constitution what the earlier federations had achieved by a long evolution.

\section{POLITICO-GEOGRAPHIC INFERENCES}

1. The origin of Indian federalism differed in its essentials from that in the United States, Canada or Australia. Unlike in the classical examples Indian federalism did not involve joining together of formerly disjointed units that had over long periods of time grown in relative disregard of one another. India had all through remained a single British colony whose different provinces had together formed an organic political unit. Thus, in relation to the classical federations the rise of Indian federalism presents a somewhat atypical case for here, unlike in the classical examples, the problem was not of creating unity from disunity. India's real political problem was to convert a dependent and somewhat imposed unity into a unity of free choice. For this reason some of the hypotheses developed with respect to the origin of the classical federations may not apply to India.

Thus the hypothesis that federalism is a form of union that often originates when a number of regionally-grouped political communities with small power potentials but strong regional identities are faced with a common threat to their survival, would not exactly fit this case. Yet, in a sense, it applies to this case also for both the provinces as well as the princely states knew that disjointed they were helpless economically as well as politically, while in union they 
could be a considerable force in the society of nations. They were impressed that in a world of aggressive and expansionist politics only large and powerful states have a fair chance of survival.

2. The consolidating effects of live political frontiers, though not to the same degree as in the classical examples, may still be discerned in the Indian example. The princely states of Rajasthan, which for long bargained for more favourable terms of union, hastened to join soon after the partition of the country, for the military implications to their weak Hindu states next door to the new and militant Islamic republic of pakistan were only too clear to them. The proposed declaration of independence by the state of Travancore, situated deep into the south away from any foreign frontiers, may provide a negative proof of this. The Hindu Raja of Kashmir finally decided to join the Indian Union only when the military invasion from across the borders in Pakistan forced him to beg for Indian protection. The consolidating effects of the Chinese aggression and the Pakistani war of 1965 were clear to every observer of the Indian political scene.

Though switzerland is the best example of how dynamic political frontiers help to maintain unity within a highly heterogeneous federation, India also presents an interesting case. India's live political frontiers are limited to its north, northeast, and northwest. Throughout its wide expanse in the south it is washed by the placid waters of an open sea. Because of this smaller events in the north, like the protracted controversy over Kashmir or the minor skirmishes on the borders with pakistan, do not agitate and frighten the southern states to the same degree that they do the people in the north. Only when the issues are vital enough to question the unity and survival of the nation per se-as the Chinese aggression or the Pakistani war--do the people in the south get emotionally charged.

3. As in most other federations, in India too, geographical contiguity of the units involved in the federation played an important (perhaps decisive) role in the origin of the Union. Had the princely states not been hemmed in by the British Indian provinces in the way they were, several of 
them might not have so smoothly and willingly joined the federation. The point is very clearly exemplified by the case of Kashmir, which not being geographically surrounded by the Indian territory.was out for independence, and entered the Union for protection only when faced by a massive military invasion. The lines of transport and communications in the pre-independence India did not so effectively link Kashmir with what became the Indian Union as they do now.

Even the largest of the princely states were very small in area and resources when compared to the united provinces of British India. Had all the princely states formed a geographically compact area, even though divided among so many Princes, the federation, if born, would have been a loose union somewhat on the eighteenth century model. Thus, geographical contiguity and the peculiar distribution of the units concerned played an important part in the rise of the Union.

4. Hinduism has aptly been likened to a sponge that absorbs everything that enters it without ceasing to be itself. Iike the sponge Hinduism has no very clear outlines at its borders nor an apparent core at the centre. Still, as selig Harrison puts it, "the common identity of all Hindus in a non-Hindu world gives validity to Indian nationalism in the world setting". 32 Due to the absence of that fanatic zeal associated with certain other religions with distinct outlines, the Indian identity as the homeland of Hindus surrounded by the peoples of other faiths was seldom very strong, but the birth of Pakistan and all the bitter memories associated with the Partition did perhaps give rise to some such feeling at the popular level--though religion has never been the raison d'être of the Indian Republic, unlike the case in pakistan. 5. The Indian example satisfies my hypothesis that in a multi-ethnic federation social and political cleavages cutting across state boundaries foster a sense of national unity by interlocking the diverse groups within the union. It also demonstrates the fact that in multi-ethnic federations with regionally-grouped cultural diversities, other things being favourable, the greater the factors of "felt" diversities the 
greater are the chances of a stable federalism for then, most likely, the patterns of the major diversities such as language and religion would not coincide, and their overlap would tend to neutralize their divisive force. As the cleavages overlap, the different groups within a union find their loyalties divided and their interests interlinked.

Despite the large number of apparent diversities in India, after the birth of Pakistan and the subsequent reorganization of the states on a linguistic basis, language has become the main factor of cleavage between the states of the Union. ${ }^{33}$ As the political boundaries have coincided with those of language, the cleavage lines between the states have hardened, and language has begun to play mischief, as in canada, to the detriment of national unity. The advantages are, no doubt, great if the regional administrations are carried out and early education imparted through a people's own mother tongue. But if a strong link language does not develop, and if English continues to be neglected as it is at present, the dangers are great that the like-mindedness among the élite, born out of a uniform education imparted through a common language, may soon disappear and the people's intercourse of ideas would become confined to their own fellow-linguists. This would weaken all-India nationality and might create a situation somewhat similar to Canada vis-à-vis quebec. This will hinder inter-state mobility of population which is a most desirable antidote to localism. ${ }^{34}$ This would create in the Indian body

For the details of the factors behind the linguistic redistribution of states see Report of the States Reorganization Commission, New Delhi: Manager of Publications, Government of India, 1956. A geographical appreciation of the linguistic redistribution of states was presented by C. D. Deshpande, "S. R. C. Report: A geographical Commentary", Indian Geographer, Vol. 1, 1956, pp. 44-50. See also his "India Reorganized: A Geographical Evolution", Indian 34 Geographer, Vols. 1 and 2, 1957, pp. 164-169.

For a fuller note on the implications of regional languages as the media of instruction at all levels of education see R. D. Dikshit, "Media of Education and National Unity", Indian Education, November 1965; and an article on the same subject in the Madhyam (Hindi), Vol. 3, July 1966. important recent publication is J. Das Gupta, Language Conflict and National Development, Berkeley: University of California Press, 1970. 
politic a number of parochial linguistic cells with hardened outsides. 35

6. Despite its large size and varied resources, regional specialization in surplus production of agricultural or industrial goods meant for large-scale internal or external export, so characteristic of the United states and Canada, is largely absent in India. For this reason sectionalism or "bloc" formation of the American or Canadian type has not been possible here. Most of the agricultural production is for the local or regional (state) use, and large-scale sectional (compact bloc of several states) specialization of primary production for export is very limited. Jute and tea are the two significant cash crops for export, but because both are experiencing severe strains in the international market, and because the Indian government being short of foreign exchange holds the interests of these exchange-earning commodities as a national concern, there has not developed any sectionalism on this issue. There is no doubt a considerable regional specialization in the cotton and sugar industries, but both these commodities are primarily for home consumption, and are so limited in their inter-state spread that they stand of little value in the rise of that log-rolling deal in the federal politics which is so characteristic of the united States or even of Canada. Thus, by virtue of the geographical pattern of the distribution of

\section{5}

It is interesting to note that despite linguistic ossification in different parts of the country, seldom did the political and other cultural boundaries in India coincide with the linguistic ones. This is evidenced by authropogeographic study of the geographical distribution of certain cultural elements in India. As Nirmal Kumar Bose writes: "When maps showing the distribution of culture, languages or physical types are superimposed upon one another, they are not likely to correspond.... This implies that another kind of cultural affinity was slowly built up through migration and diffusion of culture than the kind we are accustomed to through the history of rise and fall of empires". (See Nirmal Kumar Bose, Culture and Society in India [a collection of previously published papers etc.], Bombay: Asiá Publishing House, 1967, p. 22.) Unfortunately, however, these elements of culture are no longer recognized as identifying factors among the people of the nation. Hence they are of little value in giving rise to the much needed overlapping cleavages that might antidote the divisive force of language. 
diversities in India, linguistic regionalism has been left alone to play havoc with the national unity.

It is here that one begins to feel that the multilingual states with boundaries drawn arbitrarily with a view to administrative expediency of the British imperial government, howsoever unsatisfactory for local aspirations, were, perhaps, better from the viewpoint of overall unity and cohesion. Even an ardent supporter of the linguistic states agrees that

the fear was legitimate that a state and its people would become more conscious of their distinctiveness if the state boundaries coincided with deepseated distinctions of language and culture. It would strengthen the state's resistance to a distant Central Government which would necessarily be compounded out of areas with different languages and cultures. Differences with neighbouring states whose personalities would be similarly accentuated, would acquire a sharper edge. A state like Assam, for example, can more evocatively say "Assam is being bled for Bengal" when Assam and Bengal are both linguistic States, each with undertones of being "a people", than it could if both were multilingual. . . 36

However, having recognized the principle of linguistic states for so long the central leadership could not go back on its own promises, and the linguistic reorganization of states could not be shelved unless its implications were made clear and were accepted by the leaders supporting the linguistic redistribution of states. All this did not seem practicable at the time. It is also true that it has turned out to be a wrong-headed myth that "anyone who demands linguistic state for his language is somehow by that much lacking in loyalty to India". ${ }^{37}$ The regional loyalties (linguistic and historical) "are [in fact] aspects of selfimage . . which do not interfere with a nation's development", 38 though they are, no doubt, a hindrance in the progress of national integration.

In this connection it may be relevant to take a point about India's much confusing and much confused caste system. It should be remembered that "the caste system is exceedingly

36

Pran Chopra, Uncertain India, Bombay: Asia Publishing 37

House, 1968, p. 213 .

Chopra, op. cit., footnote 36, p. 212 . 38

Panikkar, op. cit., footnote 31, p. 226. 
complex and varies from one part of India to another". 39 By and large the linguistic boundary is the caste boundary, and because the caste ties do not generally cross the linguistic boundaries, Hinduism for all its unifying power is vulnerable to the centrifugal forces within. "Loyalty to caste" has not "inhibited the development of national patriotism" as spate thinks, for as the states are not homogeneous from a caste point of view, caste does not accentuate state feeling of patriotism. 40 Nor do "the loyalties of caste cutting to some extent across provincial boundaries . . encourage . . these groups to support wider federal union", as R. I. Watts believes. 41 It is in this sense that the geography of caste in India is unfortunate, for while imparting many evils in the nation's life, it is deprived of conferring one possible good that might have accrued from a cross-cutting nationwide cleavage that could be an antidote to the divisive. force of language 7. Alarmed by the need for resisting and containing the separatist forces let loose by the movement for linguistic states, and impressed by the need for fostering a temper of inter-state cooperation in the field of social and economic planning, the late Prime Minister Nehru felt that "the division of India into four, five or six major groups regardless of language" would be helpful in implementing the national schemes and plans and in developing "the habit of cooperative working" among the states. Thus five Zonal Councils were established by legislation of the parliament in 1956. Established with the objective of "emotional integration", the Zonal Councils were expected as a "corrective to overemphasis upon sectional and linguistic loyalties, an effort to establish values transcending language and religion, a

39

J. E. Schwartzberg, "The Distribution of selected Castes in the North Indian Plain", Geographical Review, Vol. 55, 40 1965, pp. 477-95, reference on p. 478. 41

Spate and Learmonth, op. cit., footnote 5, pp. 165-66.

R. L. Watts, New Federations: Experiments in the Commonwealth, Oxford: Clarendon Press, 1966, p. 55 . 
forum for fruitful cooperation. . .". 42 By creating a middle tier of authority halfway between the centre and the states the councils could prove "a most useful device in the development of cooperative federalism", 43 for under their aegis multistate utilities would have grown and helped the states' development to become zonal in scope. Close cooperation in matters of river-basin development, power, and inter-state transport and police might have given rise to some kind of a salubrious sectionalism over-riding linguistic loyalties.

But, though a mechanism of great promise, "the Councils [virtually] died of neglect in their childhood." 44 As some recent studies show, though there have been some positive gains in matters of power development, formation of common reserve police force, and man-power planning, in other directions, more particularly on financial issues, the councils have failed to achieve unity. They have not succeeded in evolving coordinated and integrated lines of action over a large field. But, as Ashok Chanda says, the failure of the zonal councils system "is a failure of leadership and not of the concept". Indeed,

If the Councils develop, in the fullness of time, into effective organs of zonal administration.. they should arrest the growth of linguism and "provincialism", accelerate economic growth and social progress and better fulfill the purpose for which federations exist. 45

8. India has so far been the most stable federal democracy among the post-colonial "new" states. This is no mean achievement in view of the country's multifarious diversities --linguistic, historical, religious and others. Hardly ever in the past was the federal polity required to cope with such a

\section{2}

J. V. Bondurant, Regionalism versus Provincialism: A Study in Problems of Indian Unity, Berkeley: University of California Press, 1958, p. 146. 43

W. H. Morris-Jones, "Recent Political Developments in India", Parliamentary Affairs, Vol. 11, 1957-58, pp. 475-483. 44 Reference on p. 480 . 45

Chopra, op. cit., footnote 36, p. 211.

A. Chanda, Federalism in India: A Study in Union-state Relations, London: George Allen \& Unwin Ltd., 1965, pp. 50-55; quotations on p. 55 . 
tremendous range of heterogeneity except possibly in the soviet Union which, as already noted, because of its one-party government does not qualify for the title of federalism as it is understood by modern scholarship in the non-communist world. Unlike the classical federations, India was not growing in a "new" 1 and with wide open spaces waiting for exploitation, where every disgruntled element in society, individuals and groups, could find a place leaving the bulk of society at peace. Unlike the United States, it had no frontiers of settlement under the federal control where every state, every region of the Union, could expect a pay-off and thus be attracted to attach its strongest loyalties to the federal Government.

What was it, then, that helped India to steer through these seemingly impossible conditions? On a closer examination three factors stand out prominently. The first is what has been termed the "Fundamental Unity of India", preserved in the cultural realm of Hinduism, its sacred religious texts, and its Holy Rivers and the Holy. Tirthas spread through the four corners of the country and thereby joining it into a living whole. ${ }^{46}$ Every linguistic group, however extremist, while it thinks that its language is superior to all others and that its state belongs to its own fellow linguists and no others, still thinks that India as such belongs to it and it to India. In this regionalism there is little of separatism. As a recent political commentator writes, the great distances involved between the component units of the State do create some differences in attitude 4

But all that distance does is to reduce rigidities. . . . [it] no longer breeds indifference to the territorial integrity of the country as a whole. No party could hope to win votes in Bombay if it works for separation of parts of Assam from India; even more is this true about Kashmir.

The second important factor was the charismatic leadership especially of Gandhi and Nehru, though it was not charisma alone. The people's faith in the leadership was based on the extreme devotion and self-sacrifice that the

See Mookerjee, op. cit., footnote. 1.

Chopra, op. cit., footnote 36, p. 204. 
leadership had shown in the protracted struggle for freedom. So when the hour of freedom arrived there was no scramble for power as in some other "new" nations. It only involved a change of portfolios from the struggle for national freedom to the struggle for national reconstruction. 48

Lastly, though the federal government in India lacked the resources of a Great West or the "last best West" that could automatically attract the loyalties of the constituents to it, yet soon after independence the national government under the leadership of Nehru took steps to fight the nation's poverty and backwardness by embarking upon certain broadbased programmes of national planning and took in hand some great river valley projects and public sector industries which in effect helped to create a sort of new frontier, or what Nehru called the new Shrines (Tirthas) where workers coming from different parts of the country joined hands together and shared in the common experience of building the new nation. This helped to bring about a measure of mobility in the nation's population--something that the American frontier had done on a far larger scale. The programmes helped to bind the people's loyalties to the centre. It is, perhaps; in this respect that India's federal stability would offer some object lessons for some present and future experiments in post-colonial federalism.

\section{MALAYSIA}

As contrasted to the normal "territorial federations" Malaysia has been styled a "racial federation". 1 The chief identifying diversities in the national life of Malaysia

48

For history and role of the Congress see S. A. Kochanek, The Congress party in India: The Dynamics of One-Party Democracy, Princeton, N. J.: Princeton University Press, 1968 .

1

D. V. Cowen, "Constitution-making in a Democracy", Optima (supplement), March 1960, pp. 33-41; discussed in F. G. Carnell, "Political Implications of Federalism in New States", in U. Hicks (Ed.), Federalism and Economic Growth in Under-developed Countries, London: George Allen \& Unwin Ltd., 1961, pp. 49-53. 
are not territorially grouped: The Chinese and the Malay elements in the population are present in almost equal proportions in a number of states while the "Indian" community stands only as a balancing force between the two. Thus, unlike the French community in Quebec, the Chinese or the "Indian" communities in Malaysia cannot claim autonomous "homelands". Therefore, a kind of federal compromise, in a social sense, is required not only at the national level but also in a number of the states. In fact, so far as Malaya proper is concerned, a federal form of government was adopted not because of but in spite of "racial" diversity, though it must be pointed out that the pattern of areal predominance of the communities in the country has created a politicogeographic situation that favours a federal rather than a unitary organization of state. ${ }^{2}$

2

The distribution of ethnic elements in the population of Malaya proper is such that while in the western states of the peninsula the Chinese community stands in sizable majority, in the eastern states the immigrant communities account for very small share of the state populations. Since the indigenous Malay community has throughout been very apprehensive of economic competition from the better skilled and harder working Chinese, the areal predominance of the Chinese in the west and their relatively smaller numbers in the east created in the eastern Malay states an urge for regional autonomy to safeguard their states from the stiff competition that the Chinese had already posed in the West. While in a unitary set-up the whole of the country would have become equally open to economic competition from the Chinese, in a federal set-up, with the regional affairs remaining under the control of the region governments, the rights and privileges of the Malay community could well be preserved.

Many political scientists have completely missed this vital background to the support for federalism against unitarism in Malaya. Carnell thought that Malayan federalism "was the outcome of the British system of ruling through the sultans of protected Malay states and a response to the problems posed by the survival of Malay monarchies" (Carnell, op. cit., footnote 1, p. 58), While alluding to similar causes for the sentiment for regional autonomy in Malaya, B. Simandjuntak thinks that "By this time [i. e., the inauguration of the Federation] the strength of Malay regionalism received a serious setback.. [and] Sino-Malay communalism. . . displaced regionalism"--possibly implying irrelevance of the federal solution to Malaya's communal situation. (B. Simandjuntak, Malayan Federalism 1945-1963: A Study of Federal Problems in a Plural Society, London: Oxford University Press, 1969, pp. 297-98). 


\section{MALAYSIA'S MARCH TOWARDS FEDERALISM}

All through her history Malaysia has been a cultural marchland: first between the great chinese and Indian cultures, and later with the rise of powerful kingdoms in Sumatra and Java, between them and Siam (Thailand). The marchland character of the area continued well after the penetration of European powers, and it came to an end only when the Dutch and British interests on the one hand, and the British and siamese interests, on the other, were slowly defined. Only in 1909 did Siam renounce her suzerainty over the territories forming the present-day states of Kedah, Kelantan, Perlis, and Trengganu in favour of Britain. Thus, in fact, the evolution of the present-day political geography of Malaya begins only with the establishment of British rule in the peninsula; in so far as Malaysia is concerned, the "region [as a unit] . . derives its significance from a contemporary creation", and political historians are faced with the task of "giving [the area] a historical unity", 3 for throughout British rule the Borneo territories had formed quite separate entities with very little intercommunication with the peninsula proper.

Portugal had captured Malacca in 1511. It passed to the Dutch in 164l. The entry of Britain in the area dates back to 1786 when she established a base in Penang to which the adjoining tract of Province Wellesly was later added. Britain had occupied the Dutch territories during the Napoleonic wars as custodian against the French, but with a view to naval and commercial strategy she retained control over Malacca after 1815, and also obtained singapore from the sultan of Johore in 1819. As a result of an agreement in 1824 the Dutch withdrew from the peninsula completely.

In 1826 the three separate possessions of Penang, Malacca, and Singapore were joined to form the straits settlements with singapore as its capital. Outside the straits settlements the Malay sultans ruled their own territories without any interference from the British. However, by the end of the

3

D. K. Basset, "The Historical Background, 1500-1815" in Wang Gungwu (Ed.), Malaysia: A Survey, Melbourne: F. W. Cheshire, 1964, p. 113. 
third quarter of the nineteenth century, prompted by the economic considerations of tin and rubber and the military considerations of forestalling other external powers with interest in the area, Britain reversed its policy of nonintervention in Malayan affairs. Internal tensions in Selangor and intense rivalry for succession in perak offered the straits authorities in 1873 the sought-for occasion to intervene. By April 1874 agreements were reached for the appointment of British Residents in each of the states of Perak, selangor and Sungei Ujong. The British influence soon began to spread in the surrounding areas, and in 1895 the nine small states in the neighbourhood of Sungei Ujong were joined together to form the state of Negri sembilan under the supervision of a British Resident. Johore, though it did not receive an official Resident, had through the prudence of its ruler, maintained a close contact with the British rulers in Singapore; by a treaty in 1885 it definitely agreed to British protection. Pahang, so long neglected because of its lack of minerals and plantations and its distance from the important trade routes, was brought under the British influence, and in 1888 it also accepted a British Resident.

Though the Residential system succeeded in establishing law and order in the peninsula, and a centralized system of revenue collection; for all other matters each state remained a distinct unit, for hardly any attempts were made at interstate cooperation. The attention of the officials was soon drawn to this defect, however, and the four states with Residents were made to agree to a federation which was named The Federated Malay States, and was inaugurated in 1896. This proved the first step in the direction of a peninsular federation.

Under the new scheme the states were required to submit to some uniformity in matters of common interest. With this view a Resident-General was appointed and the main departments of administration were placed under federal heads of departments. A unified civil service and police force, a federal education policy, a standard postal system, and a common code of land regulations were established. These greatly helped in the integration of the states. Indeed, though "the intention was to establish a federation, the result was in fact a union" 
and as time passed the political power of the sultans became almost nonexistent. 4

In 1909 the states of Kedah, Kelantan, Perlis, and Trengganu also accepted British Residents, but as they lay at the fringes of economic activity in Malaya little attempt was made at coordination either among these states themselves or between them and the Federated Malay states. Thus being cut off from the main currents of life in Malaya, and remaining largely confined to themselves, these states developed their own regional identities separate from the rest of the peninsula.

James Brook, a private citizen, had acquired the first British interest in North Borneo in 1842 when he was installed as Rajah of Sarawak. Soon after in 1847 the kingdom of Brunei entered into a commercial treaty with Britain, while the offshore island of Labuan had become a British dependency in 1846 . The territory of Sabah was ceded to Britain by an American company in 1881. It remained under the rule of a newly chartered British North Borneo Company until the Japanese occupation in 1941. A British Protectorate had been imposed over the two British territories and the kingdom of Brunei in 1888 . This completed the pattern of British power over North Borneo. [See Fig. 6.4]

As the above summary would show, ever since the inauguration of the Federated Malay states the administrative pattern of the present-day Malaysia (including Brunei) consisted of three separate administrations in North Borneo, five in the unfederated Malay states and Johore, a coordinated administration in the four Federated states, and three fairly separated straits settlements governed uniformly from singapore as a single colony. This diversity of administrations had fostered a sense of separation, and so a proposal in 1931 to unite all these regions into a loose Pan-Malayan Union provoked great resentment and the idea had to be dropped. It was under this administrative-political situation that the second World War broke out and the area fell under the Japanese occupation. The Japanese returned the four northern

N. J. Ryan, The Making of Modern Malaya: A History from the earliest times to the Present, Kuala Lumpur: Oxford University Press, 1963, pp. 135-36. 


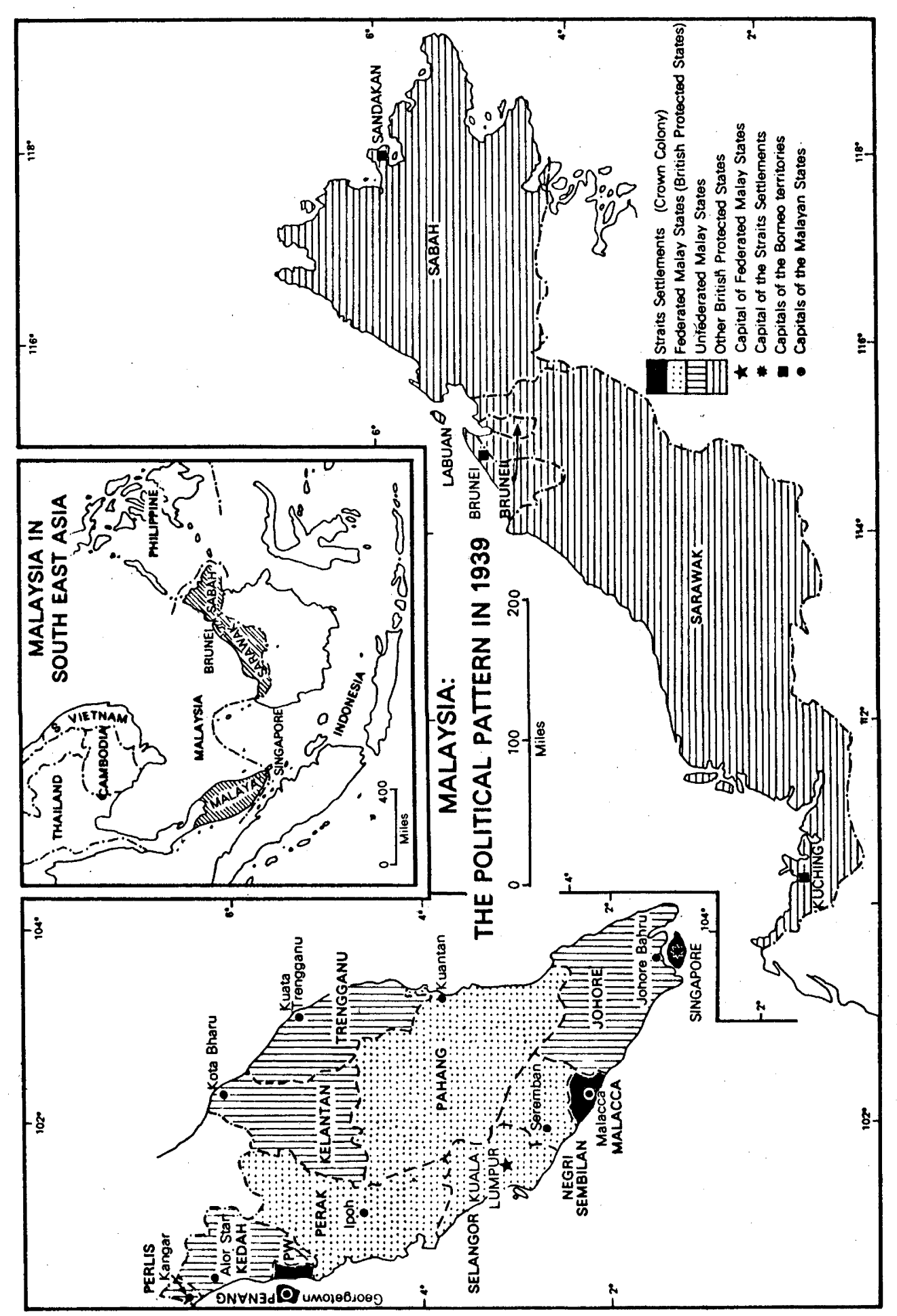

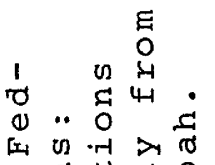

य

ठ 0 ॠ

हत्र म्र

त क्ष

व प्र

- $\begin{array}{lll}9 \\ 0\end{array}$

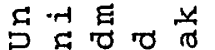

.

0 ह व द्

可

- 10 c

$\pi+\pi$ o 1

न $\begin{array}{lll}-1 & 0 & 0\end{array}$

+4 \& 40

更

द $0 \otimes 0$

- n.

(1) $4-1$ r

का स 4

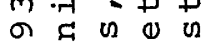

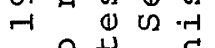

द

$H \mathcal{A}+\mathbb{E}$

- 0

बांब

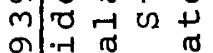

$-1>\Sigma 04$

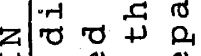

H $\stackrel{0}{0}-0$

Z

舟 $\begin{array}{llll}3 & 4 & 10 & 0 \\ 0 & 0 & 3\end{array}$

स-

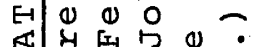

का 요

凷娄古

U द ह

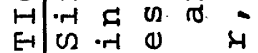

$H$

०ीद 0 व

का

त्व

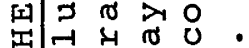

国

द 02 o 0 .

..

ब न व

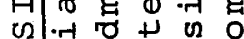

$\rightarrow-1$ ⿰冫

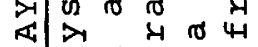

मा ति

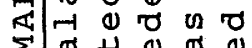

|

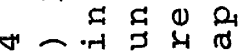

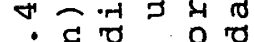
० 0 प्र 0 व -r 0 工

के - $\Rightarrow$ \& 4 .

क्य 0 质 
states back to siam and also fanned the feeling of communal hatred between the Chinese and the Malay communities. The cultural links between the two communities had always been slight, and as the result of the war their identities were only further hardened and their differences sharpened. In fact, they formed two distinct nations in the bosom of one state.

After the Japanese surrender the four northern states were returned to Malaya, and with a view to speedy recovery a union of all the Malayan territories, except singapore, was created in 1946. The difficulties in creating a unitary polity in an area which had so long enjoyed seven separate administrations were obvious, and in view of the great opposition from the local population the Union was abrogated and the Federation of Malaya declared in 1948, comprising the eleven peninsular units. The country obtained a new Constitution and complete independence in 1957.

The reason why singapore had so far been left out of any scheme of all-Malayan union was the Malay fear that inclusion of Singapore with its large Chinese population would make the chinese elements dominant in the population. But as time passed and communist forces around Malaya increased in strength, it dawned upon the Malayan leaders that the country's interests would be better served by absorbing singapore (despite the difficulty of "racial" balance) than letting her slide into the communist camp. Dictates of political arithmetic now showed that a greater Malaysia including the Borneo territories with their small Chinese and larger "Malaysian" population would provide a counterweight against the increased Chinese strength consequent upon the inclusion of singapore. Because of the economic advantages that the union with the mainland would offer, singapore was obviously quite willing. The indigenous population of the Borneo territories has few affinities with those of the mainland, and some opposition to union was encountered in sarawak, but the fear of incorporation into the entirely alien Indonesia, and hope of economic benefits in association with the more prosperous peninsular states, finally brought overwhelming support for federation. The Sultan of the oil-rich Brunei, however, found little economic 
incentive and, therefore, decided not to join.

The Federation of Malaysia was inaugurated on september

16, 1963. But soon the political arithmetic failed and

"racial" tensions between the Chinese and Malay communities began to mount, leading to the expulsion of singapore from the Federation in August 1965.

\section{The Federal Structure of Malaysia}

As Sawer puts it, 5 Malaysia

is farther along the federal spectrum in the centralizing direction than India, but the special position accorded the Borneo states may be regarded as at least creating a "weak" federal relationship between them on the one. hand--"East Malaysia"--and the peninsula states--"West Malaysia"--on the other.

Like most other federations Malaysia also has a two-House central legislature. The upper House has equal representation from each state, but here members nominated by the central government outnumber the elected ones. This greatly weakens the effectiveness of the House as a states' House. The Constitution also provides for a Conference of Rulers which consists of princely hereditary heads of the nine states which have such an institution, and the governors (who are appointed by the central government) of the other four states. The Council elects from its members an executive Head of the Federation (Yang di-Pertuan Agong) for a four-year term, and can remove him if found unfit. The Council also has a veto on some constitutional amendments and laws affecting the position and authority of the princely rulers, as well as legislations affecting the boundary of the states. Though the Yang di-Pertuan Agong is very much a constitutional monarch, he is authorized to have "some independent discretions which work in the same direction--to protect the cultural autonomy and traditional values of the Malays which have become particularly identified with the Regions". Thus the council has rightly been called "for some purposes

5

For a detailed commentary on the Constitution of Malaysia reference should be made to H. E. Groves and I. A. Sheridan, The Constitution of Malaysia, New York: Oceana Publications, 1967. A brief, but competent, analysis is presented in G. Sawer, Modern Federalism, London: C. A. Watts \& Co., 1969, pp. 50-53. This summary leans heavily on sawer, and the quotations in this paragraph are from his above mentioned book: 
a third legislative House".

The division of powers in Malaysia is on a three-list system: exclusive central powers, exclusive state powers, and concurrent powers. Though the residuary powers are given to the states, the powers given to the centre are so far-reaching that all that is left to the regions are largely the powers over Muslim religious matters, matters of land tenure, agriculture and forestry, and local government. Even in matters of land and local government, the centre has an extensive power to procure uniformity of law and policy. Then there are the Emergency Powers, beyond the reach of judicial review, which enable the central government to act without regard to the federal distribution of competence. The states have very slight independent sources of revenue, and can borrow only with the consent of the central government or its Central Bank. The superior Courts are wholly centrecontrolled, culminating within Malaya in a tribunal called the Federal Court which has some original jurisdiction (mainly constitutional) and is the appellate court on all matters.

But because of the different history of their entry into the Federation, the Borneo states have been given a slightly greater degree of protected autonomy. The central government's power to intervene in matters of land tenure, agriculture and forestry, and local government, does not apply there, and the constitutional amendments affecting the special privileges of the Borneo states require the consent of their Governors.

Although there is no constitutional guarantee of the common market between the states, the states, however, lack powers which might obstruct freedom of trade.

\section{POLITICO-GEOGRAPHIC FACTORS IN THE RISE OF MALAYSIAN FEDERALISM}

\section{Factors for Regional Identities}

While the cultural counter pulls inherent in its marchland character prevented the rise of an integrated Malayan identity in the past, the peninsula had sufficient geographic compartmentalization to give rise to diverse social groups with strong regional identities. The alignment of the Main 
Range provided a major obstacle to east-west movement, and the lower but complex ranges in upper Kelantan, inland Trengganu and Pahang with their thick forest cover repelled human occupance for a long time. ". . the peripheral distribution of the better agricultural soils was a further factor tending to foster localism, for settlement has most consistently concentrated in a few relatively favoured lowland areas, widely scattered around the edges of the peninsula as a whole". 6 Then, because the highly eroded pre-Pleistocene landscape "protrudes through its surrounding aprons of alluvials in the same way as islands stand above a shallow sea", 7 these forest-clad protrusions helped to keep the settlements on the littorals fairly isolated from one another. The widespread occurrence of jungles impeded movement any distance inland. The physical geography of the peninsula, therefore, created almost two distinct Malayas--one in the west and the other in the east. The differing identities of the east and west coast were further reinforced by the ease of maritime access in the west and the great difficulty in navigation along the eastern coast. While the western coast traditionally remained the "front door", the east has been in Sir Hugh Clifford's telling phrase, "the further side of silence". 8

Upon this east-west cleavage was established a northsouth one because the four northern states that had remained under siamese suzerainty till 1909 were, even after their incorporation in the British territory, not integrated with the rest of Malaya until the formation of the Malayan Union in 1946. The geographic cleavage between the east and west was further reinforced by the pattern of Britain's economic and strategic interests. Because of her paramount concern with the control of the Indian ocean and the navigation between India and the Far East, Singapore and the western seaboard of Malaya remained the area of Britain's primary

6

C. A. Fisher, South-east Asia, London: Methuen \& Co., 1964, 7

p. 589 .

R. Ho, "The Environment", in Wang Gungwu, op. cit., footnote 8

3, p. 35 .

Cited in Fisher, op. cit., footnote 6, p. 589. 
interest. Thus the eastern areas and the northern states remained comparatively neglected.

Malayan economy has been rightly considered as the product of two autonomous economic systems interacting over time. The first is the indigenous system which is Malay, agrarian, subsistence, non-commercial, wet-rice oriented and village organized. The other is the predominantly foreign and commercial economic system dominated by the non-Malay population, especially the Chinese, and closely linked with the world market and outside capital. Tin and rubber have been the two pillars of the latter system. Tin mining has spread rapidly through the three western states of Perak, selangof, and Negri sembilan. The growing importance of tin in world commerce by the midale of the nineteenth century gave great impetus to the development of roads and railways on the western coast of the peninsula. And the geographical patterns established by tin conditioned those of rubber. Because rubber could thrive on most of Malay's lateritic soils advantage was taken of the road and railway facilities already established by tin. Thus rubber plantations became heavily concentrated in the west. 9 Though, later on, other areas also came to possess rubber plantations, the west coast remained by far the main area of concentration.

As both rubber and tin industries were, in the main, run by immigrant labour--Chinese and Indian--this economic plurality between the two sides of Malaya gave rise to an ethnic plurality as well--one superimposed over the other. Thus the eastern and the western states of Malaya became, in some.ways, two different worlds. And distinct from either were the separately administered unfederated Malay states which were highly different from the other two components in their ethnic composition and outlook.

outside the western coastal areas there were few roads and railways connecting the different regions in general and the eastern and western regions in particular, while the Borneo territories seemed to lie a world apart. In fact, From the dawn of history until the campaigns of 1941-2

E. G. H: Dobby, "Some Aspects of Human Ecology of South East Asia", Geographical Journal, Vol. 108, 1948, pp. 40-54, reference on p. 48 . 
Malaya has repeatedly suffered from the weakness of nodality unsupported by commensurate internal strength, - . the problems to which the country is . . subjected by virtue of its geographical position are very real. 10

Because of its divided administration, the different regions of Malaya developed in course of time their separate identities, which in effect made a federal political organization of the state almost inevitable.

\section{Factors for Peninsular Unity}

Despite a certain amount of geographical compartmentalization of the peninsula, "Malaya would appear" says Fisher, "to be an almost perfect example of the hypothetical 'geographical region'", ll though unlike India this consciousness of the geographical unity of the land was seldom present in the popular mind.

However, since the close of the nineteenth century certain factors--political, economic, and strategic--were tending to pull the British territories together. The British impact on these territories had imparted them a broady similar political culture. Their patterns of education, social services, and judicial administration etc., though not unified, were broady similar. While in the north the linguisticreligious complex sharply differed from that of siam, in the south also the sharp contrast between the British administrative system and that of the Dutch"in Indonesia, helped to shear off any historical and cultural affinities that the Malayan territories had possessed with those of Indonesia. This, along with the fact that each of the British territories in the area was too small to form a viable political unit by itself, helped to develop in them a sense of common destiny. Further, because the racial-cultural cleavage between the Malay and the immigrant communities cut across state boundaries, the "racial" conflict did not bring in a divisive element in the political organization of the state.

\section{0} 11

Fisher, op. cit., footnote 6, p. 590.

C. A. Fisher, "The Problems of Malayan Unity in its

Geographical setting", in R. W. Steel and C. A. Fisher (Eds.), Geographical Essays on British Tropical Lands, London: George Philip \& Sons, 1956, p. 271. 
The post-1945 emergency, consequent upon: the Chinese communist terrorist activities that threatened to make Malaya a Chinese-dominated country, helped greatly in the rise of a strong sense of belonging together in the Malay people by giving them a sense of common destiny in face of a common danger. The federation of the peninsular states was, in this sense, a natural growth. The rapid expansion of rubber plantations in the decade preceding the second War tended to tie the eastern and the western coastal areas of the country into a single economic system. Expansion of the railway line from Johore Bahru, opposite the island of Singapore, to Gemas in Pahang and later to Kelantan, brought the two sides of the peninsula closer.

While the geography of "race" had excluded singapore from the federation in 1948, the Borneo territories were geographically and economically greatly removed from the rest of the British territory, so much so that Arnold and Reid, who in 1912 pleaded, for a closer coordination between all the British Malayan states and settlements on the ground that "The water-tight compartment system may be good for a ship, but it is bad for a colony", 12 made no reference to them. But when the British departure from the area became imminent, these territories, except the oil-rich Brunei, found themselves too weak to stand on their own. Only two courses seemed open to them--a union with Malaya or absorption with Indonesia. Of the two alternatives the former appeared preferable--first because they seemed to possess a politicocultural affinity with the peninsular state born out of their similar colonial experiences, and secondly, the Malaysian Federation rather than the Indonesian Republic offered them the better prospects for political and economic stability, and for the preservation of their regional identities developed over a long period of time.

Indeed, no matter how anomalous the established political boundaries are "provided only that they have time in which to stabilize, they tend to become accepted frameworks within which political attitudes and economic interests crystallize 
to produce a condition of politico-geographical ossification". 13 Thus, when circumstances, both internal and external, made a close union of some kind necessary, a federal union in Malaya (and more so in Malaysia) became imperative, for the legacies of the politico-geographical forces could not be completely written off.

\section{POLITICO-GEOGRAPHIC INFERENCES}

1. As in many other federations, military threat has been a potent factor in the rise and maintenance of Malaysia as a federal state. Although sponsored by the colonial masters, the Federation of all the Malayan territories in 1948 may be seen as a clear response to a military threat. With the independence of Malaya and the imminent British departure from the area, a situation typically suited to the rise of federalism had come into existence. After the British withdrawal the different political units of British Malaya would now have formed isolated political units of weak power potential that seemed to be surrounded by hostile political forces on almost all sides. It was therefore natural that the federal arrangement should be continued after 1957. Similar forces, along, with the fear of Indonesia under sukarno, helped to bring the remote sabah and sarawak into the union with Malaya. This factor had also helped to overcome, though only temporarily, the Malayan distaste for the Chinese-dominated singapore which was then accepted as a partner in the Federation.

External military threat would seem also to have proved a favourable force in the maintenance of the Federation. Despite the explosive situation in respect of "race" and culture, it was, to some extent, because of the continued military pressure from without that the Federation was able to achieve progressive centralization and stability. Similarly, the Indonesian "confrontation" of Malaysia, with an eye on Sabah and sarawak, rather than splitting these territories off from the Federation only helped to strengthen

13

C. A. Fisher, "Malaysia: A study in political Geography of Decolonization", in C. A. Fisher (Ed.), Essays in Political Geography, London: Methuen \& Co., 1968, p. 104 . 
their allegiance further to the central government. 14

It must, however, be pointed out that while security concerns were the prime force in the Malayan move towards Malaysia, in the case of the Borneo territories economic motives were equally, if not more, significant: the new land policy of the Malayan government is reported to have had great attractions for the predominantly rural population of these territories. The economic considerations were, indeed, the primary factor behind the overwhelming support for the Federation proposal in the september 1961 referendum in Sabah and sarawak. On the part of singapore, any military threats to her existence were secondary to the economic considerations which reigned supreme in the mind of its leaders. 15

2. My hypothesis that the existence of cleavages cutting across state boundaries is a favourable factor in the maintenance of federal ties finds a somewhat atypical support in the case of Malaysia, particularly Malaya. From the viewpoint of plurality of Malaya's population federalism was not the only possible method of government, 16 though, as already noted, the regional predominance of the chinese community in the western states did, indeed, provide some basis for federalism as against unitarism. 17 As the map [Fig. 6.5] of the communal composition of Malaya's population shows, the immigrant communities, especially the chinese, though in a sizable majority (but except for Penang not in absolute majority)

$\overline{14}$

The role of external military threat in Malaysian federalism has been. somewhat overstressed by simandjuntak, op. cit., 15

footnote 2 , pp. 299-300.

The predominantly economic motives for singapore's entry in the Federation were exposed by Prime Minister Lee kuan. Yew in a series of twelve broadcasts to the nation during the campaign for federation. A good summary of the contents of the twelve lectures is to be found in V. Purcell, Malaysia, 16

London: Thomas and Hudson, 1965, pp. 189-90.

See T. E. Smith, A Background to Malaysia, London: Royal 17

Society of International Affairs, 1963, p. 4.

As Watts puts it: "The regional differences in stages of economic development, in cultural tradition, in history, and in communal proportions, gave a real basis for federal government and for the continuance of the various state governments which were manifestations of these variations". R. L. Watts, New Federations: Experiments in The Commonwealth, Oxford: Clarendon"Press, 1966, p. 68 . 


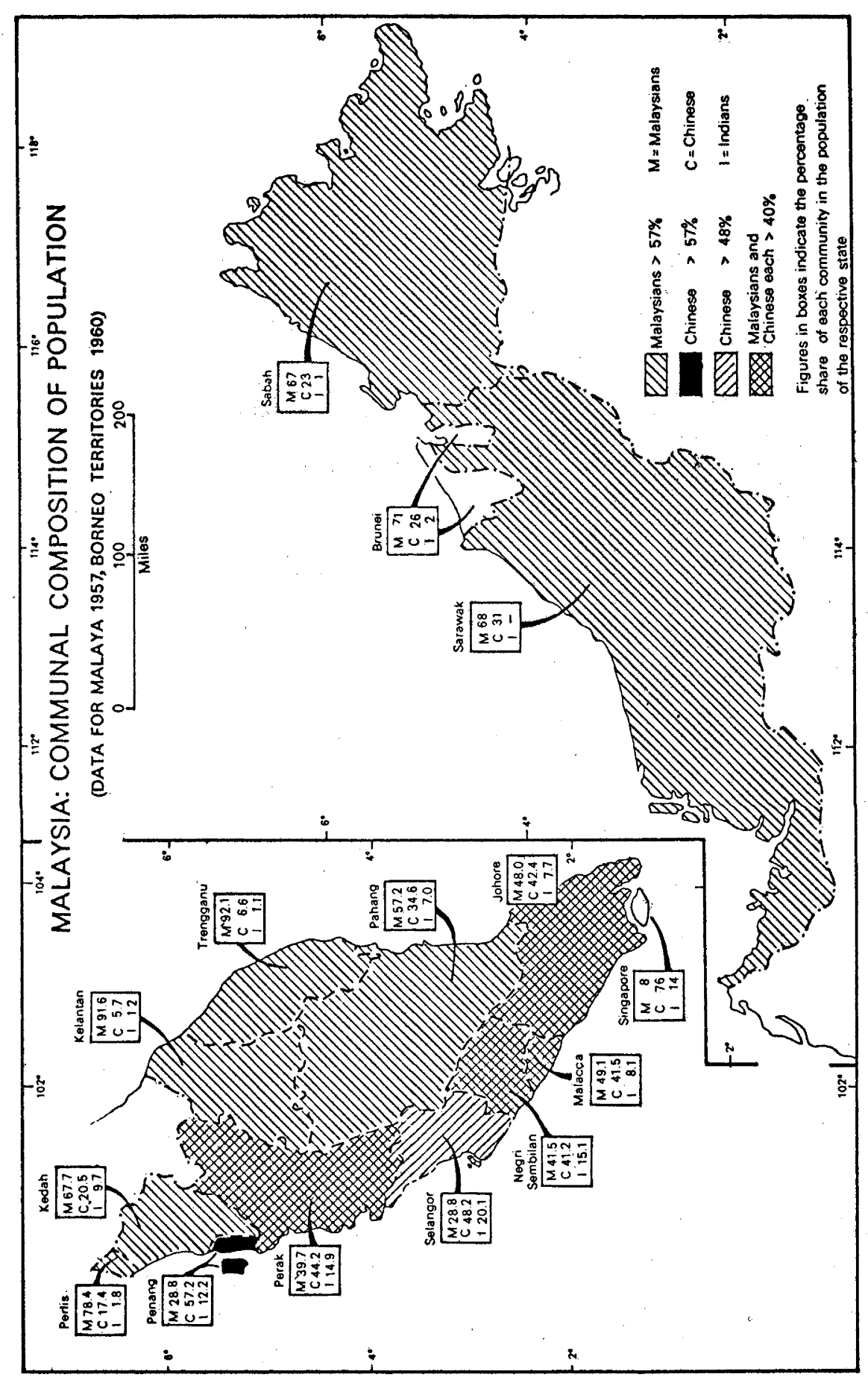

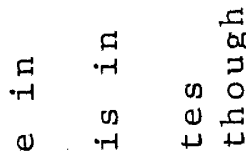

(1) $\cdot$ -

\% $>+\infty$ से क मेन

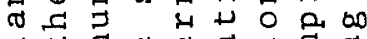
-

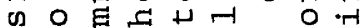

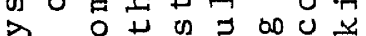

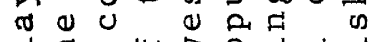
त. $\sum^{\infty}$ क 4 क द $04 \begin{array}{lllll}4 & 0 & 0 & 0\end{array}$

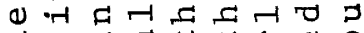
त त्र

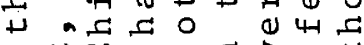

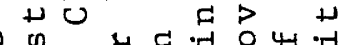

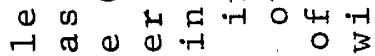

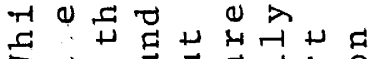
उ वृ म

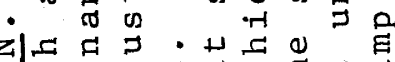

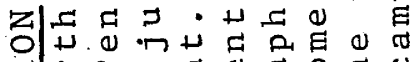
$\begin{array}{llllllll}4 & A & 5 & 0 & \pi & 0 & 5 & 0\end{array}$ 《द व $\begin{array}{lllllll} & 0 & 0 & 4 & 0 & 0 & 0\end{array}$ 号 o A مी

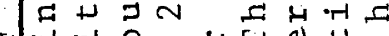
सा न का 0 त

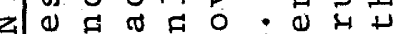
यो 0 व

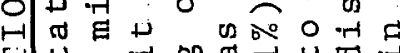

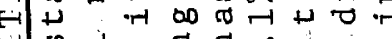

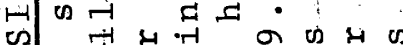

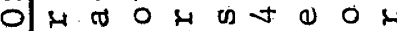

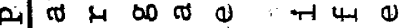

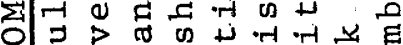
U थ 0 O

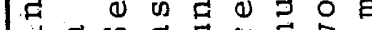

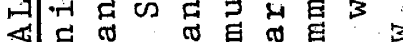
若

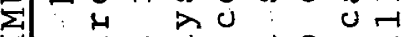

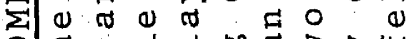

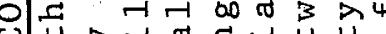

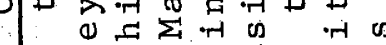

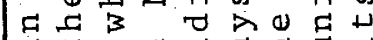

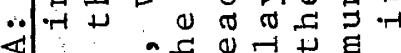

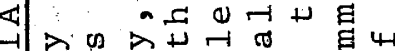
का

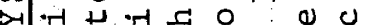
या बत्र 《)

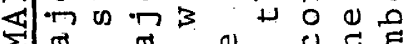
吾, 范 क 0 प 0 का

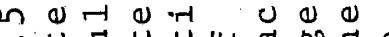
i.

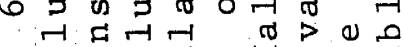
- 0 .

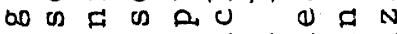

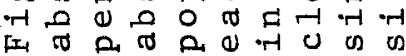


in certain states (i. e., Penang, Perak, and selangor where they account for over $44 \%$ of the total population) are nonetheless present as significant minorities in other states; while in Negri Sembilan, Malacca, and Johore both the leading communities are present in near-equal proportions--each accounting for over 40 percent of the state populations. (In Perak the percentage share in the population is chinese 44.2, Malaysians 39.7.) Under these conditions neither of the leading communities is in a position to think of breaking up the union. The two may harbour diametrically opposite policies and ideologies, but in the interests of their own collective communities they cannot follow a policy of disruption of the Union which would leave a large number of their brethren to the other side of the fence as it were. It would, in fact appear that it is the geographical distribution of the communal elements in the population that has saved the Federation of Malaysia (especially Malaya), because in view of the fact that communal cleavages in the country are almost water-tight, it is easily understandable that had the communities occupied clearly defined areas of occupance--one separate from the other--a union of any strength could hardly have been born, for the two communities in Malaysia are far more antagonistic than are the French- and English-speaking communities in Canada.

As for communal tensions, it may be expected that in course of time trade unions and the like organizations and political parties as well as other forces based on economic and secular considerations--and not on communal considerations alone as is largely the case at present-would be born. When this happens, it would create communally cross-cutting and interlocking cleavages that would form an antidote to the divisive force of cultural and "racial" differences... At present, however, "in Malaya ideological lines of cleavage are not entirely separate from communal ones". 18

3. The greatest problem of Malaysian federalism is that the absence of any common national symbols of historical

R. S. Milne, "Politics and Government", in Wang Gungwu, op. cit., footnote 3, p. 330 . See also R. S. Milne, Government and Politics in Malaysia, Boston: Houghton Mifflin Co., 1967. 
significance, the lack of any memories of having done great things together in the past, has impeded the growth of a significant state-idea to which all the communities in the country could be inescapably attached. In fact, a well-defined State-idea for Malaysia is scarcely existent even though all the communities recognize a common state-area. This results largely from the fact that the historical memories of the sufferings and rejoicings of the Malay and the non-malay populations are dissimilar, and in some ways, even contrasting. This has led to a situation in which Malaysia's essential problem remains "to discover potent Malayan symbols conducive to national unity which are not exclusively Malay". 19 In this respect the formation of greater Malaysia has only complicated the picture for only about a sixth of the population of sabah, and a minute portion of sarawak is Malay, though if the term "Malay" is used to mean all those who are either indigenous to the peninsula or the islands, and profess Islam, then 38 percent in Sabah and 23 percent in Sarawak would be Malay. In both these territories the chinese have about a quarter of the total population. The remainder belong to various tribal groups. 4. Despite all the separatist forces within the nation, however, Malaya and Malaysia carried on as a reasonably stable and efficient democratic federation until the recent racial riots rocked the nation. As already noted, for any federation to be stable it is necessary that the national government is able to command the loyalties of the majority of people in all sections of the nation. Devoid of any rich frontiers of settlement (as in the United States), Malaysia, like India, dealt with this task through wise formulation and execution of national development programmes that benefited majorities in all sections of the society. The government of Malaya's decision to extend the rural development programme to the "new villages" largely settled by Chinese, had helped to win the loyalties of large sections of that community. Similarly, as the Cobbald Commission pointed out, the population of Sabah and Sarawak had great interest in Malaya's rural

\section{9}

R. S. Milne, op. Cit., footnote 18, p. 331 . Also see R. S. Milne, "'National Ideology' and Nation-building in Malaysia", Asian Survey, Vol. 10, No. 7, July 1970, pp. 63-67. 
development programme, and the prosperity that Malaya was enjoying by virtue of its efficient government and wise planning, was a decisive factor in their option for union with Malaya. In this respect the lessons of India as well as Malaysia for new experiments in federalism are almost similar.

Table 6.1

COMMUNAL COMPOSITION OF THE POPULATION OF MALAYSIAN STATES

(Figures for West Malaysia and Singapore for 1957, for East Malaysia and Brunei for 1960)

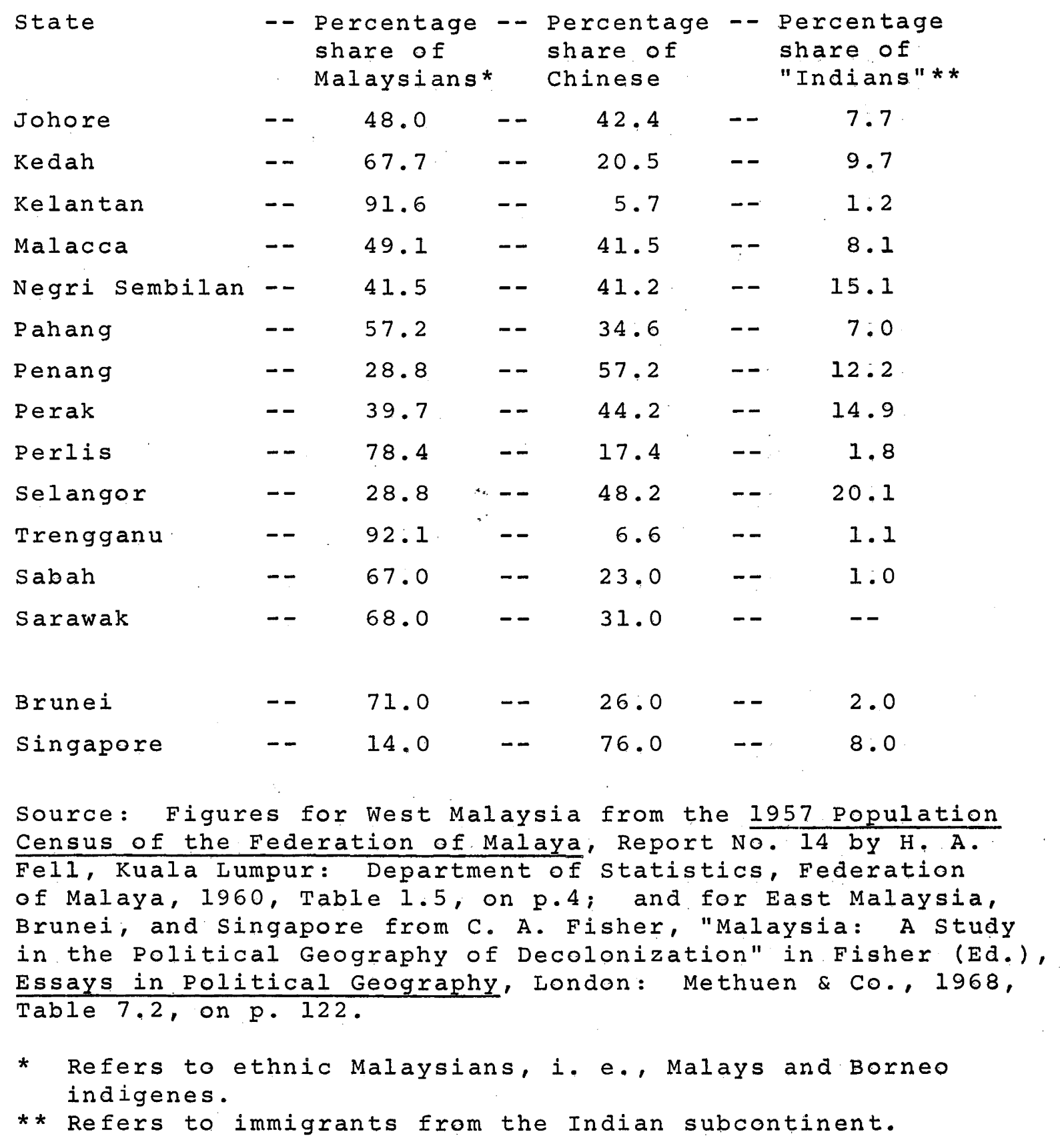




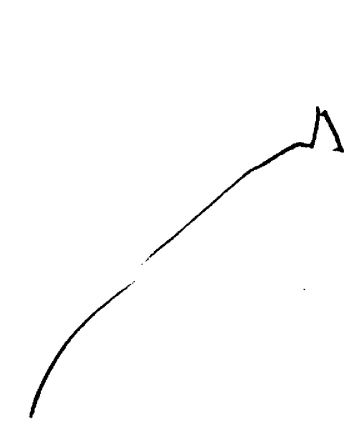

and from 1870 to 1918 the Germon Reich was

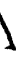
at least quasi- federse in form,

Chapter VII

FEDERALISM IN POST-1945 EUROPE

\section{WEST GERMANY}

Although right from the eighteenth century there has been a great deal of theoretical discussion on federalism in Germany, $\Lambda^{i n}$ practice federalism as it is understood in the non-Communist world today hardly ever existed in the country

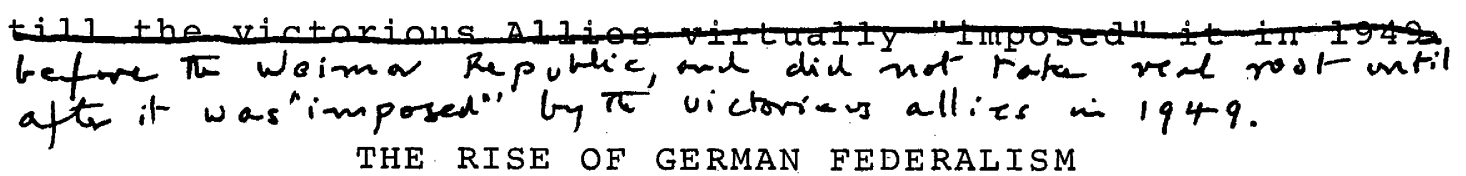

The real political history of Germany begins with the establishment of the Holy Roman Empire on Christmas Day, 800 A. D. when Pope Leo III placed the imperial crown on the head of the Frankish chief Charlemange. (who had by then expanded his domain from France and the Lower Countries in the west to the Elbe in the east) and saluted him as Augustus, the old title of the Roman Emperors. This was an effort to revive the old Empire, and on this day began the long and fateful connection between the German political ruler and the head of the Roman Church.

When the German branch of the imperial family died out in 911, an electoral as against the former hereditary system of the German kingship was established. Now the crown began to change hands between the leading German houses and, except when it was (rarely) held by strong personalities, the Emperor was little more than a figurehead. The Empire was, for all practical purposes, only a clumsy confederal alliance which did little more than elect the Emperor (or confirm dynastic arrangements) and occasionally settle disputes. In fact any really strong organization over this area was inhibited by backwardness of transport and the lack of any historical tradition of unity. A further factor hindering the growth of a united Germany was the division brought about by the religious wars that broke out in 1618, and lasted for thirty years, in which the catholic and protestant princes fought to prevent the Empire from becoming a governing 
reality. ${ }^{1}$ Ever since, the identities of the southern states, especially Bavaria, were greatly heightened, for now their Catholic bastions had to be guarded against protestantism. Even as early as the thirteenth century regional dynastic particularism had advanced so far that the Emperor could look for support only to his own feudal territories. When Napoleon amalgamated a number of German states and announced the formation of the confederation of the Rhine: (subsequently including all Germany except Austria and Prussia), the Emperor Francis II declared that the Empire no longer existed. This ended the thousand years old institution. In the absence of a really unified administration under the Empire, throughout this period Germany remained what has been called a mere "geographical expression".

After the defeat of Napoleon the Congress of Vienna regrouped the German territory and established a loose German Confederation of 38 (later 39) states under the permanent presidency of Austria. A central diet was provided for, but because the decisions of the parliament were required to be unanimous, it could achieve little in practice, especially in view of the rivalry between Austria and Prussia.

The French Revolution of 1848 spread rapidly to Germany and was initially a success. A German National Assembly elected on the basis of limited popular suffrage was convened at Frankfurt in May 1848 to produce a constitution which called for a federal empire with bicameral parliament, a responsible ministry, and popular suffrage. But by the time the Constitution was ready in 1849, forces of reaction had mobilized in the more important states, especially in Austria and Prussia. In these states, therefore, the regional governments refused to approve the proposals of the National Assembly. The Assembly was itself forcibly dissolved by Prussian troops, and the revolutionary aspirations died a tragic death. Now reestablished in their authority the German

$\bar{I}$

Cf. Herman Finer, The Major Governments of Modern Europe, London: Methuen \& Co., 1960, pp.408-409. For abrief account of the impact of religious divisions on the development of German politics see Finer, op. cit., pp. 394395. As for the Holy Roman Empire "In Voltaire's oft-quoted cynicism, it was neither holy nor Roman nor empire". Finer, op. cit., p. 407 . 
monarchs revived their old despotic régimes.

Between 1864 and 1871 prussia under the leadership of Bismarck extended its territory in north Germany and gradually pushed Austria out of the Confederation. A North German Confederation was formed in 1867; in 1871, after the FrancoPrussion War, negotiations started between Bismarck and the south German states (not members of the North German Confederation) for a united German Empire without Austria. Thus a new German. Empire under the hegemony of Prussia was established on January 18, 1871. In view of Prussia's dominant position, the new imperial confederation was, in fact, what has been called Prussia writ large. 2

The king of Prussia, by hereditary right, was the head of the Empire (or the Confederation). The king was authorized to appoint a Chancellor (or Prime Minister) to carry out the executive policies of the union. Two legislative Houses were created: an upper House called the Bundesrat, and a lower House called the Reichstag. The upper House was a House of Princes, and the lower one that of the peoples. The lower House was elected on popular suffrage.

The Empire, therefore, appeared to possess the outward form of a federation though in fact it was only a facade. The Emperor was the Commander-in-chief of the armed forces, and had the power to declare war or peace with consent of only the upper House, over whose legislation and decision he exercised considerable influence, for being the king of Prussia he controlled 17 out of the 58 (later 61) votes of the Bundesrat. The delegates to the Bundesrat being the representatives of the princes had to vote according to their instructions. As Prussia had 17 votes in the upper House its king, the Emperor, exercised an absolute veto on constitutional amendments, for any legislation was invalid if 14 votes were cast in the negative.

The Reichstag was a properly elected House of Peoples with 400 members. It participated in the enactment of legislation and was, in theory, in control of the Empire's

2

Marshall Dill, Jr., Germany: A Modern History, Ann Arbor: University of Michigan Press, 1961, p. 140 . 
budget, but since the chancellor (the executive head of the Empire) was an appointee of the Emperor and responsible to him alone, the governmental system of the Empire was in fact not a parliamentary system. For this reason the Empire left the German people without much political education in democratic self-government either at the national or the regional level. In the absence of fully democratic and responsible governments in most of the states and especially in Prussia (which controlled three-fifths of the area and population of the Empire) the scope for the development of an enduring and broad-based states-rights sentiment remained greatly limited.

After the German defeat in the first world War, dissatisfaction in the armed forces (especially the Navy) and the rise of liberal and socialist forces led to the Revolution in 1918. This resulted in the abdication of the Emperor as well as the Princes, and the establishment of republican régimes in all the states. A National Assembly of popularly elected members met at weimar on February 6 , 1919, and a new Constitution, drafted by the great jurist Hugo Preuss, was adopted by a majority vote on August 11, 1919. This established a democratic federal republic in the country. Provision was made for a popularly elected president as head of the state. The president formally appointed the Chancellor who was selected by the Reichstag. The president was not the executive head of the federation and his actions were subject to the approval of the chancellor or the appropriate cabinet minister, although in emergencies he was empowered to suspend the Reichstag and order a reelection in sixty days. In event of emergency he was empowered to rule by decree. But in peace-time the country had a normal parliamentary government. The bicameral pattern of the central legislature was retained. The lower House was called the Reichstag and the upper House Reichsrat. The Reichstag was an elected House under universal franchise, and was the chief legislative body with authority for peace and war, treaties and alliances, and financial and general legislation. The Reichsrat was a states House and was comprised of one representative from each constituent state plus an additional vote for every 700,000 people. Its representatives were 
appointed not elected, and its function was largely advisory, for the Reichstag could override its legislative proposals with a two-thirds majority.

The new federal constitution because of its provision of proportional representation (P. R.) lacked "a stateforming organ" for it did not provide "a satisfactory solution of the problem of forming a majority" in the lower House. 3 Indeed "Nowhere have the consequences of $P$. R. manifested themselves as disastrously as in Weimar Germany". " "Beginning in 1920 the German election system followed the so-called automatic type. . There was from that time onwards an almost unlimited utilization of surpluses, and a number of parties were successful which, under the majority system, would have fallen into the category of the 'also-rans'". 5 The electoral system gave a sort of guarantee to small splinter parties, and even pressure groups, that they could not be completely finished, and this in effect encouraged a plurality of parties. This plurality made it difficult for any party to emerge with sufficient majority to form a government of its own. There were quick changes in political alliances resulting into changes of governments. There were twenty-one cabinets in less than fourteen years and none of them lasted for more than twenty months. Thus the Weimar Constitution gave birth to what Hermens termed "the 'Republic without Republicans'"..6

In the election of July 1932 National Socialists and other political extremists together obtained a majority in the Reichstag, and through their obstructionist activities began to hinder smooth running of the parliamentary procedure. The parliament had to be dissolved several times until the President invited Adolf Hitler, the leader of the largest party in the parliament, to form a government. Soon democracy

3

Statement by Friedrich Naumann in 1919; cited in F. A. Hermens, Europe Between Democracy and Anarchy, Notre Dame, 4 Indiana: University of Notre Dame, 1951, p. 64 . 5 Hermens, op. cit., footnote. 3, p. 63. 6 Hermens, op. cit., footnote. 3, p. 66. Hermens, op. cit., footnote 3, p. 66. 
was dead in the country, since on March 23 the Enabling Act was passed through which the Constitution was suspended and the Hitler cabinet assumed dictatorial powers. A one-party government was established and all opposition was banned. The states were made subservient to the centre and federalism was finished.

After Germany's defeat in 1945 the country was put under quadrupartite military control. For purposes of occupation the country was divided into four occupation zones: one each under U. S. S. R., U. S. A., U. K., and France. In 1948, when the rift between the three Western. Allies and the U. S. S. R. led to the withdrawal of the latter from the Allied Control Council, the three western powers decided upon the reunification of their zones in order to create a united German state. By steps power began to be handed over to the German people after local elections produced more durable native authorities. The process was begun gradually from the lower to the upper levels. The western zones (exclusive of Saarland) had been divided into eleven states. Although in principle the former Länder were to be reconstituted wherever possible, in practice all of them had to undergo some surgery, partly in order to accommodate the carved-up pieces of Prussia, and partly to settle within the zonal boundary lines and to eliminate exclaves and enclaves. As a German representative Carlo Schmidisaid at the 1948 convention, the German people did not "recognize the Laender as they are today. Most of them are purely products of coincidence and it seems odd to make them the original constituent elements of the future German political reality". 7

When the plan for creating a united West Germany was taken up, the division of the area into eleven states was an established fact, and it was within this existing territorial and political arrangement that the constitution-makers had to devise their plans for the new state. The parliamentary Council that assembled to draft the constitution consisted of leaders and delegates from the existing eleven states that were by now enjoying virtual self-government. This in itself

7

Cited in P. H. Merkl. The origin of the west German.

Republic, New York: Oxford University Press, 1963, p. 42 . 
made a federal political organization of the state almost imperative, for the very existence of the Länder as organic political units before the rise of the united nation helped to create vested interests among the regional leaders most of whom could not hope to have much say at the national level. Then, as Elmer Plischke ${ }^{8}$ writes, the decision to establish a federal system in West Germany was not entirely an indigenous determination: seeking to provide a genuine democratic foundation the Allies had decided quite early that there should be no great centralization of power in the country. And this, they thought, could be best achieved under a federal system founded upon a clear-cut division of powers between central and the regional governments. During deliberations of the parliamentary Council for the new Constitution the Western Military Governors made determined efforts to prevent a high degree of centralization of power. 9 It was only after considerable Allied-German negotiation that an acceptable text of the Basic Law was devised which reconciled the German demand for adequate central authority with what the Allies thought was the federal principle.

A Review of the structure and operation of the west

\section{German Federalism}

The Basic Law retained the weimar pattern of the division of powers. The national government was given extensive

8

Elmer Plischke, Contemporary Government in Germany, London: George Allen \& Unwin Ltd., 1961, p. 51. In their primary post-surrender directive (issued in April 1945, and known as the JCS 1067) the Joint Chiefs of Staff expressed the aim of "decentralization of the political and administrative structure and the development of local responsibility". "In his Stuttgart address on september 5, 1946, the U. S. Secretary of state called for an early drafting of a "federal". Constitution for Germany. The point was reiterated in the official 9 policy statement known as' JCS 1779 dated July $15,1947$.

In the Aide Memoire drafted on November 22, 1948, and addressed to the Parliamentary Council, the Western Military Governors specified certain principles which the occupying powers required the parliamentary Council to embody in the new Constitution. These principles included, among other things, the establishment of a bicameral legislature, specific enumeration of powers of the central government, limitation of the financial authority of the centre, and restriction on the establishment of central field agencies only to fields in which implementation by state governments would be impracticable. 
legislative powers and its concurrent powers covered wide fields of social and economic life so much so that the occupation authorities objected to undue centralization. But except for the issue of taxing and spending, among the German representatives themselves there was no great dispute regarding the central competence. The states were granted the major responsibility for the execution of the national legislation--which to the German representatives appeared a genuine guarantee for decentralization. Powers not specifically granted to the centre were reserved to the states. These reserved powers included in the main local government, education, and cultural affairs The terms "local government" and "cultural affairs" were, however, taken in their broader sense and included radio, television, theatres, museums, libraries, press, police, public health, and regional planning. While the central government was granted the major indirect taxes, the states were assigned the dominantly direct taxes including income and corporation taxes. It was, however, provided that the national government could claim a share of the income and corporation taxes, the size of which was to be decided by the Bundesrat.

The central legislature continued to be bicameral. The Bundestag, the House of the people, is the central governing agency of the state and the central executive is responsible to it. In contrast to the Bundestag, the Bundesrat, the House of states, is not popularly elected: its delegates are appointed and controlled by, and represent the interests of, the state governments. The Basic Law provides that each state should have a minimum of three votes in the Bundesrat while the states with over two million people would have four, and those with over six million people five representatives in all.

As originally envisaged the powers of the Bundesrat were limited. Although it could participate in the passage of national legislation, it was given an absolute veto only on matters involving financial andor administrative questions; in all other matters its veto could only be suspensive. Thus the Bundesrat was not intended to be equal to the Bundestag in legislative powers, for the framers of the Constitution had assumed that the scope of legislative 
activity affected by its absolute veto would be relatively small. But practice has not supported this assumption, and the Bundesrat has successfully insisted that if a legislative bill contains provisions that are subject to its absolute veto then the entire bill, not just the particular provisions, is subject to its veto. The result has been that of the approximately 1900 bills that have been passed between 19451965, almost half (837) were potentially subject to the absolute veto power of the Bundesrat. ${ }^{10}$ Although the upper House does not exert influence in the manner of an Americanstyle senate, it has emerged nonetheless as a genuine and powerful second chamber. As a recent study concludes: "Bundesrat does in fact act specifically to protect governmental integrity and freedom of action at the Iflnd $d$ level and does in fact maintain a sensitive and protective attitude within the federal parliament toward the Ifod $2 /$. government interests". 11

In view of the extensive authority granted to the central government, the scope for judicial interpretation in Germany is rather limited. Still in two leading cases--the concordat decision of 1957 and the TV case of 1961--by upholding the validity of the states-rights, the court has clearly checked over-centralization and it, along with the Bundesrat, has helped to make federalism in west Germany very much a reality. Sawer considers west Germany "even less organic than Switzerland because the ambitions of the centre politicians are held so much in check by judicial doctrine, by the structure of the legislature and by the growth of regional dissent within the main parties". 12

10

Figures quoted in K. H. Cerny, "Federalism in the west German Republic" in V. Earle (Edo), Federalism: Infinite Variety in Theory and Practice. Itasca, Illinois: F. E. 11 Peacock Publishers Inc., 1968, p. 144.

Edward I. Pinney, Federalism, Bureaucracy, and Party Politics in Western Germany: Role of the Bundesrat, Chapel Hill: University of North Carolina Press, 1963, p. 173 . 12

G. Sawer, Modern Federalism, London: C. A. Watts \& Co., 1969 , p. 126. The Concordat and the Television cases are briefly noted in sawer, op. cit., pp. 100-101. 
POLITICO-GEOGRAPHIC FACTORS IN THE RISE OF

GERMAN FEDERALISM

A thousand years of the loose and decentralized Holy Roman Emplire had fostered in the various German states a strong sense of particularism and had created thereby a highly federalistic--rather confederalistic--situation. But when in 1806 "the Holy Empire died and was buried", it was indeed "to all appearance soon forgotten", 13 and along with it also vanished much of the regional particularism, for Napoleon welded together many of the smaller historic political units to form (the short-lived) Confederation of the Rhine. And the loose. Confederation that the Congress of Vienna created in 1815 did not materially change the territorial situation created by. Napoleon, although now Austria and Prussia emerged as two great giants. The changed territorial and dynastic situation made the rise of regional nationalism in most of the new sub-units difficult, apart of course from states such as Bavaria, Saxony, Baden, württemberg, and Hanover. (until 1866) which had long traditions as major states.

Besides this new politico-geographic situation that discouraged the rise of state particularism, there were other factors that for some time pulled the German people together and instilled in them a strong sense of unity. One such factor was the standardization of the German language. Iuther's translation of the Bible bridged the gulf which up to that time had separated the high and the low German languages by choosing a vocabulary and syntax derived from and intelligible to both the regions. Even the sections that remained faithful to the Roman Catholic creed adopted "the Lutheran German". 14 But Napoleon. I was the man who, without intention, helped to instil the vision of a free, great and united Germany in the hearts of the people so different in their cultural and political outlook as the Prussians, Saxons, Austrians and all other Germans of his age: By doing away with the hundreds

$\overline{13}$

James Bryce, The Holy Roman Empire, New York: Macmillan 14

Co., 1946, p. ix.

S. H. Steinberg, A Short History of Germany, New York: Macmillan Co., 1946; p. ix. 
of the smaller states and arbitrarily changing the boundaries of others without regard to historical and cultural factors, Napoleon virtually forced the German people to forget their age-old differences. This changed situation forced the élites to emphasize the broader German nationalism rather than the regional cultural particularisms which under the existent conditions were almost impossible to revive.

The facts of economic life were also pointing in the same direction. Since 1834 the industrially important parts of Germany, apart from Austria, had formed, a single customs union. The initiative for the union and its leadership naturally fell to Prussia, for since 1815 she had included representative elements of all the important factors in German economic. life--the agricultural east, the industrial west, the grain-producing Junkers as well as the cattle-breeding or vine-growing peasants. For this reason all the compromises that prussia had to make to reconcile the various interests within its own boundaries, were likely to satisfy most of the non-Prussian German interests as well. First, with a view to protect her delayed industrialism, and secondly because of the multi-national character of her Empire, Austria remained out of the all-German union. This assured Prussian hegemony and led to the ultimate parting of Austrian, company from allGermany.

In fact by the mid-nineteenth century the politicogeographical situation in Germany had shifted almost to the unitary extreme of the federal spectrum. When the popularly. elected representatives of the German states met after the 1848 Revolution to draft a democratic federal Constitution, "the great majority of the German states did not represent that variety in the national life which the framers of the Constitution might desire to preserve for the sake of its own merit", 15 for now there was very little correspondence between the existing states and the actual diversity in German economic and cultural life. Although there was still a great deal of diversity in the national life of Germany, the historic units did not correspond to that diversity.

15

R. Schlesinger, Federalism in Central and Eastern Europe,

London: Kegan Paul, Trench, Trubner \& Co., Ltd., 1945, p. 53. 
The historically minded romantic had to note that of the seven or eight tribal dukedoms of the ninth to the twelfth centuries, which corresponded to the still surviving varieties of dialect and folklore, only Bavaria, apart from Austria, had survived as a midnineteenth-century German state... . . In fact the German states in the nineteenth century did not reflect that national past, which had been overlaid by the splitting-up of the old units during the Middle Ages, and by the formation of new territorial units since the thirteenth century in the newly colonized border regions. 16

Though most of the German states in the nineteenth century did not represent historical realities or the actual diversities of the national life, they were nevertheless a strong political reality and had to be taken into account in any scheme of political reorganization of the country. Having formed administrative units for considerable periods of time the states succeeded in creating some degree of dynastic allegiance. The allegiance was so strong that it survived the stress of the 1848. Revolution, when only in the smallest states was there any inclination to surrender "independence" and that too on the condition that the larger states also made the same sacrifice. ${ }^{17}$ But the universal desire for a strong unity was unmistakably clear. 18

Though by virtue of her great size and strength, the hegemony of Prussia in the united Germany was inevitable, the terms of the federal bargain in 1871 were determined by two chief factors: the formidable particularism of the states in the south, especially Bavaria, and Prussia's twin desires to maintain her separate identity while gaining hegemony of

\footnotetext{
16 17

Schlesinger, op. cit., footnote 15, p. 52. 18

see schlesinger, op. cit., footnote 15, pp. 47-53,

Steinberg, op. cit., footnote 14, p. xi, writes: "The history of the Germanies is the history of the unending struggle of the continental Teutons for a working compromise between uniformity and disruption. Uniformity was and is contrary to the racial, cultural and political divergency of the Germanic tribes; the complete independence of each part would have been and will be contrary to the economic, cultural and political interests of the parts." This statement misses the point that the original tribes were no longer in the politico-geographic position to feel themselves as compact unified groups. Hence the popular sentiment, after the Napoleonic era, was seldom for "disruption".
} 
the union. 19 No solution could be acceptable to prussia that would make her only one among equals. With three-fifths of the population and two-thirds of the area of the united Germany, Prussia was the paramount state and she wanted this recognized. Bismarck's Constitution was, therefore, what Preuss described as "a peculiar combination of Prussian hegemony with federalistic disguises". 20 The constitution devised a division of powers which was "horizontal" in contrast to the United States' "vertical" division of powers. 21 Though the legislative powers granted to the central government were extensive, in contrast to the American example, the actual administration of the national legislation was to remain a state jurisdiction. Apart from the federal postal service and the Navy (and partly the Army of which the Emperor was the supreme Lord ${ }^{22}$, the national government had no separately established independent field agencies. Thus for the average citizen the Reich brought about no change in the governmental system with which he had to deal, for it meant only a minimal

\section{$\overline{19}$}

The concept of federal bargain as applied to the German

Empire is briefly explained in Cerny, op. cit., footnote 10., 20 p. 144 .

Hugo Preuss, Reich und Länder, Berlin, 1928, p. 255; cited in schlesinger, op. cit., footnote 15, p. 75. Unless otherwise stated, all the quotations from preuss are taken from 21

schlesinger and references are given as in schlesinger's book.

The distinction between the German and American federalism is drawn by Arnold Brecht in his Federalism and Regionalism in Germany: The Division of Prussia, New York: Oxford University Press, 1949 , pp. 3-7.

22

The actual structure was, however, very complex; and especially anomalous was the position of Bavaria which had received certain "reserved rights" that ". . . made Bavaria autonomous in many respects. Bavaria was permitted to maintain a separate diplomatic service, with its own ambassadors at Vienna, st. Petersburg, and the Vatican. The Bavarian kingdom controlled its own postal, telegraphic and. railway systems. Like saxony and Wüttemberg, Bavaria retained her own Army; unlike them, she possessed a General staff, and her generals were appointed by the king of Bavaria, not by the Emperor [as was the case with other states]. The Prussian Army was not permitted to enter Bavarian territory, and the Bavarian Army came under the command of the German Emperor only at the outbreak of war". R. M. Watt, The Kings Depart; The Tragedy of Germany: Versailles and the German. Revolution, London: Weidenfeld \& Nicolson, 1968, p. 281. 
interference with the long-established administrative structures. It is believed that the device was adopted with a view to preserve the position of the crowns, for it meant the strengthening of "the position of the individual states [most of them under princely aristocratic rule] at the expense of

a federal parliament in which democracy might have its say". 23

Thus the German Confederation was in fact a princely alliance, since "Not the sovereign people but the sovereign princes had joined together to form the Reich". ${ }^{4}$ This technical character of the union and its undemocratic preamble were not changed until the Empire collapsed in 1918.25 As a federation must essentially be a compact between the peoples, the German Empire cannot be called a federation in the modern sense. Thus the birth of modern federalism in Germany dates from the rise of the Weimar Republic. The technical nature of the Reich as a princely alliance had long been outmoded, however, the various factors had combined to make.". . . the national union a matter of people and the pride of common man long before the revolution finally did away with the princes whose alliance had created the empire". ${ }^{26}$. Besides the rise of an integrated national economy unhampered by barriers to trade and commerce, the universal interest in the Reichstag, which was divided, not by states but by national parties, was highly significant.

\section{POLITICO-GEOGRAPHIC CONCLUSIONS}

A. Weimar Republic

With the fall of the princes in 1918 the primary raison

\section{3} 24

Schlesinger, op. cit., footnote 15, p. 74 .

Rupert Emerson, state and Sovereignty in Modern Germany, 25

New Haven: Yale University Press, 1928, p. 105.

The Preamble of the Empire read: "His majesty, the King of Prussia on behalf of the North-German. Federation; His Majesty the King of Bavaria; His Majesty, the King of Württemburg; His Royal Highness, the Grand-Duke of Hessen and the Rhine-the latter for the section of the Grand-Duchy situated south of the river Main--conclude an eternal federation to protect the federal territory and the law of the land as well as to promote the welfare of the German people . . ". 26

Cited in Brecht, op. cit., footnote. 21 , p. 4.

Brecht, op. cit., footnote 21, p. 5 . 
d'être of the states disappeared. This greatly weakened the basis of state particularism. Naturally, therefore, the new Constitution not only dropped any reference to the princes but also to the states as such. 27 still, the new republican Constitution established a federal rather than a unitary state, even though a republican people should have had little desire to preserve the old dynastic territorial structures. The reason for this was that:

As distinct from the revolutions in the more solid national states, the German 1918 revolution was not accomplished at the centre, radiating from there to the peripheries. Rather it followed the opposite course, from the peripheries to the centre. In any case it was a highly decentralized revolution: 25 individual miniature revolutions corresponded to the traditional existence of 25 individual states, and thus the existence of the states was transferred into the new order of things. Everywhere the new rulers settled down first of all in the state governments. . The new jure revolutionis state governments immediately considered themselves, in relation to the federation, as the legal successors of their jure divino predecessors and their attitude was supported by considerable sections of the local population. 28

Although initially the revolutionaries had thought that to take over the existing administrations was the only alternative to anarchy, in fact it had meant taking over, even without the dynasties, the distinct administrative traditions of the individual states. Thus though the traditional justification of the states had disappeared, now behind the socialist state ministers stood the inertia of the Civil Services of the various states just as it had stood behind their predecessors, the Princes and Grand Dukes. The socialist Prime Minister of Prussia had behind him, besides the Civil Service, also the unbroken tradition of the officer corps of the Prussian Army "who could not but wait for the moment to jump into the seat which the 'revolutionaries' were keeping warm

\section{$\overline{27}$}

The new Constitution read: "The German people, in their united branches animated by the will to renew and stabilize their commonwealth with liberty and justice, to preserve peace at home and abroad, and to promote social progress, have given themselves this Constitution...". Cited 28 in Brecht, op. Cit., footnote 21, p. 6 .

Preuss, op. cit., footnote $20 ;$ p. 158. 
for them". 29 In this sense, the very nature of the 1918

Revolution carried within it the germs of federalism. Burdened with these states from the beginning, the Republic could not organize new ones that could have better chances of survival against the ultra-centralistic attacks to come. In fact, the form of this structure "was an empty shell which Bismarck had preserved for the coming generations. It was the Republic's lot to see that shell broken, and be broken with it". 30

Since the German states were no longer conservative bastions in need of protection against democracy, the new Constituent. Assembly that met at Weimar proceeded to establish a national government whose predominance over the states was not to be questioned. The centre was given extensive powers, and the powers of the upper House were greatly reduced. Though the principle of unequal representation in the upper House and the practice of state instruction to the delegates were retained, the role of Prussia in the House (Reichsrat) was restrained by specifying that no state would be entitled to more than two-fifths of the 66 votes, and that the Prussian vote would be split between the central Lifnd government and the a/ thirteen administrative provinces into which prussia was divided. Votes of the prussian provinces were made independent, i. e., without instruction from the Länd government. This was done because a united Prussia was bound to struggle permanenty with the federation, and either destroy it or reestablish its own hegemony. ${ }^{31}$ preuss thought: "Eliminate the princes and the people shall speak with one voice". ${ }^{32}$ It was for this reason that preuss and other right-wingers of the Revolution helped to strengthen the powers of the popularly elected President. But "Preuss's mistake was that he saw the surface rather than the essentials, Prussia, the territorial unit,

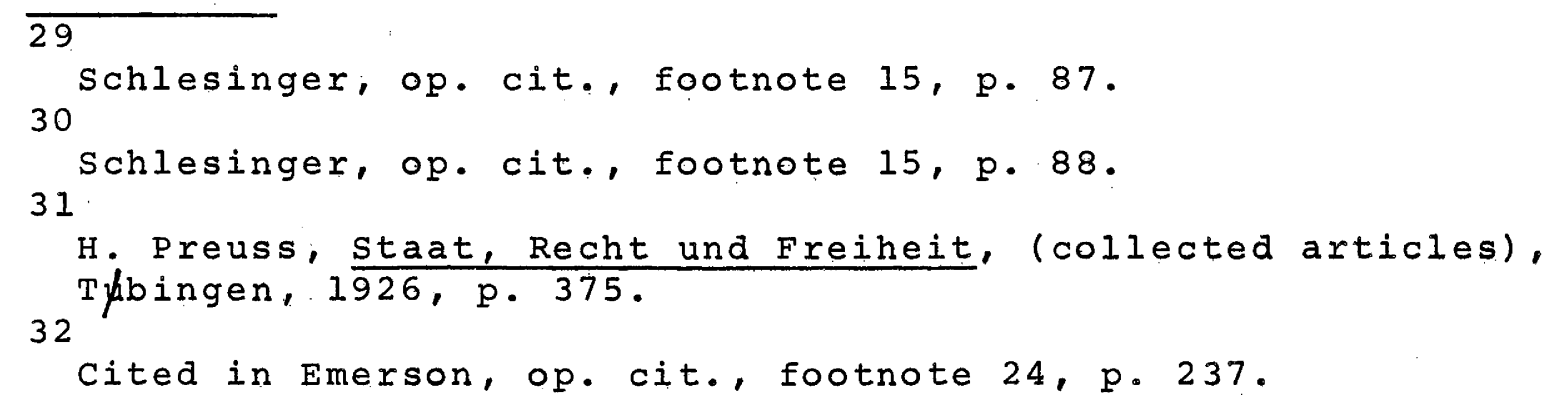


rather than the reality, the Prussian Army". 33 Thus in course of time the powers of the central government, based as they were on the surviving Army, were used to reestablish more and more centralized rule over the country.

As the state boundaries were unrepresentative of any regional differences in the national life, even the staunchest federalists (anti-unitarists) were unable to specify the social and economic interests that were to be preserved for the states. Because of the medley of social and economic interests that each state represented, every state was virtually a house divided against itself since the diverse particularistic forces within a state failed to recognize states-rights when they were exercised in a direction contrary to their own particular interest. Under these conditions it became easy for the central leadership to make deep inroads in the spheres of state autonomy and taking advantage of this, the Nazis were able to turn it into a unitary state.

The Weimar Republic showed almost all the constitutional characteristics of a federal system, and was run like one till the early part of 1923, but.". . it is impossible to regard the joint dictatorship of Army and Big Business, as established after the winter crisis of 1923-4, as anything but sham federalism", for though the state boundaries remained intact, what the states in reality ".. . could embody, and strive for, was merely distinct conceptions of the way in which the centralization of real power could be transformed into constitutional centralism." 34

To conclude, there were two politico-geographical reasons for the failure of federalism in the Weimar Republic: first, German society, despite immense diversities in the various aspects of life, was basically nonfederal since the state boundaries were highly unrepresentative of the regional

\section{3}

Schlesinger, op. cit., footnote 15, p. 94. As Emerson, op. cit., footnote 24, p. 227 , writes: "The practical futility of formal sovereignty was all too clear.. . but the wheels of state continued to turn surprisingly in the same fashion as before. [for "Broady speaking, the old administrative machinery remained intact during the Revolution".] The inherited machinery under the new master still seemed to 34 act in the spirit of the old".

Schlesinger, op. cit., footnote 15, p. 138 . 
distribution of these diversities. As there was no particular set of interests that the majority of people in the individual states identified themselves with, state rights sentiment in

the country became very weak. This made it easy for the central government to usurp even the limited autonomy that the Constitution had given the states. Secondly, the overwhelming size of Prussia had made that state virtually a second central government in the federation. 35 Hence the real cause of the breakdown of federalism in the weimar Germany was not any basic drawback in the constitution, but rather the underlying politico-geographic base which made any federal solution to the problem of its political organization quite unsuitable. [Fig. 7.1]

\section{B. Post-1945 German Federalism:}

The states-rights sentiment in post-1945 Germany was further weakened because during the Hitler regime the states had ceased to exist in fact, and after the fall of Germany its territory underwent a detailed surgery at the hands of the occupying powers. Of the eleven states in the west only Bavaria, Bremen, and Hamburg retained their essentially traditional boundaries. The other eight were curious mixtures of parts of the traditional states, and like the former states they also were not representative of the actual diversity in German life. Thus, while failing to provide them with any marked regional identities, the new territorial division deprived the states even of the historical inertia that the old states had possessed as a result of their long-established individual politicaladministrative systems. Hence federalism in post-1945 Germany was not a genuine response to deeply-felt regional identities that demanded self-expression. Further

Not only were some of the Länder artificial creations because of their new boundaries, there had been massive internal migration which had begun under the stress of Allied bombing and military advance and then had reached flood tide with the millions of postwar refugees and expellees from Eastern Europe and Soviet-occupied Germany. As they settled throughout Western. Germany, these migrants weakened the sense of local patriotism that had developed over generations, often based on distinctive cultural

\section{5}

On "Two Central Governments" see Brecht, op. cit., footnote 21, pp. 67-68. 


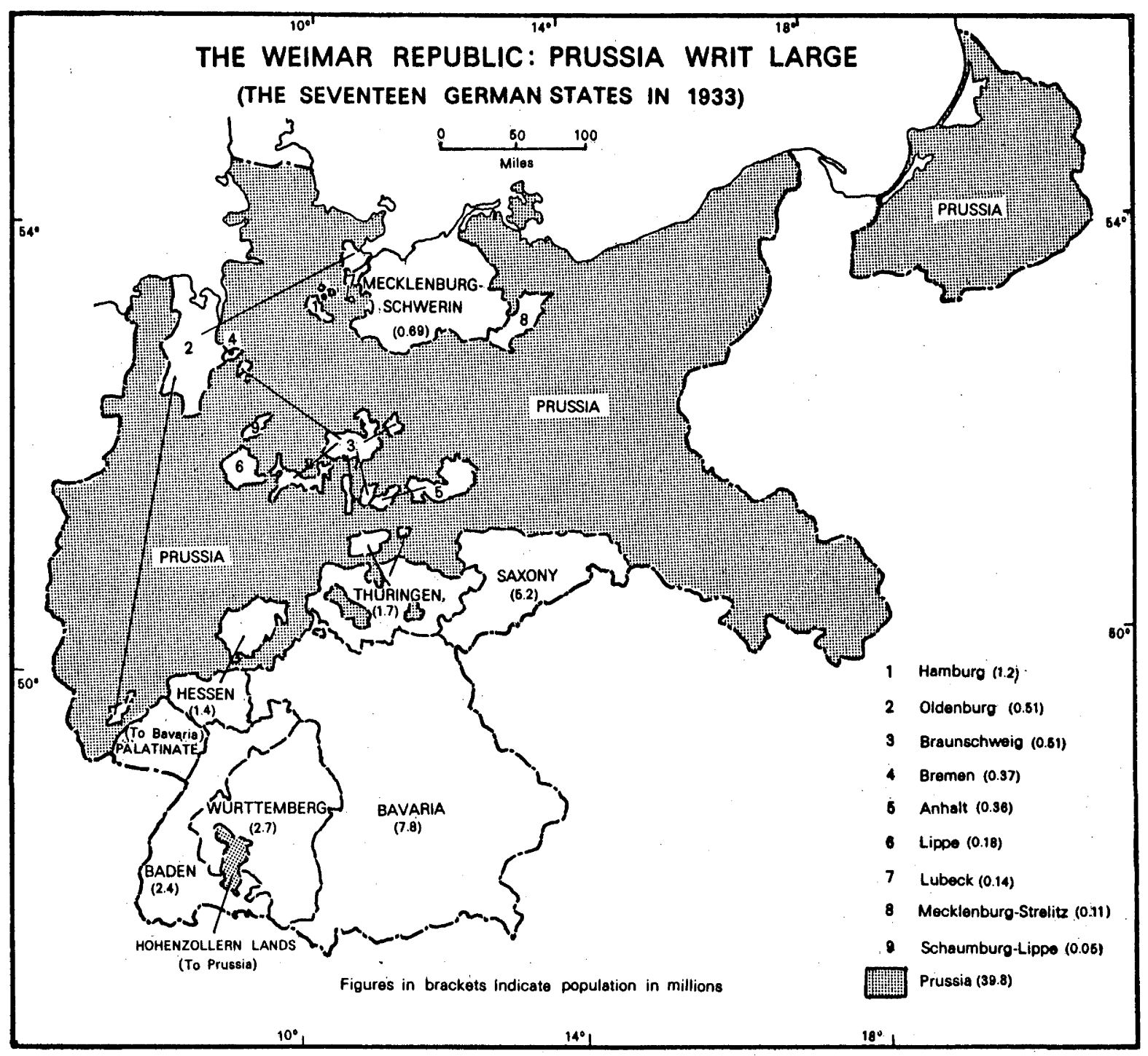

Fig. 7.1 WEIMAR REPUBLIC: PRUSSIA WRIT LARGE. The seventeen German states were by no means too many for a federal state of nearly sixty million people, but these were highly disparate in size. Prussia alone included three-fifths of the total population, Bavaria and saxony together another fifth, while all the other fourteen states made up the remaining fifth. Further: more, most of the German states were geographically split into many sections which often lay far removed from one another. This made the rise of united state identities very difficult. (Map adapted from Arnold Brecht, 1945, pp. 10-11.) 
tradition. 36

Thus the politico-geographic base in Germany in 1949 was far less federal than it was in 1919. There was one significant difference, however: now the Prussian colossus that had so long dwarfed other states and by acting as a second central government had made federalism a farce, no longer existed. The degree of disparity in size of the constituent states was greatly reduced. ${ }^{37}$ This made any compromise more workable.

As already noted, despite a nonfederal base, federalism was adopted for two reasons. First, the states were going concerns when the Constituent Assembly met, and secondly, the occupying powers insisted on a federal form of governmental organization which they considered as a safeguard for democracy. Thus what we consider the necessary geographical premise for a normal, type of federalism, i. e., that the states should represent regionally grouped diversities in the national life, was largely absent in the Germany of 1949. Still federalism in Germany has been a reality for the last twenty years and in all probability has come to stay. How is it then that politico-geographic forces for unity, that for all practical purposes looked stronger than those for separation, were not able to overwhelm the latter and turn Germany into a unitary state? Why did not federal articulation cease in Germany the way it did in the Latin American States? Does, then, our hypothesis regarding the basic geographical premise of. federalism fail? A closer look at the federation reveals that it does not.

The sense of state identity (and in that form a set of regionally grouped diversities) that had come to exist as a

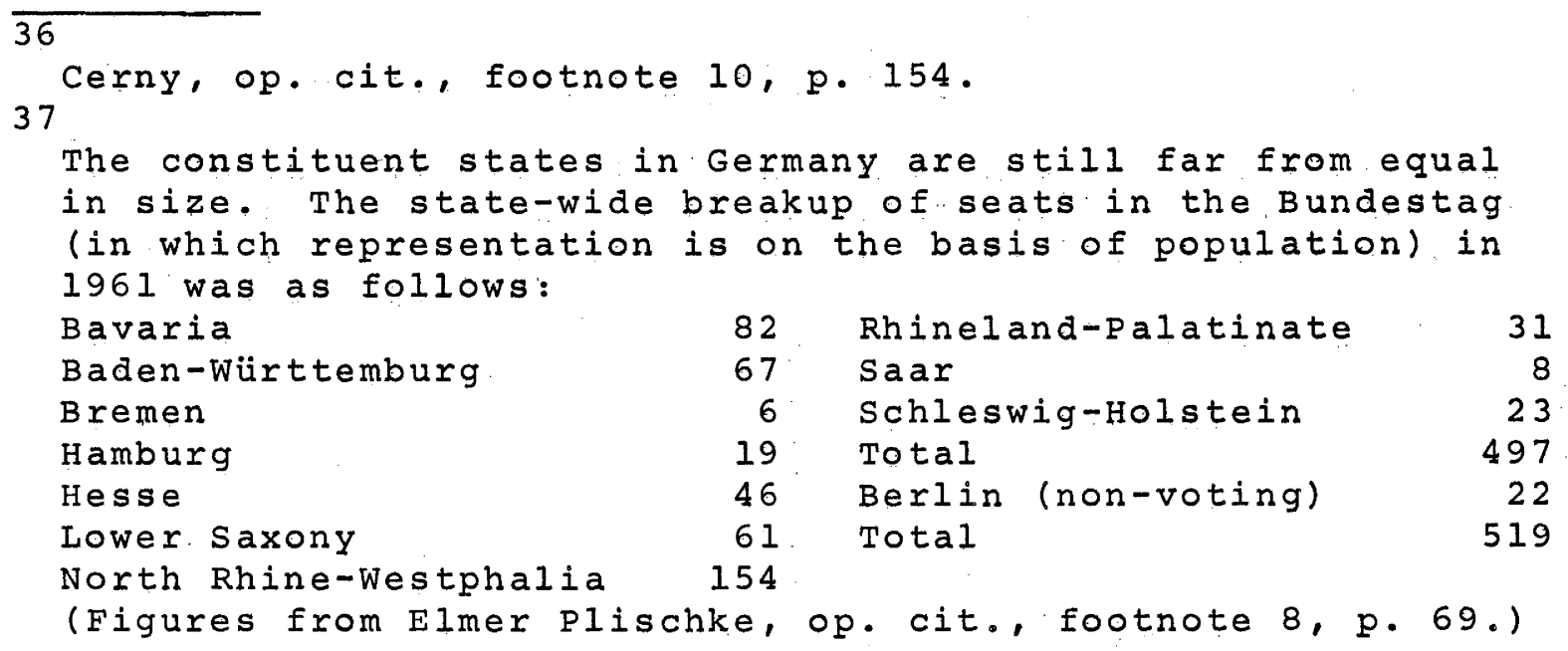


result of the existence of the Länder as organic political entities before the birth of the united federal state, was preserved till 1953 under the supervision of the Allies, who having helped to establish the federation wanted to assure the vitality of the constituent states. Marked by most intensive political activity and economic reconstruction, this period of Allied supervision greatly helped to fortify the position of the states as organic entities and created vested interests around the regional governments. These vested interests created a set of regionally-grouped diversities (around the different state governments) which, given peaceful conditions, would militate against over-centralization of power and the usurpation of state autonomy.

Further, during all these years the country was not faced with any national emergency that could have given occasion for over-extension of the central powers in the name of national survival. This left the states free to play their independent roles in the fields allotted to them by the Constitution, and thereby to develop their separate identities. ${ }^{38}$. An important contributory factor was the presence of the NATo forces that assured external security, the absence of which might in all probability have created national emergencies in response to real or supposed external threat.

Thus, the study of post-1945 German federalism seems to offer a major modification not only of Riker's military interpretation of federal constitutions but also of my own supplementary hypothesis that the presence of external military threat helps to maintain the federal bond and that the absence of it, as in the West Indies example, often leads to federal failure. Riker's insistence on the necessarily military origin of federal constitution appears excessive at least in the case of the West German example. While the condition of federal bargaining in "the hope of attracting East Germany back into the federation" may not wholly be denied, the assumption that

As Hertz writes, although the Iänder at first commanded little genuine attachment from their people, "the cake of custom by now has endowed the ten Länder structure with some kind of recognition". J. H. Hertz, "The Government of Germany", in G. M. Carter and J. H. Hertz, Major Foreign Powers, New York: Harcourt, 1967, pp. 441-442. 


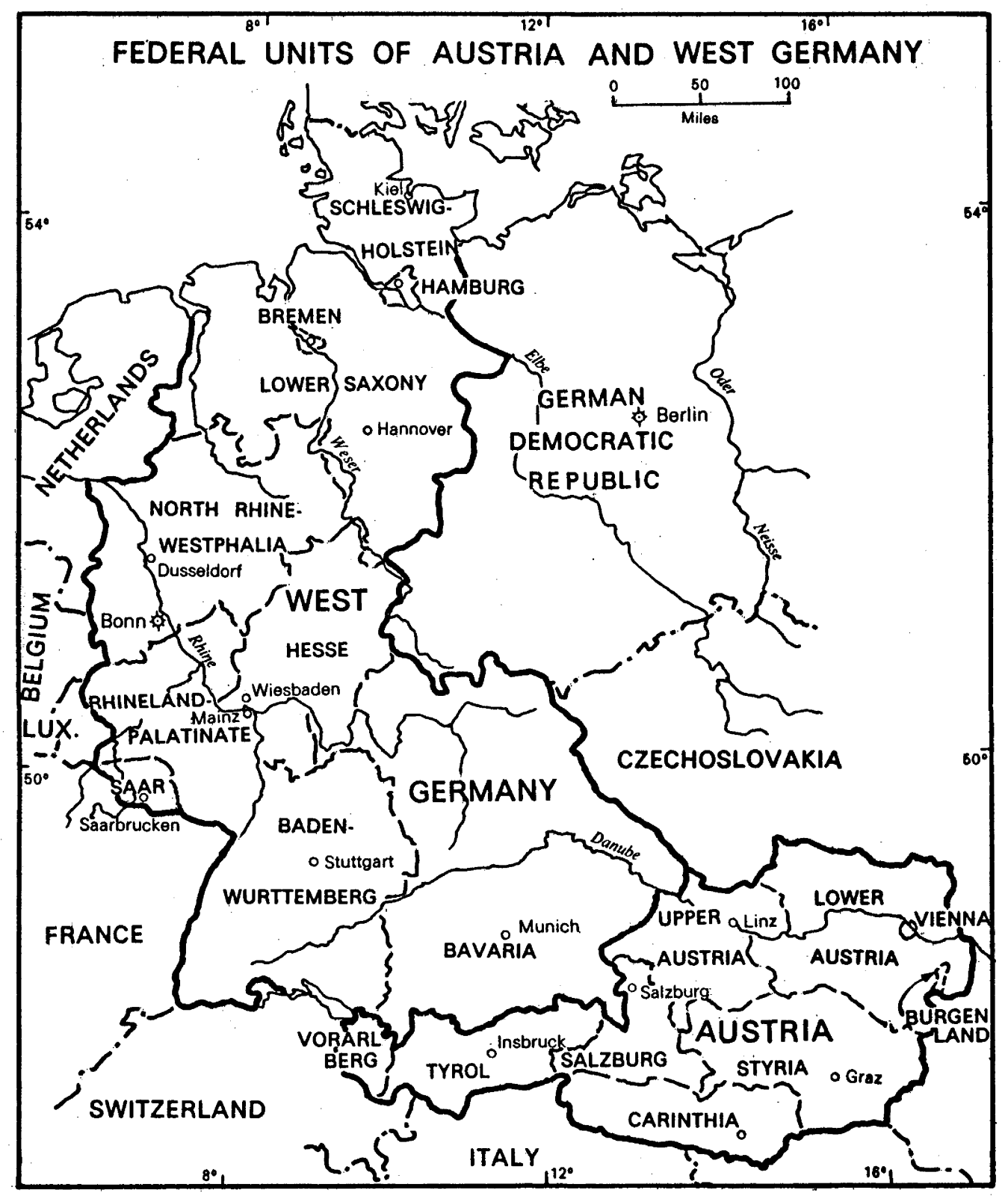

Fig. 7.2 FEDERAL UNITS OF AUSTRIA AND WEST GERMANY. 
"It was a proposed bargain in face of the soviet military threat" appears overstated in view of the demilitarized and helpless state of Germany. Even if the national consciousness realized a greater threat from the east than from the west, the continued presence of the Allied forces as the guardians of peace (if that is the right phrase) should have taken much force out of this motivation. And if this factor was a really potent force, it should have led to a unitary rather than a federal organization in view of the overall uniformity in. the national life. It becomes all the more questionable when Riker himself believes that the "constitution-making in Germany was dominated by American occupation forces who wished to impose federalism [which they thought]. . was a 'good. thing'". 39

The German example leads to the hypothesis that though in federations where states-rights sentiments are strong, the presence of external threat is a very favourable condition for the maintenance of federalism, in cases of basically nonfederal societies such as Germany represents; it is the absence of external threat that really helps the much needed rise of federal articulation and the maintenance of federalism against unitarism which should be easy to establish in the event of national emergency posed by external threats to national survival. The hypothesis is further confirmed when we compare federalism in post-1945 Germany with that in the spanish American countries.

\section{AUSTRIA}

Unlike the Weimar Republic which had found the readymade structure of the Reich to build upon, Austria after the collapse of the Hapsburg Empire in 1918, was almost a new nation (if a nation at all). As the non-German nationalities of the former Empire broke off to form independent states, the Germanspeaking provinces, the Archaucal nucleus of the Empire (containing in all six and a half million people as against fifty million of the Empire) were left alone to build a new

W. H. Riker, Federalism: Origin, Operation, Significance,

Boston: Little, Brown and Co., 1964, p. 37. 
State and, if they could, a new nation.

Throughout the imperial period the German-Austrians were, in the imperial vocabulary, the master-race who alone among the people of the Empire (apart from the Magyars) knew how to govern. Thus, the imperial system, however unjust to other nationalities of the Empire, gave rich rewards to the GermanAustrians. This helped to create among the Austrian people a strong sense of loyalty not to any specific Austrian identity but to the Habsburg monarch who was the source of their prosperity. The people who were not monarchists were permeated not by any specific Austrian nationalism but by pan-Germanism.

Thus, when the Habsburg Empire collapsed, almost no unifying principle, was left to bind the Austrian provinces together. With the passing away of the centripetal influence of the Inperial House the balance of power passed from the central government to the provinces, and Austria became what has been called "a meaningless concept". 40 It was Tyrol, Salzburg, Vorarlberg, etc., that became the centre of the loyalty of the people of the respective provinces, rather than any central ideal or authority, even though till the end of the Empire German Austria (the Archducal nucleus of the Empire) was for all practical purposes a centralized little kingdom, with the Länder much like little counties. Though the Empire by its very nature was highly decentralized, the provincial Governors in Austria were appointed by the Emperor, and the provincial Diets had little voice against them except in certain unimportant and secondary political matters. But the Revolution of 1918 changed the picture completely.

\section{POLITICO-GEOGRAPHIC FACTORS IN THE RISE OF AUSTRIAN FEDERALISM}

With the disappearance of the central authority, the provinces became real and vital political structures. For two years the writ of the central government scarcely ran outside Vienna. "The Länder, faced with an oppressive shortage of food, shut themselves hermetically up from one another and from the capital, in order to preserve their supplies... 
and in some cases organized well-equipped and well-disciplined militias against external and internal foes". 41 The provincial Diets became the supreme organs of their respective governments, leaving very little for the central control. There was practically no administrative organization left apart from that which the provincial governments had taken over. "Under such conditions Austria was, virtually, a federation (unless she was about to lapse into a state of anarchy), quite independently of the theoretical encouragement given to a federalist conception of the state by acknowledging that the Provinces had joined voluntarily". 42

But the basis for state-identity in the Austrian provinces was very weak, though the country was by no means devoid of regional diversities and antagonism. It was almost equally divided between industry and agriculture, between socialism and political catholicism, between city (Vienna) and rural societies. There had for long been a considerable antagonism between Vienna and the industrial parts of Lower Austria on the one hand, and the Alpine provinces with their conservative peasant population. (which supported the Habsburgs almost till the end) on the other. The post-1918 situation created further reasons for this antagonism. Vienna and the Lower Austrian region had during the imperial period drawn their provisions mostly from the non-Austrian regions. With these usual sources of supply now cut, Vienna and the industrial Lower Austria had to be supplied from within the German-Austrian regions. As the agricultural regions of the country hardly possessed any surplus, the industrial areas could be kept from starvation only by means of a central reguisitioning system that was introduced in $1916 \wedge$ This was greatly resented by the grainproducing Alpine provinces; and the cleavages between the two societies were further hardened. All this made it "obvious that, if Austria was to exist at all as an independent state, the form of her constitution must be pronouncedly federal"." 3

41

E. H. Buschbeck, Austria, London: Oxford University Press, 42

1949, p. 122 . 43

Schlesinger, op. cit., footnote 15, p. 253.

Macdonald, op. cit., footnote 40, p. 2 . 
But despite this division and antagonism, Austria was essentially a nationally homogeneous state in. which although the provinces were divided from vienna by differences in social and cultural outlook, the overall forces for unity far outweighed those for separation. As the issues dividing the provinces were in no way fundamental, their representatives could not decide upon the matters that they specifically wanted to reserve for themselves against the centre. In such a situation the 1920 federal constitution made the centre paramount over the states.

The First Austrian Republic: Constitutional

Structure and Performance

Although the Constitution recognized the autonomous character of the provinces, and provided that all subjects not specifically placed within the competence of the centre remained reserved for the states, in fact, the sphere of the central competence was made so wide that hardy anything of significance was left to the states whose role became limited practically to autonomous administration of the central laws. With few matters of importance being left to their independent control, the provinces became "agents and subordinates of the general [i.e., central] government". 44 Although the Constitution nowhere specifically stated that the central law took precedence over the provincial laws, in fact "the absence of this statement. . did not mean so much an accretion of strength to the Provinces as an accumulation of work for the Constitutional Court". 45

The Constitution created a bicameral central legislature: a Nationalrat, directly elected by the people through a system of proportional representation, and a Bundesrat elected by the assemblies or Diets of the provinces. Representation in the Bundesrat was weighted according to population, and Article 56 of the Constitution decreed against the members of the legislatures being instructed by outside (i. e., state) agencies. This made strict representation of provincial interests in the

K. C. Wheare, Federal Government, London: oxford University 45 Press, 4th. edn., 1963, p. 23 .

Macdonald, op. cit., footnote 40, p. 30 . 
Bundesrat almost impossible. Further, the upper House by the very terms of the constitution was not a very effective body and in a number of highly important matters its veto was only suspensive, while in financial matters it had no veto at all. As for proportional representation ( $P$. $R_{0}$ ) its results were as disastrous as in Republican Germany, and, in fact, "P. R. had destroyed the spirit of Austrian democracy before its body was buried". in 1938. 46

Hitherto the office of the President was. largely decorative, but the Constitutional reforms of 1929 granted the president considerable power over government and the parliament. He was made head of the Army which was now empowered to step into the provinces, even without being requested, in order to restore order in time of emergency. The Federal Court of Audit was now granted jurisdiction not only over the provinces but also over districts with more than 20,000 inhabitants. similarly the powers of federal police were considerably extended, and the Federal Minister of Education was given control over practically all matters concerning education.

The economic crisis into which the country was plunged in 1929 (and the civil commotion that accompanied it) led to the rise of a Catholic fascist regime under Dolfus in 1933. Soon afterwards the socialist opposition was suppressed in the country and the influence of the Nazis (who played on the latent pan-German sentiment of the Austrian people) increased greatly. This culminated into the march of Hitler into Austria in 1938. This brought the end of democracy and federalism in the first Republic.

\section{Federalism in the Second Austrian Republic}

After the defeat of the Axis powers in 1945, the provisional government for Austria adopted the Republican Constitution of 1920 as amended in 1929, which only with minor amendments has continued in operation. As in the first Republic, the central legislature continues to be bicameral: the Nationalrat elected by popular vote, and the Bundesrat elected by the provincial legislatures roughly on the basis of population but providing that no state would send less than

46

Hermens, op. cit., footnote 3 , pp. 83-86. 
three or more than twelve representatives. The Bundesrat has only a suspensive veto. The President is empowered to dissolve any state legislature with the consent only of the Bundesrat and to order fresh elections. The judicial system is entirely centre-controlled. The overall powers of the centre are very extensive. For this reason Austria has been considered as the limiting case in the unificationist direction of the "federal spectrum". Sawer regards it as the only extant example of "organic" federalism. The central competence includes the whole range of social, economic, and cultural matters, and most forms of taxation and public borrowing. No single important field has been left to the states: not even the full control of their cultural activities. In the field of education the states have exclusive authority only over the pre-school education. "The Regions are thus confined to the level of local affairs, and local administration of the Centre laws, associated in most. English-speaking countries with 'local government' of a rather limited kind". 4 Although the area of state-competence is very limited, the existence of the regional government is secured by the constitutional structure, and in principle, the states do not live at the mercy of the centre.

\section{POIITICO-GEOGRAPHIC: CONCLUSIONS}

1. Reviewing federalism in the first Austrian Republic we noted that despite the overall homogeneity in the national life, there were certain regional diversities in political and cultural outlook that made the provinces desire a type of state-organization that could guarantee them autonomous authority over local administration. But a closer look reveals that though giving a regional appearance, the diversities and divisions within the Austrian society were basically nonfederal in character. Apart from Burgenland (ceded by Hungary, in 1921) there were no basic differences in the historical experiences and political and cultural traditions of the Austrian provinces--as distinct from Vienna--that its people recognized, and that could foster among the provinces

47

Sawer, op. cit., footnote $12 ;$ p. 36 . 
a strong sense of regional identity capable of creating an enduring states-rights sentiment to resist the moves towards excessive centralization of power. The sectional division in political outlook posed a potentially federal situation largely because of the overwhelming size of the city of vienna, which with just under one-third of the country's population stood as a solid stronghold of socialism while the conservative forces were less concentrated because of their extension allover the countryside.

This was a very abnormal federal situation, for here that sense of compromise to live and let live, which is the essence of a genuine federalism, was completely absent. In view of the overall homogeneity. in the nation's life, the primary interest of the leading parties was not regional autonomy but national supremacy. Regional autonomy was, at best, only a temporary safeguard for the then individually weak Catholic Conservative provinces against the solid socialist strength of vienna.

And because the federalism was based upon an equilibrium between the two main sectional groups, it could survive only so long as that balance was maintained. As this equilibrium definitely tilted in favour of the christian social-cumGerman Nationalist coalition in the early thirties, failure of federalism was inevitable. Indeed, "A proletarian revolution in vienna would have been as portentous for it [federalism] as the definite control of Christian social policy by Big Business proved to be". 48 In this sense, federalism in the first Republic failed primarily because post-1918 Austria lacked the essential geographical base for a stable federation. A further contributing cause was the continued national economic crisis that made increase in the central powers and a closer coordination of the national life a necessity.

2. But perhaps a still greater missing prop was the lack of a definite state-idea for Austria inescapably recognized by the people after the 1918 Revolution. A state can survive as an independent unit only if the people are sufficiently united in their loyalty to a unique central ideal that

48

Schlesinger, op. cit., footnote 15, p. 272. 
distinguishes them as a group from their neighbours; further, their union should be able to maintain their economic activity at a standard of living acceptable to themselves. The "little Austria" of the inter-war years was unable to fulfil these conditions. The transference of Austrian people's allegiance from the Empire (and the Arch-Duke) to the Republic was difficult and incomplete. Though Austria and Prussia had. long been political rivals, and their people had developed some separate identity, in the post-1918 period when the Habsburg Empire broke into fragments and the German Austrians lost their position as a ruling people within the great empire, and especially when the position of all German people in Europe weakened as a result of the catastrophic defeat, the outlook of the German-Austrian people changed profoundly: the differences between Austria and Prussia began to be regarded as essentially a family quarrel within Deutschtum. ${ }^{49}$ The problem of Teuton versus slavs was posed afresh, and sentiment for unity with the rest of Germany, still great in size and population, tremendously increased. The provisional National Assembly of the new Republic declared (on November 22,1918 ) that "German-Austria is a constituent part of the German Republic".

But this resolution had no validity in the eyes of the Allies. Union with Germany was flatly forbidden, and the parliament was compelled under the Allied pressure to declare (on October 21; 1919) that "German-Austria is a democratic Republic under the name of Austria". Indeed, "it was not federalism that prevented the dissolution of Austria, but the Allies' fear of a piecemeal Anschluss as the most likely consequence of any further breaking of German Austria". 50 For this reason, unlike in most other cases, the failure of federalism in Austria did not mean dissolution of its constituent parts into independent states nor the establishment of a unitary state, but a union with Germany and, thereby, the creation of a greater German nation-state.

\section{9}

E. J. Passant, The Problem of Austria, Oxford Pamphlets on 50

World Affairs, London: Oxford University Press, 1945, p. 12. Schlesinger, op. cit., footnote 15, p. 272. 
3. Post-1945 federalism in Austria suffered from the same drawback in its politico-geographic base as the first Republic did, but with one vital difference: As in west Germany, the new federal structure was adopted under the Allied "dictation", and was run under their supervision till 1955. This was a long enough period to enforce some stability on the political structure. After the Allies left, in view of the comparative calm on the borders, and the absence of any great national crisis, the structure has continued to be maintained, Further as the central government has all the powers that a government might need in order to control a nation's life, there has been no need to interfere with the working of the regional governments in Austria. In fact, so long as democracy survives in a country, there can be little danger to the survival of an Austrian brand of federalism, for with all the essential powers in its command the central government will hardiy ever need to abolish the state structures.

4. We have seen (Chapter I) that the essential difference between Austria and a decentralized unitary state is that in the latter, though for all practical purposes the regional governments may be autonomous in the administration of their local affairs, in principle this autonomy is not guaranteed. In Austria, on the other hand, the regional autonomy. in the administration of local affairs of the states is guaranteed by the constitution. Technically, therefore, Austria stands as an example of federalism, though one is sceptical if it is proper to call Austria an "organic federalism", if by that term is implied the ultimate form of a fully evolved federalism as may be the future federalism in the United states or Australia. If it is agreed that the essential difference between the Austrian brand of federalism and a decentralized unitary state is the constitutional guarantee to the regions in respect of local administration, one wonders if the Austrian state may not better be described as a federalized unitary state or a unified federal state rather than an organic federal state.

5. As in the West German example, in Austria also, Riker's insistence on the essentially military origin of federalism appears."excessive". Riker writes "Back of the federal bargain stands the fact of anschluss, the ever present fear 
of an aggressive Germany, and, owing to that fear, the intention to give all parties and geographic areas a part in the government". 51 In view of the trend of Austrian politics between 1918 and 1945, however, this does not seem convincing. As Julius Braunthal writes, every Austrian knew that an Austrian nation (apart from the German) was non-existent; "there has never been one".

They proclaimed union with Germany when the Empire fell; they were again members of a German Federal [sic] state when the Republic fell; many of them welcomed enthusiast:ically Hitler's entry into Austria and professed fervently their German nationality until the German. Reich cracked. But when it seemed convenient they suddenly discovered that they had never been proper Germans, but they had always been a particular species. . Thus an "Austrian nationality" came into being not.. . as the result of generations' of 'growth under a common destiny, but as an act of expediency. . . they might develop in course of generations an identity somehow different from the German people ... What they . . cannot do . . is to secede not only politically but also emotionally from the wider cultural body of which they are part. . . .52

As Braunthal writes, in the post-1945 period, the Austrian people, with an eye to the Allies, were pleased to play the role of "good boys" as distinct from the "bad boys" that inhabited Germany.

In view of this, attributing the post-1945 federal structure of Austria to the fear of Germany would appear contrary to the facts of the case. This is all the more questionable when Riker himself regards the adoption of the post-war constitutional structure of Austria as an Allied "dictation". 53 Then, if this fear was at all a potent force, in view of the homogeneous nature of Austrian society, a pure and simple unitary state rather than the complicated and expensive facade of a

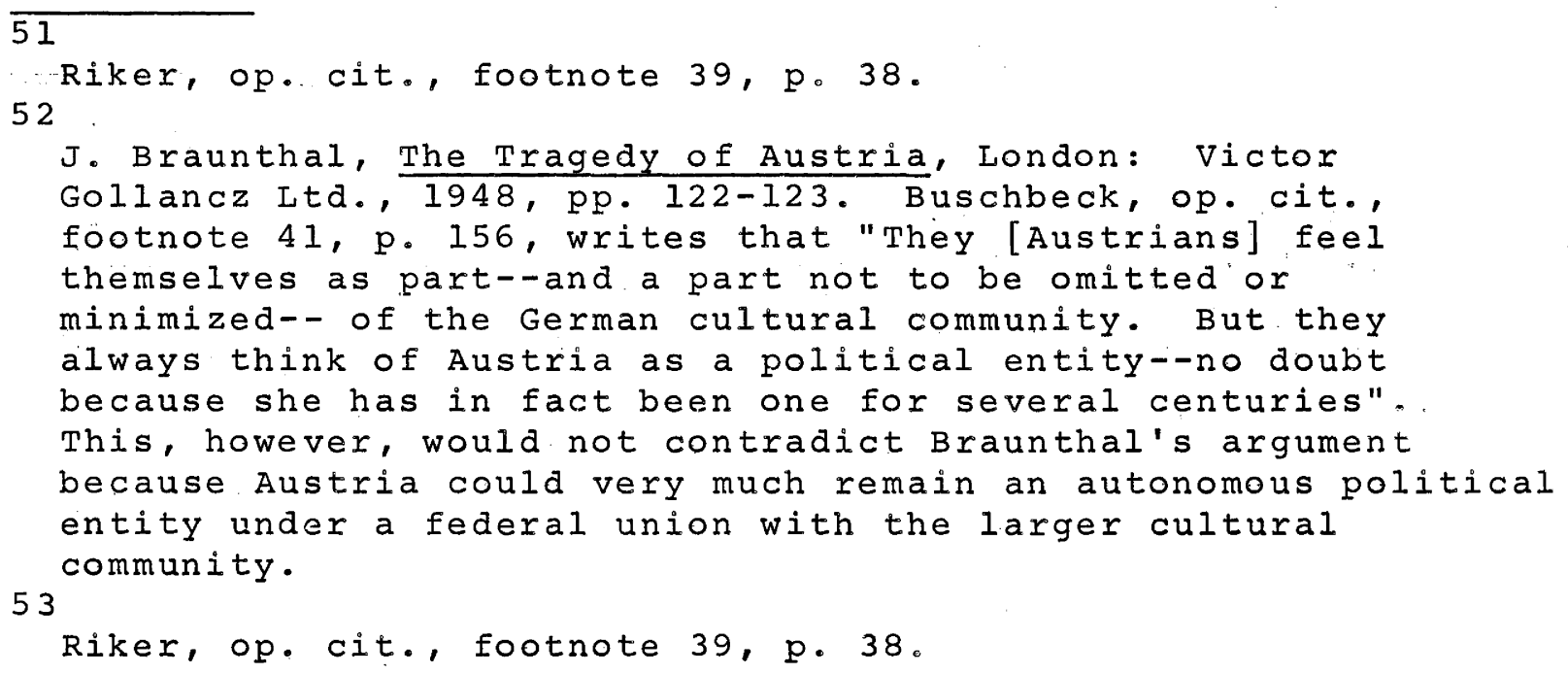


federalism should have resulted. It should, however, be conceded that the difficulty of reconciling vienna with the much more traditionalist countryside provides some sort of raison d'être for a decentralized governmental structure. 
Part 4

THE FEDERATIONS THAT FAILED 
FEDERATIONS CREATED UNDER

POTENTIALLY NONFEDERAL SITUATIONS

\section{LATIN AMERICAN FEDERATIONS}

Federalism has been much talked of but little understood in Latin America. Though Mexico, Venezuela, Argentina, and Brazil are the only four countries that describe themselves as federal today, federalism in the past has been experimented with in almost every part of latin America: in Colombia for about thirty years before 1886; in chile for a few years in the early years of independence; in central America from independence till 1838. Colombia, Venezuela, and Ecuador had formed the federation of Gran Colombia which split in 1830. Peru and Bolivia are the only. ones that did not experiment with the idea. But despite all this seeming popularity "More frequently than not, federalism was a slogan rather than a working principle of government" in Latin America.

Though federalism has been almost a universal failure in Latin America, "The reasons for the failure are [as yet] not fully understood". 2 The reason may well be that political scientists have so far tried to explain the Latin American political institutions by constantly using the contrast between "Anglo-saxon" and "Latin", seldom stopping to think that through the use of these terms they beg the question rather than solve it. "The qualities which we designate as 'Latin' and 'AngloSaxon!", warned L. S. Rowe, "are the results of well defined social and economic forces" without a proper understanding of which "our study of Latin American institutions must ever remain a play of words rather than a scientific study". 3

$\overline{1}$

W. S. Stokes, "The Centralized Federal Republics of Latin America", in Essays in Federalism by G. C. S. Benson and others, Claremont College, California: Institute for the 2 study of Federalism, 1961, p. 96.

K. C. Wheare, Federal Government, London: Oxford University Press, 4 th edition, 1963, p. 22.

3

I. S. Rowe, Federal system of the Argentine Republic,

Washington, The Carnegie Institute, 1921, p. 15. 
Indeed, "The essential nature of federalism is to be sought for. . in the forces-economic, social, political, cultural-that have made the outward form of federalism necessary"; 4 and because a geographical approach based on the fundamental premise of federalism as a polity based on regionally-grouped diversities, is primarily an analysis of these very forces, we believe that it would give us a better understanding of the reasons why federalism has invariably failed in the Latin American countries. Latin American federations may, indeed, provide a test case for the objection whether or not the concept of federalism as a polity based on essentially regionally grouped diversities, is "useful" as a "tool of analysis".

In the analysis that follows, we analyze each individual case in brief, and then proceed to find out the reasons why federalism has been a universal failure in Latin America.

\section{MEXICO}

As one of Spain's two administrative hierarchies in the western hemisphere, Mexico had attracted distinguished military, political, and clerical personnel of the Empire who helped in applying here the monarch's principle of absolute centralization of power in government. Hence, the regional autonomy that is sometimes talked of in certain other areas of spanish America, did not have a semblance of existence in Mexico. For this reason, the earlier attempts at the achievement of independence under Hidalgo or Morelos were not inspired by any particular governmental structure such as federalism. When Ferdinand VII of spain restored (in 1820) the liberal Constitution of 1812; the conservative forces in Mexico became dissatisfied. Taking advantage of this, Augustine de Iturbide with the help of the military, the Church and wealthy conservatives declared his Plan de Iguala in september 1821, which led to the complete independence of Mexico. A monarchical government was established, and Iturbide was rechristened as Emperor Augustin I. Iturbide's regime represented centrism, the opposing forces called themselves liberals and decentralists. After the over-

4

W. S. Livingston, Federalism and Constitutional Change, London: 5 oxford University Press, 1956, p. 1 .

A. H. Birch, "Approaches to the Study of Federalism", Political Studies, Vol. 14, 1966, p。17. 
throw of Iturbide in 1824, the victorious forces under santa Ana, confusing federalism with republican institutions, administrative decentralization and liberal reforms, adopted federalism as their banner; and the United states offered them a ready-made model for a new Constitution.

Though the American model was adopted, because the provinces had never functioned as organic political entities they lacked any states-rights sentiment. As a result, the constitution was highly centralized, and the new government almost immediately became a unified polity. Under the shelter of emergency powers for the President, the Congress delegated extraordinary powers to President Victoria (1825-29) even though, it is believed, there was less of an emergency than at any time in the next several decades.

The unitary Constitutions of 1836 and 1843 abolished federalism altogether; but when the liberals came to ascendency again, a federal Constitution was adopted in 1857 though, as before, power remained highly centralized. The new constitution under its Article 74 (which provided that if the Senate declared that all constitutional powers of a state had disappeared, the President was empowered to intervene and appoint a new Governor) made the states subservient to the centre. It was almost under the provisions of this Constitution that porfirio Diaz was able to establish his long dictatorial regime (1876-1911) that destroyed any semblance of regional autonomy. After the fall of Diaz a federal Constitution was adopted in 1917. Though Article 124 of the new Constitution guaranteed reserved powers to the states, Article 76 restated the provision in the 1857 Constitution relating to the power of the senate to declare the disappearance of constitutional government in any state and empowering the president to take over the administration of the state in question.

There is nothing inherently wrong with this provision, and most of the present-day federal Constitutions embody emergency powers; in the case of Mexico, however, because of the fact that her politico-geographic base was not conducive to federalism (because the country lacked any regionally-grouped diversities) this provision has repeatedly meant destruction of regional autonomy and excessive centralization of 
government. ${ }^{6}$ various writers have pointed out that while the federal government in Mexico continues to seek, aggressively, to achieve ever great centralization of power, the states remain apathetic. 7 In explaining this political scientists have found "psychological attitudes and values" as all-important; and have attributed this to the fact that "there is a disposition toward strong centralized power in Hispanic affairs". 8 A geographer may, however, suggest that one strong (and perhaps basic) reason for the failure of federal articulation among the Mexican states is the fact that the Mexican states have neyer formed organic political entities either before or since independence. This has resulted into the absence of any states-rights sentiment in the Mexican states. Furthermore, none of the ethnic elements in the country possessed a definite territorial base--the creoles,

Mestizos and the Peninsulares were mixed together in most areas

6

During 1918-1948 the Senate declared disappearance of states' powers 45 times, at least 25 of which are said to have been arbitrary. Since 1935 the use of this power has been limited because the centre has found other, and more effective, ways of maintaining and expanding centralized control. The most effective measure is the Secretaria de Gobernación which, acting under the personal direction of the president, is an authority intermediary between the federal government and the states. It watches over state elections and adjudicates most of the day-to-day political difficulties of the state governments and the federal-state relations. Its function is said to be to find out the individuals and groups in each state who will work amicably with the federal government. It is alleged that it sees to it that friends are in office and enemies are denied political power. In practice this means the rule of a single party in the states as well as the centre. The denial of free expression of regional opinion that this system entails, destroys the very basis of federal articulation and therefore tends to make the Mexican federalism a sham. From the title of his thesis, one student sees Mexico as "An Experiment in One-Party Democracy" (Frank Brandenburg, Mexico: An Experiment in One-Party Democracy, doctoral dissertation, Philadelphia: University of Pennsylvania, 1956); cited in M. C. Needler, "Mexico" in M. C. Needler (Ed.), Political Systems of Latin America, Princeton; D. Van Nostrand Co., 1964, p. 4 .

7

Robert E. Scott, Mexican Government in Transition, Urbana, Il1.: University of Illinois Press, 1959, pp. 46-47; J. L. Mecham, "Mexican Federalism: Fact or Fiction", Annals, American Academy of Political and Social Science, Vol. 208 , March 1940, pp. 23-38; and J。I。 Mecham, "Federal Interventior in Mexico", in wilgus A. Curtis (Ed.), Hispnaic American Essays, Chapel Hill: University of North Carolina Press, 1942. stokes, op。cit., footnote 1, p. 118. 
rather than being separately concentrated, and the Indians were not counted in political calculations. Thus ethnic factors could not provide a federal base. Besides, in the highly centralized political system of New spain, the provinces did not have even a semblance of regional autonomy. Thus the Regional political cultures in Mexico, unlike those in the United states during the colonial period, were everywhere similar.

In view of all this, the only basis for the existence of the states as organic entities in a federation was, as the historian Justo sierra has pointed out, that they were recognized by the Cortes of Cadiz (in 1812) as the basic units for sending deputies to the cortes. ${ }^{9}$ But as the constitution of 1812 was abrogated in 1814, this two-year period was too short to foster a states-rights sentiment in the local population. Thus, as Father Mier said, federating the Mexican provinces was equivalent to separating them--a policy that entailed upon them the very evil that the Anglo-saxons had endeavoured to avert with their federalism. He said that the creation of the Mexican provinces into "sovereign" (i. e., autonomous) states was to deny the significance of Mexico's colonial history and to court continuous division. 10

Although there may be some dissenting voices, such as that of A. O. Spain, 11 most students of Mexican government agree that federalism in the country is "defunct", and that "It is an indisputable commonplace that the Mexican nation is now and has always been federal in theory only; actually it has always been centralistic", 12 for despite the constitutional position, the autonomy of the provinces has been a sham. The former president Emilo Porte Gil described Mexican federalism as a great lie. ${ }^{13}$

\section{9}

Cited in V. A. Belaunde, Bolivar and the Political Thought of the Spanish American Revolution, Baltimore: John Hopkins University Press, 1938, p. 220 . 10

Cited in J. L。 Mecham, "The Origins of Federalism in Mexico", in C. Read (Ed.), The Constitution Reconsidered, New York: Columbia University Press, 1938, p. 360 . 11

A. O. Spain, "Mexican Federalism Revisited", Western Political 12 Quarterly, Vol. 9, 1956; pp.620-632. 13 Mecham, op. cit., footnote 10, p. 349. Cited in Needler, op. cit., footnote $6, \mathrm{p} .4$. 
The state administrations in Mexico are, says Needler, "no more than the branch offices of the national administration". 14

\section{VENEZUELA}

Because of its lack of known minerals, its belligerent Indians, and its remoteness from the main centres of spanish power in America, Venezuela was, unlike the favoured New Spain, among the most neglected regions of spanish America. In so little regard was the area held by the mother country that it was once given over to a German banking company with exclusive rights for exploration and colonization, though as the venture failed the grant was rescinded in 1650. The seven provinces of Venezuela were made into a Captaincy-General in 1777. But. owing to their economic insignificance and their distance from the main administrative headquarters, the administration of the provinces received only scant attention. Consequently regional leaders and administrators enjoyed greater powers of discretion, and the provinces were in fact not so completely integrated as say those in Mexico. It is, therefore, sometimes believed that regional identities of some kind existed in venezuela of the colonial days. It should be remembered, however, that under the feudalistic pattern of spanish colonial administration, where the people had no voice in political matters, these regional identities, if any, were confined to the administrators or the local military bosses (the caudillo). They had no popular basis (though in a restricted sense) as in the Thirteen colonies. Following the Napoleonic conquest of Spain, Venezuela had declared her independence in 1811, though internal troubles delayed the final overthrow of spanish rule until 1821. However, under the dictates of the Great Liberator, Bolivar, Venezuela was joined into a federation with colombia and Ecuador. When this federation broke up in 1830, Venezuela declared herself a republic under a unitary Constitution; but the country was soon plunged into a civil war now called the "federal war". As usual in Latin America, the two rival factions called themselves centralists and federalists, respectively. As one of the leaders of the Liberals later confessed, the liberal banner of federalism was adopted largely because the other side was

14

Needler, op. cit., footnote 6, p. 21 . 
centralist. 15 Considered synonymous with liberalism and republicanism, federalism was declared a divinely inspired principle that would harmonize all the diverse interests and forces of man. With the victory of the Liberal forces, a new federal constitution was adopted by the now twenty states in 1864. The country in fact remained under a conservative administration till 1870 when Guzman, Blanco took over power and despite his profession of federalism, ruled the country as a dictator till 1888 .

Though the Constitution was drawn on the American model, "The states were not in fact sovereign [i. e., autonomous] and had nothing to reserve". 16 with gradual extensions of the central powers, the central government has usurped almost every field in which government can operate. It acquired secondary education in 1901; post offices, telephones and telegraphs in 1914; and health in 1922. In 1925, both the central and the state governments were given only enumerated powers though credit, banks, social welfare, conservation of forests, natural resources, labour, expropriations, and public registry were taken from the state governments. In 1945 the states lost their judicial systems, and in 1953 the centre acquired exclusive powers to regulate hotels, recreational resorts, tourism, and lotteries. Although the Constitution of 1953 asserted that venezuela is a federal republic, the states no longer had any reserved powers, and there were no powers to enumerate for them. The constitution removed the last important source of revenue to the states, i. e., the sale of sealed paper for legal documents. Though the constitution of 1961 (the twenty-sixth in order), restores to the states the right to determine the organization of their public powers, municipalities, and police forces, and also restores the reserve power clause, in practice all this has meant little in view of the predominant position of the centre.

\footnotetext{
$\overline{15}$

Antonio Guzman Blanco, leader of the Liberal faction, is said to have stated: "If our opponents had said 'federalism' we should have said 'centrism'". Cited by Leo B. Lott, "Venezuela" in Needler (Edo), political systems of Latin 16 America, op.cit., footnote 6, p. 239 .

Stokes, op. cit., footnote 1, p. 157.
} 
The state Governors have almost invariably been chosen by the president. In 1925 the states lost even the theoretical right to choose their chief executive when at the instance of President Gomez the states amended their constitutions to permit the president to appoint their Governors. The 1961 Constitution restroed this power to the states though the president in practice continued to appoint all the Governors.

In view of this, federalism in Venezuela is, indeed, "A Case study in Frustration". 17 The venezuelan "devotion to federalism is to the principle and not to the practical application, and. . it remains in existence only as a response to emotional idealism of the Venezuelan people who see in it the unattainable goal of local self-government". 18 The extremely weak position of the states in the basic governmental structure of Venezuela is demonstrated by the number of territorial changes effected since 1864. There were twenty states in 1864, nine in 1881, twenty in 1899, thirteen in 1904, and again twenty in 1909. This means that the central government in Venezuela has been able to recast the state-structure almost at will. Hence, Venezuela does not satisfy even the barest minimum condition for federalism, $i$. e., the inability of the centre to abolish the state-structure. In absence of a genuine states-rights sentiment at the popular level, the states have existed only so long as the state leadership has been amenable to the powers at the centre.

As in Mexico in Venezuela also the ethnic divisions in the society cut across provincial boundaries without any marked regional concentrations to give even a semblance of identity to particular groups with particular states. Then, as in Mexico, here also the centralized and feudalistic pattern of spanish colonial administration had resulted into uniform regional political cultures rather than distinctive regional political cultures which would have resulted if the provinces had experienced a democratic self-government. Again as in Mexico, in Venezuela also the reason why federalism,

17

Leo B. Lott, Venezuelan Federalism: A Case study in Frustration, $\mathrm{Ph}$. D. thesis, Madison: University of Wisconsin, 1954, cited in Lott, op. cit., footnote 15 . 18

Lott, op. cit., footnote 15, p. 256. 
despite the Constitution, has failed to operate is that its politico-geographic base was essentially nonfederal, for the country lacked any regionally-grouped diversities which the people of the respective states identified themselves with. As a result the people of the states felt that they had nothing special to preserve for regional governments. What the people wanted was an efficient administration; it did not matter very much whether it came from the centre or the states.

\section{ARGENTINA}

Being far removed from the established highways of transAtlantic commerce, as also because of their poverty in readily exploitable minerals, the provinces of the River plate region were among the neglected areas of the Spanish American Empire. Here the central administration was less rigid, and the provincial administrators enjoyed a measure of independent discretion. The region had also possessed some bases for decentralization in the very makeup of its society. The area was colonized between 1537-1596 by three rival conquests which had given rise to three mutually hostile groups that militated against complete integration of government. Until 1776 the territories of Argentina, Paraguay and Bolivia were ruled from Lima as parts of the Viceroyalty of Peru. Under the spanish mercantilist system only three ports in the whole of Spanish America--Veracruz (Mexico), Porto Bello (Panama), and Cartagena (Colombia)--were permitted to trade directly with the mother country and through her with the outside world. An armada carried trade between Panama and Lima. It was through. Lima that the cities of the $\mathrm{Plate}$ region had their trade relations with the outside world. The overland route from Lima passed through La Paz, Potosi, Jujuy and Santiago to Buenos Aires and Montevideo. Standing as middlemen the interior towns enjoyed certain advantages over the coastal towns and Buenos Aires, and based upon this pattern of trade they had succeeded in building some industrial complexes around them. [Fig. 8.1]

The royal decree of 1774 which had legalized commercial intercourse between Peru, New Spain, New Granada and Guatamala, was two years later extended to Buenos Aires. The same year (1776) the River Plate provinces were formed into the viceroyalty of La Plata. In 1778 imports to the interior 


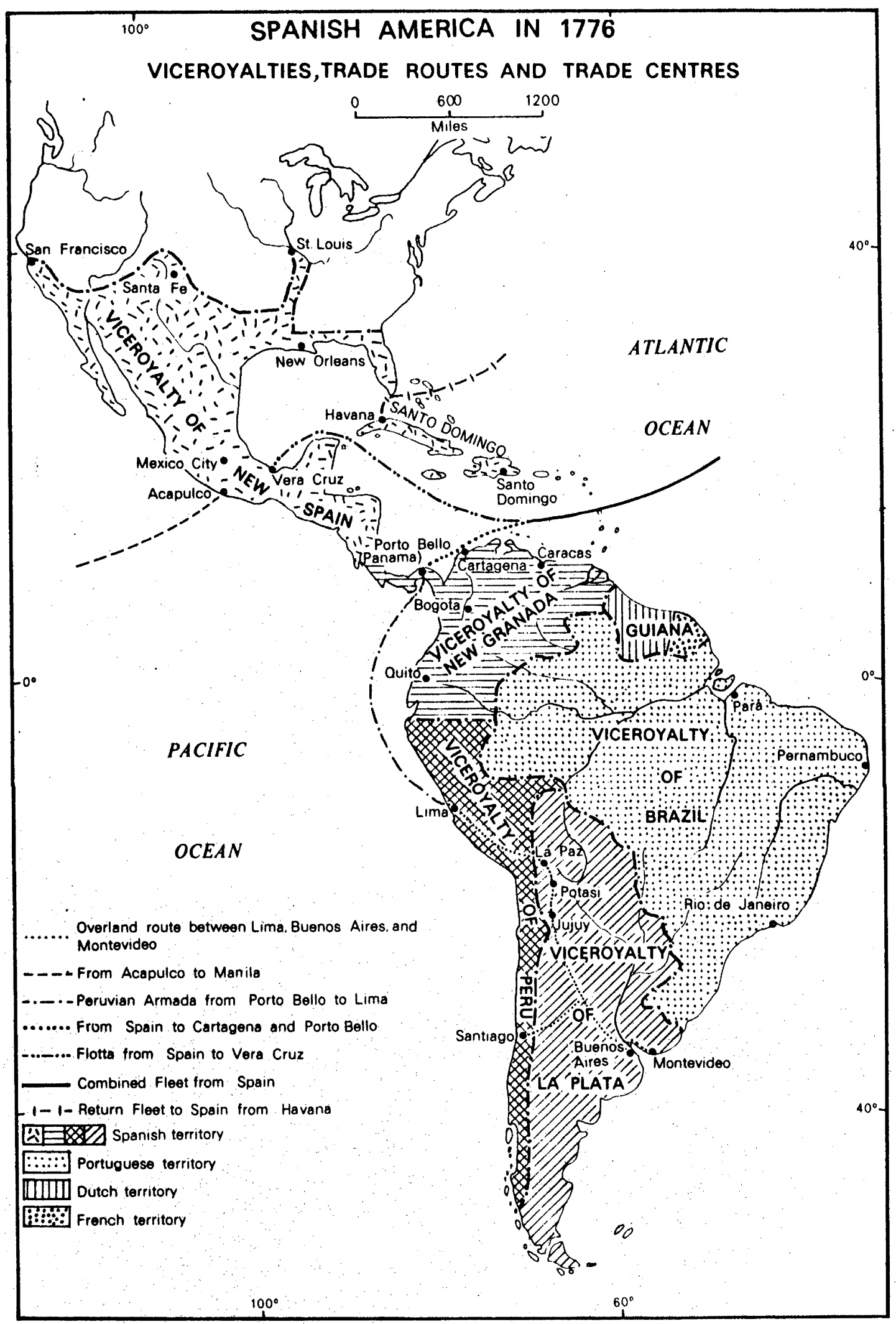

Fig. 8.1 VICEROYALTIES, TRADE ROUTES AND TRADE CENTRES IN SPANISH AMERICA IN 1776 .

(Adapted from maps on pages 163 and 189 in A. C. Wilgus, The Development of Hispanic America, 1947.) 
provinces through Buenos Aires were legalized, though Buenos Aires had still to take all her imports through the mother country, which in view of its limited manufactures served only as the intermediary between the colonies and the industrially advanced countries of Europe. This made imports unnecessarily costly. The imperial system also deprived Buenos Aires of much of the advantages of her exports, for all the trade had to be routed through the mother country. Thus with the conquest of Spain by Napoleon (1810) the Cabildo Abierto of Buenos Aires launched a revolt which was the first step toward independence, which was finally declared in 1816, and was confirmed at the battle of Maipu in 1818 .

Even before the revolt, consequent upon the confusion of the period of the Napoleonic war, the colony's communications with spain had been cut; the central administration had become extremely weak, and regional caudillos had assumed power. It was during this period that the colonists in the absence of spanish imperial support fought successfully against the invading British forces. This greatly added to their confidence in their individual as well as collective strength. Forces for regionalism that were relatively strong even in the imperial days, now became paramount, and the regions of paraguay, urăguay, and Bolivia parted company with what is now Argentina.

The provinces that remained to form the federation of Argentina were rent with economic and political rivalry. Throughout the colonial period, the economic unity of the Viceroyalty had been based on some sort of territorial division of labour under the mercantilist pattern. ${ }^{19}$ But the abolition of trade restrictions, consequent upon the disappearance of spanish authority, disrupted the regional economic balance. While the coastal provinces and the sectors of grazing industry benefited greatly under the new order, it was a very hard time for the interior provinces. Because the interior provinces had formed the termini and transit points of considerable trade between the coastal regions of Argentina on the one side, and Lima on the other, these provinces, taking advantage of their

19

Miron Burgin, The Economic Aspects of Argentine Federalism 1850-1852, Cambridge, Mass.: Harvard University Press, 1946 , pp. 1-18, deals with these factors in detail. 
geographical position, had developed certain industries which in adition to their own requirements also produced some surpluses for export to other parts of the viceroyalty. But the eclipse of the colonial system of trade finished all this, for now cheaper imports flooded the market and cut the very base of their economic prosperity. Economic self-defence became therefore the most important factor in the rise of that regional political particularism whose programmatic expression was the federalistic conception of state organization. Buenos Aires of course would have preferred a unitary organization in which by virtue of her wealth, her strategic location, and the control of the national capital she would dominate the government. But a compromise had to be made, for the port could not survive without its hinterland and the hinterland would not join unless regional autonomy was guaranteed,

Thus when the congress of Tucuman (1819) drafted a unitary Constitution for the country, the provinces were not willing to accept, and when the congress adjourned in February 1920, the Supreme Director at Buenos Aires resigned. This led to the disappearance of the central government. Now the provinces assumed sovereignty as almost independent states. Negotiations continued, however, and a Constitution that made modest concessions to regional autonomy was agreed upon in 1826 . But since the provincial Governors were made responsible to the President, the provinces remained dissatisfied. This led to a civil war which ended only with the dictatorship of Rosas. After the fall of Rosas in 1852, the victorious forces under General Urquiza called a Constitutional Convention which drafted a federal Constitution in 1853. Buenos Aires, however, refused to join till modifications were made to the original draft in 1860 .

Although drafted on the American model, the Constitution made the centre very dominant. Article 67 authorized the central government to draw up civil, commercial, penal, and mining codes for the whole of the country and conferred upon the centre the authority to promote and develop the prosperity and well-being of the entire nation. The constitution of 1949, while further expanding the powers of the central government, also compelled the provinces, through its Article 5 , to cooperate in whatever the central government saw fit 
to initiate. The constitution, therefore, made "it clear that in practice even the limited provincial sovereignty [i. e., autonomy] is moribund". 20 The dependence of provincial and local governments upon:federal aid, and the relatively limited provincial experience in regional self-government, have made the sentiment for regional autonomy very weak. This is obvious from the frequent federal interventions in the provinces. There have been over one hundred interventions from 1853, not counting those decreed by the de facto régimes after 1930. As Austin McDonald explains, these interventions have often been made on very flimsy grounds. 21 The practice of frequent interventions has made the position of the provinces so weak that they are said to "have become little more than election districts". 22

In view of the historical circumstances in which federalism was born in the country, it may perhaps be justified to say that "Argentina has been genuinely, perhaps inevitably federalistic"; 23 though it is true that the provinces did. not have in the colonial period any experience of popular self-government, nor was there anything inherently federalistic in the geographical distribution of the ethnic elements in the Argentinian society. But the sentiments for regionalism born out of the historical evolution of the economic geography of the area had provided a somewhat genuinely federalistic base in the beginning. Then for sixteen years (from 1810 to 1826), the provinces had remained practically sovereign, drafting their own constitutions and entering into treaties with one another. In view of these factors, one could well expect state identities in the Argentinian provinces to be strong enough to stand against overcentralization of government,

20

R. E. Scott, "Argentina's New Constitution: Social Democracy or Social Authoritarianism?" , Western Political Quarterly, 21 Vol. 4, 1951, pp. 567-76.

Austin F. Macdonald, Latin American Politics and Government, 22

New York: Thomas Y. Crowell, 1950, pp. 108-109.

R. A. Gomez, Argentine Federalism: Its Theory and Practice, Ph. D. thesis, Minneapolis: University of Minnesota, 1950. 23 Cited in stokes, op. cit., footnote 1, p. 101.

C. A. Haring, "Federalism in Latin America" in C. Read (Ed.), The Constitution Reconsidered, op. cit., footnote 10, p. 340 . 
and thus make federalism work.

Why then did federalism fail to operate in Argentina?

A close look reveals that despite all the pretensions to the contrary, provincial sovereignty or autonomy in Argentina before 1853 was essentially a sham. With the disappearance of centralized control, regional military leaders (caudillos) had assumed power. But the authority of these caudillos had no traditional or legal sanction. This meant that the popular sentiment for regional autonomy in the provinces was practically nonexistent. For this reason whenever central caudillos became strong enough to subdue the regional ones, the force for provincial autonomy receded. Further, by the time the federal Constitution of 1853 was adopted, the old pattern of economy had changed, and the provinces had, through a painful process, come to adjust themselves to the new situation: accepting the inevitable primacy of the strategically located Buenos Aires which alone opened to them the gateway to the outside world.

Therefore, as elsewhere in Spanish America, in Argentina also, the primary reason why federalism has failed to be effective is that a genuine broad-based regional autonomy never existed in the provinces which later became the constituent units of the Federation. In the absence of a broad-based autonomy the provinces failed to develop regionally distinct political cultures which could possibly have given them a set of regionally-grouped diversities having inclusive territorial bases. Thus despite a brief period of states-rights sentiment born out of a strong desire on the part of the provinces to preserve the colonial pattern of economy, the politico-geographical conditions did not favour federalism in Argentina at the time that the polity was actually adopted, because now the country lacked any popularly recognized provincially identifiable diversities-political, cultural, economic or other--strong enough to make the people inescapably devoted to the maintenance of regional autonomy which, in the view of most students, is the essence of federalism.

\section{BRAZIL}

Unlike the other Latin American federations, Brazil was a Portuguese colony. Although Portugal had discovered the area in 1500, its colonization did not begin until 1535 when 
the Crown decided to colonize the entire Brazilian coast through its projected plan of captaincies. The coast was divided into 15 captaincies which were distributed among twelve leading nobles. The donatarios, as the grantees were called, were invested with economic and political powers which were feudal in nature and were to be transmitted through hereditary succession. Powers not specifically granted to the donatarios were reserved to the crown. But as the system soon proved a failure, most of the rights of the grantees were abolished in 1546, and a Governor-General was appointed to whom all these rights were transferred. The territorial divisions were, nonetheless, maintained and the grantees who were partially successful (and such were not many), were allowed to retain substantial economic rights. Provision was made for the creation of new captaincies.

Because most of the states in Brazil have existed as welldefined political units for over four centuries, some scholars, like o. Lima, have found in the captaincy system the germs of the "federative-principle" in Brazil. 24 In fact, as Pierson and Gil point out, "although the Portuguese evolved an imperial system, it presented a far less systematic uniformity in patterns of administration than the one used by spain in its colonies". 25 For this reason regional administrators were given sufficient independent discretion to suit their policies to local circumstances. This naturally gave rise to some regional particularism in the states. But here also the provinces lacked any broadbased regional self-government. The germs of regional particularism that existed in Brazilian states were, therefore, not those of democratic regional autonomy that could give rise to a genuine federalism, but of administrative decentralization

24

Manuel de oliveira Iima, The Evolution of Brazil Compared with that of Spanish and Anglo-America, Stanford, California: Stanford University Press, 1914, pp. 55-56. Another Brazilian writer, Levi Carneiro, says "Federalism. . . has been the constant, unswerving objective of our political evolution for four centuries, it is the dominant preoccupation of our country. Despite delays, dissimulations, attempts at suppression, it has finally emerged triumphant". Cited in P. A. Martin, "Federalism in Brazil", in C. Read (Ed.), 25 The Constitution Reconsidered, op. cit., footnote 10, p. 367 .

W. W. Pierson and F. G. Gil, Governments of Latin America, New York: MCGraw-Hill Book Co., 1957, p. 69. 
that would suit a decentralized unitary polity.

However, by virtue of the country's sheer size, the Brazilian provinces do possess a good deal of regional peculiarities. It is said that "Any one who reads Brazilian newspapers and magazines cannot fail to notice a constant caricaturing of real or imagined cultural differences associated with the regional divisions of the country...".26 There is also a measure of psychological attachment of Brazilian citizens to their states, for the great distances between the major centres of population have made state capitals attractive as centres of cultural and educational life, and the extensive variations in regional development have heightened the sense of difference between one region and another. 27 But, as we have seen, regional diversities become potent germs for federalism only when the people of the regions recognize them as inescapable parts of their life that are so important to them emotionally and/or materially that they believe that unless they retain their rights to control theix provincial affairs their way of life or prosperity is in the danger of jeopardy. There is no such popular attachment with the seeming particularisms of most of the states in Brazil, although certain of the stronger states do display a certain degree of regional patriotism, e. g., são Paulo and Minas Gerais.

The Administration of Pedro II has sometimes been described as the "crowned democracy of America". 28 But although it had the outward form of a decentralized unitary polity on the British parliamentary system, it lacked what Herring calls the under-pinnings of a democratic system. ${ }^{29}$ There were no literate masses to voice the general will while the inarticulate proletariat was denied franchise. The electorate consisted of only a few thousand landowners, lawyers, physicians,

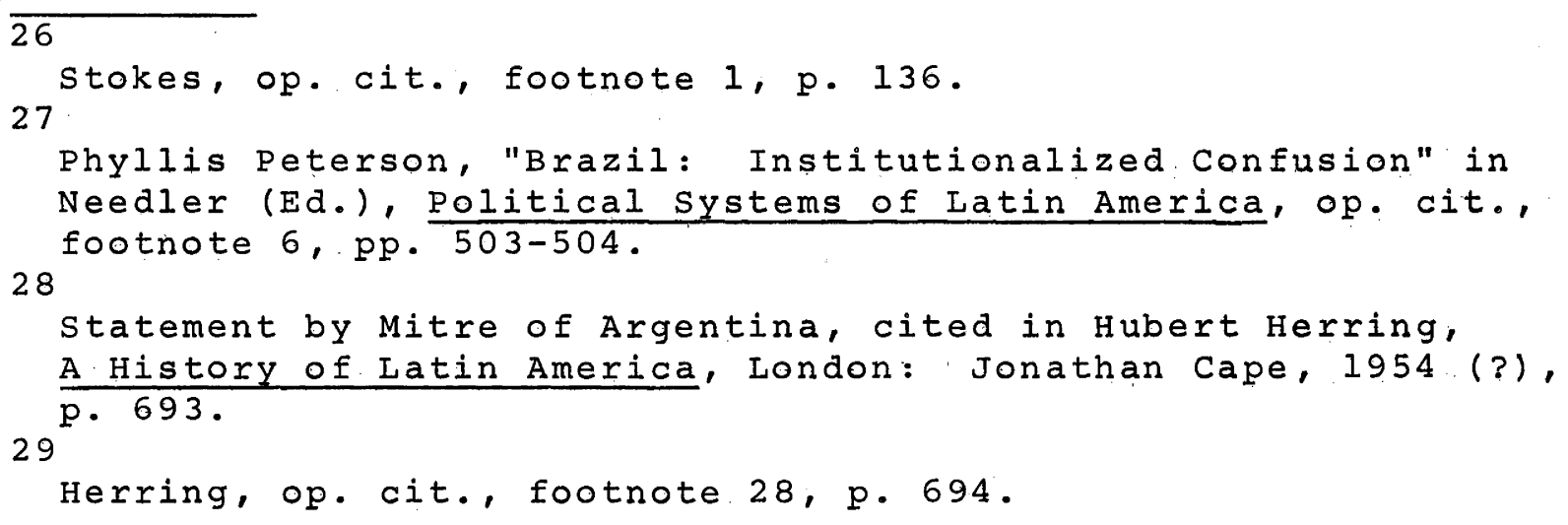


engineers, priests, and officials etc. Alan Manchester cites the election of 1881 as one of the fairest in the imperial period; but even in this election there were only 142,000 qualified voters out of a total population of almost 14,000,000; a ratio of one to a hundred. 30 In this sense then, Brazil lacked an essentially federal geographical base.

still, if things had remained tranquil in Brazil, and if the regional governments had been given a free hand in the administration of their affairs under a broad-based democratic set-up, the states could well have developed their regional political cultures born out. of a continued exercise of regional autonomy. This would have given rise to a states-rights sentiment that would very likely have made federalism in the country a living force. But this was not to be. The changeover from military leadership (that had created the Republic) to civilian leadership was a delayed process; and when things were just beginning to stabilize, the military again stepped in to help Getulio Vargas to take over power (in 1930) and finish federalism during his subsequent fifteen years of rule. After his fall in 1945 , a new federal Constitution was promulgated in 1946 .

The 1946 Constitution provides for a President, a bicameral legislature, and an independent judiciary, but the distribution of powers is such that "the national government retains considerable power over the states, enough for it and not the states to predominate within the federal relationship". 31 The national government is empowered to tax imports, consumption, production, income and profits--i.e., all the most lucrative sources of funds. This accentuates the dependence of the states upon the centre, and has helped to make Brazilian federalism, despite the constitution, a sham. The constitution also empowers the federal government to intervene in the states under "emergency". An extensive use of this power was made during the years of the Republic and the vargas regime. After the adoption of the 1946 Constitution it had fallen into disuse until the military assumed power in 1964.

\section{0} 31

Cited in Herring, op. cit., footnote 28, p. 694.

Peterson, op. cit., footnote 27, p. 502 . 
Thus although Brazil had a different colonial past its federalism fits into the general Latin American pattern; and here as elsewhere in Latin America, federalism failed to take root primarily because the constituent units of the state did not possess any popularly recognized state-identities that the people could be inescapably attached to and which they would want to guard against the central encroachment. Here again the people's primary need is efficient administration; it matters little whether this comes from the centre or the states. In fact, what a critic said of Mexico is true of Brazil also: the establishment of federalism in the country in 1891 was like a tailor destroying a suit of clothes in order to have the pleasure of sewing it again. 32 Although the Brazilian states, unlike the Mexican provinces, had possessed their own regional legislatures, in reality under the sweeping appointive powers of the Emperor, any pretensions to state autonomy were only idle.

A further factor in the failure of federalism in Brazil is, as H. G. James pointed out, that some of the states are economically so undeveloped that they are able only with the greatest difficulty to meet the minimum expense required for the organization and functioning of a very rudimentary government. In these states it is quite possible that the population would benefit by having the central government do for them what their own governments cannot do. ${ }^{33}$ This tends to cut into the very basis of federalism. However, the more wealthy, thickly populated, and progressive states are administering their affairs better than could be done by a distant central government, and these bigger provinces being zealous of their prosperity are reluctant to share their financial cake with the poorer states. This has complicated the issue and has made some kind of compromise between federalism and unitarism almost a necessity for Brazil. CONCLUSIONS AND HYPOTHESES

1. An important factor in the failure of federalism in

32

Cited, but not named, in Mecham, op. cit., footnote 10 , 33 p. 263 .

H. G. James, The Constitutional system of Brazil, Washington: The Carnegie Institution, 1923, p. 218 . 
Spanish America was that the Spanish colonial Empire did not ". . in reality consist of colonies like those of other nations or mere entrepots, but [was] an essential and integral part of the spanish monarchy. . .". 34 All the administrations, large or small, were controlled by officers appointed by and responsible to the crown. Thus the provinces that had to become the constituent states of the different federations lacked any training in or tradition of regional autonomy. Whatever sovereignty or autonomy the provinces could claim emanated from the fact that after the conquest of spain by Napoleon, local councils or Juntas had assumed sovereignty. This was in conformity with the ancient theory that in the event of a national disaster such as the capture or imprisonment of the king, the sovereignty returned to the people and the councils became the residual legatees of this sovereignty. The Junta of seville had become supreme in spain. As the Junta of quito put it ${ }^{35}$

- . the same right which seville has to form an interim junta to be supreme in the government of spain is shared by all the kingdoms in America.. . And since the governors were no longer approved, they had... ceased to exercise their functions, and the sovereignty of necessity reverted to the people.

As the Argentinian leader Moreno said 36

With the monarchy dissolved and spain lost, are we not in the condition of sons who have become of age at the death of the father of the family? Each one enters into the enjoyment of his individual rights and sets up his own hearth and governs himself.

Now as each province became "sovereign", it was thought that the best solution to the problem of political organization of the individual viceroyalties or captaincies-general was federalism. But as already noted, their politico-geographic bases were not suitable to federalism, for as Gorriti said 37

A federation presupposes states already organized and constituted [or at least having a proper regional base

34

From the Royal Order of January 22, 1809; cited in 35

Belaunde, op. cit., footnote 9, p. 89 . 36 37

Cited in Belaunde, op. Cit., footnote 9, p. 96.

Cited in Belaunde, op. cit., footnote 9, p. 99.

J. I. Gorriti, Reflectiones, 367; cited in Belaunde,

op. cit., footnote 9, p. 141 . 
to justify the organization of separately autonomous governmental units], while in the congress there were presented only inform [unformed?] provinces, without any interior organization sufficient for their own needs, and consequently, destitute for the most part of means of supporting the trials of a federation.

This explains the essential difference between the historical and administrative heritage of the spanish colonies and the Thirteen British Colonies in North America. Even though both the British and spanish colonies were alike in being outposts of their respective mother countries and were founded with a view to mercantilist exploitation, the administrative patterns in the two were highly divergent and were responsible for the rise of highly different internal political geography in the two areas. The differences in institutions, motives, objectives, human elements and policies which distinguished spanish colonies from the English, greatly account for the differences in the ultimate political organizations that the two areas evolved.

spain at the time of American colonization was an absolute monarchy, which could and did establish imperial institutions responsible to itself alone. As Pierson and Gil point out, if spain established colonial governments with an elaborate system of checks and balances, juridical autonomy, and granted to towns and guilds a limited measure of self-government, it did so by choice and acquiescence and not by any mandate from a superior authority. ${ }^{38}$ England on the other hand, although very far from having a democratic system of government, had sown by the seventeenth century the seeds of democratic institutions, and it was in the process of becoming a limited monarchy in a modern sense. During the seventeenth century parliamentary supremacy, the Bill of Rights, habeas corpus, and the beginnings of the cabinet system and party government were to be adopted. "The rights of Englishmen" were guarantees which the colonials claimed as much as residents of the mother country. Charters became constitutions that limited both the colony and the home government. So the English colonies of all origins in North America came to possess a greater opportunity for self-government which, within limits,

38

Pierson and Gil, op. cit., footnote 25, pp. 62-64. 
allowed them to develop their own distinctive regional personalities.

Thus, even though the Thirteen Colonies were (like the spanish provinces) more or less similar in race, language, etc., the very fact that they had developed their distinctive regional personalities in course of their long, experience with selfgovernment had provided them with regional sentiments strong enough to stand against attempts to overextend the central powers. This provided the united states with a set of diversities identifiable with the constituent states, a factor which was conspicuous by its absence in the provinces of Latin America--both Spanish and Portuguese. Therefore, while the politico-geographical conditions in the Thirteen colonies were potentially federal, the human geography born out of the colonial-administrative heritage in Latin America was essentially nonfederal.

A further contributory factor was that the spanish and the Portuguese colonists were primarily agents of the respective Crowns and had come to the New World to conduct crusades and gain wealth.

The agents of expansion in Latin America were not opportunity-seeking pioneers as in the united states, but government-supported conquistadors in New Spain and the community-minded bandeirantes in New Portugal. Nowhere did the reaction of men and nature generate a social environment that would stimulate the urge for self-improvement among individuals.39

What Vianna Moog has said of Brazil is true for the whole. of Latin America:

- . for three centuries ... . the main motive for going to the frontier was to get rich quickly, to find gold or other precious minerals, that labour, whether in urban or rural occupations, was denigrated as fit only for slaves; while the English and later American settlers looked for new homes based on their own work.40

As Adolf Berle observes, while "The Brazilian bandeirantes were perhaps the last band of colonial conquistadores, the

$\overline{39}$

R. A. Billington, "Frontiers", in C. Vann Woodward (Ed.), A Comparative Approach to American History, Voice of America 40

Forum Lectures, Washington: Voice of America, 1968, p. 84.

C. Vianna Moog, Bandeirantes and Pioneers, New York: 1964; paraphrased in S.M. Lipset, "The 'Newness' of the New Nation", in C. Vann woodward (Ed.), A Comparative Approach to American History, op. cit., footnote 39, p. 76 . 
American pioneers, though of all kinds, were predominantly Reformation settlers". 41 For these reasons, to the Latin American colonists America was not a sweet home in the manner it was to the Englishmen and other later immigrants who, dissatisfied with conditions in the home country, had sought in America a new home and had built around it all the fine sentiments associated with a motherland. Thus, when the hour of independence arrived, the people of the Thirteen Colonies had thirteen separate homelands (each with a somewhat distinctive political culture), while to the Latin Americans spain and portugal had remained the real "mother countries", and thus the provinces lacked any raison d'être as organic political entities. This in itself had made the federal form of union a necessity in the united states. It was not so in the provinces of Spanish and Portuguese America. 2. Even though the Latin American provinces did not have a prior experience in self-government that could have made the sentiment for regional autonomy strong, still if the provinces had possessed some regional particularisms in their human geographic base--language, religion, culture, etc.-this sentiment might well have arisen to safeguard those regional interests once the federation was born. But, as we have seen, their geographic bases were not favourable. The "true origin of [spanish] American federalism", according to the historian V. A. Belaunde, is to be explained in the following terms: 42

When the central authorities had been swept aside and the authority of the mother country no longer recognized, the government fell necessarily into the hands of local oligarchies or of caudillos who took the lead in the popular insurrection.

Thus the sovereignty of the provinces in reality meant only the sovereignty of the caudillos, who possessed no legal or broadly-based popular sanction. Hence no strong popular sentiment for regional autonomy could develop in the provinces that could in future stand against the change of power from the provinces to the centre. For this reason federalism throughout Spanish America has remained fluctuating, for

\section{1} 42

Cited in Lipset, op. cit, footnote 40, p. 75.

Belaunde, op. cit., footnote 9, p. 131. 
only when the regional leaders (caudillos) have been strong enough to demand recognition from the central leadership, has any significant concession to provincial autonomy been granted; and as and when the central leadership has fallen into strong hands--the hands of some more widely-connected or more imaginative cópudillo--unitary tendencies have been reinforced.

3. This analysis of Latin American federations should explode the myth that visible geographical factors such as large size and small population and underdeveloped transport and communication by themselves are necessary or predisposing factors in the rise of modern federalism. If it were true, there should have been no reason why federalism would not be operative in the Latin American countries, each of which possessed large areas and small population scattered in isolated pockets. Transport and communications were naturally undeveloped. But all this could not avert the failure of federalism in these countries. The essential fact to remember is that the essence of federalism does not lie in the physical geography of a country but in the-geography of the society inhabiting it: in the rise of federalism human forces are far more important than the physical ones, although in many cases physical factors may set the stage for the human geographic pattern that evolves.

4. When comparing the Spanish American federations with the United states, it should be noted that a relationship somewhat similar to that between the Thirteen colonies existed not between the provinces of the individual viceroyalties or captaincies but between the separate viceroyalties and captaincies-general themselves. As Belaunde puts it 43

These separate [American] kingdoms, according to spanish policy, were united with the principle [principal?] nucleus--the crown itself--but there were [almost] no bonds uniting one kingdom to another.. . the spanish

Belaunde, op. cit., footnote 9, p. 163. A diagrammatic representation of "Hypothetical Patterns of the Continental Empire of spain" is to be found on page 217 of D. W. Meinifg,1/ "A Macrogeography of Western Imperialism: Some Morphologies of Moving Frontiers of Political Control" in F. Gale and G. H. Lawton (Eds.), settlement and Encounter: Geographical Studies presented to Sir Grenfell price, Melbourne: Oxford University Press, 1969, pp.213-240. 
colonial Empire had a star-like form, and not the circular form of a chain. . each colony was joined directly to the crown with no connection between colony and colony. . The Revolution broke the bonds uniting the colony to crown, leaving the several unities entirely separate and free.

Thus while the separate viceroyalties and captainciesgeneral lacked the requisite geographical base for a genuine federalism, the reasons why spanish America as a whole split into separate units rather than forming a federation as the Thirteen British Colonies did, were first, its overextension that made the rise of a strong sense of belonging together difficult; and secondly (and more important), that the spanish American colonies, once independence had been gained, lacked any common external military pressures which in North America had helped to squeeze the Thirteen Colonies together: it is significant that inter-colonial federalist ideas were most in vogue in the period of revolutionary struggle against spain.

The situation was, however, different in Brazil. Unlike Spanish America, Portuguese America consisted of a single "kingdom", and the relationship between the captaincies vis-à-vis the Governor-General resembled that between the provinces and the Viceroys or the Captain-Generals in the Spanish colonies. Then following the Napoleonic invasion the Portuguese Court was transferred to Brazil, and thus here there was no occasion for sovereignty to return to the provinces. Hence the pretensions of independence that the viceroyalties, and captaincies-general or even the provinces in spanish America had assumed, were quite absent in Brazil. The external political geography of Portuguese America was more conducive to a strong union because the Portuguese Captaincies in Brazil formed a compact group and therefore found themselves together surrounded by a "people" with foreign culture, language, and values, against whom they thought they needed, a common defence. Thus, if at the time of the Napoleonic conquest of Portugal the Portuguese American captaincies had somehow assumed the sense of sovereignty that the spanish colonies had, Brazil might well have developed into a genuine federal union.

5. This study of federalism in Latin America seems to suggest a major modification of the widely held view that 
federalism is essentially a response to external military threat, as also to our supplementary hypothesis that external military threat is a favourable factor in the maintenance of federal ties. Common military threat is no doubt a favourable factor in bringing discordant units together into union, but we should distinguish between two types of federal situations that require two different types of political conditions for their maintenance. In the normal type of federal situation the territorial units are based on regionally-grouped diversities due to which states-rights sentiment in the units is strong. In the second type of federal situation regionally-based identities, if any, are very weak and the situation verges practically on the unitary extreme of the federal spectrum. This situation is exemplified by states like West Germany and the Latin American federations.

A comparison between Latin American federations and West Germany is quite revealing. In both cases regional identities were weak and the constituent states in general (with some exception in Germany) lacked any long tradition as organic political entities; yet federalism has been successfully operative in west Germany now for over two decades, while it failed to take root in the Latin American countries altogether.' Comparing their historical circumstances we find that while each of the Spanish American federations was born, and remained for some time, under shadow of possible or actual military threats from their neighbours (though not a common formidable threat to the whole of spanish America), West Germany has remained virtually secure from any such threat in view of the NATO alliance which stood as the guardian of West European security, and which was there to ensure that false alarms for such emergency were not raised. In the absence of such emergencies, there were no occasions for the west German centre to intervene into the regional affairs under the pretext. (false or true) of national survival. Allowed to govern themselves without any interventions from above, the German provinces have been able to create new regional identities and some vested interests around their regional governments. In view of this, the regions have become lively political entities that have now begun to resist 
the undue extension of central powers over the regions as is evidenced by the TV and the concordat cases.

It would appear therefore that the chief reason why federalism was able to take root in west Germany while it altogether failed to do so in the Latin American countries is that West Germany unlike the Latin American federations was at peace to experiment with this "most complicated and delicate governmental mechanism ever devised by man", 44 while in view of emergencies posed by frequent external threats (from their neighbours) the Latin American countries had no such long enough peaceful interlude during which democracy and federalism could have functioned and would, thereby, have created regional identities and vested interests of the type that has been possible in West Germany. We may therefore conclude that while in cases of normal federal situations (where the territorial units are based on regionally identifiable diversities) the presence of external military threat favours the maintenance of federalism by forcing the constituent units to learn to live together in order to preserve their common heritage and to safeguard their common interests; in cases of federations that are created under basically nonfederal situations (i. e., where the territorial units are not based on the very distinct regional identities) it is the absence of external threats, and an assured national survival that are necessary for the rise of a genuine federal articulation and for the state's continued survival as a federation rather than a unitary state.

\section{2: THE CENTRAL AFRICAN FEDERATION*}

Founded on the so-called compromise principle of partnership and multinationalism (that was more breached than honoured) the Central African. Federation consisted of three former British territories--the self-governing Colony of Southern Rhodesia, and the two protectorates of Northern Rhodesia and Nyasaland.

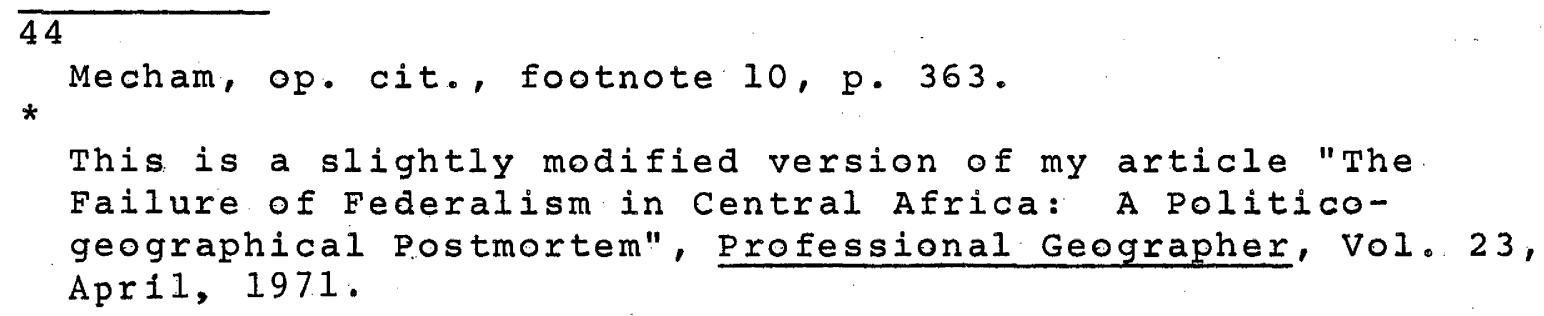


Northern and Southern Rhodesia were brought together because the white settlers in both the areas saw greater advantages in a closer political union. Nyasaland was thrown in because the British Government was finding it too expensive to administer this poor, grant-aided area as a separate territory. 1 Inaugurated in 1953, the Federation was dissolved ten years latex in December 1963.

\section{HISTORICAL BACKGROUND}

The historico-political heritages of the three units were highly diverse. Southern Rhodesia, which had from the beginning been administered by a Legislative Council in which the white settlers had gradually obtained majority, was granted responsible government in 1923 , when the territory was declared a Crown Colony, with full powers of self-government on all matters except legislation pertaining to Natives and such other affairs as were reserved for the crown. In contrast, a nonofficial majority in the Northern Rhodesia Legislative Council, was obtained only in 1945, though not until 1949 did a nonofficial member hold a portfolio in the Executive council. Even until 1953, when the Federation was inaugurated, Nyasaland's twenty-member legislative Council was equally divided between official and nonofficial members out of whom only three were natives.

The territories were also contrasted with regard to the paramountcy of the settler population in the administration of their governments. Southern Rhodesia, where the settlers were most heavily concentrated, had a completely settlercontrolled government that pursued a policy towards the natives that was hardy different from the segregationist policy pursued by the south African government. But the two Protectorates had remained under the colonial office rule which, in contrast to the south Rhodesian government, followed a policy of native paramountcy. Though the numbers and influence of the white settlers in Northern Rhodesia had increased considerably after the discovery of copper in 1925, Nyasaland, because of her lack of economic opportunities for European

$\bar{I}$

F. G. Carnell, "Political Implications of Federalism in New States" in U. Hicks et al, Federalism and Economic Growth in Underdeveloped Countries, London: George Allen \& Unwin Lta., 1961, p. 35. 


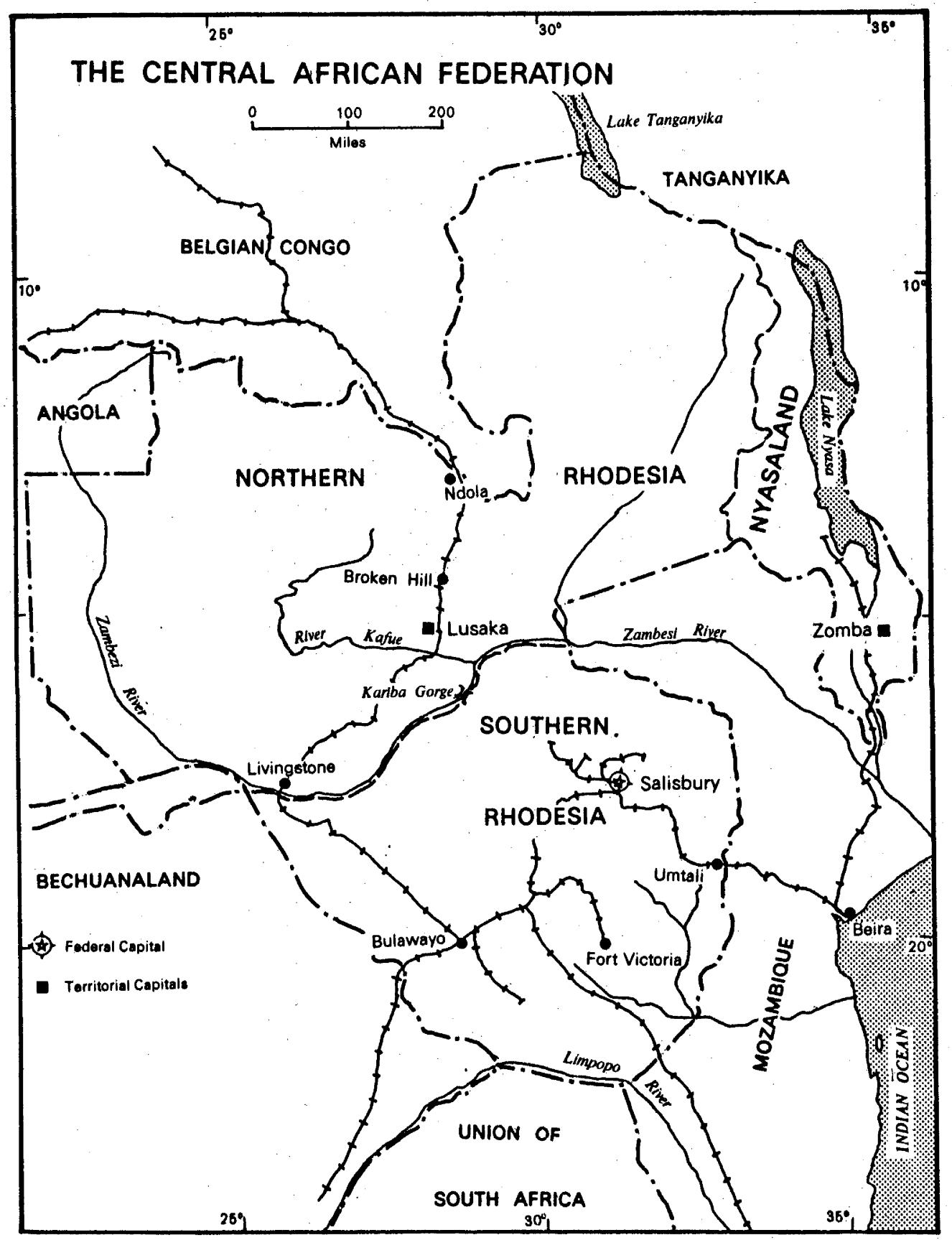

Fig. 8.2 THE CENTRAL AFRICAN FEDERATION. 
settlers, had by far the fewest settlers.

The Move for Federation

Ever since 1915 the white settlers in Southern Rhodesia had from time to time advocated the amalgamation of the two Rhodesian territories on the ground that their economies were complementary and that the united country would form a more credit-worthy and viable state which would facilitate an early achievement of dominion status and freedom from the Colonial office rule. The British Government, which had for so long paid little heed to these demands, became receptive to the idea of union after 1948 when, in view of the spate of decolonization that was sweeping the post-1945 world, the eventual independence of the territories became inevitable. The idea of a federation appealed to the British Government because it offered a solution to the problem of obtaining most of the advantages of union while retaining the policy of native supremacy in the protectorates. It is now that for the first time Nyasaland was included into the scheme of union. South Rhodesians became reconciled to the idea because the British Government would not agree to a federation without. Nyasaland.

Unlike the Labour Government that had initiated the Federation talks, the Conservative Government that came into office in 1951 was more sympathetic to the settlers' aspirations and less concerned with the natives! rights. It pushed through the federation plan in september 1953 against almost universal African opposition in the two protectorates.

The Federal structure

As finally established, the Federation had four distinctive features. It proceeded to unite territories which even after federation continued to possess sharply different constitutional status. While internal administration in the two protectorates remained the Colonial office responsibility, the settler dominated Southern Rhodesia was completely self-governing. Secondly, the electoral $l a w$ and franchise qualifications were so laid down that Africans remained nearly excluded from the federal electorate. Thirdy, the distribution of powers between the federal and territorial governments was so arranged that matters primarily of settler interest were assigned to 
the centre while those primarily of African interest remained with the regional governments. But the exclusive and concurrent powers of the centre together were so sweeping in nature that the competence of the regional governments remained strictly limited. Lastly, certain safeguards were thrown into the constitution in order to ease the anxiety of the natives. The most important of these safeguards were the provisions that any amendments to the Constitution would require the assent of the British Government, and that the Constitution would be reviewed within ten years of its inauguration. ${ }^{2}$

The Working of the Federation

Dependent upon an almost white electorate, the federal government functioned primarily as a government for the settlers; of the settlers and by the settlers. Further, as Southern Rhodesia controlled three-quarters of the federal electorate, it treated the two protectorates almost as its dependencies. The federal government was run largely by south Rhodesians, the federal capital remained in that country, and Southern Rhodesia's less economic and more expensive projects were given preference over more reasonable projects elsewhere. While the government supported increased European immigration, little was done to improve the condition of the native African population.

As the Monckton Commission reported, the opposition to the Federation, which was strong at its establishment, gathered further strength by African disappointment with the manner of its operation. 3 It "accelerated the spread of militant African nationalism and gave it a single unifying goal to work for--the breakup of the hated federation with which settler aspirations to political supremacy seemed to be bound up". 4 During 1958-60 race relations deteriorated rapidly. Emergencies were declared in each of the three territories in 1959. African leaders were arrested, and a police state was

2

R. I. Watts, New Federations: Experiments in the Commonwealth, 3 Oxford: Clarendon Press, 1966, p. 32.

Report of the Advisory Commission on the Review of the Constitution of Rhodesia and Nyasaland (The Monckton Commission Report), London: Cmd. 1148/1960, para 41. See also 4 paras 27 and 49 .

R. L. Watts, op. cit., footnote 2, p. 33 . 
imposed on Nyasaland with the help of federal troops. The Monckton Commission which was appointed by the British Government as an advisory commission on the review of the constitution felt that the Federation could "not be maintained in its present form". Drastic constitutional reforms were recommended, but all this was too late now since constitutional advances in the two protectorates had brought into power African leaders who would have nothing to do with the "segregationist" Southern Rhodesian government. Late in 1962 Nyasaland was permitted by the British Government to secede from the Federation; and a year later when Northern Rhodesia also followed suit, the Federation was dissolved (December 31, 1963).

\section{THE GEOGRAPHY OF THE FEDERATION}

The geography of the Central African Federation may be viewed in two ways: from the viewpoint of the European settlers, and secondly from the viewpoint of the native Africans.

\section{The Settler Viewpoint}

As already noted, the settlers were the real architects and the real motive force behind the Federation. They were considered (or they considered themselves) as the only. civilized people in the territories; others were still extremely "primitive" with very thin prospects of evolving to that "civilized" stage. From this point of view (which had formed, the basis of the electoral laws), the effective population of the three territories was synonymous with the settler populations in them. Practically devoid of franchise, the native population did not matter in political calculations.

Looked at thus the Central African federation would appear as almost a natural response to a characteristically federal situation. The European settlers in the three territories believed that they were bound together by ties of "race", language, religion (Christianity), and "nationality". As they saw it, the crimson thread of unity ran through them al1. Economic factors also pulled them together. The settler population in all the three territories was primarily interested in cash crops, commerce and industry, while the subsistence occupations had remained an African preserve. While Northern Rhodesia's copper complemented the Southern Rhodesian coal, both seemed complementary to Nyasaland's tea and cotton. 
Whereas Southern and Northern Rhodesia needed large supplies of labour for their mining and other industries, Nyasaland possessed a surplus of this commodity. Then, in view of their small populations and their underdeveloped state of transport and communications, union offered a further economic advantage: if run jointly, their transport and communication services would be more economical and efficient.

While these factors urged them towards union, half a century of their separate administrative histories, their contrasting levels of political and constitutional advance, the great disparities in their effective sizes, and the long distances that separated them made a centralized unitary polity unsuited to their needs. Like a characteristically federal society they desired union without desiring complete unity. Thus a federation seemed to offer an ideal solution; though as their regional identities were not in serious conflict, it would have been natural for them to create a centralized rather than a peripheralized federation. 5

From the settler point of view therefore, the politicogeographic situation in Central Africa offered almost a classic case for federation. Because the settlers looked upon themselves as a. "people" surrounded by alien and/or potentially hostile elements--the Boer-dominated South Africa to their south and the alien (non-British) and/or black countries on other sides--their external political geography also seemed to provide a situation conducive to federation: they were isolated communities that in face of common threats were seeking strength in union.

\section{The African Viewpoint}

Seen from the viewpoint of the native African majority, the politico-geographic picture was just the reverse and the Federation appeared almost a complete monstrosity. Except for the fact that the native populations in each of the territories aspired for African self-rule, and that they all felt a sense of brotherhood in that they were all underprivileged sons of the soil who were ruled by the same imperial

5

The terms "centralized" and "peripheralized" federalism are discussed in W. H. Riker, Federalism: Origin, Operation, Significance, Boston: Little, Brown \& Co., 1964, pp. 5-10. 
power, there were few common interests and traditions that could bind them together. Their national aspirations were highly divergent. They had possessed no common historical traditions before the British imperialism was imposed. Even during the British rule they never developed a tradition of a common united administration. They were ruled as three separate units with their aivergent political institutions. Above all, the two protectorates where the colonial office rule had espoused a policy of paramountcy of the natives, were out and out against any union with the segregationist southern Rhodesia.

As later events only too clearly showed, the African leaders were quite justified in their apprehensions that under the then existing franchise laws the resultant federation was bound to be dominated by settler interests in southern. Rhodesia, and that the government would be run by and for the settlers at the expense of the natives. The natives had formed only two percent of the southern Rhodesian roll; there were only eleven African voters in Northern Rhodesia and none at all in Nyasaland in 1951.

Thus, as Patrick Fletcher, a South Rhodesian Minister is reported to have said after the Victoria Falls conference in 1951, the question of the Federation was a question between "governments" (and not between the peoples as a federation should essentially be). 6 The approval for the Federation by the Northern Rhodesia and Nyasaland legislatures "was of course a farce... the two Africans and their European colleagues representing native interests were just crying in the wilderness". 7 There were only nine representatives (six Africans and three Europeans) representing African interests in a Federal House of thirty-five.

\section{CONCLUSIONS}

1. The Monckton Commission strongly argued the economic case for the Federation. Its main arguments were that a common

6

Cited in H. Franklin, The Unholy Wedlock: The Failure of the Central African Federation, London: George Allen \& Unwin Ltd., 7 1963, p. 63 .

Franklin, op. cit., footnote 6, p. 79 . 
market is better than three separate markets; the Federation would be more credit-worthy than the units individually could be; and that the three territories had complementary economies which made a political union desirable. 8 But as Frankin puts it, even if these arguments were sound, they totally ignore that man does not live by bread alone. ${ }^{9}$ The economic arguments are, however, intrinsically somewhat deceptive. The common market argument ignores the fact that the territories had always possessed a common market before the Federation and could continue to do so even without it. A customs agreement had already existed even without a customs union. The creditworthiness of the Federation, which was evident in the beginning, soon dwindled up when the flow of foreign capital stopped in face of continued political instability in the Federation. As for the complementariness of territorial economies, Nyasaland labour had always flowed into the two other territories, and even after the Federation its products found the same outside markets as before.

As Hazlewood wrote, the economic interdependence of the three territories was not exceptionally great, nothing like so great as that between Britain and the independent Republic of Ireland: Hazlewood remarked that if Nyasaland tea is drunk in Southern Rhodesia, so is China tea in London, but that was

The economic argument for the Federation has been supported by Harm J. de Blij who thinks "The fact remains that federation is a sound objective in this part of Central Africa, and the tragedy is that the word and the concept are now associated with white supremacy, colonialism, and imperialism". H. J.de Blij (Ed.), systematic Political Geography, New York: John Wiley \& Sons, 1967, p. 462. A more complete support of this position is to be found in H. J. de Blij, "Forced wedding: Federation in the Rhodesias and Nyasaland", in Africa South, 9 Evanston: North-western University Press, 1962, pp. 292-350.

Franklin, op. cit., footnote 6, p. 160. The economic aspects of the Federation have, been studied by many scholars. of special note are A. Hazlewood and P. D, Henderson, Nyasaland: The Economics of Federation, oxford: Blackwell, $19 \overline{60 ;}$ Shirley Williams, Central Africa: The Economics of Inequality, London: Fabian Society, 1960; and the two chapters "Federation and the Central African Economy" and "Federation and the Distribution of Economic Benefits" by W. J. Barber in Colin Leys and Cranford Pratt (Eds.), A New Deal in Central Africa, London: Heinemann, 1960, pp. 59-97. An excellent summary is contained in Harry Franklin's chapter on "Economies of Federation", Franklin, op. cit., footnote 6, pp. 160-170. 
no argument to federate U. K. with China. 10 In fact the main economic interest in the Federation centred around the copper revenue of Northern Rhodesia. Southern Rhodesia received six and a half million pounds sterling of this revenue while Nyasaland received three and a half million--though neither of them contributed to the revenue of Northern Rhodesia itself. Thus in so far as Northern Rhodesia and Nyasaland were concerned, there were few or no clear gains in the Federation, apart from the monetary contribution to the latter.

2. The study of the Central African Federation offers us some valuable lessons in the role of effective size of constituent units in the functioning of a federal polity. The effective sizes of the three units under the central African Federation came to be determined by the size of their electorates and the number of seats they held in the central legislature. In view of the extremely restricted franchise, the size of the federal electorate depended upon the size of the settler population in each territory. This made the predominance of Southern Rhodesia in the federal parliament inevitable. While the percentage breakup of the total population in the three territories was: Southern. Rhodesia 34, Northern Rhodesia 30 , and Nyasaland 36 ; the distribution of the federal electorate between them was. 75,23 , and 2 percent respectively. Thus, while Nyasaland had a total population greater than southern Rhodesia, her share in the federal electorate was only onefiftieth as against Southern Rhodesia's share of three-quarters of the total electorate. This explains why despite her poverty Nyasaland shunned the three and a half million pounds of annual revenue and seceded from the Federation.

In fact the Central African Federation violated one of the primary rules of federalism, i. e., in a federation "there should not be one state so much more powerful than the rest as to be capable of vying in strength with many [or all] of them combined. If there be such a one and only one, it will insist on being the master of the joint deliberations. . ." and thereby vitiate the partnership by turning the other

10

A. Hazlewood, in The Listener, December 1961 . 
components as its dependencies. ${ }^{1}$ with the control of the three-quarters of the federal electorate, southern Rhodesia proved such a unit in the Central African Federation.

3. So long as the African masses remained inarticulate, the Federation was naturally run by and for the South Rhodesian settlers. But when constitutional changes in the protectorates made the so far "dumb" native people articulate by raising them to the "civilized" level through the grant of franchise in their territorial matters, change in the effective sizes of the constituent units of the Federation became imminent, for the federal electorate could not be restricted to the settler population alone. This threatened to cut South Rhodesia to size. For the settler population in Southern Rhodesia it also raised the alarming prospect that the continued partnership in the Federation might in time mean the grant of similar concessions to its own native population. This would destroy the very basis of their "racial". supremacy. Hence, the south Rhodesian willingness to maintain the federal partnership also disappeared.

It would appear that the Central African Federation violated another essential condition for a stable federalism, i. e., the units involved in a federation should possess mutual sympathy for one another. As Mill says, a federation binds its constituents "always to fight on the same side; and if they have such feelings towards one another, or such diversity of feeling towards their neighbours, that they would generally fight on the opposite side, the federal tie is neither likely to be of long duration, not [nor?] to be well observed while it subsists". 12 As already noted, the sympathies and fears of the constituents in the Central African Federation were conflicting. The union, in fact, did not have any basis for cohesion; its failure was, therefore, inevitable.

4. Finally, contrary to what a political scientist may think, the Central African. Federation was not "proposed on purely

11

J. S. Mill, Utilitarianism, Liberty, and Representative Government, Everyman's Library, London: J. M. Dent, 1947, 12 pp. 367-368.

Mill, op. cit., footnote 11, pp. 366-367. 
geographic grounds", at least as a geographer would see it. 13 The primary misconception in the Federation plan was that it tried to square unity with diversity in an area where the major diversities rather than having any inclusive territorial base, traversed the whole society in the form of "racial" or communal conflict. The essential politico-geographic base of the society was therefore plural rather than federal, for we have seen that federalism becomes nothing if it is required to cope with diversities that are not territorially based.

13 Riker, op. cit., footnote 5, p. 33. 


\title{
FEDERATIONS THAT FAILED DESPITE THEIR
}

\author{
POTENTIALIY FEDERAL BASES
}

\section{INDONESIA}

Although federalism was a fleeting phase in the political development of Indonesia, a movement which started after the Second World War and was eclipsed soon after the Dutch left, still the reasons for its failure provide an.interesting and rewarding study in the origins and stability of federalism.

\section{HISTORICAL BACKGROUND}

Even before Dutch rule was imposed over the whole of the Indonesian realm, much of archipelago was occasionally united for short periods of time when some power strong enough to subjugate others arose in the area. Two important periods of unification were the sri Vijaya Kingdom (centred on south Sumatra) in the seventh century A. D. and the Majapahit Empire (based on eastern Java) of the fourteenth century A. D. But the periods of unification were always ${ }_{\wedge}$ comparatively short, and came only after very long intervals, since the forces of physical geography were too strong to be overcome by the rudimentary technology of the times.

The general picture of regional fragmentation did not change materially even under the Dutch for quite a long time, because the Dutch East. India Company was primarily interested in the spice-trade and the establishment of its monopoly in the trade of the south-east Asian region. When the Dutch government assumed direct responsibility for the administration of the area in 1798, much of the old emphasis and the general pattern of the company rule remained, and the country continued to be run almost like a business concern till 1870. Even the later Liberal and Ethical policies made no very significant changes in the general pattern of regional separation or fragmentation. The Dutch left the indigenous political institutions almost untouched and for a long time did not make large scale attempts at integrating their territorial dominion. They pursued a policy of concentration--i. e., concentrating 
upon development of the more important areas, especially Java and later south sumatra, and confining developmental activity in outer areas to the minimum needed to assert control. Hence local particularisms were not welded together. The primarily "indirect" Dutch rule did not favour an integrated evolution of the entire realm. Even later when all the land was declared the property of the crown, the indigenous population in the different islands was "left the enjoyment of its own administration of justice". 1

As there was only a very small western-educated élite, the nationalistic bonds born from a common education through a common medium were also largely absent, though, as Leslie Palmier says, because the most of the population was "blind", "The unseeing peasants followed the few with sight". 2 Thus, only a sort of superficial unity for the limited purpose of freedom from colonial rule existed in the pre-independence Indonesia. And when this purpose seemed to have been achieved with: the departure of the Dutch and the achievement of MERKE (freedom), divisive forces began to gain strength.

As C. D. Cowan has analyzed, though the pre-war Dutch regime had imposed its administration over the archipelago, it had failed to create a state or a nation there. The Dutch policies were "inspired and sanctioned from outside; they did not rest on the demand or consent of the governed". The result was that "Before 1949 the peoples of the archipelago had never been united in one... state". ${ }^{3}$

POLITICO-GEOGRAPHIC FACTORS IN THE RISE OF THE FEDERATION

\section{Factors for Regional Identities}

The fundamental Indonesian problem springs from its

$\overline{1}$

Article 130 of the Indies Constitution; cited in A. A. l.c. Schiller, The Formation of Federal Indonesia, The Hauge: 2 W. Yan Hoeve Ltd., 1955, p. 1 .

L. Palmier, Indonesia, London: Thames \& Hudson Ltd., 1965, p. 89.

3

C. D. Cowan, "The Political Evolution of Indonesia", in S. Rose (Ed.), politics in Southern Asia, London: Macmillan Co., 1963, p. 236. 
physical geographic fragmentation. Because the country straddles the world's largest archipelago, it has to battle with "geography" to maintain itself. ${ }^{4}$ Its geographic dispersal has conferred on Indonesia a large number of regional diversities. While on the one hand there is a wide gap in the stages of cultural evolution between Java and the outer islands, on the other their densities of population are also highly dissimilar--ranging from 1,168 per square mile in Java and Madura to a mere 18 in Indonesian Borneo and 8 in West Irian. If $B a l i$ and Lombok are grouped with Java, we find seventy percent of the country's population concentrated in less than seven percent of its area. This contrast has helped further to accentuate the manifold local rivalries which are almost inevitable in such a large and dispersed area. The degree of Indonesia's geographic fragmentation will be appreciated if we remember that its outer limits are separated by over 2,500 miles from east to west, and 1,250 miles from north to south--comparable to distances between the west coast of Ireland to the south shore of the Caspian, or from portland (oregon) to the Bermudas. Indonesia consists of some 3,000 inhabited and uninhabited islands of various sizes and resources; the country's population includes speakers of at least 25 different languages and nearly 250 lesser dialects. Because of the country's great dispersal and the negative tracts of uninhabitable swamps and uplands "the mingling and subsequent evolution of peoples and cultures have proceeded more or less independently in a whole series of separate centres, in each of which the several ingredients have been present in varying proportions and have combined in different ways". 5 Thus, physical and human geography have jointly fostered the rise of strong regional identities in Indonesia, which the Dutch rule left almost untouched.

4

Herbert Feith, "Indonesia" in George MCT. Kahin (Ed.), Government and Politics in Southeast Asia, Ithaca, N. Y. : 5 Cornell University Press, 1961, p. 155 .

Charles A. Fisher, South-east Asia: A Social, Economic and Political Geography, London: Mehtuen \& Co., 1964, p. 238 . 
Then the Indonesian islands generally lack any significant degree of economic mutuality, except of course Java's dependence, on account of its heavily concentrated population, on the surplus produce of the other Indonesian territories. Java's predominant size has further added to the sense of regional autonomy--i. e., the desire for a federation rather than a unitary organization of government. Furthermore, because the different islands were "left the enjoyment of . . . [their] own administration of justice", the archipelago was almost naturally divided into what Arthur schiller calls different "law areas". 6 This only further increased the urge for regional autonomy.

\section{Factors for Indonesian Unity}

Although the Dutch did not "create a state or a nation", still we know that, once established, political frontiers have a tendency to create national consciousness. Thus the Dutch administration, by bringing the different island regions together into a single political unit, helped to develop in the peoples "a consciousness of kind" by joining the archipelago's many patriotisms together into an all-embracing nationalism which opened up "one great channel . . . into which the countless little currents of local dissatisfaction could merge and maintain themselves in collectivity rather than dissipate themselves in the sands of their own isolated parochialism". 7

Although the nature and extent of the Majapahit Empire are often exaggerated, the memory of this glorious past was. very important, at least at the level of the élite, in the development of that community pride on which nationalism often feeds. The sense of community was greatly enhanced because of the fact that 90 percent of the people of the islands follow Islam. The religious unity acted as an in-group symbol against an alien power of a different religion. This overall religious unity coupled with the development of bazaar Malay as a strong link language between the island communities served

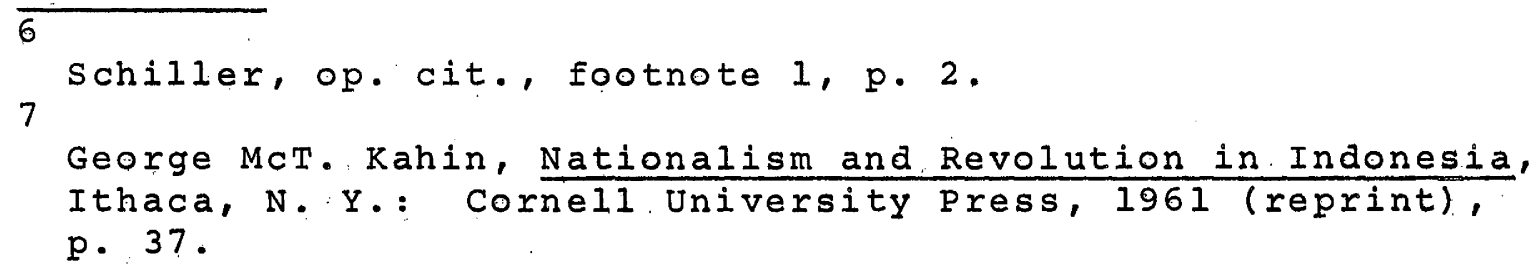


to break down parochial tendencies. The Dutch had discouraged use of the Dutch language by the native people, and had themselves frequently used Malay for administrative purposes. As a critic says, in discouraging the wide-spread use of the Dutch language, the Dutch thought that they were "forging a chain for their subjects, but they see now that they have given him a weapon, that terrible psychological weapon, a common national language with which to express their common national aspirations".8

Besides, there was the Volksraad, the top representative council for the whole of Indonesia. Although its representative character was almost a facade and its powers "not of consequence", still "In bringing together Indonesians from the various parts of the archipelago and making them more aware of their common problems and common relationships with the Dutch, this body tended to develop in them a more conscious unity . . ". 9 A further contributing factor was the increased geographical mobility of people and ideas as a result of the twentieth-century pattern of economic organization, the interisland recruitment of labour to work on farms and factories, and the development of transport and communications.

From the above summary of the politico-geographic circumstances of Indonesia at the time of departure of the Dutch, it would appear that there were sufficiently strong forces for unity and separation in the country to present a characteristic situation for the rise of a federation. In this sense, the views of writers like Kahin and schiller "that the opposition to the federal state of Indonesia was largely due to the fact that it was 'Dutch inspired! or 'Dutch imposed' rather than because of any intrinsic merit in the plan" would appear correct. 10 But as schiller agrees, there is also another view of some sound and unbiassed scholars who think that the idea of a federal state for Indonesia was artificial, and did not arise from spontaneous desires of the

\section{8}

G. H. Bousquet, A French View of Netherlands Indies,

translated from French by $P_{0}$ E。 Lilienthal, London:

9

Oxford University Press, 1940, p. 89.

10

Kahin, op. cit., footnote 7, p. 39 .

Schiller, op. cit., footnote 1, p. 9. 
regional governments (or their peoples) to federate with one another.

It is immaterial for the purposes of this study whether the proposal for federation by the Dutch was little more than a subterfuge, and that the Dutch had created puppet states so that by a policy of divide and rule they could forestall an independent Indonesia, as the Republic Indonesia delegation at the U. N。O. alleged, and as writers like Wolf and Kahin think. ${ }^{11}$ But it is important to examine whether or not there was "any intrinsic merit in the plan".

\section{MERITS AND DEMERITS OF THE PLAN FOR}

\section{INDONESIAN FEDERATION}

Although we do not question the desirability of union of the Indonesian realm as a single viable political community, in the paragraphs that follow we propose to indulge into a purely academic exercise in examining the feasibility and desirability of federalism in Indonesia in 1949.

1. As the foregoing discussion would show, regional identities in Indonesia were very strong--sometimes exclusive. Because of the extremely disparate size of Java's population, twice that of all other Indonesian territories combined, there was, it is believed, a strong desire on the part of other territories to remain separate or, at any rate, to seek guarantees for their regional autonomy. The imbalance between population and resources in Java gave cause for concern among the lesser territories of their eventual exploitation in a union dominated by Java. There would seem to have been almost a complete absence of what Riker would term, the "willingness to bargain". because most of the territories, other than Java, had little expectations of economic benefits from union either among themselves or with Java. Java of course, because of its small resource-base compared to its large population, found everything to its advantage in union. But for two reasons a genuine need or urge for bargain was absent on the part of Java. First, other than its human numbers the island had little to offer

Charles Wolf Jr., The Indonesian Story: The Birth, Growth and structure of the Indonesian Republic, New York: 1948, p. 109. George McT. Kahin, "Indirect Rule in East Indonesia", Pacific Affairs, Vol. 22, 1949, pp. 227-238. 
the other components of Indonesia; and secondly, because of its overwhelming position in the group--its individual strength being double the strength of all other constituents combined--it felt no compulsion to bargain. The economic argument against the Federation would be clear if we remember that in 1955-56 approximately 71 percent of Indonesia's foreign exchange earnings came from sumatra and 17 percent from the other outer areas, yet over 80 percent of these earnings was spent on purchasing consumer and capital goods, food and raw materials, for the population of Java. ${ }^{12}$

Viewed in this light, it would appear that there indeed was an absence of any intrinsic merit in the plan for the Indonesian Federation. But as writers have often failed to point out, this intrinsic defect lay in the highly unequal distribution of power among the component units of the union. With two-thirds of the total population of the Union, Java was a virtual colossus compared to the other members who were mere pigmies. In fact, though the Indonesian units possessed clearly identifiable regional personalities, because of the extremely disparate sizes of the units involved, the Indonesian situation was conducive to what may be termed a "hegemonial alliance" rather than a federal union. Java, therefore, violated one of the primary rules of federalism, i. e., in a federation "there should not be one state so much more powerful than the rest as to be capable of vying in strength with many [or all] of them combined". 13

Furthermore, unlike Jamaica and Trinidad in the west Indies Federation, Java had no fear of being required to pay for union with territories poorer than herself. In every way Java had only to gain. And the stronger the grip over the union, the greater the possible benefits. A unitary government was therefore the best solution to Java's objective. But to say that the federal plan had an intrinsic defect is not to say that the unitary plan was better suited. In view of the peculiar politico-geographic pattern of the archipelago,

12 13

Figures from Fisher, op. cit., footnote 5, p. 377.

J S: Mill, Utilitarianism, Liberty, and Representative Government, London: Everyman!s Library, J。M。Dent, 1947 reprint, pp. 367-68. 
some kind of marriage between the two principles of governmental organization--federal and unitary--would have been more desirable.

2. Charles fisher describes the federal Republic of the United states of Indonesia as "clearly a politico-geographical monstrosity". The main basis for his remarks is that

In status the daerahs, all but one of which contained less than one million inhabitants each, were inferior to negaras whose population ranged from 1.5 million (south sumatra) to 31 million of the Republic of. Indonesia... Yet all these sixteen oddly assorted units were to have equal representation in the senate, and even in the lower house the Djokjakarta Republic was allotted only one third of the Representatives although it contained nearly half of the total population. 14

In fact this smaller representation than the sheer weight of population would warrant, should have been taken as a condition for the bargaining that a federal union always involves. As for the charge that none of the sixteen units had any linguistic or historical validity, it may be said that the people's representatives could resolve that problem by mutual consent and redraw or modify the colonial boundaries as was done in. India. Nevertheless, one wonders if many people living in the islands other than Java do not consider it a politico-geographical monstrosity that a region which earns only about a fifth of the nation's foreign exchange eats up almost four-fifths of the total national earnings in that respect. One can imagine what a sumatran might think if he were told that in. India even on such small matters as the location of an oil refinery slogans are raised that "Assam is being bled for Bengal". 15

To conclude, the politico-geographic situation in Indonesia in 1949 was federal in the sense that it consisted of a number of regionally grouped communities that while desiring union did not desire (complete) unity; an attitude which, Dicey said, is fundamental to the rise of the sentiment for federalism. Indonesia, however, possessed one great defect which made the situation more conducive to a hegemonial 15

Fisher, op. cit., footnote 5, pp. 362-63.

See Pran Chopra, Uncertain India, Bombay: Asia Publishing House, 1968, p. $2 \overline{13}$. 
alliance rather than a federation which is essentially a union of equal partners. Like Prussia in the Bismarckian and Weimar Germany, Java in Indonesia dwarfed the other constituents and made a normal federal articulation impossible. Besides, not being rich enough to feed its own population, Java, unlike Prussia, found a greater bargain in a unitary rather than a federal organization of state. With its overwhelming size in the union Java was in a position to do whatever it chose; and because it chose the less cumbersome unitary organization, federalism died almost an instant death.

\section{PAKISTAN}

Ever since the birth of Pakistan in 1947, the political institutions in the country "Despite their federal form, in practice were worked in a highly centralized and essentially unitary manner". 1 There has all through been "a tendency to give an authoritarian tinge to all..[political] institutions" in the country. 2 : As Governor-General, Jinnah, the founding father of Pakistan, extensively used the emergency powers of the office and made himself the real ruler of the country. The premiership never recovered from this invasion, and after 1953 these were "virtually two authorities striving for the seat of power. Since there was no parliament worth the name to sustain the premiers, the cromwellian solution of army rule became inevitable". ${ }^{3}$ The head of the defence services, General Ayub Khan, took the reins of power in 1958, and after nearly four years of "no Constitution at all" the country received from the hands of the General her presently suspended Constitution in 1962. An English historian thinks that "Pakistani nationalism as a ruling passion is at present a hope rather than a motivating force", and adds that "The wonder is that the country lacking a general will strong enough to sustain an effective [united] authority has survived"

1

R. L. Watts, New Federations: Experiments in the Commonwealth, Oxford: Clarendon Press, 1966, p. 349.

2

Percival Spear, "The Political Evolution of Pakistan etc." in $S$. Rose (Ed.), Politics in Southern Asia, London:

3 Macmillan Co., 1963, p. 47.

Spear, op. cit., footnote 2 , pp. 33-34. 
even though under a military regime. ${ }^{4}$

\section{HISTORICAL BACKGROUND}

Despite such confusing phrases as "four thousand years of civilization in Pakistan", the political history of Pakistan begins from 1947 when the British at the insiptence of the Muslim League agreed to divide India before quitting it. 5 The Pakistan movement was itself launched for the first time only in 1935. Comprised of the two widely separated portions of the former British India, Pakistan was "launched with little [united] administrative or official inheritance and with none of the mystique of the old state [in union] whether of foreign or indigenous origin". 6 Devoid of any very solid foundation--material or emotional--to build upon, the nation had to derive its strength from the separatist movement that gave it birth.

After its independence and inauguration pakistan, like India, started with the 1935 pseudo-federal Constitutional Act, though power remained highly centralized under the Governor-Genéral (Jinnah). When Jinnah died and Liaquat Ali Khan was assassinated, no all-Pakistan leader of significance was left to control the reins of power. From 1951 to 1953 the country drifted towards impotence and disruption. As no agreement could be reached on the balance between East and West pakistan, the draft Constitution made little progress.

When a draft constitution was approved by the constituent Assembly in september 1954, and the Assembly began enacting laws to curtail the powers of the Governor-General, the latter dismissed the Assembly. Shortly after a new Assembly was chosen. (July 1955) and the four Provinces of the west were

4 5

spear, op. cit., footnote 2, p. 47 .

The evolution of Pakistan and the problems and prospects of the nation as they looked at the time of its birth have been presented in $O$. H. K. Spate's articles "Geographical Aspects of the Pakistan Scheme", Geographical Journal, Vo1. 102, 1943, pp. 125-133, and "The partition of India and Prospects of Pakistan", Geographical Review, Vol. 38 , 6 1947 , pp. 5-29.

spear, op. cit., footnote 2, p. 33. 


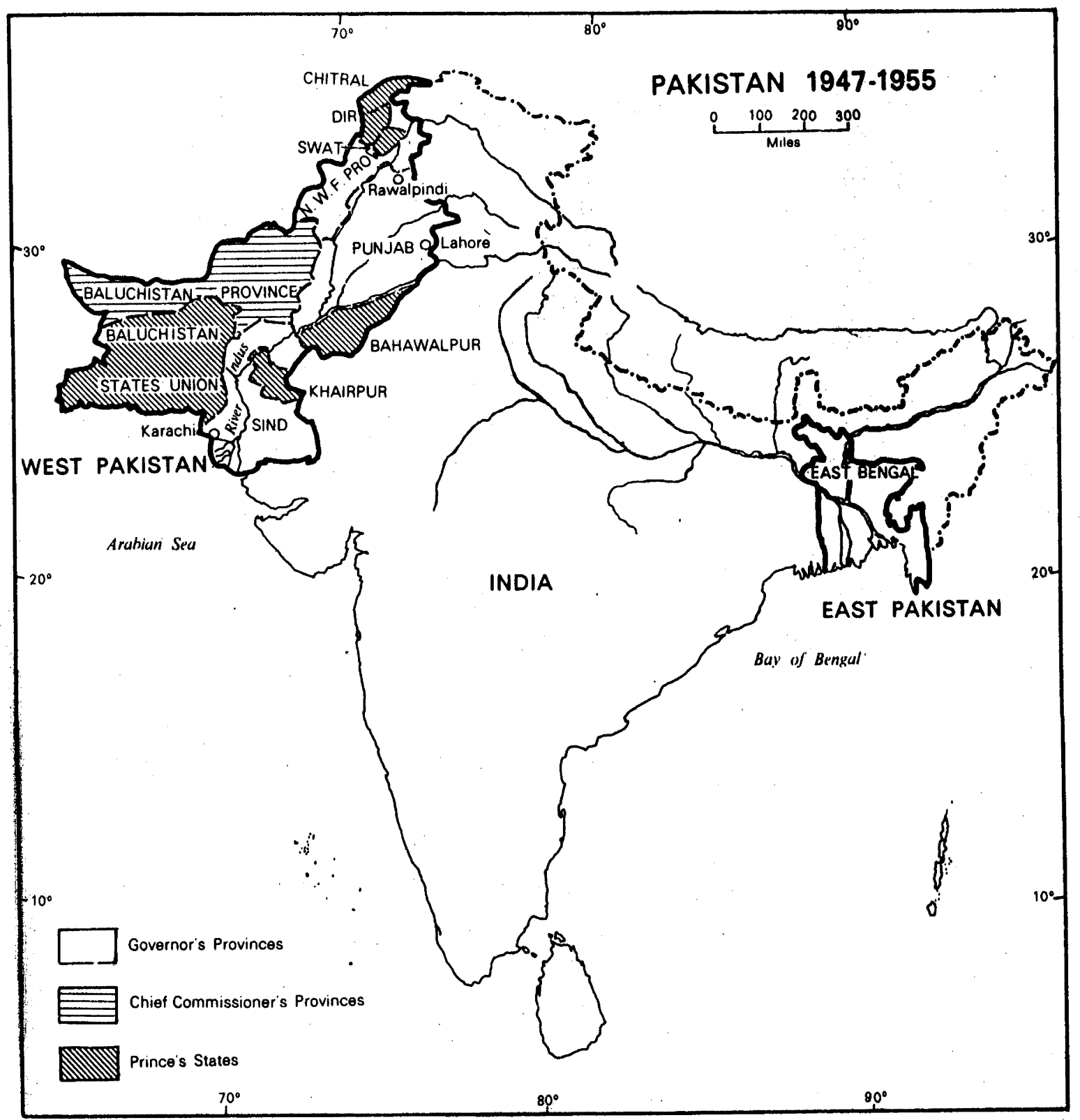

Fig. 9.1 PAKISTAN 1947-1955. 
merged together to balance the solid weight of East Pakistan. A new Constitution was proclaimed in March 1956 when the Governor-General assumed the new title of president, and the Constituent Assembly was renamed the National Assembly. Instability in the country continued, however. From March 1956 to October 1958 there were four Prime Ministers--Chaudhri Muhammad Ali, Suharawardy, Chundrigar, and Firoz Khan Noon. The President exercised considerable authority both in politics as well administration. General elections were promised for 1958 but were postponed until 1959. In the meantime president Mirza prounifed a coup d'etat and called the Army to assume power. The commander-in-Chief, General Ayub Khan, became the Prime Minister and three weeks later ousted Mirza and became himself the president. The assembly was dismissed, the constitution abrogated, and all political parties were banned.

After four years of complete military rule, a new Constitution was proclaimed by Ayub Khan in March 1962 which came in force in June the same year. The new constitution made the central government what Chaudhri Muhammad Ali called a government of the president, by the president, and for the President. 7 By granting very extensive powers to the President, and curtailing those of the provinces, the Constitution made "the federal character of . . [Pakistan] legally little more than a façade". 8 sayeed finds it "difficult to describe Pakistani federalism as even quasifederal" for "the provinces are expected to function as mere administrative agencies very much like local governments in a unitary state". 9 It is said that

President Ayub's regime can be compared to the British viceregal system which existed in India during the thirties and forties of this century. Viceroys, like Ayub, also had a legislative assembly which they could control through their powers of certification of the budget and other legislative measures essential for the safety, tranquilitty, or inertness of British India.

7

Dawn, April 2, 1963;

8 of Pakistan, Boston: Houghton Miffiin Co., 1967, p. 105. 9 Watts, op. cit., footnote 1, pp. 239-240.

sayeed, op. cit., footnote 7, p. 111. 
Like Ayub, they were also faced with opposition from political forces, but like Ayub they could often keep them under control with the help of the military and police power.10

This viceregal system has aptly been called "constitutional autocracy".

After his ten years of absolute rule, the Army has pensioned off the viceroy, and another Commander-in-chief has assumed the Presidential powers.

\section{FACTORS IN THE RISE OF FEDERALISM}

Forces Giving Rise to separate Identities

Pakistan presents an extreme example of a "fragmented" state. The two "wings" of the country sit one thousand miles apart on the shoulders of India, with which her relations have not been cordial. The sheer geographical distance between the two parts is enough to foster in them a strong sense of separateness. Pakistan is indeed a duality. It can be described in terms of two of everything. Whereas the Eastern.wing far exceeds the west in total population, the West is six times the area of the East. The two do not even share common neighbours, except of course India. While West Pakistan stands in a continuous belt with the traditional Islamic homeland of South-West Asia, East Pakistan (East Bengal), bordered by India and Burma, looks more closely to the other part of Bengal in India (with which even till the last some of its leaders were reluctant to part company), and finds itself in many respect alien to the desert culture of Islam and its Arabic-Persian linguistic complex--her own language being highly sanskritic。

The two "wings" are unconnected with a body. The only apparent binding cord between the two is the thread of Islam. The two parts are not fed by common arteries. Their geographical circumstances are also highly dissimilar. One is dry, the other wet. East Pakistan mostly consists of the great deltaic plain. Rainfall is copious, and except for a small area along. Assam and the border area with Burma, most of the surface is less than 50 feet above sea-level.

10

sayeed, op.cit., footnote 7, pp. 101-102. 
The whole of the province presents a flat and closely cultivated watery landscape.

Rivers are the chief means of transport in the Province。 Engaged in a continuous process of creating land, the rivers are frequently changing their courses. This makes the development of land transport difficult. In this region, made essentially of mud, road-metals and ballast are nonexistent. Much of East Pakistan is therefore difficult of access and out of touch with the outside world. ll Despite its dense population, the province is essentially rural. Towns, mostly market centres, are few in number and, apart from Dacca, small in size.

Against this, west Pakistan is sub-tropical, dry, and in parts harshly arid. Unlike East Pakistan, it is not a homogeneous compact bloc. It includes the snowy mountainous

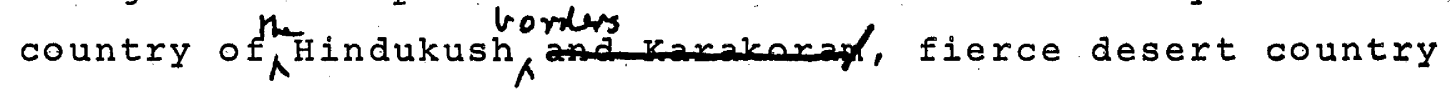
in Sind and Baluchistan, and the potwar plateau on the borders of Kashmir between the Indus and. Jhelum rimmed to the east and south by the escarpments of the salt Range with an average height of 3000 . feet. South and east from Potwar lies the Punjab-sind plain which forms a continuous belt with the rest of the Indo-Ganga flatness. While because of its more dependable rainfall and the close net of canals, cultivation is general in Punjab, in the rest of the plain arid and semi-arid conditions prevail. It is, indeed, a far cry from the humid and green East Bengal to the dry and almost desert Baluchistan. This contrast in the physical. geographical personalities of the two "wings" has led to. contrast in their human geographical personalities as well.

The people of the two wings of pakistan are predominantly Muslim, but beyond that they are ethnically very diverse. Western Pakistan is predominantly scytho-Aryan, while Bengalis are Dravido-Mongoloid. There is great ethnic diversity. among the people of the Western wing itself. The people have their own regional languages spoken in well-defined areas. Important among these are Punjabi, Pushtu, Baluchi, sindhi, and Then, while the languages of Western

11

Ian Stephens, Pakistan, London: Ernest Benn Ltdo, 1963, p. 39 . 
Pakistan lean heavily on Arabic and Persian, Bengali is primarily sanskritic. Because of their largely common sources in Arabic and Persian, the west Pakistani languages are often mutually intelligible to some extent; but there is nearly a complete linguistic barrier between the East and West. Urdu serves as an effective link language in the West, but it is not easily acceptable to the East.

Further, Bengalis are supremely conscious of their distinct identity. They believe that "they are neither Aryans nor Arabs". 12 "Bengalis feel that the land in which they live and the language they speak have together given them a uniqueness which... [is not] shared by ... the descendants of Arabs and Mughals who live in west Pakistan". 13 "Bengali culture" even though moulded by the dominant influence of Bengali Hindus, had possessed certain clearly secular strands in it. Even during the time of Partition in 1947 there were a few influential Bengali Muslim leaders like suhrawardy who seriously considered the establishment of a united and separate Bengal. Even as late as 1954 the East Pakistani Chief Minister Fazlul Haq said that he "would not take notice of the fact that there was a political division of the Province of Bengal into East and West Bengal."14 East Pakistani leaders and university students do not attach as great an importance to Islam as a bond of unity between East and West Pakistan as West Pakistani leaders and university students do; "This suggests that the élite political culture in East Pakistan differs from that of West Pakistan". 15 As an East Pakistani newspaper has often pointed out, although Islam was the main source of inspiration that united East and West Pakistani Muslims in the forties, in the sixties this integrating force has

\section{$\overline{12}$}

Shamsuddin Abul Kalam, "Social Questions in Bengali Fiction" in S. Sajjad Husain (Ed.), Dacca University Seminar on Contemporary Writings in East Pakistan, Dacca: Dacca 13 14 University, 1958, p. 60 .

sayeed, op. cit., footnote. 7, p. 185. 15

Reported in Statesman, Calcutta, May 10, 1954.

sayeed, op. cit., footnote 7, p. 188 . 
been replaced by the utilitarian economic cleavage. ${ }^{16}$

The two wings of Pakistan possess almost completely separate economies. Because of the great physical distance that separates them, there is practically no mobility of labour. Mobility of goods is also extremely difficult. It takes seven days to move goods from one Province to the other. In East Pakistan cement imported from Yugoslavia is cheaper than that from Karachi. As The Pakistan Observer noted, since West pakistani industries have been operating behind protective tariff walls, East Pakistan has been purchasing West Pakistani goods at higher prices than it would have paid for the same goods if they had been purchased abroad. 17 Besides the great barriers that stand between the East and West, there are a number of regionally based diversities in the western wing itself. Before the whole of the west was merged into one to create a single unit, most of these regionally identifiable ethnic groups in the west had possessed somewhat clearly identifiable political areas. The strength of this federalizing force is clear especially with regard to the Pathans, who like the Bengalis form a very cohesive group and are "conscious of belonging to a separate race and possessing a separate culture symbolized by pakhtun wali (tribal code of honour)."18 Indeed the demand is strong for a separate state called Pakhtunistan that would include all the pushtu-speaking areas--the tribal areas in the northwest, the former North West Frontier Province, and parts of Baluchistan. Other linguistic areas also greatly resent the so-called Punjabi domination under the one-unit

16

The Pakistan Observer, November 10 and 13, 1967; cited 17 in sayeed, op. cit., footnote 7, p. 188 .

The Pakistan Observer, editorial: "The Perils of Industrialization I", April 30, 1965. See also Economic Disparities Between East and West Pakistan, Dacca: East Pakistan Government Press, 1963, pp. 28-29, cited in sayeed, 18 op. cit., footnote 7, p. 199.

Sayeed, op. cit., footnote 7, p. 186. See also K. B. Sayeed, Pathan Regionalism, Reprint No. 13, Duke University Commonwealth studies Centre, 1964. As percival spear, op. cit., footnote 2 , p. 40 , says "The Punjabi, the Pathan, the sindhi and the Bengali has each in his mind's eye 'an emerald isle, set in the silver sea, a demi-paradise'". 
scheme, and demand their regional autonomy. The new military administration has promised advances in this direction though the exact nature of these cannot be known until a popularly elected government comes into office.

\section{Forces for Unity}

Despite all the diversities that separate East and West Pakistan, there definitely were some strong, binding factors that pulled the two widely apart regions together into a single state. After the Pakistan Resolution of the Muslim League in 1940, Islam became the only identifying feature for the majority of Muslims in the undivided India. Howsoever great the differences between the East Bengalis and other Muslims in the west, they recognized a separate identity from the Hindus, and to that extent were one. on the question of Hindus versus Muslims their feelings were exploited by the Muslim League, and on that question they were prepared to rise and fall together. But once this separate identity was granted, the sentiment for unity born out of the consciousness of religious brotherhood was numbed and "other purposes" began to stir them. Though at the level of the common man. Islam versus Hinduism continued as a uniting force between the two wings of Pakistan, frequent observations of responsible East Pakistanis would show that it has for quite some time been progressively receding in strength.

Once the Partition was effected and Pakistan became a reality, another strong factor for unity was born. This was the fear of a big neighbour (India) fed upon the hatred of Hinduism and the bitter memories of the partition. Now the two sections had to unite in order to retain any semblance of strength. Pakistan in this sense is, indeed, a very extraordinary country. Few others in the modern world can be said to have been created to embody a belief, or a doctrine or a theory. ${ }^{19}$ However, although a powerful force for union, fear is not satisfactory as the sole ingredient of national cement.

Arnold Toynbee describes Pakistan as a child of encounter 19 Stephens, op. cit., footnote 11, p. 13. 
and strife that has arisen from the impact of Islam upon Hinduism. Though "If in Pakistan political allegiance were to be decided on lines of race or language, Pakistan would immediately fall to pieces... [A] common adherence to Islam proved a stronger spiritual force among Pakistani Muslims than the differences which otherwise might have been disruptive". 20

The above analysis should make it clear that pakistan soon after its birth did possess regionally grouped political communities with strong, regional identities. The communities desired union but not complete unity. Hence a federal situation of a sort was present. But a closer look would reveal that the characteristic balance between the forces of unity and separation that is the essence of federalism was absent. The forces for separation were stronger than those for cohesion, at least in so far as the two wings were separately concerned. The sentiment for unity based solely on religion was quite fragile and limited. The situation was, in fact, confederal rather than federal. The two wings could set up a common court of consultation (i. e., some kind of alliance) but not a truly half-way house that a federation is.

In west pakistan, however, where now a single unitary government exists, a characteristic federal situation would seem to have existed. But while a unitary government was imposed in the west, the two "wings" were joined together under a form of government whose "federal character . . . [was] little more than a façade". The natural results of this unnatural creation are that "Unlike the federal system of the United States or Australia the sense of common nationality is getting weaker in Pakistan". 21

\section{CONCLUSIONS}

1. Like most other federations Pakistan also was born under

\section{0}

Arnold J. Toynbee, "Pakistan as an Historian sees Her" in Crescent and Green: A miscellany of Writings on Pakistan, 21 London: Cassell \& Co., 1955, p. 2.

G. W. Choudhury, Democracy in Pakistan, Dacca: Green Book House, 1963, p. 225 . 
a possible military threat, in this case from the predominantly non-Muslim India. The very basis of Pakistan's nationhood was the fear and hatred of Hindus. So it was natural for Pakistani leaders to play upon the fear of India when the enthusiasm for the "new paradise" was fresh. Since throughout Pakistan's existence over the past two decades relations with India have remained tense, the two wings remained strongly united despite unsatisfactory conditions within the country. Thus in Pakistan also live political frontiers seem to have fostered stability and unity. A comparison with the west Indies would show the vital importance of military threat, actual or assumed, in the rise and survival of some federations.

2. The Pakistani example is also a good reminder of the fact that superficial external threat or a temporary sense of unity born from allegiance to a common religious faith etc. are not sufficient factors for the national cohesion that a continued federal unity and stability demands. The essence of federalism is that the partners involved in the union should feel that they are better within than without the federation. For this it is necessary that the units in general benefit economically and politically from this partnership, that is, the federation should help the units to tide over certain of their urgent economic and other problems that they are not able to do in isolation. A study of Pakistan's economic development since its inauguration would show that in so far as East Pakistan is concerned, the Federation has failed to offer adequate dividends. 22 The result is that even after eighteen years of Pakistan's existence, and despite the quasi-viceregal regime of Ayub Khan, the East Pakistani Finance Minister said in 1965 that "it would be unfair to expect that our spiritual bond through Islam will be so strong that we shall forget our economic disparities and will still remain united and unified as a nation". 23 As in most other human affairs, in federalism too, the breadand-butter questions remain of vital importance.

\section{2}

See appendix to this chapter for a brief note on disparities between the two wings of Pakistan. 23

Moring News, July 1, 1965; cited in sayeed, op. Cito, footnote 7, p. 188 。 
3. Pakistan presents an interesting case study in the role of size in the rise and working of federalism. While the eastern wing is just over one-sixth of West Pakistan in area, it considerably exceeds the west in total population. Under normal conditions, when population is backed by resources, granted the degree of disparity in the relative size of the populations of the diverse units involved in the union in 1947, a federal union of the normal type would not have been possible because East Bengal; standing as a single unit with more population than all the different units in the west combined, would have become a paramount partner in the unit. And, as J. S. Mill said, in a federation there should not be one unit so much more powerful than the rest as to be capable of vying in strength with many or all of them combined. Thus, on the face of it, the situation was at best confederal rather than federal.

But two factors acted against East Bengal and reduced its effective weight in the Federation. First, to the East Bengali mind, West pakistan, despite its political fragmentation, presented a compact urdu-speaking bloc (even though Urdu is not the native speech of any of the regions in west Pakistan). The assemblage of the tall leaders of the Pakistan movement in the west further heightened the image of the strength of the western wing. Added to this was the greater prosperity of the western wing as a whole relative to the East.

Secondly, once Pakistan was born as a Muslim state based on religious intolerance and hatred towards Hindus in India, the image in the Pakistani mind of the overall politico-geographical strength of the two wings became highly different from what the mere size of their populations would warrant. While the west formed part of a continuous belt of Islamic brotherhood stretching through South-West Asia to northern Africa, East Bengal was a detached island of Islam one thousand miles away, and surrounded by infidels--Hindus in India and Buddhists in Burma. In the pan-Islamic image of the Pakistani mind the western wing seemed to form, therefore, a strong bulwark against cow-worshipping India. This mental image of the political geography of their homeland made the East Bengali doubt his country's real strength 
vis-à-vis West Pakistan。'Thus, at the time of Pakistan's inauguration, in the pakistani mind these disparities in the size of the population of the two wings did not weigh in the manner that they would otherwise do.

soon after inauguration and the achievement of the "paradise", as the nation began to settle down to business, these disparities came to the surface since under a democratic system size of population is bound to form the greatest weight in intranational affairs. And granted the political

fragmentation of the West, as compared to the solid bloc of Bengalis in the East, the latter, under a system of representation by population, were bound to predominate in the national politics. This would have shifted the axis of power in the nation from Karachi to Dacca, for in 1951 East Bengal had a total population of 41.9 million as against west Pakistan's combined total of 33.7 million.

Then, the Bengalis were able to win the support of the Frontier and the Sindhi groups in west pakistan in the central legislature because of the resentment that these groups also often displayed towards the punjabi domination. Under these circumstances the punjabi group was apprehensive that if the western wing remained fragmented as it was, the politicians from Bengal would be able to isolate the punjabis by winning support from the other smaller West Pakistani groups, and thus emerge as the leaders of the Federation. For this reason no legitimate proposals made by the Constituent Assembly with regard to the distribution of seats in the central legislature could be acceptable to the leaders from Punjab. The game of political arithmetic was started, and a proposal for a single unit for West pakistan was put forward. But the leaders of the constituent units were not agreeable to such a proposal. Attempt was then made for a sub-federation of the western units but this also failed to receive the requisite support. Faced with a showdown between himself and the Bengal-sind group in the Assembly, the Governor-General dissolved the Assembly (October 4; 1954) and appointed a "ministry of talents" consisting of a number of former or active military and civil servants who launched upon a course of "guided democracy". 
The new regime quickly set out to achieve the one-unit plan for West pakistan. Within five months of the dissolution of the national Assembly through appropriate dismissals and installations of pliable regimes in the provinces, the Governor-General was all set to legalize the creation of one-unit West Pakistan. On March 27, 1955 the appropriate ordinance was issued, though in view of the Federal Court's objection it was required to receive the assent of the National Assembly, which was reorganized in July 1955 and passed the one-unit plan on 30 september the same year. Now with only two units in the Federation, the country was put under a perpetual tug of war of which no democratic solution has so far seemed possible. Thus pakistan like Nigeria shows that in a federation it is desirable that the number of the constituent units should not be so small as to make it possible for only one type of cleavage to perpetuate itself in the federal relationship.

4. As regards my hypothesis of cross-cutting federal cleavages, Pakistan offers a negative proof. So long as pakistan was not achieved, to all questions Jinnah's reply was "First get the government, this is a nation without any territory or any government". After Pakistan was achieved, one could say that Pakistan had a government and a territory but one often wondered if it was a nation. 24 Nine years after the birth of Pakistan an East Bengali legislator could say "It is a country which is in reality not one country. We are going to form one nation out of two peoples". 25 As analyzed in the foregoing pages, except for religion the two wings of Pakistan have little in common. Their stateidea was based primarily on Islamic brotherhood and the fear of India which originated from the peculiar circumstances

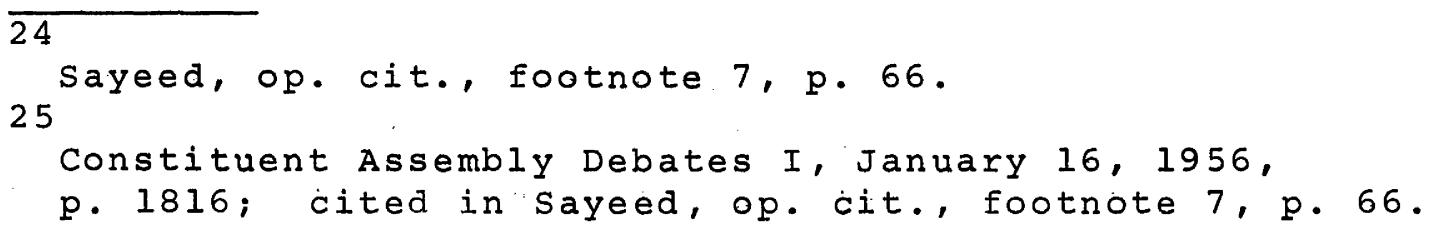


of the country's birth. 26 But though strong in the west, this fear was far less effective in the eastern wing. Furthermore, the religious bond does not provide a unique raison d'être, since there are other Muslim countries which are fairly close neighbours but the Islamic bond has not been able to unite them. Because of the absence of any interlinking cleavages the incompatibility between the two wings of pakistan has been difficult to reconcile. The attempt to yoke the camel and water buffalo together is indeed a very formidable task. 27

\section{THE WEST INDIES}

\section{HISTORICAL BACKGROUND}

From almost the very beginning of their settlement talks of a closer union of the West Indian islands were heard; certain areas shared governors; and the Leeward group had also a federation of some sort from 1871 to 1957. Yet on the whole there had been little unification in practice and each island outside the tiny islets of the Leeward group went its own way. Shortly after the creation of the Leeward Islands Federation an attempt to join Barbados in a federal union with the Windward Islands was dropped in view of violent opposition in Barbados. After this, no attempt at a federal union of the islands was made until the end of the second world War. Before the Labour movements of the 1930 s the proposals for a closer union or federation of the West Indian islands and Territories came largely from the British authorities who felt the need for administrative economy. It never came as a popular demand.

26

It seems relevant to note that Iqbal's concept of a separate and independent. Muslim state in the northwest of India, which he put forward at the Muslim League session in December 1930, did not include the Muslim majority areas of Bengal; nor does Bengal figure among the countries included in the mnemonic "PAKISTAN" put forward by its begetter Choudhry Rahmat Ali: See his Pakistan: The Fatherland of the Pak Nation, London: The Pak National Liberation Movement, 1947 ; p. 225. 27

The camel/water buffalo met phor $^{2}$ is borrowed from Professor O. H. K: Spate. 
By the 1930s, however, local opinion had begun to change especially as the Labour movement under the leadership of Arthur Cipriani and Hubert Crichlow in Trinidad and Tobago, and under Duncan O'Neil in Barbados, gained strength.

For the time being, the distinction between political reform and economic betterment was blurred, and the popular leaders agitated for constitutional change and social justice with equal fervor and in the same breath. Their main targets for attack were their different local governments and ruling classes, but the target they all held in common was the colonial office, which represented the ultimate source of constitutional reform. 1

The leaders of the eastern Caribbean territories often met for discussion and formulation of common courses of action and they accepted union of their territories as a remedy for their individual weakness. In all the legislatures the qualifications for voting and membership had been carefully restricted to exclude the working classes. Even at the end of the $1930 \mathrm{~s}$ the number of registered voters ranged only between two and ten percent of the total adult population. ${ }^{2}$ In 1932 leaders of the eastern islands met in Dominica and decided upon a west Indian federation, but the proposal was rejected by the closer Union Commission of 1932-33. This rejection of a popular demand only further helped the ascendency of the Labour movement and brought the popular forces in whole of the west Indies together. Thus, by 1938 new political leaders in the eastern Caribbean had decided that they must work together and support each other, whether in their demands on the Colonial office, or in their negotiations with sugar and other employers. "The sense of being 'all West Indians together' had taken hold. Not so in Jamaica." 3 Jamaica and the Leeward group were not represented in either of these conferences. In 1945 in a conference in Barbados, Jamaica and Leeward Islands, as also Bahamas, joined and formed the Caribbean Labour Congress. Resolutions

1

H. W. Springer, Reflections on the Failure of the First West Indian Federation, Cambridge, Mass.: Center of 2 International Affairs, Harvard University, 1962 , p. 3 .

Mordecai, The West Indies: The Federal Negotiations London: George Allen and Unwin Ltd., 1968, p. 20. 3

John Mordecai, op. Cit., footnote 2, p. 29. 


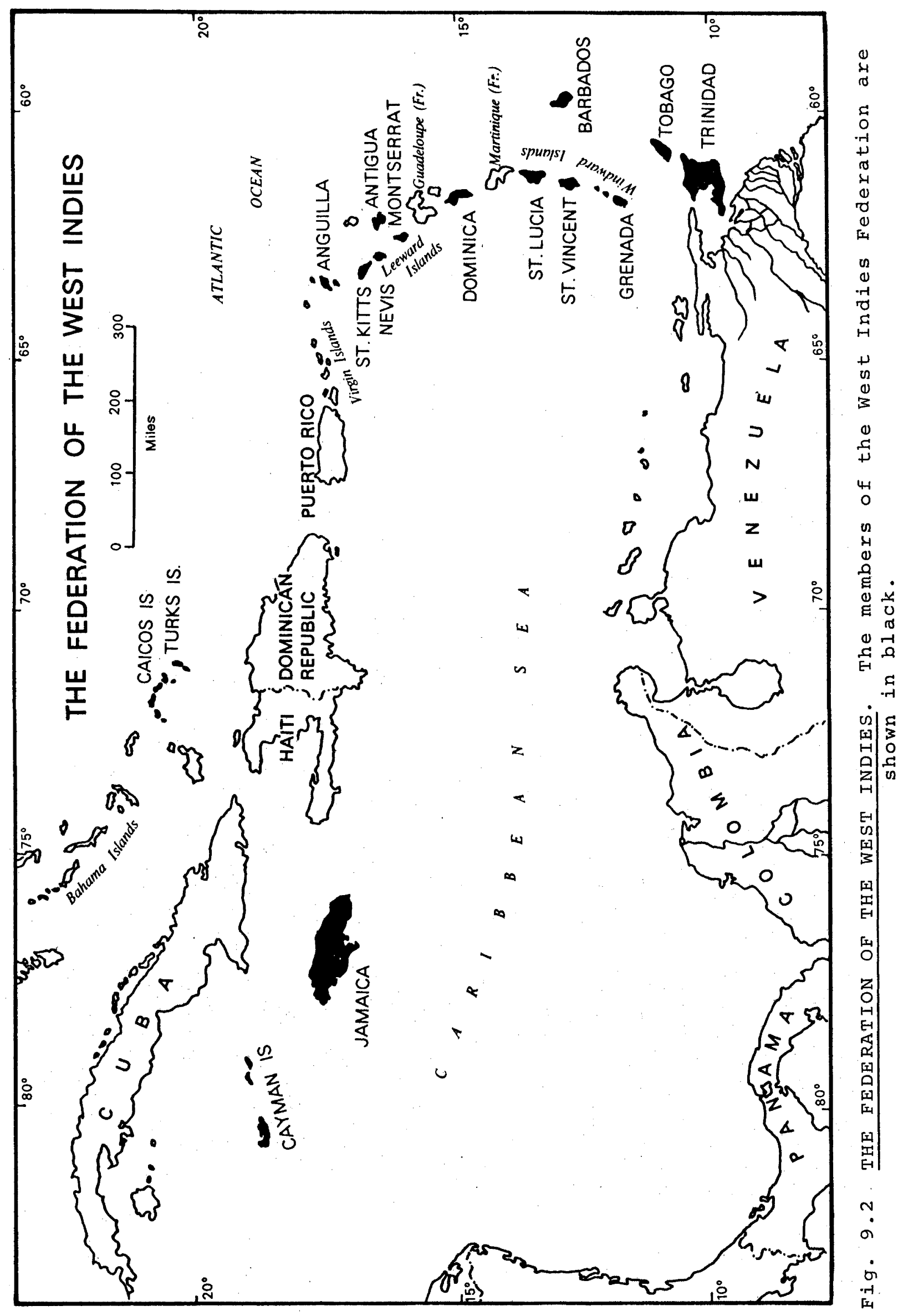


for federation and economic development were passed. Norman Manley, the Jamaican leader wrote, "we of the Progressive Movements in Jamaica have stepped right out of the framework in which we saw our problems... in isolation as affecting ourselves alone." 4

Besides the Labour movement, World War II had also drawn the west Indian colonies closer together by forcing the need for united action and the expansion of transport facilities. The Colonial Development and Welfare organization and the Anglo-American Caribbean Commission introduced the habit of planning development on a regional basis. Indeed,

here for the first time was a West. India-wide administrative unit dealing with every aspect of the islands' affairs, except political aspects. Its staff travelled all over the islands; held conferences bringing people from the islands together; and behaved generally as if West Indies were already a single political unit. 5 By the end of the second World War, at least the eastern Caribbean and the Colonial office were favourable to federation. A despatch from the secretary of state in March 1945 invited the islands to meet and discuss a positive advance towards federation. The Caribbean Labour congress met in conference in september 1947 at kingston (Jamaica) at which leaders of the various territories reaffirmed their belief in federation and submitted proposals for a constitution to the Montego Bay Conference which followed immediately. At Montego Bay representatives of the West Indian governments met with the secretary of State for the Colonies, Arthur Creech Jones. The principle of federal union was agreed upon and committees were appointed to submit proposals for a constitution and to consider other aspects of union. It took, however, nine years to decide upon the nature of the union. The agreement for federation was signed on February 23 ; 1956. By this time, however, owing to changed political and economic situation in and around the west Indies, the enthusiasm for union had waned. Consequently a very loose federation--almost a confederation--with a weak and

Caribbean Labour Congress, official Report of the Conference held at Barbados, september 17-27, 1945, pp。36-37; 5 cited in springer, op. cit., footnote 1 , pp. 6-7.

Mordecai, op. cit., footnote 2, p. 31 . 
ineffective centre emerged. The constitution finally came into operation on January $3,1958$.

\section{Nature of the Federation}

The West Indies Federation has been considered as one of the weakest federal systems ever to come into existence. Its weakness was apparent in the limited legislative powers of the federal government, the failure to agree on a customs union, the restrictions on migration between the islands and the extremely shaky state of the federal finances. Even these limited powers were not to be fully exercised by the federal government at the start. The Federation had no power of taxation. Receipts from the customs and excise duties were supposed to be adequate for federal needs. And even on this source a ceiling was fixed at $\$ 9,120,000$ (West Indian), an amount which was only a fraction of the annual budgets of either Trinidad and Tobago or Jamaica, and less than half of Barbados. It would appear, therefore, that right from the beginning it was planned as a peripheralized federation. 6

The federal legislature was bicameral. The senate was a states' House with equal representation for each of the island colonies. There were nineteen senators-two from each island unit except Montserrat which, because of its tiny size, had only one. The senate remained a nominee house with advisory rather than legislative functions. The House of Representatives was an elected body of forty-five members. Representation was not directly proportionate to population though the more populous islands were given larger representation. Jamaica had seventeen representatives, Trinidad and Tobago ten, Barbados five, Montserrat one, and each of the remaining units two. Only about four years after its inauguration the federation was dissolved on 31 May, 1962 and in the very first sitting of the House of Representatives a voice for secession had been raised by a Jamaican representative.

Details in C. B. Bourne, "The Federation of the west Indies", University of Toronto Law Journal, Vol. 13, $1959-60$, pp. 152-153. 


\section{POLITICO-GEOGRAPHICAL FACTORS IN THE RISE \\ AND FAILURE OF THE FEDERATION}

It would appear, on the face of it, that the British West Indies had every reason to succeed as a federation. Except for Trinidad's "racial" complexity, a near homogeneity was present in the ethnic composition of the population. The colonies had a long history as British possessions. They did not have any memories of historical conflicts to divide them. They had possessed some common, services, like the University College of the West Indies. They had a common language for education and intellectual intercourse. With a total area of 8000 square miles and a population of three million they could, it would appear, be easily governed from a single centre. Jamaica, no doubt was removed from the other islands by a thousand miles of sea but with modern transport it should not have been very difficult to join it effectively with the rest in view of the seemingly so overwhelming factors for unity among them. Still, the Federation failed. It is, therefore, interesting to investigate the politico-geographic factors that led to such a loose union and its quick dissolution.

Despite broad ethnic and linguistic homogeneity, cultural affinity, similarity of colonial experience and relative geographic proximity, the west Indies did actually lack some of the essentials of a centralized federation. The politicoadministrative heritages of the colonies were highly dissimilar. Despite their tiny size, each one had possessed its own separate administration except the Leeward group which had formed a federation. Even where some inter-island rapport was established, it remained limited only to sharing of a governor. Practically each island colony had its own postal stamps, its own separate economy competing with rather than complementing the others; they produced almost the same goods for export and looked to the same markets. Their currencies also varied. While the eastern Caribbean islands and British Guiana adopted the British West Indian dollar in 1951, Jamaica chose to retain its own separate currency. Unlike the British Indian provinces, in the west Indies each major island had formed a separate colony. Hence their relations to one another resembled those between 
India and Ceylon or between the straits settlements in Malaya and the British territories in North Borneo.

The eastern Caribbean and Jamaica had no direct steamship communications, they did not read each other's newspapers and at the level of the common man they were hardly aware of each other's existence except on the cricket field. Lord Halifax reported in 1922 that "the postal authorities in Jamaica [were] usually compelled to send mails for Trinidad, Barbados and British Guiana via either England, New York or Halifax". 8 As a West Indian scholar wrote in 1953, they were still unsure of themselves and "still trying to discover - . what makes us characteristically West Indian?". 9 It is said that "only when the West Indies cricket team is playing do the islanders from the Windwards and Leewards, from Jamaica, Trinidad and Barbados, recognize themselves as 'West Indians'".10 opportunities for the development of a. strong sense of belonging together were drastically lacking. Since each island was its own little world, their national aspirations were divided rather than united.

Since the 1920s, soon after the British west Indian troops returned from the First world War, an incipient west Indian nationalism had begun to rise largely as a reaction of the West Indians to their common experiences as an under-privileged minority while abroad. ${ }^{11}$ They felt the need for having and belonging to some nation of their own. This feeling was further heightened by the Labour movement of the 1930s.

But all along these cross-currents of union had flowed

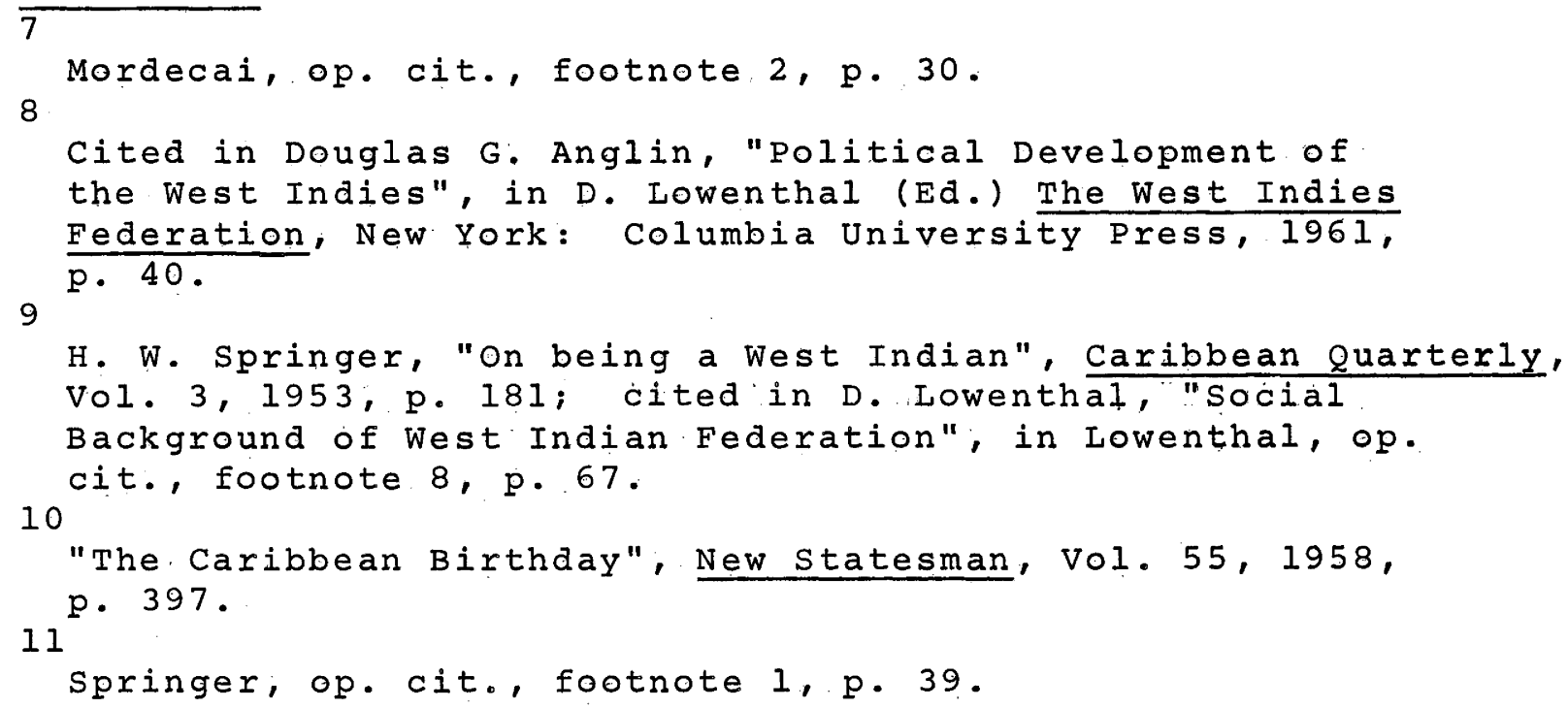


only in the eastern Caribbean. Jamaica was too remote to be affected. Thus

when the federation was created in 1958 it was for the Eastern Caribbean the fulfilment of the political ambitions of forty years,... . whereas in Jamaica it was still a recent and strange idea... which had not yet sunk into the popular sub-conscious. 12

Even in the eastern Caribbean the feeling for nationalism was not intense. In fact, the raw materials for rabid nationalism, such as long felt and long resented oppression by an alien power, or legal discrimination based on racial or cultural differences, or occurrence of affronts to personal dignity from motives of racial prejudice, which give rise to corporate resentment against the dominant power, were largely absent. Ever since the abolition of slavery, equality before the law had been provided for, and wherever expressions of prejudice occurred they were due to local rather than imperial reasons. Hence the colonial resentments were intra-island rather than between the islands and the metropolis. This meant the absence of any binding west Indiawide resentment.

Unlike countries with older civilizations such as India, that usual food for nationalism--the defence of national culture from foreign domination--was absent in the West Indies. "There is in fact no indigenous culture" says a West Indian scholar. 13 Grievances of the 1930 s against restrictive franchise and working conditions were not of the type that engender passionate feelings for nationalism. Still, the attractions for independent nationhood were great and because the islanders felt that each of their units was too small to gain independence singly, they joined together in their move for constitutional reforms and independence in a federation. But their move started too late to offer them any real opportunity for struggle. The Government of India Act of 1935 had already set the pace for internal self-government for the British colonies, and later with the independence of India, the eventual independence of other British colonies had become a real prospect.

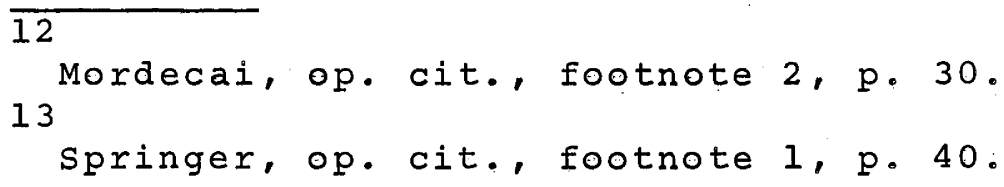


Thus unlike India, the west Indies found the imperial government willing to grant them political independence.

In this atmosphere of seemingly benevolent cooperation, the West Indian nationalism did not have a chance to develop into an intense passion. When at the Montego Bay Conference in september 1947 independence was clearly promised, no cause was left to keep West. Indian nationalism aflame, and when it became clear that union was not necessary for independence, the feeling for federation waned. After 1947, instead of being united in the struggle for independence, the leaders of the islands became engaged in bargaining and securing safeguards for their own "countries". This brought their separatist identities strongly to the fore, and in the absence of any compelling reasons--economic or military-no need for sacrifice and federal compromise was felt. Thus instead of a modern centralized federalism a near-confederation was created. The union was in this sense still-born.

Although expectations of mutual economic benefits in union were weak, and there was no external threat to the collective security of the island communities, still there are strong reasons to believe that if the Federation had been created right in 1947 rather than after a gestation of eleven years, it would have been centralized in nature and could very possibly have survived. In human affairs it is not so much the realities as the images of the realities that are decisive. In 1947 the West Indians felt that they are all on a sea of world conditions, stormy and hazardous in the extreme, each huddled in some. little craft of our own. Some hardly have oars and only a few have accomplished a rudimentary sail to take them along. And here [in the form of the Federation] offered us is a boat, substantial, capable of being made seaworthy and ready to be manned by our own captains and our own crew. If we won't leave our little boats and get into that larger vessel which is able to carry us to the goal of our ambitions, then. I say without hesitation that we are damned and purblind and history will condemn us. 14

But in the ensuing eleven years conditions in the two larger islands--Jamaica and Trinidad, which together

14

Statement by Norman Manley at the Conference on the Closer Association of the British West Indian Colonies, London, 1948. Cited in springer, op. cit., footnote. 1, p. 8. 
contained three-fourths of the population of the Federation-changed materially. They no longer found their ships in storm and their sails rudimentary. Bauxite mining and the expanding tourist trade gave a great fillip to the economy of Jamaica. Trinidad, no doubt, had all through stood above others, but her position also changed for the better when her oil production more than doubled, and her secondary manufacturing industries increased. Gross domestic production in Jamaica rose from US\$336 million in 1954 to US\$582.4 million in 1959, an increase of 73 percent. Trinidad during the same period recorded a rise from US\$235.7 million to US\$452 million, an increase of 92 percent. Further, as Mordecai explains, in 1947 the individual governments had not received internal self-government. with ministerial responsibilities. ${ }^{15}$ The politicians therefore, had not yet acquired that sweet experience of running their own island affairs, which later made them increasingly unwilling to endow the Federation with adequate powers. The results are clearly seen in that the federal government emerged from the 1953 conference with less revenue than the standing Closer Association Committee had proposed in 1949. It emerged from the 1956 London conference with even fewer powers than had been agreed in 1953; and by the time of the independence conference (June 1961) it was further away from real power than was contemplated in 1956.

Two basic factors inhibiting the rise of a strong sense of belonging together among the island communities were geographical isolation and lack of communication as well as lack of strong incentives-economic and strategic --for a federal bargain. Their isolation had heightened their differences. As the West Indian Royal Commission put it, the average West Indian labourer is "more strictly confined to his own island. . than the English labourer was tied to his parish in the most rigid phase of the settlement Law". 16 Facilities for inter-island movement

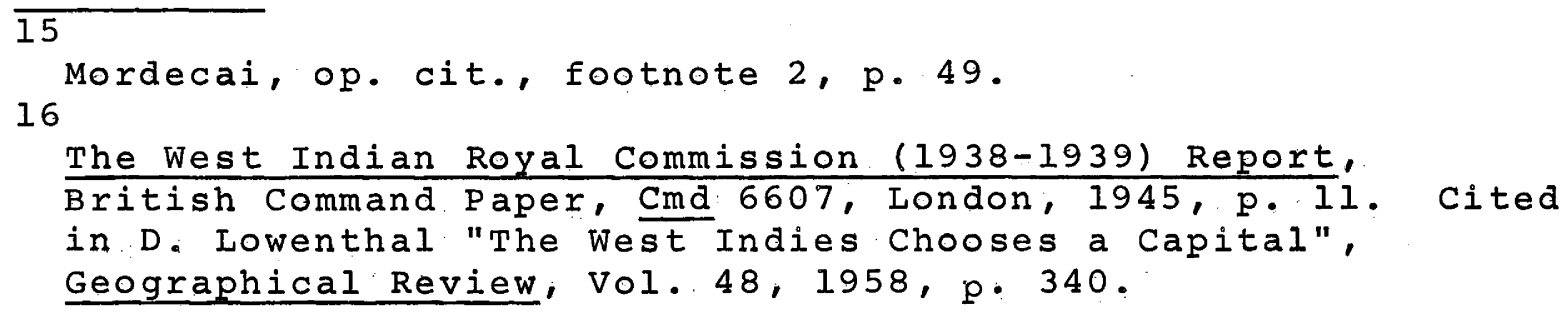


were few, and "For Trinidadians London is even now easier to reach than Jamaica". 17 Even the eastern Caribbean islands, only 50 to 100 miles apart, must rely for contact on unreliable schooners and motor vessels notorious for discomfort and inconvenience. A regular steamer service inaugurated in 1955 survived for only two years because of the lack of adequate traffic.

But while their geographical isolation and the consequent strong regional identities tended to keep the island colonies apart, there were no compeliing external threats or internal opportunities to draw them together. The small islanders had all through remained staunch federalists because the union seemed to offer them great economic dividends. Jamaica also was federalist when she found her fragile boat in a stormy sea before her economic boom that followed the bauxite mining. In the beginning the federal union with its prospects of a customs union and unrestricted inter-island mobility seemed to offer great economic advantages to Jamaica's land-hungry and unemployed population who could, under a union of the entire British west Indies, seek footings in the relatively empty British Honduras and British: Guiana. But when these two territories declined to join the federal union, much of this federalist enthusiasm in Jamaica cooled. still, however, because of its overwhelming size, Jamaica had the prospect of becoming the dominant partner in the Federation, possibly also the seat of the federal capital, and definitely the leader in the federal government. It had possessed the region's only seat of university education, and had expected to provide the first leaders of the federal government. As an important Jamaican journal put it, the Jamaicans compromised on the federal capital issue rather easily because they still believed that "It would obviously be inadvisable for Jamaica to provide the Federation with its Capital, its prime Minister and its Governor-General, as well". 18 But when the Federation actually came into being, all, these Jamaican hopes and

17 18

Lowenthal, op. cit., footnote 16, p. 340.

Public Opinion, January 5, 1957; Cited in Lowenthal, op. cit., footnote 16. 
expectations were belied. Already the distribution of representation in the central legislature as agreed in 1953 gave Jamaica only 38 percent of the seats in the House of Representatives when her population entitled her to 52 percent. Later when the federal capital was selected in Trinidad, the Federation appeared to the Jamaicans as something removed from them by a thousand miles. Then as the powers of the federal government were not of consequence, none of the top leaders of Jamaica--neither Manley nor Bustamante--stood for the federal legislature, and the Prime Ministership went to Grantley Adams of Barbados.

out of the eleven ministerial seats in the Federation only two went to the Jamaican representatives, and of these only one carried a portfolio. Thus, the Federation as it finally came into existence lost any emotional attraction for the Jamaican masses. But while offering none of the projected advantages, the Federation appeared as a definite hindrance to Jamaica's economic development by standing in the way of the island's protectionist policy for industrial development. Now with the forces of separation overwhelming those for union, Jamaica found little interest in the Union, and it, therefore, decided to withdraw. viewed thus, the Federation seems to have failed simply because the federal partnership offered no incentives to Jamaica to continue in the union.

It would appear from the above analysis that it is incorrect to see, with Gordon Merrill, a strong resemblance between Canada of 1867 and the West Indies of 1958 19 $^{19}$

Except for the size of their respective populations and the isolation of their units--which we have seen are only superficial elements in the long-run prospects of a federation --there is little, if any, resemblance to be found. Unlike

19

Gordon Merrill, "The Survival of the Past in the west Indies" in David Lowenthal (Ed,), op. cit., footnote 8, p. 20. In his article "Regionalism and Nationalism" in John Warkentin (Ed.) Canada: A Geographical Interpretation, Toronto: Methuen, 1968, Merrill says that "the federation of the four provinces of Canada is more comparable to the ill-fated and short-lived Federation of the West Indies in 1958 than to the union of the Thirteen Colonies. Success was not achieved by the West Indies, and it was by no means certain for Canada", p. 560 . 
Canada, the West Indian Federation did not offer strong incentives or any clear economic advantages, at least to one of the major partners, i. e., Jamaica. Neither was there in the West Indies any impetus for survival in union comparable to that provided for Canada by the militant presence of the American Republic of the Civil War days:

\section{POLITIC-GEOGRAPHIC INFERENCES}

The West Indian example provides, an interesting case study in the role of size of the constituent units in the maintenance of d federal partnership. Although the west Indian Federation consisted of ten units, Jamaica alone possessed more than half the total area and population of the Federation. Together with Trinidad it had three-quarters of the population of the Federation. A comparison with some other failed federations seems revealing. The West Indian Federation did not offer Jamaica, despite her preponderant size, the advantages that such an association offered Java in the Indonesian Federation. Contrary to the Indonesian situation, the smaller units in the west Indies were rich in human numbers but poor in economic resources. Furthermore, while Jamaica loomed large in the Federation with just over half its population, because of its geographically peripheral location it had none of the strategic advantages that centrality of location had offered to Java. Nor did Jamaica tower in the Federation to the extent that Java did in the Indonesian Federation. Because of the island's peripheral location and a stronger west Indian (largely nonJamaican) nationalism in the eastern Caribbean, the slight edge in population that Jamaica had possessed over the rest of the units was more than balanced, and Jamaica (even granted proper weightage to population) could not have any real possibility of overwhelming the other units, especially with the capital being located in Trinidad. It is not difficult to imagine that had Jamaica been in a geographically central location the picture would have changed materially and she would hardly have been the first to withdraw.

A comparison with Pakistan is also interesting. The position of Jamaica in the West Indies somewhat resembled that of East Bengal in the Pakistani Republic. Like Jamaica, 
East Bengal had also been given a representation in the central legislature much lower than her population would warrant. Like Jamaica, East Bengal also found the federal capital over a thousand miles away in a near-foreign territory. As in the West Indies, in Pakistan also the Federation was dominated by distantly located minority units, though unlike in Pakistan, in the west Indies there was nothing of consequence within the purview of the federal government to dominate upon. Now if unity could be maintained in pakistan, there would appear no reason why it should not have been so in the West Indies especially when, unlike the two wings of Pakistan, the eastern Caribbean area and Jamaica did not have any strong linguistic barrier to social and intellectual intercourse.

But a closer look would show, that in fact things were not as they appeared on the surface. The self-images that East Bengal and Jamaica each possessed of itself were contrasting in the extreme. The contemporary historical circumstances of the two differed greatly. Although divided by a foreign territory one thousand miles wide, the two wings of Pakistan had fresh memories of their "revolution" by which these two end organs at the extremities of a body politic had parted company from the main body. Though in the process of the separation all their interconnecting veins and arteries were cut, still memories of the "revolution" and the bitterness of its fight acted as a great binding force between the two wings. There was no such compelling sentiment for union in Jamaica.

Comparing the mental maps that the Jamaicans and the East Bengalis had of their respective "countries", we find that while East Bengal, for reasons noted earlier, found itself in a weak boat in the midst of what appeared as a storm, it saw the western wing of Pakistan as a great bulwark of strength, derived from its contiguity with the traditional Islamic homeland of South-West Asia. East Bengal was prepared to join a union with west Pakistan on clearly unfavourable terms because it then thought that the latter would offer her strength and security. Jamaicans did not suffer from any such unfavourable image of their country, for the east Caribbean islands in no way presented a more favourable 
picture. Hence whereas East Bengal could compensate for the sacrifice of its seemingly legitimate rights and advantages, Jamaica had no compelling reasons to do so, and it, therefore, quietly withdrew from the Federation.

In conclusion, the West Indian example offers a negative proof of our hypothesis that under a federal situation where the sentiment for regional identity is stronger than the urge for overall unity, unless a common external threat squeezes the constituents into unity, the resultant union is likely to be a loose alliance or a confederation. In other words, when the sense of separatism has an edge over the sense of union, external military threat may become an essential condition for the rise of a centralized federalism.

\section{NIGERIA}

\section{HISTORICAL BACKGROUND}

There was no cultural or political unit comprising the present area under Nigeria before British imperialismbrought them together under its overall suzerainty. The term Nigeria itself was coined for the first time in 1897, ? and received official recognition in 1899. As in other colonial areas, here also the flag followed trade, and the Royal Niger Company was the precursor of the British colonial rule. Although the first foothold in. Lagos was established in 1861, the actual British rule over the whole area under Nigeria came only in 1900. The geographical extension of British power in the area was determined arbitrarily by the limiting ambitions of rival colonial powers-French in the north, and Germans in the east. This arbitrary limitation of boundaries had two significant politicogeographical effects: first, it made Nigeria andits Provinces a hodgepodge of different cultural, religious and linguistic groups; secondly, ethnic ties spilled across colonial boundaries.

After revoking the Charter of the Royal Niger Company on January 1, 1900, the British Government proclaimed three separate administrations over the area--the two separate

$\overline{1}$

In an article attributed to Flora Shaw (later Lady Lugard)

in The Times, London, January 8,1897 . 
Protectorates of Northern and Southern Nigeria, and the Colony of Lagos. The administrative duality between the North and South was retained when in 1914 an amalgamated Protectorate of Nigeria was proclaimed. The two protectorates now became the two provinces, and Lord Lugard, the great proponent of Indirect Rule, became the Governor-General. Though the first Nigerian Legislative Council (created in 1922) introduced a token element of self-government in the South, the North was excluded: from its jurisdiction, and the administration of that province continued by proclamation of the colonial Governor. Thus until the so-called Richards Constitution of 1946, there was no central representative institution which could inculcate a sense of all-Nigerian unity. Because of the system of Indirect Rule the local administration in the North, in contrast to that in the South, continued to be somewhat authoritarian. The Emirs, who were also the religious heads of the local Islamic community, by using certain Islamic teachings imposed an autocratic government and inculcated in the populace habits of political deference and subordination.

Administrators in the two provinces never looked at things in the same light. Their training was quite different and their approaches to problems were very dissimilar. While maintaining a break between the North and South in matters of social and political outlook, this pattern also created a gulf: in the educational heritage of the two provinces. While activities of Christian missions were restricted in the North, in the south they got a free hand in the spread of education etc. Because education had remained largely a private enterprise, this policy greatly affected the standards of education and literacy in the two areas. The missions were specially successful among the Ibos in the southeast, though the western section of the province also benefited. The Ibos, however, became the leading élite in the country, and dominated most of the administrative positions open to the natives throughout the country and especially in the North which because of its political and social pattern retained under the Indirect Rule had remained highly traditionbound, feudal and educationally backward. Thus, the British rule had encouraged two parallel 
streams to flow in a single colonial area. Aspirations of the leaders in the North and South were different, so much so that while the southern leaders were pressing for independence from the colonial rule in the 1950s, the leaders of the North were very reluctant because to them it seemed that independence "would surely mean the substitution of the relatively detached paternalism of the British Colonial office administrators by the political domination of the ambitious and the substantially Westernized political élite of the south from whom they had been carefully sheltered by the British". ${ }^{2}$ It was only after the Northern leaders realized the political potency of their numerical preponderance under a majoritarian democratic rule, that they became ready to move with the rest of the country to independence.

\section{Constitutional Progress in Nigeria}

As already noted, it was the Richards Constitution of 1946 that for the first time established Nigeria as a single administrative unit. It also established for the first time the main political boundaries within the country--the three main Provinces: North, West, and East--corresponding to the three broad physical and cultural-ethnic divisions. The only further change effected before the Coup and the Civil War was the carving out of the Mid-West Region from the Western Province in 1963. The Constitution established a single central legislature for the whole of Nigeria presided over by the British colonial Governor. The Council consisted of thirteen ex-officio, three nominated official, and twenty-four nominated nonofficial members, plus four elected members (three from Lagos, and one from Calabar). Two of the official, and nine nominated members were from the North, while the East and West each had two official and respectively five and six nominated nonofficial members. This introduced the principle of regional representation. The Provinces were also given their own Regional Legislatures, bicameral in the North and unicameral in the other two. Though the provincial legislatures were largely advisory, each of them possessed a nonofficial majority.

2

Edward McWhinney, Federal Constitution Making for a Multinational World, Leyden: A。W. Sijthoff, 1966, pp.43-44. 
The so-called Macpherson Constitution of 1951 went a step further in the political-institutional progress. In the House of Representatives (which replaced the Legislative Council), 136 out of the total 148 members were elected through the provincial legislatures acting as electoral colleges. Of this total sixty-eight came from the North, and thirty-four each from west and East. This established the principle of parity in representation between the North and the two southern provinces combined. The new federal Constitution of 1954, which conceded far greater regional autonomy, further extended this parity in political representation. Now the power of the central legislature to override the regional legislatures was ended, and, the principle of dual polity was extended by providing for separate provincial public services, judiciaries, marketing boards, and Governors who replaced the former lieutenantGovernors. A Supreme court to act as an impartial tribunal in disputes between governments was also instituted.

on October 1, 1960 when Nigeria attained freedom from colonial rule, a new federal constitution was adopted. It made the central legislature bicameral. The House of Representatives consisted of a speaker and 312 members elected on the basis of population--one member for approximately 100,000 people. This assured the political predominance of the North, for based on census returns it would have 172 of the 312 members in the lower House. As the Senate was largely a revisionary upper House, equal representation (twelve members each) of the three regions plus four representatives for Lagos and four special members nominated by the Governor-General, could not redress the imbalance. The Constitution of october 1, 1963 which established the Federal Republic of Nigeria in place of the old Constitutional monarchy, followed the general outlines of the 1960 Constitution. The progress from complete regional subordination (though coupled with regional separation) of the $1940 \mathrm{~s}$ to almost complete regional autonomy of the late $1950 \mathrm{~s}$ (which was confirmed by the 1960 Constitution) was so rapid that many scholars feel that the "federation was formed by shearing away of the powers of the centre and giving them to the Regions, even to the extent that some- 
times one might have been pardoned for thinking that the Regions were independent countries"。 3

\section{POLITICO-GEOGRAPHIC FACTORS IN THE RISE}

OF THE FEDERATION

\section{Factors for Regional Identities}

As noted above, in so far as political evolution is concerned, the northern and southern sections of Nigeria had formed two almost separate streams with hardy any intercommunication, except in so far as minor officials in the North might be drawn from the better-educated south. The regional identities of the North versus south were always marked. After the Constitution of 1946 West and East came to exist as separate units, and their nationalisms evolved within their new political boundaries. Then, in contrast to certain other colonial areas, in Nigeria there had been no prior tradition of the entire area as a single political or cultural unit. It had been "a mass of peoples, tribes and nations: independent of each other" before the British brought it into a single political unit. The country had been "divided by language and custom, history and geography, religion and culture. . Travelling was difficult and dangerous and there was little inducement to wander far". 4

The country's principal river Niger and its tributary Benue, flowing from northwest to northeast then south through the midale of the country, divide Nigeria into three land blocs, though they also provide an easy access to the interior. It was along the valleys of these two rivers that most of Nigeria's present inhabitants entered the country in ancient times. While the coastal belt extending for nearly two hundred miles inland comprises a zone of high tropical rainforest, North of Ibadan from $7^{\circ} \mathrm{N}$ the tropical rainforest gradually gives way to deciduous forest which in turn thins down into parkland from about $10^{\circ} \mathrm{N}$. Right across the northern portion of the country from east to west between sokoto and Maiduguri is a wide expanse of

\section{3}

Rex Niven, Nigeria, London: Ernest Benn Ltd。, 1967, 4 p. 103 .

Niven, op. cit., footnote 3, p. 13. 
open terrain which allowed free movement of people and facilitated the intermingling of "races" and cultures.

Though it is said that the autochthonous populations of Nigeria were racially the same, centuries of separation into different areas and considerable new cultural influences introduced by immigrants from North Africa and the Middle East produced by A. D. 1400 great differences between the peoples of the forest and those of the savannah zones. While the latter were developing highly centralized pyramidal political structures and economic systems featuring occupational specialization and advanced agriculture, the former continued to be organized in small self-sufficient communities of cultivators and hunters with political organization still segmentary and kin-bound. The European penetration from the coast, and the rise of the Fulani in the North at the beginning of the nineteenth century further accentuated the differences between the northern and southern regions of the country.

For these reasons all-Nigerian nationalism as a lifeinspiring sentiment could not develop. Even after independence was achieved, "Nigeria's struggle to become a nation in fact as well as in legal theory had hardly begun". 5 In fact Northern and Southern Nigeria did hardy have a semblance of unity before the 1946 Constitution; and the period of fourteen years that followed was too short to inculcate the feeling of all-Nigerian partnership as a habit of life.

\section{Factors for Unity}

Though the North and South were governed largely separately for most of the British régime, the fortyseven years of existence as an amalgamated protectorate did offer the units some measure of unity and uniformity in their political cultures. ${ }^{6}$ By creating peace and order, by imposing a common government, jurisprudence, language and $\overline{5}$

Okoi Arikpo, The Development of Modern Nigeria, Harmondsworth (Middlesex) England: Penguin Books, 1967, 6 p. 84 .

These points have been beautifully summarized by R. L。 Watts, New Federations: Experiments in the Commonwealth, Oxford: Clarendon Press, 1966, p. 28 . 
educational system, currency and communications, the British rule did make possible the rise of a feeling of shared Nigerian identity. To this was added the sense of unity born from the sense of a united destiny in view of the surrounding French colonies which possessed an altogether separate political culture, different language, law, and education. Then the vision of the power and prestige of a united Nigeria that would emerge as the most populous and broadbased nation in Africa, was also a great attraction.

Because of the differences in the physical geography of the three Regions, their economic resources were largely complementary, or at least not competitive. ' While the land-locked North looked to the South for seaports for international trade and commerce, the Westernized youth from the south (especially from the densely populated East) found a vast field for the exercise of his talents in the educationally backward North. Furthermore, each of the Regions realized the greater credit-worthiness of the united country. Thus while cultural, ethnic and tribal forces pulled the Regions apart, the geography of their economy and resources contained strong factors of unity in the very pattern of their diversity. For the time being at least the factors of unity weighed over those for separation, and that psychology of desiring union without desiring complete unity was born; and this culminated into the birth of the Nigerian Federation.

\section{THE WORKING OF THE FEDERATION: A REVIEW}

For a proper understanding of the causes for the breakdown of the Nigerian Federation, it is necessary briefly to review the political game of musical chairs that led to widespread corruption, mutual distrust and the eventual estrangement of the Ibos which led to secession of the East and the subsequent. Civil War.

Nigeria had achieved freedom almost unawares. It had

7

The economic argument for the Nigerian federation is discussed in J.R. V. Prescott, "Geographical Basis of Nigerian Federation", Nigerian Geographical Journal, Vol. 2, June 1958, pp.1-13. 
none of that revolutionary zeal that accompanied the birth of many other new nations. It had no prolonged struggle for freedom, and on almost half the population freedom was virtually thrust. The country had no national heroes, no charismatic leaders, and no national parties of any significance. Democracy and self-government came almost separately to the North and South, and the federal centre in Nigeria could not become a symbol of all-Nigerian aspirations and partnership. Each of the three Regions remained an almost completely separate politico-social entity. The three major political parties of independent Nigeria were based on the three separate Regions--the Nigerian People's Congress (NPC) in the North, the National Convention of Nigerian Citizens (NCNC) in the East, and the Action Group in the west. Thus Nigeria remained largely devoid of that sense of inter-regional unity which comes from the existence of a common. (nationwide) political arena. Furthermore, no strong internal (as distinct from transit) trade movements had arisen in this largely agrarian country that could have broken the Regional and tribal cleavages by creating inter-Regional class cleavages.

The election of 1959 was fought over personalities rather than politics, and the voting patterns were largely on Regional and tribal lines. Both the Action Group and the NCNC tried to upset the pattern by large scale campaigning outside the Region of their influence with an emphasis on the North, but the results shattered their hopes. Between them the two parties along. with their allies captured a third of the Northern votes, but because the two were not in alliance, and because seats were allocated on a constituency basis, they could not present any real challenge to the NPC. The NPC had won 148, the NCNC 89, and the Action Group 75 seats in a House of 312 . As no party was in absolute majority to form a government, the NPC formed a coalition with the NCNC which continued in office till 1964 under the Prime Ministership of Balewa, a Northern leader. The lack of any nationwide political party, and the strong identification of the three major parties with the three separate Regions, by its very nature started the game of musical chairs which would at each change 
leave out one of the three major political groups. 8 And this in ultimate analysis would appear to have led to the doom of the Federation. As a result of the Northern and Eastern alliance, a new Region was carved out of the existing West, while the far larger North was left intact and no attention was paid to the equally vocal and just demand for a separate Region in the Rivers area of the Easto

The already numerically weak Action Group (which controlled the government of the West) was itself split, and a small rump of the party led by Chief Akintola aligned with the ruling central coalition. The "Establishment", consisting of the North, East and the Akintola group in the West, lasted until the 1964 election in which the NCNC and the Action Group aligned against the North, which now carried with it the new Western party of Chief Akintola who controlled the Western government. As a result of electoral manipulation which followed in each Region, the Establishment, now in association with the west, came out victorious, but the political strain that the election created had almost broken the Federation. In the 1965 election for the Western legislature the Action Group-NCNC alliance made a final bid to win power by constitutional means. And their failure amid the bitterness of a rigged election produced the chaos that directly led to the coup and secession of the East. It was not difficult for the East to imagine that it could expect a similar lot under a North-West alliance as it had given to the west when it was in alliance with the Northern group。

The federal Constitution was in force until January 1966, when widespread corruption, disorder and violence led to a military coup in which several political leaders including the federal Prime Minister were killed. The coup was led by the predominantly Ibo officers, and the main targets were the Northern leaders or those leaders from the West who were in alliance with the North. The Constitution was suspended and military Governors were appointed in each of the now four Regions. A few months 
later in July another coup followed, this time led by military officers mainly from the North. The Supreme Military Commander was killed and the present supreme Commander General Gowan took the office. Anti-Ibo feelings in the North were strong, for quite sometime, and after the July coup a terrible riot occurred in the North. (in September-october) in which a large number of Ibos were killed. Envy and resentment against the Ibos had increased as successive generations of Northerners were coming out of school to find that the best jobs were already filled by the Ibo. As a result of this mass anti-Ibo upsurge in the North, large numbers of Ibos living in that Region fled to their home-region, and thus the vital linkage between the North and East came almost to a close. The discovery of rich oil deposits had already enhanced the confidence of the Eastern Region, and now the Ibo military Governor of the Region declared secession and independence from the Federation. This started the tragic Civil War.

\section{CONCLUSIONS: THE CAUSES OF THE FAILURE}

Scholars greatly differ as to the causes of the breakdown of the Nigerian Federation. While some believe that the main reason for the breakdown was that "Nigeria without the same homogeneous cultural environment as Australia, chose the Australian pattern of government, with all the implications and problems of a loose federation"; 9 there are others who think that "The troubles experienced by Nigeria have not been due to any basic defect in the constitutional system, but to the gross numerical preponderance of the Northern Region, and the political difficulty of accommodating great cultural and tribal differences and consequent mutual jealousies". 10 some others discounted the idea of further division of Nigeria and said that "Had changes been made [that is had the North been divided into smaller units], . . the consequences might well have

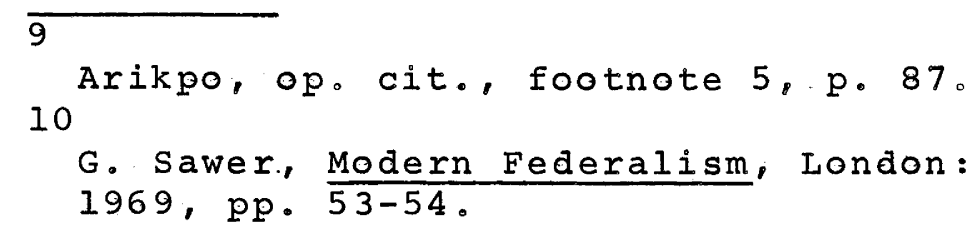


produced an even more unworkable Federation". Il In fact both these factors contributed to the difficulties though neither of them was solely responsible for the breakdown.

The very nature of the Federation and its consequent ineffectiveness led to the loosening of the sentiment for Nigerian unity. "The division of political and fiscal powers between the Federal Government and the Regional Governments . 。 [reduced] the Central Government to a mere agency of the Regional Governments". 12 In order to maintain full employment and promote the welfare and unity of the country, the federal government should have been endowed with powers to regulate the overall economic and fiscal policy of the Federation. But the constitutional powers given to the Regions, coupled with the mounting inter-Regional rivalries, rendered national planning and coordination ineffective. Each Region pursued its own independent policy, and a person, irrespective of his qualifications, had difficulty in finding employment outside his own Region. This put a brake on inter-Regional mobility --that great antidote to unhealthy localism. As a result of all this the Nigerian Federation failed to create identifiable national symbols that could attract the loyalty of the masses in all the Regions.

Then, the Northern Region in the Federation also violated the rule that in a federation no single unit should be so powerful as to outweigh several of the others combined. Further, while the North was big, it was not big enough to dominate alone. This in itself gave rise to the increasingly unplayable game of musical chairs. While this political territorial structure contained a built-in imbalance, the constitutional structure; by creating a largely ineffective Senate, made no real attempt to overcome the difficulty. Besides this disparity in the size of the units, there was a deeper malady that lay in the very political and administrative heritage of the nation, which turned this molehill into a mountain. If Nigeria had possessed a unified administration during the long colonial period, nationwide

\footnotetext{
$\overline{11}$ 12

Niven, op. cit., footnote 3, p. 96. Arikpo, op. cit., footnote 5, p. 96.
} 
political parties (in contrast to the then existing Regionbased parties) would possibly have emerged as had happened in India. In that case the disparity between the Regions would not have plunged the nation to its doom so soon after independence. Further, because of the weak centre that the Nigerian federal Constitution created, the main political leaders in the Regions (with the exception of Chief Awolowo) who could have carried the loyalties of the peoples of their respective Regions to the centre, remained within their respective provinces sending only their second lieutenants to the centre. 13

Furthermore, it would appear that it was not so much the numerical preponderance of one Region, as the very small number of the constituent units which tended to leave the odd unit out of power, that put the real strain on the Federation. Indeed "a federal constitutional structure which, with a three way only, territorial dispersal of political authority, permits or indeed encourages two regions to combine and pit themselves against the third region in the struggle for the fruits of power" is bound to subject the federal structure to a great strain. 14 This strain was further aggravated because one of the Regions (North) on account of its numerical preponderance was assured of its permanent membership of the political-power club. It was therefore necessary that the political power of the North should be checked. This could be done either by giving a greater effectiveness to the senate as a states-House (as in the United States), or to split the North into smaller Regions based on the regional preponderance of minority tribes in the manner that the West was split to carve out a non-Yoruba Mid-West Region. The East could also have been split into two. The military regime has taken steps in this direction and has divided the whole of the country into twelve administrative units. These may well form more durable units of a future federation. [Fig. 9.3] Although the sheer force of geographical location

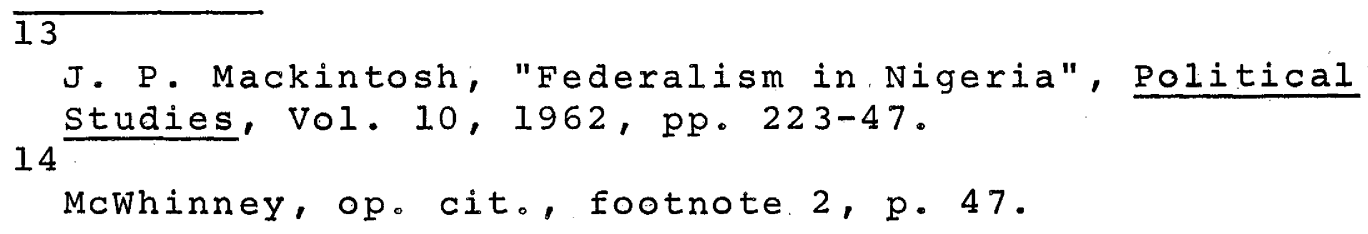




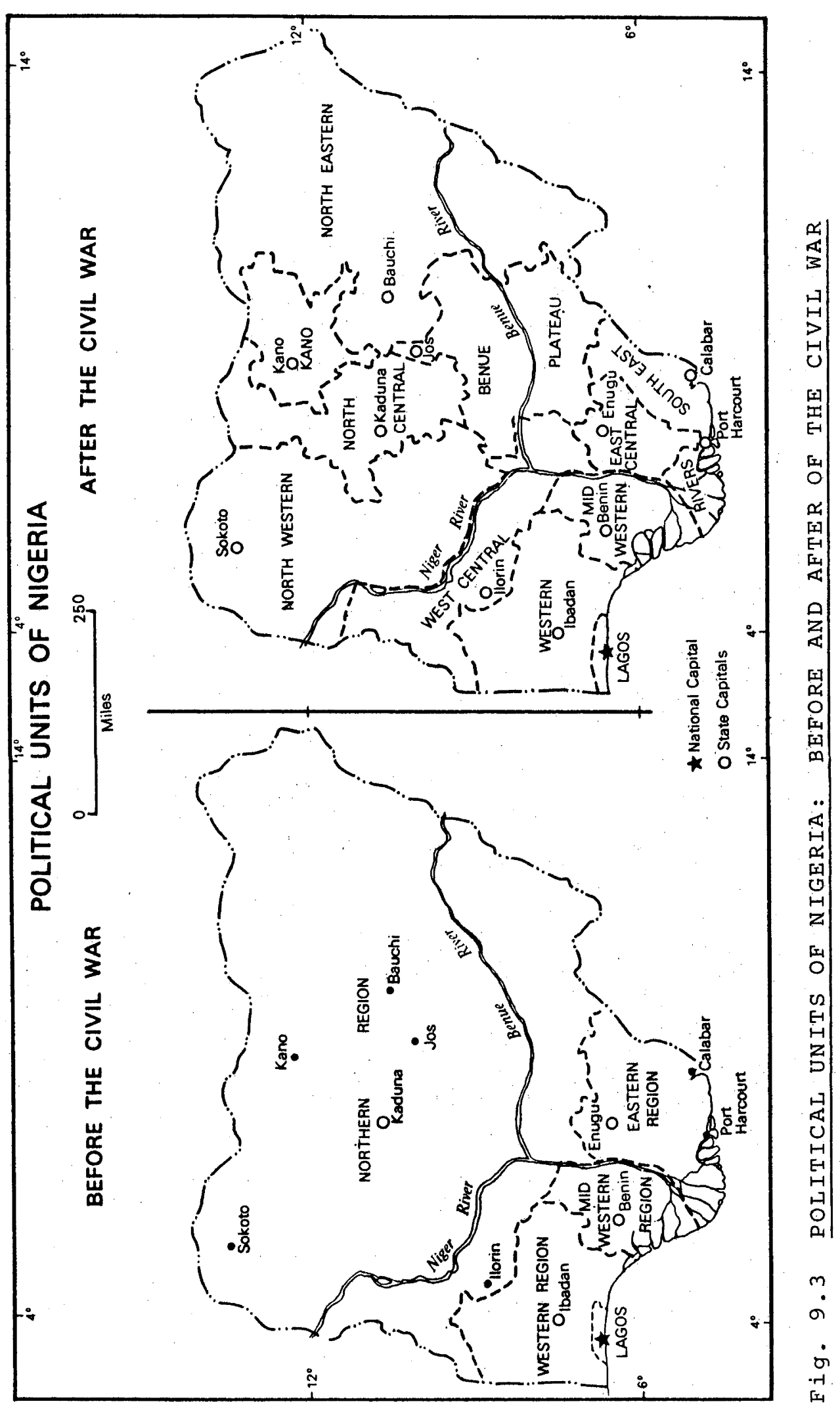


compelled the interior (North) to join. with the coast, its numerical dominance led to frustration in the south, (i.e., the East and West) which thought that it was not getting what was its due. It was this psychology which led to the secession movement in the East. It is posible that had the south not been bisected in 1946, the joint southern Region with its appeal to the Northern minority community voters might have created a somewhat more durable arrangement. In that case the South would have remained a "racially" or tribally heterogeneous unit, with at least two tribes in near-numerical-balance; and the political parties in the Region would have been some kind of coalitions between different tribal groups. These coalition parties could well have commanded some allegiance in the North, especially from the minority community areas. This would have meant that no Region as a whole could be discriminated against. This might have averted the question of secession.

It is interesting to review the changing images (or the mental maps) that each of the Regions had of itself throughout the period from 1953 to 1966. In 1953, the North was still not conscious of the value of its numerical preponderance in a federation with the other Regions. It was therefore afraid that because of their higher standard of education and skill the southerners might dominate it under a federation. It therefore wanted to remain independent, and would have done so had it possessed a seaport of its own. The North's reluctance to join the Federation also emanated from the fact that under the fiscal arrangements that were then decided, it received much less than it contributed to the central treasury. The west also contributed more than it received, while the East received appreciably higher revenue than it contributed. At that time tin, groundnuts, and cocoa, all derived from the North and.west, commanded high export prices, while palm-oil, the chief export from the East, had yet not fully recovered from the slump. For these reasons the East was then the greatest federalist in Nigeria.

By the close of the fifties, however, the situation was changing. With the discovery of oil in commercial quantity the East became quite rich and soon began to 
contribute appreciably higher revenue to the centre than it received. This changed the Region's attitude towards the Federation, while the North, wiser by the realization of the value of its numerical preponderance in the Federation, had changed from a secessionist to a unionist (federalist) stance. The west, which had always been in the middle of the way, faced with a combined (and unhealthy) opposition of the East and North after 1960, believed that its political power had fallen far short of its economic contributions. It therefore also became separatist. Later when the West and North combined against the East, the East was frustrated because despite its stronger economic position its political influence was receding. Hence, now the voice of secession came from this direction. A little later when the repeated anti-East riots in the North further disenchanted this Region and large numbers of Easterners in the North were pushed out from that Region, the East found itself with little to gain from the continued federal partnership, and it, therefore, decided to secede--a decision which could be reversed only by the superior forces of the federal Army.

Birch ${ }^{15}$ has shown that Riker's insistence on the military origin of federalism, in so far as Nigeria is concerned, is overdrawn. It needs to be pointed out, however, that although the Nigerian case demonstrates in a way that military condition is not necessary for the rise of federalism, it also demonstrates my hypothesis that in a situation where regional identities are strong and somewhat exclusive, a federation achieves greater stability if it has a continued sense of common external threat to its collective survival. As Nigeria apparently lacked any such threat, there was nothing to squeeze the discordant partners into unity.

15

A. H. Birch, "Approaches to the Study of Federalism" Political Studies, Vol. 14, 1966. 


\section{Appendix to Chapter IX}

\section{DISPARITIES BETWEEN THE TWO WINGS OF PAKISTAN \\ (Cf. footnote 22 on Pakistan)}

As A. Tayyeb (Pakistan: A Political Geography, London: Oxford University press, 1966, p. 181) says "the following table which spells out in concrete form the grievances of East Pakistan is eloquent by itself and needs no elaboration".

\begin{tabular}{lcc}
\hline & $\begin{array}{c}\text { From West } \\
\text { Pakistan }\end{array}$ & $\begin{array}{c}\text { From East } \\
\text { Pakistan }\end{array}$ \\
\hline I. Central Government Services & & \\
Civil & & \\
Secretaries & 19 & 3 \\
Joint secretaries & 38 & 10 \\
Deputy secretaries & 123 & 38 \\
Under secretaries & 510 & \\
Military & & 0 \\
Lto-Generals & 3 & 0 \\
Maj. Generals & 20 & 1 \\
Brigadiers & 34 & 1 \\
Colonels & 49 & 2 \\
Lt.-Colonels & 198 & 10 \\
Majors & 590 & 7 \\
Navy officers & 593 & 40 \\
Air Force officers & 640 & \\
\hline
\end{tabular}

II. Monetary Aid

(in million rupees)

Financial assistance

Defence expenditure

Capital expenditure

Educational grants

Share from foreign aid

P.I.D.C。project investment

$\begin{array}{rr}10,000 & 1,260 \\ 4,650 & 100 \\ 2,100 & 620 \\ 1,530 & 240 \\ 730 & 150 \\ 347 & 344\end{array}$

The following table (from K. B. Sayeed, political System of Pakistan, Boston: Houghton Mifflin Co., 1967, p. 200) would show the disparity in per capita incomes in the two wings of Pakistan:

(GNP at Factor cost of 1959/60)

$$
1959-60 \quad 1960-61 \quad 1961-62 \quad 1962-63 \quad 1963-64 \text { * }
$$

East Pakistan

West Pakistan

Pakistan

Extent of Disparity

(Pakistan $=100) * *$

\section{* Provisional}

* * The Pakistan figures cover 97 percent of the GNP. The remaining unallocated 3 percent has been excluded. 
Part 5

CONCLUSION 
Chapter $\mathrm{X}$

SOME GENERAL OBSERVATIONS

Part 1

ORIGINS OF FEDERALISM: SOME THEORETICAL

CONSIDERATIONS

The question "In what circumstances is it appropriate to adopt a system of federal government?" is the most difficult to answer, but as wheare says "It must be answered because it is in many respects the most important". ${ }^{\text {some }}$ suggestive hints toward the solution of this problem are to be found in Mill and Dicey. ${ }^{2}$ There are also some scattered suggestions in Freeman. ${ }^{3}$ Maddox, though primarily talking of international "federations", does throw, however, some useful suggestions on the prerequisites for the origin of federalism. 4 All these earlier attempts to explain the origins of federalism have been synthesized and developed by Wheare in his Federal Government. Since wheare wrote his book, other substantive works on federalism have appeared. One of these, by Riker, makes a concentrated attempt in this direction. Here we propose to review the earlier attempts in this direction and then proceed toward a new synthesis and some hypotheses on the origins of this polity.

Wheare begins his synthesis on the basis of Dicey's justly famous dictum that federalism is born when political communities in an area desire union without desiring complete unity. 5 This dictum, whose validity would hardly be questioned, presupposes two essential conditions for the origin of federalism: first, the units involved must have many

$\overline{1}$

K. C. Wheare, Federal Government, London: Oxford 2 University Press, fourth edition, 1963, p. 35.

A. V. Dicey, Introduction to the study of the law of the Constitution, London: Macmillan Co., first edition 1885 , 3 ninth edition 1939.

A. W. Freeman, A History of Federal Government in Greece and Italy, London: Macmillan Co., second edition 1893

4 (edited by J. B. Bury).

W. P. Maddox, "Political Basis of Federation", American 5 Political Science Review, Vol. 35, 1941, pp. 1120-1127.

Dicey, op. cit., footnote 2, p. 602 . 
interests in common because of which they are convinced that their destiny lies in union; secondly, while very strongly committed to union by the force of their historical, political, cultural or economic circumstances, the units concerned must also possess certain strong elements of separation which seem to them so vital for their individual group identities, and which they value so greatly as essential parts of their way of life that they are not prepared to forgo their rights to manage their own regional affairs and. want to retain their autonomy in respect of matters in which they differ from one another. In essence, then, the units should be prepared to erect a common central government for purposes that are best served in common, but at the same time they must also have a keen desire to maintain regional centres of decision-making with guaranteed autonomy in respect of matters that are served best by local involvement.

The two conditions must be present together. If the communities are not convinced of a common and united destiny, of a common cause in the preservation of a certain way of life or certain values and ideals, or security againsta common enemy against which they are weak in disunity but strong in unity, a genuinely federal union is not likely to be born. If forces for unity are all-powerful, the result should normally be a unitary state. In a federation, along with a strong sense of united destiny, a conviction to stand or fall together, there should also be an equally strong conviction among the regional communities that they have each certain unique regional interests which are so important to their way of life that they are willing to forgo certain advantages, economic and other, to be derived from complete unity. Only when this desire is deep-rooted, can federal articulation in union be assured. But it is also necessary that the factors for regional isolation be not so strong as to overwhelm the sentiment for union. This will forfeit the very purpose of federalism--which is diversity within unity. As Boehm says "The antithesis of federalism is not unitarianism, but particularism and separatism" of an extreme kind. 6

6

M. H. Boehm, "Federalism: in Encyclopaedia of the Social Sciences, Vol. 5, New York: Macmillan Co., 1931,"p.170. 
A balance between the two opposing sentiments is necessary. This balance should, however, be so struck that the forces for unity have a slight edge over those for separatism. As wheare says, "If they [the communities involved] are not prepared to submit themselves to an independent government - . they have not achieved the first prerequisite of federal government". 7 This is important, for federalism is essentially what Riker terms "a bargain between prospective national leaders [who want unity] and the officials of constituent governments [who stand for a larger regional control]". 8 Most advocates of centralized federalism would agree that "A truly federal government is the denial of national [sic] independence to every state of the federation". 9

In his chapter on "Some Prerequisites of Federal Government", Wheare has tried to isolate the various factors for union and separation which have appeared to him as necessary factors in the origin of federalism. He enumerates the following "half-dozen factors all [of which] operated in the United States, Switzerland, Canada, and Australia, to produce a desire for union among the communities concerned". 10

These factors are:

1 Need for common defence,

2. Desire to be independent of some foreign power and a realization that only through union could independence be achieved,

3 Expectations of economic advantages from union,

4. Some political association of the units involved prior to their federal union,

5. Geographical neighbourhood,

6 Similarity of political institutions.

Wheare writes that though "we may feel tempted to conclude that this desire [for union] will not be produced unless all or most of these factors are present", he thinks that such

\section{7}

8

Wheare, op. cit., footnote $1, \mathrm{pp} .35-36$.

W. H. Riker, Federalism: Origin, operation, Significance, 9 Boston: Little, Brown \& Co. 1964; p. 11. 10 Dicey, op. Cit., footnote 2, p. 607.

Wheare, op. cit., footnote 1, p. 37 . 
a notion would be going further than is warranted. But he thinks that "it is unlikely that states will desire union unless these factors-or most of them--are present. To that extent they may be classed as prerequisites for federal government". 11 As will be noted, he excludes from this list of prerequisites for union factors such as community of language, of "race", of religion or of nationality. He remarks "This is surprising, but the facts support it". In his opinion, "Community in these matters cannot therefore be described as an essential prerequisite of federal government". 12 To these six prerequisites wheare adds one more: "leadership or statesmanship at the right time".

Coming to the factors for regional separation (i.e., the factors creating the desire for regional autonomy) wheare is much less emphatic. He enumerates three important factors:

1 Previous existence as a distinct governmental unit, 2 Economic divergence, and

3 A sense of isolation through "geographical" factors; but, he says, "it does not seem possible to accept . . . [the] conclusion" that these factors form "essential prerequisites of that desire for separation within union which goes to produce federal government". He thinks that the factor of "divergence of nationality" "itself alone quite certainly could produce the desire for separation in communities otherwise prepared to unite". "Another factor which might produce the desire for separation is dissimilarity of social (including political) institutions". 13 wheare says that "These are the kind of factors which, given the existence of a desire for union, are likely to produce a desire for federal union. [But]. It is not possible to pick on any one of them or any combination of them and say that unless this or these are present, the desire for federal union will not arise. That desire may be produced by any one of them". 14 "But it must be emphasized that the capacity of

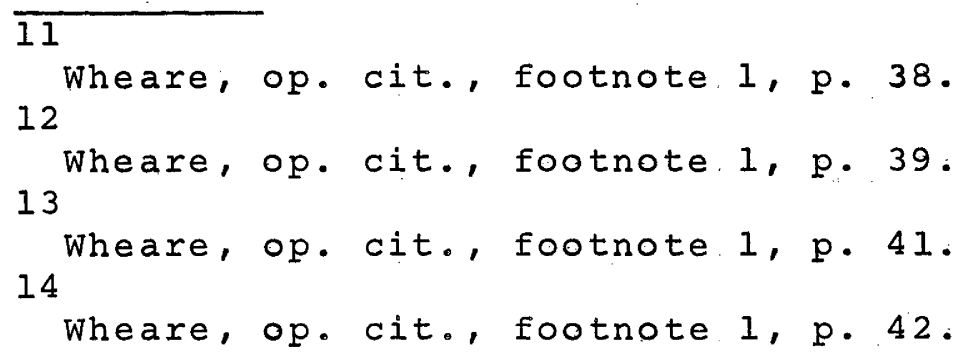


states to form and work a federal union depends upon some agreement to differ but not to differ too much". 15 "That the two loyalties must be there is the prerequisite of federal government, but that the one should not overpower the other. [though the factors for unity should have an edge over those for separation] is also prerequisite". 16 It would appear from the foregoing resumé of wheare's views that despite his very competent analysis and synthesis, Wheare has not succeeded in providing us with any theory or law (or a set of laws) on the origins of federalism. More recently another writer, William H. Riker, has attempted to formulate such a theory or law. Riker's work has generally been held in great esteem and some believe that his is "The most successful attempt to formulate a theory of federalism - . . 17 Birch regards Riker's attempt at a "theory" of federalism as "a real, if limited, gain in a period in which it seems fashionable to assume that economic and social factors are pre-eminent". 18

\section{Riker's Theory of the Military origin of Federalism}

Riker describes federalism as "a constitutional bargain" "between prospective national leaders and officials of the constituent governments for the purpose of aggregating territory, the better to lay taxes and raise armies". 19 From the "theory" of federalism as a bargain Riker infers the existence of at least two circumstances encouraging a willingness to strike the bargain of federalism. Put in Riker's own words, these conditions are:

1 The politicians who offer to bargain desire to meet an external military or diplomatic threat or to prepare for military and diplomatic aggression and aggrandizement. But, though they desire to expand, they are not able to do so by conquest... Hence, if they are not able to satisfy the desire to expand, they must offer

\section{5} 16

Wheare, op. cit., footnote 1, p. 48 . 17

Wheare, op. cit., footnote 1, p. 49.

A. Wildavsky (Ed.), American Federalism in Perspective, Boston: 18

Little, Brown \& Co., 1967, editor's introduction, pp. vii-viii.

A. H. Birch, "Approaches to the Study of Federalism", 19

Political Studies Vol. 14, 1966, p. 33 .

Riker, op. cit., footnote 9, p. 11 . 
concession to the rulers of the constituent units, which is the essence of federal bargain...

2 The politicians who accept the bargain, giving up some independence for sake of union, are willing to do so because of some external military-diplomatic threat or they desire to participate in the potential aggression of the federation...

For convenience of abbreviation Riker refers to these two conditions as (1) the expansion condition and (2) the military condition. And the "theory" or hypothesis that he sets forth is that "these two predispositions are always present in the federal bargain and that each one is a necessary condition for the creation of a federalism". Riker writes that though he was "tempted. . to assert that these two conditions are together sufficient", since he could not possibly collect "enough information to prove sufficiency", he was "constrained. to assert only the more modest hypothesis of necessity". 20

Riker asserts that he has examined all the instances of the creation of federalism since 1787, and that for those federalisms that have survived he has been able to show that the two above conditions existed at the time of their origin; and for those federations that have failed he has been able to demonstrate that either the conditions never existed or they existed only momentarily.

It may here be noted that Riker is not the first or the only writer to point out the importance of military condition or external threat and the desire for expansion as favourable factors in the origin of federalism. Many before him, including Maddox, Greaves, and Wheare have said so. 21 . There is, however, one great difference: While others have regarded these factors as two of the several efficient agents in the creation of federalism, Riker asserts that they are necessary and possibly even sufficient factors in the origin of the polity. Thus the whole question of validity or otherwise of the Riker thesis rests on the demonstration whether or not both these conditions have been present in every. instance where at least a working federation has been created. If we are able to

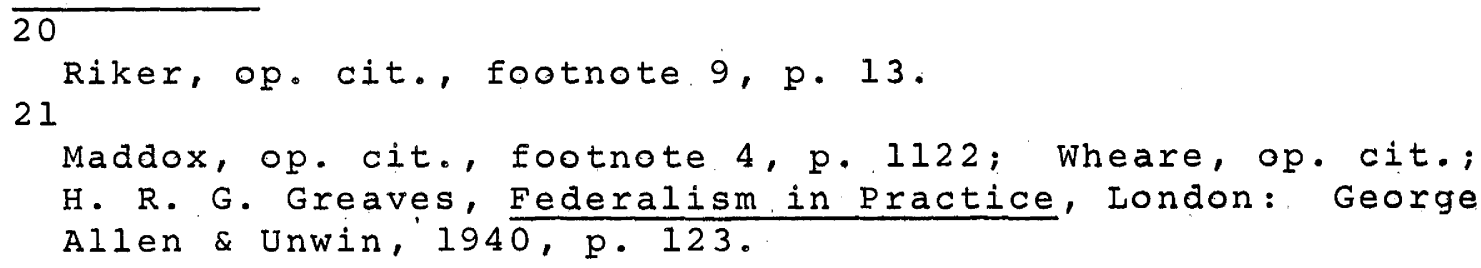


demonstrate that either of these conditions was absent in the origin of any existent federation then the theory falls. Recapitulating our analyses in the foregoing chapters, we find that in our study of the West German and Austrian federations we have clearly demonstrated that in both these examples either or both of Riker's so-called necessary conditions were absent. The theory, therefore, seems untenable in the form it stands.

We may here note, however, that though we do not think that facts support the necessarily military origin of federalism, the military condition may nevertheless be necessary in the rise of federalism under a particular type of federal situation. Such a federal situation would be the one in which the sentiment for regional autonomy is stronger than the sentiment for interregional unity. Under such a federal situation unless a common external threat squeezes the constituents into unity, the resultant union is likely to be a loose alliance or confederation. Thus, the hypothesis is: where the sense of separatism has an edge over the sense of union, external military threat becomes a necessary condition for the rise of centralized federalism. We have demonstrated the validity of this hypothesis in our preceding studies of the Swiss, the American and some other federations. As already noted, the point is most clearly demonstrated by a comparison between the Pakistani and the West Indian experiments.

As for Riker's not so strongly asserted hypothesis that his two conditions are most likely sufficient conditions for the origin of federalism, we may repeat what we observed in our study of the swiss example. Before the rise of modern centralized federalism, and its further course of integration necessitated by the rise of large-scale industrial economy, and the need for centralized national planning, federalism could often be regarded as essentially a limited purpose alliance for mutual military security in face of a common danger. In these earlier experiments the military condition may well have been a necessary and sometimes even sufficient factor in the origin of federalism (in fact, confederalism), for then military security was often the primary raison d'être of such unions or alliances. With the changed emphasis of modern federalism, however, the military factor can no 
longer be a sufficient condition for the rise of federalism of the centralized variety. Federations are no longer limited purpose associations. The primary objective of modern federalism is to create a body politic--an integrated and fully functioning political unit. For this it is necessary that the purposes that bind the prospective partners together are not narrowly political or military.

Though Riker's theory of the essentially military origin of federalism has received some passing criticism from scholars like sawer and Livingston who regard Riker's emphasis on the military-diplomatic factor as "rather over-stressed" and "excessive", only A. H. Birch has attempted a partial test of Riker's thesis in relation to the Nigerian and Malaysian federations. 22 Birch has tried to present a modification of Riker's theory of the military origin, though his arguments seem mainly in line with Riker's in regard to the necessity of the military-diplomatic factor in the rise of federalism. Thus Aaron Wildavsky thinks that despite his objections, "A. H. Birch reaches a conclusion [basically] similar to Riker's...". 23

\section{Some other Views}

Riker has pointed out two widely asserted fallacies about the origin of federalism. One is the ideological fallacy which asserts that federal forms are adopted as a device to guarantee freedom. "I am certain that there is no simple calsqal relationship between federalism and freedom", says Riker, and this author is largely in agreement with him. 24 The second fallacy Riker refers to is what he calls the "reductionist fallacy" which is found in the assertion that federalism is a response to certain social conditions that create some sense of a common interest. In this context Riker refers to Deutsch and his collaborators' nine "essential"

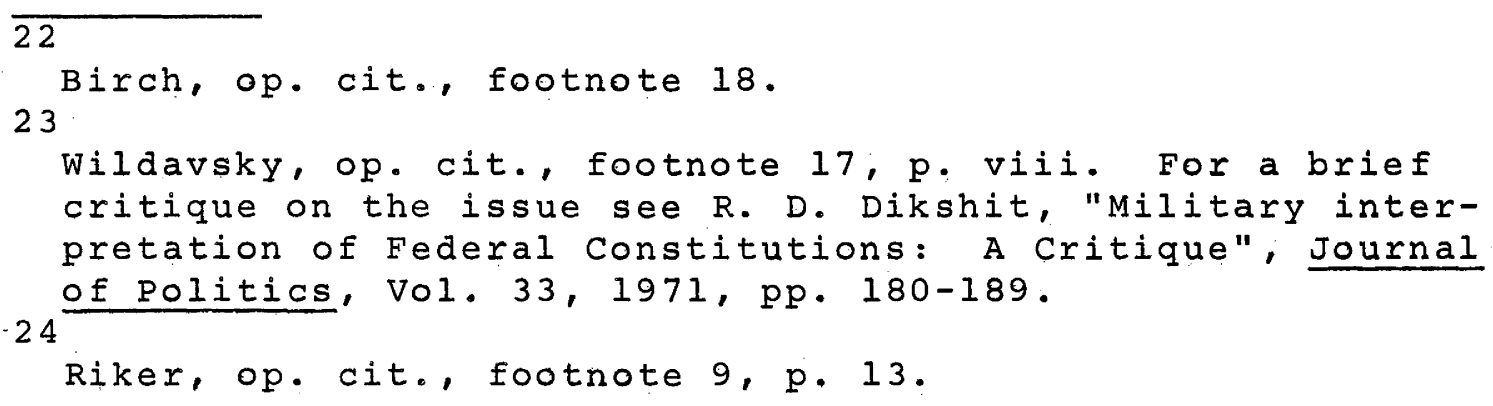


conditions for the rise of an "amalgamated security community" of which class federalism is a sub-class. The nine so-called essential conditions proposed by Deutsch and his collaborators are $:^{25}$

(1) mutual compatibility of main values; (2) a distinctive way of life; (3) expectations of stronger economic ties or gains; (4) marked increase in political and administrative capabilities of at least some participating units; (5) superior economic growth on the part of at least some participating units; (6) unbroken links of social communication, both geographically between territories and sociologically between different social strata; (7) a broadening of the political elite; (8) mobility of persons at least smong the politically relevant strata; and (9) a multiplicity of ranges of communications and transactions.

As Riker writes:

It is apparent that these conditions are not sufficient to bring about amalgamation, for, if they were, federalisms like the Central American Federation would never have broken up or a pan-Arabic movement would reunite the Arabic parts of the former Turkish empire. Nor are all these conditions necessary, for a great many successful amalgamations have violated some or even all of them, e. g., the Swiss confederation seems to have violated conditions (1) and (2) during most of its history and 19th-century colonial empires violated almost all conditions. If these conditions are neither jointly necessary nor sufficient, it is hard to imagine in what sense they are "essential".26

While Riker is justly critical of these two general fallacies, he makes no mention of Wheare's "Some Prerequisites of Federal Government" which, I believe, is quite free from the first fallacy, and only a partial victim of the second-depending upon what view one takes of the reductionist fallacy itself. After all, every theory or law develops by reducing the nonessential from the essential. In fact, Riker misses the point that the reason why Deutsch's conditions fail completely to explain the origin of federalism is that federalism results from a peculiar combination of factors for unity and regional identity, and that in this combination

25

Karl Deustch, et al., Political Community in the North Atlantic Area, Princeton: Princeton University Press, 1957, 26 p. 58 .

Riker, op. cit., footnote 9, p. 16. 
factors for regional separation are as important as those for inter-regional unity. Wheare, partly because he was writing a treatise on federalism, which Deutsch et al were not doing, presents a more balanced view because he takes into consideration either side of the picture, still, however, Wheare's analysis has failed to yield any definite theory or law on the origin of federalism.

\section{TOWARDS A NEW ANALYSIS}

It seems to me that the difficulty with wheare's analysis is not reduction but only reduction. As federalism is a product of forces of union as well as separation, interacting upon one another, a better and more valid way to this explanation would appear to be reduction combined with interaction or correlation. This is the line of approach that is adopted in the following paragraphs which attempt to use the data gathered from my study of the examples of federalism--past and present--in the preceding chapters.

\section{Factors for Overall Union}

Unlike Wheare, I propose to enumerate below most of the factors for unity or separation that seem to have played a significant role in some case or other of the federations so far experimented with, even though it is clear that these factors alone are neither sufficient nor necessary for the rise of federalism in all cases. Taking the factors for union first, we find that some of the following factors in various combinations have played vital roles in pulling diverse units together into a federal union.

Al A sense of common military insecurity and the consequent need for common defence. This may often be coupled with the desire for independence from a common imperial power and the realization that only through union is this independence possible. Both these conditions have been found together in most cases, e. g., the United States, Australia, India, Switzerland (in its earlier phases), Malaysia and others, though only the latter condition was present in the post-1945 Austria and West Germany--here, however, the sentiment for union far outweighed that for regional separation. In the West. Indies, at the time that the Federation was created, neither of these conditions was present, though earlier it 
was the second of these that had attracted the islands towards federalism. It has been thought proper to put both these factors together first, because federalism (and for that matter any type of union) is essentially a response to the need for common efforts; and secondly, when both these factors are present together the sense of unity and common purpose is stronger, but the second factor without the first may, become only a temporary and largely impotent factor for the rise of a durable union. The West Indies and the African examples of federalism would prove this point.

A2 A community of "race", language, and culture (including religion). This is a very important factor in bringing about that sense of belonging together which gives rise to the feeling of community and common destiny in relation to outsiders. In fact, Mill considered this factor so important as to write that "Free institutions are next to impossible in a country made up of different nationalities. Among a people without fellow feeling, especially if they read and speak different languages, the united public opinion necessary to the working of representative government cannot exist". 27 Examples of multi-ethnic federations such as switzerland, Canada, or even India and Pakistan would show, however, that these factors are neither necessary nor sufficient factors for the rise of federalism. But the fact remains that granted that other factors are favourable to the rise of federalism, community of language and culture is likely to give rise to a more smooth-running federal partnership.

A3 Interdependent economies and expectations of greater economic benefits from union. This factor would be found to have been present in most examples of federalism where the union has proved stable. Similarly, in most cases where federal ties have been disrupted or have been threatened. with collapse, this factor would seem to have been absent, at least in the view of the dissenting party. This factor was clearly absent in the west Indies in so far as the largest partner--Jamaica--was concerned, and as we have analyzed in a foregoing chapter, this lack of economic 
incentives was one of the prime reasons why the federation failed. This factor was also the cause of Biafran disenchantment in the Nigerian Federation, and is the main cause of the East Bengali disaffection in the Pakistani union.

A4 Prior existence of communities as parts of a single overall politico-administrative system or a common experience as parts of the same political system. This has been true of every case of federalism so far experimented with, and it may well be a necessary condition for the rise of federal union, though whether it is necessarily so or not is not vital to the discussion that follows.

A5 Easy interregional transport and communication or a close geographical neighbourhood. "Physical contiguity . . of countries which are to form a confederated [sic] state is certainly a favourable, and possibly a necessary condition for the success of federal government", says Dicey. ${ }^{28}$ Though facts prove that this factor is not an essential factor in the origin of federalism, nevertheless the examples of Pakistan and the West Indies would show that the absence of this factor is often a source of weakness. The point is partly proved also by the Western Australian example in the Australian federation.

A6 There should be a sufficient amount of mutual sympathy among the political communities involved; they should, in other words, possess an overall compatibility in their social and political institutions.

Factors Giving Rise to the Desire for Regional Autonomy Bl Perhaps the most important factor for the sentiment for regional autonomy is the existence of regionally-grouped diversities in respect of

$$
\begin{aligned}
& \text { a language } \\
& \text { b religion and/or } \\
& \text { c "race" }
\end{aligned}
$$

which are in a great measure identifiable with the individual political units involved in any particular federation. B2 Existence of units with independent or competitive economies. The existence of this factor reduces the scope for economic expectations from union, and thereby brings 
some indifference among the units with regard to union. Pakistan and the West Indies respectively provide examples of the two types.

B 3 Prior existence of the political units as a independent units or,

b regionally autonomous provinces of a broader political system or empire. It is, however, important that this autonomy is based on either

(i) a popular (even if restricted) democracy or, (ii) popularly recognized hereditary kingship etc. which in course of its long existence has helped to impart to the people a sense of regional cultural identity.

Examples of the first type were presented by the United states, Canada, Australia, and Switzerland, while Malaysia offered a weak example of the latter type.

B4 Absence of a common external threat to the survival of the units concerned. This becomes a critical factor in cases where the units involved have strong (and sometimes exclusive) regional identities born out of their ethnic, economic or physical circumstances. The West Indies provide a salient example.

B5 Presence of conflicting threats to the different units involved. As Mill says; a federation must bind the units "always to fight on the same side; and if they have such feelings towards one another, or such diversity of feelings towards their neighbours, that they would generally prefer to fight on opposite sides, the federal tie is neither likely to be of long duration, not [nor?] to be well observed while it subsists". 29

B6 Existence of groups of units following contrasting and mutually incompatible social, economic and political philosophies. Such was the division in the United states between the slave-owning and the so-called "free" states. such was also the division between southern Rhodesia and the two other units of the Central African Federation.

29

Mill, op. cit., footnote 27 , pp. 366-67. 
SOME HYPOTHESES ON THE ORIGINS OF FEDERALISM

I Now if all the various factors for unity enumerated above in set "A" were present, there would be no need to bother with federalism, for as Sir Ivor Jennings said, "nobody would have a federal constitution if he could avoid it". 30 such a group of communities should, and most likely would, evolve as a unitary state.

I Conversely, if all the factors for separation enumerated above in set "B" were present, there can be no ground for union. The communities involved should, and in all probability would, organize as separate sovereign states forming at best some limited purpose alliances or associations.

II only when some factors of set. "A", and some of the set "B" are jointly present, would there be need for a federal union--that so-called halfway house between complete unity and complete separation.

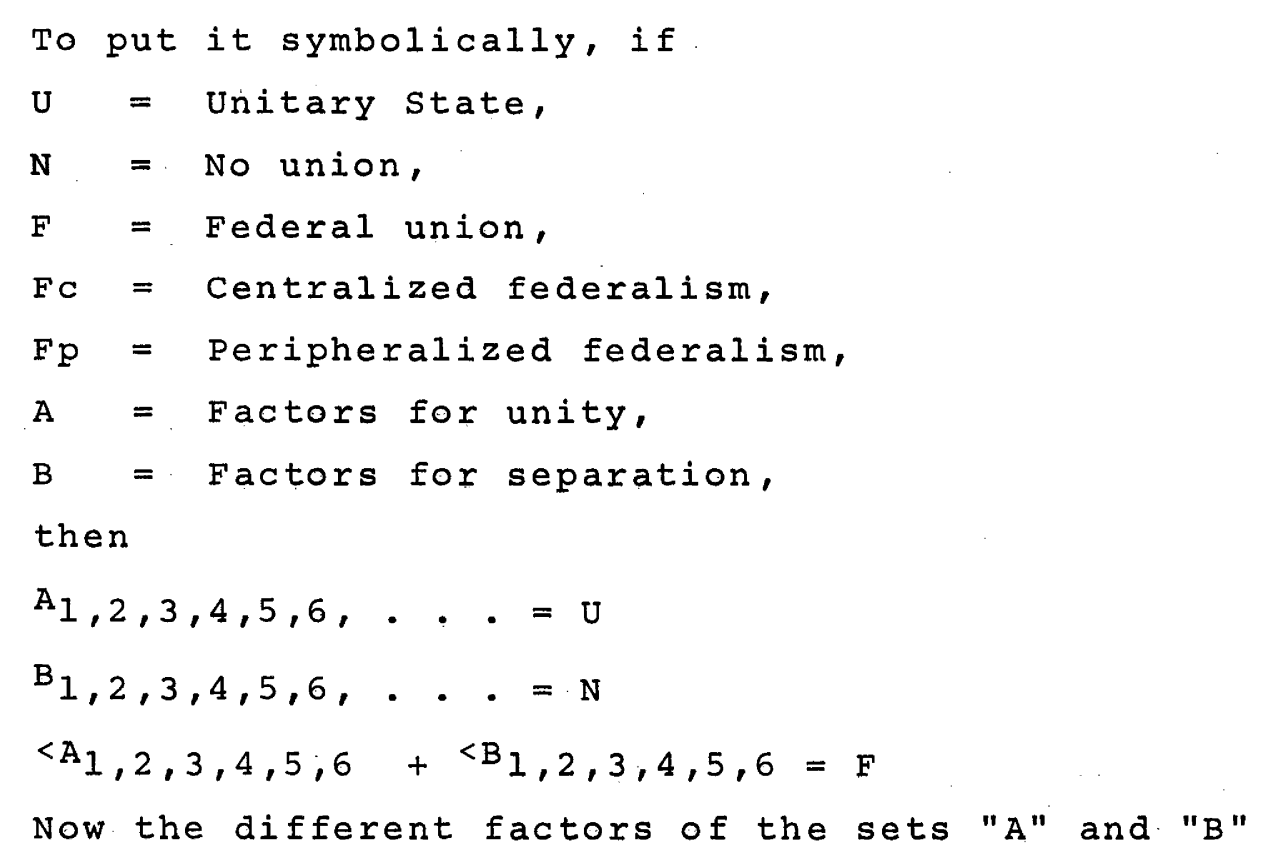
(i. e., those for unity and separation) may be present in different combinations. Accordingly, therefore, the nature of the resultant federations would also differ. From the study of the federal experiments so far made, we are in a position to envisage some of these possible combinations and the nature of the resultant unions. On the basis of these we may, I think, frame certain tentative models of the ution, Madras: oxford University Press, 1953, p. 55. 
origin of federalism. Some of these possible models that I have been able to decipher are given below:

(1) If the first factor of the first set (i.e., the factor $A_{1}$ ) is found in combination with the first three factors of the second set (i. e., factors $B_{1}, 2,3$ ), the situation is confederal. A union consummated under such a condition would last only as long as factor $A_{1}$ (that is, external threat) is formidable and is so recognized by the parties concerned. Pakistan offers a good example of this type. Such a situation can, nevertheless, change into a federal one if the actual or presumed threat to the survival of the constituents remains in existence for a long period of time during which through wise statesmanship and planning the parties involved have succeeded in creating some kind of interdependent economies mutually beneficial to all the participants.

(2) If factors 1, 3, 4, 5, and 6 of set "A" are present in combination with any one of the first group of set "B" (i. e., $B_{1 a}, B_{1 b}$ or $B l_{c}$ ), a fairly centralized but quite articulatedtype of federation is likely to result. India offers a good example.

(3) If factors $1,3,4,5$ and 6 of set "A" (i. e., $A_{1,3,4,5}$ and 6) are present along with an identical distribution of diversities in respect of the three elements (i.e., language, religion and."race") in the first group of set "B" (that is, $B_{1}(a+b+c)$ ), the resultant union may still be a centralized federation but it is likely to have some very strong dualistic undertones. Canada is a good example. The raison d'être of such a federation would depend upon factors 1 and 3 of the set "A", and if at any stage in its evolution either of these factors were to disappear, the sense of unity in the federation is likely to be adversely affected. If both these factors were to disappear together, the union would in all probability collapse.

(4) If factors 1, 2, 4, 5 and 6 of set "A" are present along with the factor 2 of the set "B", a federation may still be born but its existence will largely depend on the existence of the condition $A_{1}$, $i$. e., the factor of a common external threat to the collective security of the communities concerned. And if this factor of external threat is not present for a long enough time to have forced the constituent units of the federation to adjust themselves to the new situation to their 
mutual economic benefit (that is, if they have not succeeded in creating interdependent economies during the period that the external threat lasts), the end of this threat may mean the end of the federation as such. No historical example of this type is present, though the west Indian example reaches close to one. As will be remembered, the west Indian Federation was originally initiated by the indigenous leaders in order to achieve independence from British colonialism, but when it became clear that independence could be achieved even without the Federation, the federalistic enthusiasm began to wane. Similarly, it is not difficult to appreciate the force of possible external threat as a factor in the continued union of the two wings of pakistan.

(5) If all or most of the factors of set "A" are present along with factor 3 of the set "B" (that is, if the units concerned have regional identities based simply on their prior existence as autonomous provinces or as units of an overall system--in other words, if the units do not have any significant ethnic or economic bases for their regional identities--the resultant union may well be a centralized federation with a good amount of federal articulation provided that after the inauguration of the federation political and military conditions in and around the state remain largely peaceful so that the units are not required to forgo their regional autonomy for the sake of national security. Granted peaceful conditions during which the units are left to mould their own individual personalities, regional identities, despite the absence of any very clear-cut identifying factors of significance to the communities concerned, become rigidified; and the communities having acquired the habit of being masters of their own houses, are reluctant to subordinate themselves completely to the central government. West Germany offers a good example.

(6) If two or all of the elements of $B_{1}$ are present along with most of the factors in set "A" (except the factor $A_{2}$ ), and the patterns of diversities created by $B_{I_{a}}, B_{1 b}$, and $B_{1 C}$ are overlapping in their regional distributions in relation to the constituent political units, the resultant union is likely to be a centralized federation. It will be so because this pattern of distribution of the conflicting diversities 
tends to divide each group against itself, since despite the antagonism that a group as a whole may harbour against a group of another type, neither group is able to overplay its hand against the other because it finds a section of the people of its own group having strong sympathies with certain sections in the opposite group. As explained in the preceding chapters, this pattern of geographical distribution of diversities by its very nature forces the communities concerned to compromise and thus to learn to live and let live. Switzerland offers the best example.

(7) Presence of factor $B_{5}$ in whatever combination of factors in the sets "A" and "B" will not produce a stable union: that is, if the units involved recognize conflicting threats to their safety and security, no durable union is likely to emerge whatever other factors might be present. The central African Federation provides a clear example.

(8) The sixth factor in set "B" (i. e., the existence of groups of units following contrasting and mutually incompatible social, economic and political philosophies), in whatever combination of factors in set "A", creates an essentially confederal situation. A federation created under these conditions can last only as long as the constituents think that they derive greater economic and other dividends within than without the union. The factor ${ }^{B} 6$ will in the long run either break the union or would itself have to be broken (by coercion) in order that the union should be maintained. The United States of the Civil war days would prove the point. To summarize the points stated above,
if $U=$ Unitary state,
$\mathrm{N}=$ No union,
$\mathrm{F}=$ Federal Union,
$\mathrm{FC}=$ Centralized federalism,
$F p=$ Peripheralized federalism,
A = the factors for unity,
$B=$ the factors for separation,

then the general proposition is

$$
\begin{aligned}
& \mathrm{A}_{1}, 2,3,4,5,6, . .=\mathrm{U} \\
& \mathrm{B}_{1}, 2,3,4,5,6, . \cdot .=\mathrm{N}, \text { and } \\
& <\mathrm{A}_{1}, 2,3,4,5,6,+\mathrm{B}_{1}, 2,3,4,5,6=\mathrm{F}
\end{aligned}
$$


Based on various combinations of factors in sets "A" and "B", the following laws on the origin of federalism may be deduced:

(1) $A_{1}+B_{1}, 2,3 \ldots \ldots=F P$

(2) $\mathrm{A}_{1}, 3,4,5,6+\mathrm{B}_{1 \mathrm{a} / 1 \mathrm{~b} / 1 \mathrm{c}=\mathrm{FC}}$

(3) $A_{1}, 3,4,5,6+B_{1}(a+b+c)=F C p$ (i. e., a centralized federalism with strong dualistic undertones)

(4) $A_{1}, 2,4,5,6+B_{2}=F P$, but $\mathrm{A}_{2}, 4,5,6+\mathrm{B}_{2}=\mathrm{N}$

(5) $\mathrm{A}_{2}, 3,4,5,6+\mathrm{B}_{3}=\mathrm{FC}$, but $A_{1}, 2,3,4,5,6+B_{3}=F C \longrightarrow U$

(6) $\mathrm{A}_{1}, 3,4,5,6+\mathrm{B}_{1 \mathrm{a}}+\mathrm{B}_{1 \mathrm{~b} / 1 \mathrm{c}}=\mathrm{FC}$

(7) $\mathrm{A}_{1}, 2,3,4,5,6+\mathrm{B}_{5} \cdot \cdots=\mathrm{N}$

(8) $\mathrm{A}_{1}, 2,3,4,5,6+\mathrm{B}_{6} \cdot \cdots=\mathrm{FP} \rightarrow \mathrm{N}$ of these, (2) and '(6)' smight we ll he combirsed.

A scrutiny of the above arguments on the origins of federalism would show that in all the combinations of the factors for unity and separation that we have envisaged, wherever a centralized federalism is likely to emerge one of the first three factors in set "B" has always been present. That is, we find that in order that a centralized union is federal rather than unitary, it is necessary that the political units involved have some regionally-grouped diversity as their raison d'être for regional autonomy. These regionallygrouped diversities may result either from regional differences in the ethnic composition of the communities concerned, or from the existence of independent economies in the units involved, or it may result simply from the prior existence of the units as separate or autonomous organic political entities. Though the nature of the resultant union would vary depending upon which of these regionally-grouped diversities is the basis of the regional identities, the critical factor to remember is that only when the communities that are uniting together have separate regional identities, based on some regionally grouped diversities, would the resultant union, under normal conditions, be a federal as contrasted to a unitary polity. Indeed, federalism would often become nothing if it is required mainly to cope with diversities lacking inclusive territorial bases. In contrast 
to a unitary union, a federal union requires that the communities involved, should besides recognizing a common national boundary (political, cultural and other) around them all, should also recognize definite cultural, economic or some other boundaries along the lines that separate them from one another, although the regional political boundaries need not strictly coincide with the regional distribution of cultural, ethnic or other diversities within the state (see chapter I, section II). Thus not only diversity, but regionally-grouped diversity within unity is the essence of a centralized federalism. But it must be remembered that in federalism the sentiments for overall unity should have an edge over those for regional separation.

Though sometimes federalism imposed over a potentially nonfederal base may survive as a functioning federation, a comparative view of the West German and Latin American federations would, however, show that in contrast to federations which are created on a truly federal base (i. e., on a base where regional identities are strongl it is necessary that the federations of this latter type should in their initial phase remain free from any external threats that might requixe over-extension of central powers which might easily squeeze the constituents into complete unity (in view of their overall mutual compatibility).

Part 2

WHAT MAINTAINS FEDERALISM?: SOME GENERAL PROPOSITIONS

No less important than the study of the circumstances that favour the rise of federalism, is to answer the question "What maintains federalism?". As our study of federalism in the past would show, federal experiments have perhaps more often failed than survived. Among general inquiries on the subject, the more notable ones are those by Riker, sawer, McWhinney, and May, besides some significant observations by Mill in his classic Representative government. 31 A recent

\section{1}

Riker, op. cit., footnote 8; G. F. Sawer, Modern Federalism, London: C. A. Watts \& Co., 1969; Edward McWhinney, Federal Constitution-Making for a Multinational World, Leyden: A. W. Sijthoff, 1966; R. J: May, "Decision-making and Stability in Federal systems", Canadian Journal of political Science, Vol. 3, 1970, pp. 73-87; Mill, op.cit., footnote 27. 
book, rather than addressing itself to the problem of stability or instability, tries to explain Why Federations Fail? ${ }^{32}$ It is also relevant to this study. But the findings of most of these attempts are vitiated by the fact that their authors have insisted on purely political factors, such as the party system, ${ }^{33}$ or fiscal questions arising out of disparate size of the constituent units of the state, ${ }^{34}$ or on certain questions of general social and cultural values held by a particular society. 35 sawer and McWhinney, however, take a more general view, though both the authors (primarily constitutional lawyers) are presenting a general survey of modern federalism rather than addressing themselves to the specific question "What maintains federalism?".

In the analysis that follows I attempt to summarize and correlate my conclusions on the factors for the success or otherwise of the federations studied in the preceding chapters. (1) Our study of the various federations--switzerland, United states, Canada, India, Malaysia, etco--has shown that one of the fundamental factors in federal stability is that the regional identities on which the constituent units of a federation are based should not be completely mutually exclusive even though they may largely be conflicting. When boundary lines of the regionally-identifying diversities in a federal state highly overlap, the cleavages have a tendency to be transformed into linkages and the result is a stable federal partnership. "The point is most clearly brought out by the example of switzerland where the boundaries of language and religion are highly overlapping. The overlapping boundaries of language and religion in switzerland have weakened both language and religion as divisive forces, for each linguistic group contains representatives of both faiths, and of course vice versa. Hence, although the Catholics may

32

Thomas Franck (Ed.), Why Federations Fail? : An Inquiry into the Requisites for Successful Federalism, New York: 33 New York University Press, 1968.

Riker, op. cit., footnote 8 , 34 35 May, op. cit., footnote 31.

Franck, op. cit., footnote 32 . 
harbour a distaste for the protestants (or vice versa), they cannot discriminate or fight against them because each (the Catholic as well as the Protestant bloc) is divided within itself since a sizable number of its own group has a close affinity with a sizable section on the opposing side owing to the ties of a common language of communication despite the differences in faith. Thus neither side has been able to fortify its camp without risking a fair segment of its group in the opposite camp. Thus neither language nor religion has been able to overplay its hand and the fissiparous tendencies have cancelled out.

When we compare Switzerland with Canada, the moral is easily drawn. Because both the French language and the Roman Catholic faith have been very highly identifiable with the province of quebec in Canada, here the religious and linguistic division, in contrast to the situation in switzerland, has been plaguing the federal partnership. The point is obvious in the case of India also, where ever since the creation of linguistic states in the nineteen fifties, fissiparous tendencies have raised their ugly heads. As I have explained in my chapter on the United states, the point is amply clear when we closely analyze the American partnership in the first sixty years of the nineteenth century.

It may need clarification that the federal situation that we are discussing here is clearly distinguished from a functional situation where the identities or conflicts within the society permeate the entire nation rather than having distinct territorial bases. In our examples regional diversities are territorially arranged, and each component unit of the state possesses some clearly identifiable personality, though despite their clear regional interests their overall interests are not mutually exclusive because their internal. political boundaries do not completely coincide with the linguistic, religious or economic divisions within the nation.

(2) Many students of federalism (the American, Canadian and Australian) have paid attention to the role of the structure of the party system in the maintenance of centralization or peripheralization of federalism. Some of the best known studies on this topic are those by Truman, and Grodzins 
on the United States; Wildavsky on Australia and a more recent essay by Muller on Canada. ${ }^{36}$ All these studies have focused attention on the role of the party system in the operation of the state as a federal system. William Riker, evidently drawing from these studies, has asserted (what was only implicit in the previous studies) that

The federal relationship is centralized according to the degree to which the parties organized to operate the central government control the parties organized to operate the constituent governments. This amounts to the assertion that the proximate cause of variations in the degree of centralization (or peripheralization) in the constitutional structure of a federalism is the variation in degree of party centralization. 37

Whatever the general social conditions, if any, that sustain the federal bargain, there is one institutional condition that controls the nature of the bargain... This is the structure of the party system, which may be regarded as the main variable intervening between the background social conditions and the specific nature of the federal bargain. 38 [Emphasis added.]

This line of approach to the problem, which seems currently to have become quite popular, clearly appears to have confused the effect with the cause. Political parties or interest groups arise in response to certain inherent social or other conditions of a given area, they cannot by themselves be the structural features of any political system. The extent to which the party ruling at the centre would be in a position to control the governments in the regions would depend upon the nature of the geographical distribution of economic, social or cultural elements which are relevant in the national political life. If such elements have a somewhat exclusive regional distribution, the chances are slight that under peaceful conditions, the party ruling at the centre would be

Especially relevant are the following essays: D. B. Truman, "Federalism and Party System"; Morton Grodzins; "American Political Parties and the American System"; Steven Muller, "Federalism and. Party system in Canada"; and A. Wildavsky, "Party Discipline Under Federalism: Implications of the Australian Experience". Though originally published in different places (except the article by steven Muller), these different essays are reprinted together in Aaron Wildavsky (Edo), American Federalism in perspective, op. 37 cit., footnote 17 .

Riker, op. cit., footnote 8, p. 130 . 38

Riker, op. cit., footnote 8, p. 136. 
in a position to control all or even most of the regional governments as well. But if the regional distribution of diversities on which the federal partnership is based is not exclusive, or the nation as a whole has developed a strong nationally-conscious division of classes, the chances are greater that political parties would be few in number, and that the party in control at the centre is most likely in control of a number of regional governments as well. Such a situation prevails in Australia where the "Australian Labor Party . . . in a sense.. . became a national party even before Australia was a nation". 39

The point was equally clear with reference to the Indian National Congress during its first flush of power under the leadership of the late Jawaharlal Nehru. The reasons were twofold: first, it was the party that had, in a sense, given birth to the new political nation; and secondly, it took some time for the new state units organized on a linguistic basis to ossify as linguistic homelands of some sort. This ossification has now become somewhat apparent. with the rise of linguistic patriotism, evident in the adoption of regional languages as the media of highest education, and with the field of enterprise for the common man becoming limited to his own linguistic homeland (i. e., the state in case of states other than those that have a language common with some other state, as the states in the Hindi belt). Hence regional political parties like the DMK party in Tamil Nadu (Madras), or the Siromani Akali Dal in Punjab, have come into power in some states. The number of such parties is likely to increase over time as the increasing popularity of regional senas (militant political organizations), the most forceful of which is the Siva sena in Maharashtra, would show. Such a situation would not be easily conceivable in Australia, ax the llnited states whe in the event of a futura numarial supariarity of the

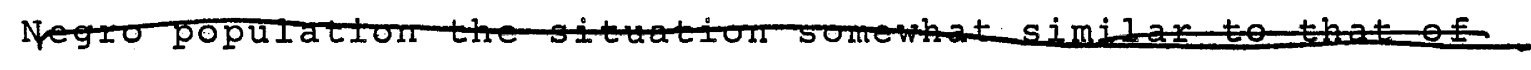
Quebec versus Engtish opak ing

Thus the essential fact in federal stability is not the

39

I. Overacker, The Australian Party System, New Haven: Yale University Press, 1952, p. 30. 
political party organization but the nature of the federal situation which gives rise to such a political interest. If the social, economic and other cleavages cut across regional political boundaries, as in Australia and to a lesser extent in the United States, then the political organization is likely to be centralized. But if the cleavages in national life are somewhat watertight as in quebec versus canada, the result is likely to be just the reverse.

(3) Relevant in this context is our supplementary hypothesis to the one noted above. The hypothesis is that in multiethnic or otherwise heterogeneous federations with regionallygrouped diversities, other things being favourable, the greater the factors of "felt" diversities in the national life, the greater are the chances of a stable federalism, for under such a condition chances are great that the resultant spatial pattern of these diversities would not coincide, and that their overlapping boundaries would neutralize the fissiparous tendencies.

The point, we have noted, is well demonstrated by the example of India where despite a large number of apparent diversities, language has come to be recognized as the only cleavage-forming factor in the national life at the level of the common man. As internal political boundaries have now coincided with the linguistic ones, the cleavage lines between states have hardened, and language has begun to play divisive mischief. Granted the serise of general overall national unity and the recognition of strong. State-idea unique to the nation itself, the chances for a more stable federal partnership would have increased if the country had possessed some cleavages other than those of language. For instance, if, as some wrongly believe, 40 the universal system of caste among the Hindus had run across the nation uniting all those of similar caste together, rather than the caste ties being largely limited by linguistic boundaries, as in fact is the case, the divisive influence of language would have been very greatly neutralized.

(4) Our next general proposition is that in multi-ethnic 
or otherwise highly heterogeneous federations with strong regional identities, a continued external threat to the collective security of the nation is a very favourable factor in the maintenance of the state as a centralized federation, for if external threat continues for a long enough time, the parties to the federal union, despite their sometimes mutually exclusive identities, are compelled to adjust their differences and learn to live together as a close-knit family. This factor squeezed the discordant cantons of switzerland into unity; the French spanish, and the British threats kept the otherwise discordant Thirteen Colonies together; the militant United states of the Civil war days forced the two quarrelling partners in "Canada" and the indifferent Maritime Provinces to join in order to create a united force against the seemingly encroaching Republic from the south. As already noted, the point is well explained when we compare the continued unity of Pakistan with the so rapid collapse of the west Indies federation. It was primarily the fear of Hindu-dominated India that had united the two "wings" of Pakistan, and many within and, without the country think that it is the same factor that largely kept them together, though prominent East Pakistani leaders have frequently voiced the opinion that the bond of a common religion (or a common distaste for another religion or group of people) may not keep them together for long, ${ }^{4}$ especially since the political cultures of the two wings are so different, 42 and the economic dividends are considered highly inadequate. 43

Conversely, opportunities for expansion may also foster federal sentiment by offering common rewards, as with the U. S. A. vis-á-vis Mexico in the nineteenth century. It has also been demonstrated that in areas removed from active political frontiers, sentiment for union is usually 4I

A reported statement by the East Pakistani Finance Minister. Reported in Morning News, July 1, 1965; cited in K. B. Sayeed, Political system of Pakistan, Boston: Houghton 42 Mifflin Co., 1967, p. 188. 43

sayeed, op. cit., footnote 41, p. 188.

The point is well taken by sayeed, op. cit., footnote 41, pp. 185-211. See also A. Tayyeb, Pakistan: A Political Geography, London: Oxford University Press, 1966, p. 181. See appendix to chapter IX. 
relatively weak compared to such sentiments in the areas bordering on active international frontiers. Julius pratt has shown this with reference to the United states of the 1812 War days. 44 The point is equally clear in relation to India. There is a comparative indifference to the border problems with Pakistan (which do not seem to threaten the security of the nation as a whole, in view of Pakistan's relatively small military power) in the southern states of the Indian Union, though when the nation was faced with the Chinese assault from across the Himalayas, the entire nation was alert to the danger. The passing of the Indonesian expansionist threat after the overthrow of president sukarno, may be part of the explanation for the failure of the "racial" partnership in Malaysia, though in Malaysia the spatial pattern of federal diversities largely rules out the question of disruption of the united nation as such. The quarrel in Malaysia is for a better deal: it does not question the unity of the Federation.

It may, however, be relevant to note in this context that contrary to the situation in federations where regional identities are quite strong, in countries where federation has been imposed over a largely nonfederal base (as in the Latin American countries or the post-1945 west Germany) it is the lack of external military threats that favours the continuance of the state as a functioning federalism rather than its transformation into a unitary organization. This is so because a federal political system once in motion tends to create vested interests and regional identities where none might have existed before. In order that these vested regional interests around the regional governments are able to take a deep root in the popular consciousness, it is necessary that the regional governments are left to manage their affairs uninterfered from outside for a long enough time during which the people of the regions concerned catch the habit of being masters of their own regional affairs and begin to resist central interference in matters that are purely regional. As already shown, a comparison 
between the West German and Latin American examples proves the point.

(5) When we proceed from the negative examples of federations that have failed we are drawn to the conclusion that in most cases of failure of federalism (e。go, Indonesia, the central African Federation, the West Indies, Pakistan, and Nigeria before the Civil Warl one common factor in the breaking or straining of the federal tie was the presence of one unit numerically so large as to be capable of vying in strength with many or all of the others combined.: Java was such a unit in the Indonesian Federation, Southern Rhodesia in the Central African, Jamaica in the West Indian, East Bengal in the Pakistani, and the Northern Region in the Nigerian Federation before the Civil war. In fact, as Mill pointed out long ago, for the stability of a federal experiment it is necessary that "there should not be one state so much more powerful than the rest as to be capable of vying in strength with many [or all] of them combined. If there be such a one and only one, it will insist on being the master of the joint deliberations...".,45 and thereby vitiate the federal partnership by turning the other components into its dependencies.

The examples of East Pakistan and Jamaica, however, show that numerical preponderance in population is not always a guarantee that the largest unit would predominate in the federal partnership. The overall locational advantages have much to contribute in deciding whether the largest unit would or would not become the dominant partner. And this would also largely decide whether the numerically dominant partner would or would not stay in the union, for if for no other reason, because of its numerical preponderance the numerically dominant unit is in a position to make its secession accepted.

R. J. May has tried to elaborate upon the effect of disparity in the size of the constituent units of a federation in the state-centre fiscal relationship and the relationship between the states. From his analysis May concludes that

45

Mill, op. cit., footnote 27 , pp. 366-67. 
The outcome of federation is determined by a number of factors.。[But] Two factors which exercise an important and fairly systematic influence on the outcome are the relative size and wealth of units. The evidence suggests that, in general, when large, rich units are ranged against small, poor units there is some chance of federation being preserved, but the likely outcome is centralization with large unit dominance; in the extreme case federalism may yield to a unitary state. When small rich units are ranged against large poor units, on the other hand, there is strong tendency for the small unit to secede。 46

(6) Mill's other dictum, already quoted in the first section of this chapter, may be relevant in this context also. As Mill says, a federation binas its constituents "always to fight on the same side; and if they have such feelings towards one another, or such diversity of feelings towards their neighbours, that they would generally fight on the opposite sides, the federal tie is neither likely to be of long duration, not [nor?] to be well observed while it subsists". 47 The Central African Federation, the united states of the Civil War days, and Nigeria before the Civil War would prove the point.

(7) Another point about stability of federalism, that has been emphasized by scholars like McWhinney, watts and sawer, 48 is that there should be a sufficient number of federating units (Sawer thinks, probably at least five) to prevent continuous face to face conflict of one or two potential rival units. The point is best explained by the example of Nigeria before the Civil war, where the federal structure "with a three way only, territorial dispersal of political authority, permit[ted] or indeed encourage[d] two regions to combine and pit themselves against the third region in the struggle for the fruits of power." 49 As already shown, this strain on the federal relationship was further aggravated because of the numerical preponderance of one of the units--a situation

\section{6} 47

May, op. cit., footnote 31 , pp. 86-87. 48

Mil1, op. cit., footnote. 27, pp. 367-68.

McWhinney, op. cit., footnote 31, p. 47; Watts, op. cit., footnote 40, pp. 154-155; Sawer, op. cit., footnote 31, 49 p. 132 .

McWhinney, op. cit., footnote 31, p. 47 . 
which assured permanent membership of the political power bloc to the largest partner, $i$. e., the North. We have already reviewed the game of musical chairs born out of this territorial pattern which by leaving the odd unit out of power at each turn brought the Federation to a breaking point. Where there are only two units in a federation, or only two clearly defined groups of units, there is likely to be a kind of permanent tug of war between the units or the groups concerned. This situation is bound to put great strain on the federation concerned, and if the units or groups were to develop mutualiy incompatible regional identities, the federation would most likely break. The point is amply proved by the united states during the Civil war days, and by the example of the uneasy partnership between the two wings of Pakistan (here, however, the units concerned are by no means mutually incompatible, though they have very limited common interests and do not derive many mutual economic advantages from the union).

(8) We now ask ourselves if, as was formerly believed, federalism is essentially a temporary wayside station to be pulled down in the course of a nation's journey towards a. fully unitary state-structure. Such a view is, however, no longer in vogue though at times one comes across scholars who still seem to believe in it. Though federalism is, in some senses truly a halfway house towards unity and integration in a world where large-scale nationwide planning has become largely necessary, federalism is not, in our opinion, just a stage towards unitary polity. This is because once a federation is established, it tends to rigidify existing regional identities by giving them continued opportunity for articulation. In fact

If a federal system is once established, and if human good will and ingenuity are sufficient to keep it going for a certain period of time--ten years?--then the relative importance for federal stability of the various factors for initial federation may change materially. Incidental benefits may loom larger... [and] The very fact of working a federal system may bring into existence "favourable" factors which were initially lacking. 50

50

sawer, op. cit., footnote 31 , pp. 133-34. 
As sawer further writes,

one enduring factor tending to preserve Region autonomy is the self-interest and momentum which a Region governmental apparatus . . acquires merely from its existence. So long as the people with this vested interest are reasonably competent, and serve obviously useful functions, . . Conservatism, $0^{\circ}$ will be sufficient [to maintain the status quo], $51^{\circ}$

even in countries where there are no very clear-cut regional interests to preserve. As various writers have noted, countries with the so-called "structural" 52 federalism such as Australia and West Germany, prove the point.

Finally, as explained in the introduction to this study, federalism is essentially a democratic process-it is a democratic union of consenting partners. In order that it should continue as a union of largely consenting partners where the constituent regions have proper articulation of their needs and problems, it is necessary that the country concerned remains under a democratic system of government with a multiparty political system. Indeed a functioning federalism cannot exist without a guaranteed multiparty democracy.

\section{1} 52

Sawer, op. cit., footnote 31, p. 135.

Wildavsky, op. cit., footnote 36 , p. 178; L. Mayer ("Federalism and Party Behavior in Australia and Canada", Western Political Quarterly, Vol. 23, 1970, pp. 795-807) calls it "formalistic", the other type being called "congruent". 


\section{Appendix}

\section{FEDERAL CAPITALS AND TERRITORIES \\ AS FACTORS IN FEDERAL STABILITY}

\section{FEDERAL CAPITALS}

As political nerve-centres of states national capitals are of great importance in political geography. The choice of capitals is particularly important in federal states for national capitals have sometimes played crucial roles in the success or otherwise of federal organizations per se. But despite the fact that federalism has generally been considered as the most geographically expressive of all forms of government, little attention has so far been given to the study of federal capitals as a class: all that exists are some stray observations in general studies such as the one by spate.l The reason may well be that the study of capitals is a. "topic that has been well developed in European studies in political geography" while "American geographers on the other hand, have largely neglected capitals".2 This has meant a neglect of the study of federal capitals, for federal capitals are a feature more characteristic of Americas than of Europe.

Although our main objective in this study is to concentrate on the role of national capitals in the stability of federalism, in order to appreciate the problem fully we must cleax certain misconceptions that may be held with regard to their nature. If capitals were to be classified into "natural" and "artificial"--a classification that spate has shown to have been ill-conceived--then federal capitals all the world over would mostly rank in the latter category. Federal capitals are artificial in the sense that they often are not the "primate" cities 3 of their countries, and have often not developed from some original nuclei of the statearea. The reason why federal capitals are usually new creations rather than centres established on some old nuclei, is that, as opposed to most unitary state-structures,. a federal structure often means almost a new evolution--the creation of a new polity in place of an old one, and, in some senses, joining together of parts that formerly regarded themselves as more or less disjointed. But this would hardly justify to call them "artificial". In fact, the distinction between "artificial" and "natural" capitals "completely begs the question".4

$\overline{1}$

O. H. K. Spate, "Factors in the Development of Capital 2 Cities", Geographical. Review, Vol. 32, 1942, pp. 622-631.

R. Hartshorne, "Political Geography", in P. E. James and

C. F. Jones (Eds:), American Geography: Inventory and 3 Prospect, Syracuse: Syracuse University Press, 1954, p. 2.15.

M. Jefferson, "The Law of the Primate City", Geographical

4 Review, Vol. 29, 1930, pp. 226-232.

Spate, op. cit., footnote 1, p. 622 . 


\section{CAPITALS IN CLASSICAL FEDERATIONS: ESSENTIALLY "NEW" AND "NEUTRAL"}

In federal states of the older type, as exemplified by the United States, Canada, and Australia--where the new state-structure did not evolve from a somewhat integrated unitary organization, the capital of the new nation had of necessity to be built afresh. This was because the federal government was created partly (at least) to serve as an arbiter between the constituent units of the state. The arbiter could not possibly be expected to be impartial if it were to be housed and fed by one of the interested parties --i. e., one of the constituent states of the federation. For this reason federal capitals had often to be located on neutral ground.

The United States, which "invented" the modern centralized federalism, also showed the way in this respect. As Whittlesey points out, the United states capital, Washington, is "almost between the southern and northern boundaries of original States and only 50 miles from the Mason and Dixon Line, boundary between slave soil and free". 5 washington's site was, therefore, in most respects neutral and central, and, therefore, best suited to serve as the seat of the central arbiter--the federal government. This principle is equally clear in relation to Canada, where ottawa was chosen to avoid ill feeling which would in all probability have resulted had any of the four capitals of the constituent units been selected. The city marks "the end of Frenchspeaking territory within ontario as well as quebec, and is divided into two almost equal linguistic sections. Therefore it is as nearly neutral ground as can be found". 6 Similarly Canberra was selected on neutral ground between sydney and Melbourne, the two leading partners in the federal bargain of 1900 .

Berne, which was selected as the capital of the swiss Confederation in 1848 , is not located on a new and neutral ground in the sense that federal capitals in the three largely Anglo-saxon federations are, though the principle of federal compromise between the main linguistic and religious components of the state is quite obvious in its choice as the seat of the central government. As a compromise location between Protestants and Catholics on the one hand, and the German- and French-speaking groups on the other, Berne and Fribourg were the two best choices--each bordering on the other, and representing respectively the Protestant-German and French-Catholic alignment (though as we have seen, in Switzerland the boundaries of language and religion do not coincide). In 1848 religion was the main identifying cleavage in the country, and since the Catholic group had just been defeated in the sonderbund. War, the decision on the part of the ascendant protestant-German bloc to locate

5 6

D. Whittlesey, The Earth and the State, New York: Henry Holt \& Co., 195i, p. 555.

Whittlesey, op. cit., footnote 5, p. 555 . 
the national capital on its western borders rather than in its geographical heart, was a sufficient concession for compromise.

In this sense then, in each of the classical federations the national capital was located largely on a "neutral" or compromise site, though, unlike others, Berne was not a "new" capital.

\section{NEW AND NEUTRAL CAPITALS NOT NEEDED IN EVERY TYPE OF FEDERATION}

A significant point that has often been missed is that only in those states where the federal structure is more or less a new creation, rathex than some kind of recasting of a somewhat unitary structure, does the need for new and neutral capitals arise. In the formerly more or less integrated unitary organizations, as most of the post-1945 federations in Asia and Africa were, the former colonial capitals have often continued to serve as the seats of the respective new governments, irrespective of the fact whether they are sited on neutral ground or not. This was also the case in the Latin American federations where most of the former colonial capitals (and the principal cities of the respective areas), continued to serve as the capitals of the new federal states; though after being designated as federal capitals these cities were shorn of much of their tributary areas directly under their control by carving out federal capital territories around them.

\section{Latin American Capitals}

In the absence of a long tradition of regional autonomy (which was so characteristic of the British colonies in America), conditions conducive to a long-drawn federal negotiation which would necessitate a compromise capital did not exist in Latin America in general. Grant of local autonomy in certain spheres was enough to satisfy a people who had seldom, if ever, tasted it. For this reason the former colonial capitals continued to serve as the seats of the respective new governments.

Mexico City, the earliest capital of conquest in America, remains "a neat example of an outmoded defence point maintaining its political leadership in face of a radically changing economic world, supported by vested interests and location near the geopolitical centre of gravity".7

Similarly, venezuela, after its independence from Colombia, converted its provincial capital Caracas to the capital of its newly formed federation. The case of Buenos Aires is too clear to need emphasis. Its predominance in Argentinian affairs was seldom in doubt and continues to remain so. But all this did not prevent its selection as the seat of the national government in favour of some neutral site at the time the country declared itself a federation.

In the like manner Rio de Janeiro was chosen as the 7 Whittlesey, op.cit., footnote 6, p. 463 . 
capital of Brazil in 1726 when its importance was greatly increased because of the exploitation of gold in the highlands north of the town, though its choice as the national capital had been fortunate in that it could be looked upon as a compromise location between "the waxing upland south and the waning, coastal north-east". "Rio probably comes nearer than any other place could to representing the diversity of interests that make up Brazil".8 It was one of the reasons why the city was retained as the capital when the country declared independence in 1822. When a federal Constitution was adopted in 1891, the city continued as the seat of the federal government though a provision was made in the Constitution that the capital would be removed from Rio and established at a place near the geographical centre of the country.9 But the city continued as the capital of the country for over seventy years after the adoption of the federal Constitution despite some rivalry between the capital and săo Paulo--the industrial giant of Brazil; and the jealousy in the heart of the rest of Brazil against the two leaders.

The example of Brasilia cannot be taken as an evidence of federal compromise of the type witnessed in the classical federations discussed above. Though pious hopes have been expressed that the new capital may provide the much needed "focus of national unity, that element of stability in the confusion of the nation's life",l0 "The most often heard and perhaps the most persuasive single argument for the construction of Brasilia is that it would open up the vast, empty core of the nation. - . Moreover, this no man's land offers potential routes for overland connections among the peripheral cells of the existing settlements".ll

\section{Capitals in post-19.45 Federations.}

Among the post-1945 federations, most of which are colonial successor states, the question of new and neutral capitals has often not arisen because in most of these the colonial administration concerned had already established a seat of government from which the different regions now forming the constituent states of the respective federations, were effectively governed. During the long period of colonial administration these centres had often become the focus of transport and communication lines in their countries. Under these conditions choice of a new capital would have meant the disruption of a settled pattern in the nation's economic and political life.

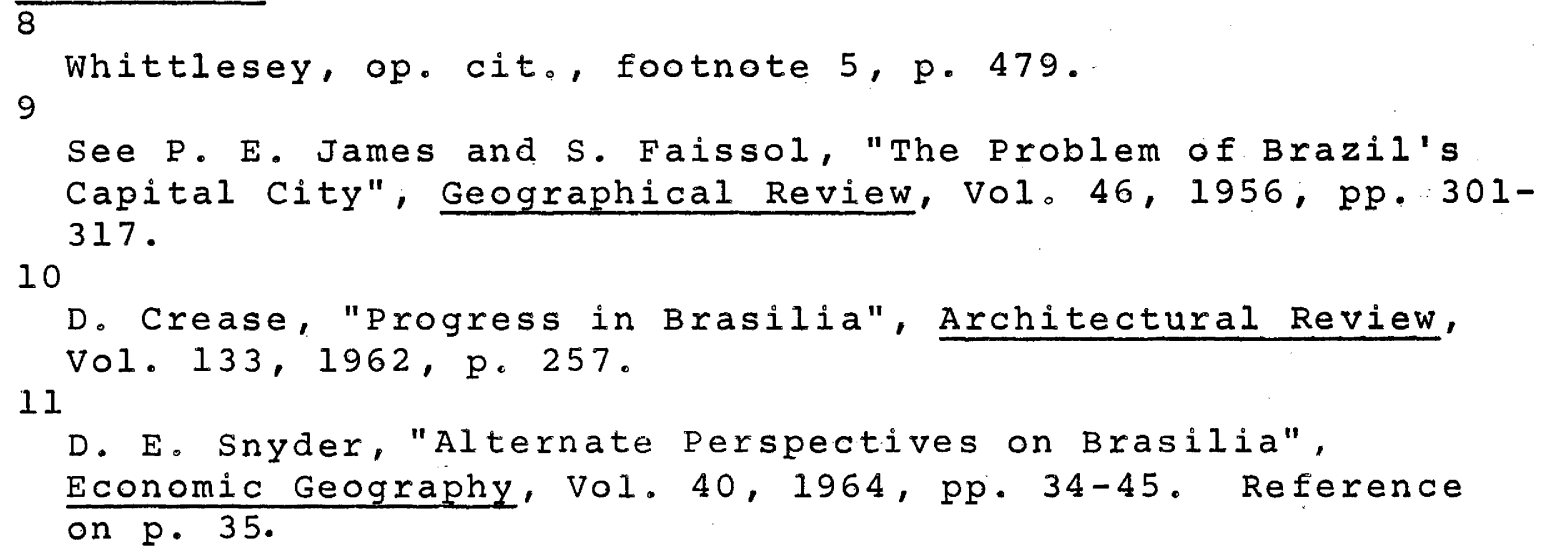


Neutral capitals were needed only in those post-1945 federations where for one reason or another the federal structure that was being erected was essentialiy a new organization as in the West Indies or in Pakistan. The question could very well have arisen in the Central African Federation if the African population in the two protectorates had possessed the vote. In the absence of franchise to the natives, the minority government under the overwhelming predominance of southern Rhodesia made its regional capital Salisbury as the seat of the federal government as well. In West Germany also the new federation meant almost a new creation, although regional identities in most of its component units were not strong. West Germany was not "all Germany"; and no traditional seat of government for all of Germany was left within the area. Such other centres as there were had already strong claims as capitals of the component units. Cologne was an exception, but perhaps accidental factors (e. g., bomb damage) came into play. Thus Bonn as the new capital was almost a neutral site.

Kuala Lumpur, the capital of Malaya and now of Malaysia, has been a large city only since the second War. It was selected as the capital of the newly amalgamated Federated and Unfederated Malay states in 1948. "The choice was made because Kuala lumpur happened to be the existing local administrative center with a reasonable site which was most nearly central and accessible within the populated and economically developed area of Malaya, still essentially the west coast plain"..12. The town had previously been the head-quarters of the Federated Malay states. When Malaysia was created by joining the Borneo territories of Sabah and Sarawak (originally also singapore), no question of relocating the capital arose even though the city of Kuala Lumpur was so far removed from the new components of the Federation east of the Malayan mainland.

The same is true of Lagos which as the capital of Nigeria is a legacy from its colonial past. It has continued as the capital of the Federation even though ethnic character of the city is not much different from the traditional yorubacapital, Ibadan. As a result of its location on the margins of the Western region, and its peripheral location in relation to the overall area of the state, the capital tends to have a regional rather than a truly national colour around it. 13

In case of India, Calcutta, the original river-mouth seaport of maritime penetration, remained the capital until 1911 when the seat of colonial administration was moved to Delhi (New Delhi). The move was "in part a conscious effort to harmonize the alien rule with the historic tradition", and

12

R. Murphey, "New Capitals of Asia", Economic Development and Cultural Change, Vol。 5, 1956-1957, pp. 216-243. 13 Reference on p. 236.

See G. Hamdan, "Capitals of the New Africa", Economic Geography, Vol. 40, 1964, p. 245. 
in part a recognition that the port of penetration was no longer more important than the rest of the country. Lying in a narrow lowland passage where desert on the west, mountains on the north, and hills to the southwest give way to the productive valley of the Ganga and to easy routes to the south, Delhi possessed some compelling advantages which no ruler aiming at a tight control over the subcontinent could fail to discern. It is therefore rightly said that "as a conveniently central administrative location it [i.e., Delhi] is India's natural capital", and "has persisted as the major control point of India since at least the tenth century A. D., and was prominent for a millenium before that". 14 No doubt, then, that Delhi has been considered as "the only capital in the world at once so old, so big, and so exclusively devoted to administration. 15

New Delhi may sometimes be considered to have been selected as a neutral site between Calcutta, Bombay, and Madras, the three original control points of the British administration and penetration in India. But the decision to shift the capital from Calcutta to the central core of the country was an administrative expediency on the part of the imperial government rather than a compromise resulting from a federal bargain. (It may also be that for the selfconscious imperialism of the British Raj, there was an obvious attraction in a site so strongly identified with the whole tradition of Empire in India.) The city may, however, be viewed as a compromise location (though not a neutral

I slamic ont Hindu location) between the though this compromise was not by design.

A parallel has sometimes been drawn between New Delhi and Canberra. It is, indeed, true that ". . both the lusty giant New Delhi and the lusty infant Canberra approximate in function", for both being capitals of functioning federal States have almost "an identical political geographical role".16 It need however be remembered that the two had highly different historical and geographical origins. While the site of Delhi is, in the now discredited old vocabulary well fitted for a "natural" capital, Canberra is, we have seen, a leading example of the so-called "artificial" and neutral capitals. Indeed, the two capitals though serving almost similar functions, were not the products of similar politico-geographical forces of federal bargain.

National capitals in most colonial areas are characterized by an excessively marginal location in relation to the overall area of the state concerned. This was an obvious result of their origin as colonial footholds. As colonial footholds they were central between the "hinterland" of the colony on the one hand, and the invisible metropolitan

\footnotetext{
$\overline{14}$ 15

Murphey, op. cit., footnote 12, p. 225 . 16

Murphey, op. cit。, footnote 12, p. 229.

O. H. K. Spate, "Two Federal Capitals: New Delhi and

Canberra", Geographical Outlook, Vol. 1, 1956, pp. 1-8. Reference on p. 8 .
} 


\begin{abstract}
"foreland", on the other.17 For this reason they were best suited as colonial capitals. But in the post-independence era their peripheral location has proved a definite disadvantage especially in countries with large areas and relatively more underdeveloped transportation and communication since in these conditions it has often meant a weak grip of the capital over the outlying provinces, and has tended to give the capital a regional rather than a national outlook. For this reason some tendencies towards the shift of capitals from the former "windows" (mostly maritime) to the interior may be noted, both. in federal as well as nonfederal states. But such movements of capitals should be viewed for what they are--administrative conveniences and a return to old national traditions--rather than examples of any federal compromise. Shift of capitals from petersburg to Moscow, or from Karachi to Islamabad, or a possible future shift from Rangoon to Mandalay,18 would all come under this category.
\end{abstract}

Among the more recent examples of federal, experiments, only in pakistan and the West Indies was the situation somewhat similar to those found in the United states, Canada, or Australia in the pre-federation days. In neither of these new states was there any previous tradition of an united and integrated administration of the areas that were now to form the new state. As the two end organs cut off from. a body politic (British India), the two "wings" of pakistan found themselves as near-strangers to each other. Because the two "wings" are removed from each other by over a thousand miles of alien territory, any neutral site for a federal capital that would satisfy both the wings could not be found. The capital was previously located at the port city of Karachi but was later shifted to the relatively minor inland town, Rawalpindi, close to which has been erected the new city of Islamabad, near the Indo-Pakistani frontier. Islamabad should, in this sense, be regarded as a "forward" rather than a neutral capital.19

\title{
CONCLUSION
}

Balancing role, not the Neutrality of site is the Essential feature of Federal Capitals

The choice of a national capital was more crucial and complex in the Federation of the West Indies in view of the

\section{7}

"Forelands [as opposed to 'hinterlands'] are the land areas which lie on the seaward side of a port, beyond maritime space, and with which the port is connected by ocean carriers". G. Weigend, "Some Elements in the study of port 18 Geography", Geographical Review, Vol.48, 1958, p. 195.

See O. H. K. Spate, "Mandalay and Rangoon: The Old and the New in Burma", Transactions and Papers, Institute of British Geographers, Publication No.44, 1968, pp。155-168. 19 Reference on p. 164 .

The concept of "forward capitals" was first formulated by V. Cornish, The Great Capitals, London: Methuen \& Co., 1923. 
highly disparate size of the constituent units of the Federation, and the fragmented nature of its state-area. Though the causes for the failure of the Federation were complex, an unsuitable site of the federal capital was itself a contributing factor. The Federation, as it finally came into existence, had greatly reduced the weightage of Jamaica by means of its underrepresentation in the central legislature. In view of this already effected neutralization of the size of Jamaica, it would have been better if the capital was sited somewhere within Jamaica. But as the capital was sited in Trinidad, the Jamaicans lost any emotional attachment with the Federation whatsoever, and the people of the island eventually decided to secede. 20

In this sense, it is not so much the neutrality of site as its essentially balancing role between the constituents of the federation that is the fact of primary importance in the character of a federal capital. Though in earlier ("classical") examples of federalism this balance was often achieved by locating the federal capital on a new and neutral site, such neutral sites may, however, not always be available because of the nature of the units involved. The point was, long back, obvious from the example of Switzerland.

As the West Indian example amply proves, because of its essentially balancing role, the national capital in a federal state is almost literally like a key-stone (though not in the same sense that it is in a nonfederal complex state ${ }^{2}$ ) wherever a federation proceeds to bind formerly largely disjointed (or loosely joined) and/or discordant units. In all such examples the national capital should be so selected that it helps to balance the emotional attachment of the chief partners to the federation. Washington, ottawa, and Canberra were able to do so, and so they have survived along with the structures that were built upon them. The West Indian capital failed to accomplish this (in the eyes of the Jamaicans at least) by tilting the balance disproportionately against Jamaica. The West Indian federal capital, therefore, rather than resolving the issues, only contributed to the collapse of the arch of the federation that was being erected over the west Indies.

\section{FEDERAL TERRITORIES}

By the term "federal territories" we mean the areas-inhabited or otherwise--that for certain reasons are left under the direct control of the central government in a federal state. In the newer lands of vast open, spaces, such territories are likely to consist of near-virgin areas awaiting exploitation and settlement. Such precisely was the nature of the frontier territories in the united states

20

An account of factors leading to the choice of the West Indian capital is contained in D. Lowenthal, "The West Indies Chooses a Capital" Geographical Review, Vol, 48, 1958, pp. 336-364。

21

see spate, op. cit., footnote 1, p. 631. 
and Canada. To a lesser extent, the same was also true of Australia. In the older lands forming new federations, as for example India, these territories may usually consist of smaller political units which either for reasons of their separate identity or backwardness were not considered fit to be merged with some neighbouring state of the federation, or for strategic reasons the central government and the constituent states agreed to let these areas remain under the direct supervision of the central government. In some cases federal territories may also consist of newly acquired areas which, being won by the blood and treasure of all the federal units, could not fairly be annexed to two or three of them. Federal capital territories are also included under this heading.

In the case of federations in newer lands with vast open spaces, the chief importance of federal territories is to keep in reserve, under the control of the central arbiter (the federal government), a great resource for the future in which the people of each constituent unit of the union can look forward to new areas for settlement and enterprise. such territories by their nature tend to strengthen the power and prestige of the central government. They help to win the loyalties of large sections of the peoples in the constituent states who are in search for new opportunities and better prospects. By helping to make the central government look like a great santa claus, the federal territories in such federations help to blunt the teeth of divisive particularism among the constituents in the federal relationship.

The point is amply clear from the example of the United states where the great Frontier in the west helped to keep the highly conflicting groups of states on either side of the Mason-Dixon Line together in the federation. As long as the Frontier remained open to the people both in the slave-soil and "free", the united states, despite all the differences between its two sections, continued to develop as a united nation. But when in the middle of the nineteenth century it appeared to one of the sections, i. e., south, that the West was being closed to her for ever, the Union came almost on the verge of collapse.

As new states are carved out from the extensive territories under the control of a federal government, the process of centralization within the federation is further strengthened; first, because the new states that are so created depend for a good deal of their development on the central government, and secondly, because these areas usually lack any preexisting regional loyalties that sometimes vitiate the relationship between the original states. It may be significant to note that in the U. S. A. while both the New England group as well as the south at one time or another, harboured secessionist sentiments, the noncommitted west had always been for the Union. This point is also proved. by the Canadian example. Australia, however, presented quite a different case. Here the area of the continent was completely shared between the states when the Federation was born in 1901. Apart from the Australian Capital Territory and Papua and New Guinea (and some unimportant islands), the only federal holding of the Commonwealth of Australia is the 
Northern Territory, taken over from South Australia in 1911 simply because that state had not the resources to develop a huge and very difficult area, isolated by semi-desert from its own nucleus in the south. For these reasons the federal territories could have no significant effect in the maintenance of the federal tie in Australia.

Among the Latin American federations, the extent of the federal territory was quite significant in Brazil. But first, because federal loyalties in the Brazilian states were not seriously at issue and the unificationist tendencies were widely prevalent, and secondly, because each of the original states had enough area and resources of its own to develop, the federal territories were not required to make any significant contribution to the maintenance of the federal ties. The same had generally been true of the other Latin American federations.

The Latin American federations are, however, instructive in another sense. In each of these federations the federal territories, especially the Federal Capital Territory, has possessed considerable population and/or resources to make it possible to tower over some of the constituent states. For instance, in Argentina the Federal Capital accounted in 1961 for 14.82 percent of the total population while only one state (Buenos Aires) had a share larger than this ( 33.58 percent), and the rest of the twenty-one constituent states accounted for the remaining just over half of the total national population. Similarly in Mexico while the federal Capital District accounted for 14.0 percent of the total population in 1960, none of the thirty constituent states had more than seven percent of the national share. The case is still more glaring in Venezuela where the Federal Capital Territory accounted in 1962, for 16.71 percent of the total national population while the share of the most populous state, Zulia, was only 12.23 percent of the national total. In Brazil though the former Federal Capital Territory around Rio (now the state of Guanabara) accounted for only 4.66 of the total population, it had in 1964 accounted for a revenue of over twelve percent of the national total, a share higher than that of any state except the giant săo paulo which accounted for just under thirty percent. With such large shares of national populations directly under their control, the central governments are not likely to remain impartial arbiters which they are often required to be. While on the one hand, it helps to strengthen centralization of government in the countries concerned, on the other by making the central government as a partisan in federal matters, it tends to vitiate the federal partnership. 23

In the not-so-new lands that have formed federations

23

The figures for population and revenue for the Latin American

federations are taken from Harry Kantor, "Latin American

Federalism: Aspiration and Futility", in V. Earle (Ed.)

Federalism: Infinite Variety, in Theory and Practice,

F. E. Peacock Publishers, Itasca, Illinois: F. E. Peacock Publishers, 1968, pp. 185-208. 
after 1945, the federal territories are often settled areas rather than store-houses of resources for the future, as the federal territories in the United States and Canada were. For this reason federal territories have not been able to play the centralizing role in the new federations as the vast frontiers of settlement in the North America did. Here federal territories could have some significant influence on the centralization of power only if these territories, Spanish/ like those in the three ation American federations, possessed it possible for them to tilt the balance in favour of the national government. 
Aiyar, S. P., Federalism and Social Change, Bombay: Asia Publishing House, 1961.

Alexander, F., Australia Since Federation: A Narrative and Critical Analysis, Melbourne: Thomas Nelson (Australia) Ltd., 1967 .

Alexander, L. M., The World Political Patterns, New York: Rand MacNally \& Co., 1957.

Allen, H. C., "F. J. Turner and the Frontier in American History", in Allen, H. C. and Hill, C. P. (Eds.), British Essays in American History, London: Edward Arnold, 1957, pp. 145-166.

Allen, H. C., The United States of America, London: Ernest Benn Ltd., 1964 .

Anderson, W. , Federalism and Intergovernmental Relations: A Budget of Suggestions, Chicago: Public Administration Service, 1946 .

Anderson, $w .$, The Nation and the States: Rivals or Partners?, Minneapolis: University of Minnesota Press, 1960 .

Anderson, W., Intergovernmental Relations in Review, Minneapolis: University of Minnesota Press, 1960.

Andrews, C. M., The Colonial Period of American History, four volumes, New Haven: Yale University Press, 1943-1947.

Andrews, C. M., The Colonial Background of the American Revolution, New Haven: Yale University Press, revised edition, 1948 .

Anglin, D. G., "The Political Development of the West Indies", in Lowenthal, D., (Ed.), The West Indies Federation, New York: Columbia University Press, 1961, pp. 35-62.

Arikpo, 0. The Development of Modern Nigeria, Hammondsworth (Midalesex), England: Penguin Books, 1967.

Barber, W. J., "Federalism and the Central African Economy", in Leys, C. and Pratt, C. (Eds.), A New Deal in Central Africa, London: Heinemann, 1960, pp. 59-80.

Barber, W. J., "Federalism and the Distribution of Economic Benefits", in Leys and Pratt, A New Deal in Central Africa, pp. 81-97.

Barnard, M., A History of Australia, Sydney: Angus \& Robertson, 1962 . 
Basset, D. K., "The Historical Background, 1500-1815", in Gungwu, W. (Ed.), Malaysia: A Survey, Melbourne: F. W. Cheshire, 1964, pp. 113-127.

Beard, C. A., Economic Interpretation of the Constitution of the United States, New York: Macmillan Co., first published 1923 .

Beard, C. A. and Beard, M. R., The Rise of American Civilization, London: Jonathan Cape, two volumes in one, $\overline{194 . . . ? ~}$

Beck, J.M., "Canadian Federalism in Ferment" in Leach, R, H. (Ed.), Contemporary Canada, Durham, N. C.: Duke University Press, 1967, pp. 148-176.

Belaunde, V. A., Bolivar and the Political Thought of the Spanish American Revolution, Baltimore: John Hopkins University Press, 1938.

Benson, G. C. S., The New Centralization: A study of Intergovernmental Relations in the United States, Toronto: Oxford University Press, 1941.

Billington, R. A., The American Frontier, Washington, D. C.: Service Center for Teachers of History, second edition, 1965 .

Billington, R. A. (Ed.), Frontier Thesis: Valid Interpretation of American History?, New York: Holt, Rinehart \& Winston, 1966.

Billington, R. A., "Frontiers" in Vann Woodward, C. (Ed.), A Comparative Approach to American History, Voice of America Forum Lectures, Washington, D. C.: U. S. Information Agency, 1968, pp. 81-96.

Birch, A. H, Federalism, Finance and social Legislation in Canada, Australia and the United States, London: oxford University Press, 1955.

Birch, A. H., "Approaches to the study of Federalism", Political Studies, Vol. 14, 1966, pp. 15-33.

Blainey, G., Tyranny of Distance, Syaney: Sun Books, 1967.

Blainey, G., "Botany Bay or Gotham City?", Australian Economic History Review, Vol. 8, 1968, pp.154-163.

Blaut, J. M., "Space and Process", Professional Geographer, Vol. 13, July 1961, pp. 1-7.

Boehm, M. H., "Federation", Encyclopaedia of the Social Sciences, Vol. 5, pp. 169-172, New York: Macmilian Co., 1931.

Bombwall, K. R., The Foundations of Indian Federalism, Bombay: Asia Publishing House, 1967. 
Bondurant, J. V., Regionalism versus provincialism: A Study in Problems of Indian National Unity, Berkeley: University of California Press, 1958.

Bonenfant, J. C., The French Canadians and the Birth of Confederation, The Canadian Historical Association, Historical Booklets, No. 21, 1966.

Boorstin, D. J., The Americans: The Colonial Experience, New York: Random House, 1968 .

Bose, N. K., Culture and Society in India, Bombay: Asia Publishing House, 1967 .

Boudeville, J. $-R$, Problems of Regional Planning, Edinburgh: Edinburgh University Press, 1966.

Boulding, K., "The General systems Theory: The Skeleton of Science", Management Science, Vol. 2, 1956, pp. 197-208.

Boulton, G. C., "The Hollow Conqueror: Flax and the Foundation of Australia", Australian Economic History Review, Vol. 8, 1968, pp. 3-16.

Boulton, G. C., "Broken Reeds and Smoking Flax", Australian Economic History Review, Vol. 9, 1969, pp. 64-70.

Bourne, C. B., "The Federation of the west Indies", University of Toronto Law Journal, Vol. 13, 1959-1960, pp. $135-165$.

Bousquet, G. H., A French View of Netherlands Indies, translated from French by P. E. Lilinthal, London: oxford University Press, 1940.

Bowie, R. R. and Friedrich C. J. (Eds.), studies in Federalism, Boston: Little, Brown \& Co., 1954.

Braunthal, J., The Tragedy of Austria, London: Victor Gollancz Ltd., 1948 .

Brecht, A., Federalism and Regionalism in Germany: The Division of Prussia, New York: Oxford University Press, 1945 .

Brogan, D. W. , The American Political System, London: Hamish Hamilton, first published.1933, reprinted 1947.

Brown, R. E., Charles Beard and the Constitution: A. Critical Analysis of. "An Economic Interpretation of the Constitution", Princeton, N. J.: Princeton University Press, 1956.

Brown, R. H., Historical Geography of the United States, New York: Harcourt, Brace \& Co., 1948 .

Brunn, S. D. and Hoffman, W. I., "The Geography of Federal Grants-in-aid to States", Economic Geography,

Vol. 45, 1969, pp. 226-238. 
Brush, J. E., "The Distribution of Religious Communities in India", Annals, Association of American Geographers, Vol. 39, 1949, pp. 81-98.

Bryce, J., The Holy Roman Empire, New York: National Book Co., 1886 .

Bryce, J., American Commonwealth, two volumes, New York: Macmillan Co., 1888 .

Bryce, J., Modern Democracies, two volumes, London: Macmilian Co., 1929,

Bunge, W., Theoretical Geography, Lund Series in Geography, Series C, No. 1, Lund: G. W. K. Glerrup, 1966 (revised).

Burgin, M., The Economic. Aspect of Argentine Federalism, 1850-1852, Cambridge, Mass.: Harvard University Press, 1946 .

Burnett, E. C., The Continental Congress, New York: Macmillan Co. , 1941 .

Buschbeck, E. H., Austria, London: Oxford University Press, 1949 .

Cahnman, W. J., "Outline of a Theory of Area Studies", Annals, Association of American Geographers, Vol. 38, 1948, pp. 233-243.

Canaway, A. P., Failure of Federalism in Australia, London: oxford University Press, 1930 .

Careless, J. M. S., Canada: A Story of Challenge, London: Cambridge University Press, 1952 .

Carnell, F. G., "Political Implications of Federalism in New States", in Hicks, U. K. (Ed.), Federalism and Economic Growth in Underdeveloped Countries, London: George Allen \& Unwin Ltd., 1961, pp. 16-59.

Cerny, K. H., "Federalism in the West German Republic", in Earle, V. (Ed.), Federalism: Infinite Variety in Theory and Practice, Itasca, Ill.: F. E. Peacock. Publishers Inc., 1968, pp. 185-212.

Chanda, A., Federalism in India: A Study in Union-state Relations, London: George Allen \& Unwin Ltd.., 1965.

Chanda, A., "Should the Constitution be Redrafted?", Illustrated Weekly of India, Vol. 91, March 15, 1970, pp. 20-2I.

Chopra, P., Uncertain India, Bombay: Asia Publishing House, 1968 .

Choudhury, G. W., Democracy in Pakistan, Dacca: Green Book House, 1963. 
Clark, A. H., and Innis, D。 Q., "The Roots of Canada's Geography", in Warkentin, J.(Ed.), Canada: A Geographical Interpretation, Toronto: Methuen Publications, 1968, pp. 13-53.

Clark, C., Australian Hopes and Fears, London: Hollis \& Carter, 1958 .

Clark, J. P., The Rise of New Federalism, New York: Columbia University Press, 1938 .

Clark, M., A Short History of Australia, London: Heinemann, 1963 .

Coatman, J., India: the Road to Self-government, 1908-1941, London: George Allen \& Unwin Ltd., 1941.

Codding, G. R., Jr., The Federal Government of Switzerland, London: George Allen \& Unwin Ltd., 1961, new impression 1965 .

Cole, T., "New Dimensions of West German Federalism", in Pinney, E. L. (Ed.), Comparative Politics and Political Theory, Chapel Hill: University of North Carolina Press, 1966, pp. 99-122.

Collins, Tom, Such is Life, first published 1903, Sydney: Angus \& Robertson, 1948 .

Commonwealth of Australia, official yearbook of the Commonwealth of Australia, No. 55, Canberra: Commonwealth Bureau of Census and statistics, 1969.

Cook, R., Canada and the French Canadian Question, Toronto: Macmillan Co., 1966 .

Cook, R., (Ed.), Confederation, Canadian Historical Readings, No. 3, Toronto: University of Toronto Press, 1967.

Cornish, V., The Great Capitals, London: Methuen \& Co., 1929.

Corry, J.A., "Constitutional Trends and Federalism", in Lower, A. R. M. and others, Evolving Canadian Federalism, Durham, N. C.: Duke University Press, 1958, pp. $92-125$.

Corwin, E. S。, "The Passing of Dual Federalism", Virginia Law Review, Vol. 36, 1950 , reprinted in McCloskey, R. G. (Ed.), Essays in Constitutional Law, New York: Vintage Books, Random House, 1957, pp. 185-210.

Coupland, R., The Durham Report (An abridged version with an introduction and notes), Oxford: Clarendon Press, 1945 .

Cowan, C. Do, "The Political Evolution of Indonesia", in Rose, S. (Edo), politics in Southern Asia, London: Macmillan Co., 1963, pp. 235-249. 
Cowen, D. V., "Constitution-making in a Democracy", Optima (Supplement), March 1960, pp. 33-41.

Craven, A. O., The Growth of Southern Nationalism, 1848-1861, Baton Rouge: Louisiana state University Press, 1953.

Crawford, R. M. Australia, London: Hutchinson University Library, $19 \overline{52}$.

Creighton, D. G., The Commercial Empire of the St. Lawrence, 1660-1850, Toronto: Ryerson Press, 1937 .

Creighton, D, G., Dominion of the North: A History of Canada, Boston: Houghton Mifflin Co., 1944 .

Creighton, D. G., The Story of Canada, London: Faber \& Faber, 1959 .

Creighton, D. G., British North America at Confederation, Ottawa: Government Printers, first published 1939, reprinted 1963.

Crisp, L. F., Parliamentary Government of the Commonwealth of Australia, London: Longmans, Green \& Co., 1962,

Currie, D. P. (Ed.), Federalism in the New Nations of Africa, Chicago: University of Chicago Press, 1964.

Dale, E. H., "State-idea: Missing Prop of the West Indies Federation", Scottish Geographical Magazine, Vol. 78, 1962 ; pp. 166-176.

Das Gupta, J., Language Conflict and National Development, Berkeley: University of California Press, 1970.

Davis, H. A., "The Fenian Raids on New Brunswick", Canadian Historical Review, Vol. 36, 1955, pp. 316-334.

De Blij,H. J. (Ed.), Systematic Political Geography, New York: John Wiley, 1967.

De Blij,.H. J., "Forced Wedding: Federation in the Rhodesias and Nyasaland", in Africa South, Evanston: Northwestern University Press, 1962, pp. 292-350.

Deshpande, C. D., "S. R. C. Report: A Geographical Commentary", Indian Geographer, Vol.1, 1956, pp. 44-50.

Deshpande, C. D., "India Reorganized: A Geographical Evaluation", Indian Geographer, Vols. 1 and 2, 1957, pp. $164-169$.

De Tocqueville, A., Democracy in America, two volumes, New York: Knopf, 1945 .

Deutsch, K. and others, Political Community in the North Atlantic Area, Princeton, No. Jo: Princeton University Press, 1957 . 
Dicey, A. V., Introduction to the Study of the Law of the Constitution, London: Macmillan Co., first edition, 1885, ninth edition 1939 .

Dikshit, R. D., "Media of Education and National Unity", Indian Education, November 1965.

Dikshit, R. D。, "The Idea of Nationalism: Indian and. European", Indo-Asian Culture, Vol.15, 1966, pp. 15-30.

Dikshit, R. D., "India's Evolution as a Nation-state", Indo-Asian Culture, Vol. 16, 1967, pp. 211-226.

Dikshit, R. D., "Toward a Generic Approach in Political Geography", Tijdschrift voor Economische en Sociale Geografie, vol.61, 1970, pp. 242-245.

Dikshit, R. D., "Military Interpretation of Federal Constitutions: A Critique", Journal of Politics, Vol. 33 , 1971 , pp. 180-189.

Dikshit, R. D., "Geography and Federalism", Annals, Association of American Geographers, Vol. 61; 1971, pp. 97-115.

Dikshit, R. Do, "The Failure of Federalism in Central Africa: A Politico-geographical Postmortem", Professional Geographer, Vol. 23, April, 1971.

Dikshit, R. D., "Influences of Governmental systems on The Location of Economic Activities (with special Reference to India)", in Linge, G。J.R. and Rimmer, P. J. (Eds.), Government Influence and The Location of Economic Activities, Canberra: Dept. of Human Geography, Australian National University, 1971, (forthcoming).

Dill, M.,Jr., Germany: A Modern History, Ann Arbor: University of Michigan Press, 196I.

Dobby, E. G. H., "Some Aspects of Human Ecology of South East Asia", Geographical Journal, Vol. 108, 1948, pp. 40-54.

Dominion Bureau of Statistics, Canada One Hundred Years 1867-1967, Ottawa: Queen's Printers, 1967.

Duchacek, I. Do, Comparative Federalism: Territorial Dimension of Politics, New York: Holt, Rinehart and Winston, 1970 .

Elazar, D. J., The American Partnership in the Nineteenth Century United States, Chicago: Chicago University Press, 1962.

Elazar, D. J., "Federal-state Collaboration in the Nineteenth Century United states", Political Science Quarterly, vol. 79, 1964, pp. 248-281. 
Elazar, D. J., American Federalism: A View from the states, New York: Thomas Y. Crowell Co., 1966.

Elazar, D. J., "Federalism", in International Encyclopaedia of the Social Sciences, Vol. 5, pp. 353-367, New York: Macmillan Co. and Free Press, 1968.

Elkins, S. and McKitrick, E., "The Founding Fathers: Young Men of the Revolution", Political Science quarterly, Vol. $76,1961, \mathrm{pp} .181-2 \overline{16}$.

Emerson, R., State and Sovereignty in Modern Germany, New Haven: Yale University Press, 1928 .

Faulkner, H. U., American Economic History, New York: Harper, 1943 .

Febvre, L. (in collaboration with Bataillon, L.), A Geographical Introduction to History, translated by Montford, E. G. and Paxton, J.H. London: Kegan Paul, Trench, Trubner \& Co., 1932.

Feith, H., "Indonesia", in.Kahin, G. MCT. (Ed.), Government and Politics in Southeast Asia, Ithaca, N. Y.: Cornell University Press, 1961.

Fergusson, E. J., The Power of the Purse: A History of Public Finance, 1776-1790, Chapel Hill: University of North Carolina Press, 1961.

Finer, H., The Major Governments of Modern Europe, London: Methuen \& Co., 1962 .

Fisher, C. A., "The Problem of Malayan Unity in its Geographical setting", in steel, R. W. and Fisher, C. A. (Eds.), Geographical Essays in British Tropical Lands, London: George Philip \& Sons, 1956, pp. 269-344.

Fisher, C. A., "The Malaysian Federation, Indonesia and the Philippines: A Study in Political Geography", Geographical. Journal, Vol. 129, 1963, pp. 311-328.

Fisher, C. A., "Geographical setting of the Proposed Malaysian Federation", Journal of Tropical Geography, Vol. 17, 1963 , pp. 99-115.

Fisher, C. A., South-East Asia: A Social, Economic and Political Geography, London: Methuen \& Co., 1964.

Fisher, C.A., "Malaysia: A Study in Political Geography of Decolonization", in Fisher, C. A. (Ed.), Essays in Political Geography, London: Methuen \& Co., 1968, pp. 75-145.

Franck, T. (Ed.), Why Federations Fail?: An Inquiry into the Requisites for Successful Federalism, New York: New York University Press, 1968.

Franklin, H., The Unholy Wedlock: The Failure of the Central African Federation, London: George Allen \& Unwin Ltd., 1963 . 
Freehling, W. W., prelude to Civil war: The Nullification Controversy in South Carolina, 1816-1836, New York: Harper, 1966 .

Freeman, A. E., History of Federal Government in Greece and Italy, London: Macmillan Co., second edition, (edited by Bury, J。Bo), 1893 .

Friedrich, C.J., "Federalism, National and International, in Theory and Practice", (Basic paper of the rapporteur general), International Political Science Association, Oxford Round Table Meeting, September 19-24, 1963, pp. 61 .

Friedrich, C. J., Man and His Government: An Emperical Theory of Politics, New York: McGraw-Hill, 1963.

Friedrich, C. J., Impact of American Constitutionalism Abroad, Boston: Boston University Press, 1967.

Friedrich, C. J., Trends of Federalism in Theory and Practice, New York: Frederick A. Praeger, 1968 .

Forsey, E. A., "Canada: Two Nations in One", The Canadian Journal of Economics and Political Science, Vol. 28, 1962, pp. 485-501.

Gilliard, C., A History of Switzerland (with concluding pages brought uptodate by Biaduct, J. C., and translated by Hartley, D. L. B.), London: Macmillan Co., 1961.

Ginsburg, N., "Tasks of Geography", Geography, Vol. 45, 1969 , pp. 401-409.

Glazebrook, G. P. de T., A Short History of Canada, London: Oxford University press, 1950.

Gluek, A. C., "The Riel Rebellion and Canadian-American Relations", Canadian Historical Review, Vol. 36, 1955, pp. 199-221.

Goldwin, R. A. (Ed.), A Nation of States, Chicago: Rand MCNally \& Co., 1 1963 .

Gollan, R., "Nationalism, the Labour Movement and the Commonwealth", in Greenwood, G. (Ed.), Australia: A Social and Political History, sydney: Angus \& Robertson, 1955, pp. 145-195.

Gosal, G. S., and Mukerji, A. B., "The Religious Composition of India's Population", Tijdschrift voor Economische en Sociale Geografie, Vol.61, 1970, pp.91-100.

Grattan, C. H., The Southwest Pacific to 1900, Ann Arbor: University of Michigan Press, 1965 . 
Greaves, H. R. G., Federalism in Practice, London: George Allen \& Unwin Ltd., 1940 .

Greenwood, G., The Future of Australian Federalism, Melbourne: Melbourne University Press, 19.46.

Greenwood, G. (Ed.), Australia: A Social and Political History, Sydney: Angus \&. Robertson, 1955.

Griffiths, P., Modern India, London: Ernest Benn Ltd., 1962 .

Grodzins, M., "The Federal system" in The Goals for Americans, The Report of President's Commission on National Goals, New York: Prentice-Hall Inc., 1960, pp. 265-282.

Grodzins, M., "American Political Parties and the American system", Western Political Quarterly, Vol. 13, 1960 , pp. 974-998.

Gross, B. M., "Political Process", in International Encyclopaedia of the Social sciences, vol. 12, pp. 265-273, New York: Macmillan Co. and the Free Press, 1968.

Groves, H. E. and Sheridan, I. A. , The Constitution of Malaysia, New York: Oceana Publications, 1967 .

Gulley, J. I. M., "The Turnerian Frontier: A Study in the Migration of Ideas", Tijdschrift voor Economische en Sociale Geografie, Vol. 50, 1959, pp. 65-72. and $81-91$.

Hamdan, G., "Capitals of the New Africa", Economic Geography, vo1. 40, 1964, pp. 239-253.

Hamilton, A., Madison, J. and Jay, J., The Federalist Papers, with an introduction by Rossiter, C., New York:

The New American Library, 1961.

Hammeon, J. C., "Trade and Tariffs in British North American Provinces Before Confederation", Proceedings of the Canadian Political Science Association, Vol. 6, 1934, pp. 51-59.

Hancock, W. K., Australia, Brisbane: Jacaranda Press, first published 1930, reprinted 1961.

Haring, C.A., "Federalism in Latin America", in Reid, C. (Ed.), The Constitution Reconsidered, New York: Columbia University Press, 1938, pp. 341-347.

Harrison, S.S., India: The Most Dangerous Decades, Princeton, N. J.: Princeton University Press, 1960 .

Hartshorne, R., "The Functional Approach in Political Geography", Annals, Association of American Geographers, Vol. 40, 1950, pp. 95-130.

Hartshorne, R., "Political Geography", in James, P. E., and Jones, C.F., (Eds.), American Geography: Inventory and Prospect, syracuse: syracuse University Press, 1954, pp. 167-225. 
Hazlewood, A. and Henderson, P. D., Nyasaland: The Economics of Federation, Oxford: Blackwell, 1960.

Hermens, F. A., Europe Between Democracy and Anarchy, Notre Dame, Indiana: University of Notre Dame, 1951.

Herold, J. C., The Swiss Without Halos, New York: Columbia University Press, 1948 .

Herring, H., A History of Latin America, London: Jonathan Cape, 1954 (?).

Ho, R., "The Environment", in Gungwu, W. (Ed.), Malaysia: A Survey, Melbourne: F. W. Cheshire, 1964, pp. 25-43.

Holcombe, A. N., The Political Parties of Today, New York: Harper, 1924 .

Hol combe, A. N., Our More Perfect Union, Cambridge, Mass.: Harvard University Press, 1950 .

Hudson, J. C., "A Location Theory for Rural settlement", Annals, Association of American Geographers, Vol. 59, 1969, pp. 365-381.

Hughes, C., The Federal Government of Switzerland, oxford: Clarendon Press, 1954 .

Hughes, C. J., Confederacies, Leicester: Leicester University Press, 1963 .

Hughes, C. J., "The Theory of Confederacoes", paper read at the International political Science Association, Oxford Round Table Meeting, September 19-24, 1963, pp. 13 .

Husain, S. S. (Ed.), Dacca University Seminar on Contemporary Writings in East Pakistan, Dacca: Dacca University, 1958 .

Ilbert, C., Government of India, London: oxford University Press, third edition, 1915 .

Innis, H. A., The Fur Trade in Canada: An Introduction to Canadian Economic History, Toronto: University of Toronto Press, first published 1930, new edition, 1956.

Jackson, W. A. D。 (Ed.), Politics and Geographic Relationships, Engelwood. Cliffs, N. J.: Prentice-Hall, 1964.

James, H. G., The Constitutional system of Brazil, Washington, D.C.: The Carnegie Institution, 1923.

James, P. E., "Some Fundamental Elements in Analysis of the Viability of states", in Fisher, C.A. (Ed.), Essays in Political Geography, London: Methuen \& Co., 1968, pp. 33-37.

James, P. E. and Faissol, S., "The Problem of Brazil's Capital City", Geographical Review, Vol. 46, 1956, pp. 301-317. 
Jefferson, M., "The Law of the Primate City", Geographical Review, Vol.29, 1939, pp. 226-232.

Jennings, I., Some Characteristics of Indian constitution, Madras: Oxford University Press, 1953.

Jensen, M., The New Nation: A History of the United states During the Confederation, 1781-1787, New York: Knopf, 1950 .

Johnston, R. E., The Effect of Judicial Review on FederalState Relations in Australia, Canada and the United States, Baton Rouge: Louisiana State University Press, 1969 .

Jones, M. A., American Immigration, Chicago: Chicago University Press, 1960 .

Jones, S. B., "A Unified Field Theory of Political Geography", Annals, Association of American Geographers, Vol.44, 1954, pp. 111-123.

Jose, A., Australia: Human and Economic, London: George Harrap \& Co., 1932.

Kahin, G. McT., "Indirect Rule in East Indonesia", Pacific Affairs, Vol. 22, 1949, pp. 227-238.

Kahin, G. MCT., Nationalism and Revolution in Indonesia, Ithaca, N. Y.: Cornell University Press, 1961.

Karve, D. G., Federations: A Study in Comparative Politics, London: Oxford University Press, 1932 .

Kasperson, R. E., and Minghi, J. V. (Eds.), The Structure of Political Geography, Chicago: Aldine Publishing Co:, 1969.

Keith, A. B., Constitutional History of India, 1600-1935, London: Methuen \& Co., 1937 .

Kennedy, W. P., The Constitution of Canada 1534-1937: An Introduction to its Development, Law and Custom, London: Oxford University Press, 1938.

Key, V. o. Jr., Politics, Parties and Pressure Groups, New York: Thomas Y, Crowell Co., fifth edition, seventh printing, 1969.

Kochanek, S. A., The Congress Party in India: The Dynamics of One-Party Democracy, Princeton, No J.: Princeton University Press, 1968 .

Kollmorgen, W., "Political Regionalism in the United States -Fact or Myth?", Social Forces, Vol. 15, 1936-1937, pp. $111-122$.

Kristof, L。K. D., "The Russian Image of Russia: An Applied study in Geopolitical Methodology", in Fisher, C. A. (Ed.), Essays in Political Geography, London: Methuen \& Co., 1968, pp. 345-387. 
Kulkarni, V. B., British Dominion in India and After, Bombay: Bharatiya Vidya Bhawan, 1964 .

Laski, H. J., "The Obsolescence of Federalism", The New Republic, Vol. 98, 1939, pp. 367-369.

Leach, R. H., "Intergovernmental Cooperation and American Federalism", in Dietze, G. (Ed.), Essays on the American Constitution, Englewood Cliffs, N.J.: PrenticeHal1, 1964, pp. 125-138.

Leach, R. H., Interstate Relations in Australia, Lexington: University of Kentucky Press, 1965 .

Levy, L. W. (Ed.), Essays on the Making of the Constitution, New York: Oxford University Press, 1969.

Levy, M. J., Jr., "structural Functional Analysis", in International Encyclopaedia of the Social sciences, Vol. 6, pp. 21-29, New York: Macmillan Co. and The Free Press, 1968.

Lima, M. de $0 .$, The Evolution of Brazil Compared with that of Spanish America, Stanford, Cal.: Stanford University Press, 1914 .

Lipset, S. M., "The 'Newness' of the New Nation", in Vann Woodward, C. (Ed.), A Comparative Approach to American History, Voice of America Forum Lectures, Washington, D. C., Voice of America, 1968, pp. 67-79.

Livingston, W. S., "A Note on the Nature of Federalism", Political Science Quarterly, Vol. 67, 1952, pp. 81-95.

Livingston, W. S., Federalism and Constitutional Change, London: Oxford University Press, 1956.

Livginston, W. S. (Ed.), Federalism in the Commonwealth: A Bibliographic Commentary, London: Cassell, 1963.

Livingston, W. S., "Canada, Australia, and the United States: Variations on a Theme", in Earle, V. (Ed.), Federalism: Infinite Variety in Theory and Practice, Itasca, Ill.: F. E. Peacock Publishers Inc., 1968, pp. 94-141.

Loewentein, K., "Reflections on the Value of Constitutions in our Revolutionary Age", in zurcher, A. (Ed.), Constitutions and Constitutional Trends since World War II, New York: New York Unịversity Press, 1951, pp. 191-224.

Logan, W. S., "The Changing Landscape Significance of the Victoria-South Australia Boundary", Annals, Association of American Geographers, Vol. 58, 19 $\overline{68, \mathrm{pp}} .128-154$.

Lott, L. B., "Venezuela", in Needler, M. C. (Ed.), Political Systems of Latin America, Princeton, N. J.: D. Van Nostrand Co., 1964, pp. 233-266. 
Lowenthal, D., "The West Indies Chooses a Capital", Geographical Review, Vol. 48, 1958, pp. 336-364.

Lowenthal, D., "The Social Background of the West Indies Federation", in Lowenthal, D. (Ed.), The West Indies Federation, New York: Columbia University Press, 1961, pp. 63-96.

Lower, A. R. M., "The Two Ways of Life: The Primary Anti-. thesis of Canadian History", The Canadian Historical. Association Report of the Annual. Meeting, 1943, pp. 5-18.

Lower, A. R. M., Colony to Nation: A History of Canada, Toronto: Longman, Green and Co., 1946.

Lower, A. R. M., Canadians in the Making: A Social History of Canada, Toronto: Longman, Green \& Co., 1958 .

McDermott, J. F. (Ed.), The Frontier Re-examined, Urbana, Il1.: University of Illinois Press, 1969.

MacDonald, A. F., Latin American Politics and Government, New York: Thomas-Y. Crowell Co., 1950.

MacDonald, F., We The People: The Economic Origins of the Constitution, Chicago: Chicago University Press, 1958.

MacDonald, M., The Republic of Austria, 1918-1934, London: oxford University Press, 1946 .

Mackinnon, V. S., Comparative Federalism: A Study in Judicial Interpretation, The Hague: Martinus Nijhoff, 1964 .

Mackintosh, J. P., "Federalism in Nigeria", political studies, vol. 10, 1962, pp. 223-247.

Mackirdy, K. A., "Geography and. Federalism in Australia and Canada", Australian Geographer, Vol. 6, No. 2, March 1953 , pp. 38-47.

MacMahon, A. W., "Federation", in Encyclopaedia of the Social Sciences, Vol. 6, pp. 172-177 New York: Macmillan Co. 1931 .

MacMahon, A. W., (Ed.), Federalism: Mature and Emergent, New York: Doubleday \& Co. Inc., 1955.

McWhinney, E., Federal Constitution-Making for a Multinational World, Leyden: A. W. Sijthoff, 1966.

McWhinney, E., Comparative Federalism: States' Rights and National Power, Toronto: University of Toronto Press, second edition, 1965.

Maddox, W. P., "The Political Basis of Federation", American Political Science Review, Vol. 35, 1941; pp. $1120-1127$. 
Main, J. T., "Charles Beard and the Constitution: A Critical Review of Forrest MacDonald's 'We the People'", William and Mary Quarterly, third series, Vol. 17, 1960, pp. 86-102。

Mallory, J。R。, "The Five Faces of Federalism", in Crepeau, P. $-A$. and Macpherson, C. B。 (Eds。), The Future of Canadian Federalism, Toronto: Toronto University Press, 1965 , pp. 3-15。

Martin, A。 W. (Ed.), Essays in Australian Federation, Melbourne: Melbourne University Press, 1969.

Martin, C., "British Policy in Canadian Confederation", Canadian Historical Review, Vol。13, 1932, pp. 3-19.

Martin, C., Foundations of Canadian Nationhood, Toronto: University of Toronto Press, 1955.

Martin, P. A., "Federalism in Brazil", in Read, C. (Ed.), The Constitution Reconsidered, New York: Columbia University Press, 1938, pp. 367-384.

Martin, P. E., "Swiss Confederation", an article in The Cambridge Mediaeval History, London: Cambridge University Press, 1932, Vol. 7, pp. 183-215.

May, R. J., Federalism and Fiscal Adjustment, oxford: Clarendon Press, 1969 .

May, R. J., "Decision-making and stability in Federal systems", Canadian Journal of Political Science, Vol. 3, 1970, pp. 73-87.

Mayer, L., "Federalism and Party Behavior in Australia and Canada", Western Political Quarterly, Vol. 23, 1970, pp. $795-8 \overline{07 \text { 。 }}$

Mecham, J. L., "The origins of Federalism in Mexico", in Read, C. (Edo), The Constitution Reconsidered, New York : Columbia University Press, 1938, pp. 349-365.

Mecham, J. L., "Mexican Federalism: Fact or Fiction", Annals of the American Academy of Political and Social Science, Vol. 208, March, 1940, pp. 23-38.

Meekison, J. P. (Ed.), Canadian Federalism: Myth or Reality?, Toronto: Methuen of Canada, 1968.

D) Meiniłg, D. W., "A Macrogeography of Western Imperialism: Some Morphologies of Moving Frontiers of Political Control", in Gale, F. and. Lawton, G。 H。 (Eds.), Settlement and Encounter: Geographical Essays Presented to Sir Grenfell Price, Melbourne: Oxford University Press, 1969, pp. 213-240。

Merkl, P., The Origins of the West German Republic, New York: oxford University Press, 1963。 
Merril, Go, "The survival of the Past in the west Indies", in Lowenthal, Do (Edo), The West Indies Federation, New York: Columbia University Press, 1961, pp, 17-34.

Merril, G。, "Regionalism and Nationalism", in Warkentin, $J$. (Ed.): Canada: A Geographical Interpretation, Toronto: Methuen Publications, 1968, pp。556-568。

Merritt, $R$ 。 Io, "Perception of Unity and Diversity in Colonial America 1735-1775", paper read at the sixth Congress of the International political science Association, Oxford Round Table Meeting, September 19-24, pp. 30 .

Merton, R. K., Social Theory and Social structure: Toward a Codification of Theory and Research, Glencole, III.: The Free Press, first published 1949, revised edition 1957 .

Mikesell, M., "Comparative Studies in Frontier History", Annals, Association of American Geographers, Vol. 50, 1960, pp. 62-74.

Mill, J.S., Utilitarianism, Liberty, and Representative Government, Everyman's Library, London: J.M.Dent, 1947, reprint.

Miller, J. Co, Origins of the American Revolution, London: Faber \& Faber, 1945 .

Miller, J. D。 B., Australian Government and Politics, London: Duckworths, third edition, 1964.

Miller, W., A New History of the United States, London: Faber \& Faber, 1958 .

Milne, R. So, "Politics and Government", in Gungwu, W. (Ed.), Malaysia: A Survey, Melbourne: F. W. Cheshire, 1964, pp. 323-335.

Milne, R。 S., Government and Politics in Malaysia, Boston: Houghton Mifflin Co., 1967。

Milne, R. S., "National Ideology" and Nationbuilding in Malaysia", Asian Survey, Vol. 10, No. 7, July 1970, pp. 63-67.

Mogi, S., The Problem of Federalism: A Study in the History of Political Theory, two volumes, London: George Allen \& Unwin Ltd。, 1931:

Mood, F., "The Origin, Evolution, and Application of the Sectional Concept, 1750-1900", in Jensen, M. (Ed.), Regionalism in America, Madison: University of Wisconsin Press, 1952。

Moog, C.V., Bandeirantes and Pioneers, translated from the Portuguese by Barrett, L。L。, New York: George Braziller Inc。, 1964 。

Mookerjee, R。 Ko, The Fundamental Unity of India, Bombay: Bharatiya Vidya Bhawan, 1954。 
Moore, B., Canada, Life World Library, Life-Time International, 1965.

Mordecai, Jo, The West Indies: The Federal Negotiations, London: George Allen \& Unwin Ltd。, 1968 .

Morison, S. E。, and Commager, H。S., The Growth of the American Republic, two volumes, New York: Oxford University Press, fifth edition, 1962 .

Morris-Jones, W. H., "Recent Political Developments in India", Parliamentary Affairs, Vol.11, 1957-1958, pp. 475-483.

Morris-Jones, W. H., Government and Politics of India, London: Hutchinson University Library, second edition, 1967.

Morton, W. L., The Canadian Identity, Madison: University of Wisconsin Press, 1961 .

Morton, W. L。, The Kingdom of Canada: A General History from Earliest Times, Indianapolis: Bobbs-Merrill Co., Inc., 1963 .

Morton, W. L., The Critical Years: The Union of British North America, 1857-1873, Toronto: McClelland \& stewart, 1964 .

Morton, W. L., "The Geographical Circumstances of the Confederation", in Megill, W. J. (Ed.), Patterns of Canada, Toronto: Ryerson Press, 1967, pp. 62-75.

Muller, S., "Federalism and Party system in Canada", in Wildavsky, A. (Ed.), American Federalism is Perspective, Boston: Little, Brown \& Co., 1967, pp. 144-162.

Murphey, R., "New Capitals of Asia", Economic Development and Cultural Change, Vol. 5, 1956-1957, pp. 216-243.

Needler, M. C., "Mexico", in Needler, M. C. (Ed.), Political Systems of Latin America, Princeton, N. J.: D. Van Nostrand Co., 1964, pp. 1-33.

Nevins, A. and Commager, H. S., America: The Story of a Free People, Oxford: Clarendon Press, third edition, 1966.

Nicholas, H. G., The American Union, London: Christofers, 1948 .

Niven, R., Nigeria, London: Ernest Benn Ltd., 1967.

Norris, R., "Economic. Influence on the 1898 South Australian Federation Referendum", in Martin, A. W. (Ed.), Essays in Australian Federation, Melbourne: Melbourne University Press, 1969, pp。137-166。

Odegard, P. H., and Baerwald, H. H., The American Republic: Its Government and Politics, New York: Harper \& Row, 1964 . 
Odum, H。W. and Moore, H. E。, American Regionalism: A Cultural Historical Approach to National Integration, New York: Henry Holt, 1938.

Overacker, L., The Australian Party System, New Haven: Yale University Press, 1952 .

Palmer, V., The Legend of the Nineties, Melbourne: Melbourne University Press, 1954 .

Palmier, L., Indonesia, London: Thames \& Hudson Ltd, 1965.

Panikkar, K. M. , A Survey of Indian History, Bombay:

Asia Publishing House, chird revised edition, 1957.

Panikkar, K. M., The Foundations of New India, London: George Allen \& Unwin Ltd., 1963.

Parker, R. S., "Australian Federation: The Influence of Economic. Interests in Political Pressures", Historical Studies in Australia and New Zealand, Vol, 4, 1949, pp. 1-24.

Partridge, P. H., "The Politics of Federalism" in Sawer, G. (Ed.), Federalism: An Australian Jubilee study, Melbourne: Melbourne University Press, 1952, pp. 174-199.

Passant, E. J., The Problem of Austria, Oxford Pamphlets on World Affairs, London: Oxford University Press, 1945.

Peterson, P., "Brazil: Institutionalized Confusion", in Needler, M. Co( $\left.\mathrm{Cd}_{0}\right)$, Political Systems of Latin America, Princeton, No J。: D. Van Nostrand Co., 1964, pp. 463-510.

Pierson, W. W., and Gil, F. G., Governments of Latin America, New York: MCGraw Hill Book Co., 1957 .

Pinney, E。 L., Federalism, Bureaucracy, and Party Politics in Western Germany: Role of the Bundesrat, Chapel Hill: University of North Carolina Press, 1963.

Plischke, E., Contemporary Government in Germany, London: George Allen \& Unwin Ltd。, 1961 .

Potter, D. and Manning, T. G. (Eds.), Nationalism and Sectionalism in American History: Select Problems in Historical Interpretation, New York: Henry Holt, 1949.

Pounds, N. J。G., Political Geography, New York: McGraw Hill Book Co., $19 \overline{63}$.

Prasad, B., Origins of Provincial Autonomy (1861-1920), Allahabad: Kitabistan, 1941.

Prasad, R., India Divided, Bombay: Hind Kitabs, 1956. 
Pratt, J. W., Expansionists of 1812, Gloucester, Mass.: Peter smith, first published 1925, reprinted 1957.

Prescott, J.R. V., "The Geographical Basis of Nigerian Federation", Nigerian Geographical Journal, Vol. 2, 1958, pp. 1-13.

Prescott, J. R. V., "Geographical Basis of Kenya's Political Problems", Australian Outlook, Vol。16, 1962, pp. 270282 .

Prescott, J.R. V., The Geography of State Policies, London: Hutchinson University Library, 1968 .

Purcell, V., Malaysia, London: Thomas \& Hudson, 1965.

Pyle, M. V., India's Constitution at Work, Bombay: Asia Publishing House, 1962 .

Quick, J. and Garran, R. R., Annotated Constitution of the Commonwealth of Australia, Sydney: Angus \& Robertson, 1901 .

Raiker, Y. A., Indian History: A Study in Dynamics, Baroda: M. S. University, 1960 .

Rappard, W. E., The Government of Switzerland; New York: D. Van Nostrand Co., 1936.

Rappard, W. E., Collective Security in Swiss Experience, 1291-1948, London: George Allen \& Unwin, 1948 .

Ray, A., Inter-governmental Relations in India: A Study in Federalism, Bombay: Asia Publishing House, 1967.

Ray, B., Evolution of Federalism in India, Calcutta: Progressive Publishers, 1967 .

Riker, W. H., Federalism: Origin, operation, Significance, Boston: Little, Brown \& Co., 1964.

Robinson, K. W., "Sixty Years of Federation in Australia", Geographical Review, Vol. 51, 1961, pp. 1-20.

Robinson, K. W., "Political Influence in Australian Geography", Pacific Viewpoint, Vol. 3, 1962, pp. 73-86.

Robinson, K. W., "Diversity, Conflict and Change--Meeting Place of Geography and Politics", Australian Geographical Studies, Vol.8, 1970, pp. 1-15.

Roche, J. P., "The Founding Fathers: A Reform Caucus in Action", The American Political Science Review, Vol. $55,1961, \mathrm{pp} .799-816$.

Rose, A. J., "The Frontier Between Queensland and New South Wales: A Study of Political Geography in a Federal Union", Australian Geographer, Vol. 6, No. 4, 1955, pp. 3-18. 
Rose, A. J., "Some Boundaries and Building Materials in Southeastern Australia", in McCaskill, M. (Ed.), Land and Livelihood; Geographical Essays in Honour of George Jobberns, Christchurch: New Zealand Geographical Society, 1962, pp. 255-276.

Rothchild, D。S., Toward Unity in Africa: A Study of Federalism in British Africa, Washington, D. Co: Public Affairs Press, 1960 .

Rowe, L. S., Federal system of the Argentine Republic, Washington, D。C.: The Carnegie Institute, 1921.

Ruthnaswamy, M., "The Ark of the Federal Covenant", New Review, December 1946.

Ryan, N. J., The Making of Modern Malaya: A History from the Earliest Times to the Present, Kuala Lumpur: oxford University Press, 1963.

Sawer, G., "Federalism in West Germany:, Public Law, 1961, pp. $26-44$.

Sawer, G., The Constitutional System of the European Common Market, Canberra: Royal Institute of Public Administration, A. C. T. Group, 1963, pp. text 1-14, appendix pp. 15-42.

Sawer, G., Australian Government Today, Melbourne: Melbourne University Press, ninth edition, 1967.

Sawer, G., Modern Federalism, London: C.A. Watts, 1969.

Sayeed, K. B., Pathan Regionalism, Reprint No. 13, Durham, N. C., Duke University Commonwealth Studies Center, 1964 .

Sayeed, K. B., The Political system of Pakistan, Boston: Houghton Mifflin Co., 1967.

Schaefer, F. K., Political Geography, an unpublished and incomplete book written around 1950; copy lodged in the library of the American Geographical society, New York. (Reference from Bunge, W., Theoretical Geography, 1966.)

Schaefer, F. K., "Exceptionalism in Geography: A Methodological Examination", Annals, Association of American Geographers, vo1.43, 1953, pp. 226-249.

Schiller, A., The Formation of Federal Indonesia, The Hague: W. Van Hoeve Ltd., 1955 .

Schlesinger, R., Federalism in Central and Eastern Europe, London: Kegan Paul, Trench, Trubner \& Co., 1945.

Schwartz, B., The Reins of Power: A Constitutional History of the United States, London: Chatto \& Windus, 1964 .

Schwartz, W., Nigeria, London: Pall Mall Press, 1968. 
Schwartzberg, J。E., "The Distribution of selected Castes in the North Indian Plain", Geographical Review, Vol. 55,1965 , pp. 477-495.

Scott, R. E., "Argentina's New Constitution: Social Democracy or Social Authoritarianism?", Western political quarterly, Vol.4, 1951, pp. 567-576.

Scott, R. E., Mexican Government in Transition, Urbana, I11.: University of Illinois Press, 1959.

Sellers, C. G., Jr., "The Travail of Slavery" in sellers, C. G., Jr. (Ed.), The Southerner as American, Chapel Hill: University of North Carolina Press, 1960, pp. $40-71$.

Semple, E. C., American History and its Geographical Conditions, New York: Houghton Mifflin, 1933.

Serle, G., "The Victorian Government's Campaign for Federation 1883-1889", in Martin, A. W. (Ed.), Essays in Australian Federation, Melbourne: Melbourne University Press, 1969, pp. 1-56.

Sharma, B. M., Federalism in Theory and Practice, two volumes, Chandausi, India: Bhargava \&. Sons, 1951 and 1953.

Shaw, A. G. I., The Story of Australia, London: Faber \& Faber, 1961 .

Siegfried, A., Canada: An International Power, Translated from French by Hemming, D., London: Jonathan Cape, 1949.

Siegfried, A., Switzerland: A Democratic Way of Life, translated from French by Fitzerald, E., London: Jonathan Cape, 1950.

Simandjuntak, B., Malayan Federalism 1945-1963: Study of Federal Problems in Plural Society, London: Oxford University Press, 1969.

Singh, T., "Administrative Relations in Planning", Indian Journal of Public Administration, Vol. 1, 1955, pp. $137-151$.

Smiley, D. V., "The Two Themes of Canadian Federalism", Canadian Journal of Economics and Political Science, Vo1.31, 1965, pp. 80-97.

Smith, G., Canada and the Canadian Question, Toronto: Macmillan Co., 1891.

Smith, J. P., "A United States of North America: Shadow or Substance?", Canadian Historical Review, Vol. 26, 1945 , pp. 109-118.

Smith, T. E., A Background to Malaysia, London: Royal Society of International Affairs, 1963.

Smith, W., History of Post Office in British North America, London: Cambridge University Press, 1920 . 
Snyder, D. E., "Alternate Prespectives on Brasilia", Economic Geography, Vo1.40, 1964, pp. 34-45.

Solomon, R. J., "The Geography of Political Affiliation in a Federal-State System: Tasmania 1913-1966", Australian Geographical Studies, Vol. 7, 1969, pp. 28-40.

Spain, A. O., "Mexican Federalism Revisited", Western Political Quarterly, Vol. 9, 1956, pp. 620-632.

Spate, O. H. K., "Factors in the Development of Capital Cities", Geographical Review, Vol. 32, 1942, pp. 622-631.

Spate, O. H. K., "Geographical Aspects of the Pakistan Scheme", Geographical Journal, Vol. 102, 1943, pp. 125133.

Spate, O. H. K., "Geography and Federalism", Indian Geographical Journal, Vol. 14,1944 , pp. $\frac{24-36}{\text {. }}$

Spate, O. H. K., "The Partition of India and Prospects of Pakistan", Geographical Review, Vol. 38, 1947, pp. 5-29.

Spate, O. H. K., "Toynbee and Huntington: A Study in Determinism", Geographical Journal, Vol. 118, 1952, pp. $406-424$.

Spate; O. H. K., Discussion on K. C. Wheare's paper "When Federal Government is Justifiable?", in Sawer, G. (Ed.), Federalism: An Australian Jubilee Study, Melbourne: F. W. Cheshire, 1952, pp. 131-132. The main paper on pp. 110-117.

Spate, O. H. K., "Two Federal Capitals: New Delhi and Canberra", Geographical Outlook, Vol. 1, 1956, pp. 1-8.

Spate, O. H. K, "India and Pakistan" in East, W. G. and spate, O. H. K. (Eds.), The Changing Map of Asia: Political Geography, London: Methuen \&. Co., third edition, 1958, pp. 121-180.

Spate, 0 . H. K. and Learmonth, A. T. A., India and Pakistan: A General and Regional Geography, London: Methuen \& Co., 1967 .

Spate, O. H. K, , Australia, London: Ernest Benn Ltd., 1968.

Spate, O. H. K., "Mandalay and Rangoon: The old and the New in Burma", Transactions and Papers, Institute of British Geographers, No. 44, 1968, pp. 155-168.

Spear, P., "The Political Evolution of Pakistan: A Study in Analysis", in Rose, $S$. (Ed.), Politics in Southern Asia, London: Macmilian Co., 1963, pp. 33-51,

Spear, P., A History of India, Vol. 2, Hammondsworth (Middlesex), England: Penguin Books Ltd., 1968 (first published 1956). 
Springer, H. W. Reflections on the Failure of the First West Indian Federation, Cambridge, Mass.: Center of International Affairs, Harvard University, 1962 .

Stacey, CoP., "Fenianism and the Rise of National Feeling in Canada at the Time of Confederation", Canadian Historical Review, Vol.12, $1931, \mathrm{pp} .128-161$.

Stacey, C. P., "Britain's Withdrawal from North America 1864$1871 "$, Canadian Historical Review, Vol. 36, 1955, pp. $185-198$.

Stanley, G. F. S., "Act or Pact? Another Look at Confederation", Canadian Historical Report, 1956, reprinted in Cook, R. (Ed.), Confederation, Toronto: Toronto University press, 1967, pp.94-118.

Stein, M., "Federal Political systems and Federal, Societies", review article, World Politics, Vol. 20, 1968, pp. $721-747$.

Steinberg, S. H., A Short History of Germany, New York: Macmillan Co., 1946 .

Steiner, J., "Nonviolent Conflict Resolution in. Democratic Systems: Switzerland", Journal of Conflict Resolution, Vol. 13, 1969, pp. 295-304.

Stephens, I., Pakistan, London: Ernest Benn Ltd., 1963.

Stokes, W. S., "The Centralized Federal Republics of Latin America", in Benson, C.G. S. and others, Essays in Federalism, Claremont College, Calif.: Institute for the study of Federalism, 1960, pp. 93-166.

Subbarao, B., Personality of India, Baraoda: M. S. University, 1956 .

Sydnor, C. S., The Development of Southern Sectionalism 1819-1848, Baton Rouge: Louisiana state University Press, 1948 .

Tarlton, C。D., "Symmetry and Asymmetry as Elements of Federalism: A. Theoretical speculation", Journal of Politics, Vo1. 27, 1965, pp. 861-874.

Tarlton, C. D., "Federalism, Political Energy, and Entropy: Implications of an Analogy", Western Political Quarterly, Vol, 20, 1967, pp. 866-874.

Tayyeb, A., Pakistan: A Political Geography, London: oxford University Press, 1966 .

Thomson, D., Aims of History, London: Thomas \& Hudson, 1969 .

Toynbee, A., "Pakistan as an Historian sees Her", in Crescent and Green: A Miscellany of Writings on Pakistan, London: Cassell \& Co., 1955. pp.1-4. 
Trotter, R. G., Canadian Federation: Its origins and Achievement, London: J. Mo Dent, 1924.

Trotter, R。 G., "An Early Proposal for Federation of British North America", Canadian Historical Review, Vol.6, $1925, \mathrm{pp} .142-154$.

Trudeau, P. E., Federalism and the French Canadians, Toronto: Macmilian of Canada, 1968.

Truman, D. B., "Federalism and Party System", in Macmahon, A. W. (Ed.), Federalism: Mature and Emergent, New York: Doubleday \& Co., 1.955, pp. 115-136.

Turner, F.J., The Frontiex in American History, New york: Henry Holt, first published 1920, reprinted 1947.

Turner, F. J, The Significance of Sections in American History, with an introduction by M. Farrand, New. York: Peter Smith, 1932, reprinted 1950.

Ul lman, E. L., "The Eastern Rhode. Island-Massachusetts Boundary Zone", Geographical Review, Vol. 29, 1939, pp. 291-302.

Ullman, E. L., "Human Geography and Area Research", Annals, Association of American Geographers, Vol. 43, 1953, pp. $54-66$.

Underhill, F. H., The Image of Confederation, Toronto: Canadian Broadcasting Corporation, 1964.

Van Alstyne, R. W. Empire and Independence: The International History of the United States, New York: John Wiley, 1965 .

Van Tyne, C. H., The Causes of the War of Independence, Vol. 1, Boston: Houghton Mifflin Co., 1922.

Van Valkenburg, S., Elements of Political Geography, London: Issac Pitman \& Sons, first published 1939, eleventh printing 1949 .

Vile, M. J. C., The Structure of American Federalism, London: oxford University Press, 1961.

Waite, P. B., The Life and Times of Confederation, 1864-67, Toronto: Toronto University Press, 1962 .

Ward, R., Australian Legend, Melbourne: Oxford University. Press, 1962 . "A l Warner, D. F., "Drag Mach Norden: The United States and the Vol. 34, 1953, pp.693-712.

Warner, DoF。, The Idea of Continental Union: Agitation for the Annexation of Canada to the United states, 1849-1893, Lexington: University of Kentucky Press, 1960 . 
Watson, J. W., "Canadian Regionalism in Life and Letters", Geographical Journal, Vol. 131, 1965, pp. 21-33.

Watson, J. W., North America: Its Countries and Regions, New York: Frederick Praeger, 1967.

Watson, J. W., "Role of Illusion in North American Geography: A Note on the Geography of North American Settlement", Canadian Geographer, Vol.13, 1969, pp. 10-27.

Watt, R. M., The Kings Depart: The Tragedy of Germany: Varsailies and the German Revolution, London: Weidenfeld \& Nicholson, 1968 .

Watts, R. L., New Federations: Experiments in the Commonwealth, Oxford: Clarendon Press, 1966 .

Weigend, G., "Some Elements in the study of Port Geography", Geographical Review, Vol. 48, 1958, pp. 185-200.

Wellborn, F. W. , The Growth of American Nationality 14921865, New York: Macmillan Co., 1948.

Wheare, K, C., Federal Government, London: Oxford University Press, fourth edition, 1963 .

Whitelaw, W. M. , The Maritimes and Canada Before Confederation, Toronto: oxford University Press, 1934.

Whittlesey, D., "The Impress of Effective Central Authority on the Landscape", Annals, Association of American Geographers, Vol. $2 \overline{5,1935}$, pp. 85-97.

Whittlesey, D., The Earth and the State, New York: Henry Holt \& Co., 1939, reprinted 1951.

Whittlesey, D., "The Horizon of Geography", Annals, Association of American Geographers, vol. 35, 1945, pp. 1-36.

Whittlesey, D., "The United States: The Origin of a Federal State", in East, W. G. and Moodie, A. E. (Eds.), The Changing World, London: George Harrap \& Co., $1956 ;$ pp. 239-260.

Wildavsky, A., "Party Discipline Under Federalism: Implications of Australian Experience", Social Forces, Vol. 28,1961, pp. 437-458.

Williams, S., Central Africa: The Economics of Inequality, London: Fabian society, 1960 .

Wolf, C., Jr., The Indonesian Story: The Birth, Growth and Structure of the Indonesian Republic, New York: John Day \& Co., 1948.

Woodburn, J. A., "Western Radicalism in American Politics", Mississippi Valley Historical Review, Vol, 13, 1926, pp. 143-168.

Woodger, J. H., Biological Principles: A Critical study, London: Routledge, first published 1924, reissued 1948 . 